


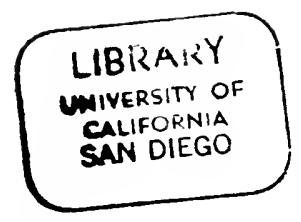




\section{Notable New Books}

BELGIUTA

By Brand Hhitlock

Unquestionably the grertest book which has come out of the War. The story of the German invasion by the one man whose testimony is final.

With portraits. Two vols. \$10.(10) net

\section{FRENCH WAYS AND THEIR MEANING}

By Lidith Wharton

An intimate, brilliant study of the French by one cf America's foremost writers.

$\$ 1.50 \mathrm{net}$

SIBERIA TODAY

By Capt. Irederick H. Hoore

An unusually interesting account of present day $:-$ heria, showing the results of Bolshevism. \$2.01 net

\section{SMALL THINGS By Hargaret Deland}

Small things-little stories, everyday episodes whic.t a great novelist experienced in lirance. \$1.5t) net

\section{THE CAREER OF LEONARD WOOD}

$$
\text { By Joseph Hamblen Sears }
$$

A sketch of an unusually varied and eventful life, presenting General Wood as a great American, a fine man and a distinguished patriot.

$$
\text { Illustrated, } \$ 1.75 \text { net }
$$

\section{GEORGES CLEMENCEAU, Tiger of France}

By Georges Lecomte

An intimate study of the man and his work by a well-known French journalist. \$1.75 net

\section{THE STORY OF GENERAL PERSHING}

By Everett T. Tomlinson

An up-to-the-minute and aecurate account of General Pershing's career and personal life.

Illustrated, \$1.75 net 
$\mid$ 


\section{CONTEMPORARY FRENCH POLITICS}





\title{
CONTEMPORARY FRENCH POLITICS
}

\author{
BY \\ RAYMOND LESLIE BUELL \\ BOMETIME FELLOW IN POLITICS IN PRINCETON UNIVERSITY
}

WITH AN INTRODUCTION BY

CARLTON J. H. HAYES

PROFESSOI OF HISTOIRY IN COLUMBIA UNIVERSITY

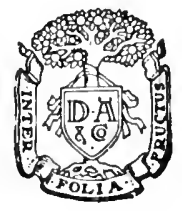

D. APPLETON AND COMPANY NEW IORK LONDON 
COPYRIGHT, 1920, BY

D. APPLETON AND COMPANY

PRINTED IN TIE V VITED ST ITF: OF AMERICA 
MY MOTHER 



\section{PREFACE}

To many, the results of the French elections of November 16, 1919, eame as a welcome surprise. An American observer in Paris who had perhaps taken but a easual interest in French domestic problems would have been convinced, upon visiting the Palais Bourbon, that France was on the verge of being engulfed in a tidal wave of Bolshevism from the Russian deep. He would have heard aghast, the Extreme Left, led by the grandson of Karl Marx, Jean Longuet, shrieking its defiance at all things bourgeois. Possibly to his dismay, he would also have heard the thunderous stamping of feet by which the Soeialists drowned the sound of the huge silver bell, through insistent ringing of which the President of the Chamber bravely struggled to maintain order. To the Amerieans at home the situation must have appeared no less ominous. Judged by the press reports, the tumult arising from the First of May eelebrations, and the Soeialist vituperations against the Peace Conference, surely gave cause for grave foreboding.

But a deeper knowledge of the eurrents which underlie the surface of the political waters in France belied any such eatastrophe as the "storm prophets" had predieted. Those currents were deep; they were silent. Indeed, to their depth they owed their relentless power and their persistence in their normal course.

The strongest of these forces was the sterling eharacter of the French people themselves. Only a very superfieial estimate of national temperament will judge the French to be excitable, unpractieal and unstable. Although the history of France has been marked by whirlwinds in which the nation has been blown hither vii 


\section{PREFACE}

and thither by the gust of every fresh political doctrine, French character possesses at least three qualities of impregnable strength.

The first of these is a personal attachment to property, whether a farm or a wine shop, which no gilded theory of Communism can shake. This attachment is nearly universal, for it is based upon the small holdings of 20,000,000 peasants and petit bourgeois. Moreover, the sentiment embodied in the Code Napoléon has been and is likely to remain the breakwater protecting the Republic against the lashing waves of the "Internationale." This great legal monument has given to France a scheme of social and economie principles which has exalted individualism and encouraged an almost devout attachment to property.

The second eharacteristic is a respect for authority. To us Americans who were recently in France, and to all Amerieans accustomed lightly to regard constituted power, the innate obedience and discipline of the French was something to be wondered at. It was first noticeable at the very gates of the city, where French farmers complacently allowed gendarmes to scarch their vehicles for objects upon whieh to levy the time-revered and superlatively irritating octroi tax. It appeared again amidst the solemnity of public bodies, whether at the Chamber of Deputies or the Hôtel de Ville, where chamberlains and attendants, girt about with great sashes and elanking swords, rendered due homage to officials whom they served. Even in the Chamber of Deputies, where members were allowed the greatest license, those who constituted the crowd filling the visitors' gallery were kept in docile submission by claborately uniformed and decorated guards who did not hesitate to eject those who might attempt too boisterously to join in the Chamber's levity.

$\Lambda$ the universities, this characteristic love of ceremonial and order was yet more noticeable-doubly viii 


\section{PREFACE}

so in contrast to American institutions of learning. French professol's invariably dcliver their lectures wearing their academic gowns; they are followed into class by an attendant who carries the lecturer's notes and deposits them respectfully upon his desk. At the professor's entrance, his class rises and maintains a restrained silence until he has taken his seat; and when he leaves at the close of the hour, they again dutifully stand until he has left the room. One must not altogether seoff at these niceties. They may be an inheritance from the Monarchy and the Empire, observed under the Republic to give it an added discipline which the force of kings formerly imposed. They may be a reflection of the ceremonialism dear to the Catholie Church-last vestiges of the union of Rome with the State. But whatever their eauses. they apparently oppose one of the staunchest obstacles to any elements endeavoring to snatch authority from those in whom it has been legally vested.

Finally, the French possess a civie spirit which amounts to more than enthusiasm, is wider than patriotism and different from religious zeal. It is a wholesouled devotion to the canse each man feels is his own, yet at the same time extending beyond worship at particularistic shrines and uniting before the altar of La Patrie. The differenee between French and American temperament was illustrated on the night of the armistiee. Poilus and midinettes forgot their (herished cynicism to join in singing, with a genuine spirit of thankfulness, the "Marseillaise." IIow could such as they understand the Americans, who, on the otlee hand, serpentined aloug the rues and boulevards, singing, not the "Star Spangled Bamer," but "IIail, Hail, the Gang's All ILere!" America cheered at the finishing of a dirty job and went ont to celebrate. Franee thanked Providence for wimning a Crusade.

The passionate devotion to La l'atrie allows the ship ix 


\section{PREFACE}

of state to drift on the swells, but alwars within the limits which the length of this spiritual anchor ehain imposes. Whether it be found in the street song of "Conspuez Guillaume,"'which French students shouted day after day during the first weeks of the armistice, or in some Catholic Te Deum, a devout and enthusiastic nationalism, completely submerging class selfishness, is the dominant trait in French eharacter to-day. France, in spite of the fact that Paris has ever been a feemnd breeding ground for new creeds and theories of social and moral destruction, is nevertheless the most conservative country in the world.

There are some singular misconceptions in Ameriea as to the nature of French political organizations. Textbooks, when they can be persuaded to deal with the subject, often assert that in reality Freneh political parties do not exist. Organizations spring up in the eool of the night, only to have the burning sum of a new political faction witler them away on the following day. But although France does not have the two-party system as it exists in England and Ameriea, I have tried to point out what are the lasting and the continuous features in French political organization and to prove that party multiplieity is not due entirely to an undisciplined resentment to control, but has canses which, if existing in any other country, would produce identical effects. Also I have tried to show that, although some parliamentary groups may be transient and unstable, French parties possess an organization and a personnel which are well defined.

I may have burdened the reader with wearisome details, but I have folt these necessary to show the elements of organization and the differences in the doetrines of present political grompings. The first part of the book may perhaps be described as a study of the political forces of France. Along with the political partics, I have included the French Press, for it pos- 


\section{$\operatorname{PREF} \Lambda \mathrm{CE}$}

sesses distinctively political charaeteristics and it assumes an aggressive political leadership.

The second portion of the book may be called a study of the movements for political reform. Under this heading I have discussed the recent electoral bill which has offset the predominance of the Radical and Socialist vote in the Chamber of Deputies, a predominanee to which, hitherto, they were not wholly entitled. The demand for constitutional reform-inchding decentralization of government administration-is most insistent. I have attempted to show the eauses of these demands and also the likelihood of the adoption of the proposed remedies. Of special interest to Americans should be the attempt to do away with the present system of parliamentary govermment and to substitute for it a govermment modeled upon that of the United States, in which the President plays a more prominent rôle. Likewise, the question of the demand for experts in administration, and even for professional representation in political bodies, that is to say, legislatures composed of business men to supplement, if not entirely to replace, political assemblies, should be of added value, in view of our own problems.

The poliey of the French Government during the past war has also been touched upon, notably, the questions raised by the state of siege, the censorship, the State control of nearly every phase of industrial life, the prohibition of importations, and the "consortium" poliey followed up to and throughout the armistice. Americans who have witnessed the gradual development of the power of their President should also be interested in the exactly opposite phenomenon noticeable in France, viz, the inereasing dominance of French legislative authority.

It has been impossible to separate enmpletely a consideration of political forces from the study of the various movenents of reform. Indeed the raison d'itre 


\section{PREFACE}

of many of the political parties is, logieally, to bring about these reforms. The latter questions all figured more or less prominently in the November elections.

Many people believed that the issues of this eleetion lay between those who sanctioned the war and those who opposed it. The Unified Socialists were the principal opposition. Personal antagonism to M. Clemenceau, partly arising from a faction within his own party, led by M. Franklin Bouillon, also played a part.

The issue of Bolshevism was of even more importance. The Unified Socialist party in its Easter eongress definitely pledged itself, as we shall see, to work for the inauguration of a Sovict form of government and the complete establishment of proletariat control. The issue which they brought before the voters was therefore clear-eut. The temper of the French people again proved its eonselvatism and its loyalty by an overwhelming defeat of such extremists as Jean Longuet, Jaeques Sadoul, Raffen-Dugens, and Brizon, who had insistently preached the Social Revolution. Their hopes of bringing about the revolution through peaceful means have been sadly disappointed. Whether or not this failure will dampen their efforts to achieve a coup de poing for the same end, is another question.

Bnt the third issue in the French election, one obscured by the two larger issues, yet of equal importance in the eyes of many electors, was the question of principle involved in the opposition of State Socialism and individual initiative. This issue I have tried to outline in a chapter on the "French Bureaucracy and State Socialism," and to show how the war has accelerated the participation of the Govermuent in industrial artivities which have hitherto been reserved to individual effort. The Frencle Radioal party-which has maintained the balance of power in the French (hamber sinee the beginning of the century-is definitely pledged to Colleetivism. Its program is to take over all public servies xii 


\section{PREF $\Lambda$ CE}

and all industrial enterprises when the latter beeome sufficiently organized to permit the experiment, at least, of State operation.

This tendeney, differing widely from the pure Marxism preached hy the Inified party, which demands a complete bouleversement of the present order and the directorate of the proletariat, conflicts with the sturdy individualism which is one of the most distinctive traits of the Frenel people. The existence of State Socialism in France is partly accounted for by the fact that nearly all of the public services owe their origin to the State and not to individuals, as in Ameriea. The adventures of Ameriean private initiative in the development of virgin resources have no eounterpart in Freneh history. Furthermore, the French character is conservative, while the American eharacter is sanguine and given to "plunging." A Frenchman does not often possess that large share of imagination and business capaeity which has made American "steel kings."

Again; the Radical party has been maintained in power upon issues other than economic, such as anticlericalism. Their collectivist program has been partly imposed by the strength of their own position. The war, which so exaggerated the Statist tendeney, placed the issue squarely before the Fremeh public. Measures taken permanently to fasten this incubus upon France were legalized by a Parliament and a Ministry whose mandate had been extra-legally prolonged and which owed its election to other issues. Business elements, such as the Union of Eronomic Interests, and all of the Conservative and Centrist parties proclaimed against a further injection of State effort into imbustry. It became certain that the issue wonld come up before the elections for settlement. Signs of this diseontent were evideneed by the fall of Vielor Boret, Minister of Agrieulture, in .July, 1919. The elections apparently placed the seal of disapproval on the Government's anti-individxiii 


\section{PREFACE}

ualistic program by the defeat of five members of the Government, two of whom, at least, M. Clémentel, Minister of Commerce, and M. Morel, Undersecretary of the Liquidation of War Supplies, were directly responsible for many of the more radical features of the policy. Finally, the reduction of the Radical representatives by a hundred at the last eleetion seemed to have been caused partly by their over-insistence upon policies of State Socialism.

The last part of this book deals with French opinion as it was expressed toward the peace settlement. Originally, France demanded terms of peace which would either ereet the Rheinish provinces into a buffer state or annex them to France. She also asked for military guarantees which would supply the only seeurity of which the "old diplomacy" was capable. Ameriea's insistence on a League of Nations, however, led to the abandonment of many of the old theories of "guarantees," and to the formal adoption of the policy of a League of Nations as furnishing the only means (1) of providing permanent international security and (2) of enforeing well-defined rules of justice.

It has often been said that at no time was France convinced of the efficacy and the practicability of a League of Nations, but that her only trust was in a permanent alliance of her present allies. However, this assertion is open to grave doubt. During the early weeks of the Peace Conference, there was abundant evidence that French opinion had been whole-heartedly won over to the League of Nations and that it was exerting itself toward the creation of a Leagne which would actually provide guarantees. To secure this end her representatives at the Peace Table advanced some very definite proposals. The first of these was for the pooling of that part of the war deht of the Allies which the indemnity could not pay. France believed that if the Allies were sincere in their repeated declarations that xiv 
she had saved the world from ruin, they would agree to apportion equally among themselves the material eharges of the war. The second measure to vitalize the League was the proposal to create an international police foree, subject to the direction of an international exeeutive. This fore would be immediately available for the suppression of illegal international disorder. France did not wish to be placed in the position of fearfully waiting for months-perhaps even yearsuntil her former Allies should decide whether or not to aid her again. These suggestions were both rejected by the Peace Conference, prineipally because of Ameriean opposition. Doubtlessly, President Wilson and his advisors favored them in modified form; but the opposition in the United States had already shown itself so opposed to the creation of any league imposing definite responsibilities upon Ameriea that they believed an extension of its powers would mean its total rejection.

The refusal of the Conferenee, at America's instigation, to ereate an efficient-in the military sense-league was largely responsible for the exaggeration of French demands based upon the policies of a discredited diplomacy. When some of these demands were in turn rejected (such as the amexation of the left bank of the Rhine), the most violent protests were made by public opinion. These protests were very natural. The League of Nations was aeceptable to France only upon the assumption of providing an equally secure guarantee of safety. This substituted promise of guarantees prevented the annexation of the Rhine, which at least seemed to offer temporary seeurity against German aggression. But the final form of the League did not live up to its promised remedies. It offered no positive military guarantee eommensurate with the policy it supplanted. Conseruently, France felt that her safety had been jeopardized for the empty satisfaction of realizing 


\section{PREFACE}

an ideal which America urged in form yet now refused to adopt in faet. It is needless to say that the treatment which the United States Senate aceorded the Treaty aroused a further skepticism among Frenchmen as to the real worth of a League of Nations.

The obligations accumulated in the writing of this book are many. My first is due to the Government of the lnited States. To one who holds 'Temnyson's "do or die" eonception of a soldier, it may seem rather audacious of an culisted man in the American Expeditionary Forces to have departed beyond the eustomary fields of guard mount and "K. I'." But, at any rate, I am grateful for having had the opportmity to go to France, to do what little I did, and when it was over, to spend four delightful months at the French University of Grenoble. I was there fortunate to find myself in the very heart of France, not the Franee of Paris, but the France of the Provinees.

I wish to thank the different politieal organizations in Paris who, by means of personal interviews or through correspondenee, very graciously aceorded me whatever information I desired.

To Monsieur Chastenet, the editor of the Droit $d u$ Peuple of Grenoble, a fiery Bolshevik and a late candidate for the Clamber of Deputies, I also owe my thanks. His amiability and kindly spirit somemhat dissipated, I must eonfess, my natural bourgeois terror of the class struggle and its missionaries.

On the other hand, to l'aul Bozon-Verduraz, likewise of Grenoble, a modern knight upholding the ideals of melieval kingship, a sturdy follower of l'hilippe VIII, I owe much inspiration. Through him, my confidence in repullies las been rudely shaken and my prejudices araminst the dortrine of l)ivine Right somewhat removed.

Finally, to Marano .J. Fournier I am greatly indebted. From the aloof colonial vantage point of Moroeeo, she xii 


\section{PREF ACE}

is able to pass serene judgment upon all the works of human frailty-political and otherwise. To her nothing can be perfeet. Although the Republie has its viees, it governs Franee "pretty well,-just as it is."

Space does not permit me to name the many friends in Ameriea who have given assistance and eneouragement in the writing of this book. I3ut I am under especial obligation to Professors Edward S. Corwin, Henry R. Shipman, and Philip Marshall Brown of Princeton University ; to Professor Carlton J. II. Hayes of Columbia; to W. P. Cresson and C. L. Barrett. I also am greatly indebted to Stoddard Dewey, IIenry Adams Gibbons, and Wm. Morton Fullerton for the kindly interest they have shown in, and the advice they have given upon, a subjeet coneerning which they have a much more profound knowledge than the author.

Raymond Leslie Buell 


\section{CON'TENTS}

PREFACE

\section{CHAP'TER I \\ PARTY PHILOSOPHIES}

I. Reasons for party multiplicity.-II. The Royalists.III. The Action Libérale Populaire.-IV. The Progressists.-V. The Democratic Republican Alliance.-VI. The Republican Radical and Radieal Socialists.-VII. The Unified Socialists.-VIII. The Repul)liean Socialists.-IX. Reform Societies.

XXV

\section{CHAPTER II \\ PARTIES AND PARLIAMENT}

I. The theory of parliamentary government.-II. Parliamentary groups, their relation to parties, and their manner of functioning.-H. Ministerial instability, a result of the group system.-IV. Dominance of Parliament, a second result. $-V$. The growth of parliamentary power during the war. . . . . . . .

$$
\begin{gathered}
\text { CHAPTER III } \\
\text { THE "BLOC" AND THE SACRED UNION }
\end{gathered}
$$

I. Former party combinations, the Bloe.--II. The internal relations of the members of the Bloe.-III. Party regroupings before the War.-IV. The origin of the Sacred Union.-V. Socialist opposition to the Saered Union, the minoritaires, Zimmerwald, Kienthal.VI. The victory of the minoritaires, the Villain trial. .

\section{CIIAP'TER IV \\ PARTY REALIGNMENTS}

I. The Socialist platform, an effort to conciliate Revolutionists and Reformists.-II. The Easter Congress, the xix 


\section{CONTENTS}

Loriot sovict program.--III. The motion on "General Policy."-IV. The Third Internationale; more victories for the minoritaires. $-V$. A bourgeois Bloc against the Socialists.-VI. Future party regroupings, the decadence of the Radicals and the Action Liberale, the hope for three major parties. . . . . . .

\section{CHAPTER V \\ WOMAN SUFFRAGE AND THE "R. P."}

I. The movement for woman suffrage.-II. The Family Vote.-III. The demand for the scrutin de liste and proportional representation.-IV. Legislative efforts for the "R. P." $-V$. The Electoral Reform Bill of Juty 12, 1919-VI. Effect of electoral reform on French parties.

\section{CHAPTER VI \\ THE 1919 ELECTIONS}

I. The Peace Treaty, the first issue.-II. Two party conventions.-III. The formation and the program of the National Bloc.-IV. The election campaign.V. Bourgeois opposition to the Bloc.-VI. The effect on the election law upon th: Bloc.-VII. The results of the elections.-VIII. The New Parliament.-IX. The Socialist Strassburg Congress . . . . .

\section{CHAPTER VII}

\section{THE DEMANI FOR A NEW CONSTITUTION}

I. The demand for a government hased upon the doctrine of the separation of powers.-II. The conflicts in the French Constitution of 1575 , a cause for present defects.-III. Theoretical objections to the proposed remedy.-IV. Historical objections to an independent executive in France.

\section{C'HAP'TER VIII}

SYNDI(ALISM: PROGRAM AND TACTICS

I. The difference between syndicalism and socialism; the r'onfédération Cićnérale du Tranail.-II. The Minimum 


\section{CONTENTS}

Demands of the C. G. T.--III. French wayes, the cost of living, strikes.-IV. The passage of the EightHour Day law.-V. A turbulent First of May.-VI. Some resignations and the Socialist withdrawal from the Chamber.-VII. The failure of the political strikes.

\section{CHAP'TER IX}

\section{THE PRESS AND THE CENSORSIIP}

I General characteristies of the French press.-II. The conservative press, L'Action Française, La Vieille France, Le Temps. - III. The liberal press, La Démocratie Nouvelle L'Eure. - IV. The Socialist press, L'Humanité, La France Libre, Le Populaire, Le Journal du Peuple, La Vague, Notre Voix.-V. The Censorship, its legal basis, functioning and repeal.

\section{CHAPTER X}

THE BUREAUCRACY AND STATE SOCIAI.ISM

I. The malfunctioning and extent of the bureaucracy.-II. -Government food control.-III. The eonsortium poliey.-IV. The prohibition of importations after the armistice. $-V$. The protests against, and the final repeal of this prohibition, July, 1919.-VI. General growth of and movement against State Socialisin.

\section{CHAPTER XI}

A GOVERNMENT BY INTERESTS AND EXPERTS

I. The reform of the bureaucracy by deeentralization of services.-II. Experts in French administration.III. Necessity of organization of functionaries; history and extent of their organization.-IV. Demand for professional government, a Parliament of Interests. -V. A demand based on syndical organization of industrial groups; extent of industrial organization in France.-VI. The defects of professional government. 340

\section{CHAPTER XII}

REGIONALISM

I. The extent and result of the centralization of loeal govxxi 


\section{CONTENTS}

erning activities.-II. The history of French centralization.-III. The movement for regionalism.-IV. Legislative efforts toward regionalism.-V. The objections to regionalism. . . . . . . . .

\section{CHAPTER XIII}

WHAT THE FRENCH PEACE TERMS MIGHT HAVE BEEN

I The universal demands for guarantees of security.-II. The devices of the Old Diplomacy: the disintegration of the German Empire, the annexation of the left bank of the Rhine, a Rhenish Republic, the annexation of the Saar.-III. The total disarmament of Germany and an inter-Allied alliance.-IV. The defects of the Old Diplomacy. $-V$. The substitute which the League of Nations theoretically offered. . . . . .

\section{CHAPTER XIV}

THE FRENCH CONCEPTION OF A LEAGUE OF NATIONS

I. The nominal acceptance of the League of Nations idea. -II. The French demand that the League assume the War Debt.--III. The French exclusion of Germany from the League; its effect; the demand for an international police force.-IV. The effect of the League, as created, upon the French territorial demands: a defeat and a compromise.-V. Dissatisfaction, partly caused by the character of the Lcague created. . . .

\section{CHAPTER XV}

WIAT FRANCE THOUGITT OF AMERICAN "IDEALISM"

I. Early enthusiasm for President Wilson.-II. Readjustment of personal estimates.-III. The reappraisal of American help.--IV. The attempt to divide the P'resident and American opinion.- $V$. The charge of im practicability of Ameriean idealism.-VI. The charge of its inconsistency.-VII. The Trench opinion of the Senate's action. 


\section{(ONTENTS'}

\section{APENIICES}

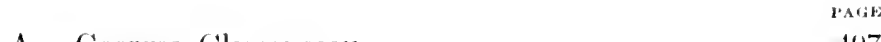

A. Cieorges Clemenceaul . . . . . . . . . 497

B. French Taxation during the War . . . . . 501

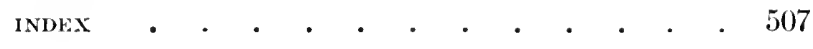





\section{INTRODUCTION}

One hundred and forty-two years ago the proud French Monarehy of the Old World came to the active military and naval assistance of thirteen obscure colonies that were struggling in the New World for their freedom and independence. One hundred and thirty-one years ago these eolonies put into effect the Constitution of the United States and set up the federal, republiean government under which they have since prospered and expanded and grown powerful; and in the same year was inaugurated in Franee the Great Revolution which, amid terrors and travail, was destined to uproot the hoary traditions and habitual abuses of the old Bourbon monarehy and to plant in European soil the fructifying seeds of modern and contemporary France. No wonder that for more than a century a potent sympathy has existed between the French nation and the people of the United States.

Sinee the schism of the English-speaking peoples in the eighteenth century, the development of the United States has been, in certain respects, more akin to that of France than to that of England. Present-day France is a country of farmers and business men and laborers, quite devoid of a privileged, land-owning nobility and of a state-supported eeclesiastical establishment ; she is a country without a king, a country in which republican institutions and thoroughly democratic practices and the spirit of soeial equality have taken firm root, a country which has repeatedly been stirred by sincere altruism and lofty idealism. What truer description could be given of outstanding national traits of us Americans?

Despite the community of major interests and ideals, xxv 


\section{INTRODUCTION}

there are eertain obvious though minor differences between the United States and France. The latter, politi(ally speaking, is a highly eentralized state, while the former is a decentralized federation of autonomous commonwealths. Government in the United States is earried on alternately by two well-organized politieal parties, while in Franee the existence of multifarious and transitory political groups gives to French publie life an appearanee of the gravest and most alarming instability of governments and even of policies. Moreover, the French nation is as homogeneous and as long established as the American people are heterogeneous and recently come together, a eontrast which aecounts in part for the fact that patriotism has more often produced chauvinism among the former than among the latter, and likewise for the fact that the former have been more handicapped, perhaps more vietimized, than the latter by tradition and antique usage. Certainly the problems of the appropriate relations between Chureh and State have harassed Americans less than Frenehmen, and, on the whole their solution has been happier and more just in the United States than in Franee. Besides it should be noted that France is a relatively small country whose boundaries have always been exposed to attack by powerful neighbors, and that both in 1814-1815 and in 1871 her eapital eity was eaptured by military foes. To Americans, inhabiting the richest and widest portion of an isolated continent and never menaced by numerous or greedy neighbors, what has been represented by the French to be merely precautionary has too of ten appeared to be selfish and glaringly vindictive.

It is the façade of a temple that first arrests the eyeand a façade is not neeessarily the index of the beauties and familiarities of the temple's interior. If the average American, bofore the late war, eould have pressed past the obvious external strangeness of France and gotten into the mind and soul of the French people, he would xxyi 


\section{INTROI)UCTION}

have found much the same temple as he had reared at home and much the same sort of worship as he himself paid, abbeit in a different language and with some variations in detail, to the spirit of liberty and equality and human brotherhood. But before the war, the average Ameriean stopped short at the facade: he was alienated by the strange language and deceived by writers and eritics who unsympathetically stressed what was peculiar to the French rather than what was common to French and Americans; his traditional morality was shocked by the "realism" in French literature and art-the "realism" that was typically unrevealing of the truest and deepest aspirations of the French people; and he eame to believe, while he continued to do sentimental homage to the land of a Lafayette and a Rochambeau, that contemporary Frenehmen were degenerate deseendants of illustrious sires.

The Great War has given us a new perspective. "Degenerate" people could not fight as unflinchingly and as heroically as did the French during the past five years. To put if mildy, France and the French people surprised and astonished us Americans. And on the other hand, the United States availed herself of a supreme opportunity to repay with interest the debt she owed Franee sinee the days of 76 . At Montdidier, at Châtean-Thierry, in the Belleau Woods. at St. Mihiel, in the Argonne, and on the Somme, was eonseerated anew the Franco-American entente.

That the newer perspective may not be lost, that the reeently hallowed entente may not be destroyed, is a hope which will be realized only if on both sides of the Atlantic there is a systematic and sympathetic interpretation of one people to the other. Vague rhetorieal sentimentalizing will not suffice. There must be somnd study and moderstanding; there must be adequate and unprejudiend presentation of all phases of national life -polifiral, social, eronomic and coltural. 


\section{INTRODUCTION}

Among the hundreds of thousands of young Amerieans who journeyed to France in 1917-1918 as modern knights and crusaders in the cause of demoeraey and international solidarity were a goodly number who pondered the meaning of the Great War and who in their camps or on furloughs or even in the trenches studied France and the French people freshly and at close range and without the prejudice of bookish professors or pedantic publicists. To the goodly number belongs the author of this book, Mr. Raymond L. Buell.

Mr. Buell utilized to the full his military experience in France. With amazing insight and perseverance he collected first-hand a vast amount of reliable information concerning contemporary French polities-the conditions which have shaped them, and the direction toward which they tend. And with no little skill and literary ability has he incorporated his information in this volume. If one wishes to know about the political groups in France, about the French parliamentary system, about the last elections, about the most recent phases of French socialism and syndicalism, about current agitations for woman suffrage, for constitutional amendment, for proportional and professional representation, one will read this book. Furthermore, if one desires to obtain an idea of what the bulk of the French people themselves think of the Peace Treaty, of the League of Nations, of President Wilson, and of American idealism in general, one will do well to study this volume. The volume is interesting, but it is neither dogmatie nor sentimental. It deseribes and analyzes; it never flatters or scolds. In its tone as well as in its content, it ocrupies a unique position among Ameriean commentaries on political France; it forms a vital contribution to a sound and lasting accord between the first Repullie of the Old World and the first Republic of the New.

Carlton J. II. IIayes 


\section{CONTEMPORARY FRENCH POLITICS}


La politique, c'est notre sang, notre argent, notre honneur.

- Le duc d'Audiffret Pasquier 


\section{CONTEMPORARY FRENCH POLITICS}

\section{CHAP'TER I}

PARTY PIILOSOPHIES

Pour rester unis, le véritable moyen est de rester distincts. JULES FERRY.

The system of party government in Franee, if indeed it ean be characterized by such a term, is perhaps the most interesting and baftling feature of Freneh political organization. Semi-organized, sporadie, over-numerous, these parties follow out an uneertain existenee, each drawing its support from a devoted following. Their charaeteristic of multiplieity is usually attributed to the French type of mind which is unwilling to eompromise and assoeiate differing shades of thought. The greatest diversity of opinion exists upon every political subjeet; and each element feels that it must seek representation in a "group," which, despite its fluctuating and dissolving eomposition, eontimually puts forward its candidates upon a eomplete program and doctrine. An undiseiplined independence of politieal beliefs is thus one of the eauses 0 e the multiplicity of French partiesan independence whieh does not allow Frenehmen to be 


\section{CONTEMIPORARY FRENCH POLITIC̣S}

bound by caucuses, and at the same time precludes political opportunism.

This individualism a French author accounts for in these words:

It is said that Frenchmen are rebels to association. That is true. Unfortunately in our divisions and in our quarrels our chief desire is not to do as our neighbors. You say White, I say Black; you go to the Left, I go to the Right. Is not this our temperament? At all times we are seeking to find the things which separate us, rather than a common ground. We form a party, we divide ourselves into factions which fight each other and detest each other reciprocally. We are united before an immense peril, but only when necessity constrains us... .

Cireumstances have aggravated this natural defect. At the head of these, we may place, first, the existence of a government ordinarily without authority; secondly, our resistance to all sanction-our unacknowledged quest for a "comfortable" life where every one may take his ease and do only what pleases him; thirdly, our false pride of equality which in reality makes us hostile to superiority and to talent. Finally, there is the insufficiency of our moral education which develops a sentiment of personal dignity and aspirations for independence without giving as a counterbalance, the spirit of sacrifice and of subnission to anthority. It is very well to drive superstitution from our sehools and to abolish old ideas which do not accord with progress, but nothing can be gained by suppressing even these if they are not replaced by some equivalent. If the principle of authority or of subordination of all to the common good is no longer understood as it was fomerly, its value is not less apparent. In the spirit of our fresent institutions, obedienee is voluntary; nevertheless, it must be obtained or we will play into the hands of the reactionaries who lie in wait for us.

${ }^{1}$ Lysis, Iers la Démocratie Nouvelle 144. 


\section{PAR'TY PHILOSOPHIES}

Pointing out the motives which inspire French voters, another writer adds:

It eamnot be denied that the clearly individualistic and independent spirit of the Frenchman adapts itself with diffienlty to the rigorous discipline of British parties. And in fact, by observing the results of an election, it will be noted that at present a deputy who is elected does not often obtain the entire number of the rotes of lis political sympathizers. On the contrary, he reeives rotes of electors who, although not supporting his ideas, nevertheless give him their votes from considerations bearing upon his person, his family, his situation, his past, and the services which he has rendered... . They rote for an individual and not for an idea or a program. If this were general, it would make any party régime impossible..$^{2}$

'Léon Jaeques, Les Partis Politiques sous la III République, 451.

One of the best deseriptions of the temperament of the French people was portrayed by Alexis de Toequeville many years ago:

"When I examine that nation in itself, I eannot help thinking it is more extraordinary than any of the events of its history. Did there ever appear on the earth another nation so fertile in contrasts, so extreme in its acts-more under the dominion of feeling, less ruled by principle; always better or worse than was antieipated-now below the level of humanity, now far above; a people so unchangeable in its leading features that it may be recognized by portraits drawn two or three thousand years ago, and yet so fiekle in its daily opinions and tastes that it becomes at last a mystery to itself, and is as much astonished as strangers at the sight of what it has done; naturally fond of home and routine, yet, once driven forth and foreed to adopt new enstoms, realy to earry prineiples to any lengths and to dare anything; indocile by disposition, but better pleased with the arbitrary and even violent rule of a sovereign than with a free and regular government uniler its ehief eitizens; now fixel in hostility to subjection of any kind, now so passionately wedled to servitude that nations maile to serve cannot vie with it; led by a thread so long as no worl of resistance is spoken, wholly ungovernable when the standard of revolt has been raised-thus always deeeiving its masters, who fear it too much or too little; never so freo that it cannot be subjugated, nor so kejt lown that it eannot break the yoke; qualified for every pursuit, but exeelling in nothing but war; moro prone to worship ehance, force, suceess, éclat, noise, than real glory; endowed with more heroism than 


\section{CONTEMPORARY FRENCH POLITICS}

This Freneh attitude is not wholly a weakness for, although a lack of party diseipline may be a civic defect, one of its ehief eauses-the vigor of political thoughtis a virtue. Theoretically a party régime necessitates a minimum of political issues, or at least their reduetion to two broad eategories, eaeh one of whieh some party supports. But as a matter of fact, the complexity of modern politieal life, when aceompanied by a keen interest in its problems, makes this simplifieation almost impossible. Furthermore, as noted above, the Frenchman in his attitude toward politieal issues does not seek a solution of each limited in itself; but he molds these immediate issues into a larger philosophy, be it political, religious, or eeonomie. IIe is not content with the solution of single and isolated problems. He will only be satisfied by working for. the eomplete attainment of his ideal. It is upon this ideal that his party rests. Party programs are really unchanging doctrines-expounding philosophies which more than fill the theoretical omissions of the Constitution of 1875. Upon immediate issues they are often vague, but their real purpose, at least, attempts to be logieally homogeneous.

Among other factors which aeeount for party diversity

virtue, more genius than common sense; better adapted for the conception of grand designs than the accomplishment of great enterprises; the most brilliant and the most dangerous nation of Europe, and the one that is surest to inspire admiration, hatred, terror, or pity, but never indilierence?"

De Toequeville, The Old hégime and the Revolution (translation by .Joln Bonner) $253,254$.

Guy de Maupassant's eharacterization of the French people is of equal interest. (see his short story The Horla):

"The populace is an imbecile flock of sheep, now stupidly patient, and now in ferocious revolt. Say to it: 'Amuse yourself,' and it amuses itself. Say to it: 'Go aml fight with your neighbor,' and it goes and fights. Say to it: 'Vote for the Emperor, and it votes for the Emperor, and then say to it: 'Voto for the Republic,' and it votes for the Republic."' 


\section{PARTY PIILOSOPIIIES}

and which are perhaps even more tangible than this tendeney of mind just noted, are eertain historical issues, peeuliar to France. These have been either long since solved or else never arose in other eountries possessing a similar form of govermment. The Monarchy presents the first of these issues. France has not had to ehoose merely between the Monarchy and the Republic, but between three different sorts of Monarchy and the Republie. These divisions were illustrated in the National Assembly of 1871-1875 where the Legitimist party, led by the Count of Chambord and supported by the more reactionary landlords, officers, and churehmen, stood for the unrestricted restoration of the Bourbons to the throne. They wished to govern the eountry "absolutely" and under the drapeau blanc. The seeond division was formed by the Bonapartist party, or the Imperialists; under the leadership of P'rince Jerome and Roulher, they endeavored to restore Napoleon III, who had sought refuge in England. Ilis sole claim to the throne rested on "the will of the people." The death of the ex-emperor in 1873 upset the immediate plans of the Bonapartists; but under the leadership of the Enpress Eugenie, they placed their hopes in her son, the Prince Imperial. ${ }^{3}$ The third division, the Orleanist party, wished to restore the line of Lonis Philippe; they were loud in their promises to goveru eonstitutionally and liberally. The Count of Paris was the eandidate of this party for the throne. ${ }^{4}$

Aside from the Monarehist issue, Cleriealism has

- The Prince Imperial, son of Napoleon III, joined the British expedition to Zululand, in 1879 , where he met his death (.Tune 1).

- The history of the struggle of these factions may he found in lletail in G. Ilanotaux, (ontemporary Fronee, ii. Jaeques, op. cit., $90-169$, also gives a good summary of the Assembly period. 
eaused party divisions. In the period following the War of 1870 , and for some fifteen or twenty years thereafter, the Catholie eause was completely associated with that of the Monarehy. The Count of Chambord declared himself in favor of the restoration of the Pope's temporal power. Since then, the Catholic interests have been openly espoused by the Orleanists. But the Republie ereated a division. Its establishment on a firm basis, despite Catholic and monarehial opposition, finally led Leo XIII, a skilled politician as well as a learned priest, to issue the famous Eneyclical letter, "Inter innumeras sollicitudines" (tenth of February, 1892). It besought Catholics not to judge the Republie by the irreligious character of its government, and explained that a distinction must be drawn between the form of the government, whieh should be aeeepted, and its laws, which should be improved.5 The policy enunciated in this letter, known as Ralliement, gave rise to a Catholie party, known as the Conservateurs Rallics, which pledged its support to the Republie. ${ }^{6}$ This policy was

- The early Catholic attitude toward the Thiri Republic and demoeracy in general, was illustrated by the following words of M. do Mun, one of the founders of the Liberal Action party:

"Tho Revolution is neither an act nor a faet, it is a politieal doctrine, which pretends to found society upon the will of man instead of founding it upon the will of Gorl, which places tho sovereignty of human reason in place of divine law. This is the Revolution, the rest is nothing, or rather all the rest results from it, from this proul revolt from whence the modern State has emerged, the State which has taken the place of all, the State which has heeome your God and which we (tho Catholies) refuse to alore with you. The eounter-revolution is the contrary principle; it is tho loetrine which makes soeiety rest upon Christian law! . . " From a speech in the Chamber of Ileputies, November, 1878, quoted in lebillour, hapports de l'Eglise et de l'Etut cn France de $178: 9-1870$, 6i3:3.

"A good account of the origrin of the "Rallies" will ho found in tho ratholis Enryelopedia, vi, 177, mmler "lrance." On May 6, 1692, leo Xill wrote to the French carlinals: 


\section{PARTY PHILOSOIMIES}

also later expressed in the movements represented by the parties of the Action Liberale I'opulaire, the sillon, and the Jeune R'publique. But the Monarehist Catholies vigorously protested against any policy of concession, asserting that the Republic and the Church were organically antagonistic. ${ }^{7}$

A third cause for party division has been Socialism, which had its birth in France and received its political baptism in 1848. Suceeding years gave rise to two differing tentencies in this doctrine: the tendeney of Reform versus the tendeney of Revolution. The latter, of Marxian origin, has largely controlled the Freneh Soeialist party; but the first, which is directed toward participation in bourgeois governments and the improvement of bourgeois soeicty, has led to the ereation of an independent Soeialist party. Both tendencies have at one time or another given rise to half a dozen Soeialist party divisions.

Finally, the supporters of the Republie have divided themselves into first, the Conservatives, headed originally by Thiers, and standing for a conservative Republie in which the people would have little participation; second, the Liberals or Radicals, at first headed by Gambetta, then by Clemenceau, and standing for popular government and collective reforms. Both of these divisions

"Accept the Republie, that is to say, the power now constituted and existing among you,-respect it. As representing the power coming from God, submit to it."

E. Zévort, Histoire de la Troisic̀me République, iv, 171.

"For the Monarchist view upon the "Ralliés", see Charles Maurras La Politique religieuse, 345. Many writers, aside from the Monarchists, question the suecess of the policy of ralliement. M. J'aul Sabatier silys, "The policy of Leo XIII, far from bringing about a reconciliation between the (hureh and Demoeracy, had quite the opposite result. It malde their incompatibility more conspicuous." Disestablishment in France, 60. 


\section{CONTEMPORARY FRENCH POLITICS}

have been united in the defense of the Republie against the Monarchists; but they have differed widely concerning the conception of the character of Republicanism and the powers to be given to its government.

These tendencies have been very potent in French party history. They are based upon differences whieh camnot be charged merely to fickleness of mind or to a frivolous resistance to authority. They have formed very natural bases for party divisions, and it is difficult to see how, under similar circumstances, even England or the United States could have avoided party multiplicity.

\section{II}

The history of modern party organization begins about 1900. In 1898 a "Comité d'Action Française" announced the birth of the "Ligue de la Patrie Française." Becoming more mature in its program, it proclaimed its Rovalist (Orleanist) aspirations in 1905 under the changed title of the "Ligue d'Action Française." In 1899 a group was formed in the Chamber of Deputies under the name of the "Action Libérale Populaire." In 1901 the Republican Radical and Radical Socialist party was founded. In 1902 the Democratic Republican Alliance was likewise created. In the same year, the sillon announced itself. In 1905 the Socialist groups hecame united and took the name of the "French Section of the International Workingmen's Association.' Soon after, in 1906, the moderate Republicans orcanized the Republican Federation. Finally, in July, 1911, the Socialists who had refused to adhere to the part of Amsterdam of 190t, formed the Republi"an Sorialist party, which during the war took the name of the National Socialist party. In the same year, 


\section{PARTY PIIILSOIIILS'}

1911, the Democratic Republivan Alliance changed itself into the Democratie Republean party.

Dividing the parties according to their doctrines and aecording to the manner in which they sit in P'arlianent ${ }^{8}$ they may be classified as the lifight, composed of: the Monarehists, in turn divided into (a) the Orleanists, (b) the Bonapartists; (2) the Nationalists, including the so-called plébiscitaires and conservatives, differing little from the Monarchists; (3) the Liberal Action party or Catholic Republicans; the Center, composed of (1) the Moderate or Progressist Republicans, whose party is the Republiean Federation; (2) the Republican Democratic party or Alliance; the Left, composed of (1) the Radieal Socialist party ; (2) the Republican Socialist party; (3) the Unified Socialist party.

Of these parties, at least seven are strong enough to warrant a discussion of their doctrines, organization, and strength.

Two of the three aspirants to the French throne have been virtually eliminated from among the Royalists. The death of the Count of Clambord in 1883 left no heir to the Legitimist or elder Bourbon line, and the suceession passed to the Count of Paris, the grandson of Louis Philippe, of the younger Bourbon or Orleanist line. Although the Emperor, Napoleon I, has no direct male descendants living, the line established by his brother Jerome, is now represented by Prince Victor Napoleon, the acknowledged eandidate of the Bonapartists for the French throne. Before the war he found refuge in Brussels, where he married the third daugh-

${ }^{8}$ To avoid confusion, it must be stated that this elassification is not by parliamentary groups, but by outside party organizations. Thus the Right contains only two groups, but three or four parties. 
ter of Leopold I, the former king of Belgium. As he was born in 1862, age will soon eliminate his suitability for the throne, while his only direct descendants are a daughter born in 1912 and a son born in 1914 - the latter are rather unpromising candidates for the suceession. ${ }^{9}$

Vietor Napoleon is a son of Prince Napoleon (Napoleon-Joseph-Charles-Paul Bonaparte). The latter was the son of the ex-King Jerome, and was known for the part he played in the movement for Italian unity. $\mathrm{Na}$ poleon III is said to have urged a plan of Italian confederation as opposed to Cavour's plan of a united Italy, in order to give the Prince the throne of one of the minor states, probably of Tuscany. The marriage of the Prince (who was a eousin of Napoleon III) with the daughter of Vietor Emmanuel II, king of Sardinia, sealed the Franeo-Piedmontese alliance in the war against Austria for Italian unity. From this union two ehildren were born, Vietor and Louis. The Prinee was expelled from French territory in 1872 by order of Thiers. He was never popular even among Bonapartists, although he attempted to assume the leadership of the Bonapartist party. The ex-Empress Eugénie was bitterly opposed to him for fear he would usurp the rights of her son who was born in 1856. The majority of the party supported Victor, the Prince's son, as the Bonapartist pretender, even while the Prince was alive.

In 1911, the Bonapartists, through a Comité politique plébiscitaire, published a program ealling for a Bonapartist Republic. 'They also took a small part in the eleetions of 1914. A majority of the Independent group

- The Baroness Adolphe de Rothschild is reported to have described Victor Napoleon as "an eaglet whose whole life is spent in molting." E. A. Vizetelly, Republican France, 185. 


\section{PARTY PIILOSOIIIES}

in the Chamber of 1914 were Bonapartists, among them being some brilliant men, such as Fernand Engerand. In the elections of 1919, many Bonapartists appeared on the tickets of the Republican Bloc. Prince Murat was elected to the Chamber from the provinees.

L'Ordre Public, established in the winter of 1919, is strongly suspected of being a Bonapartist newspaper. But despite the distinguished men connected with the movement, the Bonapartists have ceased to figure among the Republic's disturbers.

The Monarehist movement in France, on aceount of the death of the Comnt of Chambord and of the feebleness of the Bonapartist heir and following, is now led by the Orleanists through the organization known as the Ligue d'Action Française. The Orleanist eandidate for the throne is the Duke of Orleans, Philippe VIII. IIe aequired this title and became chief of the Orleans house in 1894 at the death of his father, the Count of Paris. ${ }^{10}$ The Duke was born in England in 1869, was partly edueated in France, but was exiled shortly after the establishment of the Third Republic, by a law passed in 1886. In 1890 he made a great show of patriotism by entering France despite the decree of banishment against him, and presenting himself for the military service to which every French youth is subject. As a result, he was tried by the govermment and imprisoned for four months. After being freed, he went to America and risited the battlefields of the Civil War upon which his ancestors, his father and the Prince of Joinville, had fought. In 1905,1907 , and 1909 he undertook three voyages to the Aretic regions. Before the war he lived in Belgium.

${ }^{10}$ The Count of Paris was a grandson of Jonis Philippe. He wrote a six-volme history of the American Civil War and a work on the linglish trades unions. 


\section{CONTEMPORARY FRENCII POLITICS}

Upon its outbreak he tried to enlist in the French army, but M. Viviani, then President of the Council, refused the reqnest beeause of the law of banishment. IIe suggested, however, that the Duke apply for admittanee in the armies of the other Allies. A similar request addressed to the King of England, of Belgium, and to the Emperor of Russia, was also refused. Consequently the Duke of Orleans had no opportunity to show his military prowess, and, as his opponents feared, to establish a dangerous prestige.

Althongh the Orleanists deseribe their eandidate, the Prinee, as "an energetie and resolute man, of prompt spirit and sure judgment," 11 his enemies eall him "Philippe the Red Nosed," beeause of his fondness for strong liquors. Soeialists point to his marriage with Maria Dorothea Amelia ${ }^{12}$ the daughter of Arehduke Joseph, cousin of the former Emperor of Austria, as proof of the inconsisteney of the party's vaunted patriotism. Generally it is believed that the Prince has none of the outstanding qualities necessary in a man who eould overcome the present régime by personal foree.

The philosophieal justifieation of the Royalist position is set forth in a very talented book by Georges Valois, L'IIomme qui vient. MI. Valois attributes the pernicious theories of the Revolution to "the three great eriminals, the three great impostors, Fathers of Lies, who have turned our intelligence, at the end of the nineteenth eentury, against our welfare: Jean Jacques Rousseau, the false Man of Nature; Immanuel Kant, the false Man of Dnty; and Karl Marx, the false Man of Necessity." 13

"Almanach de l'Action Frangaise for 1919, 46.

${ }^{12}$ The Duke has no children. Upon his death the headship of the House of Orleans will pass to his brother, Ferdinand, Duke of Montpensier.

1: $\mathrm{I}$ 'llomme qui vient, preface, $\mathrm{x}$. 


\section{PARTY PIIILOSOHIIIES}

The doetrine of the Monarehy itself is completely embodied in the Enquête sur la Monarchie, a eompendinm of Monarchist opinion, edited by Charles Mamras, and eontaining interviews with the Duke of Orleans, and such men as Sully-Prudhomme, Paul Bourget, Jules Lemaître, Jaeques Bainville, INenri Bordeanx, and IIenri Vaugeois, all of whom expound some phase of the Monarehist program.

After first eondemning the Republiean régime as based on false principles and maintained by Jews, Masons, Protestants, and Métèques, ${ }^{14}$ a régime from which real Frenchmen are exeluded, it offers, as the one redemption of France, the kingship based on the following principles :

The monarehy must be traditional. . . . The monarchy must be hereditary ... the monarehy must be anti-parliamentarian ... in favor of a nominative, personal, and responsible govemment. . . The monarehy must be decentralized. ${ }^{15}$

Itolding high the principle of integral nationalism, the monarchists offer a program eontaining definite political and religious changes. When the kingship is established, Parliament will be supplanted by an assembly of professional interests of practically no political power. The framing of laws will be entrusted to a body of experts directed by the King. Politieal parties will have no reason to exist, and the King will direct every national affair. Decentralization of administration through regionalism ${ }^{16}$ will overeome the abuses of Republican administration.

"Hetique-n class of forpinners exploiting the government for their own ends.

${ }^{15}$ Enquete sur la Momarrhie, 182.

${ }^{16}$ See Chapter XII. 


\section{CONTEMPORARY FRENCH POLITICS}

The religious program of the Orleanists is frankly reactionary. It gives to the Catholie Chureh a "manifest privilege over other confessions" because of its historic and national rights. In the economic field, the hours of labor will be unrestricted for adults, any limitation being a "reflection on their dignity." Labor, however, will be protected from all disorders; and the King will organize both labor and capital into offsetting and collaborating bodies. Generally speaking the King will be absolute; in this respect the Orleanists have departed from their liberal and constitutionalist tendencies exhibited in the policies upheld in the National Assembly of 1871-1875.

The Royalist plans for the restoration of the Monarchy, set forth in the last chapter of the Enquête, are of interest: "The Monarehy must be set up just as all the govermments of the world have been established sinee the world has been the world : by force." ${ }_{17}$ Such a restoration would not be opposed by the country. " $\Lambda$ vigorous solution would not be unpopular. It would even be extremely popular. He who said: 'France loves the sword,' has uttered a great truth."

$\Lambda$ t the beginning of the war the Duke of Orleans urged his adlierents to support the national defense, and thronghout its course the French Royalists were the most vigorous defenders of the Fatherland. Although they have been charged with plotting to restore the king, they have never been aceused of pro-Germanism. In fact, latred of Germany is an essential element in their nationalism. By means of the vigorous campaigns of L'Action Frengarse, the official paper of the party, edited

\footnotetext{
${ }^{17}$ Enemite, 499.
} 


\section{PARTY PHILOSOI'IHES}

by Charles Maurras and Lém Dantet, many traitors and psemblotraitors have been exposed. ${ }^{\text {s. }}$

Although the Orleanists profess to distain ordinary parliamentary tactics, they possess a remarkably combplete organization. The Ligur, whose center is in Paris, has sections in most of the larger aities of the provinces. The yomuger Royalists are formed into the anxiliary organizations of the C'amelots du Rot and the Etudiants de l'Action Frangaise, while the Royalist women and girls are similarly gromped. Nembers of the League must sign a pledge ending in these words: "I assoeiate $m y$ self in the work of monarchieal restoration. I promise to serve it by every means." Each must pay minimum dues of three francs a year.

The intelleetual ativity of the League is not only earried on by the daily journal, L'Action Française, but by an Institute in which courses are given upon the problems which the monarehy will have to solve. In addition there is a Review, which likewise studies these problems (suspended during the war), an annual Almanae, and a publishing house, the Nouvelle Librairie Nationale, which issues books of Royalist sympathies.

The list of the adherents to this party is not published. Naturally it is not large, although they claim to have doubled their number dning the war. The old nobility, residing chiefly in Touraine and the Midi, is its rhief support.

There is little likelihood of the Restoration. The many admireses of Charles Maurras, the leader of the party, do not necessarily adopt his Royalist theories. It is his patriotism, seholarship, and vigor whide attract them. The party is not completely reartionary, as its decentral-

${ }^{18}$ see PP. $273,274,277$. 


\section{CONTEMPORARY FRENCII POLITICS}

ization and its labor platforms suggest. The incompatibility of its doetrines with modern tendeneies, was completely illustrated during the Peace Conference. But despite this, the French Royalist movement offers a unique and interesting feature of Freneh polities. The remote probability of their suceess permits a certain respect for Royalists by Republicans. Their sincerity, their love for La Patrie, and their unmistakable, if misdirected desire to serve and advance the land of their birth are traits which all parties might emulate.

Closely akin to the Royalists may be placed the Ligue des Patriotes, an organization purely nationalist in purpose. This League was founded in 1882; and, under the leadership of its first two presidents, IIenri Martin and Anatole de la Forge, it limited its aetivities to the urging of patriotie and military education. But after 1885, when Paul Déroulède became its head, it turned into in active, jingoist organization, which urged the return to France of all territory hitherto forcibly taken from it-especially Alsace and Lorraine. It strove to awaken the idea of La. Revanche, by preaching against the dissipation of national effort in colonial enterprise. In 1889 the Leagne was suppressed for its support of General Boulanger, but it was soon afterward reëstablished. During the Dreyfus affair, Déroulède attempted another sensational overthrow of the Republic, but failed. ${ }^{19}$ The League, with which the so-called plibiscitaires are asso(riated in sympathy, is supposed to stand for a Republic headed by an executive of dictatorial powers. Maurice liarrès, the present head of the League, is accused by

\footnotetext{
"Sce Maurice Barrès, Scènes et Doetrines du Nationalisme, v, La Part de Déroulède.

For the dissolution of the Ligue des Patriotes, see E. Zévort, II istoire de la Troisième Républizuc, iv, 79.
} 


\section{PARTY PIIILOSOPIIIES}

the Royalists of not having the eourage of his predeeessors, while the Socialists genuinely hate him. He is partieularly ridieuled by Léon Werth in Clavel Soldat, a novel suppressed during the war. In this book M. Barrès was represented as arising every morning to stretch his arms, and saying: "I am Joan of Are; I am Napoleon." In another place, Clavel is sent with the army to Alsaee-Lorraine, where he supposes he will find M. Barrès, gun in hand, at the erossroads to meet him, but to his well-feigned surprise, M. Barrès is nowhere to be found! As the Socialist press pointed out, his field of action lay in a Paris offiee, far from the battle-line! MI. Barrès is naturally a strong Catholic as the Chureh is an essential element in his doetrine of nationalism. But his relation to the Church appears to be merely political, for, so far as his religion goes, he seems to be much more pantheist than Christian. For instance:

The thoughts of our remote ancestors always exercise their mysterious and powerful influenees on our lives. The people of the fairies and the spirits who lived in the waters, the wood and the eaves, have disappeared, but in dying, they have bequeathed to the plaees which they loved, titles of veneration. They still guard our race with the tears of their friendship or of their terror. The centuries but little consider those who in the solitude listen to their own eonscienees and receive from them profomd murmurs and the source of their being,- - dispossessed Gods.

Fantastie woods, sweet fairies of the meadows and springs, inysterious emanations of the trees! The night wind which passes aeross the eopses! Oh, fragmentary sentiments!... Nature for me is filled with the essence of Gods half wasted! ... These vanquished hosts sleep at the bottom of the lakes and in the valleys under dead leares..., waiting for the people of France to awaken to their beanties. ${ }^{20}$

"From the "Grande Pitié des Eglises de France," quoted in Le Hercure de France, November-December, 1916. 


\section{CONTEMPORARY FRENCII POLITICS}

It is in this literary style that M. Barrès urges France to rally round la terre et les morts, the only substitute for the kingship as a guardian of national permanency.

Apart from its insistence on the French annexation of the left bank of the Rline and on the "Family Vote," the League, mder his direction, takes little part in polities. It has buried the body of Déroulede in Alsace as a fitting tribute to his passionate struggle for the recovery of the lost provinces; and likewise, since the war it has published a beautifully illustrated work commemorating their restoration to France.

\section{III}

The Liberal Action party (the Action Libérale Populaire) is another organized party of the Right. It was founded in 1902 and until lately directed by MMI. Piou and Mun, for the purpose of defending and securing "all the freedom essential to the life of the nation, particularly religious liberty, which is of a superior order and which to-day suffers the greatest injury." 21 In as much as it is an offspring of the "Rallies," a religious issue naturally constitutes its principal basis. Firm in its devotion to the Republie, it insists upon freeing the Catholie Church from the antielerical legislation passed sinee 1901.22 Nevertheless it is opposed to a distinctively Catholic party in which issues of cult would be the only ones insisted upon and which would be suljeeted to the direction of ecclesiastical anthorities. The party is intended for Catholies, but it must be open to all-

\footnotetext{
"Jacques, op. cit., 321.

It seems, however, that the antielerieal legislation las strengthened the Church's position instead of weakened it.
} 


\section{PARTY PIHLOSOPHILS}

even those who, believing in religions freedom, are not Catholies.

In addition to this conception of religions liberty, the A. L. I'. wishes to inaugurate a society based upon Cluristian principles. Althongh standing for an advanced program of social reform, it asserts that "the increase of salaries will remain but a powerless palliative if the soul of the people is not saved from the yoke of materialist doctrines and does not find a divine irleal. . . . The Ten Commandments and the Gospel are the great factors in true soeial progress. . . . The solution of the soeial problem lies in Christianity.", 23

Politieally, the party program demands nine major reforms: A Declaration of Rights, a Constitution, a Supreme Court, election of the President by a speeial electoral eollege, professional organization and representation, proportional representation, the referendum, ${ }^{24}$ provincial and municipal decentralization, and the granting of a definite status to government officials.

As a religious program, it declares that there ean be no possible legal organization of the Churel without a preliminary agreement with the Pope. It affirms the absolute right of the father and the mother of a family to form their ehild "in their own inage and resemblance, to educate him aecording to their views and eonvietions, and to have him share their ideals in this world and their eternal hopes in the one beyond. . . ', As $^{25}$ it is the first duty of Catholic parents to oversee the education of their ehildren, they must not be. eontaminated by lay education. Ideally they should be taught

\footnotetext{
23 Jaeques, op. cit., 331.

2" The Liberal Action party is one of the few to adroeate the popular review of any legislistive act.

${ }_{25}$. Jacques, op. cit., 326.
} 


\section{CONTEMPORARY FRENCH POLITICS}

Catholic doctrines in the public schools. But as this is impossible under an anticlerical government, in a country where there are many different cults, the party advocates the proportional division of school funds, so as to enable each seet to establish its own schools to which the children of each would be sent and educated in the religious faith of their parents. From the duty of Catholie parents to send their children to Catholic sehools, arises the practice generally followed by them in France even now, although the proportional division of resources never has been, and is not likely to be, achieved. To carry out its theories of religious education, the party has ereated the Association of the Fathers of Families, which before the war eontained over 800 associations divided into seventeen federations.

The party's advoeacy of répartition proportionnelle of school funds, of représentation professionnelle, and of représentation proportionnelle, has won for itself the name of "The party of the Three $R$ 's."

In addition to the religious program of the party, it is characterized by its interest in the amelioration of labor conditions. Believing in the moderate intervention of the State in economic questions, it stands for the regulation of the hours of work, the establishment of a minimum wage for home work, labor eonciliation and arlitration, and professional and technical education. The party appeals to all elasses to assist the workingmen. Under its auspices, Catholic syndicates have been organized-the so-ealled "free" unions-which are independent of the General Confederation of Labor, and have been brought into friendly toueh with Catholic employers' organizations. ${ }^{26}$

\footnotetext{
${ }^{20}$ The Liberal Action party is one of the best organized in France. Along with a centril committee established at l'aris, a
} 


\section{PARTY PIILLOSOPIILS}

Before the war this party had nearly forty federations, over 2,005 committees or groups of adherents, and 265,000 members. It appears to have lost weight in suceessive elections, for in 1902 it had seventy-nine representatives in the Chamber of Deputies, sixty-four in 1906, and thirty-one in 1910. In 1914, however, its numbers rose to thirty-two, while in 1919 the party was suceessful in electing sixty-nine deputies.

In conclusion it may be said that the Action Liberale Populaire presents a very powerful organization with a very definite program. Both its demands for eonstitutional reform and for social betterment are practicable and meritorious. Although the party's idea of liberalism is perhaps warped by its Catholic prejudices, it is one of the few parties, beyond those of strietly elerical composition, which builds its platform upon a moral and religious foundation.

The Sillon, now disbanded, is another Catholic Republican group. Although it never claimed to be a party, it loyally attempted to reconeile a sincere attachment to the Republie with a love for Catholicism.

\footnotetext{
"Secrétariat général" exists, subdivided into sections. The party organization is composed of (1) the committees constituter or agreed to by this central committee; such as the auxiliary groups of the Jeunesse Liberale, the Jcunesse Catholinue, the Union of Free Workmen, and some unions of employers; (2) active members, paying a sum of one hundred dollars and an annual fee of at least five dollars; (3) assoeiate members paying an annual fee of at least one franc. Women nay belong to the party. The members are divided into communal, cantonal, and department committees. An effort is being marle to establish a central committee in every department as the head of all party activities in that district.

Every two years the party holds a general or national Congress at which discussions are held concerning " organization," "celectoral questions," and "soeial reform.", A weekly Bulletin is issued to its active members, a quarterly Bulletin and an almanac to its associate members.
} 


\section{CONTEMPORARY FRENCII POLITICS}

Its purpose was to bring about in France a "democratie, honest, just, and fraternal Republic." Like the Action Liberale, it insisted upon the fundamental importance of religious principles in society, and upon Christianity as "an ineomparable souree of demoeratic energy, since it identifies the individual and the general interest." 27 It advocated the organization and protection of both labor and capital and the extension of coöperative societies. Strangely enough it also stood for the development of communal property, which every laborer might in turn enjoy. It especially urged popular education as a means of spreading its doetrines. In 1909, however, the Sillon, whose advanced teachings angered eertain eonservative Catholies, was dissolved by order of the Pope. It was suceeeded by a group ealled the Jeune République, which especially urged the referendum, proportional representation, and a protected status for government officials. It existed for the propaganda of opinion rather than for the mere election of deputies, a characteristie, it may be added, of all leagues as opposed to parties.

\section{IV}

Turning now to the parties eomposing the Center, we first find the Moderate or "Progressist" Republieans organized under the title of the Republiean Federation. Since this was the most eonservative of all the Republican parties, it practically controlled the govermment during the first twenty years of the Republic under the direction of such men as Ferry, Ribot and Méline. In 1898, however, the Moderates began to lose power-some of its members athering to the "Ralliés;" while the Bloc,

${ }^{27}$ Jaeques, op. cit., 345. 


\section{PARTY PIILOSOPIIIES}

formed by Waldeck-Rousseau, uniting the Radicals, Radical Socialists, and Socialists, secured control of the Chamber. The recent organization of this party dates from the 18th of November, 1903, when a meeting was held at which the Republican Federation was organized. ${ }^{28}$ $\Lambda$ that time the National Republiean Association, which had been headed by M. Audiffret, the Liberal Republican Union, which had been headed by M. Barboux, and the Alliance of Progressist Republicans, which had been headed by Jules Méline, were fused into the Republican Federation. The Moderates vigorously opposed the government of M. Combes, and especially his anticlerical poliey. In 1906 the party underwent a reorganization and gained new members; and in 1910 it made a net gain of thirty seats in the Chamber, a sign which the party interpreted as indicating the return of the comntry to its program. In 1914 it practically maintained its parliamentary strength, polling about ten per cent of the votes cast $(1,810,679)$. Although the nmmber of adherents is not published, it is estimated to be between 7,000 and 8,000. The party's influence is mueh wider than its limited membership-a statement true of all Freneh parties.

The Moderate or Progressist Republican party is the most idealistic of the parties of the Republic. Strongly imbued with the prineiples of 1789 , it is founded on the prineiples of the dignity and worth of the individual ; consequently it is strongly against State Socialism, tolerant in religious matters, and liberal in its eeonomies. Three marked divisions may be found in its ranks: the Progressists proper, to whom stability and

${ }^{29}$ La Féderation Républicaine, December, 1919, the monthly Bulletin of the Republican Federation. 


\section{CONTEMPORARY FRENCH POLITICS}

immobility is the controlling doetrine; the moderates, who do not fear radicalism, and are willing to saerifice old doetrines to regain political power; and between these two, a conciliatory group, playing the part of juste milieu. Composed largely of the wealthy upper classes, the party is insistent upon the rights of private property ; it is vigorously opposed to state monopolies and to the socialization of the means of produetion. Its motto, "Progress by Order," and its watchword, "Conserve and Create," have indicated its parliamentary poliey. ${ }^{29}$

As to political reforms, the party desires a Bill of Rights, a Supreme Court (to decide the corstitutionality of laws) proportional representation and the scrutin de liste, ${ }^{30}$ the representation of interests in the Senate, and the enactment of stringent laws against fraud. It also asks for administrative deeentralization through an increase of the powers of departmental assemblies. As judicial measures, it asks for the reduction of arrondissement tribunals, for the simplification of procedure, and for the reduction of the expenses of justice. It also stands for publie assistanee to the old, the infirm, and the sick. ${ }^{31}$

${ }^{20}$ For letails of the Feleration's Program, see Compte Rendu du Congres, from 1906 to 1914, the reports of the Annual Conventions of the party.

Charles Benoist, French minister to Ilolland, Alexandre Ribot anł Jules Méline, two former prime ministers, are prominent members of this party.

${ }^{30}$ See $\left.\mathrm{P}\right)$. 1.52, 153.

"The organization of the party is known as the "Republican Felleration." It is administered by a general council of fifty members elected by itself. The conncil merely gives its advice, while a directing committee of twenty menbers proposes measures for tho consideration of a burean consisting of a president, six vice-presilents, a seeretary-general and a treasurer. In each arrondissiment or commune and lepartment, cither a committee, a foleration, or a union, directs the party activities. In some centers, such as Iyons and Toulouse, there are regional organizations. A 


\section{PAR'TY PIILOSOPIIIES}

In its electoral methods, the party is often willing to support candiclates of other parties professing similar doetrines, if its own have no chance of suceess. As long as the purely progressist element of the party is in control, its prospeets for eleetoral victories are slight; but under more advanced leadership, it would doubtless have a considerable following among the great class of "moderate" Frenchmen.

The "Democratie Republican Alliance" is the other great party of the parliamentary Center. It is not so conservative as the Progressists, and it is not radical. It amounces its platform as "Neither Reaction nor Revolution, Neither Imprudence nor Adventure." Its part has been to reconcile the conservatism and the radiealism of the Republic.

The Alliance was the first party after the war to announce a program of reeonstruction and reform. It denounced all attempts to stir up class antagonism as an invention of Teutonic imperialism, and it pleaded for the union of all parties in the task of reeonstruction. It emphasized the necessity for the creation of a great Republican party, "boldly reformist as well as firmly resolved to prevent the outbursts of revolutionary or reactionary violenee; this party must be strongly enough organized, numerous enough and powerful enough, to give stability and duration to the govermment which gains its support."' 32

national congress closing with a banquet is held annually. The Federation has the pledged support of nearly three hundred publicists and nearly eight hundred newspapers; consequently, it exercises considerable influence.

${ }^{23}$ From a brochuro distributed by the Alliance. 


\section{CONTEMPORARY FRENCII POLITICS}

It has advocated electoral and administrative reforms, the introduction of industrial methods in the pulblic services and decentralization; a law for the protection of government employees (including the prohibition of the right to strike); complete reparation by the State for the damages of the war; the early return to commereial liberty and the cessation of State control over industry ; the confederation of representatives of industry, commerce, and agriculture to consider the economic needs of the country; technical education; the conciliation of labor and capital; the development of social insurance; measures combating the "rural exodus"; measures destined to increase the birth rate and to curtail infant mortality and alcoholism; the financial seetion of a League of Nations, and the reform of the taxation system.

Finally, the Alliance stands for "any measure calculated to ensure for the country general prosperity, liberty, social justice, economic advancement, intellectual renaissance and moral grandeur.', 33

The party's strength is not exactly known, ${ }^{34}$ but it includes many of the most representative statesmen of the Republic. Among its honorary presidents have been

\footnotetext{
${ }^{23}$ Ibid.

Although the Alliance was founded as early as May, 1901, by Adolphe Carnot, it was not until 1911 that it first took a prominent and independent part in French polities. M. Carnot is still its president, holding his office for life. On account of his age he attempted to resign lately, but was reëlected. He is assisted by a secretary-general, an assistant secretary and a secretary of committees, surrounded by a superior eouncil composed of one delegate from each department, the whole forming a central executive committee. The eantons, arrondissements, and departments have their respective eommittees. A weekly bulletin is issued by the party while the local associations earry on, by means of eircles, linraries, and social organizations, an active campaign tending to develop civie edueation and communal life by every means.
} 


\section{PARTY PIIILOSOPIIIES}

Emile Loubet, former Presilent of the Republie, M. Waldeck-Rousseau, who founded the famous Bloc, and Joseph Mangin, one of France's prominent generals. Raymond Poincaré is vice-president of the organization. Paul Deschanel, the new President of the Republic, is also a member. In 1911 the Alliance had 140 Deputies in the Chamber-seventy-one belonging to the group of the Democratic Left, fifty to the Radical Left, and about fifteen to the Radical Soeialist Ieft. In the Senate it had eighty members inseribed in the group of the Republican Union. In the 1914 eleetions it polled the hirchest number of votes of any party, receiving 1,564 578. In the 1919 elections 133 of its members were elected to the Chamber.

\section{VI}

The principal party of the parliamentary Left and one of the most powerful in the Republic, is the "Republican Radical and Radical Socialist Party," often known as the "Unified Radicals," the "Radical Socialists," or plainly, the "Radieals." This party, rooted in the Jaeobin elubs of the Revolution and in the followers of Ledru-Rollin during the Revolution of 1848 , really came to light with the dawn of the Third Republic. About 1850 a group of advanced Radicals detached themselves from the "Repulblicans," and beeause of their bitter opposition to the conservatism of Thiers and even to the opportunism of Gambetta, they soon became known in contrast with the "Opportunists," as the "Intransigeants." 'They stood solidly and without eompromise for the absolute aclievement of Republican ideals. This group increased in 1885 and 1899 until it became a factor in the elections of the latter year. In 


\section{CONTEMPORARY FRENCH POLITICS}

1887 it fought for the suppression of the right of the Senate to authorize the President to dissolve the Chamber; from 1888 to 1898 it opposed the moderate Republicans, although uniting with them whenever the Republic was threatened. Thus many so-ealled concentration ministries contained many Radieal leaders-Floquet, Brisson, Goblet, Sarrien, and Rieard. Clemeneeau was one of the most destructive leaders of the group. His partieular delight was the defeat of ministries, and he became known as the "Ministry Smasher." He is said to have tried to defeat twenty-three of them and to have been successful in the case of eighteen.

In 1892 many Radieals beeame Radical Socialists, urging collective reforms and the general betterment of labor conditions. But in 1893 the group was successful enough to elect 120 members to the Chamber. Beside them were grouped the Radical Socialists, some of whose members, notably M. Millerand, were passing over to pure Socialism. The Radical Soeialists and the Soeialists in this Chamber had about sixty members. Upon a strongly anticlerical, an ineome tax, and soeial reform platform, the Radicals, combining forees with the Radical Socialists, and pure Socialists, were successful enough in 1895 to establish a completely Radical ministry, headed by M. Bourgeois. In 1901 the fusion of the Radieals, the Radieal Socialists, and the Socialists, was officially made. The adoption of the formula, "No enemies on the Left," led many Radieals, who were unwilling to associate with pure Socialists, to desert the party and adhere to the Democratic Alliance. But nevertheless the Radieal party gained power. ${ }^{35}$

\footnotetext{
${ }^{3}$ An interesting story is told of the initial success of the reorganizerl Radicals shortly after 1900 . There was a certain jeweler and his brother who were conducting a very suceessful business
} 


\section{PAR'TY PIILOSOPIIIES}

The Radieals assert that they are essentially a party of the middle class, the petite bourgeoisie, wishing to establish a united, fraternal and social Republic in which every eitizen will be rewarded upon a basis of his own labor and merit.

The party still adheres to the "Program of Naney" adopted in 1907, whieh eontains a eomplete outline of its political, eeonomie, and soeial reforms. Although annual "declarations" have subsequently interpreted or modified this program, it still remains the ereed of their political beliefs.

Politically, the party stands for the direct election of senators. Until 1919 it refused definitely to commit itself to proportional representation, although it has stood for the scrutin de liste. It also seeks eertain administrative reforms, the supremacy of the Chamber of

in Paris in a shop on the Boulevard de la Sébastopol. The firm grew to such an extent that its traveling salesmen carried the firm's jewelry into every part of France. At the time of the elections, the jewelers, through some sort of negotiation with tho Radieal ehiefs, turned over their salesmen to the party as propaganelist agents. They were so suecessful that the country returned an overwhelming majority for the Radicals and with it, the government. Tho Radieals, as a reward, promptly elected the jeweler to the Senate, an extraorlinary step for one who had not first served in the Chamber. The gentleman is still serving very prominently in that eapacity, and is very proud of his remark. able achievement.

From 1902 to 1906 , the Rarlical party formed, with the Socialists and the moderate Radicals of the Democratic Alliance, the Bloe of the Left; in 1906 they and the Socialists won an ag. gregate of 400 seats; in 1910 , excluding the Socialists, they had 334 seats. At the Congress of Pau in 1913 the party reorganized itself, deciding that all of its deputies must adhere to a strictly Radical gromp. Atter this, the party became known as the Unifed Radieals. The elections of 1914, partly beeause of the bitterness of their anticlerical policy, their pacifism, and this measure of reorganization to which many deputies refused to adhere, rellued their number to 257 members. In 1919 this number was still further redueed to 143 . 


\section{CONTEMPORARY FRENCH POLITICS}

Deputies over the Ministry and the Senate, and the reorganization of the Judiciary.

It was, however, the anticlerical platform of the party which brought it to power and still constitutes the sine qua non of its existence. Although the issue is practieally dead, the party is still pledged to the rigid maintenance of all anticlerical legislation, the suppression of illegally existing religious orders, and the exclusive control of education by the State.

In addition to anticlericalism, the party's support of collectivism is its principal characteristic. Although recognizing the value of private property and of individual initiative, it desires to eorrect the abuses of the present régime through the assumption by the State of every actually existing monopoly. The conclusions of M. Chauvin at the Congress of Dijon in 1908 still represent the party's position upon State control of industry:

1. Individual property, properly so called, arising from labor, and maintained by labor, we must conserve as sacred.

2. Individual property must give way to the general interest when the interest of the proprietor is found to be in manifest contradiction to the interest of society.

3. Finally, if for the creation or for the conservation of industrial property, where all the work and all the efforts of the proprietor have ceased to exist, and if this property is a monopoly in the possession of a single person, or if it is wealth entirely created by society or by others, this property, truly capitalistic, can and should be taken over by the State. ${ }^{36}$

These prineiples the Radicals have extended to include natural resources and industrial enterprises now dangerously centralized.

${ }^{30}$ Quoted by $\mathrm{A}$. Charpentier in Le Parti Radical et RadicalSocialiste à travers ses congrès, 445. 


\section{PAR'TY PIIIUOSOPHISS}

Socially, the party "attempts to give to the proletariat the full consciousness of its rights and duties, and, with the responsibility for its action, the authority necessary to establish a more rational and just social constitution." 37 It is ready to take every legal measure to guarantee to each the product of his toil and to prevent capitalistic domination of the consumer. "Resolutely hostile to the egotistical conceptions of the school of laissez faire," the party favors State intervention in the relations of capital and labor. It promises assistance to needy children, the sick, the infirm, and the old. It promises a pension to workers overeome by work or age. It has demanded the enactment of a labor code embracing laws (1) upon the employment of women and children in industry, (2) upon labor and apprenticeship contracts, (3) upon the regulation of differences between labor and capital by compulsory arbitration, (4) upon labor accidents, the risks and diseases of industry, and the responsibility of employers, (5) upon the limitation of hours of labor and a weekly rest, (6) upon the organization of government insurance in favor of every worker in industry, commerce, and agriculture against the riskis of accidents, sickness, and unemployment, (7) upon mutual insurance and savings funds to improve the condition of labor, (8) upon conditions of health and hygiene in industrial and commercial establishments.

Financially the party has stood for the income tax and the suppression of the "four direct contributions"; it is also against consumption taxes, stamp and registry fees, and taxes weighing on agriculture, commerce, and small industry.

\footnotetext{
${ }^{37}$ I'rogram of Nancy, a brochure distributel at farty head. quarters.
} 


\section{CONTEMPORARY FRENCII POLITICS}

As an agrarian program, it urges the development of agricultural education, coöperative associations, agrieultural eredit, and insurance against fire, hail, frost, and the death of eattle. ${ }^{38}$

Many prominent men are associated with the Radieals-among them being MII. Clemencean; Caillaux, now in disrepute; Combes and Herriot, two prominent Senators; René Renoult, former president of the Exeeutive Committee of the party and president of the Army Commission of the Chamber; Franklin Boullon, former head of the Foreign Affairs Commission; and Senator Léon Bourgeois, president of the Senate and a representative on the French Peace Delegation. ${ }^{39}$

${ }^{34}$ On July 26, 1919, a petit congris of the Radical party was held in Paris where a reconstruction program was drawn up. It contained little in allition to previous platforms exeept to urge more vigorous measures against speculators, modification of the income tax so as to exempt small salaries, and the abolition of the three-year military service law and gradual disarmament in view of the League of $\mathrm{Nations}$.

${ }^{39}$ The organization of the Radical party is very coherent. It is based on the communal committee, upon which repose arrondissement, eanton, department, amd regional federations. The arrondissement and dopartment committees are the most active. A central Executive Committee with offices in Paris directs all party activities. The members of the party in each locality form its committee. In each department, lelegates of these committees meet at least onee a year and choose department delegates to the Annual Congress. Since 1909 the Executive Committee has been eomposed of (1) all of the deputies and senators, actherents of the party, members by right; (2) delegates elected at the Congress by the department delegates. Before the war the Executive Committe contained over six lumdred members. From its own members, it eleets a president, sixteen viee-presidents (eight of whom must bo members of P'arliament), sixteen secretaries (eight of whom also must be members of Parliament), an administrative secretary-general and a treasurer, - a total of thirty-five. The president is not immediately eligible for reidection, and this lurean is renewed, one half each your. 'This committce is subdivided in turn into committeres on rules and discipline, finance, preparation for Congresses, propaganda, and party organization. Tho burean is divided into five permanent committees: party administration, elections, propagamla, bulletin, and demands. 


\section{VII}

Following the parliamentary groupings toward the Left we find the Socialist representatives, divided into the Republican Socialists and the Unified Socialists. This division is the result of events which must be briefly summarized.

The earlier groupings of the French Socialists after the banishments following the Commure, oceurred at the Congress of the French Workingman's party held in 1874. Several years later the organization then formed broke up into two groups: the Marxist group, reeruited in the North, and led by Jules Guesde, and the French Federation of Socialist Workingmen. This latter organization was of reformist tendencies and eonsequently became known as the "Possibilists." It was led by Paul Brousse. In 1890 this Federation of Socialist Workingmen split into two branches, the eause being a question of eentralization of party organization. The revolutionary element beeame known as the "Allemanists," from the name of their leader, Allemane. The other section eontinued under the leadership of Brousse. Under the guidanee of Guesde and Allemane, most of the divisions of the Socialist party supported Marx's advoeacy of the Soeial Revolution in eontrast with the purely Freneh idea of progressive reform. At this time a fourth seetion of the Socialist following, that led by Blanqui, ${ }^{40}$

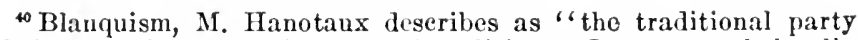
of insurretion, conspiracy, and sedition. It possessed haraly any other political coneeption exeept that of opposition to the last breath, by all means, to all governments. It was integral, republican, leveling, the adversary of social order, but neither communist, separatist, nor socialist: in fact, anarchist." Contemporary France, i, 161. 


\section{CONTEMPORARY FRENCH POLITICS}

constituted about a quarter of their fores. In the Chamber of Deputies there were also attempts to form a Labor party. Thus at least five Socialist organizations, many of them antagonistic to each other, eame into existence, each struggling for the labor vote. In addition to them, a strong group of men unassociated with parties but having eollectivist doetrines, are to be noted: Millerand, Viviani, and André Lefèvre. In view of the elections of 1893 reformist elements among the Socialists and some discontented Radicals united in a "League of Revolutionary Aetion for the Inauguration of the Social Republic." This coalition was successful in eleeting fifty-five Radieal Socialists, who took their seats in the Chamber at the extreme Left. Twenty-five Socialists were elected, more than half of them coming from the department of the Seine.41

In 1899 an effort was made to unify further the different factions, and a general Socialist committce was organized to effect a union. This combination was praetically achieved when an incident arose which resulted in the withdrawal of the Guesde following. This was the noted "Millerand Case." M. Millerand had been appointed Minister of Commerec in the Waldeck-Rous-. seau Ministry in 1899, but as he was affiliated with the Socialist party, Guesde and Sembat insisted that it was contrary to the tearhings of Karl Marx for a Soeialist to collaborate in any way with a bourgeois government. In opposition to these out-and-out revolutionists, however, another group within the party, men of a reformist tendency, content with a policy of improving present socicty, men such as Aristide Briand, René Viviani, Paul Brousse, and Jean .Jaurès, asserted Millerand's right to

"1. Seo I'. F'. Desmartres, “La Frence Politique à la Veille des Serutins;"' Europe Nouvelle, Mareh 22, 1919. 


\section{PARTY PHILOSOHIIISS}

be assoeiated with the government. In a party congress held at Paris in 1899 ministerial participation was consented to by a vote of 818 to 6.34 ; but the International Congress held in Paris, in 1900, virtually resulted in a negation of this decision by adopting a motion (offered by Jules Guesde) to the effect that this was only to be eonsidered a measure of expediency caused by exceptional conditions. At Bordeanx in 1903 Millerand was again justified by a party declaration for remaining a member of the Cabinet, but was censured for not following party principles in his ministerial policy. ${ }^{12}$ The unwillinguess of the party to expel Millerand led Guesde to withdraw, and, joining the Blanquists in 1901, he formed the P'arti Socialiste de F'rance. Soon afterivard, the followers of Jaurès, who had now become the leader of the reformists, together with the independents, formed the P'arti socialiste Fransais. In 1902 the Chamber contained forty Socialist members.

In 1904 the International Socialist Congress at Amsterdam not only settled the Millerand case, but secured the definite trimmph of Marxism over the purely French doctrine of "reformism." Despite the vigorous defense of the latter by Jean Jaurès, the German delegation, led by Rosa Luxemburg and Bebel, forced the Congress to adopt a resolution "rejecting in the most energetic manner revisionist attempts . . to substitute a policy of concession to the established order for the conquest of politieal power througl an open struggle against the bourgeoisie." $\$ 3$ It pronouneed itself frankly against any "party satisfied with reforming bourgeois soriety"; and

42 Millerand was exprelled from the Federation of the Seine in 1904.

43 Zévàs and Prolo, Lne Campa!ne Politiquc: le Parti Républicain Soctaliste, S. 
further deelared that "soeialist demoeraey eannot aecept any participation in a government of a bourgeois soeiety." 44 M. Jaurès, though defeated, loyally aceepted this decision; and upon his return to France, all his personality and great intelleetual powers were exereised suceessfully in uniting the Revolutionary Socialist Workingmen's party, the Socialist party of Franee, the Freneh Socialist party, and five autonomous Federations, into the Unified Socialist party. This union was finally consummated at the Congress of Rouen in March, 1905. The deeision of Amsterdam, however, displeased not only Millerand, but also many other prominent men, such as Viviani and Briand, who refused to join the Unified party. That party now took the official name of the French Section of the International Workingmen's Association.

Beginning with the elections of 1906 the party, ostensibly at least, repudiated the $B l o c$, and pursued an independent policy even to the extent of voting against appropriation bills. Under the leadership of Jaurès, however, who was still at heart a reformist, it took an active part in urging social reforms. Because of its splendid unity and diseipline, its electoral sueeesses were astonishing. In 1910 the party eleeted 75 deputies; and in 1914,101 . The latter eleetion was won upon a purely paeifist and antimilitary platform as well as upon the reassertion of a new social and financial poliey. The unity of the party in the 1914 elections was so eomplete that only five of its eandidates were defeated in the provinces, and but three in Paris. $A$ s will be seen later ${ }^{45}$ however, this mity has been seriously disrupted

1) Ibid.

46 sine 1. 9.7. 


\section{PARTY PIILOSOPHIES}

during the war. Unless present divisions are mended, future party sueeesses appear improbable.

Little need be said of the doctrine of the Socialist party, which in most of its outstanding features resembles that held by Socialists everywhere. The real purpose and aim of the party was set forth in the "MIutual Deelaration of Socialist Organization," adopted January 13,1905 , a part of which follows:

1. The Socialist party is a party of Class which has for its object the socialization of the means of production and exchange, that is, to transform eapitalistic society into a collectivist or a communist society, and for a means, the economic and politieal organization of the proletariat. Its object, its ideal, and the means which it employs, make the Socialist party (while pursuing the realization of immediate reforms demanded by the working-class) not a party of reform, but a party of class struggle and of revolution.

2. The representatives of the party in Parliament form an independent group opposing all the political factions of the bourgeoisie. The Socialist grouj in Parliament must therefore refuse to the government all the means which assure the domination of the bourgeoisie and its maintenance in power; it must consequently refuse military credits, credits for colonial conquest, secret funds, and indeed the entire budget. ${ }^{46}$

On one point in its doctrine, the French Unified Soeialists have become frankly opportunistie and from the standpoint of pure Socialist principle, despicably so. Realizing that the doctrine of the elass struggle and the soeialization of property is ineompatible with the ideas of the peasant population of France, whose adherence to the Socialist cause is necessary for suecess, the party has made exceptions to the Marxian dogma. The peasant population, comprising about $15,000,000$, is cil.

" Réglement du Parti Socialiste, issued by the National Coun- 
divided into so many different eategories that the rough division of "capitalist" and "laborer" (amnot possibly be made. There are thousands of small farmers owning their farms and at the same time working scveral days of the week for larger owners. ${ }^{47}$ Owners who exchusively oceupy their own places, and cmploy dozens of laborers-cannot be ealled capitalists because they themselves engage in manual labor and borrow capital. Even tenant farmers hire help and invest capital; they are evidently both eapitalist and cmployer, employec and debtor. In short, the agricultural situation in France completely belies the doctrine of the struggle and the opposition of elasses. It illustrates, on the other hand, their actual interpenctration.

The last attempt to meet this situation was made by the Administrative Commission of the party in the early summer of 1919, when a declaration was framed de-

${ }^{47} \operatorname{In} 1882$, there were $2,150,000$ peasants cultivating their own lands, to the exclusion of all other work; there were $1,374,000$ peasants cultivating their own lands and in aldition working for some one else,-nraking a total number of $3,524,000$, not including their families.

Imletstration of Increase in the Number of Peasants

\begin{tabular}{c|c|c|c}
\hline & 1862 & 1882 & 1892 \\
\hline $\begin{array}{c}\text { Peasants cultivating their own } \\
\text { land exclusively........... }\end{array}$ & $1,812,000$ & $2,150,000$ & $2,199,000$ \\
Peasants working for another ... & $1,987,000$ & $1,37 ., 000$ & $1,888,000$ \\
\hline
\end{tabular}

Although fignres for a later priod are not available, these just cited wonld seem to disprove the Socialist thesis that the preasants aro gradually heing expropriated by and subjected to capitalism. As a matter of fact, independent propriotors are increasing in numbers, while peasants working for a landlord, ete., are decreasing. Sies Ia lievue Politique et l'arlementaire, November 10, 1919, "L'aceroissement du nombre des paysans-propriétaires.", 


\section{PARTY PIIILOSOPIIILS}

nouncing "men who are recognized by their conservative opinions," and parties "who, disguising their reactionary desires under equirocal labels," wish to antagonize the peasants against socialisu. The manifest stated that the Socialist party is not the adversary of the rural masses, that it is not concerned solely with protecting the city workers to the detriment of those in the comtry. Socialism, it maintains, wishes "to bring back to the laborers themselves the means of production... . It does not struggle against the small owners who themselves produce, whether they be in the comntry or in the rity." The Socialists nct only wish to defend these small holders, but they even appear to wish to increase them.

"The Socialist party," it continnes, "does not wish to rob you of your labor-which it wishes only to render more productive-but to guarantee to you its possession." The manifest concludes by ontlining a program dealing with the means of agricultural reconstruction and proposing new methods in production, and projeets in favor of increased salaries. But the matter of "eommunal ownership" of rural property is assiduonsly a voided. $^{48}$

The contradiction between this concession to peasant prejudices and the principles of the party formulated in 1905 is comspicuomsly evident. Moreover, the peasant population of France is so conservative and individualistic, that the successes won by this abdication of principle appear too meager to justify the means employed. Indeed the Socialists must place their revolutionary lopes in the l'aris mobs, the factor from which, since the days of Nareel, the Commune, and the last "First of

4x Manifesto reported in Ie Temprs, Tune 1, 1919. 


\section{CONTEMPORARY FRENCH POLITICS}

May," disorder in France has always been evoked. Their enemy and the source of their defeat will come from the paysans who have sacrificed most for La Patrie and who now cherish more than ever their personal share in its prosperity. ${ }^{49}$

Before the war the Socialist party had about eighty department federations. Its adherents in 1905 were 34,688 , a number which increased to 63,000 in 1912 . On account of the war this number decreased to 37,073 in 1918, although by the middle of April, 1919, it had retrieved most of its former strength-mustering 57,159

${ }^{49}$ In kecping with its idea of democracy, the Socialist party has no permanent president; but there is a permanent alministrative conmission (known as tho C. P. A.) of twenty-two members, and a seeretary, who is charged with the executive work of the party. These members are elected by the National Congress, an annual meeting of the party, which deeides its policies. The delegates to this Congress are elected by congresses of the department federations in proportion to their dues-paying members-one delegate for the first humbled members, and one for every two hundred thereafter. Between congresses the party is directed by a National Couneil composed of (1) the Socialist nembers of Parliament, (2) delegates from the department federations, (3) the administrative conmission above deseribed. This national couneil is the supreme boily of the party when the Congress is not in session. It meets ordinarily once every two months; it is charged with the general propaganda and with executing the decision of the Congress. The Alministrative Commission aets in its absenee and for it. The Socialist group in the Chamber is required to submit an annual report to the party Congress and each deputy is required to pay a monthly fee of fifty dollars.

The only requirements for joining the party are the obligations to subseribe to its declaration, pay an annual fee of five cents, and belong to the labor union of the members' trade.

The party maintains a seetion in every commune-which loolds a meeting at least once a month. These sections are administered by a commission which holls bimonthly metings. At Paris and Lyons there are sections for every arromlissement. These sections form a federation in every department which is arministered by a federal committee. There is also a Feleral Council, composed of delegates of the sections, which is a deliberative borly. Inisputes between repartment federations are arhitiated by themselves, or in easo of failure to reach an agreement, by an arbitrator designated by the National Couneil. 


\section{PARTY PIILOSOPIIISS}

members. In September the membership had jumped to $104,000 . .^{50}$ The party's electoral influence is naturally much larger than the number of pledged supporters indicates; the number of rotes cast for Socialist candidates increased from 30,000 in 1885 to $1,200,000$ in 1910 , 1,400,000 in 1914, and 1,700,000 in 1919 .

The history of the Unified Socialist party slows that it has been a tremendous power in French polities-for it has drawn its suppert from bourgeoisie as well as proletariat. In fact, few of its leaders can be classed as laboring men. МГL. Bracke and Loriot, two of the most extreme Socialists, are school teachers; M. CompèreMorel is an agrienlturist; M. Mistral, arother prominent deputy, is a wine merehant; M. Albert Thomas is an agrégé of the University of Paris and is reputed to have great wealth; Mareel Seml)at is a lawyer. Indeed, from the standpoint of Socialist theory this has been the party's weakness in the past. Ilowever, its pronomeed tendeney to move further toward the Left, under the leadership of Longuet and Loriot, ${ }^{51}$ is rapidly alienating most of its hourgeois and moderate elements-and at the present time future electoral successes of the party are not likely to be so important as in the past.

\section{VIII}

Many Socialists, friends of Millerand, who were originally associated with the movement of 1880 , prided themselves on opposing the doctrine which the German

${ }^{\circ}$ The growth of the Socialists is not as remarkable as the above figures indicate, for aceorking to M. Hanotaux (op. cit., i, 166) tho International Workingmen's Association in Paris alono had between 70,000 and 80,000 memhers in 1870 .

"See P. 11:. 


\section{CONTEMPORARY FRENCII POLITICS}

delegates forced upon the Congress of Amsterdam. These believers in progressive reform and in participation in bourgeois government did not adhere to the Unified Socialist party in 1905. Just previous to the elections of 1910 about thirty deputies, some of them elected as Republican Socialists, others as Independent Socialists, and few as Radieals, formed a group at the Chamber which took for its title the "Republican Soeialist Group." On June 7, 1910, the group issued a deelaration of prineiples:

Resolutely and exclusively reformist, the group believes that reforms can be considered only as steps towards a more complete transformation and as degrees in the progressive inauguration of a new social order where labor will have been assured its integral rights. ${ }^{52}$

The Declaration outlined a gradual transformation of those industries in which capital was suffieiently concentrated, from private to state operation. It stood for eollective bargaining, for the development of labor organizations, and for their participation in the profits and management of commercial enterprises. In the field of agriculture, it offered encouragement to the small individual proprietor.

Among the deputies adhering to this declaration were three prominent statesmen: $\Lambda$. Millerand, Paul Painlevé, and René Viviani. Aristide Briand had been elected to the Chamber by the Republican Sorialist Federation of the Seine, but berause he was President of the Conneil at the time of the organization of this group, he reserved his adhesion.

This party differs from the Tnified Socialists in that it repudiates the "class struggle" and the "revolution"

"Zévais and I'rolo, Une Campagne P'olitique, 17. 


\section{PAR'TY PHILOSOPIIES}

-it stands for the maintenance of publie order. Seeondly, it is nationalistic. It has even stood for the threeyear military service law which the "Unifiés" opposed; it has moreover always looked upon Germany as an enemy of France.

The organization of the Republiean Socialists is largely patterned upon that of the Unified Socialists. $\Lambda \mathrm{s}$ to the strength of the party, it appears to poll about one third of the votes of the Unified Socialists. In the elcetions of 1910 it made a gain of 140,121 votes over those east for it in 1906. In 1914 it polled 323,326 votes. In 1906 it had twenty-nine representatives in the Chamber; in 1914, this number had increased to thirty; in 1919, it had twenty-seven.

\section{$\mathrm{IX}$}

This ends the deseription of the French parties. In addition to these regular parties there are, however, a multitude of societies and "groupements" which pose either as new parties or reform organizations. In this manner the party of the "New Democraey" was launched in April, 1919. By November it claimed to have 25,000 adherents. It ambitionsly demands effeieney in government, the exelusion of members of Parliament from office in the Ministry, the representations of trade interests, the suppression of State Socialism, the union of elasses, and full religious toleration. The writings of Lysis in his organ, La Démocratie Nouvelle, are widely read; but the party's program eauses it to be suspeeted of conservative designs. ${ }^{53}$ Its following is until now largely a personal one and it is unlikely to attain the strength of its older competitors.

s See 1) 299. 


\section{CONTEMPORARY FRENCII POLITICS}

A similar movement, the League of the Rights of Man, is of interest. This organization was founded at the time of the Dreyfus affair. Although it is not a political organization in the sense of attempting to get candidates elected, it nevertheless proposes to protect every citizen "in the exercise of the rights assured him by the Declaration of the Rights of Man of 1789." ${ }_{54}$ This program has taken the form of defending eitizens too poor to secure counsel in the courts. The League has likewise protested against several alleged illegal processes, sueh as the conviction of Malvy during the war. Although largely composed of Socialists and Radicals, it is by no means revolutionary. During the peace negotiations it was practically the only organization in France, except the Socialists, to advocate a liberal peace settlement.

There are many other organizations, each urging the adoption of a speeific or a general reform, such as the Civic League, the Party of the Fourth Republic, the League of Professional Representation and Regionalist Action, the League of Proportional Representation, the Ligue des Gouvernés, the Union of Economic Interests, the Ligue des Hommes Libres, the National Association for the Organization of Democracy, the Republican Union of Commeree and Industry, the Circle of the Boulevard of the Capucins, and the Union of Former Combatants-all of which illustrate the riotous and the prolifie character of French polities. Many of the doctrines and activities of these organizations will be mentioned in subsequent chapters.

${ }^{6}$ The League of the Rirhts of Man has hal several illustrious precursors. In 1830 the Socjety of the Rights of Man was orgatiized, and during tho reign of Louis J'hilippe it earried on an effective propaganda for the Republic. Soe Georges Weill, Ilistoiro du Parti Républicain cn France, 9S-142. 


\section{PARTY PIILOSOPIIIES}

From the diseussion of the programs and organizations of French political parties it may also be eoneluded that the charge of party instability can be overexaggerated, ${ }^{55}$ for at least seven of these parties maintain offices in Paris and sections in great numbers of the eommunes and departments. A majority of them exact the regular payment of dues, a practice contributing more than anything else, to the fixity of organization. Nearly all of them have annual Congresses in which local units are represented. This is a eustom which American parties lack. Finally, the French parties are centers of social intereourse and of education to a much greater extent than American parties, as nearly all of them are supported by auxiliary organizations among the women and youth. In these respects the French party system, apart from its parliamentary expression, manifests many elements of continuity.

${ }^{5}$ Parties must always be distinguished from parliamentary gromps. While the former since 1900 have been fairly continuons, the latter, as we shall see in the next chapter, are constantly changing. 


\title{
CHAPTER II
}

\author{
PARTIES AND PARLIAMENT
}

Notre Parlement, institution esscnt:̈lle, était, il est encore, un, théâtre.-CRÉER.

\section{I}

A parliamentary, in contrast to a eongressional, govermment, is based upon a legislative body directly elected by and responsible to the people. The Ministry or the Government is chosen from among the member's of the party or parties having the majority in this legislative body. Such a govermment not only looks after the administrative services, as does the American executive, but it actively directs legislation. Throngh its memleers who at the same time belong to Parliament, it introduees measures and urges their passage. So important is this legislative function, that in England a measure has little chanee of suceess unless it directly emanates from the Ministry. Although this is not so true in Franee, here a distinetion is made between a project of law, introduced by the government, and a proposition of law, introdueed by an ordinary member of Parliament. Generally, it may be said that the Ministry, under a Calinet form of government is supreme so long as it possesses the confidence of Parliament.

But such a Ministry is always responsible to the rhambers for its eollective and individual acts, theoretie- 
ally, both to the upper and the lower; in reality, only to the lower. ${ }^{1}$ If defoated upon any proposition it must either resign as a body, or dissolve Parlianent and call a special election. In the latter case, the people decide whether they approve the Ministry or Parliament by returning representatives favolable to the one or the other. If the sime Parliament is retumed the Ministry must resign and one representing the dominant opinion is appointed. If a new Parliament favorable to the old Min. istry is returned, the latter eontinues in power. Thus responsibility of the Ministry to Parliament and to the people-and of Parliament to the people-is ideally assured.

To be eompletely successful, the parliamentary system of government must be founded upon strongly organized parties. If ministers are to come from a sympathetic Parliament and if they are to fall when they lose its sympathy, that is, of a majority of its members, a coherent organization, composed of two balaneed and stable divisions, must exist. This division must be just flexible enough so that members outside of both (or inside, for that matter,) may throw their weight from one side to another whenever the Ministry in power loses their confidence. But the party coming into power should be strong enough to govern alone, unsupported by other groups, in order that unity and responsibility be exereised by its Ministry. In a satisfactory parliamentary government, then, there must be two large parties, nearly equally dividing the support of the nation. Such has been the experience in England; but the impossibility of such a stable and equal division in France, as we have noted in the last chapter, has

${ }^{1}$ For the control of the Freneh Senate on the Ministry, sce p. 225. 


\section{CONTEMPORARY FRENCH POLITICS}

brought about some features in parliamentary government which may be called defeets.

\section{II}

Before examining these defeets we must first consider the manner in which French parties function in Parliament. On their election, by far the greater number of Deputies and Senators become associated with what is called a "parliamentary group." These groups, composed of members of like political views, are supposed, to a certain extent, to represent party organizations. But the very remarkable thing about these groups is that the majority of them have no eonnection with Freneh party organizations and they are almost absolutely free from external party control. Out of the nine prineipal groups in the Chamber of Deputies in 1919, four were organized upon a definite party basis: The Unified Soeialist, the Republican Soeialist, the Radieal Soeialist, and the Liberal Aetion group. In the other five, the Radical Left, the Republicans of the Left, the Republican Radieal Union, the Group of the Entente, and the Group of the Right, party lines overlapped. Although, generally speaking, each group represented a eonservative or a liberal tendeney, parties, as ontlined in the previous chapter, were merged into different groups; strietly party men found themselves joined with complete independents in the same group; and men of antagonistie polities, such as an Orleanist and a "Rallie," sat together.

Among the members of the Right, there appears to be absolutely no relation between party organization and membership in parliamentary groups. Often this is be- 


\section{PARTIES AND I'ARIJAMENT}

cause there is no party organization to speak of, and it is also not inconsistent with the "irresponsihle" dortrines this element holds. (The Liberal Aution gromp offers a slight exception, perhaps, for a majority of the executive eommittee of the party organization must be members of Parliament and the party maintains a distinct party group, insuring a certain amount of discipline and unity.) Similarly, there is little relation between the rerresentalives of the Republiran Federation in Parliament and the party organization itself, or between those of the Republican Democratie Allianee and its party organization. Indeed many of the adherents of this group belong to the Group of the Entente. In the Radical party, however, Senators and Deputies professing to be members of it, must accept at least its minimum program. They must pay their dues, assist at party congresses and adhere to the "party group." Senators and Deputies are ex officio members of the Exeeutive Committee. ${ }^{2}$

Thus Radieal members of Parliament can only obtain the "approval" of their party if they have formally adhered to the party's program and if they maintain the loyalty this implies throughout their term of offiee.

Candidates for office are selected by the department Federations. There ean be only one eandidate in each constitueney; and no party representative or journal is allowed to oppose a Radical candidate by supporting a candidate of another party. If any Radieal representa-

\footnotetext{
${ }^{3}$ Likewise, sixteen of the thirty-five members of the Bureau of the Exeeutive Committe must be memlers of Parliament. Thero is a commission upon discipline which reports to the Executivo Committe upon any fracture of party manlates. The latter boly may impose the penalties of warning, censure, or exclusion. Such a penalty ean only bo imposed by a majority of two-thirds of the committee.
} 
tive in Parliament lends his support to a candidate condemning the poliey of the party, he is liable to discipline. By these means, a very close relationship exists between the Radical Socialist group in Parliament and the Executive Committee of the party. The latter, by wielding its diseiplinary power, may virtually direet the parliamentary group. Although the Radieal group is strongly represented in the Committee, a firm bond between party interests and members throughout the country is maintained. ${ }^{3}$

But the Radieal party has not always maintained this control over its parliamentary members. Until just prior to the war, there was no distinet and all-inelusive Radical group in the Chamber. Although they possessed the balanee of power and the majority for a long period of time, their representatives were seattered between a number of groups, eaeh working quite independently of the other. In 1911, the Radieal Left eontained 113 representatives of the party, while 149 of them were inseribed in the Republican Radical Soeialist group. Just before the eleetions of 1914, the members of the party were divided into three parliamentry groups-four belonged to the Demoeratic Left, and the remainder split their allegiance between the Radical Left and the Radical Socialist group. The Congress at Pau attempted to remedy this eondition and to effeet a general reorganization of the party by deciding that the Senators and Deputies of the party must constitute the "group" of the Radical and Radical Socialist party, and that they may not inseribe themselves in parliamentary groups

\footnotetext{
3 These particulars will be foumd in the Party Statutes and Regulations, griven in the appenlix to Jneques, op. eit., 484-541. See also lonaime Congris du Parti liépublicain, Radieal ct RadicalSocialiste, at Tours, a brochure, 199.
} 


\section{PARTIES ANI PARLIAMENT}

of other parties. It was also deedided that the "party" group" must he exclusively eomposed of all the lonuties of the party, and no others." The concentration of fores, resulting from this dorision, gave rise to the name, Unified Radicals, whith charaterized the party in the 1914 elections, but which in 1919 seemed to hare disappeared.

The Republican Socialist party also compels candidates seeking election to sign both its declaration of prineiples and its program. The party representatives in Parliament constitute a part of the administrative eommission of the party, and they fortu a unicue latey group. But aside from their parti ipation in the administrative commission of the party, the members of this group are responsible only to their own department federation.

The Unified Socialist party maintains the strictest control and discipline exercised by a party orer its parliamentary representatives. 'They form an exclusive group in the Chamber. Every eandidate for office must sign a declaration promising to observe its principles and regulations and to follow the tacties of the party, and the decisions of national and international eongresses. A Deputy who leaves the party is under the obligation, althongh it is difficult to see how the provision an be enforced, of resigning from office if the organization originally electing him, refuses him further support. The Socialist group in Parliament must present an annual report to the annual congress of the party. A eollective delegation from the group forms a part of the

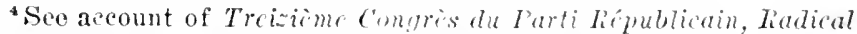
et Radical-Socialiste, at J'au, a lirochure, 3.5.
} 


\section{CONTEMPORARY FRENCH POLITICS}

National Conneil. ${ }^{5}$ As previously noted, the members of the group must pay a monthly fee of 250 franes, 100 franes going to the National Council and 150 franes to the organization which bore their election expenses. If a member fails to pay this fee for three months he is read out of the party. A Socialist Deputy must consequently replenish party funds and must subject himself to direct control.

By means of an arbitral commission the Soeialist party settles conflicts between members, sections, or groups. This eommission, subject to appeal, may "warn" a member, temporarily suspend him from any delegation, or even exelude him entirely from the party. The parliamentary group itself is under the eontrol of the National Council and the latter body deeides how the members of the group should vote upon any questions of importance before the Chamber. The expulsion of members, because of refusal to comply with party decisions, has been frequently employed.

Department federations, following the famous example of the federation of the Seine in expelling Millerand, expelled numerous ex-majoritaires ${ }^{6}$ during the summer of 1919, Mr. Compère-Morel being one to suffer such a fate. The organization and discipline of the Socialists has been and continues to be the great cause of Socialist successes. Similar tactics on the part of the bourgeois parties will be a necessity if they are suecessfully to combat the Marxian Socialists.

The Unified Socialists and the Radicals are the only parties maintaining an immediate control over their parliamentary groups-the only ones to establish a

sirglement du P'arti, brochure distributed by the National Council.

- Fur the origin of the ex-majoritaires, see p. $10 \pi$. 


\section{PAR'TIES ANI) PARLAANEN'T}

firm relationship between the regular party organization and the party representatives. The other partiesnotably those of the Right-exereise no such control over their representatives. Among the latter, party diseipline is unkmown. This is one reason for the weakness of the conservative forces in France-lack of organization. It likewise areounts for one of the weaknesses in French parlianentary gorernment, for as English practice illustrates, there must be the rosest bonds between the constituents of a party and its parliamentary repuesentatives.

As for the groups themselves, they are regularly organized. They hold meetings resembling eaneuses, exeept that the decisions reached camnot be enforeed upon their members. As they are at liberty to resign from their group and adhere to another, discipline ean be enforced only with difficulty, especially when the group member's party maintains no "party group." The groups are supposed to cast homogeneous and solid votes; but as a matter of fart, they seldom do. The only practical purpose these gromps appear to serve is as a basis for the eomposition of the "Permanent Committees of the Chamber." At the beciming of every Chamber (that is, every four years), nineteen such "eommittees" or "commissions" are elected, each composed of forty-four members. ${ }^{7}$ The different parlia-

TRegulation voted . Tanuary 29 and Feloruary 4, 1915. These commissions are (1) General, Ilepartmental and Communal Administration, (2) Foreinn Afrairs, l'rotectorates and colonies, (:3) Agrieulture, (4) Army, (5) Social Insurance and Pensions (Prevoyanes), (6) Budget, (7) Commoree and Industry, (a) Definite Aceomts and Eeonomies, (9) Tarift, (10) bilueation and Fine Arts, (11) Jublie Tyriene, (12) Civil and Criminal Legislatiou, (13) Fiscal Legislation, (14) Marine and War, (15) Merehant Narine, (16) Mines, (17) P'osts and Teleuraphs, Tli) labor, (19) Public Works, Railways aml Communication Facilities. 


\section{CONTEMPORARY FRENCII PUIITICS}

mentary groups are proportionally represented in these commissions in the following manner: Five days before the date fixed for the nomination of these commissions, the different political groups of the Chamber must furnish to the President, for publication, a list of all their members. No representative is allowed to appear on more than one group list. Three days before the date fixed for the nomination, the groups submit to the President of the Chamber a list of eandidates for these commissions, varying in number according to the strength of the groups, as indicated on the lists previously submitted. Finally, the mere submission of such a nominating list, provided it does not exceed the number of candidates to which each group is entitled, is considered equiralent to their election by the Chamber. Thus each group elects its own representatives to these commissions. In case a certain percentage of the Chamber protests the nomination of any member to a commission (as was done with the Socialist group nomination of MM. Longuet and Mayeras to the Commission for the Ratification of the Treaty), a vote is taken by the Chamber on all of the candidates. Special commissions acting for limited and specific purposes are chosen in a similar manner. ${ }^{8}$

In order to secure a majority in the Chamber, it is obviously necessary for a certain number of these groups, temporarily at least, to enter into combination. But be-

\footnotetext{
${ }^{8}$ As an example of the representation upon such a commission, the ratifieation eommission, chosen by the Chamber, June 25th, 1919, eontaind sixty members, of which the Soeialists originally nominated eleven; the Republienn Soeialists, threr; the RarliealSowialists, eighteen; the Rablieal Inft, six; the Remulliean Left, six; the Republiean Radical Union, two; the group of the Butente, seven; Liheral Artion, two; Group of the Right, one; group of "mon-inserits." one; Indepenients, three.
} 


\section{PARTIES AND T'ARLIAMENT'}

eause of their number alone, regardless of their lack of diseiphe and their independence of party, control, such coalitions are generally of the most transient instability. Yet a new Ministry can come to power only by effecting such a combination. In the presenee of such a large mumber of groups, it is practivally impossible for one party to have a majority, although the Radieals several times have been able to. Thus, instrad of a majority and a minority party consistently offsetting each other, France is governed by a group system, in which, because of the number of these grouls, the majority is continually changing in composition. As a result ministries depend on no one party for support; and they ean follow no strietly party poliey.

Furthermore, these groups are contimally shifting, disappearing, dissolving, and reappearing. Of the last two groups whicle formed a part of the National Assembly from 1871 to 1876 , one, the Extreme Radical and Socialist Left, disappeared in 1906, and the other, the Center Left, vanished slortly after the clections of 1910. The terms, "Legitimists," "Orleanists," and "Imperialists," which figured in this Assembly, were applied to eombinations which lave long since been merged into the "group of the Right." This gromp of the Right in 1902 was known as the Reactionary group. The "Rallies" and "Nationalists" have completely lost their significance, most of the former now adhering to the Iiberal Action group, and the latter, grouped with the Right, or "Tndependents." The Ministerial and Radiual Dissident groups of 1902 disap)peared in the Chamber of 1906; and the members of both aprear to have merged with the Democratie Left. Similarly, the group of the Extreme Radical and socialist Left and that of the Ind pend:ont Sorolalists, existine 


\section{CONTEMIPORARY FRENCII POLITICS}

in 1902, disappeared after 1906, while a new Parliamentary Soeialist group came into being. The latter disappeared in the 1910 Chamber where a new Republican Socialist group made its début.

A similar confusion exists in the Senate where the Republiean Left eorresponds to the Republiean Union of the Chamber of Deputies, and the Republiean Union of the Senate may be eompared with the Demoeratie Left of the lower house.

These instances will indieate the eonfused complication of the party machinery and the difficulties in which Freneh parliamentarism is called upon to function. With the exeeption of one or two groups, there is no relationship between the parties proper and their parliamentary representatives; the latter are organized into independent, shifting groups of little diseipline or homogeneity. ${ }^{9}$ Consequently, parliamentary representatives are really free from all obligation; and there is no way to enforce their adherence to a certain program or a eertain cabinet. Thus, the most essential basis of a satisfactory parliamentary government-party discipline-is absent.

\section{III}

Two general results, already implied, arise from the eondition just deseribed. The first is the instability of ministries and the ineritable lack of eontinuity in poliey. The second is the overwhelming predominance of Parliament over the Ministry.

As no one party commands an absolute majority in

M. Aristide Briand offers an example of the independeneo of a French leputy. Elerted by the Repulliean Socialist party from St. Etienue, he lolones to no parliamentary group, althrongh the Ropublican socialists are organized in one. 


\section{PAR'TIES AND PARLIAMEN'T}

the French Chamber, the President of the Ropublice must select a man as l'resielent of the Council of Ministers (the Prime Minister), who will command the support of several parties. The dilemma of the l'remier is increased by the necessity of selecting an entire cabinet from these differing, of tem lostile elements. In England the task of choosing a I'rime Minister is comparatively simple because the leader of the party in power is generally distinguishable. But in France, on account of the reason above given, the President is allowed to use a great deal of personal discetion becanse no outstanding party leader can exist. There may be three or four available candidates, but becanse of their number, the final choice must rest with the Presiflent of the Republic alone. As a result of this condition, long intervals frequently clapse between the fall of one eabinet and the formation of another. Even when a Prime Minister is chosen, he must carry on negotiations with groups, securing their adherence by the judicious distribution of seats, and often by the ereation of new ones merely to satisfy certain representations. This necessity was increased during the war when the willing collaboration of every group in the Ministry became a necessity. The Viviani Cabinet, already in power when war was declared on August 3, 1914, immediately enlarged itself to include MM. Deleassé, Ribot, Millerand, Briand, Sembat and Guesde. (The latter was given no administrative position, but was merely denominated "Minister without Portfolio." It is said that he did nothing in the Council of Ministers ${ }^{10}$ except draw a salary and insure the So-

${ }^{10}$ The Council of Ministers as oplyosed to the Cabinet is the administrative body of ministers recognized in the Constitution; the Cabinet is the politioal borly. The President of the Republie meets with the former but not with the latter. 
eialist support of the war.) In the Briand Cabinet, which followed that of Viviani, a new device was used to secure the political representation of all parties. This was the ereation of Ministers of State, of whom there were five. MIM. Freyeinet, Emile Combes, Léon Bourgeois, Jules Guesde and Denys Cochin oecupied these new positions, the first being a Moderate, the second two, Radical Senators, the fourth, a Socialist, and the fifth, a member of the Extreme Right.

The Viviani Ministry which eame to power on June 13,1914 , illustrated the diffieulty of the formation of a new calsinet. On June 2, 191t, the Dommergue Cabinet resigned, and because of the inereased strength of the Left, René Viviani, a Republican Socialist, was immediately asked to form a new government. It took him exactly eleven days to come to terms with the Radicals, notably upon the three-year military service law to which the Radicals were opposed. Concessions were passed back and forth unsuecessfully until June 9, when President Poincaré, despairing of Viviani's suceess, asked 1 . Ribot, a Moderate belonging to the Republican Union of the Senate, to make the attempt to form a abinet. II. Rilot judiciously selected a cabinet from the Left and C'enter groups, but beeause of his support of the three-year law, the Inified Soeialists and the Radicals overthrew him on June 12 hy a vote of 306 to 262. Finally, upon June 13, Viriani sueceeded in coming to terms with the Raticals, and took over the Ministry. In his cabinet were five Raldials, two Republican Soeialists, three Schators from the Democratie Left, one Repullican of the Left, and one member from the Radieal Left. More than half of these twelve ministers had voted for the three-year law of August 7, 1913, although collectively the ealinet had cone to power 
pledged to overeone it. Tout as soon as the cabinet was firmly seated in power, it annomered its firm intention to give it its support. Surh a change of polieices is a

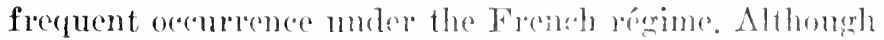
the Unifed Socialists withlew their support, the Ratlieals were able to muster a majority which kept M. Viviani in power.

The attempt of M. Ribot to form a gorermment, as above related, resulted in what was known as the One Day Government from the length of its tenure. This affords an illustration of the mucertainty and the instability of French ministries. Areording to figures eompiled by M. Léon Muel, ${ }^{11}$ duriner a period of a humdred years, from 1789 to 1890 , France las had ninetyfour Ministers of Jnstice, 117 of the Interior, ninetynine of Foreign Affairs, ninety-nime of Finance, 109 of War, and eighty-eight of Marine. Thus the average term of offiec of the Ministers of Justice, Finance, and Marine, was a little over a year; that of the Ministers of the Interior and of War, a little less than a year.

From the advent of the eabinet of .Jules Dufamre, on March 9, 1876 (who was the first I'resielent of the Coumcil under the Third Republic), to the accession of the Clemenceau Ministry in November, 1917, there were fifty-six ministries-during a period covering forty-one years. In other words, a French Ministry has had an average life of less than nine months. Contrasted with the ministerial tenure in England, where from 1873 to $191 t$ there have only been eleven ministries, the advantages of a stable party organization can realily be scen. During the same length of time-1876 to 1917 France had five times as many ministries as Fngland.

\footnotetext{
"Cited in Eilmond Villey, Les rices de la Constitution Fran. saise, 12:.
} 
Although both countries nominally have the same parliamentary form of government, they work quite differently in practice. Of eourse the essential thing about a "eabinet" government is that it holds office only so long as it maintains the sympathy of the majority of Parliament or of the country. But as already noted, while this majority in England is organized and stable, and its sympathies definitely determined and expressed, in France there ean be no majority in the English sense. There are combinations, coalitions, and blocs, temporarily held together by a common ambition. ${ }^{12}$ The number, the independence, the changing interests, and the laek of diseipline of these groups do not long allow them to endure. When these combinations break up, it usually means that another combination will be formed, antagonistic to the Ministry-and the latter must fall. The result upon the conduct of the government is plain. An ordinary Ministry will try to perpetuate its power as long as possible. To do this, it will have to satisfy the demands of the four or five groups supporting it. But these demands are usually eonflicting and they eannot be carried out to the satisfaction of all. Consecuently a Ministry usually "marks time"; at least it is subjected to the temptation of temporizing. Reforms which it is pledged to enact are found impossible of realization if it wishes to remain in power. Measures demanding immediate adoption drag through suceessive Parliaments, their principle not being accepted because groups differ on details. This has been especially true of the income tax. Promised by the Radical party in 1906 , adrocated many years before, it was finally enaeted in 1914. This has been truc also of electoral re-

12 For a history of these combinations, soc chapter 111 


\section{PARTIES ÁND PARLIAMENT}

form, advocated in one form or another ever since the ercation of the Third Republic, and only cnacted in 1919. Unless a Ministry is comagreous beyond the ordinary, it is not likely to urge reform measures which may react against the self-interest of some parliamentary group. If a strong Ministry urges them it is sooner or later bound to fall. As a result pressure for reforms does not usually come from the Govermment. This is true espeeially in matters of social and economie legislation. It eomes, if at all, from independent members of Parliament ontside the Ministry, and more strongly, from great, organized extra-parliamentary bodies such as the General Confederation of Labor who, by threat, lave forced the passage of greatly needed measures. ${ }^{13}$

In faet, the weakness of the Government and the inability of Parliament to accomplish results seem to be one of the chief reasons for the strength of these ontside, and purely extra-legal bodies. As far as the French Ministry is concerned, its virtual powerlessness to initiate reform legislation and its meertain lease on life, has a strong tendency to keep the stronger men of the comntry out of the cabinet. But their places are greedily held by sueeessive swarms of men who in other comntries would be wholly mable to hold ministerial positions.

Criticism upon this score is often exaggerated, how-

${ }^{13}$ The demand of the National Association of Functionaries, for salary increases by July 21, 1919 , seems to have been the only reason why Parlianent provided them. Other organizations, such as the Civie League, the league of the Rights of Men, the league for Proportional Representation, the League for Regional Action have lei fights for reform. The Electoral Reform Bill of July, 1919, is an instance of a great reform which was spon. sored by members of Parliament, withont the support of the Ministry. In fact, the Clenenceall Ministry appeared to be secretly opposed to it. 


\section{CONTEMPORARY FRENCII POLITICS}

ever, for the effects of the unstable tenure of ministries is partly overeome by several offsetting institutions and practices. In the first place, the officials who directly manage the Government services and administration have been given a status, assuring them permanency in office. This has resulted largely from the demands of organizations composed of these employees. To a eertain extent this has overeome the so-called "Spoils System" by which a new Govermment fills all positions with its camp-followers. Consednently, government administration has a permanence and a stability on which even frepuent ministerial changes have little effeet. The granting of a permanent status to functionaries has been further necessitated by the eentralization of the French govermment and the vast control which it exereises over business enterprises. For example, it would be inconceivalule for university professors or tobaceo manufacturers to be removed upon every change in ministry. Their permanency of position has overeome what would otherwise be a hopeless and impossible situation.

Secondly, a rhange in ministry is not so wide-sweeping in its effect as it is in England. In the latter eountry, it is customary for an entirely new eabinet to take the place of the one just fallen; and the new body adopts an entirely different policy. But in France, ministers of old calbinets are usually foumd on new. There are always some "hold-overs," men who have had previous experience in eahinet positions. A defeat of a Government often amounts to nothing more than a ministerial shakb-up. Surle a drefuat is usually caused by the aroused lostility of one of the four or five gromps constituting its majority ; and a roformed calninet is often changed only to the extent of eontaining representatives of anothere groule to take the place of the one which has 
drifted away. It is enstomary for a dofeated prime Minister to take a poldfolio in the cabinet smoereding his own. 'Thus Viviani after lis lall heame Minister" of Justice in the Briand Cabinet which stlececed him

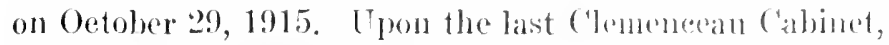
three members, MII. Clementel, claveille, and Temelsems, "held over" in the same positions from the Painlevé cabinet. 'The Minister of Finance, Lonis Klotz, served in the same position on three previous calbinets, those of Caillaux, Poinearé, and 13riand. The Mlinister of Commeree, M. Clémentel, held a similar position on four previous cabinets; at one time he was also Ministel of Agriculture in the Barthon Ministry and Minister of Finanee in the Ribot Cabinet of 1!)17. M. Pams, Minister of Interior, was Minister of $\Lambda$ grifonlture in the Caillaux and Poincaré Cabinets; M. Lafferre, Minister of Instruetion, was Minister of Labor under the Briand Ministry of 1910 ; M. Leygues, Minister of Marine, was Minister of Colonies in the Sarrien ('abinet of 1!)6; while Stephen Piehon, Minister of Foneign Altains, held a like office in previous Briand (1910), Clemencean (1906), and Barthon (1914) Cabinets. Thus a French cabinct, despite its shifting eomposition, is assmed of members who have had previous political and ministerial experience.

Finally, the instability of French govermments amnot be eharged only to organic defects in the parliamentary system of the Thire Republic. 'The whole history of France has been one of constant turmoil, one form of govermment foreilly tmming inte another, Republic, Ilonarely, and Empire, as following tho

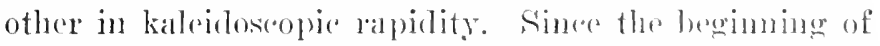
the Revolution eleven comstitutions latve, at one time or another, governed France; but until the Funtamental 


\section{CONTEMPORARY FRENCII POLITICS}

Laws of the Third Republie, no one of them has been in effect longer than twenty years. ${ }^{14}$

Franee has been twiee an Empire, and three times a Constitutional Monarchy; she has seen the régime of three Republics. Since the death of Lonis XIV only two monarehs died in the occupancy of the throne. Under the Third Republic, the first three Presidents, MM. Thiers, MacMahon and Grévy, were forced to resign; the fourth, M. Carnot, was assassinated; the fifth, Casimir-Périer, voluntarily quitted office in disgust; and the sixth, Félix Faure, died prematurely-even mysteriously. It was not until the Republic was in its thirtysixth year that a President at last quietly laid down his office at the expiration of his term, as Loubet did in 1906. The present parliamentary system in France surely cannot be responsible for the instability of past history or for the eheckered eareers of its Presidents who were removed from its operation.

\section{IV}

The second defeet of French parliamentary government arises in part from the first. This is the tyrannical dominance which Parliament-or the Chamber of Deputies-maintains over the Government. In England the Cabinet directs Parliament; it not only handles govermment administration, but it actively leads legislative work. It is nearly a free agent in the direction of the chief duties of the central government; Parliament intervenes only to hold it aceomutable to its trust. The French l'arliament, on the other hand, shows no such

14 For a list of these laws and constitutions, see F. R. Dareste, Les Constitutions Hodernes, i, 1-9. 


\section{PAR'TIES AND PARLIAMENT}

amiable disposition. It constantly interferes in the affairs of the Ministry, it dietates its policies, and continually demands explanations and dofenses. Generally, it assumes a highly dietatorial attitude. The Ministry often finds itself at its absolute merey,-not of that of a stable, reasonable majority,-but of a whimsical and often insignificant group. Patience, therefore, becomes a chief-even essential-ministerial virtue.

There are several devices by which Parliament may eontrol the Ministry. Oral questions may be asked a Minister at the begiming of a session. They eamnot be debated and the author is the only one allowed to respond to the Minister's reply. Written questions may also be submitted to the President of the Chamber; they are printed in the Official Journal along with the response from the proper minister within eight days. The latter, however, may declare in writing that the public interest does not allow an answer. The chief means by which Parliament lays a heavy hand on the cabinet is by the means of "interpellations." An interpellation is the act by which a member of either the Senate or the Chamber ean force a minister to answer questions and generally to defend his administration. The President of the Comeil may even be brought to defend the entire general policy of the Govermment. ${ }^{15}$ Indeed, interpella-

${ }^{25}$ The following is a summary of the Rules of the Chamber in regard to interpellations:

The Chamber fixes the day upon which interpellations are heard. Interjellations upon interior polieies eamot be postponed more than a month.

No order of the lay motivé upon interpellations can be presented unless it is in writing.

The orler of the day pur et simple, if it is requested, always has priority.

If the orier of the day pur et simple is not alopted and if it is not ordered to the bureans, the president submits the order of the day motive $e^{\prime}$ to the vote. 


\section{CONTEMIPORART FRENCII POLITICS}

tions are seldom used merely to obtain information; they more often eonstitute a ehallenge to a debate in whieh all members of the Chamber and of the Ministry may partieipate. Originating in teehnical and unimportant matters, such discussions often end in the overthrow of the Govermment. An interpellation is made in writing and it becomes a special order of the day, the time for the debate it provokes being definitely set in advance. After such a debate-in which the interpellators may place the Minister under a grueling examination, which is limited by no restrietion of time -the vote "of the order of the day" is taken. This vote usually inchudes an expression of confidenee in the Government. For example, last June (1919), after an interpellation in which certain members of the Chamber questioned the Government as to searehing eertain offices, the Chamber passed the following order of the day:

The Chamber, respecting the guiding principle of the separation of powers and confident that the Govermment will allow justice to follow its course in full independence, passes to the order of the day.

If the Chamber refuses to pass such a motion, "laek of eonfidence" is expressed and the Minister individually, if not the eabinet collectively, is bound to resign. 'The latter result may be avoided, if a new Minister is appointed who will conform to the Chamber's wishes.

The order of the day fur ct simple is a vote which neither censures nor praises the ciovernment, but which proceesls to the other business of the Assembly withont comment.

The oriter of the day motive expresses a lefinite opinion upon the interpellation; $i e^{3}$. it either exonrates or condemns the govermment pelicy under debate.

Sire líglements de la Chambre alos Députés, Chapter VI, Artieles

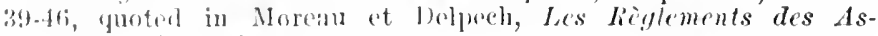
semblés línislatires. 


\section{PARTIES ANI) PARLIAIIENT}

The Chamber, however, may rote the "order of the day" with no mention of confidence. This novel proeeeding in the Frenidh system has often raised puestions as to its exact status. For instance, on the 18th of July, 1919, after listening mfarorably to the Minister of Agriculture (M. Boret) in a defonse of the economie policy of the Government, ${ }^{16}$ the Chamber of Deputies passed the following resolntion:

The Chamber, believing that the price of living has diminished one half in Belginu sine the month of Jamuary, 1919;

That the price of living has diminished one quarter in England since the armistice;

That it has not cessed to increase in France since that date, and judges this result to be due to the economic policy of the govermment;

Passes to the order of the day.

Althongh perhaps it was the intention of the Chamber that the Minister of Agriculture should resign, the resolution contained no word of confidence or lack of eonfidence. In the minds of many, there was a question whether the Minister was mder the obligation to resign and whether it was the intention of the Chamber that he should do so or whether it merely desired to bring about the ehange of his policy. But whether or not the Chamber directly expresses lack of confidence, such a motion clearly indicates that the Minister does not have its approval. In comnection with this incident, the Unified Soeialists asserted that this vote should be interpreted to mean that the whole Clemenceau Ministry had fallen. But such a contention in French practice was inadmissible, although it would porhaps be valid in England.

The whole system of interpellation is subject to the greatest eritioism. Its use and aluse are too frequent;

10 sice P. 326. 


\section{CONTEMIPORARY FRENCH POLITICS}

its causes are so superficial that the mere debating of them is often a waste of time. The publie, indeed, regards them rather facetiously, for every Friday (the principal day set for interpellations) Parisians throng the Chamber to enjoy the spectaele and do their best to assist the opposition in unseating a ministry! ${ }^{17}$ The frequency of these interpellations is illustrated by the two years' tenure of the Méline Ministry in which there were 218 interpellations, one abont every two days. The Socialists became so obnoxious in introdueing interpellations under the Clemenceau Government that during the war the latter actually refused to consider most of them, moving for adjourmment sine die on the ground that the national defense would not allow publie diseussion,-a prartice which led the Socialists to brand the Clemeneeau Ministry as the sine die Govermment. During the armistice, this device was especially abused ; every week, two or three interpellations would be filed upon the Government's fimaneial policy, the evaeuation of troops from Russia, the Govermment's attitude toward strikes, and the debates at the Peace Conference. By these means the Govermment is kept in a continual state of belligerent defense; and an enormous amount of the time of its ministers is wasted in disenssion whieh ordinarily adds no light, and which elears up no misunderstandings. 'The Soeialists, who make the greatest number of these interpellations (although they eonstitute but a sixth of the Chamber) are already fixed in their opinions. They intentionally pursue an olstruetionist policy to which the interpellation is readily adaptable. If the interpellation would be utilized as is the "question" or" the vote of ronfidence in England, the Chamber and

${ }^{17}$ This flastime, alonir with others, was largely foregone during tho war. 
the Government could coöperate with and clearly understand each other. As it now stands, however, it is a political diseomadement to the Ministry and a tremendous and largely useless handicap to its administrative duties.

\section{V}

By a decree of September 3, 1914, the extraordinary session of the French Parliament, ealled August 1 on accomnt of the German declaration of war, was closed; and another session was not convoked until December 22,1914 . During the interval between these two sessions, the Govermment exercised both executive and legislative functions; under the powers granted to it by the laws establishing the state of siege, it exercised great powers, and, by means of its decrees, it virtually and repeatedly enacted Jegislation.

In aceordance with the law of July 16, 1875, the Chambers were again convoked on the second Tuesday, that is, the 12th of Jamuary, 1915, by the President of the Republic. Acrording to this constitutional provision, the Chambers must remain in session at least five months. ${ }^{18}$ 'hereafter the President of the Republic may close the session and call an extraordinary session whenever he may wish during the remainder of the year. But in the course of the year 1915, the Government, without any other offieial declaration, made it known to the press ${ }^{19}$ that during the period of hostilities it would not use its riglıt of closing l'arliament. As a result, sinee the beginning of 1915 and until the end of the war Parliament in the fall of 1919, the Chambers sat

${ }^{18}$ See Art. 2 of the law of .July 16, 1975 .

19 See 1. Dugnit, Wanucl de I) roit Constitutionnel, 203. 


\section{CONTEMPORARY FRENCH POLITICS}

in a permanent session. Recesses were frequently taken, it is true; but all adjournments were made by the Chambers themselves. Parliament in this manner took over a power whieh the Ministry in a parliamentary government usually exercises.

This war practice was the outgrowth of another French practice which marks a difference from that followed in England. Ender a parliamentary government, the Ministry may in times of dispute dissolve Parliament, order a general election, obtain a majority and remain in power, or vice versa. Such an oceurrence was illustrated in the speeial elections in England in 1910. In France the President of the Republic enjoys this theoretieal right of dissolution of the Chamber-a right which differs from that of closing the ordinary sessions of Parliament above described. It may be exereised at any time, but it must have the assent of the Senate, another difference from the British practice. But a more essential factor is that the President has never exereised this right sinee 1877 when MacMahon used it in an attempt to seeure an anti-Republiean majority. The abuse of this power was so evident that its exereise has since been held in disfavor. As a result, a French Ministry has no recourse to the people in a confliet with Parliament. There is, therefore, no means of knowing if it is pursuant to the will of the people rather than to the mere will of Parliament that a certain Ministry is caused to fall. This distinction is vital beeause it makes the French Parliament absolutely supreme, in contrast to the American Congress which has no eontrol over the composition of the Executive once the latter is established, ${ }^{20}$ and it is nore powerful than the British Parlia-

${ }^{20}$ Exeept by impeachment, ete. 


\section{PARTIES AND PARLIAMEN'T}

ment, which is responsible to the people like the Cabinet itsell. 'The Frenclu Parliament is kept within bomols hy the nultiplicity and eontradiction of its own components. If these eomponents were ever fused into one mind under a powerful leater, there would be no limits to the usurpation of powers by Parliament.

Two other instanees will illustrate the growth of parliamentary power during the war. One of these was the utilization of the P'ermanent Committees of both the Senate and the Chamber in assisting and supervising the Government in military and industrial preparations; the other is by the exercise of the power arising from deeisions reached in seeret sessions.

Commissions of Inquiry have always been used by Parliament to investigate the aets of a Covermment when an interpellation wonld divulge seerets of state. But until the passage of a law on the 23rd of March, 1914, (after the scandalous "Rochette affair") the Chamber had no general right to summon wituesses to appear before it, although it could eall Government officials. Now, however, this right has heen granted and Commissions of Inquiry (such as the Commission of Metallurgy at present investigating the alleged intervention of the Committee of Forges in the operations of the army) actively seareh ont the administrative activities of the Government in a mamner far more efficient than the method of interpellations.

The Government's refusal to give the Chamber information concerning army operations in 1915 and the early months of 1916 was very irritating to the members of that boty. Especially upon matters such as Balkan diplomacy, the Iligh Command, the removal of General Joffre, and the independener of the General Staff, did the Deputies wish to be informed. The Government's 


\section{CONTEMPORARY FRENCH POLITICS}

refusal to dirulge this information was upon the gronnd that such public discussion in Parliament would aid the enemy.

To overcome this diffienly and to assure parliamentary supremacy, the Unified Socialist group introduced a bill into the Chamber which provided for the nomination of a speeial eommission charged with investigating all questions bearing upon mational defense in the zone of the armies as well as in the zone of the interior. Another proposition supported by the same party provided for the creation of an "organism" composed of Senate and Chamber delegates with the same powers as that of the commission above. Both of these propositions were defeated upon the 9th of February, 1916.

This idea, however, made great progress in the Chamber, and upon Jume 22, 1916, by a vote of 444 to 80 , it adopted an "order of the day," a portion of which read as follows: "The Chamber deeides to institute and organize a direct delegation which will undertake, with the coopperation of the Govermment, to exercise the effective and immediate control in situ of all the services whose function it is to supply the needs of the army." 21

This bill, providing for a new organ of government, which might interfere directly with every phase of army operations-excepting perhaps the actual disposition of troops in combat, met with the greatest resistance from the Government. After an eloquent diseonrse from the President of the Conncil, on the 20th of July, 1916, this bill was abandoned. But on the 27th, a proposition introduced by M. Chammet was passed by a vote of 269

${ }^{21}$ For a more detalent discussion of the work of the "Government of Ibordeanx," the recrime of deceres, and the eventual cstablishmont of paliamentaly control over war ministries, see

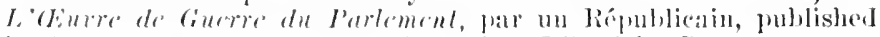
in "Le fart de la somaine", series, Librairie Grasset. 


\section{P'ARTILS AND PARLIAMENT}

to 200 , which placed on the "permanent commissions of the Chamber" the "ontrol of the govermment in regard to the condurt of the war. This control, aceording to the bill, the commissions already exereised. The only addition it made was to repuire the commissions to make a quarterly report to the Chamber. Thereafter the commissions took a considerable part in all questions dealing with army supplies. It was dne to the activities of the Senate Committee on the Army that the Underseeretary of Aviation resigned. The commissions also sueceded in securing the resignation of a Minister of War who eherished superammated doetrines upon artillery. Later they also brought about the ereation of the Undersecretaryship of Munitions. They even sueceeded in speeding up the inertia of other government services,-the reorganization of the liealth service and an adequate supply of artillery, mmitions, and machine guns being attributed to them. ${ }^{22}$ Although strictly limited in the exercise of their powers, the French commissions appear to have functioned very suecessfully.

The original decision of the Chamber to constitute a "direct delegation" was taken in seeret session. These seeret sessions were themselves an imovation which Parliament forced upon the Government for the same reason as it foreed the commission jurisdiction. The Constitutional law of .July 16, 1875, provided that each Chamber might go into "secret eommittee" at the request of a certain number of members, to be fixed by the house regulations. This right, however, like that of dissolution, had never been exereised. But finally, in order to obtain a more intimate knowledge of the conduct of the war and to exereise more fully the right

\footnotetext{
335 .

we Soseph Barthélemy, Démocratie et Politique Etrangère,
} 


\section{CONTEMPORARY FRENCII POLITIC'S}

of interpelation, both the Senate and the Chamber, overoming old precedents, decided to constitute themselves into "secret committees" in the spring of 1916. In June, the Chamber held seven such sessions. Throughout the year it held ten others,-both series followed by votes of confidence in the Briand Ministry. On Jamuary 26,1917 , another secret session was held to diseuss affairs in Greece, and upon the 28th a new vote of confidence was given to the Briand Ministry. Tpon the 14th of March, 1917, the Chamber in secret session diseussed an interpellation upon the aireraft service; and as a result of an incident following this session, General Lyautey, Minister of War, resigned. This resignation finally brought about the fall of the Briand Cabinet. Similarly, the Senate held seeret sessions, interpellating the Government upon its eonduct of the war. Neither assembly emitted votes of confidence within their so-called seeret committees; they were always voted upon in public session..$^{23}$

On the part of the executive, an attempt was made by the Briand Ministry on the 14th of December, 1916, to arrogate distinctly legislative powers. The project of law laid before the Chamber at that time would give it power virtually to legislate by decree. Promptness, it was urged, necessitated immediate action which the slow processes of legislation could not give. This suggestion raised such a storm of protest, howerer, that the bill was not pressed, although the Chamber, upon agreement with the Ministry, enacted a law providing for emergency legislation. The bill stipulated that in time of war the Govermment might introduce a law with a declaration that its enactnent was immediately neces-

${ }^{23}$ L'Evere de Guere du Purlemont, 46-61. 
sary. The Chamber then fixed the maximum delay, at the most not to exceed five days after the "deposit" of the project, in which it must be discussed. ${ }^{24}$

Aside from the extratolinary powers exercised by the Govermment moler the rights granted by the deelaration of the State of Sicge, the Chambers have suffered a diminution of control in only one respect. Ordinarily one of the most sweeping and detailed methods of eontrol over the Government has been by the anmual voting of the budget. By the discussion of the different ministerial requests, by refusing to rote certain items, ete., the Chambers could virtually dictate Government polieies. But during the war no regular budget was voted, and the Chambers merely granted en bloc the eredits whieh the Government asked. This was done by what is known as the douzièmes provisoires. The financial year in France eommenees the 1st of Jamnary and ends the 31 st of December. This requires that the budget, in peace time, he roted and promulgated not later than December 31st. Int it frequently happens that Parliament does not vote the budget by that time, although withont it, the Govermment cannot raise taxes or pay expenses. To overcome this diffeulty, it has beeome eustomary to grant the Government provisional authority to raise taxes and make expenditures neeessary to the operation of the publie services during a period of one, two or three months, as the ease may be. (As the amount of this expense is estimated by the month, or by

"Discussion upon the bill is limited to the rapportcur of the commission and to a speaker chosen by the minority of the commission, exeejt when a Minister speaks. Upon amemlments only the ciovermment, the presilent and the rapporteur of the commission and the anthor of the amemlment may speak. Unuler no eireumstance ean an orator other than those of the Government or of the commission have the fhor more than onee every quarter of an lour. Duguit, op. cit., $436,515$. 


\section{CONTEMPORARY FRENCII POLITICS}

a twelfth of the year's total, the system is ealled the douzièmes provisoires.) This system was employed during the war, credits being granted every three months. An anmual budget was impossible because no one knew what war expenditures, ete., would be. But it resulted that Parliament, in not debating and voting the budget chapter by chapter as was its previous practice, lost one of its most effective means of ministerial control. The end of the war and the possibility of again aecurately estimating neeessary expenditures will undoubtedly bring back the old system.

Taken as a whole, through the systems of interpellation, permanent sessions, the war eommissions and the seeret committees, the Chamber of Deputies as well as the Senate, has increased its power over the exeentive branch of the govermment during the last five years. Such an increase is opposed to the evolution of exeeutive power which war activities elsewhere produced. Ordinarily, increased legislative power may be considered a sure defense against those who might overturn the Government for personal interests. But in the French Chamber, whose power is based on changing, independent, and even rebellious groups, many regard reeent events as a sign of inereased impoteney of the French executive and a tyrannieal usurpation of legislative authority.

The importance of the intrusion which the French Parliament has theoretically made into the provinee of executive power may, however, be exagrgerited. The fact yet remains that the personal equation in French politics may still override the processes of parliamentary machinery. As long as the French party system contimes as it is, political leaders, who naturally ocenpy Cahinet positions, will always enjoy greater personal in- 


\section{PARTIES ANI PARLIALIENT'}

fluence than in countries where party discipline mechanieally organizes and directs party activity. The influence which M. Clemenceau maintained over the French Chamber during a time when public opinion was severely eritieal was extraordinary. In debates on ministerial polieies, such as the censorship, which when considered individually different parliamentary groups had roundly condemned, M. Clemenceau won sweeping majorities. $^{25}$

This inconsistency illustrates a weakness in the present system of parliamentary government: Parliament often refuses to press an isolated reform in the face of ministerial opposition if it believes that a Ministry whose eontinuance in power is necessary for the solution of more important problems, will resign on account of its passage. In the ease of the Clemenceau Ministry, there is little question that a majority of the Chamber opposed the maintenance of the state of siege and the censorship during the armistice, the prohibition of importations, and even the Government's reconstruction poliey. But the primordial necessity which faced Parliament was the belief that Clemeneeau and no one else could secure a peace settlement which would guarantee France against future invasion. Consequently, when the Prime Minister appeared before the Chamber and made any consideration of Government policies to which the Chamber objected, a matter of confidence upon which the Ministry wonld resign if the Chamber voted against it, eomplaints were hushed up or parliamentary grumblings vented on lobby walls.

${ }_{25}^{25}$ This statement is somewhat inconsistent with that made in the first of this chapter ju regard to Parliamentary domination. But the lack of party discijline allows dominant personalities to gain an ascendancy whili $f^{2}$ a a time may offset gromp control. 


\section{CONTEMPORARY FRENCH POLITICS}

From another standpoint, the personal element in the French political situation prevents an undue arrogance of parliamentary power. In England and in the United States, parties are nationalized. The organization of each party supports candidates, often with no expense to themselves, with the aid of a vast machinery and upon a party platform. It is not for the eandidate so much as the principles for which the candidate stands, that ballots are cast; he is a brick in the wall for which his party supplies the mortar. In France, on the contrary, party organizations do not have the inherent strength or the discipline to select a candidate or to provide him with the support necessary for his election. A French eandidate is largely dependent upon his immediate constituency for his election and continuance in office. Upon their favor he stands or falls, msupported by the backing which American or British parties afford their representatives. As a result, French elections usually turn upon personalities; and a Freneh Deputy, and even a Senator, continually keeps his ear to the ground in an endeavor to follow the opinions of those upon whom his reëlection is dependent. A desire for reëlection is as keen among Frenchmen as it is among Amerieans. Their utter dependence upon their political constitnencies keeps their parliamentary activities within hounds established by public opinion. 


\section{CHAP'TER ITI}

THE "BLOC" AND THE SACRED UNION

La Franee sera héroïquement défendue par tous ses fils, dont ricn ue brisera devant l'ennemi l'union sterée.-

Raymond polncaré.

As pointed out in the last clapter, the large number of political groupings in the Chamber necessitates their frequent, though often temporary, combination in order to assure and maintain a ministerial majority. $A$ discussion of past combinations and of the complete union of political parties which the war exacted, may indieate the efforts which have been made to improve and facilitate the processes of French party govermment.

After the elections of 1885 there were three general groupings in the Chambers,-the Conservatives, the Republicans (Opportunists), and the Radicals (Intransigeants). As no one of the three was capable of mustering a majority alone, combinations became necessary. When the two Republiean groups, the Opportunists and the Intransigeants, united their efforts to offset the Conservative or Monarchist group, surh a eombination was known as "Republican concentration." When one of the Republican groups united with the gromp of the Right, it became known as a mion of "parification." Until 1898 parliamentary grovernment was generally car- 
ried on by the two policies or expedients of "coneentration" or "pacification."

The first "Concentration Cabinet" was formed by IIenri Brisson, a Radical, in April, 1885. It contained elements from all the Moderate and Radical groups,despite the hatred which already showed itself between the Union des Gauches, led by Gambetta and Ferry, and the Radicals properly so-ealled. The Rouvier Ministry, formed in 1887, was the first "Pacification Ministry." In the following years, attempts were made to form exclusively party cabinets, but without suceess until the Bourgeois Ministry of 1895-1896 came into power upon a purely Radical platform of social and financial reform. Foreed to resign because of its policy in Madagascar, in turn it was suceeded by a nearly lomogeneous cabinet of Moderate Republicans nnder Méline. These instances aroused the hope that France might at last settle down to a stable system of two-party government. But this belief, partly founded on the elimination of the Monarehist-Clerieal element from all serious participation in the Government after its disereditable support of General Boulanger, was in the end thwarted hy this very element itself. The Dreyfus ${ }^{1}$ ease, reawakening a fear of clericalism, resulted in the fusion of the gromps of the Left in the famous Bloc. ${ }^{2}$ The elections of 1898 returned about 250 deputies divided among the Radirals, the Radiral Sorialists, and the Socialists. With

sine 1. 29 .

"The name of the Ploc is sibit to have been invented by Clemencealu in 1891. A play, by the name of Thermidor, written hy Sardou, in whin Rohespierre played the leal, was forbidden, aiter one performance at the comedie Francase. M. Clemeneean mpheld this suppression of the play in Parliament, saying, "The First Revolution is a 'hloc,' which you must take or leave.' 'Tle name still lives in French polities. See Jerroll, Fronee To dat!., loi:3, note. 


\section{TIIE "PI,OC" AND TIIE SACRED WNION}

the aid of the Liberal Republirans (who soon formed the Democratic Republican Alliance) these groups effeeted an alliance whieh controlled the fovermment at least until 1906. Originally under the leadership of Waldeek-Roussean, President of the Counril from 1899 to 1902 , this $13 l o c$ acemplished the separation of the Chureh and State by passing the Associations law of 1901, and hy abrogating the Concordat in 1905, which in turn was supplemented by the law of 1907 .

The policy of the Bloc was vindieated in the elections of April, 1902, when 321 adherents were returned, the opposition electing only 268. It was in this year that the line between Conservatism, represented by the Monarchists, Nationalists, and Liberal Catholies, Progressism, represented by the remnants of the Moderate Left of the Assembly of 1871, and a portion of the Republiean Union which followed Gambetta, and Reformism, represented by the Radicals and Radieal Socialists, the Demoeratic Republican Alliance and the independent Socialists,-became clearly drawn. Reformism constituted the Bloc; while Conservatism and Progressism were its deadly enemies.

The Bloc maintained a govermment of the Left through the Ministry of Emile Combes, a Radical (19021905), through the Ronvier Ministry (1905-1906), and throngh the Sarrien Ministry, which came to power in March, 1906. The program adopted by the Socialist Congress at Amsterdam in 1904 caused the Radicals to fear that the Socialists might be obliged to withdraw from the Bloc. But althongh they officially refused to allow their members to become cabinet ministers, and even to eöperate with reformist parties, in reality, under the leadership of Janlès, they supported Radical measures of reform. The election of 1906 increased the 


\section{CONTEMIPORARY FRENCII POLITICS}

combined power of the Left, its seats rising to 375 ; the Progressists were reduced one half, while the Reactionaries maintained their numbers. The entire Right was able to muster only 140 votes.

In October, 1906, Georges Clemencean took over the leadership of the Sarrien Ministry. IIe was himself responsible for the first real break in the Bloc. Of a dictatorial and independent character, he relied upon the Radicals alone; and althongh his achievements were reformist, they were apparently accomplished without seeking the active coopperation either of the Republicans of the Alliance or of the Socialists. In fact, the first event of the new Minister's reign was his acrimonious debate with Jaurès upon Socialism in the Chamber. $\mathrm{He}$ further antagonized the Socialists by refusing to allow Govermment officials to form syndicates and adhere to the General Confederation of Labor. ${ }^{3}$ Likewise, the wholesale discharge of the postal employees (who struck in Mareh, 1909) offended the labor vote. 'The Briand Ministry, coming into power in 1909, included, in addition to the Premier, men of distinetly socialistic tenden(ies. In spite of this fact, they nevertheless came in conflict with the Unified Socialists. This became apparent as the result of the Government's action in suppressing a nation-wide railway strike in the antumn of 1910, by mohilizing the employees subject to military service, and making them operate the roads moler a military régime. Opposition from the Socialists was so intense that in 1911 Briand was foreed to resign.

In 1910 the Dreyfus incident had become ancient history, and the questions of anticleriealism and the reorganization of the army had been solved to the satis-

\footnotetext{
sice p. 350.
} 


\section{TIIE "BLOC" AND TIIE SACRED UNION}

faction of the Radicals. 'The purposes for which the Bloc had been formed had thus been achieved, white new issues were arising, such as the incone tax, proportional representation, and militarism, upon which not only the parties of the Bloc but divisions in them could not agree. Moreover, the members of the Democratic Republican Allianee felt that the anticlerical movement had now gone far enough and that a policy of conciliation should be undertaken. This attitude was especially objectionable to the Combists of the Radiral party, who believed that their future suceesses depended upon the maintenance of elerical issues. There were thus many reasons for the disintegration of the Bloc when the elections of April-May, 1910, divided it further. The new Chamber was composed as follows: Right, 19; Liberal Aetion, 34; Progressists, 76 ; Democratic Left, 73 ; Radieal Left, 112; Radical Socialists, 149; Independent Soeialists, 30 ; Unified Socialists, 75 ; Independents, 20.

The Ministry of Joseph Caillaux, which came to power in 1911, did much to discredit the Radical party with the eountry and to shake its eonfidence in the old Blocnow fast disappearing so far as it represented any eommon feeling between the parties of the Left. Caillaux, having defeated Clemencean for the Radical learleship, aimed to follow a policy of parification toward Germany. We also stood for the maintenance of the two-year military service law, adopted by the Ronvier Ministry, in place of the old three-year service law, a measure which those who feared German armament were now trying to reënact. The questionable financial dealiness of M. Caillanx, especially his speculations on the Bourse, com-

* Election figures for 1910 vary greatly aroorling to somrees. The above are taken from the Animal licfister (Iomiton) for 1910, 259. 


\section{CONTEMPORARY FRENCH POLITICS}

pleted the formidable list of eharges against him, resulting in the downfall of his Ministry and the retirement of the Radical party from power. On January 13, 1912, M. Raymond Poinearé became President of the Council. A member of the Democratic Republican Allianee, he brought into being a cabinet of moderate tentencies. By this time not only the homogeneity but the numerical foree of the Bloc had been overcome, and new grompings and combinations were in the process of formation.

\section{II}

Before diseussing the new groupings, however, the interior relations of the members of the $B l o c$ must be reviewed in order to understand to what extent they were willing to bring about real party combinations.

This Bloc had actually been formed in 1901 at the first Congress of the Radieal and Radieal Socialist party, where a union between all Socialists was organized, and where the slogan, Pas d'ennemis à gauche, was adopted, and indeed eontinued as a party motto until very reeent times.

Thus in the Radical Congress of 1904, M. Debierre secured the adoption of a motion affirming "the neeessity of alliances with other parties of the Left . . . during the eleetions." 5 None the less he asserted the complete independence of the Radical program. This motion showed that the contemplated alliances were not to be considered as fusions, but merely as opportunistic combinations. The French electoral system lent itself quite readily to such temporary junctures. Elections to the Chamber are decided by an absolute majority vote.

\footnotetext{
"Quoted in Charpentier, Le Parti Radical et Radical-Socialiste, 428.
} 


\section{TIIE "BLOC" AND TIIE SACRLD UNION}

If no canclidate received a majority of all the votes wast, a supplementary alection must be leeld two weeks later at which the same candidates may present themselves and where their fate is decided by a simple plurality. Now under this system, every party ustally ran a eandielate in every arrondissement during the first balloting. In case no party eandidate received a majority, combinations between parties for the second election were ordinarily effected. It was by this method that the Bloc seemred the return of its eandidates, Radieals voting with Socialists or with Alliance Republicans upon the seeond ballot.

Despite the decision taken at Amsterdam, the Radieals did not give np the hope of Soeialist support. ${ }^{7}$

However, the antipatriotic preaching of Gustave Herve, actually urging soldiers to desert, caused the Congress of Radicals held at Naney in 1907 to declare that although the Bloc must continue, the members of the party wonld refuse "their votes to any eandidate who adroeates the disorganization of the armies of the Republic, either by desertion in time of peace, or by insurrection and the general strikes in the face of the eneny. ..."s

This motion was a direct attack upon the entire Socialist party program because at its Congress of Limoges in November, 1906, it had voted to prevent the outbreak of war "by every means, from parliamentary intervention, public agitation, and popular manifestations, to the ganeral workingmen's strike and insurreetion." g But the Radical Congress held at Dijon in 1908, while

'This system has been changed by the Electoral law of 1919 . See 1). 16.5-169.

${ }^{\top}$ See Charpentier, op. cit., 430.

${ }^{8}$ Ibid., 432.

- Alexamlre Zévaès, Le Parti Socialiste Unifié ct La Gucre, 13. 


\section{CONTEMPORARY FRENCII POLITICS}

repudiating any alliances with the progressist or liberal parties, declared "itself ready to reconstruct the old Bloc of the Left in order to realize social and economic reforms." This olive branch not being accepted by the Socialists (whose Marxist tendeneies, on the eontrary, continued to develop), the Radicals at the Congress of Nîmes (1911) deeided to postpone the matter of their future relationship) with them for a year. This decision was taken in order to conciliate and eompromise the element who wished to repudiate all relations with the Socialist party (when the latter had refused to vote conficlesee in the Monis Government, simply because it was a "bourgeois" government). Many Radicals, however, still felt the necessity of Socialist coöperation. Thus, while the rupture between the Radicals and the Socialists was not quite complete, the hearty understanding existing between the two parties in 1901 certainly continued no longer in 1911.

The union between the Democratic Republican Alliance and the Radicals, which eonstituted the other part of the Bloc, experienced a similar crolution. Between 1901 and 1910, both parties acted in complete accord, and it even appears that until 1911 these liberal Republicans were regarded as the right wing of the Radical party. Consecuently the definite constitution of a Democratic Repullican party hy the Alliance in 1911 somewhat antagenized the Radicals, especially as many of them belonged hoth to the Alliance and to their own barty at the same time. Noreover, the Radicals in 1910 had formally disapproved these domble affiliations and at the congress in honen it was decided that the reabtionary peril having been removed, ach party should dovote itself to its own oromization and platform. The Alliance received the decision that Radicals could no 


\section{THE "BIOC" AND TIIE SACRED INISN}

longer be affiliated with their organization with some resentment, which later led to a complete separation of the two.

Lastly, the Republican Socialists did not maintain wholly cordial relationships with the Raditals, although before 1911 they acted in eoöperation with them and formed part of the Bloc. At a eongress of the party held in Tonlouse in 1911, the Radicals were declared to be solely a party of anticleriealism; while the Unified Soeialists were condemned as exponents of direct action and antimilitarism, neither of which the Republican Socialists could support. In Jume, 1912, when the Radicals attempted to form an alliance with the Republican Socialists in the Paris municipal eleetions, the later replied that while they would support the Rarlieal clerical program, they exclusively reserved entire freedom upon all other questions.

\section{I}

Such were the respective attitudes of the parties of the Left at the time of the areession of the Poincare Ministry in 1912. Although it was a Moderate Ministry, it eontained such Radicals as Léon Bourgeois, Pams and Steeg upon it. Despite this the Ratical Congress at Tours, October, 1912, expressed a deep resentment toward the Democratic Alliance of which M. Poincaré was a nember, acensing it of voting for elerical candidates in the Chateandun, Apt, and Iaut-Rhin. ${ }^{10}$ Meanwhile Aristide Briand was urging the policy of pacification towards the Chureh and the mion of the moderate

1o See Dousième Congris alu Parti Républicain, Radical ct Radical-Socialiste, Tours, hrochure, 21. 


\section{CONTEMPORARY FRENCH POLITICS}

elements into a single party. His efforts were also repudiated by the Congress of Tours which condemned what it termed "an intolerable policy of pacification." Upon the election to the Presidency of Raymond Poinearé over Jules Pams, the Radical candidate, M. Briand, a bitter opponent of the Radicals, was made Premier. At his fall upon the issue of electoral reform in March, 1913, another Republican of the Alliance succeeded him, Louis Barthou. Thus three successive ministries were headed by anti-Radical men. M. Barthon's Cabinet was especially attacked by the Radicals because it contained a Progressist Republican, Mr. Thierry. When Charles Dumont, one of the vice-presidents of the Radical party bureau, was asked to join the Barthou Ministry, the officers of the Executive Committee vigorously protested against Radical participation in any other but a strictly Left Ministry.

Beginning with the Poincaré Cabinet and continuing through the Barthou Ministry, there was a movement to unite all the moderate elements of the Chamber in order to appease certain antagonistic elements in the Republic, especially the Catholics. One of these attempts was known as the Entente Démocratique et Sociale, organized in the Chamber by M. Maginot, with the object of combining the deputies in a "Center group," completely independent of other political combinations. This group later eame to be known as the Centre Gauche, and included members of both the Radical and Independent Socialist parties. This grouping soon was vigorously attacked by the Executive Committee of the Radical party ; and as the result of a letter written on the 18th of June, 1913, it suceeeded in securing the withdrawal of right Rarlicals from this combination.

Both of these developments, i.e., Radical participa- 


\section{TIIE "BLOC" AND 'TIIE SACRED) UNION}

tion in a Cabinet which inchuded a Progressist liepublican and Radical adlerence to a group hased upon a policy of conciliation, were condemned by the Congress of Pau, in Oetober, 1913, as throwing the Republic back into the hands of the Clericals. The fundamental importance in a democracy of "distinct parties, conflicting in their ideas, opposing program to program," was emphasized. ${ }^{11}$

The month following the Congress (in December, 1913), M. Aristide Briand, in a famous speech at St. Etienne, proclaimed the necessity of a Republiean entente. He protested against socialistic attempts at revolution, strongly attacking the Radicals; he pleaded for reconciliation with the Catholies; he urged proportional representation and the three-year military law; and, finally, he denounced Joseph Caillaux in no uncertain terms.

It was about this same time that the Radieals, who now were called the "Unified Radicals," were able to win control of the Ministry, Senator Doumergue becoming its head. This Cabinet was pledged to earry ont the Pau program which ealled for (1) the repeal of the three-year law which the Bartlon Cabinet had enaeted; (2) "laic defense," or further legislation to drive Catholic schools out of France; (3) an income tax. The Cabinet, however, was very opportunist; Senator Doumergue supported the three-year law and did virtually nothing with respect to laie defense; no agreement could be reached with the Senate over the inclusion of rentes in the income tax; and as Senator Clemenceau was hostile to proportional representation on the grounds that it would increase Catholie power, the party made no

"Troizième Conarìs du l'arti Républicain, liadical et RadicalSocialiste, l'au, 1913, brochure, 357. 


\section{CONTEMIPORARY FRENCII POLITICS}

progress with electoral reform. Finally, the activities of M. Caillanx, Minister of Finance and the acknowledged leader of the Radicals, at last became openly disseputable. He was aecused of using his position not only to favor foreign banks in which he was interested, but also to forward his speculations on the Bourse. In addition, he was accused of obstructing the course of justice in the Rochette case, that of a notorious swindle involving Mexican railway stock. These factors increased hostility to the Radicals and also the demand for a great Republican and Moderate party. This demand finally eulminated in the formation of a gromp called the Federated Parties of the Left, or simply, the Federation of the Left, upon January 14, 1914.

This group was composed of 124 members, including MII. Barthou, Baudin, Millerand, Klotz, and Bérenger. Naturally, M. Briand was its president. It included most of the "Centrist" elements, a few Radirals, and some independent Socialists. It announced a program of labor and social legislation, of parliamentary reform, and of eonciliation with the Church. It denounced the Radicals for their equivocal attitude in officially protesting against the three-year law and then, when in power, of supporting it. It also criticized the ragueness of their social reform program, and their eternal pleading for "liberty" in contrast to their severe oppression of the Church.

Against the Federation of the Ieft, then, stood the Unified Radieals and the Unified Socialists. This was the last stage of party evolution before the outbreak of the war. Meanwhile, Jean Jamrès was manfully trying to swing the Socialists back into line, and to bring about a mion of the Radicals and the Soeialists. Such a restoration of the old Bloc would mean the con- 


\section{THE "BLOC" AND THE SACREJ) UNION}

trol of the Chamber by the Left-withont the help of the Federation of the Left-which was the bitter enemy of both Unified parties. At the Socialist Congress of Amiens, held in the latter part of Jannary, 1914, Jaurès urged that upon second ballots, Sorialists should coöperate with Radicals. In order to avoid the appearance of too flagrantly violating their eherished principles, he introduced a carefully worded resolution which reaffirmed the absolute murillingness of the Socialist party to enter any alliance with a bourgeois party, but which suggested that upon seeond ballots Socialist voters might support "the cantidates of other parties who most elearly and rigorously combat the three-year law, war, chauvinism, and the military-elerical combination." As this could obviously mean none other than the Caillaux Radicals, the motion met with the greatest opposition from such leaders as Allemane, Chanvin, Negre, and Le Gléo, who sairl that "the resolution voted at the International Congress of Amsterelam which forbarde Socialists of all nations to form agreements, eoalitions or ententes with bourgeois political parties, has been trodden under foot by the majority of the Soeialist party. The majority has hypocritically conchuded an illegal alliance with the most despicable and the most eriminal of all political parties, the Radical party." Upon the adoption of the Jaures motion, under the leadership of Allemane, these protestants withdrew and attempted to form a Labor party, an attempt, however, which proved unsuceessful, and the break was soon mended.

The ensuing provisional union between the two Unified parties, and the purely pacific program of both resulted in the return of a Chamber strongly Left in its tendencies as the result of the elections of the spring of 


\section{CONTEMPORARY FRENCH POLITICS}

1914. ${ }^{12}$ The Unified Radieals and the Unified Soeialists, as we noted in the last ehapter, were strong enough to drive the Ribot Ministry ont of power, Jume 12, 1914, because it supported the three-year law. In the Cabinet of Viviani, who was a Republican Socialist, which followed, the names of five Unified Radicals appeared; but, in keeping with their policy, no Unified Soeialists were inchuded. Following the decision of the Viviani Government to support the three-year law, the Unified Socialists withdrew their support, and the Government was maintained by purely bourgeois parties.

Amidst the growing signs of a eonflict with Germany, a congress of the Unified Soeialists, held on the 16th of July, 1914, adopted the following motion:

12 The results of the 1914 elections were as follows:

Republican Demoeratic Allianee ........ 1,564,578

Unified Radicals ................... 1,496,058

Ferleration of the Left . . . . . . . . . .

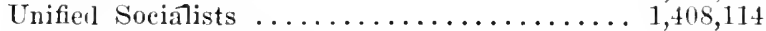

Right and Liberal Action . . . . . . . . . 1,297,712

Republican Ferteration ............. 810,679

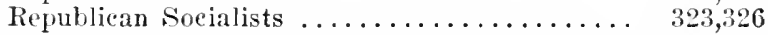

In the Chamber, the groups presented this composition (these figures differ accorting to sourees; but those given below seem to be the average).

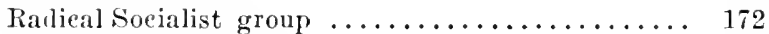

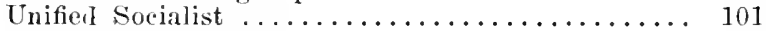

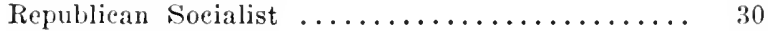

Liberal Action .................... 32

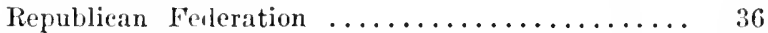

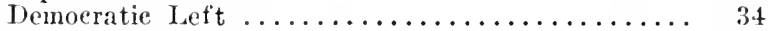

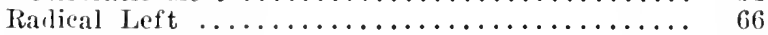

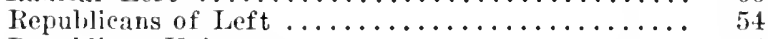

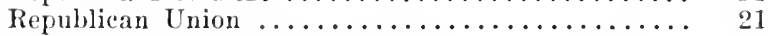

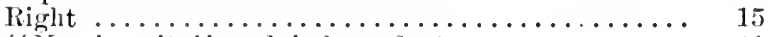

"Non-inserits", and independents .......... 41

602

It will be noted that tho Federation of the Left maintained no listinet parliamentary group.

About seventy Radicals wero also to bo found divided among other groups. 


\section{THE "IBLOC" AND TIIE SACRED UNION}

Among all means employed to forestall and prevent war and to impose npon governments a recourse to arbitration, the Congress considers as particularly effective the methor of a general fabor strike simultaneously and internationally organized in the interested conntries.

In addition to its oft-repeated refusals to vote appropriations, especially war credits, for a bourgeois government, and to aet in collaboration with the Ministry of such a government, the party now reiterated its theat of a general strike in the face of imminent hostilities. It was with considerable misgiving, therefore, that the patriotic elements of the country saw war being forced upon them; and it was doubtless with considerable encouragement that Germany pushed her preparatory noves.

\section{IV}

On the 3rd of August, 1914, Germany declared war on France; and on the 4th of August, the Parliament was assembled in extraordinary session. In the Chamber of Deputies, M. P'aul Deschanel pronounced a eulogy upon Jean Jaurès who had been assassinated upon the 31st of .July. ${ }^{13}$ From the grave of the man," he said, "who has perished, a martyr to his ideas, rises a thought of union; from his clay-cold lips rises a ery of hope for the fatherland, for justice, for the human conscience. Is this not the most worthy homage we can render him?", It was on the same day that MI. Poineare, President of the Republie, issued his famous call for mity in the face of danger: "France," he wrote, "will be heroically

${ }^{13}$ For a short diseussion of the life and work of this great socialist leader, see Ican Jaurs, with a preface by Pierre Renaudel, puhlished in "Le Fait de la simaine" series. 
defended by all of her sons, united in the Sacred Union which nothing can break. They will stand before the enemy, bound together by a common indignation and in a common political faith.",

The members of the Socialist party, joining with every other group in the Chamber, unanimously voted to accept the eighteen projects of law which the Government considered necessary to meet the circumstances. The Unified Socialists approved the eredits requested by the Government. They moreover unanimously voted to declare the State of Siege, and for a law restraining the liberty of the press. Three weeks later the Viviani Cabinet was enlarged to include, not only representatives of all parties (except the Right), but the most fiery opponents of ministerial participation among the Unified Socialists,-Jules Guesde and Mareel Sembat. Thus France saw the Socialist party in this hour of national peril deserting all the principles of "bourgeois" opposition, laid down in the Congress of Amsterdam, to become completely identified with the Saered Union, upon which the safety of France now depended.

Yet even in the face of this erisis the Soeialists attempted to explain the abandonment of their Marxian tenets in a declaration published on August 28, 1914, which read as follows:

\section{Citizens,}

As the consequence of a mature deliberation and after a deeision earefully arrived at, the Socialist party las authorized two of its menbers, our comrades, Jules Guesde and Marcel Sembat, to form part of the new govermment; and it has made them its delegates in the work of national defense. Every representative of the Socialist group in Parliment ... has anreed to assume with them the grave responsibilities which they have consented to midertake.

If it were only a question of readjustment within the 


\section{TIIE "BLOC" AND TIIE SACRED INION}

Ministry, if it were only a question of contributing to an old government some of the forces in which our party is so rich; even more, if it were only a question of ordinary partieipation in a bonrgeois government, neither the eonsent of our friends or of omrselves wonld have been obtained.

It is, however, the future of the nation, the life of France which is the question to-day. The party has not hesitated. . ...

In these words the party justified its collaboration in a Ministry of the bourgeoisie, and for the first time sinee the organization of the party in 1905, permitted a nember of the Unified Socialists to serve on such a Ministry.

Of the sincerity of the patriotism shown by the other groups there was no question. The German peril beeame infinitely more near and real than Monarehism, Clericalism or Combism. Every element united in the national defense; the union of Freneh politieal antagonisms proved a possibility when the welding foree, exercised from without, was of sufficient strength. The spectacle was now afforded of $\mathrm{M}$. Ribot working side by side with the Soeialists who had just turned out his Ministry, and of M. Guesde onee more eoöperating with his former bitterest enemies-Millerand, Viviani, and Briand-whose "heresy" had excluded them from the Socialist party.

Outside of Parliament, the same transformation united every effort in the national defense. Even Gustave Hervé exhibited a most remarkable change of heart. Originally the most rabid antimilitarist among the Socialists, a preacher of desertion and of sabotage, he now freely offered himself for enlistment in the army. Upon January 1, 1916 , he changed the name of his formerly revolutionary paper, La Gucrre sociale to La Victoire, 
and while carrying on an ardent campaign of criticism - exposing defects in the military administration-his policy was adopted solely for the purpose of better assuring victory. As a climax to his reformation he finally became so nationalistic that he was at last read out of the Socialist party! The General Confederation of Labor, likewise, urged its arlherents (nearly a million) to fight and overcome German imperialism, as the first essential step in the achievement of social democraey. Among clerical circles, thousands of members of the excluded religious orders hurried back to France and entered the army; equally large numbers of priests joined its ranks either as chaplains or eombatants.

In January, 1915, the Socialists in the Chamber-who had previously nominated a separate list of candidates for the presiding officers of the Chamber-decided to do away with this practice and unite with the other groups in an almost unanimous reëlection of M. Deschanel as President. Well might the President, in his inaugural address, enlarge upon the Sacred Union and praise the willingness of all parties to forget political antagonism in the face of a common danger! The Briand Cabinet, formed on the 29th of October, 1915, even more foreefully acknowledged the strength of this Union, for out of its twenty-two Ministers, eight were former Prime Ministers: Dommorgue, Ribot, Viviani, Combes, Bourgeois, Freycinet and Méline, representing widely different shades of politioal opinion. One member rame from the irreconcilable Right (I)enys Cochin); a Socialist Minister of State (Jules Gueste), and another Socialist, as Minister of Munitions (Albert Thomas), completed a ministerial eombination the like of which had never been thought possible in France. 


\section{THE "BLOC" AND TIIE SACRED UNION}

\section{V}

While these adjustments were taking plaee, certain Socialist elements, secretly clinging to the old Marxist theory of the "inherent class struggle," and convinced that the war was eaused as much by French as by German capitalistic exploitation, were beginning to chafe under the bonds of the Union. Fresl courage was given this group by the widespread depression which German suecesses brought to French morale. The Unified Socialist Federation of the IIante-Vieme in May, 1915, passed a resolution-now famous-addressed to all the federations of the party, announcing what purported to be "its eriterion and its judgment upon present events." The language of this resolution, very moderate in comparison with those which followed, reproached certain members of the party for writing chanvinistic articles, and proposed that the Socialists keep a reeeptive ear open for "any propositions of peace, from wherever it may eome." The federations of the Isère and of the Rhone approved the resolution of the Haute-Viemne; and a very strong minority in the federation of the Seine, led by Jean Longuet, the grandson of Karl Marx, also adhered to its program. ${ }^{14}$ This resolution marked the birth of the first division in the Socialist party, the first sign of a tendency which step by step caused its withdrawal from the Sacred Union. The majoritaires of the party, i.e., those who held a majority in the Socialist group in Parliament, opposed the Haute-Vienne motion. They attempted to conciliate the national duty with the

"At a congress of the Feleration, December 19, 1915, the Renaudel-Fiancette motion received 6,000 votes; while the Longuet motion received 4,000 . 


\section{CONTEMPORARY FRENCH POLITICS}

care of international labor interests, and they believed that Germany was completely responsible for the war. IIoreover, they did not believe in the opening of international negotiations with the enemy Socialists until the war had ended, and they even opposed a discussion of peace terms until victory had been won. To insure this victory, the majoritaires believed in Socialist participation in the Govermment and in the voting of credits. The leaders of this section of the Socialists were Albert Thomas, Alexandre Varenne, and Compère-Morel.

In opposition to the majoritaires, the minoritaires arose, led by Jean Longnet, Mistral, Mayéras, and Pressemanne, who were the original supporters of the HauteVienne motion. ${ }^{15}$ Although they still supported the prosecution of the war, they began little by little to question its enemy origin, attributing it to universal capitalism. They more and more insistently stigmatized the "imperialism" of the Entente, and began to demand a declaration of Peace Aims which should define the Allies' exact position. Between these two major divisions of rather indefinite principles a small Centrist group arose, attempting to conciliate both extremes. This group was led by Marcel Cachin, Pierre Renandel, and Mareel Sembat. Of these, Cachin was of undoubtedly minoritaire sympathies, while Renaudel represented the majoritaire bent (although, because of his editorship of L'IImanite, the official Socialist newspaper, he attempted to remain neutral).

In July, 1915, at a meeting of the National Comeil, the majoritaires showed their preponderating desire for

\footnotetext{
${ }^{15}$ 'The dissident movement started by the Hante-Vienne feleration was supported by the limousin Deputios, whose Sorialist constituents had heen turned against the Government because of a number of military executions.
} 


\section{TIIE "BLOC" ANI TIIE SACRED UNION}

the continnance of the war-a determination which was voted for by an overwhelming majority. In Septronber, however, another split ocenred in the party of even more extremism than that ansed by the minoritaires. This element, bolder and perhaps more honest than the latter, condemned appitalism outright as the cause of the war, affirming that it was waged in the interest of eapitalist oppression of Labor. Pure Marxists, the adherents of this group urged the immediate opening of negotiations with the enemy Socialists to the end of stopping the war by the hitherto unsuceessful international strike, a means which now meant a refusal longer to bear arms. To this clement the "class struggle" was still the fundamental issue which the war, far from belying its truth or postponing its application, had em. phasized.

From the 5th to the 9th of September, 1915, at Zimmerwald, in Switzerland, this extremist element of the French Socialist party met representatives of the Italian, Rommanian, Bulgarian, German, Swedish, Norwegian, Swiss, Polish, Duteh, and Russian Socialists. They agreed to a manifesto addressed to the "Proletariat of All Nations" condemning the war, demanting an immediate peace, and proclaming that the "national defense is not socialistic." MII. Bourderon and Merrheim signed this declaration as representatives of the French Socialists. But at the Christmas Congress of the Unified party in France (toward the end of 1915), the Zimmerwald program and the German proposals for peace were voted down by the overwhelming majority of 2,736 against 76 - the majoritaires thus again exhibiting their supremacy. But what the minoritaics, particularly the extreme element who had attended the Zimmerwald conference, lacked in numbers, they made 


\section{CONTEMPORARY FRENCII POLITICS}

up in enthusiasm. In the latter part of April, 1916, a second "International Congress" was held at Kienthal, another little town in Switzerland. Forty delegates attended this congress, chiefly from the official Italian Socialist party, and from the Swiss and Russian parties. Two German representatives, one of whom was the editor of Vorwärts, were present. The French Socialists were represented by three Deputies-MII. Blanc, Brizon and Raffin-Dugens. Their attendance indeed was a remarkably bold act because of the official position they held in a Parliament charged with the prosecution of the war. The Kienthal meeting emphasized the program adopted at the meeting of the previous autumn. Thereafter, the three French Deputies systematically voted against all war credits, and upon the 22nd of September, 1916, Raffin-Dugens aggravated this attitude and created a sensation in the Chamber by speaking of "his comrades in Germany."

The vigor of this extremist movement, and the force of the agitation which was now being earried on throughout all the Socialist federations, was shown at a meeting of the National Couneil of the party, held on April 9, 1916. Here the minoritaires were able to muster about one third of the votes. Their strength was exhibited in the Longuet-Pressemanne motion to renew international relations with the German Socialists and for the immediate diseussion by the Government of peace terms with Germany ; it was defeated by a vote of 1,996 against 960 . The majority motion, which was finally adopted, eontained many eoncessions to the minority. Although it demanded the liberation of Serbia and of Belgium as the sine qua non of peace, it made no mention of the return of Alsace-Lorraine.

Finally, the motion recommended that the other see100 


\section{THE "BLOC" AND TIIE SACRED UNION}

tions of the International Workingmen's party should frame principles which Sorialism should exact in the peace settlement, and that they should also determine the responsibility for the war's origin.

Concerning the result of this important meeting, Le Droit du Peuple, a minority organ of the Federation of the Isère, said:

Certainly, the result obtained is not that which we had desired. But it must be admitted that the minority is not a negligible quantity since it inchudes a third of the party. The elements which compose it are capable of deploying the greatest energy and of becoming, perhaps sooner than it is generally believed, the majority of the party. ${ }^{10}$

M. Chastenet, the author of these words, was a better prophet than he knew.

Gustave Hervé in La Victoire pointed out the moral of this vote according to his own lights :

The gravest and the sadkest thing about this decision is that the socialism of Zimmerwald which controlled only a handful of rotes three months ago, has this time united a third of the party. This is surely a bad day for the national defense. ${ }^{17}$

Meanwhile, the minoritaires were gradually gaining eontrol of whole federations, espeeially in the industrial centers of France, where assertions of the war's "imperialism," the impossibility of vietory, and the necessity of an immediate peace, were boldly made. The National Congress of the party, held in Paris from the 24 th to the 28th of December, 1916, again resulted in definite minoritaire increases. On a motion whieh expressed eonfidenee in the parliamentary group, and stated "that no aet be done by the gromp which would

\footnotetext{
"Grenoble, issue of April 12, 1916.

17 Issue of A pril 10, 1916.
} 


\section{CONTEIIPORARY FRENCH POLITICS}

result in lindering the national defense," 1,595 favorable votes were cast representing the majoritaire element; 233 votes were east against it, representing the Kienthalian element; but there were 1,104 abstentions, representing the minoritaires. Thus nearly one half (1,337) of the Congress refused directly to anthorize its representatives in Parliament to eontinue their support of the National Defense! At the same convention, Albert Thomas was authorized to eontinue in office as Minister of Munitions in the Briand Cabinet; but his collaboration was to be exercised "under the responsibility of the Administrative Commission of the party." This decision, however, was barely agreed to by a vote of 1,637 against 1,372. Thus it appeared that the Socialist party was on the verge of breaking the Sacred Lnion, and of refusing longer to support the vigorous prosecution of the war.

The rote upon another resolution concerning international relations showed the gravity of the situation. This was a substitute for a Kienthalian motion intended to open the way for negotiations with the German Socialists and for immediate peace "at whatever price." However, the substituted motion provided for erentual negotiations subject to certain conditions. This motion rereived 1,537 votes while 1,407 opposed it. Measured by figures, therefore, the growth of the minoritaires had increased (since the vote in April when they ohtained 960 as against 1,996$)$, to a present voting strength of but a hundred less than the mojorituires. 'This certainly was a remarkable and a disennorting evolution toward the Left. The supremacy of the minoritaires meant that the Sarered Iniom would he shattered and that the party would resume its Amsterdam program even in the fare of forman invasion. 


\section{TIIE "BLOC" AND TIIE SACRED UNION}

In the spring of 1917 the Storkholm agritation arose. Commonly supposed to have been of Russian origin, a movement was undertaken to hold a meeting of all of its sertions, Allied and Germanie, of the Intermational Workingmen's Association. 'The purpose of this gathering was to define terms of peace and to bring an immediate end to the war. All the well-known arguments for such a Conference were out forward: it would prove to both the Russian and German Socialists that the Allies had no imperialistic ambitions, and that as a result, Russia wonld stay in the war, and the German Socialists would resist its molongation. The Allied Governments, however, susperted the conference to be of Germanic origin, and purely defeatist in its purposes. This attitude indeed was taken at first by the Fremeh Socialist party which, at the end of April, 1917, voted not to participate in the Stockholm conference. Ilowever, agitation for participation grew with the gathering strength of the minority element, until on May 28, 1917, the French decision was ehanged and it was derided to go to Stockholm "to define war aims and to prepare for a full mecting of the Internationale." The not illogical refusal of the French Govermment to give passports to this conference naturally angered the Socialists. At its bordeaux Congress, lold in October, 1917, the party (with the remarkable exeeptions of MM. Guesde, Bracke and a few others), was determined to go to Stockholm. This manimity was itself a victory for the Kienthalians, the party now officially recognizing the legitimacy and the value of the artion taken by the few extremists who hat attented the conferences at Zimmerwald and Kienthal in the fall of 1915 and the spring of 1916.

In addition to the Storkholm question, the Congress $10: 3$ 
was again faced with that of ministerial participation. Albert Thomas had continued to be the Socialist representative in the Ribot Ministry, which had succeeded Briand on Mareh 19, 1917. MI. Ribot was foreed to resign on September 10 and his suceessor, Paul Painlevé, a Republican Socialist, also retained Albert Thomas in his Cabinet. But because of the violent criticism of the minoritaires as to the war aims of the Government-as well as to the principle of ministerial participation, he resigned in order to preserve the unity of the party.

In the preceding Ministries (notably those of Viviani, of Briand and of Ribot), the Socialists had been represented. Consequently, the withdrawal of Socialist support from the Government was generally interpreted as the breaking up of the Sacred Union-the return to the Marxian theory of unmitigated opposition to a bourgeois government. Moreover, on account of the loss of the Soeialist support on which his Govermment largely depended, M. Painlevé was forced to resign. He was replaced on November 13, 1917, by M. Georges Clemenceau, a vigorous Radical. Here was a man of different stamp. Aceepting the Socialist challenge, he declared a relentless war on their antipatriotic, maneuversopenly declared as such; and thoroughly antagonistic toward their antipatriotism, and confident in his own powers, he successfully formed a Cabinet without their representation or support! ${ }^{18}$

Thus, so far as the safety of the Saered Union was eoneerned, the Bordeaux Congress made little differenee. The Socialists now found themselves unable to reënter the Govermment even had they chosen so to aet. But the Congress nevertheless voted a majoritaire motion,

\footnotetext{
"For a short account of $M$. Clemenceau's life, see $\Lambda_{\text {puendix }} \mathrm{A}$.
} 


\section{THE "BLOC" AND 'TIE SACRED UNION}

which declared for representation at Stockholm, for support of the war, for voting war aredits, for participation in the Govermment, ${ }^{19}$ and for the revision of Allied war aims. 'This motion was adopted by a vote of 1,552. Another motion, introduced by the minoritaires, was somewhat similar. It expressly favored, however, Socialist adherence to the National Defense only so long as the war continued to be a defensive war. This motion received 831 votes. The third motion, introduced by $\mathrm{M}$. Brizon, representing the Kienthalians, demanded immediate peace and suggested that the Soeialists should refuse to vote war eredits; a motion which received 385 votes. A still more extreme group fostered another motion against war eredits, which received 118 votes. The comparatively strong vote for the majoritaires $(1,552)$, did not necessarily indicate a weakening of the minority ; first, because the former adhered in the latter's demand for the Stockholm Conferenee; seeondly, the minority was really divided between the supporters of the three motions-their total being 1,334 votes.

\section{VI}

After the Bordeaux Congress, the minority carried on an increased agitation against the "imperialism" of the Government. The failure of the Allies to state definitely their war aims and the suceess of the Bolsheviki in Russia, gave the minority some ground for the belief that a bourgeois Govermment could never inangurate a policy leading to democratic peace. In the spring of 1918, the minority organized itself into a definite group, and through the eolumns of Le I'opulaire, edited by its

${ }^{10}$ Subject to certain qualifications. 


\section{CONTEMIPORARY FRENCII POLITIC'S}

leader, Jean Longuet, carried on a systematic campaign for peace. To meet the inereasingly extensive and effectual activities of the minoritaires, the majority started a new paper, La France Libre, the first number appearing in July. Thus the figlit between the two divisions of the Socialist party became more hitter than ever. Victory finally came to Longuet and his following at a meeting of the National Comeil of the party, held on the 29 th and 30 th of July, 1918. The minority, with the assistance of its vanguard, the Kienthalians, was at last able to muster a elear majority of rotes. Upon the Longuet motion asking for a revision of war aims, definite eonditions of peare upon the basis defined by the Russian Revolution, and a determined refusal to vote further military eredits in ease the Government persisted in refusing passports to an international conferenee, 1,544 votes were mustered. The Renaudel majoritaire motion calling in general terms for the maintenance of the war, reeeived only 1,172 votes. To the majority now held by Longuet should be added 152 votes reeeived by a strictly Kienthalian motion, offered by M. Loriot, the new leader of the group. Thus the element in the Soeialist party which demanded the renewal of relations with the German Socialists, a peace which would not necessarily include the return of Alsace anil Lorraine, and which meant the virtual recognition of the Bolsheviki, eame into power. The victory was even more eomplete than the vote showed, for the Renandel motion also provided for an international conference and for the refusal of war crefits if the Government longer denied the issmance of passports for the delegates.

In Oetober, 1918, the National Congress of the party definitely ronfirmed the lately acruired power of the old minoritaires. The former majority, led by Albert 


\section{'THE "IBLOC" ANI) 'THE SACRLD INION}

'Jhomas, Vareme and compreme-Hoter, now became known as the e.r-majoritaires, and the mew majority led by Longuet and Mistral, leanne the e.r-minoritaires. The control of I/ umanitr had alpeady passed ont of the hands of Renaudel, who now belonged to the ex-majoritaires, and its comtrol was plated wilh Malreel Cachin, a Centrist, but of minority sentiment, subject to the direction of a committee of fifteen.

Thus the Socialist party gradually had broken away from the sacred Union in spirit, if not in fact. Fros. a patriotism which called the war a crusade "of justice" and the national defense "the highest duty," it now turned to Marxian encepts which denounced both as of oppressive injury to the working class. Deserting its new-born nationalist conceptions, it had again returned to its theories of class eonscionsness and internationalism. It no longer was represented in the Ministry, and with the exception of twenty-eight exmajoritaires, many of whom subsequently left the party, it refused to rote the military eredits for the seeond quarter of 1919. By the end of the war the party had completely returned to the principles of the Congress of Amsterdam. The patriotic, nationalist elements in France were begimning to oppose the Unified Socialists not only because of their Marxian theories, but because of the domination of the party by .Jean Longuet, a grandison of Karl Marx-a eomnection which public opinion invariably interpreted to be assoerated with the serviee of Germany.

One other event, although it oremped after the rose of the war, will indieate the final severance of the Sorialist party from the spirit of the Sared Enion-an event in faet whidh confirmed the socialist conviotion that injustice was inherent in a bourgeois régime. This 


\section{CONTEMPORARY FRENCH POLITICS}

was the Villain trial. It will be recalled that Jean Jaurès, the great reformist leader of the Socialists, was assassinated on July 31, 1914, by Raoul Villain, a member of the old Sillon party and a fanatical nationalist. Arrested immediately after the act, Villain admitted his guilt. He justified himself by saying that Jaurès was a traitor who, in opposing the three-year military law, wished to deliver France to the enemy. From the legal standpoint, the case was quite elear. A murder had been eommitted, the murderer had been apprehended in the act, and had confessed his guilt. Although his justification was entirely irrelevant, the majority of the country believed that Jaurès was a great patriot, striving to keep France in a state of honorable peace. Villain should have been brought before the Court of Assizes within three months, tried and convicted. But the Government perhaps imprudently kept him in prison nearly five years without even a hearing. Unfortumately, French justice is not aequainted with the liabeas corpus proceeding and so Villain remained in prison, as the friends of Jaurès suggested, safely protected from the trenches where otherwise he would have gone. The motives for the murder were variously interpreted. According to the prevailing opinion, Jaurès was assassinated through German instigation so as to stir up internal turmoil in Franee. Divided internally upon such an issue, France would the more easily suceumb to a German attack. To offset this possibility, the Viviani Government issued a proclamation, condemuing the "abominable attack," and urging that "all should have eonfidence in the law" and give in this "hour of peril the example of coolness and of union." 'The manifesto recalled that the eountry was in danger and promised that the assassin would be punished. 


\section{THE "BLOC" AND TIIE SACRED UNION}

The probable reason for the postponement of the trial was the fear that it might stir up class dissension fatal to the national defense, if held during the war. The case finally eame before the Court of Assizes on the 24th of Mareh, 1919. The President of the Court informed the jury that the ease was very simple since Villain had assumed complete responsibility for the act. But notwithstanding the admitted guilt of Villain and the testimony of the most prominent men in the Republic as to Jaurès' patriotism, the jury, after a deliberation of an hour and a half, returned a verdict of not guilty! ${ }^{20}$ At one time the procedure of French justice may have justified Alexandre Dumont's remark: "If I am ever acensed of stealing the towers of Notre Dame, I am going to get out of the country.'" Now, however, as the trial of Mme. Caillaux for the murder of Gaston Calmette in 1914 had already showed, the contrary is apparently true.

As a strong contrast to the Villain ease, a contrast which the Socialist press was not slow in pointing out, was the trial of Emile Cottin, who had attempted to assassinate M. Clemenceau, at about this same time. He only succeeded in wounding him in the shoulder; but within four weeks of the crime, ${ }^{21}$ he was brought before a Council of War, eonvicted in a session of a few hours, and senteneed to death. ${ }^{22}$ On the other hand, Villain, avowedly guilty of a worse offense, was confined fiftyone months before trial; he was then brought before a civil, not a military court, and aequitted. In the first case, the Socialists pointed out, the head of the Govern-

${ }^{20}$ On Mareh 29, 1919.

"Cottin attacked Clemenceau on February 19, 1919; he was senteneed on Mareh 14.

${ }^{23}$ Presilent Poineare later eommuted this seutenee to ten years' imprisonment, at the request of M. Clemenceau. 


\section{CONTEIIPORARY FRENCH POLITICS}

ment had been wounded; in the second, an opponent of the Government, a representative of the proletariat, had been killed." ${ }^{23}$ The parallel was too obrious to pass without seathing eriticism.

The Paris press, with the exception of $L$ Action Française, was unanimous in condemming the Villain verdiet. But despite this empty sympathy, the Socialists and the labor elements finally judged the verdict as a ease of pure rlass discrimination. On the 1st of April, the Lnion of Syndirates of the Seine dectared that the "verdict of the 29th of March brutally reminds us that there is nothing in eommon between good sense and bourgeois justice. It leads us to a clearer vision of realities and shows the immense effort which must still be made to bring about the advent of a truly just soriety.",

La Terité, a Socialist paper, on Mareh 30, in an editorial entitled, “La. I'arole est a.u P'cuple," wrote:

Villain is acepuitted.

Villain is fice. 'To-murrow he may kill whomever he wishes!

The Bomrenis conscience has passed its jurlgment. The political master of the bour is wommled hy a shot; the verdict is death. Tamres, the master of the world's thonght, is killed; it is acpuittal!

\section{Le Journul du T'euple, on the same day, wrote:}

Villan is arpuitterd. . . We rejoice in this verdict. It rearly shows that there are two Frances. The France of Labor which pays with its sweat for the sloth of wealth, . . and the liance of the liommenisie whinh does not hesitate

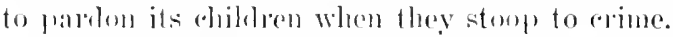

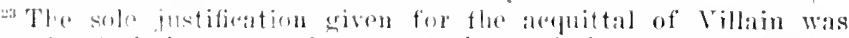
that the sowialists would have usud his eonviction as a vindieation of thrir Witr olpusition and policy. There seoms to be no reason why a jury andel not have comvireded Villain and at the same

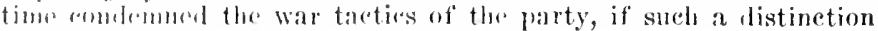
was monessilry. 


\section{THE "BLOC" AND TIHE SACRED INION}

Thus this verdiot, whose injustion was artunitted by all, gave to the growth of the ex-minoritaire movement, now the majority clement of the s'relalist party, an immense impetus. It brought romutless adluerents to a freshened faith in pure Marxism and it remewed the reality of the (lass strugole. It was the final stej) in the complete abandomment of the poliey of oppontunism inangurated hy .Janrès, which the inferior laderes who had sneeeded him had vainly attempted to perpetnate during the war. Moreover, in the imperialistic demands whith varjous delegations were making at the Jeace Conference, the Socialists found new excuses to justify this retum to their former ereed.

From this brief review of the combinations which French parties have recently effected, it will perhaps be noted that these have always been for mere electoral purposes. Indeed none of the parties has shown any real willingness to sacrifice their doctrines or independence to form greater and more stable grompings. Roughly, these party ealitions have been directed from the begimning of the Republic till ahout 18.99, first, against Monarehism, and secondly (from 1900 to 1912), against Clericalism. From 1912 to 1914, while no definite combination seemed realizable a division appeared to be forming upon the subject of militarism. Int when the war was foreed upon France, the third Iiloc arose, ineluding all parties, against Germanism. The next (hapter will discuss probable future combinations and groupings. 


\title{
CHAPTER IV
}

\author{
PARTY REALIGNMENTS
}

Nous voulons un pays plus large qu'un drapeau.-Goyard.

The divisions of the Unified Socialist party into $e x$ majoritaires and ex-minorituires was of serious concern to party leaders. Together with the Centrists and the Kienthalians, these divisions were upon the point of disrupting the mity of the party which Jaurès had so carefully maintained. The real differenes between these four divisions, however, did not arise from the war, althongh the Socialist leaders generally attributed them to that overshadowing eause. But as subsequent events proved, these dissensions were ansed by the fundamental difference separating the supporters of Revisionism and Revolution.

Realizing how fatal such party diseords might prove to future electoral sueeesses, a program was drawn up and presented to the Federation of the Seine, on March 31, 1919, which seriously attempted to compromise and reconeile both the majority and minority elements. This program ${ }^{1}$ asserted that the war had hut preved that the

"The Socialist program, quotol in part, is taken from $L$ ' $I u$ manité. 'The accounts of the congres's are also tiaken from L'Il numanilé. 


\section{PAR'TY REALIONAENTS}

tenets of Socialism, which had predicted it as a result of capitalism, were true; and that it illustrated once more the fundamental principle of the class strugrele by creating new wealth in the hands of a few, while at the same time increasing the miseries of Labor. Socialism, the program asserted, is the sole solution for the overwhelming problems which the war has produced; it is the only preventative of another and larger war. "International Socialism is the ultimate stage of human civilization." Strengthened by this eonviction, the Soeialist party "declares that the final aim of its efforts is the social revolution." Such a revolution is nothing more or less than the "substitution of a collectivist régime of production, of exchange and of eonsumption for the present economie régime, founded on private property, an economic order which belongs to a past period of history." The social revolution must finish the task which the French Revolution began by effacing the hereditary privileges of property and the hereditary servitudes of Labor. The program next analyzes the party's attitude toward violenee.

Whether this revolution shall eome "by the legal transmission of power under the pressure of miversal suffrage, or by a movement of foree," depends solely upon the future. "The Socialist party" does not eonfuse revolution with violence. . . . It ardently desires that its victory be accomplished in peace. . . But the proletariat eamot renounce any means of combat which will forward the eonquest of political power; the form of the revolution will finally depend... upon the nature of the resistance opposed to it."

This was the first compromise eontained in the program. To satisfy the new majority, led by Jean Longuet, it proclaimed the necessity and the imminence of 113 


\section{CONTEMPORARY FRENCII POLITICS}

the revolution. At the same time it softened the fiereeness of such a prophecy, dombly bold in the face of Russian and Hungarian excesses, by drawing a fine distinction between revolution and violence. Thus, if the bonrgeoisie would peacefully acruiesce in the demands of the party, there would be no bloodshed-quite naturally. This empty declaration was intended to appease the moderates of the party while it pledged no one to any definite course of action. Soothing the complacency of the old majoritaires it palliated the revolutionary verbalism of the Left. On the other hand, it antagonized the Kienthalian group, led by Loriot, which demanded the immediate revolution, if need be by fire and sword, overturning bourgeois parliaments and substituting therefor "Councils of Workingmen."

The program also contained this significant Marxian statement: "Whatever the form which the revolution may take, the assumption of power by the proletariat will probably be followed by a period of dictatorship." But this dictatorship, meaning the exchsion of the bourgeoisie from power, will be "transitional," lasting only until a commmuist régime is firmly established. To minimize the terrors which such a dictatorship has caused in Russia the party urges labor to complete its organization so it may intelligently direct society. Thus the revolution is hailed as a "supreme neerssity"; but "whether its coming be near or still far off"," it is the duty of the party, the "presumptive heir of the capitalist world whose walth is made from the arcumulated labol of generations," to "preserve and prepare for its heritage."

While awaiting the revolution, however, the party is uread to romtinne its efforts to reform present society so that the transition to a now social order will be less 


\section{PARTY REALIGNMLNTS}

diffienlt. $^{2}$ The party manifesto, therefore, stands for the complete organization of labor. It asks for the revision of the Constitution so that it will be based on (1) miversal suffrage of both sexes, (2) direct consultation of the people, (3) right of popular initiative, (4) integral proportional representation by regions, (i) a single legislative assembly, (6) administrative decentralization, (7) refusal of legislative positions to the heads of public business enterprises, ete., (8) creation of economic Chambers, (9) reorganization upon an industrial basis of all public services and state monopolies. The manifesto also demands the complete reestablishment of the constitutional liberties of the press, assembly, and of opinion.

Under the heading of economic reconstruction, the party condemns the penury and disorder into which a eapitalist war has thrown France. Asserting that Germany will not be able to pay for the damages it las inflicted upon France, it asks that the difference be raised by (1) State seizure of exeess profits, (2) conseription of fortunes, (3) a tax on eapital and on increasing wealth, (4) the striet collection of the income tax, (5) the estalnlishment of new monopolies, (6) State participation in every sufficiently centralized industry, (7) the nationalization of the railways, and all other means of river and land transportation, of the great steel factories, of water power, of refineries, of banks, of insurance, and the manufacture of alcolool. This is a much more inclusive plan of govermment ownership than that which the Radical party supports.

The party does not conc"al the fact, however, that these measmes may prove inadequate to meet the pres-

2 As we shall see, these reforms were a direct eoncession to the old majority. 
ent crisis. "The capitalist régime may suecumb under the weight of the charges which it itself has created." What is fundamentally needed is an increase of produetion. To seeure this end the State must not "spend less, but more and more." To bring about this increase (and under the heading of "Immediate Reforms"), the party demands that labor be made compulsory, idleness to be punished by law. It also asks that edueation be gratuitous, dependent not upon the means of parents but upon the child's aptitude. To insmre Labor its complete share of the products of eivilization, the party wishes to impose eertain principles. Concerning the organization of labor: (1) the suppression of unemployment by means of employment bureaus, (2) inerease of social insuranee, (3) the protection of the health and security of workmen, (4) the reduction of hours of work, (5) a minimum ineome, (6) unreserved reeognition of a right to organize. Conceming agricultural labor, the following proposals are made: (1) extension of laws of industrial labor to agriculture, (2) alleviation of the tenant system, (3) coöperative organization of small proprietors and tenants for production, sale of products, purchase of seed, machinery, and insuranee. Concerning measures of social uelfare: (1) rigorous protection of mothers and children, by the medical control of ehildren, the ereation of numseries, school sanatoriums, and open air colonies, (2) the fusion of all education, free and rompulsory, under national control, "permitting, by a series of selections and of specialization, the utilization to the best end of the social interest, of the variety of individual aptitudes." Concerning the welfare of labor: (1) the general expropriation of unsanitary property, (2) the creation by the rommmnes, of a public housing serviee, (3) the immediate use of public funds for 


\section{PAR'TY REALIGNALENT'S}

the construetion of healthy lodgings, $\left(\frac{1}{2}\right)$ the organiza. tion of a public food service, (5) the public organization of leismre, by sports, theatrical representations, art, and culture.

'This program, the party asserts, cannot be carried out until peace is inangurated. As a further compromise and eoncession to the old majority, the program says: "Convineed that the integrity and the independence of nations are fundamental to the international organization itself, the Socialist party has unstintingly spent itself for the defense of the eountry." But its efforts were premised upon the acceptance of a Wilsonian peace. And the party "remains opposed to every eondition of peace which exalts the deerepit forms of an exasperated nationalism, forms which will but tend to unloose the confused mîle of imperialistie ambitions, piotecting in every comntry the efforts or the revenges of reaction. . . . It also deplores the fact that the Goverrment did not support whole-heartedly the intentions and the propositions of President Wilson."

The party denounces the practices of a secret diplomacy which "threatens to falsify the significance of peace which it forestalls." It is "ardently attached to the ilea of a League of Nations, eonsidering that it should embrace every people, equal in rights and duties -and not merely a few governments." It demands that it he provided witl sanctions eapable of assuring its authority. But this League of Nations, in addition to its rôle of Peacemaker, must gradually direct and regulate the economic life of the world. International legislation must supplement national reconstruetion, thromgh regulation of labor and economic competition between nations. "The League of Nations . . is, therefore, obliged, ly the very fact of its existence, to regulate the 


\section{CONTEMIPOR.IRY FRENCH POLITICS}

conditions of production and of consumption suitable to each county. It must control the establishing of rates of transportation, assuring between nations... an ecpitalle distribution of raw materials and of products. . . It must facilitate by every means the exchange of food supplies, of capital and of persons. . . . In working for the coöperation of peoples, toward prosperity and peace, the League of Nations will necessarily move forward along the path of international socialism. . . ."

But now deserting at last this program of reformism, the doemment we are considering returns to its fundamental Marxian hasis by declaring that in the end it is the revolution which "must always inspire the means, and the means must never be diverted from the end." While the outlines of a Socialist régime may be laid down under a bourgeois soeiety, the ultimate goal of the party is the soeial revolution, wherein not only the govermment but industry, eduation, and eulture, will be dominated by the dictatorship of the proletariat.

Finally, the program under analysis closes with this peroration :

There will be true equality only when the sole reengnized distinetion between men slall be that of their social value. True justice will exist only when the sole property recognized in men will be that which arises from man's own labor; when the tithe levid by the empluyer upon the employee, by the proprietor of the soil mpon the tenint, shall have disapfeared with the form of property of whirls it is the direet expresion. There will only be true harmony when the activity of earh man shall be applied to his natmral task and the commumealth of the soil is expluited for the wood of all.

The Socialist farty therefore ealls mon all laborers to assist ly their efforts in this beneficent exolution of history. It calls npon them to assist it in the work of social regeneration which is its end and object. The general interests of the nations, and those of entire civilization, are indissolnbly con- 


\section{PARTY REALIGNUENTS}

founded with our own. Ileirs to the benefit of every effort of organization which has developed in the world, we must omselves realize a frowam, the aremplishment of which a fallen bourgeoisie and a covetous eapitalism would not even dare to attemint.

It will be noted that this program contains many finely balanced distinctions between inmediate reforms and the revolution. In fact, the principles of reformism even assume a predominant position. The measures adrocated, although more advanced, are practically the same in principle as those for which the Radical party stood-a program of collectivism. As such, many non-Marxian liberals could have sincerely supported them. And for this very reason they were severely attacked by the Loriot group. This group was opposed to any program attempting to improve bourgeois society. It believed that the adoption of immediate reforms and the amelioration of the economic conditions of Labor would benumb Labor's revolutionary desires. Eeonomie content under the present regime would kill the ohief stimulus which urged the revolution on. The aim of the proletariat should not be "the full stomach" alone-it should aim to seize and achieve power and work toward the entire assumption of political, social and economic activity. To seeure the adoption of reforms would but weaken the impelling incentive to revolution. The increase of porerty, of misery, and of discontent was the best guarantre of the Internationale. Such was the argument of the Loriot group; from the Marxian standpoint, it was admittedly logical. Tts adoption, however, wonld ecrtainly have meant the destruction of the French Socialist party. Consequently, the draft of the program retained its reformist features, and the Loriot group refused its adhesion. 


\section{CONTEMIPORARY FRENCII POLITICS}

\section{II}

The extraordinary session of the National Congress of the Unified Socialist party was held in Paris on April 20,21 , and 22, 1919. It was ealled primarily to adopt this program and to settle other issues upon whieh the party was still divided. Mme. Saumonneau, for the Loriot group, opened the attack on the program during the first day's session of the Congress. She made the following motion, whieh embodied the extreme demands of the Kienthalians-largely patterned upon the ideals of the Russian Soviets:

1. The complete assmption of power by the proletariat.

2. Institution of compulsory labor.

3. Socialization of the means of production and exchange, land, industries, mines, means of transportation, under the direct management of the peasants, workmen, miners, railway men and sailors.

4. Distribution of products by coöperative societies and municipal stores under collective control.

5. Mfunicipalization of private dwellings and of hospitals.

6. The forced transformation of the government services and their transfer to the direct management of the employees.

7. Universal disarmament as a result of the nnion of all the proletariat Republies in a Socialist Internationale.

$\Lambda$ second group, led by M. Verfeuil and Paul Fanre, introduced another program, eontaining the reforms of the original one, but more boldly demanding the revolution.

The debate upon these programs was very acrimonious-the 20th and 21 st were marked by a seathing addhess from M. Loriot declaring a program of reforms to be "monstrous," and reproaching the party with weakness. Ile was followed by M. I éon Blum, speaking 


\section{PARTY REAIIGNIIENTS}

in favor of the original program, who made what was considered the best speech of the convention. It was finally decided to rofer the three programs to the committee on resolutions. But on the 2.nd the committee reported it could rearly no decision and that it had decided to have a representative of each speak before the convention, after which a vote would be taken. $\Lambda$ fter this was done, the following decision was announced: For the original program, 1,39t votes; for the Verfenil program, 296; for the Loriot program, 245. Thus the compromised measure was adopted and so far, at least, a nominal unity between the two major elements of the party had been assured.

\section{III}

IIowever, there were certain matters of importance which this program, becanse of its eompromised character, had onitted, and which the new majority, supported by the Kienthalians, felt should receive party sanction. Thus no declaration had been made with respeet to the Russian and German revolutions, the eauses of the war, partiripation of Socialists in bourgeois govermments, party discipline, and the reconstruetion of the Internationale. Consequently, two motions were made on "general policy" to supplement the program and to supply its omissions. Discussion upon these two motions, presented by the new majority and by the Joriot group, led to scenes of disorder and ill-feeling in which Renaudel, an ex-majoritaire, acrused Longuet, the new leader of the party, of being in German pay. ${ }^{3}$ The motion on general poliey, submitted by the new majority

${ }^{3}$ See p. 274. 
and finally adopted, declared that the war was "the direct consequence of the economie political anarehy in which the eapitalist system maintains the world." It declared that events justified the present policy of the new minority and condemned the compromises which the party maintained during the first years of the war. This war, represented by the bourgeoisie as a war of light, the party eondemns as imperialistic. "The party denounees the hyproerisy of the French Govermment which, after having exploited the ignorance and the credulity of the people by making them believe that it urged only a war of national defense, a war to secure the liberty of peoples to dispose of themselves, a war for the destruction of armaments, now prepares to give to the results arising from this war a purely imperialistie and capitalistic solution from which new conflicts will emerge if the international proletariat does not soon lecome master of his destinies."

The motion also condemmed the Leagne of Nations, as constituted by the Peace Conference. A real "League of Nations must be the international organization of the proletariat finally delivered from capitalist oppression." The conflicting policies of imperialism illustrated by the proceedings of the Peace Conferenee, it declared, again proved the incapability of the bourgeoisie to reorganize society upon a just basis. Consequently the revolution was more necessary than ever.

As an equitable basis of peace, "the Socialist party extends a fratermal land to the German people. It stigmatizes the excessive pretensions which, under pretext of material reparations, tends to reduce the entire German people to slavery. . . It greets the German revolution... It likewise greets every revolution which the great shock of wall has caused to arise. . . 


\section{PAR'TY REALIGNMEN'S}

Its sympathies are addressed to every oppressed people without distinction, whether they be oppressed by the Central Powers or whether they still undergo the yoke of the Entente apitalists. ... The mupuestioned strengthening of the Republic of the Soviets... the comrage and the tenaeity with which the working and the peasant class of Russia are carrying on their struggles.. prove low much the French Socialist party was right in placing confidence in the Russian Revolution and in combating the orininal intervention by which the bourgeoisie of the Allied countries have aimed and still aim to destroy it."

The motion again emphasized the declarations of the program by asserting the "inalienable light of the dispossessed class to expropriate the possessing class by means of the revolution." It affirms that the "dietatorship of the proletariat at the beginning of every triumphant revolution" is a necessity. To this end, force is also necessary.

Again reeurring to the principles set forth at the convention of Amsterdam, the motion declares:

The struggle of elasses demands uneompromising opposition to bourgeois power; it condemns any participation in the exercise of this power under whatever form this may present itself; it implies the systematie refusal of military and eivil ereditsand the rejection of the whole budget. The absolute antonomy of the Socialist party as the political party of the working elass naturally exeludes all possibility of alliance or electoral coalition with a bourgeois party.

To enforce party unity, those who will not recognize these principles and who "will continue to grant eredits to a bourgeois government" will be read ont of the party.

Finally, the "Socialist party makes an appeal to the 123 


\section{CONTEMPORARY FRENCII POLITICS}

revolutionary force of the proletariat, against capitalist society which is responsible for the war. It appeals for the total destruction of militarism and for the emancipation of the workingmen by the establishment of eollective production and property. It intends to employ "every possible form of action" to bring about these ends.

After another bitter debate wherein the old majoritaires and the Sacred Union were both bitterly criticized, the Faure motion was adopted by a vote of 962 ; the Loriot motion, going to still further extremes, received 232. There were 789 abstentions representing the old majority who, not having a motion of their own, nevertheless refused to condemn the war as imperialistic and the Sacred Union as discreditable to the ideals of Soeialism.

To carry out the motion respecting a general poliey, another motion was almost unanimously adopted on electoral discipline. This declared that: (1) No one ean be a party candidate without expressly adhering to its program; (2) any kind of clectoral eoalition in the coming general eleetions, with bourgeois parties, is expressly prohibited; (3) any candidates opposing this last provision will find themselves opposed by other candidates, supported by the entire party organization.

These two motions-on general policy and on electoral discipline-seemed to nullify completely the compromises which had been made in the program for the sake of the old majority. In fact, the policy of the latter during the war was expressly condemmed. The party now denomeed the war as being Freneh as well as German in origin. The program which originally extolled the League of Nations, now denonneed it as but another deviee to enchain the Labor world. The motion 


\section{PAR'TY REALIGNMENTS}

emphasized the neessity of a soeial revolution by foree; while the program alloged its peacoful advent. The motions made no mention of reforms, but they implied their uselessness hy forbidding Socialist participation in a bourgeois Ministry and the voting of the budget. How conld collectivistic reforms be carried ont without an appropriation? The Soeialists in condemming the one had to condemn both. IJenee the Loriot group had really trimmphed. The party program henceforth laid its emphasis upon the revolution. Despite this doctrinaire vietory, the dismity which the program attempted to heal was now definitely exaggerated by these motions, eondemning ontright the old majority poliey and its eontimuanee. The Socialist party thus virtually rejeeted a poliey of reconstruction, through which Franee might lave been aided, and relapsed into the hopeless and destructive ideology of pure Marxism.

\section{IV}

The last matter of importance to come before the Congress was that of the Third Internationale. The First lnternational Workingmen's Assoriation was founded at London in $186 t$ in response to the now classic appeal terminating the Communist manifesto, "Workers of all comntries, mite!'

By no means purely Socialist in its original tendencies, the elofuence of Marx gradually won it over to his doctrines mntil at the Congress of Brussels in 1868 it became definitely a Socialist organization. The disappearance of the First Internationale in 1873 was brought about hy struggles between the Russian anarchist, Baknnin, the British Unionists who believed in the formation of labor parties, and the German Marx- 


\section{CONTEMPORARY FRENCII POLITICS}

ists. The stigma which the Paris Commme fastened upon Socialism hastened the dissolution. Between 1873 and 1888 numerous attempts were made to ereate another " International Congress of Workingmen." Finally, in 1889, a new organization, the Second Internationale, was effected at Paris. From that date to 1914 the Internationale made great advances; thirty nations were represented in its organization and its congresses were often composed of a thousand delegates. But despite the elaborately arranged plans of this organization, it failed to stop the war in 1914 by means of an international strike. Its efforts to hold international conferences during the war also largely failed $;^{4}$ and for five years the union of its different national sections was prevented.

The close of the war and the desire to bring pressure upon the Paris Peace Conferenee led to the resurreetion of this organization at the conference of Berne, Switzerland, which was held on the 1st of Fehruary, 1919. But in many respects, this meeting of the Seeond Internationale was unsatisfactory. There were only about a hundred delegates present. Neither Italy, the United States, Russia, Serbia, nor Belgimm was represented. The convention was marked by disorganization and confusion, hy the dofense and special pleading of the German majoritaires, and by indecision toward l3olshevist Socialism-perhaps the most vital issue disenssed.

The failure of the Seeond Internationale to prevent the war, its impotency during the five years of the war's progress, the half-hearted support which Labor gave to the compress of Berne, and the ronservatism which developed in its strering rommitte gave the extremist So-

"The Sitockholm conference was one attempt. Chaptor III does not attempt to givo them all-merely those affecting the Sacred Inion. 


\section{PAR'TY RIALIGNMENTS}

eialists an incentive to organize a Thior lonternationale. Under the guidane of the Bolsheviki, the 'lhird or Communist Internationale met at Moseow on March 2, 191!. Thirty-two delegates with full power to art, wele present from partics or gromps in Germany, Russia, IImngary, Sweden, Norway, Bulgaria, Rommania, Finland, Tkrainia, Esthonia, and Armenia; and comsultative representatives were present from gromps in Switzerland, IIolland, Bohemia, Jugo-Slavia, France, Great Isritain, Turkestan, Persia, Korea, China, and the Inited States." M. Guilbeaux, an outeast renegate who hat been eondemned to death by a French Comncil of War, took it upon himself to aet as a representative of the French party. ${ }^{6}$

The Third Internationale, thus formed of minority groupings prineipally from Russia, Italy, Switzcrland, and Germany, eondemmed the Internationale at Berne for its impoteney and for deserting the fundamental principles of Socialism-notalbly the prineiple of the social revolution. It asked the parties of all nations who could athere to the tenets of the newly-organized Bolshevist régime, to desert the Serond and adhere to the Third International Workingmen's Organization.

The French Socialist party, therefore, again found it neeessary to decide where to cast its allegiance. Three views were represented at this emgress. The first, helk by the old majority, was for the retention of membership in the Berne Internationale as at pesent constituted; the seeond view, held by the new majority, under Tonguet, was for athesion to the old Internationale pro-

B A full aceomt of this meetine will be fom in the liberator, July, 1919 .

- This unathorized representation was denounced by the federation of the seine, April 13, 191!), hy a vote of $5,(1202$ against 970. 


\section{CONTEMPORARY FRENCII POLITICS}

vided it moved toward the Left. The third view, held by the Kienthalians (whom, in fact, the Bolsheriki had declared, were alone "advanced" enongh of the French Socialists to adhere to their organization), was for adhesion to the Third Internationale.

M. Jean Longuet, in the last session of the eongress, declared that the old Internationale was "mutilated and incomplete," that it had failed to prevent the war because the French ex-majoritaires would not agree to its assembly during the war, and that it needed the expurgation of its conservative elements and the vigorous reconstruction upon a radical basis. With such changes, the Berne Internationale, in his opinion, would be more satisfactory than that of Moscow becanse it already had the support of a greater number of parties. The motion which he read invited the sections not represented at the meeting at Berne, to send delegates to the next eongress, with the purpose (1) to expel its conservative members, (2) to restore fully the principles of the class struggle and of the irreconcilable opposition to bourgeois parties and government, (3) to direet the Internationale toward the soeial revolntion, following the example of Russia, IIungary, and Germany. At the same time, the French Socialist party declared itself willing to enter into "fraternal relations" with the Moscow organization.

This motion was finally adopted by a vote of 894 against 757 for the motion of the old majority, and 270 for the Loriot motion for the Third Internationale.

The congress thus took one more step toward a repudiation of the moderate poliey whinh had controlled the party during the war. It dict not immediately enter the new Tuternationale-which the Bolsheviki entrolledbut it limited its adherence to the old Internationale 


\section{PAR'T REALIGNMENTS}

by insisting that the latter prepare for a revolution along lines which the Bolsheviki had already made effective. Thus it assured the moral dominance of IBolshevism over the old Internationale and over the policies which the French party would pursue at home.

Within three days the French Socialist party had burnt down all the bridges of nationalism and of reformism liberal well-wishers had built for it. It now eentered its hopes upon the revolution. Inspired by the examples of Tenin and Bela $\mathrm{K}$ m, it heneefortl preached the "Red" Gospel with tireless insistency. Its task appears to be a hopeless one. The French people are extremely individualistie. Despite their theorizing, despite the fantastie projects whieh their reaty political imaginations often devise, Frenchmen are realists. As lovers of personal independenee, they eherish their small holdings, whether a vineyard or an épicerie. In theory, they may understand and even admit the advantages of collectivism. But these theoretical advantages are completely outweighed by the repulsion which the exeesses of Russian Bolshevism have produeed. The Frenehman is essentially a pragmatist; although he may admit the defects in the present form of society, he will not saerifiee eertainty for meertainty.

Revolutions generally have their eauses in deep-laid political or social misery. These conditions are usually the product of years of abuse and of oppression; they are tolerated until misery makes them intolerable, or until external forces, such as military defeat, break down the oppressing power. But no such eonditions can be said to exist at present in Franee. Although Labor has many just grievances, ${ }^{7}$ it is by no means

${ }^{2}$ See PP. $244-246$. 


\section{CONTEMPORARY FRENCII POLITICS}

weighed down by that economic hardship which La Bruyère so foreibly described, preceding the Revolution of 1789 :

Certain wild animals, male and female, dark, pale, burned by the sun, might be seen spread over the comntryside, bound to the soil which they dug and which they tilled with strange olstinary. They had an articulate roice, and when they rose to their feet they displayed a hmman face; in short, they were men. At night they returned to their hovels where they lived on black brear, water and roots. They saved other men the trouble of sowing, working, and gathering for their food.

It would be hard to find the counterpart of such beings in France to-day!

There were few Frenchmen who aceepted the Socialist theory that the war was a product of capitalist govermments. liberals in other countries have indeed sustained this thesis. But among Frenchmen, outside of some fifty thousand simon-pure Socialists, it had absolutely no support. To them the present economic disorder is not conceivably part of a capitalist scheme of oppression; it is the result of a war outwardly imposed. Consermently, the great majority of the nation jomed as one to build up what had been torn down. A class struggle is beyond their comprehension. In the future, the nation may adopt collective methods in earying out its remonstrution tasks, hut that these methods will go to the extent of overturuing the broad ontlines of the existing order, is an extremely remote possibility.

\section{V}

The drfinite proclanation of a revolution of the Russian type as the renal of one of the most powerful polit- 


\section{PARTY REALIGNMENTS}

ieal parties in France came as a distinet shock to the other parties. The contimume of the Sacerel I'nion had been advoeated even before the close of the war hy a few members of the press. The Socialist dreision to abandon its moderate stand conserpently gave the distinetively "bourgeois" parties another motive for contimuing the poliey of a Bloc which they had faithfully maintained during the war. As has been noted, Monarchism, Clerieahism and Germanism have earh in turn been the three causes powerful enough to bring about party combinations. Party combinations have been successful in overeoming all three of thesedangers. But these issues having passed away, there is little possibility of another Bloc umless an equally threatening menace again appears. For the future, there appears to be only one outstanding clanger likely to threaten the Repulnlic: the social levolution which the Lnified party is now preaching assiducusly and which it hopefully experts soon to aceomplish. ${ }^{8}$ It is quite certain that every bourgeois party in the Repulnlie, except possilly some Radicals, would combine to oflset the Sorialists. The fourth great Bloc of the 'Thind Republic, it can confidently be said, will be against the peril of the Rerolution.

Signs of this new Bloc soon made their appearance. As early as December, 1918, a group was formed, a Republican entente, upon the basis of the solidarity of classes. It was not until the summer of 1919, howeverafter the Socialist party had declared its intention of

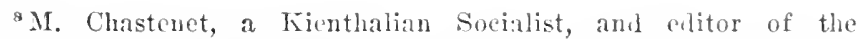
Gremble Droit du P'cuple, told the author that the party expeeted the revolution within a year: and hence it made no diferenee to them whether the Sante killed the hill gring Gorermment culployees the right to organize or any other lablor bill. He confilcntly expects that within a you liarliaments will bo overcome and workingmen's councils estiblished in their place. 


\section{CONTEMIPORARY FRENCII POLITICS}

bringing about the "Fourth Republic" - that signs of an extended union appeared.

Some elements wished to contimue the Sacred Unioninchuding Monarchists as well as Radicals. Thus on the 18th of July the Dnke of Orleans issned a manifesto which urged the continuance of the Sacred Union against the Socialist danger. About the same time, the Liberal Action party, at a banquet presided over by Jacques Pion, asked for a "national party" grouping in a $B l o c$ all the patriotic elements against "every attempt at dictatorship on the part of one class." On the 8th of July at a meeting of the Democratic Republican A1liance, M. Chammet, director of the propaganda of the Alliance, said, "The time has come to constitute a great and all-embracing Republican party in which all our different groupings may find a place."

\section{VI}

In addition to the new Bloc which it is certain every party of a bourgeois character in the Republic will join against the Unified Socialists, there are signs that some other and perhaps more stable and coherent party realignment is under way. The causes which brought the old parties into existence are largely disappearing. It is certain that the monarohy will never be reëstablished. If the orrasion for it should conceivally arise, there is no candidate able to attract a following strong enough to seat him on the throne. The Ligue d'Action Fransraise will probably outlast the lifetime of its leaders, MM. Maurras and Dandet. But sigus are not wanting that in the future its rritioism will be larogly destructive and mationalistie. Litte will be said of the kingship. 


\section{PAR'Y REALIGNMENTS}

As far as the Liberal Action party is concerned, there is slight probability of the repeal of the anticlerieal legislation. The Government appointnent of bishops in Alsace-Lorraine aronsed Catholic hopes, but this anomalous action was explained by the fact that AlsaceLorraine has to be governed under the old Concordat until the anticlerieal legislation is extended to its jurisdietion. The policy of the Govermment toward the Chureh was brought out in the Chamber of Deputies last July when Jean Bon aceused it of having a secret representative at the Vatiean. This, MI. Pichon, Minister of Foreign Affairs, vigorously denied, adding, "the policy of separation as now practiced in eonformity to the law, satisfies the Government." The Catholic strength has been dissipated between the "Ralliés" and the Monarehists. They may unite; but it seems that the Chureh is losing popularity as an issue in polities, and that it is seeretly satisfied with its present independenee from the eontrol which the Coneordat formerly imposed. As for the social doctrines of the Liberal Aetion party, they find their embodiment elsewhere.

The Progressists, as alrealy pointed out, have split into a conservative and a moderate group. There seems to be some indication that the former may mite with sympathetic elements in the Right, although both are so independent and umreasonable in holding to their antiquated doetrines that as a parliamentary foree it does not appear that they will ever be effeetive. Similarly, it is quite possible that the moderates of the Republiean Federation may mite with the Democratie Alliance. Upon this latter organization (the Demoeratie Allianee), the future control of French polities is probably eentered. Its program is a molerate one; it is thoroughly Republiean; it stands for a policy of pacification. Un- 


\section{CONTEMPORARY FRENCII POLITICS}

der its present leadership, it may even prove strong enough to absorb other yarties within its organization.

The Radical party, on the other hand, has passed the zenith of its carecr. It rode to power on the issue of clericalism. Now that this issue is dead, the party, like the Action Liberale P'opulaire, has lost its chief reason for existence. In its enforcement of the clerieal laws, especially during the Ministry of M. Combes, the party was untaetful and orerviolent. In driving the religious orders ont of France, nuns were driven into the streets, and Good Friday was deliberately chosen to remove the erosses hitherto hung in court rooms; every effort was apparently made needlessly to antagonize the Catholies. Now that this issue appears definitely settled, it would be the worst of policies to harp eontinually upon a past menace. Yet it is this policy which the Radicals are fatuously trying to perpetuate, and because of which they are vigorously opposed to the "paeification poliey" proposed by the Democratic Alliance and M. Briand.

Secondly, the Radicals have been found guilty of the worst opportunism. The Doumergue Ministry eame into power in 1913 pledged to fulfill the Pau program, calling for the repeal of the three-year military service law. Yet the Ministry supported it. As far back as 1906 the party promised the income tax, but when in power it failed to enact any such measure until the outbreak of the war made it a neeessity. Upon the issue of clectoral reform, the party was equally vacillating. Always opposed to the representation of minorities, it was not until 1919 that it finally agreed to the partial incorporation of this principle in the electoral reform law. Finally, the Radicals had become vague and lukewarm in regard to questions of social reform; their declaration of July, 1919, seemed merely to mark time until the 


\section{PARTY REALIGNMENTS}

coming of some wind should point the direction of suecess.

Thirdly, the party is suffering from a discreditable leadership. Until the beginning of the war at least, $\mathrm{M}$. Caillanx was in complete control. He alone determined its program, a principal feature of which was pacification with Germany, obviously unpopular, to say the least, in France at the present moment. Not only in his eabinet but as Minister of Finanees in the Doumergue Ministry, he was guilty of shielding embezzlers, as the Rochette ease proved; and he was moreover frequently and openly charged with finaneially profiting by his position as Minister of Finanees. The murder of Gaston Calmette, editor of Le Figaro, by Mine. Caillaux, through fear that he would eontinue to reveal the personal and financial immoralities in Caillaux's life, further implicated him. Ifis reeord during the war has also been disereditable. Its treasonable extent has not yet been deeided; but his actions appear to have been very far from patriotic. ${ }^{9}$

Two other prominent Radicals, Malvy and Deselaux, have also brought the party into disrepute. Malvy, Minister of the Interior in sereral war eabinets, in July, 1918, was judged by the French Senate, sitting as a Iligh Court of Justice, to have "ignored, violated, and betrayed the duties of his charge." Desclaux, who had been Caillaux's secretary when the latter was Minister of the Interior, was an army contractor who was aecused of stcaling army supplies. A prominent Paris dressmaker was found to have eoncealed the stolen goods; and upon the basis of this proof Desclaux was

'In the latter part of April, 1920, the French Senate voted Caillaux guilty of having har " commeree" and "correspondence" with the enemy. 
sentenced to seven years of solitary confinement. And by a strange perversion of loyalty the Radical party has stood behind their former leaders to the bitter end. This statement is proved by the fact that Caillaux was again nominated by the Radicals as a candidate for the Chamber of Deputies from the Sarthe, in the elections of November, 1919. But on the refusal of the High Court of Justice to grant M. Caillaux "temporary liberty" in which to carry on his campaign, he declined the nomination.

It now appears that Clemenceau has taken the leadership of the Radicals away from Caillaux; but the latter still retains some of his old following in the Left wing of the party, the Radieal Socialists proper. The division caused by this issue has not been the only one in the party. Countless other differences have arisen, nearly as serious and quite as numerous as those in the Unified Socialists. Thus an element led by Franklin Bouillon, has bitterly opposed M. Clemencean. There are some moderate Radieals who are opposed to the extension of collectivism; there are extreme Radicals who wish to ally themselves with the Unified Socialists, despite the latter's revolutionary program. There are Radicals who stand for a peace of annexation; many others who eondemn the present treaty as violating principles of justice. These countless divisions will all inevitably contribute to the weakening of a party whose ascendancy was reached several elections before the war.

But the chief of these weaknesses is the lack of leadership. Among the senators, MM. Bourgeois, Combes, and IIerriot figure prominently. Mr. Bourgeois is a scholarly man, but not gifted with any brilliant qualities of leadership. M. Combes, it seems, has already contributed his full share to the direction of the party; only 


\section{PAR'TY REALIGNMENTS}

M. Herriot, an intellectual leader, appears likely to beeome Prime Minister some day, althomgh he is also deprived of the mannetism of M. Clemenceau.

As for the Republican Socialists, they have profited by their patriotism, and have won over to their doctrines many former believers in Socialism of the "unifié" variety, who have beeome dissatisfied with its "proBolshevist" domination. Pure reformists, belicvers in eolleetivism, there seems to be little difference between them and the Albert Thomas ex-majoritaire type of Unifies or the extreme Radieals. A grouping of these three elements upon a Reformist-Collectivist program, such as that urged lyy the British Labor party, ean easily be imagined.

As for the future of the Unified Socialists, the outlook from their standpoint does not appear bright. We have already indicated the reasons why they have such small chances of bringing about a revolution "lyy force." This chance has still further diminished since the signature of peace. Politically, they have absolutely no prospect of winning a majority on account of the $B l o c$ which will always be formed against them in the elections, a Bloc representing the overwhelming majority of the French people, alsolutely opposed to a replica of the Russian and Hungarian experiences. The extremism of the Unified Soeialist party is the natural source of its weakness, for it has hopelessly divided it into factions and deprived it of its leaders. Such men as Briand, Millerand, Viriani, and IIervé, who refused to be swept into an avowal of the revolutionary tenets which have continually controlled the party, have been excluded from its membership. The party thus has lightly east away the only elements which can alssure its suecess, with each step in its evolution toward the Left. This 


\section{CONTEMPORARY FRENCH POLITICS}

evolution has already deserted the seholarly opportunism of Jaurès for the milk-and-water Bolshevism of Longuet. It bids fair to seek its inspiration in the iconoclasm of Loriot.

The real issue in France to-day, aside from the question of Bolshevism, is the projection of the State into industry-that is, State Socialism. This movement is not the same as the Socialism preached by the "Unifiés." It adroeates no change in the direction of industry as far as the proletariat assumption of power is coneerued; on the other hand, it advocates the gradual absorption of industries by the State as at present constituted. This program of collectivism or of nationalization is advocated by the Radical party and the Republican Socialists. But it is even more vigorously opposed by the Republicans of the Alliance and of the Federation. Because of this additional issue, it seems reasonable to believe that two strong bourgeois groupings will arise in France-one, probably eentering around the Republican Alliance, which will oppose eollectivism, and the other, grouped around the Radicals and nationalist Socialists, which will advocate collectivism. In addition to these parties, the Unified Socialists will always exist. But whenever the latter threaten the Government, it is equally certain that the two bourgeois combinations will unite to overthrow them. The Clerico-Monarchists likewise will exist-a glostly community - until the old nobility becomes only a historical tradition.

It may be hoping too much to prophesy the elimination of all lut these three major groupings in Franec. ${ }^{10}$

${ }^{10}$ In the first days of the 12th Chamber of Deputies (1919$1923)$, cuconraging indications were given of the desire to climinate and to consolidate parliamentary gromps. Attempts were malo by the Ralieals, led by M. Herriot, to form a llnion ales Gauches, out of the two old groups of the Radical Socialists and the Re- 


\section{PARTY REALIGNMENTS}

The final settlement and elimination of old issues may not materially affect present party aligmments; the independence dear to the Frenchman and the attitude of je m'en fiche may prevent any serious rearljustment of parties and the stabilization of the party régime.

Iowever, it hardly need be recalled that a suecessful party govermment is not dependent upon the elimination of all but a majority and a minority party. Even in England, the home of party governments, there are four or five parties, the smallest one of which, the Irish Hone Rulers, held the balance of power in Parliament for years. In the German elections of January 19, 1919, under the new Republie, six parties received a considerable number of seats. In the Italian elections of $\mathrm{No}_{0}$ vember $16,19^{1}$, six parties polled great numbers of votes. In the Spanish elections of 1919, as many as twelve parties likewise secured a sprinkling of seats in the Cortes. Finally under the Bolshevist dictatorship in Russia, fifteen or more groupings were brave enough to express different remedies for the hierarchy which attempted to keep them silent. Thus the multiplicity of parties is not limited to France alone, or caused by any special defeet of the Freneh political mind. There is, moreover, a strong probability that the Third Republie may yet enjoy the benefits of a stable, party govermment. Some scholars, notably Moisei Ostrogorski, believe that party régimes in all comntries will give way to temporary organizations, springing up to accomplish some reform, dissolving again upon its achierement. Although this

puhlieans of the Left. Because of the vital difference hetween these two groups, the union naturally failed. But upon the 15th of January, 1920, a union of the group of the Republinams of the Ieft with the group of the Radieal Left was effecter. This united the forees of the Demoeratic Allianee into what was eallel the Group of the Republican Demoeratie Left. 


\section{CONTEMIPORARY FRENCH POLITICS}

tendency is visible in France (as the activities of the various electoral reform leagues show), it is not likely to do away completely with permanent parties in France, beeause, as noted above, party programs are really philosophies, which remain after the achievement of many of their immediate demands. 


\section{CHAPTER V}

WOMAN SUFWRAGE AND THI" "R, I'," 1

Bcaucoup pensent qu'il vaut mieux ne rien changer.-Midas.

Purely eleetoral issues have induced lively diseussions and important differences throughout the eourse of modern French history. Two revolutions-those of 1830 and 1848-were in a large part caused by them; Ministries have come to power and have fallen on their account. Universal manhood suffrage has existed in France sinee the time of the Constituent Assembly of May 4, 1848, a body which was elerted upon that basis. Although in 1850 the principle of miversal manhood suffrage was virtually abrogated for a time by requiring a three-year domieile as an electoral qualification, its full acceptance has long since ceased to make it a possible politieal issue in France. But lately, there has arisen a demand for a further extension of the suffrage, first, to women, and secondly, by the so-ealled plural or multiple vote.

French women already may vote for members of the conseits de prudhommes, arbitral bodies romposed equally of employers and employees, and for judgess of

'The "R. P.', is the French nickname for proportional rep. resentation (représentation proportionnelle). 


\section{CONTEMIPORARY FRENCII POLITICS}

the commeree courts. But as they do not otherwise possess the ballot, a movement has naturally arisen for its acquisition, following those in other eomtries. But becanse of the French conception of a woman's sphere in life, the French feminist movement has not yet obtained either the following, adherents, or the temper of its comterpart in America or England. To quote an cminently French opinion: "The Freneluwoman is no feminist as yet. She has little faith in the political systems devised by mere men, and thinks she wields far more power in her informal way than she could ever exert if she were an elector."' 2

This French attitude was perhaps better illustrated by the replies received during a symposium which a popular review conducted in the winter of 1918-1919. In this comnection Professor Edonard Barthélemy wrote: "Political dualism in families must not be risked. A legal political dualism, in ease of dissension, would certainly disintegrate the home...'; while MI. G. Deherme, a prominent editor, expressed himself even more frankly: "The feminists are barbarians and enemies of woman, since they wish to make a beast of her by luere and pride, degrade her in the factory, and disgrace her by the promisenity of the street and by dissolnteness. The progress of civilization has always consisted in the increasing preeminence of persuasion and devotion over constraint, of the spiritual over the temporal, and therefore in the extension of feminine influence." 's 'These aroments singularly approach those until recontly heard in America.

But the feminists have two things in their favor: First, the very important fart which wench women played

${ }^{2}$ I. Sallions, Farts about France, 276.

${ }^{3}$ If Sols Toul, issues of Iammary-February, 1919. 


\section{WOMAN SUFHRAGE ANI) 'TIIE "R. I'."}

in the war; sceond, their greatly needed help in the solution of moral problems. It may be true that Fremedr women did not engage in gratuitous war-work as extensively as did Amerian or English women. Thry were indeed excluded (the majority of them, at least) from such a comparatively nonessential work, by the very vital necessity of maintaining the greater part of the economic system of France. 32,000 women were employed upon the railways and 684,000 in muntion works; comtless peasant women tilled the soil and fed their sons and husbands, engaged in the mproductive work of war. Their heroic work in sustaining the industrial processes of the country, as well as in earrying on works of merey in the Freneh armies, ${ }^{4}$ earned for them the unending gratitude of the country. This experience also gave them a much needed lesson in independenee, organization, and soliclarity. As a result many women partially, at least, lost the eustomary conception of their inevitable domesticity. Moreover, the enormous demands which the task of reconstruction is making upon French women and the necessity of taking the places of men fallen in battle, are still funther contributing to the movement whi h seeks to grant them rights eommensurate with the dutios they now willingly and joyously perform. Organizations such as the French Lnion for Wroman Suffarge (having eighty departmental groups), the National Comeil of French Women (composed of one hundred and fifty women's associations), the Freneh Leagne for Women's Rights, the Women's - Fraternal Inion, the Soriety for the Improvement of the Conrlition of Women, and even such jommals as Lat. Torir des Frmmes (extromely Sorialisti. though it lue),

${ }^{4}$ The French lied Cross has a membership of over 25,000 . 


\section{CONTEMPORARY FRENCH POLITICS}

illustrate the widespread organization supporting this campaign for woman suffrage.

As for the moral problems of France, Parliament has not even attempted a serious legislative solution. Aleoholism is the first of these problems. By a decree of 1851, drinking places were subject to supervision and license by local authorities; but these restrictions were completely removed by a law passed in $1880,{ }^{5}$ and now in force, which provitles that any person desiring to open a eafé, or to engage in the retailing of liquors, has only to serve a notice on the mavor of the town in which he resides. ${ }^{6}$ Permission cannot be refused any one wishing to sell liquors, unless he has been convicted of eertain serious erimes. The sale of liquor is restricted only by the power of loeal anthorities to forbid drinking places within certain distances from schools, cemeteries, churches, hospitals, ete.,-a power which it is understood is never exercised. The effect of this law las been to increase the number of drinking places in France from 179,000 in 1872 to $1,070,451$ in 1913 ,-one for every thinty-nine inhabitants. Despite the worthy efforts of the Ligue Nationale contre l'Alcoolisme, the per capita consumption of absinthe doubled between 1907 and 1911, and the consumption of 100 per eent aleohol tripled between 1830 and 1912 .

Parliamentary efforts to control this ever-growing evil lave almost always failed, largely becanse of the winemerchant element within the legislature. Aside from the prohibition of absinthe, heary taxes on drinks, and the state monopolization of industrial alcoliol during the

"For the decree of Derember 2!), 1sisl, see A. Carpentier, Codes it Lois pour la France, l',llgririe et les Colonios, ii, 457. For the latw of July $17,18 \mathrm{~s} 0$, see ibid., 858.

"lixerpt in l'aris, where notifieation must be fijed with tho prefecture of police. 


\section{WOMAN SUFFRAGE ANI 'THE "R. P.'”}

war, every controlling neasure has been defoated. For example, on the 1tth of March, 1918, M. Siegfried asked the Chamber to prohibit, for the period of the war, the sale to consmmers, on the place or to be carried away, of all drinks containing more than 18 per cent aleohol. The measure was defeated by a vote of 442 to 43 , a signifieant majority. The Govermment even refused to cntertain a suggestion that "drinkless days" be inaugurated as a measure of war economy.

Ifowever, Parliament, though not choosing to curtail the sale of liquors, attempted (by a law passed October 1, 1917) to punish drunkenness. It imposed a fine upon any one found in a state of "manifest drunkenness,'” the penalty increasing to imprisonnent for three days for the second offense, and from six days to a month for the third offense, in addition to the fine. The law further deprived habitual drunkards of electoral and certain other civil rights. It prohibited shops from selling liquors to minors of less than eighteen. Any one who succeded in getting such a minor intoxicated became liable to imprisonment from six days to a month. The law, however, has remained a dead letter, despite its moderateness. It offers a very good example of the uselessness of legishation when unsupported by publie opinion.

The inability of man-composed Parliaments or municipal bodies to curtail this vice has led such men as Joseph Reinach and Senator ILerriot to ask that women shonld be given the vote, at least in mmicipal and department elections, with the principal hope that they will secure the enactment of restrictive if not prohibitive laws.

This demand for moral purification has also extended to prostitution, which at present is subject to practically 


\section{CONTEMPORARY FRENCII POLITICS}

no control by municipal anthorities. The chief argument for woman suffrage is therefore an appeal to their moral superiority. Whether or not that moral superiority ean be any more effectively exercised through the ballot than it is now through persuasion and example, is another question.

The two distinctively French arguments ${ }^{7}$ against woman suffrage are economic and elerical. Although great numbers of women entered the war industries, they were largely compelled to do so through economic needs, - that is, by porerty. It is this elass of women who want the ballot and who, it is feared, would be the only ones to use it. The women of the higher classes did not enter French industries becanse they were under no economie eompulsion. Their patriotism exercised itself in more philanthropic and non-remmerative war work. Thus they have not experienced the same feeling of feminine solidarity as have their poorer sisters. According to the conservatives, the women of the better families of France, with few exceptions, do not want the right to vote, and would not exercise it if it were granted to them; and their negleet of the ballot wonld disproportionally inerease the political power of the labor and Socialist vote, aided by the support of women in industry.

The anticlerical argument is substantially this: France is still nominally a Catholie nation. Although many men have come to oppose Catholie dogma and its inflnence, large numbers of women, beranse of their more emotional and religious natures, are still completely controlled by the priesthood-so the arrument goes. The anticlericals fear that the priesthood will utilize its

${ }^{7}$ For the Freneh arement in general agninst woman suffrage, see Jismein, Droil Constitutionnel (5th ed.), 300-30.4. 
religions influence, as it lass so frequently done before, to obtain politioal advantages; in other words, it is feared that the priesthood will dictate what candidates its women parishioners should rote for, under fear of displeasure of Gorl and the Church.s 'This arwument, very energetically urged in the debate on the Suffrage IBill in May, 1919, seems to be of little real value. The control of the Church over its members appears nominal, even in religious aftairs; while many women of the working classes,- - at least the feminists imbued with Soeialist teachings,-are decidedly anti-Catholic.

The Church, one would naturally think, would be op: posed to woman suffrage. Tet, possibly because of the prospect of increasing its political power, it has taken an advanced stand on the question? At a Journée Dioésaine, held on the 19th of February, 1919, in Paris, a report of the "Action social de la femme" was adopted, stating that if the right to vote were granted to them, women were under the moral duty of exereising it, and asking that, in the futmre, this duty be tauglit young girls by the Church.

Legrislative artivity for woman suffrage hegan in 1906 with the introduction of a hill by M. Dussausoy, granting women the ballot in mmicipal affairs, and in the election of general romcilors. The proposition was adopted by the Commission on Universal Suffrage, but discussion was delayed during four rears, finally to be dropped.

Later projeets are numerous. In 1918, M. Magniex, deputy from the Somme, drew up another proposition, which granted the ballot to women in municipal, can-

${ }^{8}$ For this and other arguments, sec three artioles hy Louis

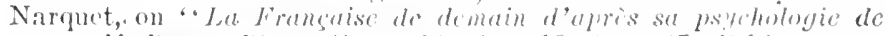

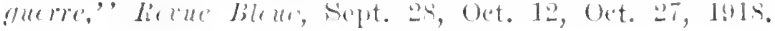




\section{CONTEMIPORARY FRENCH POLITICS}

tonal, legislative, and senatorial elections, under the same conditions as it is exereised by men. Senator Martin also advocated the unrestricted right to vote for women above twenty-five years of age. During the debate on the eleetoral bill in April, 1919, MI. Lonis Andrieux moved an amendment to include woman suffrage in the bill. Although it was defeated by a vote of 325 to 116, the Commission on Universal Suffrage promised to introduce it later as a "special measure." This promise was in part fulfilled by the introduction of the so-ealled Flandin bill, which granted women the limited right to participate in the election of munieipal, arrondissement and general councilors. They were not, however, to vote for members of the Chamber of Deputies. This bill eame up for discussion on Tuesday, May 20th, 1919. It was evidently a compromise between the Feminists and their opponents, - a eompromise necessitated, the Commission urged, by Senate opposition. But this did not satisfy the Chamber, and, after vigorous arguments in support of granting the complete right of suffrage to women, from two former prime ministers, René Viviani and Aristide Briand, the Bon amelldment was adopted by a vote of 329 to 95 , giving the women identical suffrage rights with men. Although some believed that the opponents of suffrage had roted for the integral right in the belief that the Senate would kill the entire measure, it was generally felt that the Chamber was at least sincerely desirous of acknowledging the eountry's debt of gratitude to the women of France.

The measure thus passed by the Chamber was sent up to the Semate. No one seemed to expect that this body would ratify the bill. The arguments against it weighed too heavily with these conservative rlignitaries. Upon 
May 22 the Senate appointer a commission to examine the bill; and on the 18th of July, the Commission reported it unfavorably. It is still penting before the Upper Clamber, but there is slight chance of its passage.

On Oetober 7, 1919, the Deputies passed a resolution urging the Senate to aet on the Chamber's Woman Suffrage bill.

On the Senate's failure to att hefore the elections of November 16th, L'Excelsior, a l'aris newspajer, lueld a mock eleetion for the Deputies upon the 16th, in Paris, at which the women might vote. The eandiclates voted upon were identical with tlose of the general election.

\section{II}

Plural voting has been advoeated under some very unique forms. On April 4, 1919, M. Roulleaux-Dugage introduced an amendment to an electoral bill under diseussion, to the effect that fathers of families should be given a vote, in addition to their own, for every one of their children. Ile again introduced a similar proposition during the dehate on woman suffrage which read:

Any person enjoying French nationality, whatever his age or sex, possesses a right of political suffrage which is the corollary of his eivil personality. The father of a family exereises the right of suffrage for himself and for all the persons legally placed mnder lis eivil anthority, that is to say, for his legitimate wife and for his minor children of both sexes, legitimate or reeognized.

The idea that every person, irrespective of age or of sex, is entilled to the "right of political suffrage," is indeed a novel one. But it is also pointed out that there are about 11,000,000 voters in France; over 7,000,000 of them are either bachelors or the fathers of but one or 149 


\section{CONTEMPORARY FRENCH POLITICS}

two children; only $4,000,000$ are fathers of three or more chilkren. The first class, which represents but 16,000 ,000 inhabitants, has one vote for about every two persons; while the fathers of large families, representing $23,000,000$ people, have less than one vote for each six persons-obviously an injustice if the premise of the argument is correct. This innovation is also urged to secure another end of the utmost importance to the country, viz., as a reward and stimulus to large families. ${ }^{9}$

But there is eonsiderable doubt both as to the right

${ }^{\circ}$ The depopulation question in France is generally considered serious; with the exception of twenty-one departments, the death rate is anumally in cxess of the birth rate; nearly $2,000,000$ out of the $11,000,000$ families have no chiliren whatever. Since 1867 the Prussian population has increased four times faster than the French.

Figures compiled by the Ministry of Lahor, published in Le Tcmps for Octoher 8, 1919, show that the depopulation erisis in France is increasing.

For the two years 1918 and 1917 mortality figures were as follows:

Births. . . . . . . . . . . . . . . . 399, 041

343,310

Deaths

$78 \mathrm{~S}, 616$

Exress of Deaths over Births. . . . . . . . . 359,575

Marriages.................... 177,572

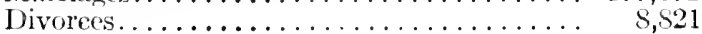

(j) 3,148

269,838

156,508

5,572

The executive committee of the National Congress of Natality and 1'opulation, which holl a mational comeress at Nancy, September 25-28, 1919, has urged the following program to overcome this erisis:

1. The Family Vote.

2. Correction ot" "fiseal inequalities" weighing upon hearls of numerous timilies.

3. Allotments, premiums ant gifts to families with a large number of ehilirem.

4. Campaign against poor housing and for sanitary ant comfortalle lublemes for larege families.

5. Suppression of aluotion, neo-Malthusian propacanua, and prostitution.

6. Creation of at National Onice of Natality.

7. 'Tle rxemption, in times of peace, of lathers of largo families from military service. 


\section{WOMAN SUFFRAGE AND TIIE "R. P."}

of a child to the ballot (even if exereised by the father as a trustee), or as to the effeet of such a measure upon inereasing the size of families. To offere an additional vote as a solution of the depopulation yuestion appears so weak that it is a wonder it is serionsly eomsidered. It is signifirant, however, that M. Romlleaux-l)ugage's amendment nearly sureeded in passing-and was only defeated by the vote of 219 to 200 . Moreover, no less than eleven societies interested in measures of reform are sponsoring the idea, in addition to many of the eandiclates at the recent election (November, 1919).

Still another phase of the plural voting plan is urged (for different reasons, however, by Maurice liares, the president of the Leagne of Patriots.

In an ingenious appeal to sentiment and patriotism, Manrice Barres advocates the plural vote as a reoconition and memorial of the sacrifices of the dead. For every member of a family killed upon the battlefield, he would give a "family" vote to be cast by the father", mother or widow, as the case may he. Thus he would create a "family" instead of a "fither"s" rote, as adrorated in M. Roulleaux-Ingage's plan. The "family vote" was formulated in an amendment to the electoral bill, and was introduced by Jules Delahaye, in the Chamber of Deputies on April 19, 1919. This amendment gave the right to vote to the widows, or in their default, to the mother's of soldiers killed by the enemy; it was defeated by a rote of 375 to 113.

All of these projects of phural voting, while finding a certain following, appear to be rather fanciful as well as inconsistent with the trends of modern demorracy. The progress of electoral reform, in recent times, has been away from-rather than toward-the system of phural ballots. Some of these projects introduced in 


\section{CONTEMIPORARY FRENCH POLITICS}

the French Chamber, projects which only a politically imaginative Frenchman can devise, illustrate the length to which the theory, so prevalent in France, of the right of representation of interests as opposed to that of the nation, ean be permitted to go. That these systems of plural voting violate the simplest maxims of sovereignty, that they misrepresent and misplace the will of the nation, and that they are practically impossible of application, is, without deep study, apparent.

\section{III}

But the greatest electoral issue in France has not been so much in the extension of suffrage as in the adjustment of the methods through which suffrage is exercised and in the devising of means by which one voter may enjoy as much influence as another. The "rotten boronghs" of England, the old three-class tax-qualification system in Prussia, and the practice of "gerrymandering" in the United States, through which great numbers of voters have been deprived of their ballots, are approximated, to a much less extent, in France by a faulty method of election known as the scrutin d'arrondissement.

The Chamber of Deputies is elected by distriets, known as arrondissements (until the law of 1919), each alecting one deputy, unless its population exceeds 100 ,000 . In the latter case a new district is formed, electing another deputy for every 100,000 or fraction thereof. ${ }^{10}$ The vital question in France has been whether there should be a large number of small districts, such as the arrondissement, earh elereting a deputy, independently

${ }^{10} \mathrm{~A}$ new distrioting is male ater exery quinquennial eensus: the last law fixing these districts was of Mareh 27, 1914, hased (3) the rensus of 1911. The number of districts was set at 602 . 'The return of Alsace and Lorraine increased the number to 6:6. 


\section{WOMAN SUFFRAGE AND TIIE "R. I',"}

of the others; or whether there should be a smaller number of larger districts, such as the department, each eleeting several deputies on a general ticket, as Presidential electors in the United States are ordinarily chosen.

The issue has therefore been between the serutin d'arrondissement and the scrutin de liste. The former method of election was established in 1875, although Gambetta and Ricard vigorously demanded the latter. The sturdy arguments of these Radieals, however, finally led to the adoption of the serutin de liste in 1885. But it was only in use for four years. ${ }^{11}$ In fact, at that time the ease with which General Boulanger, making use of the "multiple candidary" privilege, threatened to win the elections, led to its hurried repeal by the Republicans. To eontrol departmental eleetions was within the plysical power of the Government; but to dominate arroudissement elections, so numerous were the districts, was an impossible task. From 1889 to 1919, this old arrondissement system was eonseruently maintained.

Despite long established usage, the serutin d'arrondissement is open to some grave objections. The eleetoral district is so restricted in extent that the election of a deputy depends too often upon the promises he makes to local interests. He usually regards himself as the mandataire of a restrieted and privileged district, in the service of which he neglects the wide interests of "la nation toute entiere," as the Constitution of 1791 defined it.

${ }^{11}$ For the "organic law" of November 30, 1575 , see Les Constitutions Modernes, i, 24. For the law of June 16, 1sis.5, establishing the scrutin de liste, see ibid., 35; for the law of February 13,1859 , repealing it, see ibid., 36. 


\section{CONTEMPORART FRENCII POLITICS}

The restricted size of the arrondissement also makes bribery more probable. The use of money and wine has been a feature of many elections. The Chamber Commission on Universal Suffrage, as far back as 1905, in its report on the Klotz bill said that the deputy was too often notling more than a veritable local "chargé d'affaires" at Paris. For this reason he had little time to consider propositions of law becanse the olsligation of his arrondissement needed his exclusive attention. In regard to bribery, the commission was "struck by the increasingly preponderant part played by money in the elections. . .." "But what," it asks, "can be said of the scandalous habit of certain districts, happily rare, where wine distributed broadcast takes the place of diseussion and a program?... Such practices constitute a double danger: they falsify the expression of national sovereignty, and they demoralize the locality where they are practiced."

Furthermore, the arrondissement method permits the effectual control of elections by the Govermment. There is little question but that by bringing pressure through the Sous-prefet (the administrative head of the arrondissement), the Govermment is tempted to interfere in elections to secure its own ends. ${ }^{12}$ The Sous préfot sometimes appears to be little more than the "election agent" of the l'refeet, whose advaneement depends upon his swinging the elections in a scuse favorable to the Government. The evil of such an interference, which has long been practiced in France, ${ }^{13}$ is tolerated becanse nearly every party has in turn profited by it.

\footnotetext{
${ }^{12} \mathrm{At}$ least in the elections in country districts; city elections are nore diflicult to aontrol.

13 The I'rovisional fincemment during the licvolution of 1548 , through Ieelru-liollin, Minister of the Interior, boldly issued writ-
} 
But the greatest objection to the serutin d'arrondissement is the molue representation this system grives certain sections of the comutry. Aceording to the law, an arrondissement containing 100,000 inhabitants, or a fraction thereof, is entitled to cheose a deputy. 'This provision of the law has led to the greatest injustive and inequality. For example, in two arrondissements, one containing 100,000 inhabitants and another containing 100,002 inhabitants, the first will have one deputy ; and the second, after being divided, will have two. The first deputy, therefore, represents 100,000 inhahitants; the last two each represent 50,001, a manifest injustice. There are many instances bearing ont this bypothesis. For further example: ${ }^{14}$

\begin{tabular}{|c|c|}
\hline City & Names of Voters \\
\hline 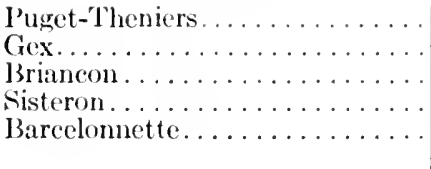 & $\begin{array}{l}6,527 \\
6,557 \\
6,375 \\
5,973 \\
3,413 \\
\end{array}$ \\
\hline & 29,175 \\
\hline
\end{tabular}

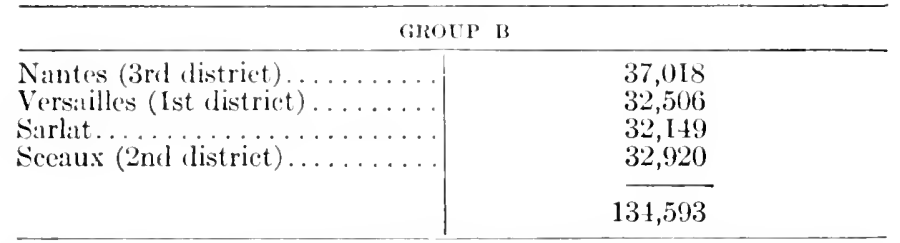

ten instruetions to the departmental arents defining these duties: "Through the elections which are going to take flace, you (the political agents) hold in your hands the destinies of France." Gaston Bomiols, II istoin de la liérolution de 1sts, 86. The government of Napoleon 111 interferel with olections to a greater extent perhaps than any other govermment before or after it. For the "ofticial "mmlislates," ete., see de la Gorce, Histoire du Seeond Empire, ii, 191-19t. 1907 .

"Alapted from Rapport 57, Doe. Parl., Chamb. Sess. Ord., 
Thus 29,175 voters in five arrondissements (Group A) elect five deputies, one for every 5,835 roter's; while 134,593 voters in four arrondissements (or districts, Group B) eleet only four deputies, one for every $33,6 \pm 8$. One vote in the A Group has, therefore, abont five times the weight of one in the $B$ Group; the town of Barcelonnette with its $3,4+3$ voters has the same representation as the third district of Nantes, with its 37,018. In other words, a Barcelomnette voter has ten times the electoral strength of one in Nantes.

The scrutin de liste would in a measure overeome these inequalities. For example, in the department of the Isère there are eight arrondissements. Under the scrutin d'arrondissement, eaeh arrondissement eleets one deputy, separately from the others. Under the scrutin de liste, the whole department would eleet eight deputies upon a general ticket. Hence minorities, now voiceless in the arrondissement, by combining forces throughout the department, might secure a representation. This possibility will bring many to the polls who hitherto may have stayed away becanse of the hopelessness of making their ballots eount. Furthermore, the enlarged district would be a prerequisite to any of the sehemes of proportional representation which the Chamber has favored. Under any such plan, more than one eandidate would have to be eleeted by an electoral distriet. Ifenee a change from the arrondissement electing one eandidate, - to the department (or other enlarged district) electing several candidates-is a necessity if this measure securing minority representation is to be made praeticable.

In later years, the agitation for proportional representation has not only been combined with the demand for the scrutin de liste, but it has also been even more 


\section{WOMAN SUFFRAGE AND TIIE "R. P."}

insistently mrged. The demand for this reform arose from causes common to all countries. Any strictly majority system, whether it be muler the scrutin d'arrondissement or scrutin de liste, is really unrepresentative of the will of the nation, and virtually amounts to the rule of an organized minority. As the following table will illustrate, in every French election since 1881 the unrepresented votes have been more numerous than those who actually secured a representation:

\begin{tabular}{|c|c|c|}
\hline & $\begin{array}{l}\text { Voters rejresented } \\
\text { by deputies elected }\end{array}$ & $\begin{array}{l}\text { Voters not repre- } \\
\text { sented }\end{array}$ \\
\hline 1881. & $4,778,000$ & $5,600,000$ \\
\hline 1885. & $3,042,000$ & $6,000,000$ \\
\hline 1859. & $4,526,000$ & $5,800,000$ \\
\hline 1893. & $5,513,000$ & $5,930,000$ \\
\hline 1898. & $4,906,000$ & $5,633,000$ \\
\hline 1902. & $5,159,000$ & $5,818,000$ \\
\hline 1906. & $5,209,000$ & $6,830,000$ \\
\hline $1910 \ldots$ & $5,300,000$ & $6,739,000$ \\
\hline
\end{tabular}

In the vote on the law governing the Separation of the Church and State (passed July 3, 1905) the majority consisted of $3+1$ deputies, representing $2,647,315$ voters, while the tolal number of those registered equaled $10,967,000$. The average pereentage of voters represented in the total number of elections between 1876 and 1906 was 45 per cent; while 55 per eent of the eleetorate had no representation whatever. Even under the scrutin de liste method in 1885 all of the thirty-two seats in the Chamber of Deputies from the departments of the Nord and Pas-de-Calais were secured by the votes of 267,900 Conservatives, 202,000 Republieans going withont representation. ${ }^{15}$

\footnotetext{
${ }^{15}$ Professor Esmein, on the other hand, says that the representation of minorities is likely to menace the very principle of au* thority and of politioal sovereignty. See his Droit Constitutionnel (5th ed.), 263-297.
} 


\section{CONTEMPORARY FRENCH POLITICS}

Obviously, this condition is contrary to Mirabeau's famous dictum: "Representative assemblies should be comparable to geographical maps which reduce all the elements of the country in their proper proportions, without the more considerable elements forcing the lesser to disappear." The strong desire to remedy the existing contradiction by some system of proportional representation has been erystallized in an organized agitation which the League for Proportional Representation has insistently ear'ried on since the begiming of the present century.

\section{IV}

Parliamentary activity respeeting the adoption of the scrutin de liste and proportional representation began in 1905. M. Louis Buyat then deposited, in the name of the Commission on Universal Suffrage, a report upon the Klotz proposition providing for both of these measures. ${ }^{16}$ To carry out the latter, the voter was to be given as many votes as there were places to be filled, with the liberty of casting as many of these votes as he wished for a single candidate. The Commission on Universal Suffrage of the legislature of 1906-1910, of which M. Charles Benoist was president and M. Alexandre Varenne, the rapporteur, combined a number of projects calling for the scrutin de liste and the "R. P.," as the Represcutation proportionclle is called. Despite the opposition of the Clemencean Ministry, the Chamber took up the discussion of the bill in October, 1909. While the dehate was in progress, the Clemenceau Min-

${ }^{10}$ Journal Officiel, Doc. Parl., Chamb. Sess. Ord., 1905, 389. For an extensive treatise npon French electoral reform up to 1910 , see .lules tharion, La Réforme Electorale en. France. 
istry was voted out of office upon a foredgn affairs issue and was snecested by the Briand Ministry. The Chamber lad already passed the proposed bill by sections; but on Norember 8, 1909, the President of the Council declared: "The immediate vote of such a drastic re. form would create a grave situation, dangerous to the Republican régime." If also derlared that the eountry had not expressed itself npon the matter. Asking for a vote of confidence, he was given it by the Chamber (by a vote of 291 against 245). Thus the whole project was for the time being rejected and the Parliament of 1906-1910 came to an end with the matter of electoral reform still pending.

But the elections of the spring of 1910 revealed an insistent and eontinuing demand for the reform. Out of 597 deputies elected, 271 were on record as favoring the scrutin de liste and proportional representation. The remainder, with the exeeption of thirty-five defenders of the status quo and about 100 "mon-declarants," were all in favor of some sort of a change. It was estimated that out of $8,517,000$ votes cast, the principle of electoral reform received $1,162,333$ and that of the proportional representation, $4,4+2,800$, a majority of 200 ,000 for the "R. l'." In the face of such an expression of public opinion the Briand Ninistry recognized that some reform "was neeessary and just," that "it is even necessary for the future of parliamentary control, that, while reserving for the majority the preponderance which rightfully belongs to it, the minority of opinions expressed by miversal suffrage should be given due eonsideration.", 17 'This was an adroit change of face and poliey. The Govermment therempon introdured a

${ }^{17}$ Duguit, Traité de Iroit Constitutionnel, i, 385. 


\section{CONTEMPORARY FRENCII POLITICS}

bill (June 30, 1910), instituting the scrutin de liste and the electoral quotient system of proportional representation, and extending the life of the Chamber from four to six years. While the bill was pending the Briand Ministry fell. Little progress was made in the matter under the two succeeding Ministries of Monis and Caillaux. Diseussion of the bill was, however, renewed May 29, 1911. When the Poinearé Ministry eame into office in the beginning of 1912 , the President of the Couneil openly deelared himself for the reform; and owing to his strong insistenee, the Chamber passed a bill, eomprising most of the features of the Briand measure (July 10, 1912), by a vote of 339 to 217 . It was the Senate, however, whieh now rejeeted the prineiple of proportional representation (in its session of Mareh 18, 1913); although on the 10th of June, 1913, it voted a substitute projeet establishing the scrutin de liste, without proportional representation. A seeond time (November 18, 1913), under the Barthou Ministry, the Chamber voted a project of eleetoral reform, ineluding proportional representation, by a vote of 333 to 225. But the Senate's conservatism again rejected the Chamber's bill on the 10th of March, 1914 .

These failures onee more made electoral reform a pop. ular issue in the general eleetions of $A$ pril 8,1914 . As a result, 602 Deputies were eleeted, 320 of whom had teclared themselves as favorable to the scrutin de liste and proportional representation, 100 who were favorable to the scrutin de liste and the "representation of minorities," 100 who were favorable to the scrutin de liste pure and simple, 40 who emitted no opinion on the subject, and finally only 40 who were categorical partisans of the existing scrutin d'arrondisscment.

On the and of July, 1914, in comnection with the 160 


\section{WOMAN SUFERAGE AND TIE "R. P."}

Benoist proposition to establish both the scrutin de liste and proportional representation, the Clamber adopted the following resolution:

The Chamber has resolved to realize an electoral reform by adopting the system of proportional representation. It asks the Commission of Universal Suffrage to prepare a bill for enactment without delay. ${ }^{18}$

But upon the 10th of July, the Commission of Universal Suffrage, by a vote of 20 to 13 , rejected Article I of the project which M. Groussier, its rapporteur, submitted. Before further action could be taken, the Chamber adjourned on the 13th of July. On the $3 \mathrm{rd}$ of August, Germany declared war upon France, and the solution of the problem of electoral reform was necessarily postponed until the return of peace.

\section{$\mathrm{V}$}

The official life of the Clamber of Deputies would have expired nomally in May, 1918, but the exigeneies of the war compelled the enactment of laws postponing all legislative elections until the close of hostilities. ${ }^{19}$ Almost immediately after the signing of the armistice in November, the Paris newspapers commenced a campaign for the holding of the elections. I3ut as a preliminary recpuisite, it was urged that the long-deferred question of electoral reform be given a solution, a reform which

${ }^{18}$ Duguit, Manuel de Proit Constitutionnel, 176.

${ }^{10}$ The first law was passed December 24, 1914; it aljourned the Senate elections of 1915 (Series 13); other laws postponing elections for munipipal, general and arrondissement eouncils, were passed April 15, 1916, and July 31, 1919. The law postponing the election of the Chamber of Deputies was passed December 31,1917 . 


\section{CONTEMIPORARY FRENCII POLITICS}

had been agitated since 1905, which the eountry had repeatedly approved and which the Chamber of Deputies on several occasions had voted to adopt.

The newspapers were insistent upon the reform, notably Le Temps. Most of the politieal parties, with the exeeption of the Radicals, had favored the scrutin de liste and proportional representation. It was of some significance, therefore, that the Radical party in February, 1919, changed from its original position to agree to the compromise measure which had just been submitted to the Chamber. Other organizations such as the Civic League urged the reform. But the Government remained noncommittal; M. Clemenceau had always vigorously opposed proportional representation for the reason that eaused the Radicals generally to oppose itfrom the fear that Catholic supremacy might be established. His Ministry, through MI. Pams, Minister of the Interior, therefore took the position that it had not come to power on that issue and must consequently place the entire responsibility for the enactment or rejection of the bill on Parliament. As the debate subsequently proved, the Clemencean Ministry, however, used its influence secretly to oppose the reform in question.

As a result of this aytation, M. Dessoye, on behalf of the Commission of Iniversal Suffrage, laid a project before the Chamber (30th of January, 1919). Frankly a compromised measure, this project ealled for the departmental scrutin de liste; it abolished second or supplementary elections (nsed when a candidate did not receive a majority of the votes cast at the first). It also provided that ballots be supplied and distributed at public expense, that there be one deputy for every 75,000 inhabitants or major fraction therefore, that deputies be elected by a majority vote, as formerly; but in 
case no majority was maintained that the seats be disposed of by proportional representation.

The debate on the bill lasted over a month,-from March 14th to April 18th. The Commission justified the partial "proportional representation" feature of the bill as the only kind of project which the Senate would ratify. Ilowever, to the surprise of every one, this did not satisfy the Chamber. On $A_{\text {pril }} 8$ th, Article I of the proposition, "The memlers of the Chamber are elected by the scrutin de liste in a single election,' was debated. After the passage of the first line, ending in serutin de liste, had been discussed, M. Bracke moved an amendment substituting for the words of the next line, "in a single election," those of, "by proportional representation." This three-word amendment, rejecting the Commission's compromise and installing complete proportional representation, was adopted by a vote of 235 to 201 . The next day the intecral reform was again voted for by a majority of 100 . Many felt that this was a move of the opponents of the reform to secure the adoption of a measure so radieal that the Senate would kill it entirely. Others thought, however, that the reform had at last triumphed.

The Commission modified the remainder of the bill in accordance with the twice-expressed desire for complete proportional representation. Opponents of the reform obstructed its progress, hoping to delay diseussion until after the Easter recess, which would mean postponing it indefinitely. Finally, on the 15th of April, the Chamber did another strange thing. Article XTI was under discussion, containing the artual application of a complete proportional system, as amended to meet the Chamber's desire. Bnt M. Bouffandean, a Rarlieal, at this point introduced an amendment which almost identically re- 


\section{CONTEIPORARY FRENCI POLITICS}

produced the Commission's original project of partial proportional representation. Despite the vigorous opposition of M. Bracke, the Chamber adopted it by a vote of 235 to 177. After twice repudiating the Commission's hybrid proposition, it had returned to it. This indecision and pliability in the hands of effusive leaders, by no means inereased the Chamber's prestige. But it was characteristically French.

These tacties were commented upon by a clever writer, thus :

The Deputies are not partisans of the Dessoye system, nor of proportional representation; neither do they favor the scrutin d'arrondissement, with the exception of a few who have made it a matter of prineiple. The majority of them wish merely to be reëlected-and this is the secret of their Machiavellism. As they are good servants of the country, their desire is nothing more than patriotic! 20

Another noticeable feature of the debate was the part M. Briand took in it; espousing a reform for the defeat of which he was at one time largely responsible, he now made several spectacular addresses in its support. On the 18th of April, M. Pams, the Minister of the Interior, and M. Briand engaged in a lively tilt, in which the latter aceused the Government of secretly trying to defeat the measure. After several exchanges of elever repartec, M. Briand appeared to emerge the victor.

On the 18th of April the hill, as amended, was passed in the Chamber by a vote of 287 to 138 . The compromise measure, calling for the scrutin de liste and partial proportional representation, now went before the Senate. Fear that this body, as it had done before, would reject any measure embodying the principle of propor-

${ }^{20}$ Midas, in "Sur les Gradins, dans les Couloirs," L'Europe Nouvelle, April 19, 1919. 


\section{WOMAN SUFHRAGE AND THE "R. P.",}

tional representation, was increased by the appointment on the 15th of May, of a eommission headed by Senator Bérard, a vigorous defender of the scrutin d'arrondissement. It was composed of twenty-seven members, fourteen of whom were avowed opponents of the Chamber's bill. When the Commission finally reported back to the Senate it was found that it had gone so far as to admit in principle the scrutin de liste and the double eleetion feature in case no one received a majority, while it completely rejected the principle of the representation of minorities, even the compromise plan included in the Chamber's bill. Upon the 21st of June, however, M. Paul Strauss introduced an amendment which embodied in principle the Chamber's proposition. The amended bill differed from the original one passed by the Chamber only in the matter of the public supply and distribution of ballots. The Senate believed that eandidates should themselves bear this expense. It was earried by a vote of 120 against 90 . Upon Thursday, June 26, this bill passed by a vote of 134 to 0 . Thus, despite the prophecy of M. Delahaye that the law meant "the invasion of the Chamber by the Bolsheviki," the Senate finally ratified this long-delayed and much-desired reform.

The Chamber, upon the 4th of July, voted the first four artieles of the Senate bill. On the 7 th it aecepted the entire proposition by a vote of 308 to 103 .

The law as finally promulgated upon the 12th of July provides (Article I) that the members of the Chamber of Deputies be elected by the department scrutin de liste. Each department (Article II) elects one deputy for every 75,000 inhabitants of French nationality (or the major fraction thereof). Each department elects at least three deputics upon a general tieket; and until 


\section{CONTEMIPORARY FRENCHI POLITICS}

a new eensus is taken, it will have the same number as it formerly elected. The department (Article III) is the electoral district. When the number of deputies to eleet is greater than six, the department is to be divided. Each division will elect at least three deputies. This division will be made by law. No one can be a eandidate (Article IV) in more than one district. The declarations or platforms of candidates may be eollective or individual.

The tickets (Article V) will be eonstituted for eaeh district by groups of candidates who sign a duly legalized declaration. A ticket cannot have a number of candidates exceeding the number of deputies to be elected in the district. Any isolated candidate is eonsidered as forming a ticket alone; but his deelaration must be signed by at least 100 voters of the district. The "tickets" (Article VI) are to be deposited at the prefeeture after the opening of the electoral period-at least five days before election day. These tiekets are registered by the prefect; but those carrying more than the number of deputies to be elected, or those earrying names of candidates inscribed upon another ticket, cannot be registered. A candidate inseribed on a tieket (Article VII) can only be taken off of it at his own request-which shall be made to the prefect at least three days before the election. New eandidates may be inscribed (Article VIII) on any ticket at any time $u_{p}$ to five days previons to the election. Two days before the election (Article $I X$ ) the eandidates will be posted at the different places of election at the expense of the prefocture.

Any candidate (Article $\mathrm{X}$ ) who receives the absolute majority of the votes east is proclaimed eleeted. If any scats still remain, or in ease no one receives an absolute 


\section{WOMAN SUHFRAGE AND THE "R. P."}

majority, the seats will be disposed of by determining, first, the electoral quotient by dividing the number of voters, deductions being made for null and blank ballots, by the number of deputies to elect. After determining the average number of votes east for each ticket by dividing the total number of votes which the ticket received by its candidates, this average is divided by the electoral quotient to determine the number of seats which each ticket will obtain, if any. ${ }^{21}$ A single eandi-

${ }^{21}$ The exact working of this Electoral Reform Bill is shown by the following hypothetieal election results from the district of tho Rance:

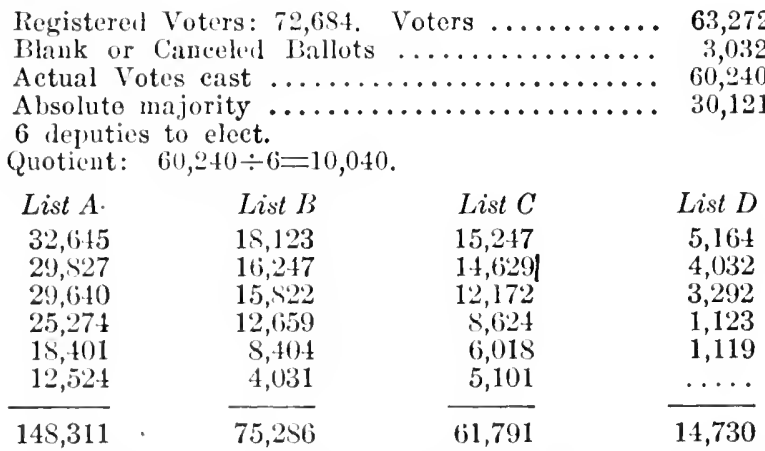

Average number of rotes for Tirket $A$ (with six candidates): $148,311 \div 6=24,718$.

Average for Ticket $B$ (with six eandilates): $75,286 \div 6=-12,547$.

Average for 'Tiiket C' (with six candilates): $61,791 \div 6=10,299$.

Average for Ticket D (witl five candidates) : $14,7: 30 \div 5=2,916$.

The first candidate in Ticket $\mathrm{A}$ reecivel 32,645 , or more than the absolute majority of 30,121 ; he is therefore elected. Ticket $A$ is further cntitleit to two more seats because the quotient of 10,040 gres inte its average of 24,715, twice. Theket 13 is entitled to une seat, hecause the quotient only goes into its average of 12,517 once. Tiuket $C$ is also cutitled to one seat for it has an average of 10,2969 . Tirket 1) receives no seat for its arerage is only 2,946. One seat still remains to be disposed of; 


\section{CONTEMPORARY FRENCH POLITICS}

daey (Article XI), if it does not obtain an absolute majority, will not figure in the division of seats until the candidates belonging to other tickets and having obtained more votes than it, are proclaimed elected. In case of equality of votes (Article XII) the election goes to the oldest candidate. If a seat belongs equally to several tickets, it is given to the candidate having the most votes, or in ease of equality, to the oldest. The eandidate can be declared elected only if the number of his votes is superior to one half of the average number of the votes of the ticket of which he is a part. When the number of voters is not greater (Article XIII) than half of those registered or if no ticket obtains the electoral quotient, no eandidate is declared elected, and a new eleetion is called within fifteen days. If in this election, no ticket receives the eleetoral quotient, the seats are given to the eandidates who have obtained the most votes.

A report of the eleetion (Article XIV) of each commune is made in duplicate, one copy going to the secretary of the mayor; the other is sealed and mailed to the prefect to be turned over to the Committee on Recount (Recensement). This Committee (Article XV) is ereated in every department, meeting at the chef-lieu of the department, in public, sitting at the latest by the

and according to the law, it goes to the ticket having the largest average, or A. Therefore there are eleeted:

Four candidates of Ticket $A$

32,645 (absolute majority)

29,827 (quotient)

29,640 (quotient)

25,274 (seat going to ticket having largest average)

One candidate of Ticket 13

18,123 (quotient)

One candidate to Ticket C

15,247 (quotient) 


\section{WOMAN SUFFRAGE AND TILE "R. P."}

Wednesday following the election. This Committee is composed of the presilent of the Civil 'Tribunal, and the four members of the General Council having served the longest, or in case of equality, being the oldest.

In case of a vacancy due to any cause ( $A$ rticle XVI), an eleetion may be held within a delay of three months, exeept in eases when the vaeaney occurs within six months before the regular time for the renewal of the Clamber. In such a ease no special election will be held. The present law (Article XVIII) will apply to the departments of Algeria and to the colonies which will continue to return their present number of deputies. A later law will determine the application of the reform to Alsace and Lorraine. Previous legislation contradicting the law (Article XIX) is deelared void. ${ }^{22}$

\section{VI}

The effect of partial proportional representation upon the composition of the Chamber and indeed its effect on French parties in general will be interesting to wateh. During the debate in the Chamber it was argued that the representation of minorities eould be secured only by definite party groupings. It was, moreover, held that France, especially since the Sacred Union, had no well-defined party system, and that, therefore, the proposed reform would not succeed.

${ }^{22}$ In the first week of March, 1920, the Commission of Universal Suffrage examined the electoral law of .July 12, 1919, with a view to its amendment. $13 y$ a vote of 11 to 3 it was deeided not to return to the old majority system. 13y a vote of 10 to 1 it was decided to do away with the present partial system of partial proportional representation. It is very probable that the Commission will eventually favor an integral system of proportional representation, entirely discarding the present compromise. 


\section{CONTEMPORARY FRENCII POLITICS}

All indieations, however, point to the strengthening of parties by this reform. Certainly parties, which through unfortunate geographic location or dispersion of their members have hitherto been excluded from proper representation, will be strengthened. Under proportional representation, it is very probable that the Right will secure some representation from such districts, as the Sancerrois, eastern Nivernais, and the Morvan, from which the majority system has hitherto excluded it. It is believed that the possibility of making every vote effective will have the tendeney to encourage minority parties, to develop their organization, and to bring party issues more into prominence.

The abolition of supplementary eleetions (the method hitherto employed in ease no ine received a majority) will do much toward breaking up party combinations and "bargains" on second ballots. As noted previonsly, it was through this means that the Bloc of the Left so long remained in power and that the Socialists and Radicals won so many electoral successes. For example, in the Gard, in the Ilérault, and in the Haute-Garomne, even the eonservative parties, in ease their candidate was hopelessly defeated at the first election, threw their votes to Socialist eandidates in the seeond election held two weeks later,-in order to defeat the Radicals. (Thus Louis Bernard, elected at Vigan as a Socialist by a vote of 7,125 , received only the votes of his party at the first election, viz., 1,749.) In other districts, such as in the Valenciennes, the Socialists have received the help of the Radicals.

These combinations-usually undesiralle from the standpoint of party integrity-proportioinal representation and single elections will do much to overeome. The final result of this new law may be a reduction of the 
WOMAN SUFFRAGE ANI TIL" "R. P."

Socialist and Radieal elements in the Chamber. Whatever the eventual result, France now has the assurance that its Chamber of Deputies will more nearly correspond to popular sympathies and that it will be composed of stronger and more representative forees than has before been possible. 


\title{
CHAPTER VI
}

\author{
THE 1919 ELECTIONS $^{1}$
}

Nous ne voulons pas la contrerécolution, mais le contraire de la révolution.-JOSEPH DE MAISTRE.

\section{I}

The day before the Treaty of Versailles was signed by Germany (.Jume 27th), the Chamber of Deputies proreeded to the election of a Special Commission of Sixty to examine the Treaty. This Commission seleeted René Viviani as its president and M. Barthou as its rapporteur,-two former prime ministers. Thronghont the month of July the Commission heard MI. Clemenceau and other members of the French Peace Delegation in defense and in explanation of the Treaty elanses. Finally, it voted 35 to 1 to approve it; on the 5 th of August M. Barthou presented his report to the Chamber.

Opposition to the Treaty came from two sonrees: first, the Socialists; second, the Conservatives. On the 15th of July, the National Council of the Socialist party voted, despite the protests of such high-ninded men as Albert Thomas, to instruct its deputies to vote against ratifiation. This motion was passed by the overwhelm-

'The sources for this aceount of the French elections are: La P'resse de Paris and Le Tomps, for the period covered. Ac-

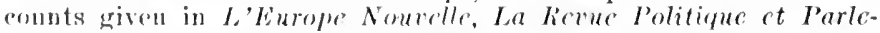
mentaire, Ia lictue des I) Mor Mondes, La Revuc de l'aris, and personal correspondence, are also used. 


\section{TIE 1919 WLEC'TIONS}

ing majority of 1,420 to 54 . The Socialist objection to the 'Treaty was hased upon its "imperialistice" features. In the debates in the Chamber, Mareel Sembat attacked partienlarly the Damzig settlement, saying it would always be a somre of irritation between France and Germany. Jean Longuet demanded the independence of Treland, Fgypt, and India. ITe took particular exeeption to the Austrian settlement which forever separated Austria from Germany, unless the Allies expressly deeided otherwise.

From the other extreme opposition was nearly as strong. It was led by Louis Marin who insisted that the dominant position held by France at the end of the war, had been bartered away needlessly; and that France had not even secmed adequate "guarantees" against future attacks. Maurice Barrès and Charles Benoist, eonservatives, expressed their legret that the left bank of the Rhine had not been given to France, while Franklin Bouillon and Charles Chaumet were espeeially caustic in their denunciation of the 'Treaty's shorteomings.

Both M. Clemencean and M. Tardien vigorously defended the Treaty from the charge that it failed to safeguard France. Both pointed out that France had one of two choices before it at the Conferenee: an alliance with England and the United States, or the ammexation of the left bank of the Rhine. The French Peace Delegation had believed that the former was by far the preferable.

But M. Barthou raised a point which it was more diffieult for M. Clemencean to answer. What guarantees did the treaty supply if the Cuited States Semate failed to ratify the Leagne of Nafions Covenant? M. Clemenceau replied that the leagne of Nations and the Treaty 


\section{CONTEMTPORARY FRENCII POLITICS}

would function immediately after its ratificaticn by three of the four principal powers, regardless of the United States. But a Socialist Deputy pointed out very keenly that if America rejected the Covenant, France would be left alone in a League with those who did not believe in it. Furthermore, there was no indication that America would ratify the treaty of Alliance with France if it refused to accept the Covenant. If it did reject the Covenant but ratify the treaty of Alliance, the latter could not function because it was inextricably tied up with the League of Nations. For this reason M. Barthou suggested that the Chamber should change the terms of the Alliance so as to make it completely independent of the Leagne.

The Prime Minister, however, vigorously repulsed all suggestions as to the amendment or "reservation" of the Treaty. IIe made it clear that the Chamber had to reject the Treaty cnscmble or ratify it cuscmble, that it had to take it or leave it in the form which he presented it to them. He made this categorical position evident not only upon the Barthou suggestion as to the Alliance but also upon the Lefère motion demanding complete German disarmament. In an encrgetic speech before the Chamber, M. Clemenceau declared that he would tolerate no motion which it would be neeessary to refor to the Allies for approval before the 'Treaty was definituly ratified. The Chamber amenably followed his direction by rejecting the Lefève motion, on September 30 th, by a vote of 262 to 188 . This was in striking contrast to the tacties employed in the United States Senate shortly afterward.

The chamber was by no means satisfoed with the 'Treaty from the standpoint of reparation and of mili- 


\section{TIIE 1919 HLECTIONS}

tary guarantees." But it came to the eomelusion that the Prime Minister lad produced the best possible treaty which a strange combination of cirrumstances had permitted. C'onserfuently, it ratified the 'l'reaty on the 'und of October loy the stromer majority of 372 to 5.3. Fortynine Thified socialists voted against it, as also dicl Franklin Bonillon and Lomis Marin. There were seventy-three abstentions, thirty-three of whom were Unified Socialists, inchnding Albert Thomas and Nlexandre Varenne. Eighteen Radieals and about half a dozen Conservatives refused to vote. On October 11 th the Senate mamimously ratified the Treaty, and on the following day the President of the Republic promulgated its ratification.

The opposition to the Treaty therefore assumed nearly the same alignment as had the former opposition to the war; that is, it was a question of the Socialists versus the patriotic parties. The 'Treaty vote adder another eount in the indietment against the "Unifies"; it provicled one of the issurs which the November eleetion was called upon to settle. As for the conservative opponents of the 'Treaty, they were insignificantly few. T'heir opposition did not assume party dimensions; the issme created by their rejertion of the theaty was therefore largely a personal one between each conservative and his constituency. There were, then, three relear-ent issues before the voters: 'The first was that of Bolshevisur (ontlined at the Socialist Easter coneress) $;^{3}$ the second was that of the Clonemeon 'l'reaty, as just indicated; the third was that of State participation in industry."

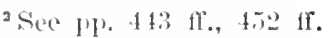

sce Ply. $110-102$.

* For a dis'ussion of this issue, see pp. 302-339. 


\section{CONTENPORARY FRENCH POLITICS}

\section{II}

Two national party conventions of especial interest were held in the month of September. The first of these was held by the Unified Socialists, beginning on the 11th of September; 450 delegates, representing 104,000 members, were present. The chief purpose of this congress. was primarily to effect a reconciliation of the old majority with the extremists, which the Easter congress had failed to bring about. Many of the old majority had roted for military credits in express contradiction of the decision reached at the Easter congress, and some of them had also declared their intention of voting for the Peace Treaty. The extremist elements insisted on the exclusion of these deliberate violators of party law from the party. But those more interested in winning the November elections than in purifying party ranks, cautioned a more moderate policy. In this they were successful. By a vote passed by 1,427 to 490 , the Congress decided merely to censure or "blame" those who had hitherto violated party discipline. With this moral punishment, they would be allowed to remain. Consequently, the Socialist press proclaimed that party "unity" had been preserved and that the party would enter the elections with a compact front. A motion of equal significance was passed by a vote of 1,163 to 133 . It forbade any coalition whatsoever of Socialist candidates with candidates of even the most advanced bourgeois parties. This obriously inchuled the Radicals. As to the future, the party satisfied its qualms of conseience by repeating its frepuently violated determination to exchude automatically any Socialist representative who again voted military eredits. 


\section{TIIE 1919 EIECTIONS}

The subsequent action of the Socialist Federation of the Seine completely offset this eoncession to the old majority and definitely dismupted the ranks of the Socialist party. The Federation voted to exclude from a Socialist ticket of candidates to the Chamber of Deputies any member of the party who refused to give the proper "revolutionary guarantees." Naturally this was unsatisfactory to the old majority. It was a poor concession which permitted them to remain within the party but which refused to allow them to be Socialist candidates for office. Unsuccessful efforts were made by Pierre Renandel and other's to ehange the Federation's decision; but on October 26th it reaffirmed its intention to keep the ex-majoritaires from its tickets in the eoming elections. As a result, three elements of the "Unifies" revolted and formed a party of their own, known as the Dissident Socialists. These elements included the old ex-majoritaires who had voted for military eredits, some of those who had refused to vote against the Peace Treaty, and others who objected to the presence of such men as Jean Longuet and Jacques Sadoul upon a Soeialist ticket. Jaeques Sadoul was a former French officer who had heen convicted by a comncil of war for desertion and for griving intelligenee to the enemy. IHe had been sentenced to death; but so far he had eseaped this fate by seeking employment with the Ukramian Bolsheviki. About twenty-five or thirty deputies joined this organization; and it inchuded such men as Veber, Aubriot, Gromssier and Rozier. The creation of this insurgent group definitely disrupted the ramks of the Socialist party as those who had watrhed the growth of the differences within it, had prophesied. Ilowever, the new gromp did not renounee the theories of Socialism for it proclaimed its atherence to the principles laid 


\section{CONTEMPORARY FRENCH POLITICS}

down in the International Congresses of Amsterdam of 1904 and of Lucerne in 1919..$^{5}$

Upon the 21st of September the Radical party held their convention in Paris. The prineipal matter of deliberation was the reeonstruetion of the old Bloc. At the "petit congrès" in July, a strong element in the party had been resolutely opposed to assoeiation with the Right, and had favored a rapprochement with the Unified Socialists; it had demanded a revival of the old battle ery of pas a'cnnemis à gauche. But the Braeke motion, passed at the Soeialist eongress in September, condemmed the Radicals as much as any other party. Consequently it definitely stopped the efforts of the Radieals to align themselves with their more advauced brethren. The only other alternative before the party was to enter an alliance with bourgeois elements. The decision was finally reached to enter into an entente with Republican Socialists and other Republicans who believed in anticlerical legislation. With timeworn insistenee, the Radicals still harped upon clericalism which to them seemed to be a greater enemy than Bolshevism. By "other Repulblicans," they meant the Demoeratic Alliance. They expressly excluded the new party of the New Democraey, and tacitly exeluded the Republican Federation or l'rogressists. Finally, a common program for this "cartel," as it was called, was drawn up.

\section{III}

The movement for a coalition of parties against the Sorialists, as noted in a previous chapter, was started

SApril \&, 1920 (Temps, April 9), these elements ormanized a new Soralist party, frawing ${ }_{1}$, a constitution, ete, and electing liul Aubriot as president. 


\section{TIIE 1919 ELEC'TIONS}

early in the year of 1919. The Democratic Allianee assumed from the first the leadership in this movement. But the personal hostility of M. Chatumet, who was in clarge of the Allianee's propaganda, toward M. Clemenceau was somewhat damaging to the Alliance's prestige. M. Claumet was so open in his eritirism of M. Clemencean that in September, André Tardieu and MI. Ignace, both members of M. Clemeneeau's Government, resigned thcir membership in the Demoeratic Alliance. The executive committee of the latter announeed that M. Chaumet's opinion was not that of the party, but that it did not believe in controlling the individual opinions of its members. But despite this explanation, the party lost adherents.

On the 5th of October a meeting was called by the National Soeialist party to organize a Bloc of all Republieans against the Unified Socialists. Adolphe Carnot, President of the Alliance, presided at this meeting. The Radieals were not represented, obviously because of the presenee of elements from the Right, such as the Liberal Aetion party. The assemblage adopted the following motion:

Considering that for the reconstruction of Franee, for the maintenanee of the advances of the Repmblic and for the protection of all publie liberties, it is necessary for every citizen to unite against bolshevism represented by the Cnified Socialist party, this gathering aftirms the neeessity of establishing a single Republican ticket, composen of upright, energetie and eompetent eitizens, resolven to assure social peace by the association of Labor and Capital, by the development of eeonomie prosperity of the country, and by the grandeur of Republiean France.

The Republiean Federation, or the Progressists, adhered to this newly ereated "Bloc National Républicain" 


\section{CONTEMPORARY FRENCII POLITICS}

upon the 14th of October. Such was the beginning of the bourgeois coalition against the Socialists.

Meanwhile additional complications arose on aecount of Radieal obstinacy. The first split arose over the "cartel" known as the National Union of Republicans, to which the Radical Congress of September 21st had agreed. The Demoeratic Alliance insisted that the Radicals permit the Republican Federation to join it. Many Radicals were bitterly opposed to association with these Progressists; for the original Bloc of 1902 had been formed expressly against them. However, in view of the Socialist peril, the moderates in the party agreed to a compromise. It was finally agreed that Adolphe Carnot, President of the Alliance, would personally stand responsible, over his signature, for every member of the Republican Federation that desired to join the "cartel." Upon these terms the Radicals promised their adherence.

Sometime in October, by a process which press dispatches refuse to reveal, this "cartel" was merged into the National Bloc. The latter organization had become well-organized under the Presidency of M. Carnot. The members of this Bloc in the department of the Seine were: The Republican Democratic Alliance, the Republican Federation, the National Republican Union (which seems to be the old "cartel"), the Federation of Republican Democrats, the Liberal Aetion party, the National Socialist party, the Civic League, the Democratic League of Moral and Social Action, and the Radicals.

The program of the National Republican Bloc called for :

(1) Energetic opposition to Bolsherism, Civil War or ('lass dictatorship;

(2) Government and parliamentary reform to assure the separation of powers, ministerial stability, and the 


\section{THE 1919 EIEC'TIONS}

employment of technical experts in the arministrative services;

(3) The reorganization of public services;

(4) Short-term military service and the democratic organization of the national defense;

(5) Liberty of conseience, maintenance of loeal laws and the mutual respect of beliefs;

(6) Enconragement of private initiative and the association of labor and eapital;

(7) The right to organize and the extension of the civil capacity of syndicates;

(8) Social reforms-development of soeial insurance and eheap housing;

(9) The fulfillment of engagements toward war veterans and the inhabitants of invaded regions.

\section{IV}

The Freneh legislature ame to the end of an extralegally long existence upon the 19th of October, 1919. From that time until the 16th of November, the date finally set for the legislative elections, domestic polities ocenpied public intrest. Twenty days before the 16th, the electoral period was officially opened; after that date nominating petitions conld be filed with the proper anthorities. Also certain restrictions upon public assemblies and advertising were removed. Five days before the $16^{\text {th }}$ the filing period eame to an end. ${ }^{6}$

\footnotetext{
${ }^{\circ}$ One of the interesting things attendant upon French elections is the limitation on advertising. Oricrinally (by a law of July 29, 1881), candidates might piste bills upon every kind of public building and ellifice, ete., except churehes. Duriner every electoral period, the artistic monuments of the french hepublie used to be marred with electoral alvertisements. By a law passed in 1902 , the mayors were empowered to provent the pasting of bills on monuments and buillings of an artistir charater. Another law passed in the same year prohibited any campaign 
Scenes of disorder were numerous and undignified during the electoral period. The Socialists even had the audacity to break up meetings of the National Bloc by cat-calls of the "Social Revolution" and "Vive Lenin and the Social Republic!' At a meeting in the Passy quarter, held on November 13 th, when a Bloc candidate, MI. Evain, referred to the "wave of idleness" which was overflooding l'aris, workingmen in the balcony became violent. They flung chairs and other missiles at the stage and succeeded completely in dispersing the meeting as well as breaking a few bones of those participating in it. Upon the same day an attempt was made to assassinate Georges Mandel, who had been the secretary of MI. Ciemeneeau; and who was a candidate for the Chamber of Deputies from Bordeaux.

The elections were also featured by the alleged attempt of the Socialists to close down every newspaper in Paris, excepting their own. This was done by means of a printers' strike, and as a result practically every bourgeois paper in Paris was foreed to suspend publieation. The Socialists obviously hoped to get a monopoly upon publicity hy this move. But they were defeated by the fusion of fifty of the Paris papers into

advertising which made use of the colors of the French flagred, white and blue. Finally, a sweeping reform was marle by a law passed Mareh 20, 1911, whose prarpose was to establish complete equality hetwern candidates for oftice, so far as advertising was ecncerned. This law strictly limited the amount of anvertising and hill-posting to sperial implacements set aside for that furpose by the mumicipal authorities. Thus each candidate or tirket was granted the same amount of space. The number of these boarls st asile for alvertising was strietly limited: five in communes having 500 voters or less; ten in other commumes, flus onc for every $\$, 000$ voters or fraction grater than 2,000 , in rommunes having moro than 5,000 voters. Any hill posting ano outsicle of these pullie bill-boards is prohifitel molor penalty of fine. See Duguit, Manucl de Drois r'onstilutionncl, 371-72. 


\section{TIIE 1919 HLECTIONS}

one edition, known as La Presse de Paris, the first number of which appeared on November 11. This eombination paper appeared botlo morning and evening. Abont half of it was given over to editorial expression. Each of the eontributing papers alternated in writing editorials, a dozen or fifteen appearing daily. All but three of the papers which combined in La Presse de Paris supported the National Bloc. Those who opposed it were La Démocratie Nouvelle and L'Action Française, which supported their respective parties, and La Voix Nationale, which leaned toward the Royalists. On election day La Presse de Paris had a eireulation of $6,000,000$.

At no time during the eampaign was there any doubt as to the result of the election. The Socialists themselves seemed to realize that their doetrine of the Social Revolution was eompletely macceptable to the greater part of the nation. Consequently their eampaign emphasized present economic distress and the necessity for immediate reform.

For example, one flaming doenment aslied "eitizens" to vote for Socialist candidates for these reasons:

In unitedly supporting, as so many of you are, the program of the Socialist party which represents your aspirations and your class interests, you not only will support candidates ready to struggle in your name:

For tile Maintenance of tile Eigitt-Hour Day and the Right to Organize;

For the Hardionizing of Political Ixstitutions with the New Econouic Necessities;

For the Takixg Oyer, for the Pexefit of the Nation, of all tue Great Sistras of Traxsport, of Ixsurance, of Grata Sthel Factories, Eac.;

For a Single Selrice of National kidcation Gratuitodsh ACCessible at HerY s'tage; 


\section{CONTEMIPORARY FRENCII POLITICS}

For Universal Disarmament of Which tile Disarmament of Germany Must be the Preface;

But you will have done much more:

You will have responded by your own progress to the progress of your brothers of labor throughout the civilized world.

You will have struck at the roots of a régime which, resting upon the antagonism of conpeting interests, is only able to maintain war as a permanent state.

You will have contributed to establish The True Republic in which a pretended political equality will not be condenned as a falsehood by economic inequalities.

You will have assured The Disappearance of Classes, and by this very fact, you will have established conditions of constant peace between individuals and between nations.

Such a manifesto eould have emanated from the Radicals as well as from the Soeialists. Uniquely Socialist theories were veiled under insignificant eatchwords as "The True Republic." Demands for complete revolution, so insistently urged at party congresses, were now noticeable by their absence. ${ }^{7}$ Noreover, many Socialist 1)eputies carried on their campaign upon a nationalistie platform. Despite the party's official attitude toward the war, many eandidates openly supported the Allied cause. So in reality the Socialists acknowledged defeat from the begiming.

Aristide Briand, one of the most outstanding figures in French politieal life, played a very disappointing part in the election eampaign. Naturally M. Briand has political ambitions. But at the same time he is a true patriot and an able leader. As Prime Minister upon six different occasions he has shown the highest type

7 “ $A s$ a matter of fact, Socialist deputies would obtain very few votes if they diel not manace to convince the general public that they aro very reasonable people, great enemies of the old practiens of liboly men, and solely ocenpied in meditating on the philosophy of future law.' Goorges Sorel, Reflections on l'iolenec, 107. 


\section{TII 1919 WLACTIONS}

of statesmanship. He exhibited his great power in the conciliatory part he played in the struggle with the Church in 1905-1907. He frepuently attacked the Clemencean Ministry during the armistice, figuring prominently in the debates on electoral reform, on woman suffrage and on the eight-hour day. Despite the shadow which rests upon his last Ministry on account of the Greek fiasco, he remains a powerful leader at the Palais Bourbon.

At the end of the war M. Briand realized the necessity of organizing a great Republican party to fight social disorder and monarchical reaction. It seems that he was trying to resume the work he started with the Federation of the Left in 1914. In Angust, 1919, he made a specch at St. Etienne which was so widely misinterpreted that it completely deprived him of further leadership in a bourgeois coalition. In this speech he said the time had come to put an end to the Sacred Union, because it had eontained both Royalists and Socialists who were avowed enemies of the Republic-now that the war was over; Republirans should rid themselves of their temporary bedfellows. Furthermore, the continuance of the Sacred Union would mean necessarily vague programs and the submersion of the real issues before the country. Therefore he favored the establishment of a great Republican party upon definite, clear-ent issues. Objecting to the principles laid down in this speech, M. Jommart, ex-Governor General of Algeria, engaged in a lively debate with MI. Briand in the columms of Le Temps; ${ }^{8}$ he interpreted $\mathrm{II}$. Briand's remarks as a desire to hold himself aloof from a Republican coalition against the 13olsheviki. This obviously was not M. Briand's meaning; but, neverthe-

${ }^{8}$ Letters published in Le Tomps, August $25,1919$.

185 


\section{CONTEMPORARY FRENCH POLITICS}

less, he found moderates turning away from his leadership.

The aseendaney of M. Briand was also prevented by the fact that he is a Socialist in doetrine. It will be recalled that he was one of the original members of the Republican Socialist party. Although he and his party differ eompletely with the Unified Soeialists upon the elass struggle, he believes in increased government ownership and interferenee in private industry. Upon Oetober 31st he made a speech at Nantes in which he ontlined his platform of political and religious reforms. Le Tcmps afterwards inquired why he did not definitely diselose his plan of economie reconstruction. Did M. Briand believe in an extension of State Soeialism or did he believe in the restoration of private initiative? The natural fear that M. Briand was a collectivist deprived him of the support of those opposed to the increase of the industrial power of the State. As for the Radicals, they are M. Briand's most bitter enemy because he has preached a policy of reconciliation with the Church for many years. Naturally the Unified Socialists detest him. So this statesman found himself not socialist enough for the Socialists, not radical enough for the Radicals, and not eonservative enough for the Conservatives. M. Clemeneeau's popularity added to the almost tragie isolation in which M. Briand was placed. IIowever, M. Briand proved his attachment to the $\mathrm{Na}$ tional Bloc by refusing to run on a ticket from his home district in the Loire hecanse it excluded members of the Democratic Alliance. I3ut he was nominated on a ticket from the Lower Loire, and elected to the Chamber. IIs victory was one of personality and not of leadership. IIe groes back to the Chamber a free lance, and without an organized following. 
Although every sign pointed to the overwhelming victory of the National Bloc, it by no means united every bourgeois party against the Socialists. The first insurgent was the Republican Committee of Commerce and Industry which, shortly after the Bloc's formation, refused to join it becanse of the presence of the Radicals. The Committee implied an unwillingness to assoriate itself with any party proclaiming the doctrine of State Socialism. The next faction to withdraw was the New Democracy party, headed by Lysis. This party stated with poorly feigned self-interest, since it had no representatives in the Chamber, that the Bloc was merely a device to secure the reëlection of deputies whose incompetenee had been repeatedly proved. This party placed tickets in three out of the four districts in Paris. Among its candidates were André Chéradame and Victor Cambon. The party was successful in polling a total vote of only about 22,000, and it did not win a single seat in the Chamber.

Thirdly, the Royalists refused to join the Bloc-or rather, they were not invited to join it because of their avowed hostility to the Republic. Consequently L'Action Française placed tickets in every one of the districts in Paris-for the first time in its history. It polled about 40,000 votes, and it sneceeded in eleeting Léon Daudet, one of the editors of L'Action Française, to the Chamber.

$A$ fourth opponent to the Bloc. was found in a few Catholies who believed that the antielericalism of the Radieals was a greater enemy than the Bolshevism of the Socialists. IIappily the majority of the Catholies did not openly harp upon the elerieal issue. But $L a$ 


\section{CONTEMPORARY FRENCH POLITICS}

Croix, the leading clerical journal, illustrated its religious bias by demanding "pas de eartel" with candidates who did not promise to work for the modification of existing clerical legislation. However, this attitude was offset by such pastoral letters as that from Mgr. Amette, arehbishop of Paris, dated October 31, 1919. It advised Catholic voters that it was better to vote for eandidates from whom useful service to the country could be expeeted, although they did not promise to satisfy Catholic demands-than for others whose platform might be more "perfect, but whose defeat would more eertainly run the risk of opening the door to the enemies of religion and of social order";-a reference to the Unified Socialists.

A very interesting feature of French elections is the part played by the Catholic elergy in advising their parishioners how to vote. With few exceptions, Catholies receive pastoral letters which lay down the principles which should guide them in the exercise of their electoral duties. Many of these principles are of common morality; others are strietly clerical. The whole spirit of the letters is naturally directed toward influencing elections so that the "legitimate interests" of the Church shall not be harmed. The Catholic clergy apparently feel it a divinely imposed duty to guide political thought from a religious point of view.

The final bourgeois opponents of the Bloc were odds and ends of "dissident" groups. Some were opponents of M. Clemenceau, such as Gustave Tery, editor of L'Cuvre. Others were Radical Socialists who opposed association with the parties of the Right. Thus the Radical Socialist group of the Radical Federation of the Seine on November 2tth denounced "the treason of the Radicals who, under cover of the National Bloc, have 188 


\section{TIIE 1919 ELECTIONS}

beeome the aceomplices of the worst reaction." They demanded the restoration of the old Bloc of the Left. Other dissidents were Republican Soeialists such as Paul Painlevé, Mr. Clemenceau's predecessor as Prime Minister. He insisted on placing tickets in the field against those of the National Bloc; and he was responsible for splitting the vote of the Bloc in Paris between three tickets, upon which sueh men as General Sarrail and Professor Aulard ran. Much sympathy has been expressed in Ameriea for M. Painlevé because of his defeat (his defeat is by no means eertain, for the Commission on Recount decided to refer his seat to the Chamber of Deputies, which was convened in extraordinary session on December 8 for deeision). But if M. Painleve had entered heartily into the National Bloc instead of doing everything he could to oppose its suecess, he doubtless would have been returned to the Chamber without a question. ${ }^{9}$

These examples will show that the bourgeoisie were by no means solidly united against the Socialists. In Paris alone, ten different tickets appeared upon the ballot. In the departments the confusion was even worse. IIere party coalitions usually did not exist. Usually the Liberal Action party would run a separate tieket; sometimes it would be the Democratic Allianee and more often, the Radicals who refused to combine. Programs of the widest variance were announeed by those departments in which blocs eould be effected. Thus the Republican Union of the Isère was so conservative that it asked for the resumption of diplomatic relations with the Pope, repeal of anti-Catholie legislation, and the proportional division of school funds. These were distine-

${ }^{\circ}$ The Chamber of Deputies dechared M. Painlevé legally elected on January $23,1920$. 


\section{CONTEMIPORARY FRENCII POLITICS}

tively Catholie measures to which no Radical would agree.

In other words, the coalition activities in the November election eompletely bore out the oft-repeated aeeusations against the lack of French organization. These activities were totally decentralized. The National Bloc in Paris maintained no eontrol over the few blocs established throughont the provinces. In fact, it was unable to ereate them in most departments on aceount of local disagreements among parties. So the attempt to fuse all bourgeois parties against the Unified Socialists was not so successful and the fusion was not so complete as both the French and American press reported. It was not as narrow and it did not funetion as well as the Sacred Union. The reason for this was quite evident: the menace of Bolshevism was by no means as real to Franee as the menace of Germany had been. ${ }^{10}$ There was no fear of Bolshevist invasion. If Bolshevism should win it would be a purely moral victory, for even if Soeialist majorities were retmrned to the Chamber, every Frenchman knew that Soviet methods would never be instituted. The bourgeois eharacter of many of the Soeialist candidates was an eloquent testimony to that.

\section{VI}

Very oddly, one of the strongest factors in bringing about the formation of the National Bloc was the Electoral Law of July, 1919. Under the provisions of this

${ }^{10}$ Toting in this election was not as heary as it was represented to be. In the first listrict of l'aris, for example, there were 64,000 abstentions ont of 200,000 registerel; in the second district, there were $5.2,000$ alstentions ont of 221,000 registered; in the thirel distriat there were $61,0(00$ abstentions out of 254,000 ; and in the fourth district 102,000 abstentions out of 380,000 registered. 


\section{TIIE 1919 ELECTIONS}

law, the bourgeois parties were obliged to unite, if the compact and well-disciplined organization of the Unified Socialists was not to win.

For example, if the National Bloc in Paris should muster 92,000 votes and if the Socialist ticket should receive 70,000, all of the Bloe candidates would be elected, beeause they all reeeive a majority. IIowever, if the Republiean rote should be divided between two tickets, this advantage wonld be overeome. Thus if the Bloe vote should be split between two tickets, each reeeiving 46 ,000 votes, and if the Socialists shonld maintain their 70,000 , the Socialists would reeeive the majority of the seats. If there are five deputies to elect, the Bloc would reeeive all five, in the first case. In the seeond ease, when the Bloc vote is divided, the Socialists would win three seats, and each of the Repullican parties, one seat. In both eases the Socialist ticket poll exactly the same number of votes. But in the first ease, where the Republieans are mited, the Socialists wonld receive no seats; while in the second case, where the Republicans are divided, they (the Soeialists) would win three seats -a majority of one.

When it dawned upon the bourgeois parties that such would be the result of the election law, a great clamor arose. Although they had voted for it originally, they now denounced it as another device of the Socialists to win the eleetions. This argument together with the arrondissementer's fear of losing lis seat led to attempts in the Chamber to postpone the anplication of the eleetoral law until the elections of 1923. Fortunately this attempt was unsuceessful, and the maintenance of the election law became one of the greatest auxiliary factors in eementing the different factions of the bourgeois parties. In the face of a mited and well-organized 


\section{CONTEMPORARY FRENCII POLITICS}

opposition, sueh as the Inified Socialists presented, faetional groupings had little hope to survive.

\section{VII}

The events of the election day itself, November 16 th, may be passed over with little comment. There was no disorder; and there was a heavy vote east.

The results were not known until the 30 th of November, and even then sixteen seats lad not been disposed of. The eomposition ${ }^{11}$ of the new Chamber ${ }^{12}$ may, however, be summarized as follows:

\begin{tabular}{|c|c|c|c|}
\hline & Reelected & New & Total \\
\hline 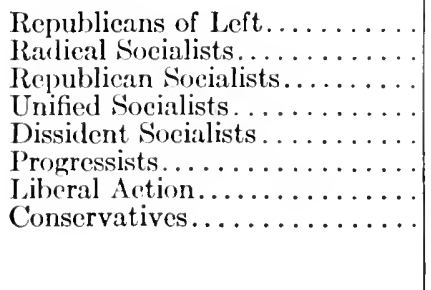 & $\begin{array}{r}55 \\
77 \\
18 \\
35 \\
5 \\
34 \\
14 \\
12 \\
250\end{array}$ & $\begin{array}{r}78 \\
66 \\
9 \\
33 \\
1 \\
99 \\
55 \\
19 \\
360\end{array}$ & $\begin{array}{r}133 \\
143 \\
27 \\
68 \\
6 \\
133 \\
69 \\
31 \\
610\end{array}$ \\
\hline
\end{tabular}

"These figures are taken from La Revue Politique ct Parlemontaire for Dec. 10, 1919.

${ }^{12}$ In the Bas-hhin there were 160,957 voters in 1914 ; in 1919, after the elimination of the German clements, there wero 155,707 . of these, 130,737 voted. The fact that there were no more climinations seems to show that the election was conducted fairly. Alsace did not return a single Socialist or lialieal to the Chamber. In both Alsace and Lorraine, "patriotic" or proFrench candidates were returned, and the election was ample evidence of the desire of the provinees to return to France. See two articles in La licvue des Iowx Mondes for Deember 15, 1919, on "Le Vote de l'Alsace," hy 1'. Bourson, and "Le Vote do la Lorraino Liberée," ly l'. Braun. Alsace-lorrane was allotted 2.4 seats- 8 for the Moselle, 7 for tho llaut-lilin, and 2 for the Bas-lihin by party representation. 


\section{TIIF 1919 ELECTIONS}

The Chamber of $1914^{13}$ compared with that of 1919 :

\begin{tabular}{|c|c|c|c|}
\hline & 1914 & 1919 & Difference \\
\hline Republicans of Left. & 77 & 133 & gain -56 \\
\hline Radical Socialists. & 257 & 143 & loss -114 \\
\hline Republican Socialists. & 30 & 27 & $\operatorname{loss}-3$ \\
\hline Unified Soctialists. . . . & 101 & 69 & loss - 33 \\
\hline Dissident Socialists. & & 6 & gain -6 \\
\hline Progressists....... & 36 & 133 & gain -97 \\
\hline Iiberal Action. & 32 & 69 & gain -37 \\
\hline Conservatives... & 27 & 31 & gain $-4^{14}$ \\
\hline
\end{tabular}

${ }^{13}$ By party representation.

14 The elassification of the new Chamber by profession may also bo interesting to note. It contains:

140 lawyers.

41 doctors or surgeons.

50 manufacturers.

52 proprictors.

52 agrieulturists.

27 merehants.

32 professors.

44 publicists and men of letters.

5 secondary sehool teachers.

13 engineers.

8 juiges.

5 iliplomats.

4 Catholie priests (all from Alsace and Lorraine).

3 Protestant ministers.

10 avonés.

4 notaries.

4 members of the Couneil of State.

4 chofs de cabinet of the ministries.

6 iruggists.

5 bankers.

3 heals of societies.

2 generals and 20 former offieers (by profession).

1 viee-almiral and three naval ofliecrs.

11 former government employees.

8 employees of the public services.

16 employees of commeree or of banks, ete.

4 entrepreneurs of publie works.

15 workers of different professions.

1 arehiteet.

1 agrégé (a degree higher than a loctor of philosophy').

1 business ageut.

2 aviators. 


\section{CONTEMPORARY FRENCH POLITICS}

The eombined loss of the four Socialist parties above, in the 1919 Chamber, is $14 t$ seats. The gain of the parties of the Center and the Right is 194 .

These figures portray three striking results.

The first was the reduction of the Unified Socialist representation from 101 to 68 . On the face of it, this meant a national repuliation of the Socialist party. In reality, however, it meant quite a different thing, for the Socialists polled 300,000 more votes in 1919 than in $191+(1919,1.700,000 ; 1914,1,400,000) .{ }^{15}$ If this be so, how can the reduction in Socialist representatives be explained? The explanation lies not so much in the National Bloc as in the electoral law.

This law provided for the redistricting of Franee; as a result population in different districts was equalized; and whatever advantage the Soeialists had held unfairly was overcome. Consequently they lost seats. On the other hand, election by the majority principle in the law of July 12 also worked against the Soeialists, many of whose candidates would have been eleeted under a complete system of proportional representation. This is true of the fourth distriet of Paris, a strong labor district, where the Bloc ticket of fourteen candidates was elected by absolute majority over the Socialist ticket hearled by Jean Longuet. Although the latter tirket pelled a total of $1,576,602$ votes against the 2,102,411 votes which the Bloc ticket received, it did not rereive a single seat. The Bloc tivkst, under the majority principle, received all fourteen. Under a system of eomplote proportional representation (with such a vote),

${ }^{15}$ In 1911, 8,700,000 votes were cast in France, exclusive of Alsace-Lorrabe. In Nowember, 1919, only 6, 800,000 were east (imelouling Alsace-Iorraine) a derense of $1,900,000$. The Socialjst votn in 1911 was therefore 16 Jer eent of the total; whilo in 19l9 it was 25 jer rent. 


\section{TIIE 1919 ELECTIONS}

the Soeialists would have received six out of the fourteen seats, eight going to the Bloc.

Consequently it is a mistake to believe that the French Socialists have lost any real popular support during the last five years. In fact, it appears that they have gained. In a sense the nation has repudiated Socialism, for the Bloc lolds 550 seats in the Chamber. But. the nation presented no different attitude toward Socialism in 1919 than in 1914. In both elections three fourths of the 10,000,000 voters in France pronouncel against it. But a solid body of Soeialist votes remains intaet, increased somewhat by the recent adherence of some malcontented Radicals. On the other hand, the French Soejalist party has repudiated the extreme leadership which for the last several years has controlled it, for the most violent directors of the party have been defeated. Of the fourteen candidates on the Socialist tieket in the fourth distriet of Paris, Jean Longuet was the lowest, receiving 111,015 votes, while the highest candidate, M. Laval, received 114,147. M. Longuet eonsequently was defeated, and his downfall can be interpreted only as an express repudiation of his leadership. Likewise Jaeques Sadoul was third lowest on the Socialist ticket in the third district. MIM. Brizon and RaffinDugens, two of the deputies to go to Kienthal, were defeated, as was also M. Mayéras. M. Loriot was not in the Chamber. IIence it is quite evident that the extreme elements of the Socialist party must carry on their activities ontside of parliamentary circles. liut the Soevilist vote nevertheless revealed the fact that there were still nearly 2,000,000 voters in France who were devoted to the prineiples of Socialism.

The second feature of the election was the reduction of the Radieal representation from 257 to 143 , a loss of 


\section{CONTEMTPORARY FRENCH POLITICS}

114. Part of this loss was also probably due to the new election law. But it appeared to be more largely eaused by the policies supported by the Radieal party, outlined in another chapter: their perpetuation of the anticlerieal issue; their support of Caillaux and other persons eharged with treason; and their insistence on State Soeialism. The opinion of the eountry on the latter point is indicated, to some extent, by the defeat of M. Clémentel, Ninister of Commeree, and author of the "Consortimm", poliey ; of M. Morel, Inderseeretary of Liquidation of War Supplies, around whom many stories of scandal in regard to the liquidation of supplies had eentered, and M. Colliard, Minister of Labor, as well as two other members of the Government. The elections may be ealled a personal victory for M. Clemenceau; but they certainly were a defeat for M. Clemenceau's party, and also for the eollectivist poliey of his Government.

The third point of interest in the elections was the large gain of the Conservative parties. The Progressist representation was increased from 36 in the old Chamber to 133 in the new; the Liberal Aetion group was inereased from 32 to 69 ; the Conservatives was inereased from 27 to 31,5 of the new deputies of this latter eategory coming from L'Action Française. The Republicans of the Ieft or the Democratic Alliance increased from 77 to 133. The total number of deputies in the new Chamber, pledged to fight against the State Socialism and extreme anticlericalism of the Radical and U mifie party is 366. The combined Radical, Republican Socialist, Dissident Sorialist and Unified Socialist vote is only 244. So it seems that the opponents of bureancrary will have an opportunity to reform the abuses which they have so caustically criticized. 


\section{'TIL 1919 ELECTIONS}

For the first time in twenty years, France has a conservative Clamber. It is one of the most conservative in the history of the Third Republic. The Radicals and the Unified Socialists have lost the halanee of power. If it lies anywhere, it is with the Demoeratic Allianee, to which the politieal leadership of the comntry has apparently fallen.

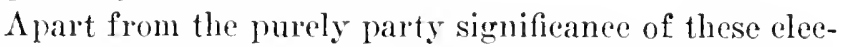
tions, there were many personal incidents of interest. In the distriet of Seine-et-Oise the Radieals entered a ticket, headed by Franklin Bouillon, Mr. Clemeneeau's bitferest enemy, against the Bloc ticket, headed by André Tardien, M. Clemeneeau's warmest friend. The Radical tieket and MI. 13ouillon were overwhehmingly defeated. Charles Chaumet, another opponent of the Treaty of Versailles, was likewise defeated. In Paris three anarehist tiekets appeared on the ballot; they reeeived a combined vote of 121 ! M. Lafferre, Minister of Publie Instruction, a vigorous Free-llason, was defeated, probably on aecount of his fraternal attachments. René Renoult, until last fall l'resident of the Radical party and chairman of the Army Commission of the Chamber, was also defeated. ${ }^{16}$ Prinee Murat was eleeted on a Bloc tieket from the distriet of lot. General Sarrail, a compatriot of Painleve, was defeated in Paris. Il is rejeetion may be taken as publie disapproval of the political ends which he was alleged to have served during the war. On the other hand, Cencral Castlencan, Marshat Foch's Chief' of Staff, was elected. It was he who comntermanded the order to evacuate Verdun; for this le eertainly deserved publie reengnition. Four senators who entered the eampaign for seats in the ('hamber of

${ }^{16}$ Both he and M. clémentel were later eleeted to the Senate. 197 


\section{CONTEMPORARY FRENCH POLITICS}

Deputies were elected. Among them was Edouard Herriot, the new President of the Radical party. He is in the rather novel position of being Mayor of the eity of Lyons, ex-Senator from the Rhone and now a member of the Chamber. The move appears to be a bid for the Premiership.

On the 11th of January, 1920, the elections for the Senate were held. These elections are not by direct, popular vote, but by departmental electoral eolleges composed of (1) the deputies from the department, (2) members of the general council, (3) members of the arrondissement eouncils in the department, (4) representatives from the communes likewise situated in the department.

The result of this election did not greatly modify the composition of the Senate so far as parties were coneerned. Two hundred and forty seats were to be filled, 294 of which had been ocempied by Senators whose terms had expired or who had died in office. Fourteen seats were allotted to Alsace and Lorraine, and two had been held by life Senators who had beeome deecased. Aecording to the law passed in 1884, such seats are to be awarded to eertain departments by lot at the death of their original incumbents. ${ }^{17}$ These two plaees were awarded in this manner to the departments of Loiret and Loire-et-Cher.

M. Poincare, the retiring President of the Republie, was elected to the Senate without even entering his candidacy. IIe was eleeted from the Meuse by a rote of 742 to $30 . \Lambda$ few defeated eandidates for eleetion to the Chamber of Deputies in November, were elected to

\footnotetext{
${ }^{17}$ tien Article III, Taw of December 9, 185., in F. R. Dareste, Les C'onstitutions Modernes, 33.
} 
the Senate, such as MII. Clémentel, Lafferre, and de Monzie.

The results may loe tabulated as follows:

\begin{tabular}{|c|c|c|c|c|}
\hline & Old Senate & New & Gain & I Joss \\
\hline 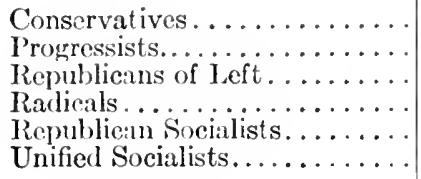 & $\begin{array}{r}27 \\
22 \\
45 \\
129 \\
1 \\
\ldots\end{array}$ & $\begin{array}{r}29 \\
31 \\
68 \\
106 \\
5 \\
2\end{array}$ & $\begin{array}{r}1 \\
9 \\
23 \\
\\
4 \\
2\end{array}$ & 23 \\
\hline
\end{tabular}

\section{VIII}

On January 13th, 1920, the new Parliament was officially called into existcnee. M. Paul Desehanel was reëlected President of the Chamber of Deputies by a vote of 445 to $10 .^{18}$ In the Senate, M. Léon Bourgeois defoated the incumbent, Antonin Dnbost, for the presideney of that body, by a vote of 147 to 125 (January $1+\mathrm{th})$.

Althongh it eame as a surprise to the world, the defeat of $M$. Clemencean for the presidency of the Republic, was to have been expected. France perhaps would have liked to see M. Clemenceau President. II is popularity with the comntry was immense, and it would have

is The following vicepresilents were elected: MM. Ravoul Péret, Lefelsyro du Prey, André Lefèvre, Iranoois Arago; sceretaries: Paul Simon, Barety, IIenri Amrol, Manrisson, Joseph Barthélemy (the distinguished professor of polities), Jean Eirlich, Laurent Eyuac, Amlré l'iyer; questors: Mid. Sammande, Lenail, DuelauxMonteil. On accomnt of his election to the presilency of tho Republie, M. Deschanel resigned his position as heal of tho Chamber. His place was filled by Raoul léret, who was elected on February 12.

These sixteen officials eonstitute the "bureau" of the Chamber. The loureal handles all the husiness routine of the lecislative boly; the seeretaries keep the records and count the votes when there is a division: the questors have elarge of the findnces. 


\section{CONTEMPORARY FRENCII POLITICS}

liked to confer upon him the highest honor which the Republic could bestow. Many of his enemies also wished to place M. Clemenceau in an office which would force his retirement from active polities. ${ }^{19}$

But the election of a French President, unlike the election of Deputies, is remored from the impress of public opinion. Chosen as he is by the National Assembly, ${ }^{20}$ the President owes his election largely to party maneurers and party considerations. M. Clemenceau, when forced to become a candidate for this office at his friends' behest, found himself without a party. The Radical party, to which he nominally belonged, eontained his most bitter enemies. The Republican Left, which had won sweeping victories in the November elections, was opposed to the domestic policies for which M. Clemenceau stood. The Unified Socialists, whose defeatism and Bolsherism, Clemencean had vigorously fought, naturally refused to vote for him. This factor, added to the fact that he lacks the social graces and the temperament which have characterized the French presidency, led to M. Clemenceau's defeat and to the eleetion of Paul Deschanel. ${ }^{21}$

His defeat may be looked upon as an aet of ingrati-

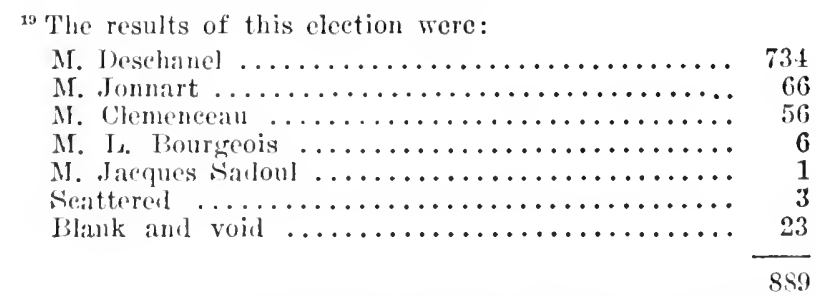

${ }^{20}$ The National Assembly is emposed of the members of the Chamber of beputies and the somate meeting in che body.

${ }^{21}$ Syeaking of the defeat of $\mathrm{N}$. ('lemeneran, one of the editors

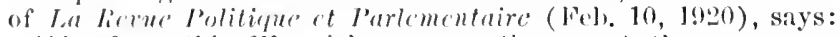

"In fact, this Warwick was overthrown at tho very moment 


\section{THE 1919 EHEOTONS}

tude. He lad saved France from a German victory; and he deserved well of La l'atric. lint other grast men of France, as well as of other (o)mutries, have suffered a similar fate. M. 'Thiers, who leaded the provisional government of France from 1871 to 1873, whose tears secured the mitigation of the peace terms which Bismarck wished to impose upon France after the capitulation of Paris in Jamuary, 1871, whose diplomacy raised France's position among nations and whose statesmanship laid the foundation for its political and economie regeneration, - was forecel into resignation hy a political cabal. MI. Clemencean will find sympathy, as M. Thiers probably did, in the realization that in polities virtue is its own reward.

Panl Deschanel, the new President of France, is well qualified to contime the traditions of the office. A scholar, an orator, and a typical French gentleman, he will preside over the Elysée l'alace with charm and equipoise. He probably will be content with the social duties with which in the past the President of the Republie has oeenpied himself. On the other hand, there is a possibility that he will attempt to assert executive prerogatives which hitherto have been exereised by the

when he helieved he haci only to stretch forth his ham to take possession of the crown. Anil he was sueceederl by a man who, a week before the Congress, did not even wish to be a emilidate so long as his ehances secmed eompromised by the eternatly proelaimed glory of his opponent. IBut sareely a month has passed sinee these events haw taken place, and the great Frenchman of yesterday is alreaty forgotten.

"Why was he thus removed from power? In truth, beeause his mistakes and his defeets have heen too evilent for a year. Nous n'avons plus Clemenceau: "'st injuste, mais préférable.",

These mistakes the writer enumerates as administrative ineapaeity, prodigious pride, and an impulsive temperament. Although this characterization may he too severe, it was nevertheless held by many deputies who feared that Clemenceau, once elocter president, might establish a dictatorship such as Boulanger attempted. 


\section{CONTEMPORARY FRENCII POLI'ICS}

Ministry. In polities, M. Deschanel is a member of the Republican Allianee. IIe is a reformer of the classical school, but at the same time, a eonservative who probably reflects as well as any man could, the opinions of bourgeois France.

Following parliamentary usage as well as his own inclination, MI. Clemeneeau resigned as President of the Couneil (January 18, 1920) immediately after the eleetion of M. Deschanel as President of the Republie. On the 19th of January, M. Alexandre Millerand formed a eabinet. $^{22}$ The appointment of M. Millerand as Prime

22 The Millerand Ministry was composed as follows:

President of the Comneil and Minister of Foreign affairs: Alexandre Millerand (deputy).

Minister of War: Anelré Lefèvre (deputy).

Minister of Marine: Landry (depnty).

Minister of Justice: Gustave Lhopiteau (senator).

Minister of Finanee: Francois Marsal not a nember of parliament).

Minister of the Interior: Steeg (senator).

Minister of Commeree: Isaae (deputy).

Minister of Agrieulture: Henri Ricard, Agrieulturist (not a member of parliament).

Minister of Public Works aud Transports: Le Troequer (deputy).

Ninister of Colonies: Albert Sarraut (deputy).

Minister of Public Instruetion and Fiue Arts: André Honnorat (deputy).

Minister of Labor: Jourdain (deputy).

Minister of Social IIyerene: J. Is. Breton (deputy).

Minister of the Liberated Regroms: Ogier (seeretary-general of the liberated regrions, not a member of Parliament).

The Nine Undersecretaries of State are:

I'resident of the Coumili: Riciled (deputy).

Interior: Robert Davial (aleputy).

Finanees: F. Brousse (deputy).

food supply: R. Thoumyre (deputy).

Ports ami Morehant Mariwe: l'aul Bignon (deputy).

Ifylraulic l'ower: 13orrel (deputy).

Josts and Telegraphis: I. Heschamps (deputy).

Agriculture: Queuille (deputy).

Ä̈ronauties and Aïral Transportation: I'. I. Flandin (deputy). J'rofessional Elueation: ('oupat (not a member of T'arliament).

The Cabinet is thiss composed of eighteen deputies, two seuators, and four mombers who aro not members of parliament. 
Minister in some ways might have been antieipated. As Governor of Alsace-Lorraine he had made a notable record and he had been actively engaged in publie life for a great many years. IIowever, by political profession he was a Republican Socialist, intimately associated with such men as Viviani and Painlevé. Yet there was no question of his patriotism. And as he was reputed to be in faror of renewing diplomatic relations with the Vatican, he was probably acceptable to the Conservatives; at the same time, his socialistic ideas recommended him to the parties of the Left. But on the other hand, his Ministry is sure to be fraught with diffienlty. IIe apparently has overlooked the faet that the new Chamber of Deputies is overwhelmingly Centrist in composition, for seventeen out of the twenty-four members of lis Cabinet are Republican Socialists and Radicals. As such, the Cabinet eertainly fails to represent the Chamber. Furthermore, the war and M. Clemenceau's Ministry have left to M. Millerand problems which will require the greatest tact and statesmanship to solve. Of these, the financial problem is perhaps the most serious. France has a national deht of 5,161 franes per head. IIer budgetary demands for the year $1920^{23}$ execed 17,000 000,000 franes, not ineluding war pensions or interest charges on loans for reconstruction, while so far, means for meeting but 10,000,000,000 of these expenditures have been provided. M. Clemencean's Minister of Finanee, Louis Klotz, pinned his hopes on the German indemnity for the ultimate solution of France's difficulty. But the prospeet of securing this indemmity seems to grow dimmer with sueceeding days. IIence Mr. Nillerand's task is beeoming stmpendous.

${ }^{23}$ In 1914 tho bulget was only $5,000,000,000$. See also Appen$\operatorname{dix} 13$. 


\section{CONTEMPORART FRENCII POLITICS}

The new Chamber of Deputies was organized into groups on January 30, 1920. Nine of them filed lists of members with the President of the Chamber. They were as follows:

Republican and Social Action ....... 46 members

Republican Democratic Entente .......183

Republican Democratic Left ........93

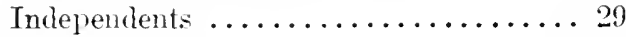

"Non-inscrits" ................21

Radical and Radical Socialists ...... 86

Unified Socialists .............68

Republicans of Left .............6 61

Republican Socialists ${ }^{24} \ldots \ldots \ldots \ldots .26$

$613^{25}$

The creation of such a large number of groups (although three less than those in the 1914 ('hamber) was somewhat disappointing. There seemed to be no reason why the most of them could not have coaleseed into two large groups-Conservative and Liberal.

The "Independent" group still includes the Conservatives, the pure Nationalists (including the Monarchists), and a part of the old Liberal Action party, whose parliamentary group has now disappeared.

The "Republican Demorratic Entente" had also existrod in the old Chamber, where it had arisen from a combination of some Progressists and the right wing of the Democratic Alliance. This groul) now stands for a Centrist polier. In addition to the Progressists and the members of the Alliance, it contains about forty members of the former Jiberal Action group. Tnder the

${ }^{21}$ lt is interesting to note that Aristile Briand has finally curolled himselt with the Republican Socialists.

25. Ser Iomrnal Officicl, Séaneo du 30 janvier 1920, Chambre des Iéputés. 


\section{TIIE 1919 ELECTIONS}

leadership of its President, M. Arago, this group seems to be genumely and somewhat sucessfully attempting to mite the moderate Republicans into one organization. Its suceess is indicated by the fact that it is already the largest group in the Chamber.

Unfortmately, there were some Republicans, incheding many members of the Democratic Alliance, who refused to join the "Entente." They had formerly constituted the groups of the Republicans of the Left and the Radical Left. In the 1920 Chamber most of the members of these two groups have united into the "Republican Democratic Left." Among its prominent members are MIM. André Lefèvre, Barthou, Bérard, and Boret.

Still other members of the Democratic Alliance (old Republicans of the left) refused to unite with either of the above groups. Consequently, they formed or rather maintained the old group of the "Republicans of the Left." A few progressists and moklerates, disturbed at the preponderance of the liberals in the Entente, have also joined this gromp. MII. Ignace, Lonchenr, Tardien, Le 'Troequer, and P'aul Simon are among its prominent members.

The "Action Républicaine et Sociale" is an entirely new group. It has been formed hy the younger men of the Chamber, belonging to nearly every party from the Catholies to the Republican Soeialists. The gromp desires to work without regard to party lines, and places social reform in the foremost part of its program.

The three groups of the Unified Socialists, the Radirals, and the Republican Socialists exist as they we'e in the 1914 Chamber. $^{20}$

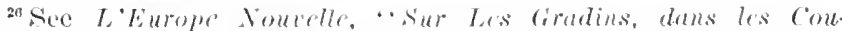

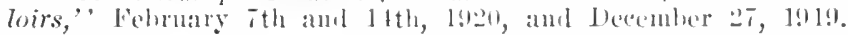




\section{CONTEMPORARY FRENCI POLITICS}

The question arises: what may be expected of this new Chamber? In the first place, there is slight probability that the National Bloc will remain intact. Its centrist and conservative elements will doubtless hold together; the Radicals proper may also adhere. But the Radical Socialists, the extreme Left of the Radical party, will unquestionably separate themselves from the Bloc and probably come to an understanding with the Unifies. Such was the intention of the Radical Socialist group of the Radical Federation of the Seine, above quoted. But even if the eighty-six members of this group do coöperate with the Unified Socialists, the Extreme Left will only have some 130 votes to oppose to the rest of the Chamber. But the elief significance of the intention of the Radical Socialists to side with the Bolsheviki is that it marks a growing eleavage between them and the Radicals proper. The problem of unity between the Right and the Left divisions of this party has been very grave. The Radicals believed it was solved at the Pau Congress in 1913; but the National Bloc of 1919, and the official decision of the party to coöperate with the parties of the Right, again opened up this wound. Its existence will be fatal to future party snccesses, just as divisions among the Unified Socialists have decreased their strength and prestige. In neither party are there signs of recuperation. It may prove true that Radiealism will be eonsumed by its own children and bring upon itself an ahrupt ent.

Secondly, it is probable that the new Chamber will be malterably opposed to the State Socialist policies inangurated by the Clemencean Government and which the Left now insistently urges. IIowever, the Iemo"ratic Alliance and the liberal $\Lambda$ ction party, if not the 


\section{TIIE 1919 ELEC'TIONS}

more conservative organizations, are pledged to a platform of social reform and labor amelionation.

From the standpoint of foreign policy, the ('hamber will probably support a Ministry which will restore French diplomacy npon its old hasis. This will undoubtedly oceur if the United States refuses to lend its aid to European affairs. If the League of Nations does not materialize and if Ameriea rejects the Alliance, the French Chamber will doubtlessly demand the annexation of the Rhine. It will support a policy which will build up a network of allianees protecting France from Germany. It will purchase these alliances with eoneessions in principle; i. e., it will eonsent to the Italian annexation of Finme and the Polish amnexation of Eastern Galicia in return for pledged support. Finally, the Chamber will stand for a policy of aggressive nationalism.

As to cleriealism, the Catholies now have a fighting elance to secure the repeal of existing anticlerical legislation. Despite the assertion of Stephen Pichon last June that there was no prospect for the resumption of diplomatic relations with Rome, a recognition of the temporal authority of the l'ope is by no means impossible. ${ }^{27}$ Lé Journal des Débats is already advocating such a recognition; and former P'rime Minister Viviani and Aristide Briand are even quoted as being in favor of it. The Liberal Aetion party's demand for the proportional

\footnotetext{
${ }^{27}$ In a speech made, Fehruary 6th, 1920, Premier Millerand sail that a resumption of relations with the latiean was jossible. If diplomatic relations are renewed, however, it is not probable that the separation rérime in Frame will he alterent in any way. See an article, entitled "A propess de la politique religicuse,' Journal acs llébats, Hution Heblomadaire, Feb. 6, 1920 .
} 


\section{CONTEMPORARY FRENCH POLITICS}

division of school funds and the separate maintenanee of Catholic schools also may possibly be granted.

French conservatism has won the day. Upon it rests a tremendons responsibility. If it shows an ability to solve outstanding social questions, the present organization of society will undoubtedly be maintained, and the conservatives will remain in power. On the other hand, if it turns a deaf ear to genuine demands for reeonstruction and if it stubbornly maintains outworn formulas, its days will be numbered. The Freneh people may be driven in despair from one extreme of the social order to the other. Although Socialism has its vital defects it may appear to them to be superior to the "stupidity" and rock-like immobility of the present régime. This helief, whieh ean be aequired only through generations of abuse, is the one foree of sufficient strength to bring about the advent of Socialism in France. In this respect Socialism is in practically the same stage in France as it is in the United States. Its surest preventive is neither in force nor in a reign of terror; it is in a righteous policy of social reform. The French conservatives are thoroughly aware of their responsibility. They have the interest of the whole nation at heart. There is every reason to believe that they will use their opportmity to heal the burning sores with which France so long has been afflicted.

\section{$\mathrm{IX}$}

The Soeialist Congress, which was held at Strassburg the 25 th of Feloruary, 1920, ilhstrated the growth of the extremist tentencies within the party. This congress had heen preceded by a meeting of the Socialists of the 208 


\section{TIIE 1919 ELECTIONS}

Department of the Seine (February 8, 1920), at which a program, to be placed before the Strassburg convention, was diseussed. The chief question of importance was that of adlierence to the Third Internationale-the same subject which had caused so much debate at the Easter Congress. Three motions were introduced, calling for (1) adherence to the present Internationale, (2) reconstruction of the present or Second Internationale, unconditional adherence to the Noscow or Third Internationale. The extremists liad gained control of the Socialist organization of the Seine so completely that the Loriot motion demanding immediate adherence to the Bolshevist organization was adopted.

The victory of the "Ultras" in the Seine Congress presaged a severe struggle by them for the control of the Strassburg eonvention. Here three motions were likewise introduced. The "Reconstructionist" motion, which proclaimed, first, that none of the fundamental deelarations of the Moseow Internationale were inconsistent with the essential prineiples of Socialism; that the prineiple of the dictatorship of the proletariat, in so far as it might be ntilized to assure the transition from a capitalist to a socialist regime, was the basis of every revolutionary conception; and that the creation of workingmen's eonncils and soviets was a legitimate method of exercising proletariat power. Thus the first part of this motion was an indorsement of the Russian Bolsheriki and their principles. Seeondly, the motion provided that the French Scetion of the Second Internationale should withdraw immediately from the old organization, and that they should rall a meeting, in coöperation with the German Independent Soeialists, of the nembers of the Third Internationale, to effeet a platform upon which they all conld stand. This mo209 


\section{CONTEMIPORARY FRENCII POLITICS}

tion was important beeause it really meant the eventual adhesion of the French Socialists to the Third Internationale of Moscow. But of even greater signifieance, it meant that the French party must expel its members who were opposed to Bolshevist prineiples. This point was elearly brought out hy Loriot in the debates: The Russian Socialists will not associate themselves with opponents or even lukewarm sympathizers of their doctrines.

The second motion was that introduced by the Kienthalians. It ealled for an nneonditional and immediate adherence to the Third Internationale. It was an unabashed declaration in favor of the principles of Bolshevism and their adoption in France.

The third motion was introdueed by MI. Renaudel, representing the old majority, now so pitifully reduced, which had supported the prosecution of the war. This motion was for adherence to the Second Internationale, providing certain ebanges were made in its organization and its program.

The vote on these motions was: The Reeonstruetionist motion, 3,031; the Thind Internationale motion, 1,622 ; the Second Internationale motion, 337.

Thus 4,652 votes were east in favor of withdrawal from the old Internationale. Although the motion supported by the Longuet clement (the Reconstructionist motion) had been adopted, it was a virtual vietory for the Kienthalians for, as shown above, it (the Reeonstructionist motion) was openly sympathetic with the Bolshevist program. Furthermore, the levoted followers of Loriot, measured by the supporters of his motion, had increased at a rate which must have been alarming to those who still hoper that the Socialists would derote themselves to the needs of the comtry, rather than 


\section{THE 1919 HLEC'TIONS}

to the sterile expression of "fraternal" sympathies. It will be remembered that at the Waster congress the Loriot element numbered less than a seventh of the members of the convention. At strassburg it har? increased to over one-half.

This rapid devolution toward the Left thus proceeded mhindered by the results of the November elections. The extremist leaders who now controlled the Socialist party, despite the fact that they had been defeated at the polls, profited little by the lessons of that election. Perhaps their very defeat had but increased their disregard for the will of France and their desire to inaugurate a minority rule. It is needless to add that this extremism will result only in the impairment of the unity of the party and in the diminution of its parliamentary strength. 


\title{
CHAPTER VII
}

\author{
TIIE DEMAND FOR A NEW CONSTITUTION
}

Tant que l'idée républicaine ne se sera pas reconciliée avee l'idée autoritaire, la démoeratie française restera inorganique et discutée.-HENRY LEYRET.

The Govermment of the Third Republic is perhaps the most abused and criticized in the world. This criticism does not come from foreigners dissatisfied with the manner in which the French Government fulfills its international obligations or in which it represents its people. But it comes and comes vigorously from Frenchmen themselves. There are a multitude of explanations for this. The French temperament is critical and the "demon of reforms" governs it in a tyramieal fashion. Dissatisfaction is always rampant among a few. Moreover, history has left its survivors, from the Monarehy, the Empire, and the Commune, who, through the eurtain of a roseate past, magnify ancient virtues and multiply present vices. The warning of Joseph de Maistre, "Misfortune to bad govermments, thrice misfortune to those who try to mend them," does not daunt their demands for political reconstruction.

The charges against the parliamentary form of govemment in France are the most varied. For the Royalists, Ixom Daudet arraigns "this antiquated, useless, 


\section{DEMANI FOR A NEW CONSTITUTION}

expensive, ant fatal instrument, called l'arliament, an institution which can only live on civil discords which it stirs up and exploits.' 1

The Party of the New Demoeracy, although not denouncing the Republic as organically evil, attacks its present malfunctioning as responsible for the commereial and industrial ills of France as well as her political misfortunes. These reformists point to the fact that during the history of the Third Republie, France has failed to advance as a material power. Compared with Germany she has woefully and fatally lagged behind.

If France is to be thoroughly renovated after the war, the government "must be purged on the inside of the band of adventurers and parasites who have taken possession of the Republic ... and transformed it into an immense employment bureau . . ." for their friends. "To-day progress has ceased. The mockery of the clerieal peril is worn out. The people are aware that what they defended was not the Republie, but very simply the privileges, positions and favors-the seats of Deputies, the profiteers of the Republic of Comrades. . . The Republic is common property. No one any longer ean think of confiscating it to his profit or to the profit of a sect, but unanimous opinion is that it must be reformed to be rendered habitable. . . ."2

In addition to these somewhat far-fetehed attaks, there are many who seriously believe that parliamentary govermment in France will always be inherently and hopelessly defeetive. They have no hope that the French party régime will ever approald the stability which is necessary for a satisfactory parlianentary government.

\footnotetext{
${ }^{2} L$ Action Fransaise, ller. 1:, 1918.

"La Démocratic Nouvelle, Nay 3, 1919.
} 


\section{CONTEMPORARY FRENCII POLITICS}

But in its place they really advoeate a government based on the prineiple of the Separation of Powers, such as exists in the Inited States, with an executive of fixed tenure, and independent of parliamentary control. On the other hand, many believe that the Constitution of 1875 is heing violated, that its provisions have been deserted, especially in the reduction of some members of the government to impotency and the elevation of others to virtual supremaey. They therefore demand a elarification of the powers of each governmental branch, and although they are not elear as to the powers they would grant to each, they are very insistent upon elevating the power of the Executive, and making him a force coördinate with Parliament. To effeet this, a new constitution really becomes necessary.

The distinction between a government based upon parliamentary responsibility and one based upon the Separation of Powers is very marked. The essentials of the former have already been noted. ${ }^{3}$ The latter, which Montesquieu ${ }^{4}$ popularized and which the Ameriean Government put into practice, assumes the existenee of three governing departments: the legislative, the exeeutive and the judiciary, the two former, at least, deriving their powers from the electorate. Each funetions in its own sphere and limits the other by a earefully devised system of checks and balances. Thus the legislature makes the laws, but subject to the veto power of the President and the annulling power of the judiciary. The legislature itself is divided into two bodies, eaeh of which prevents usmpation by the other. The President or executive atministers the government, limited by the lecpislative ratification of appointments, appro-

s.re [1. 46.

- See Montesquieu, The Spirit of the Laws, Book XI. 


\section{DEMAND FOR A NEW CONSTITITION}

priation of funds, directions of law, and when necessary, by impeachment. The judiciary really possesses no positive powers; it merely prevents encroachments; in turn it is indirectly influenced by the appointive and financial power of the executive and the legislature. Such a system, based npon the existence of bodies of nearly equal powers, constantly offsetting each other, is directly opposed to the parliamentary theory, based on the supremacy of the legislative, from which emanates both the executive and the judiciary power.

\section{II}

In point of fact, the French Constitution of 1875 does not definitely assert one or the other of these two principles. France has a Republican form of government to-day, not through choire but through eireumstance. Conserpuently, its structure has been molded by custom and usage, even in violation of the spirit of its fundamental document. The Constituent Assembly of 1S71-75 was Royalist in composition, and had no intention of bequeathing a Repullic to the State. If it liad not been for the obstinacy of the Count of Chambord and his insistency that "The king reigns and governs," it appears likely that the monarohy would still exist. But the National Assembly of 1871 did not represent. French opinion upon this point, for it had been eleeted purely upon an issue of peace with Germany. The Republicans, led by Gambetta and Clemencean, wore not for peace; but, on the other hand, the Monarehists were, and the eomutry, eompletely disarmed by the diplomatic and military

"Julieiary to the extent of itself passing on the constitu tionality of laws. 


\section{CONTEMIPORARY FRENCH POLITICS}

stupidity of Napoleon III, was for peace, whatever the cost. Consequently a majority of Monarehists were eleeted to this Assembly whose original purpose was to "decide on the question, whether the war ought to be continued, and on what conditions peace ought to be made.", 6

But it did not stop when this was achieved. Necessity compelled it to declare a provisional government; in August, 1871, Thiers was given the title of President; and he directed the government until he was forced to retire two years later. His successor, Marshal MaeMahon, was elected for a term of seven years (law of the Septemnate, November 20, 1873). Meanwhile debate continued between the Royalists, divided among themselves, and the Republicans. As the result of these divisions, and of the eountry's repugnance to the renewal of the monarchy, a govermmental system was designed as a mere modus vivendi, operative only so long as neither royalist nor republican tendency became dominant. As a result, the constitution was no complete chart of governmental powers and limitations, eontaining individual guarantees, such as the eighteenth eentury philosophers had designed, or such as the American Constitution embodied. ${ }^{7}$ On the contrary, it was composed of only five fundamental laws ${ }^{8}$ whieh created

"G. Hanotaux, Contemporary France, i. 31.

"Many legal authorities take the position that personal liberties are still guaranteel to Frenchmen by the l)eclaration of the ligglits of Man of 1759 , despite the fact that the Constitution of 1875 does not renew this dectaration. They hold that any law abrilging these tiberties would be uncoristitutional. Sce Juguit, op. cit., 220, and Esmein, Droit Constitutionnel (5th ed.), 499 .

"These laws wore (1) on the organization of the Senate, February 24, 1575; (2) on the Oreanization of the I'uhlie l'owers, Fepruary 25, 1s75; (3) on the lielation of l'ullie lowers, July 16,$1875 ;$ (1) on the Election of semators, Ausust :3, 1875; (5) 


\section{DEMAND FOR A NEW CONSTITUTION}

certain publie powers, and established their relationship and method of election. These laws made no direct mention of the Republie, although they did speak of the President of the Republic in defining his functions; it was not until the amendment of 1884 that "the Republican form of government" was mentioned. The Constituent Assemblies of 1791, of 1793, and of the Year III, preeeded their work by a Declaration of the Rights of Man; and the Assembly of 1848 prefaeed its Constitution by defining its purpose as the establishment of the Republic; but the laws of 1875 made no mention either of it.or of the sovereignty of the people. They are silent upon the nature of the State, its extent and its limitations. No mention is made of even the annual budget or the judiciary.

But as is so well known, no new Constitution was devised at the end of MacMahon's Septennate in 1879. Although the accession of M. Grévy to the presidency definitely assured a Republican form of government, the Constitution originally designed as a makeshift, still remains the law of the land.

It appears that the framers of these laws of 1875 were partly inspired by the theory of parliamentary responsibility, neeessary to a constitutional monarchy, and by the theory of the separation of powers, so dearly held in 1791 and in 1848. Professor Duguit denies that this latter coneeption influenced the Assembly. He says: "The Assembly of Versailles had too mueh experience

on the Election of Deputies, November 30, 1875. Amendments have been made to these laws in 1879, 1854, 1855 .

Sec Les fíglements des Assemblécs Législatives, edited by Félix Moreau and Joseph Delpeeh, ii, France, 179.263. This work gires in addition to extracts from the Constitutional and Organie Laws, the Regulations governing the proeedure and organization of the French Senate and Chamber of Deputies. 


\section{CON'TEMIPORARY FRENCII POLITICS}

with politieal affairs to consider for a moment as the basis of the politieal legislation it was to vote, the metaphysical theory of the division of sovereignty into distinet powers. ...", 9

But if the Assembly was not inspired by this doctrine, it very indistinctly reeognized the other. In faet, it appears to have attempted to incorporate both. The French laws of 1875 provide for a legislative body of two houses, the Chamber and the Senate. Both represent the entire nation, although the first is elected directly and the second indirectly. ${ }^{10}$ The executive power

${ }^{9}$ Léon Duguit, Manuel de Droit Constitutionnel, 157. However, in another place Prof. Duguit seems to contradict himself and even to confuse the essential difference between a government of parliamentary responsibility and one of separation of powers. On page 198, after mentioning the checks the Constitution of 1875 placed upon the President and the Chambers, he says, "Notwithstanding these precise provisions, France eertainly does not practice the parliamentary system. The political preponderance belongs exclusively to the Parliament, and in Parliament to the Chamber of Deputies. The President of the Republic is in fact no longer consilered as a representative organ of the national will, the equal of Parliament, but simply as an executive agent, a parliamentary elerk. ... Thus withont being expressly violated, the Constitution of 1875 has been deformed; it established a parliamentary régime; and up to the war we have como to a sort of an oligarehical régime where omnipotence belongs to a group of politicians who do not represent even a numerical majority of the electoral body." But the essential nature of a parliamentary régime is the suhordination of the executive to it; as we shall try to point out, even the President is not the exeentive; tho real executive being a Ministry ordinarily chosen from Parliament and virtually by Parliament itself. As long as this system is maintained, the I'resilent will always be a "parliamentary elerk."' J'rof. Duguit's confusion between these two types of government is general throughout France; those urging an independent and powerful President do not see that such a creation would instantly kill the theory and the practice of parliamentary responsibility.

10 "The Chamber is elected as deseribed in the ehapters preceding; the Senate originally was composed of 75 Semators chosen by the National Assembly, and 205 ordinary Senators chosen by departmental eleetoral eolleges, formed of the deputies, general councilors, the arrondissement councilors, and one elected dele- 
is vested in a President, elected every seven years by a joint session of the Chamber and the Senate, sitting as the National Assembly at Versailles. ${ }^{11}$ Here the first contradiction of the theory of separation of powers and of parliamentary responsibility appears. Under the former theory, the President should be elected by the general electorate, directly or indirectly, in order to assure his independence from Parliament. But the French Constitution provides that he shall be elected by Parliament, thus necessarily making him dependent upon Parliament, as the theory of parliamentary responsibility would do in the case of the Ministry. But the Constitution again returns to the Separation theory by providing that he "is responsible only in ease of high treason.", 12 Thus in his origin he is dependent on Parliament; in the exereise of this power he is theoretieally not responsible to it. But to prevent the abuse of such a fictitious independenee, the Constitution further says that "the Ministers are solidarily responsible before the Chambers for the general policy of the Government, and individually for their personal aets." 13 This provision is certainly based on the theory of parliamentary responsibility. The Separation theory is again returned to by providing the President with a suspensive veto and the right of adjourmment. But the obtrusion of the executive into the legislative power, in aceordanee with the English theory, is assured by granting lim the initiative in lawmaking and the right of dissolution of the Chamber. But here again, the theory

gate from each municipal council. An amendment of 1884 abolished the life senators, and granted a greater number of delegates to the municipal conneils, aceorling to size.

"Article II, law of February 25, 1575.

12 Ibid., Article V'I.

${ }^{13}$ Ibid. 
of checks and balances bobs up by making the assent of the Senate necessary for the Chamber's dissolution.

In theory, the French Constitution granted the President, many of the powers of the executive of both a parliamentary and congressional govermment, ${ }^{14}$ aceentuated by the extreme centralization of government activities. If he were allowed to exercise them with the freedom of an executive under a government based on the principle of the Separation of Powers, such as the President of the United States, he would become a powerful, independent and perhaps aggressive authority. This power would be increased by the added authority in legislative affairs which the Constitution grants him. Consequently, there grew up the idea of ministerial responsibility, first used under the presideney of Marshal MacMahon; and the acts of the President have not only been eontrolled by his Ministry, it being neeessary for some one of them to eountersign presidential acts, but it has arrogated to itself nearly all of the President's theoretieal powers. The President has neeessarily become what the English King became when English parliamentarism asserted itself-a symbol of power with its substanee held elsewhere. The French President has fared even worse than the English King. As Sir Ilenry Maine put it, the King of England rules but does not govern, but the President of Franee neither governs nor rules; he has become, as Casimir-Périer somewhat bitterly remarked after his resignation (he held the office for only 180 days), a mere master of ceremonies. He is paid a salary of $\$ 240,000$, and given a spacious residence at the Elysée Palace, enabling him to enjoy a brilliant social existence. He guards the

"Article III, law of Felpruary $25,1875$. 


\section{DEMAND FOR A NEW CONSTITUTION}

hospitality of the nation toward foreigners, to a certain extent he personifies the State, and he contributes to the continuity of the government, sadly disturbed by passing eabinets. Aside from this, he is dependent on Parliament for his election and on his Ministers for the exercise of executive power. ${ }^{15}$

The Constitution, in creating a responsible Ministry and an irresponsible President, even though it theoretically endowed the latter with vast powers, really created two exeeutives, both of which could not exist under either form of govermment. Under a government of the separation of powers, the Ministry is solely responsible to the President. Under the theory of parliamentary responsilbility, the Ministry is responsible to the Parliament; this ean only mean that Parliament may potentially, at least, control the aets of the Ministry. The Ministry cannot be subject to Parliament and to the President at the same time. Legally dependent upon Parliament, the Ministry is under no obligation to the President, whom it controls by the necessity of countersigning his measures. By this means, the President is bound to the Ministry and to P'arliament. In sum, a strong independent l'resident and a responsible Ministry are as inconsistent under the French Government as an absolute King and a responsible Cabinet would be

${ }^{15}$ The duties of the Presilent of the Republic were eloquently deseribel by a writer in La Revue Politique et Parlementaire (Feb. 10, 1920), as follows:

"M. Poincaré las given the example of seven years of disinterested service, even going to the point of abnegrition. Indeel a particularly diflicult task for such an intelligent man! To ocenpy the highest oflice in the Ropulnlic and to be nothing; to understand everything, to be able to say nothing, execpt to people who do not hear you; to sec everything being done, hut not to be allowel to command that something be lone; - is certikinly a sorrowful task, esporially in these troublesome tintes in which the fate of the Romblie is latily at stake." 


\section{CONTEMIPORARY FRENCH POLITICS}

under the British Government. If parliamentarism is to dominate, a strong President eamnot exist.

It was very far from the intention of the framers of the French Constitution thus to reduce the President. On the contrary, as seen from his wide grant of powers, they-a monarchist majority-wished to elevate his authority. As a concession necessary to even a eonstitutional monarchy, a Ministry was created, responsible to Parliament. ${ }^{16}$ But no provision was made that members of the Ministry should be chosen from members of Parliament, a custom invariably followed in England, and almost necessary to seeure parliamentary control. In France, although a majority of the Ministers are usually taken from the Chamber of Deputies or the Senate, Cabinets often contain members having absolutely no eonnection with either legislative body. ${ }^{17}$

Furthermore, although the right was incorporated in the Constitution, the President, as we have seen in a previons chapter, ${ }^{18}$ has never used the right of dissolution of the Chamber since 1877. Thus the people have been given no opportunity to pass on the merits of a parliamentary-executive struggle; and as Parliament can always overthrow a Ministry, while nothing ean overthrow Parliament, the latter, until the regular eleetions, reigns supreme. The revival of the exercise of the right of dissolution seems to be essential if the theory of parliamentary responsibility is to be fully earried out.

\footnotetext{
${ }^{10}$ For a thorough deseription of the government of France, Poincaré's Ilow France Is Governed, is of value. The latest work is Joseph Barthélemy's, Le Gouvernement de la France, Payot et rie, Paris.

${ }^{17} \mathrm{MM}$. Jonchenr and (laveille, on the 1917 Clemenceau Cabinet were not members of l'arliament.

${ }^{14}$ seo p. 70.
} 
The weaknesses arising from these eonstitutional inadefuacies lave led to the demand for a strengthened presilency. The reformist organization, the National Association for the Organization of Democracy, headed by Probus, demands a I'resident chosen by regional assemblies, to serve for a term of six years. This would in a measure sever his original dependence on Parliament. The association also demands that the Ministers be named by the President and be responsible only to him. The politieal program of the Party of the New Democraey likewise asks that the "President be ehosen by the Chambers of Commeree and the general Councils of the country... who will propose laws and seleet his Ministers from men of worth, no matter from what circles they come." 19 "The Party even demands that members of Parliament be specifically excluded from ministerial positions. The Liberal Action party asks for the extension of presidential powers, and the socalled plibiscitaires owe their name to a demand for his popular election; the conservative press generally deplores exeentive impotency and asks for the actual participation of the President in the govermment.

Most of these organizations demand that the President's election be taken away from Parliament and placed with the people, either by direct rote or by the ereation of an electoral college, apart from Parliament. There is considerably more agitation for the latter than the former. If this change is ever effecter, it will open the way for his resumption of power. But this involves

${ }^{10}$ This program is daily printed in La lémocratie Nouvelle. 
a much greater problem-that of the relation of the Ministry to the President and to Parliament.

The Ministry camnot contimue in a responsible relationship with Parliament if the President is to beeome independent. The two things are mutually inconsistent. If the President is to be independent of parliamentary eontrol, he must be his own Prime Minister, direct Govermment policies himself, and act as the real head of the govermment. His Cabinet will assume the same responsibility as the Ameriean Cabinet assumes, an individual obligation to the President alone. This will mean the total suppression of ministerial responsibility, the fixity of ministerial tenure, the suppression of parliamentary control, in a word, the substitution of a government based on a separation of powers for the present form based on parliamentary responsibility, partial as it is.

There are at least two other reforms urged to remedy present defects, and which will eomplete the separation of powers in the French Govermment. The first of these is in strengthening the French Senate. The long term (nine years) of its members and its indirect system of election naturally make it conservative. In the spring of 1919 it defeated the Chamber's bill granting governmental officials the right to organize $;^{20}$ mntil recently it repeaterlly rejected Chamber bills of eleetoral reforms ; ${ }^{21}$ it appears to have also defeated the bill for woman's suffrage. Still it feels the weight of opinion, as its passage of the eighthour law shows. Its opposition, however, seems to be the rhief somed of its influence; and as it is gradnally lessening, the conservative elements demand a rebirth of power. Many ask a ehange in the mamner in which the Semate is ahosen. The

"Sine p. 3.51.

${ }^{21}$ siee 1) 160. 


\section{DEMAND FOR A NEW CONSTITUTION}

Radieal party has gone as far as to ask its direct election; others demand an electoral college from which, deputies are eliminated. In addition to freeing it from this legislative trammel, a more active assertion of the Senate's power, especially in ministerial control, is urged. Theoretically, the French Senate has identical powers with those of the Chamber, except in the matter of money bills. The Senate, in addition, acts as a High Conrt of Justice. Aceording to the Constitution, the Ministry is as much responsible to the Senate as to the Chamber. But it is very seldom that a law of any importance originates in the Senate; the Government projects are usually first introduced in the Chamber. From the legislative standpoint, the Senate acts as a mere ratifying body.

In the past the Senate has exereised some eontrol over the Ministry. By votes of lack of eonfidence, refusal of eredits, political opposition, or personal aetion, it caused the overthrow of the Tirard Cabinet in 1890, the Bourgeois Cabinet in 1896, the Caillaux Cabinet in 1912 and the Briand Cabinet in 1913. Question of confidence have been asked from it by the Dupuy Cabinet in 1899 on the question of expropriation, by the Waldeek-Rousseau Cabinet in 1900 on the law of amnesty, by the Rouvier Cabinet in 1905 on the law of separation, and by the Clemenceau Govermment in 1908 on the purchase of the Western railway. ${ }^{22}$ But aside from these examples, the Senate now never attempts to overturn a Ministry, and if it were to, it is doubtful if a Ministry would resign. Despite the demand for the reassertion of the Sellate's equality of powers, it is difficult to see how that body can oceupy a place coördinate with the Chamber, in a

${ }^{23}$ These eases aro eited in Leyret, Le Gouvernement ct le Parlement, $\mathrm{S} 6$. 


\section{CONTEMPORARY FRENCII POLITICS}

govermment based on parliamentary responsibility. In England the interference of the IIouse of Lords in the legislation of the Commons has become so inconsistent that by the terms of the Parliament Aet of 1911 money bills passed by the latter become effective without the consent of the Lords, and other public bills, having been passed by the Commons in three suceessive sessions, though rejected by the Lords in each of these sessions, likewise beeome effective. ${ }^{23}$ From the parliamentary standpoint, the Senate camnot readily reflect the changing opinion of the country because of its indirect election and fixed tenure. There is no provision in the French Constitution for the dissolution of the Senate. It is not intended that it shall be a popular but a deliberative body of restraint. Although this is its virtue in a government based on the separation of powers, it is absolutely ineonsistent with the parliamentary system in which the legislative body controlling the Ministry must be directly responsible to the people. In fairmess, it must be added that muder the French system, where the right of dissolution of the Chamber is never exereised, it is just as logical for the Senate as for the Chamber to vote a Ministry out of office on the ground of being a responsible body. However, if such a prineiple were admitted, a very difficult situation might arise in which the Senate would rote confidence in a Ministry, at the same time and upon the same issue as the Chamber passed a vote of lack of confirlenee. So long as the theory of ministerial responsibility is retained, it is diffieult to see how two branches of the legislature ean exercise coneurent powers.

The other reform, certainly part of the Separation

${ }^{23}$ For details of this Act, see F. A. Ogg, The Governments of Exorope, $112 \cdot 113$. 


\section{1)EMANI) FOR A NEW ('ONSTITLTION}

of lowers theory, thomgh it may not be inconsistent with Parliamentarism, is the establishment of a Supreme Court. 'l'he Constitution of 1875 overlooked the judiciary, and the Court of Cassation has never attempted to pass upon the ronstitutionality of laws. The only distinetion hetween an ordinary and constitutional law is a formal one; the Presidents of the two legislative houses freguently rule upon the constitutionality of propositions placed before the Chambers. ${ }^{24}$ If Parliament finds itself definitely obstrueded by a constitutional provision, which it rarely does lecause the Constitution of 1875 contains few limitations, it ean itself, meeting as the National Assembly and hy a majority vote, amend the Constitution. Whus Parlianent is the interpreting and the amending power of the Constitution. This is indeed contrary to the Separation of Powers theory, where the Constitution is interpreted by the eourts and where anendments cannot be passed soldy by legislative enaetment.

Frimels of a Supreme Court wish it to assure the metaphysieal liberty whinh Montesenien asserted would be destroyed "if the power of judging is not separated from the legislative and executive power. If it were joined to the legislative power, entrol over the life and the liberty of ritizens would be arbitrary, because the judge would be the legislator. If it were joined to the excrutive power, the judge would have the foree of an oppressor.',

The New Democraey party adrocates "a supreme compt, composer of enlightened men, chosen for a long

2 On April 4, 1:19, P'resislent Deschanel of the Chamber ruled the Raynaud resolntion asking the government to secure complete German disarmanent, menenstitutional on the grounds that it interfored with Artiele Vlll of the law of .July 26,1875 , giving the Presilent sole power in traty negrotiations. 


\section{CONTEMPORARY FRENCII POLITICS}

period, watching over the constitutional laws and nullifying abusive acts of power.' The Liberal Action party, to assure the guarantee of religious liberty, removed from the "caprices of parliamentary majorities," also advocates a "rigid Constitution eonfided, as in the United States, to the care of an independent Supreme Court.", 25 The National Association for the Organization of Demoeracy calls for a similar reform. ${ }^{26}$

${ }^{25}$ Quoted in Jaeques, op. cit., 486.

${ }^{20}$ Tho attitude of the Progressist Republicans toward the present French Government may be understood from the following excerpt from their program:

"For forty years the Republie has been erected, or rather, eneamped, as bail as it is, npon the ruins of the Imperial palace, itself hastily rebuilt with the rubbish of former ruins, upon a soil formed of fourteen eenturies of monarehy. . . . For forty years we have followed the paradox of making a demoeracy live without the organs of a demoeracy; so although the monarehical organs have been abolished, the democratic organs have not been created and the vital fumctions (of govermment) are no longer carried out. Thus we present to the world tho spectacle of a Republic in which essential liberties are not guaranted, and where every power is overlapped and confused, without a moderating foree to control, limit and divile them. In a monarehy this power exists and is naturally aflirmed in the king. In a demoeracy, invarler by a parliament, where it is none the less necessary, this can only be done by a supreme tribunal of adjudication-from whence comes the neeessity of establishing a Supreme Court.

"To be unlimited (in power) is undoubtedly one of the worst fanlts of parliamentary government such as we practice it; but this is not the only nor even the first defeet which must be remedied. The erisis in the parliamentary régime is evident. . . Tho true canse, the funlamental eause, is tho fact that the balance is broken between onr politieal institutions and our social state. This parliamentarism, so awkwarlly imitated from the English, a system whieh suited England chiefly in tho seventeenth or eigliteenth entury, and whieh is alrearly much less suited to contemporary England, this régime which is based upon an aristoeracy or at least a bourgeoisie, upon a very intelligent, moral and independent governimg class, as disinterested as men can be, it is not impossible to arlapt to a democracy; but it must bo adapted to it. One of the great problems of the future will certainly eonsist in reistablishing this lost equilibrimm, in placing political institutions and particularly parliamentary institutions in harmony with the social state. ..."

Quoted from tho accomt of the "Congrès do 1912," under 


\section{DEMAND FOR A NEW CONSTITUTION}

The Supreme Court is undoubtedly an essential insti. tution in a govermment of the Separation of Powers. But in a parliamentary government, it again appears to be anomalous and an interference in the will of the nation expressed through a responsible Parliament and Ministry. The place of the Supreme Court may be a question apart from that of Parliamentarism; but even as a feature in a Separatist govermment, it has been severely eriticized. The United States has been the chief example of its use; it is indeed true that the eourt has exercised a tremendous power and that, as de Tocqueville said, "in the hands of the judges of the Supreme Court the peace, the prosperity, and the very existence of the Union, reposes.' But it is a matter of doubt whether we have been spared any of the turpitudes in which the supposedly ill-eonsidered action of French and English parliamentarism has resulted.

\section{IV}

If these reforms are ever inaugurated in France, they will result in the condnet of the govermment by an aggressive and independent President, in complete charge of the public administration; in the assertion by the Senate of powers commensurate with those of the Chamber; in a Ministry subordinate and responsible only to the President whose tenure of office will be fixed by law; in a Supreme Court to adjudge the relations of each. Such reforms will neessitate a new Constitution, and these organizations complete their demands for

Programme An Parti, brochure issued by the Fédération Républicaine. This part of the program is reprated in substance in 1913 and 1914. 


\section{CONTEMIPORARY FRENCII POLI'TCS}

reform by asking for the ealling of a Constituent Assembly. Their adoption would moan the complete submersion of the French cabinet as it is to-day eonstituted as well as the position of the Prime Minister, or as he is ealled in France, the P'resident of the Council. It would likewise mean that Parliament would no longer eause the fäll of a Ministry. In sum, French parliamentary government would be completely overthrown. The French reformists appear to hide this result, but an examination of the implieations of their demands will indicate that such an outcome would be inevitable.

Generally speaking, something is to be said for both forms of government. Theoretically, the ministerial responsibility theory is mueh the more democratic. The division of sovereignty among three distinct powers has no real basis. Such a conception holds that the finality of power is in the gouvernants, and that its exereise ean be eontrolled only by its balaneed division between them. Such a conception fulther looks upon the gouvernés, the electorate, as a ward in the charge of the gouvermants. Although the latter must have their powers periodically renewed, the exercise of those powers is theoretically subject to no eontrol. But as a matter of fact, the souree of all power must eome from the gouvernés who are at the same time gouvernants, merely exercising a power of surveillanee and control. ${ }^{27} \mathrm{At}$ least, such is the theory muder a government of parliamentary responsilility,-that the people are supreme. Now the advantage of the separation of lewers is that it cheres lassty and harmful ateiom on the part of a

${ }^{27}$ The great objection to Prof. Muguit s theory (soe p. 3.58)

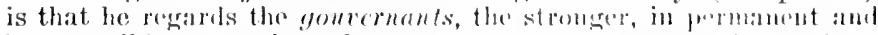
irresponsible possession of power over the gomernes, the weaker;

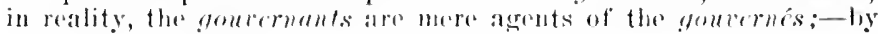
no means stronger, often weaker. 


\section{DEMAND FOR A NEIV CONSTITUTION}

legislative body subject to no restraint. But in so far as controlling the different organs of goyernment, it does not appear to function auy better than (or as well as) a parliamentary govermment. As for the ill-considered acts of a single legislative body, arising from passion and from misinformation, it may be said that the inereased study being given to pulslic affairs, outside of legislative eircles, in the press and at the miversities, is gradually sweeping away the ignorance with which public opinion formerly might have been charged. Also, the character of men serving in legislative bodies, in the majority of eases, is inferior both as to the knowledge of affairs and in capacity of judgment to that of the men who direct public thought outside of legislative eircles. The latter, in fact, usually control the decisions of Congressmen. In the last analysis, it is publie opinion, the gouvernés, which decides. From this standpoint, a parliamentary govermment more surely reflects the popular will.

The conflicts botween the 65th and the 66th Congresses and President Wilsom have certainly illustrated the defects of a government based on the Separation of Powers theory. Opponents of the President, some of them opponents of the war, were speakers in the IIouse of Representatives and heads of congressional eommittees on which the functioning of the government was dependent. Filibustering, the blocking of appropriations, and other obstructionist measures were used in the attempt to hinder the exercise of executive power. Of more intermational importance was the Senate opposition to the Peace 'Treaty. The comntry, through the press, business, sorial and religious organizations, seemed to demand the ratifieation of the Peace Treaty and to desire a League of Nations. But because of the 


\section{CONTEMPORARY FRENCH POLITICS}

provisions of our Constitution, a minority (one-third) in one branch of the legislature, in the Senate, is able completely to block ratification. Sueh a situation eould not long exist under a parliamentary govermment. If at any time a difference between the executive and the legislative powers should arise, the former would dissolve the latter, the country would decide the issue, and the power deeided against would find itself out of offiee. In the partieular ease of the Treaty, under such a system, members of Congress would run for reëleetion on a platform standing for the ratification of the Treaty unamended, its adoption with amendments or reservations, or its complete rejection. The decision would be with the country. Ordinarily, as suggested, these defects in America are overcome by the forces of public opinion. But under our form of government there is no legal and forcible way of making this public opinion felt, if the Senate or Congress stubbornly closes its ear to it.

Aside from the general objection to the theory of the Separation of Powers, there are others peculiar to France itself, whieh will work against its adoption there. We have spoken elsewhere of the centralization of power in France, the vesting of which in an independent exeeutive would be of the greatest danger. ${ }^{28}$ This danger is exaggerated by the fear of the reëstablishment of a popular dictatorship. Fven yet, the defenders of the Republic are haunted by the chilling apparition of the Napoleonic Empire. Napoleon Bonaparte will ever be enshrined among the French Immortals even though his body may not lie within the Pantheon. II is is a name to summon sentiments which the anonymity of Parliaments can never arouse. Napoloon appealed to the people. No ordinary despot, he declared:

\footnotetext{
24 sien p1. 310, $811,373-381$.
}

$$
2: 34
$$




\section{DEIIANO) HOR A NEW (ONSTITUTION}

I an the emperor of the peasants, of the plebeians of France. In spite of all that has passed, you see how the people retum to me. There is sympathy between us, because I am arisen from the ranks; I am different from the privileged classes.

And the French people have shown the same devotion to his descendants as they did to him; it was illustrated in the mamner in which they eleeted Louis Bonaparte to the Assembly under the Second Republie; in the 4,000,000 majority they gave him for the Presidency over General Cavaignae; and finally in the tremendous majority of nearly 7,000,000, which approved his establishment of the Second Empire. Even though the peasants may have thought they were voting for Napoleon I, Napoleon III and his descendants still inspire a dread in the defenders of the Republic. The country and the commercial populations of France, reënforeed by their disdain for petty politicians, can be readily eaptured by a leader of persuasive powers.

This fear has not only extended to the line of the Napoleons, but also to such others as General Boulanger who have tried to overturn the Republic. General Boulanger was Minister of War from January, 1886, to May, 1887. On aecount of the adoption of certain army reforms and his popularization by musie-hall songs, he became associated as the leader of the movement of "revanche" against Germany. Due to the apathy of the Govermment toward this movement, he was very free in his eriticism; and in 1857, while commanding an army corps, he was arrested for remarks made against the Govermment. Supported by a band of malcontents, composed largely of Orleanists, he soon attracted a great popnlal following; in 1888 and 1889 he was eleeted Deputy from several districts; and the Government mo- 


\section{CONTEMIPORARY FRENCII POLITICS}

mentarily feared a coup d'étut, overturning it and establishing Boulanger as I'resident, independent of parliamentary control; a position which it was eertain he would eventually turn over to the royalty. But the General did not have the courage of his illustrious predecessol's; and from fear of prosecution by the Government, he fled to Brussels, where in 1891 he committed suicide. The Senate subseruently eonvicted him of malfeasance, and it was later definitely established that he was in the pay of the Royalists, the Duchesse d'Tzès having furnished him with a fund of three million franes.

At the time of the Dreyfus affair, ${ }^{29}$ another attempt was made to overthrow the Republic by a motley coterie of nationalists such as Antré Buffet, Paul Déroulède and Jules Guérin. The stern action of the Senate likewise prevented or at least punished their attempt. ${ }^{30}$

${ }^{20}$ The Dreyfus case was that of a Jew, Captin Alfred Dreyfus, who in $159 t$ was tried and convicter of giving military information to Germany. On Jamuary 5, 1895, he was conducted to the courtyard of the Ecole Militaire in Laris and publiely degraded, aurl then exiled on the lle du Diable, althougl he repeatedly declared his imocence. Finally, upon the suicille of Colonel Henry who confessed to have committed a forgery, upon which evilenee Dreyfus was eonvicter, and on the agitation of the Socialists and Liberals against an obviously anti-Semitic and nationalist movement, the Court of Cassation ordered a retrial. Another court martial sat at Rennes in 1899 ; he was again convicter but parloned by l'resilent Loubet. The question was again opened in 1906 by the Conrt of Apheal which derelared the decision annulled. Inryfus mas reinstater in the army; aml it is mmlerstood he servel as a Colonel in the Creat War and was lecorated for bravery.

${ }^{30}$ The Senate has justificd its existence in the Ropublie by the part it has played as a Migh Court of Justice. It has acted in this capacity on four occasions: (1) In 1859 , for the first time, it adjurgerl boulanger, Henri Rocbufort anl Count 1)illon, his henchmen, (2) in 1 s.99 it tried Déroulesle, Mareel Inabert, Buffot, Guérin, cte., and comdemned them to banishment, (3) 1901, it

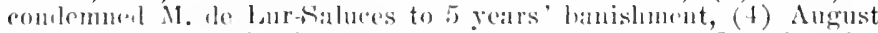
1918, it banished M. Malvy, former Minister of the Interior, for 


\section{DEMANI) FUR A NEW CONSTITUTION}

'These various eflorts made to overturn the Republie have led to the strengtheming of the legislative side of the government as being the most difficult to overeome. The ereation of a strong, independent executive would immediately lay the position open to seizure or usurpation by the Royalists. That this fear is still real may be shown by a motion, unanimously adopted by the National Congress of the Radical Socialist Party in 1903, condemning the Govermment for having appointed a former Bonlangist as Consul-General to New Orleans. ${ }^{31}$

At the Congress of Tours in 1913 a motion for the abolition of the Senate was voted down by this same party, chiefly on the ground that as a IIigh Court of Justice, the Senate is the hulwark of the Republic.

Now that the Repullic is firmly established, it may be that these fears will subside. Naturally they will exist much longer than their canse. Until they are overeome, a government of the Separation of Powers is not likely to be established. If the defocts of the present party régime are not remedied, if the right of dissolution is not recognized, and if Ministers are not chosen from the Parliament, it seems certain that French parliamentarism, with its defeets as well as its virtues, will continue to exist.

five years. It is now trying M. Caillaux in that capacity (April, $1920)$.

31 See Armand Charpentier, Le I'arti Radical et Radical-Socialiste à travers ses Congrìs, 367 . 


\title{
CHAPTER VIII
}

\author{
SYNDICALISM : PROGRAII AND TACIICS
}

Un peu de désordre est profitable à la libertś; comme l'erreur, témoignage do l'activité inventive, est utile ì la science.Maxime Leroy.

The point of departure and the point of arrival of Syndicalism and Socialism are identical. Both demand the ereation of a new socicty in which the eapitalist is suppressed. To both Marxian formulas and coneeptions are eommon property. The difference between the two appears to be in the means by which a Marxian soeiety is to be erected. Socialism, at least of the old Freneh school, demands its eonquest by the aequisition of political power. Syndicalism, inspired by the philosophies of Georges Sorel, Lagardelle, and Berth, on the other liand, denies the worth of political means and asserts that direct action alone is powerful enough to introduee the new order. Direet action means, first, the general strike $^{1}$ so to disorganize means of production that eapi-

Wee Chapters IV and V, Georges Sorel, Reflections on Iriolenee. G. Sorel's distinction between Socialism and symlicalism is of interest: "Parliamentary Socialists ma be compared to the offieials whom Nilpoleon inade into a nolility and who labored to strengthen the State lequeathed by the Aneiont lifime. Revolntionary Syndicalism corresponds well enough to the Napoleonie armies whose soldiers aecomplished such leroic arts, knowing all the time they would remain poor. What remains of the limpire? Nothing but the epic of the Grand Armée. What will remain 


\section{SYNDICALISM: PROGRAM AND TACTICS}

tal will be obliged to capitulate. It means also the hoycott; and although the Syndiealists are not loud in proclaining the doctrine in France now, it means sabotage, - the destruction of instruments of production. To the ont-and-out anarehists who form the left wing of the French Syndicalist movement, it may mean assassination and destruction by bombs.

The labor union, according to the Syndicalists, is the natural organ for earrying on the elass struggle. In fact, ontside of the union,- the organized foree of labor, - there can be no class struggle. The Syndicalists, furthermore, plan the government of their new society upon the basis of the union and groups of unions. Although Socialism is satisfied with political democraey as it now is, for the political foundation of the communist state, Syndicalism, repudiating parliaments, governments and laws, places the complete direction of public and industrial affairs in its labor bodies. Tnions in eö̈peration with each other will suffice for the needs of soeiety. Syndicalism is suffieient unto itself. ${ }^{2}$

The French organization which includes the exponents of the theory of revolutionary Syndicalism, is the Confácution Ginérale du Travail (the General Confederation of Labor), popularly known as the C. G. T. It claims to have from 900,000 to $2,300,000$ members affiliated with it, ranging from day-laborers to school

of the present Socialist movement will be tho epic of the strikes." licflections, 299 .

11. Sorel also says: "Syudiealists do not propose to reform the State, as the men of the eighteenth century dill; they want to destroy it, becanse they wish to realize this iclea of Marx's that the Socialist revolution onglit not to eulminato in tho replacement of one governing minority by another minority. . .' Reflections on Violence, 128.

2 For a letailed disenssion of the differenees between Socialism and Syndicalism, seo liertrand linssell's I'roposed lioads to Frecdom. 


\section{CONTEMPORARY FRENCII POLITICS}

teachers and dramatists. ${ }^{3}$ The Confederation itself is the product of a series of under-organizations whieh have the union as their fundamental basis. About two thousand of these unions are assoeiated in the federation. They in turn are grouped into forty-three national federations of industry, each representing a separate industry, delegates from which eompose the Confederation. The worker joins the union of his trade, the union joins the federation of its industry, and the federation adheres to the C.G.T. In addition to these federations of national industry, the C.G.T. is eomposed of the Bourses du Travail, which are local, regional or department groupings of unions of all industries. This grouping, therefore, is not by industry but by region. No labor union can become a part of the Confederation if it is not nationally federated or if it does not belong to a Bourse du Travait or to some other kind of mion of department, regional or local groups. Each organization, whether national federation or Bourse du Travail, affiliated with the C. G. T., is represented by one delegate, the total number of these delegates forming the confederal committee. ${ }^{4}$ The General Confederation of Labor is divided into two sections, eorresponding to its composition, (1) the section of the federations of industry, and (2) the section of the federation of the Bourses du Travail. Each seetion has its own offieers. The confederal committee, formed of the nnion of the officers of these two sections, directs the entire federation. The organization has three important committees, one on

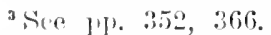

1'This is a very undemocratic provision as a local Bourse du Trarail is griven the same representation as a national federation containing many times as many members. 


\section{SYNDICALISU: PROGRAM AND TACTICS}

strikes, one on eontrol, and one on the supervision of La Toix du Peuple, the official paper of the federation. ${ }^{5}$

Ever since the complete independence of the C. G. T. was announced at the Congress at IIavre 111 1912, it has remained aloof from the Socialist party, although Soedalist candidates lave received thomsands of rotes from Syndicalist members. The Symdicalists, despite their theoretical opposition to political Socialism, nevertheless vote for Socialist candidates in preference to the bourgeoisie. The C. G. T. prided itself, before the war, upon its abstention from politieal affairs. Three different factions, however, were to be recognized in the organization: First, the revolutionary element which saw in Syndicalism an entire sufficieney for labor's needs, and which therefore demanded an immediate revolution and the erection of a labor State. Second, the Guesdists, who believed in the use of legislative as well as direct action and favored collaboration with the Socialists. Third, the reformists, who did not believe that the Syndicalist movement should go beyond the urring of purely economic demands.

The Syndicalist organizations rallied, as did the Soeialists, to the support of the war. ${ }^{6}$ M. Jouhaux, the seeretary-general of the C. G. T., served on a governnent committee of "national relief," along with an archbishop, a rabbi, a Protestant minister, a Royalist,

"For a history of symlieal organization in Franee, of the different tendencies in the syndiablist movement, and of the extent of syndical organization among agrioultural workers, sce M. Martin Saint-Léon, Syndicalisme Outrier et Syndicalisme fgricole, Paris, Payot Co., 1920.

"Before the war the Govermment kept a list of the names of revolutionary workmen, known as "I, "arnet I:," who were to be arrested on the outhreak of war. When the war eame these men were not arrested, but were trusted. l'or two years Franco went without a strike. 


\section{CON'TEMIPORARY FRENCH POLITICS}

and a Radieal. A representative of the C. G. T. served on a government committee for war factory personnel; a representative likewise was on the eommittees of Economic Aetion and the National Coöperative Federation. As proof of its entrance in the field of politieal action, the C. G. T. repeatedly demanded the repression of the censorship, the granting of an amnesty, non-intervention in Russia, and the raising of the state of siege. It joined the Socialists in a manifesto addressed to President Wilson upon his first arrival in Paris in December, 1918. It also joined a Socialist and Radieal protest against the condemnation of Malvy. Its offieial existence was recognized by the Government in the appointment of M. Jouhaux as the representative of French Labor at the Peace Conference. Moreover, the C. G. T. was offieially frank in its denunciation of the Peace Conference. Thus, in a multitude of ways, it has definitely entered the political world. ${ }^{7}$

During the five years of the war, the C. G. T. was controlled by such moderates as M. Jouhaux. But toward the end of the war a strong minority movement arose under the leadership of l'ierre Monatte, editor of La Tie Ouvriore, which drew its ehief support from the International Woodworkers' Union and the Metal Workers.

\section{II}

The moderates and the extremists of the C. G. T. compromised upon a program of Minimum Demands which were published by the confederal committee in December, 1918. After asserting that the solution of

\footnotetext{
${ }^{7}$ See an article on Fremcli labor by Albert Thomas, in tho London Times (French number) of September 6, 1919.
} 


\section{SYNDICALISM: PROGRAM ANI) TACTICS}

the present erisis rests exclusively upon the laboring class, it admits that it will not "be sufficient to change the political order by making the revolution," for the development of production must be increased. But to realize immediate reforms "is not to ahdicate the ideal of the revolution; on the contrary, it is to prepare for the new order toward which we are guided.", 8 This is certainly a moderate statement compared with those which the adrocates of the general strike and sabotage were making.

The program asked for the creation of a league of nations, the abolition of protective tariffs, the end of eeonomie wars, the ereation of an offiee of international transportation to divide raw materials among nations, and general disarmament.

It asked that the individual liberties, suspended during the war, be reëstablished.

Under the eaption of "the Rights of Labor," it demanded that labor no longer be treated as a commodity, that the equality of the two sexes be recognized, that functionaries be given the right to organize, and that collective bargaining regulate wages and conditions of labor. It asked for an eight-hour day in commerce, industry and agriculture, and for the prohibition of nightwork in bakeries, etc., and in any industry in which women, or children of less than eighteen years, are employed. It asked that the compulsory school period be prolonged to fourteen years.

It demanded the creation of a national exomomie conncil, upon which unions should have responsible representatives, to draw up the general principles of demobilization and economic reconstruction.

${ }^{8}$ Brochure distributed by the confederal committee. 


\section{CONTEMPORART FRENCII POLITICS}

It asked that the devastated regions be recoustructed, not by private contractors, but by collective organizations of producers, consumers, and government offieials. Worker's' lodgings and public playgrounds should be created by municipalities.

The program insisted that property is a trust, held by individuals for the good of society, and that the nation should watch over the exercise of property rights which owe their value to the protection of society. If it is not desirable that the State direetly produce everything, the program asserted that the production of neessities should be minute!y regulated (i. e., the conditions of labor and the division of profits) by the State. Sueh a control should be exercised in industries which still permit the play of initiative and competition.

But whenever a private monopoly gains control of raw materials, products, or organizations, the program says that the State should appropriate it for society. The State must "establish its social right to collective wealth and to the means of producing or exchanging it.' Public monopolies should not be operated by the old centralized statism, but by decentralized and autonomous grompings of producers, eonsumers and government officials.

The C. G. T. also demanded measures against aleoholism, poor-housing, unemployment, and disability.

The program declared that a foreign worker is entitled to all the privileses of French union organizations and should receive the same salary as a French laborer for the same work. The recruiting of foreign labor should be controlled by the labor organizations of the (ountry of emigration.

It also asked that social insurance be extended to cover the total anomit of the salary of a rictim of a 


\section{SYNDICALISM: PROGRAM ANI) TA("IIC'}

labor aceident during his incapacity. Industrial disease should be considered in the same category as accidents.

As measures to combat the cost of living, it asked the abolition of tariffs and the octroi, and the creation of a publie service of alimentation upon which there should be Labor representatives.

As will be noted at onee, the program of the C. G. T. is very mueh more moderate and pratetical than that of the Socialist party. The C. G. T. offers some very definite functions for the Society of Nations to perform; the Socialists condemn the League as an organ of capitalism. The C. G. T. engages in no defense or justifieation of Marxian theories as do the Socialists. It makes no sweeping accusations; it speaks neither of the revolution nor of the dictatorship of the proletariat. It affirms the supremacy of the State and asserts the doctrine that private property is but a trust from the State to be exercised for the good of collectivity. Although this program was doubtless framed with many arrierepensécs, it was a serious effort toward Freneh reconstruction which others outside of the labor world, such as the Radical party, eould have endorsed. A victory for the moderates, the program was natmally an object of scorn for the extremists who believed that the revolution by direet aetion was the sole legitimate object of the C. G. T. At any rate, the realization of these Ninimum Demands now became the official aim of the C. C. T. by the First of May, the Labor Day of Enrope. If the country by that time did not see fit to grant these demands, the C. G. T. insinuated that it would not return to work until compliance had been seenred. 


\section{CONTEMPORARY FRENCII POLITICS}

\section{III}

Labor agitation was stimulated by the unrest following the armistice, an unrest which grew steadily because of the uncertainty of the peace negotiations. The cost of living, la vie chère, and the eonsequent inadequacy of salaries were even a greater foree in provoking diseontent.

Freneh wages are inconceivably low. Aceording to the publieations of the Ministry of Labor, ${ }^{9}$ the average salaries of agrieultural workers are 800 franes a year. Journeymen printers receive a daily wage of $4 \mathrm{fr}$. 06 ; tanners, 3 fr. 35 ; saddlers, 3 fr. 50 ; shoemakers, 3 fr. 24 ; tailors, 3 fr. 73 ; wheelwrights, 3 fr. 37 ; coopers, 3 fr. 68 ; eabinet makers, 3 fr. 99 ; upholsterers, 4 fr. 15 ; carpenters, 4 fr. 15 ; joiners, $3 \mathrm{fr}$. 86 ; coppersmiths, 4 fr. 46 ; tinworkers, 3 fr. 89 ; plumbers, 4 fr. 04 ; blacksmiths, 4 fr. 20 ; locksmiths, 3 fr. 82 ; masons, 3 fr. 94 ; day-laborers, $2 \mathrm{fr}$. 67 . Mine workers receive an average of 1,300 franes (\$260) a year; employees in eommerce, about 1,200 franes $(\$ 240)$; railway labor received 4 or 5 franes a day.

The Government paid its laborers even less; thus the roadkeepers received from 500 to 1,000 franes a year; foresters, 975 franes; prison-kcepers in the provinces, 1,365 francs; mail-earriers, 800 to 1,200 franes in the country; canal-kecpers, 500 to 700 franes; customs collectors, 1,100 to 1,200 franes. Such a salary was virtually a starvation wage, even before the war.

It was little wonder, consequently, that repeated demands were made for increases to keep up with the tremendons bounds which the anst of living made during

- Quoted in Lysis, Fers la llémoeratie Noucclle, 65. 


\section{SYNDICALISM: PROGRAM ANI) TAC'TICS}

the five years of the war as elsewhere. This eost rose out of all proportion to the rise in wages. If one rontsider's whenlesale prices in France in 1914 as 100, this increase would be denoted as follows:

December, 1914...... 113.

June, $1915 \ldots \ldots \ldots \ldots 1.40 .3$

January, $1916 \ldots \ldots \ldots .166 .7$

June, $1916 \ldots \ldots \ldots \ldots 192.4$

January, 1917 . . . . 207.8

June, $1917 \ldots \ldots \ldots \ldots 271.8$

January, 1918....... 279.

June, $1918 \ldots \ldots \ldots \ldots 380$.

September, $1918 \ldots \ldots \ldots 410.6$

Retail prices likewise inereased, but not to the same extent. Thus, the retail priee of food produets inereased in towns of more than 100,000, 233 per eent between July, 1914, and April, 1918. In other words, it would take $\$ 233$ to buy at the latter date what $\$ 100$ bought before the war. Aeeording to figures published in Le Petit Journal ${ }^{10}$ the price of beef, mutton, pork, and veal inereased nearly six times between 1914 and March, 1919; eggs, eheese and butter inereased four times. Eggs were selling in the spring of 1919 at nine eents a pieee; and butter rose from forty eents in 1914 to two dollars a pound in 1919. Aecording to the statisties of the C. G. T., it would take 9,000 franes $(\$ 1,800)$ a year for a family of two to live upon deeently-an amomt far greater than the average laborer or even professional salaried man reeeived. In comparison with other countries, it would take sixty-two eents in Paris to buy what forty cents purchased in New York or thirtyfive cents bought in London; making the eost of living in Paris from fifty to seventy-five per cent higher than in New York or in London.

Despite the efforts of the Government through the establishment of the so-ralled Vilgrain booths, in whieh the Govermment sold goods directly to the comsumer,

${ }^{10}$ Issue of Mareh 13, 1919. 


\section{CONTEMPORARY FRENCH POLITICS}

succeeding months did not diminish the cost of living, itself partly eaused by a stupid Govermment eontrol. ${ }^{11}$ This factor led to much diseontent which took the form of repeated strikes. The strikes upon the transportation lines in P'aris in the latter part of January, 1919, were among the first. The men asked for a wage increase of two franc's a day, shorter hours and other reforms; but the strike eame to an abrupt end on the 25th of January by the Govermment requisition and operation of the "metros" on a military basis, it being understood that the demands would be settled favorably later. At the same time and later the electricians, the streetsweepers, who before the war reeeived twenty dollars a month, the employees in the great banking firms, such as the Crédit Lyonnais and the Bourse, whose salary at the end of four year's' service was only ninety eents a day, the women employees in the department stores, who demanded a salary of at least forty dollars a month, stopped work in what appeared to be thoroughly just demands for a living wage.

\section{IV}

It was perhaps of some signifieanee that the C. G. T., instead of directing its energies toward the inerease of wages during the early months of the armistice, oeeupied itself with securing the "(eight-hour day" 12 one of the most important of its Minimum 1)emands. On Mareh 5th, the Seeretary-General of the Railway Fedcration wrote to M. Clemencean, saying that the men

"Sion pr. B14-332. Also Appendix 13.

12 For an excellent tratise upon French labor legislation, see l'aul l'ie, Traité ale Législation Industrielle. 


\section{SYNDICALISAI PROGRAM AND TACTICS}

were absohutely determined upon the immediate realization of this reform. At a session of the Confederal Committee of the C. G. T., from March 2:nd to 25th, the matter of the application of the eight-hour day was taken up. The comnittee resolved that the "efforts of all organizations must be coördinated to assure a demonstration of power and of will on the filst of $11 \mathrm{ay}$, 1919. After the warning whieh the manifestation of the first of May will express, it will fall upon the Federations ... to limit the period of negotiations and to fix a date for the application of the demand." Thus if Parliament refused to pass a law to that effect or if the employers refused to install the eight-hour day, the C. G. T. was determined to force it upon them.

During the month of April, a propagandist campaign for the eight-hour day was very effeetively carried on throughout Franee. Graphic appeals, in writing and by eartoon, were made to laborers everywhere to support the demands of the C. G. 'T., and especially to coöperate in the May Day eelebration. About the first of $A$ pril, seven of the principal national federations belonging to the C. G. T. organized a "cartel" to promote the agitation of the eight-hour reform and to lay plans for the first of May. This "cartel" was formed of representatives of the federations of the railway workers, the miners, the doek employees, the marine workers, the firemen, the transport workers, and the metal workers. They pledged their own organizations to a eomplete cessation of work on the first of May, and persuaded other organizations not represented in the "eartel," such as the clothing workers, the butchers and the men in the building trades, to eease work also.

Hastened by the threatening attitude of different labor organizations and the disturbance which featured 


\section{CONTEMIPORARY FRENCII POLITICS}

the Jaurès manifestation of Sunday, April 6, 1919, the Government laid a project before the Chamber granting the eight-hour day. The text of this law provided that the duration of work for laborers of either sex or of any age in industry and commerce should not exceed eight hours a day or forty-eight hours a week. Administrative regulations were to determine what delays and under what conditions this day would be installed in each industry. These regulations were to be drawn up only after both employers' and employees' organizations had been consulted.

On the 17th of April, 1919, discussion upon this projeet was opened by Albert Thomas who asserted that labor would produce as mueh in eight as in ten hours. M. Thomas moved an amendment to the bill providing that the salary of the reduced day remain the same as formerly. Upon the assurance of M. Colliard that the law carried such guarantees, the amendment was defeated by a vote of 253 to 233. But M. Briand again showed his magnetic power by reintrodueing the identical amendment and vigorously asserting its neeessity. After a lively debate with the Minister of Labor, his amendment was finally carried by a show of hands. Immediately afterward the whole bill was passed. On the 23rd of April the Senate voted the law without modification. Thus one of the chief points in the Minimum Demands of the C. G. T. had been won without direct action, but by a sort of threatening persuasion.

The conscrvative element, although timorous in expressing its opinion, folt that the adoption of this law at such a time was harmful. Desprite whatever logic there was in the theory that men would do as much in right as in ton hours, it was certain that they would not do so until after a period of readjustment. But it was 
just at this time that liance needed to devote all its energy to reconstruction problems. A shortened working day would exaggerate the cost of living, grive labol more leisure to be exploited by unserupulons leaders, and, on the whole, retard the requickening of French life. ${ }^{13}$ Labor, however, assmmed that the strategic time to foree this reform-that is, the time when its forre was the strongest and the Government's the weakest-had come. Unquestionably it was a great measure in Labor's anelioration; but it had issued out of a purely class struggle in which Labor had proved its superior force.

\section{V}

The passage of the law did not lessen preparations for the fête of the First of May. Although the principle

${ }^{23}$ For a very fair statement of this point of view and for a general diseussion of the effects of the eight-hour law, see an article ju La lievue lilcue Oetober 11, 1919, entitled “'La.Journée de huit heures," by l'aul Pie, professor of law in the University of lyons.

In February, 1920 (Temps, Feb. 14), the Lille Chamber of Commerce passed a resolution asking for the modification of the eight. hour day law. It stated that this law had disorgauized brauches of production, decreased activity in the mines, industry, and transportation, that it had led to increased prices in manufactures, and of foremost importanee, it had led to a coal shortage.

Tho output of tho French mines in 1919, exclnding the mines of Iorraine, was only about $19,500,000$ tons compared with 26,322,000 tons procluceil in 1918, and 28,929,000 in 1917. At a conference of the Ministry of Public Works on January 25, 1920, it was estimated that the requirements of coal exeed the present possibilities by 40 per cent.

It is diffeult to explain the decrease in coal production except by the lessened productivity of labor. It would naturally be supposed that with the demobilization of troops and the advent of peace, coal proluction would be increased. It is but natural, therefore, for the belief to arise that the diminution of coal production has been largely eaused by the reduction of the hours of labor. The hours of labor in mines, however, were not regulatel by the ordinary cight-hour law, but by the Dufaure mining law. 
of the eight-hour day had been secured, doubled efforts were still necessary to seeure its application to industry.

Curiously enough, the fête of the First of May had its origin in the United States. In 1886 a Federation of Trades Unions decided at a convention held in Chieago to fight for the eight-hour day, not by appeal to Congress or legislatures, but by refusing to work after May 1st until it was granted. The First arrived and with it, 5,000 strikes; by the end of the month the eight-hour day had been granted to nearly 250,000 workmen. The labor organizations in France followed this American example at the third Congress of the National Federation of Syndicates in 1888 where a resolution was adopted deciding that on Sunday, February 10, 1889, every labor union in Franee should petition the prefeeture for an eight-hour day and a minimum wage. On the 24 th, they were to return for a response, accompanied by as much of a manifestation as possible. The manifestation oecurred and was so sucessful that the International Labor Congress at Paris decided to organize an international manifestation in every country and of all laborers. The date of May 1, 1890, was decided upon by the French Socialists. But the Paris unions, under the influence of eonservative elements, declared themselves against the demonstration. Despite this opposition, however, the manifestation was held. It was chiefly marked ly the presentation to MI. Floquet, President of the Chamber of Depnties, of a petition requesting the eight-hour day, by a delegation of workmen, while troops kept the boulevards eleared of those who wished to parade. The First of May, 1891, was more disçuieting and it resulted in many arrests. But sureessive echlotrations lost their belligerent features and more and more tended to become purely a holiday 


\section{SYNDICALISII : PROGRAM ANI) 'TACTICS}

in nature. The pacifie character of these fêtes was overeome by the organization of the C. G. 'T. in 1900, which immediately commenced agitation for direct aetion. La Voix du Peuple in its number of May 1, 1903, advoeated the Ameriean theory of strikes to bring about the eight-hour day. Adopting this point of view, the Confederated Congress at Bourges in 1904 decided that after May 1, 1906, no worker should consent to work more than eight hours a day. Sinee that time every May Day has been used to present forcibly labor's demands to the publie and to the employers. The Congress at Havre in 1912 advocated the eight-hour day and the forty-four hour, or English, week. The eighthour day, as noted, was again arlvocated in the Minimum Demands of 1918. Despite the passage of the law incorporating this reform, May Day, 1919, was more than ever ealculated to impress the French public with the strength and the unity of the working classes.

The speeifie demands which the C. G. T. asked its organizations to urge on the First of May, were arranged as follows:

\section{To demand:}

The eight-hour day.

An amnesty for all.

Rapid and complete demobilization.

A just peace and disamnament.

To protest against:

Intervention in Russia.

The form of the present tax on wages.

The state of siege.

The censorship.

It is interesting to note that nearly all of these demands were purely political. They definitely marked 


\section{CONTEMPORARY FRENCH POLITICS}

the evolution of the C. G. T. toward the attainment of political ends by direct aetion. But now that the chief economic demand (the eight-hour day) had been met, Labor leaders eautioned against violence. Thus the Railway Federation, upon the 17th of April, resolved that "the first of May should not be . . a cause of economie disorder." On the 18th, the C. G. T. published an appeal, defining the nature of the manifestation: "The demonstration will be made with ealm and dignity. To show thoroughly what the force of Labor ean do when it is disciplined, work will be resumed the seeond of May in order that the value of our efforts may be judged."'

When April 30th arrived, the "eartel" had done its work well. Preparations had been made for the almost complete cessation of work upon the following day in every district of France. Trains were to stop for only three minutes, commencing at 10 o'clock; but city transportation facilities, even taxicals, were to stop for the entire day. The post-office employees were to go to work two hours late and stop two hours early. No newspapers were to be published except La Toix du P'euple, the official organ of the C. G. T. The Paris Stock Exchange was to close. No hotels or restaurants were to serve meals; guests were not even to be given hot water to shave with. In Paris it was estimated that 750,000 would have to go hungry. Barber shops were to do no business; theaters, music halls,-all places of entertainment,-were to be dark. Even the electric plant workers were to stop for two hours. The Central Markets were also to be elosed. In short, a nation-wide, silent but impressive strike had been arranged for, to prove that labor was the essential factor in the industrial world. As La Vague said, "If Labor stops, life 


\section{SYNDICAIISM : PROGRAM AND TACTICS}

stops. . . But is Gold, the king of the earth, then nothing? Yes, it is nothing. . . . And whoever has gold by privilege or by birth, and does not earn it by labor, is supported by us who work. They eat our corn, inhabit our houses, wear our elothes, ride in our automobiles, smoke our cigars. . . Then are they parasites? Yes, they are parasites like the mistletoe on the apple tree."

In addition to the general strike throughont France, a great manifestation or parade through the streets of Paris had been planned. The direction of these manifestations was obscure from the first, and it did not fully appear until after the fête had occurred. But the Government upon the 29th of April did what many labor leaders and Socialists suspected it would do, namely, it issued a note forbidding any attempt at a Labor parade on May 1st. Consequently it was with many fears that the Parisian population saw the light of this eventful day.

In the provinces the day passed like a New England Sabbath. There was little activity of any kind-even the street cars refused to rum. In the afternoon mass meetings were held at which resolutions were adopted, asking for amnesty and the raising of the state of siege, and protesting against intervention in Russia. At the close of the meetings, processions formed in the streets headed by the "Red" Flag, while the erowds sang the "Internationale." ${ }_{14}$ 'There were no attempts

"The worls of the "Internationale", are as follows:

Il n'est pas de sauveur suprême,

$\mathrm{Ni}$ l)ien, ni César, ni tribun.

Proulucteurs, sauvons-nous nous-mêmes!

Deerétons le silut commun! 


\section{CONTEMPORARY FRENCH POLITICS}

on the part of the authorities to break up these provincial manifestations, to capture the "Red" Flag, or to muffle the communist hymn. Throughout the provinees the First of May passed without disorder or expressed ill-will.

Things were different in Paris. A steady, drizzling rain, lasting nearly the whole day, came as a providential help to the French police. Their task was to stop the great demonstration from the Place de la Coneorde to the Place de la République, which the C. G. T. insisted should be carried on, in defiance of the Government's prohibition. The morning passed quietly; work everywhere had ceased. Except for meals served out of rear doors and many drinks surreptitiously seeured through temporary "blind pigs," idleness reigned supreme. But early in the afternoon, every street leading to the Place de la Concorde had been barred by a cordon of poliee, the Republican Guard and detachments of eavalry and infantry. Unable to get through,

Les rois nous saoûlaient de fumées,

Paix entre nous, guerre aux tyrans!

Appliquons la grève aux armées,

Crosse en l'air et rompons les rangs!

S'ils s'obstiment, ces cannibales,

A faire de nous des héros,

Ils sauront bientôt que nos balles

Sont pour nos propres généraux!

\section{Refrain}

Debout! les damnés de la terre!

Debout! les forçats de la faim!

La raison tonne en soll cratère,

C'est l'éruption de la fin.

Du passé faisons table rase,

Foule esclave, debout, debout!

Le monde va changer de baso:

Nons ne sommes rien, soyons tout!

Quoted in W. Morton Fullerton, Problems of Power, 197, footnote. 


\section{SYNDICALISM : PROGRAM AND TACTICS}

groups of workingmen finally gathered in the Rue Royale in front of the Churcl of the Madeleine, where they suceeded in foreing their way beyond the first line of the troops and the police. Cheering the poilus who allowed them to pass, they suceeded in getting into the Place de la Comeorde. I3ut here the cavalry eharged and the parade was dispersed into groups, each one of which became the object of a police attack. The manifestants rushed to get out of the place, and the poilus again let them pass. A number of injuries resulted. Whenever a "Red" Flag was shown it was captured, and the "Internationale" was squelehed with the aid of a fire-hose.

Labor leaders now attempted to reorganize the erowd at the Gare du Nord and the Gare de l'Est. The crowds succeeded in breaking through the police cordons and in barricading themselves behind the station's gates. On the arrival of new crowds the police began to attack; blood flowed freely and Red Cross ambulances found much to do. With the attacks of the poliee, the mobs became more violent, breaking windows and tearing up tile for anmunition. The police, it was eharged by the Socialists, drew their revolvers and fired steadily for four mimutes. Seventy-five minor easualties resulted from the fracas, and one boy, Charles Lorne, was killed. The fusillade eventually suceeded in breaking up the mob. Neanwhile, three Socialist Deputies, MII. Marcel Cachin, Paul Poncet, and Mayéras, together with M. Jouhanx, the secretary of the C. G. T., were trying to restore order among the workingmen and to parley with the police. l3ut they were all eaught in one of the assaults, and the three Deputies were slightly injured in body and mortally ruftled in dignity. 


\section{CONTEMPORARY FRENCH POLITICS}

The First of May in Paris ended with a total casualty list, according to the Prefect of Police, of 428 wounded police, nearly as many wounded civilians, and one boy killed; 118 arrests had been made. The Socialist argument was that the Government had hopelessly antagonized the laboring classes by its refusal to tolerate the manifestation, a right which the Declaration of the Rights of Man gave to them. If the Government had followed the policy in Paris which it had followed in the departments, peace and order would have been maintained.

However, there was widespread eriticism from the public directed toward Labor. Thus La Démocratie Nouvelle wrote:

The holders of public authority no longer give orders to the citizens in the name of the law, but it is the C. G. T. In the name of whom? In what capacity? Can such a condition, in a free demoeracy, be toler'ted? This is a nameless tyranny! ${ }^{15}$

The Socialist press was naturally jubilant at the outlawry of the mobs,- - this was a precursor of the Revolution. Marcel Cachin wrote in L'Iumanité:

At no moment in no country has the First of May been observed with such fullness and with such manimity. Labor for the first time has given the spectacle of its all-powerful diseipline and of its decisive importance. As for the bloodshed, it falls entirely upon the head of the Government who has taken it upon himself to oppose a peaceful workers' movement by a formidable preparation of troops and of police. ${ }^{16}$

In the same number Daniel Renoult more bitterly attaeked M. Clemencean as follows:

20 Issue of May 3, 1919.

20 Issue of May 2, 1919 . 


\section{SYNDICALISM: PROGRAM AND TACTICS}

This most incoherent and incapable of all men, ... has one domain in which he rules: the police. At attacking women and children in the streets, M. Georges Clemenceau is a master.

\section{VI}

The subsequent action of the Labor and Socialist leaders largely destroyed whatever sympathy they originally had with the French people. The explanations given by the Government for its aetion before the Chamber were also illuminating.

The Socialist group at the Chamber, on May 2nd, protested against the Government's interferenee with the parade, and decided to interpellate it upon its actions. The administrative commission of the party, on May 3rd, took similar action, congratulating Labor for its disciplined conduct, and placing entire responsibility for the riots upon the Government. Of greater importance was the resignation of M. Jouhaux, secretary-general of the C. G. T., from his position as labor delegate of the French Peace Delegation. In a letter to M. Clemencean, condemning the Government for suppressing the manifestation, he said:

The prineiples of right and liberty are not only valuable in diplomaey. The people have a right to them. . . In forbidding a demonstration which yon knew would be entirely pacifie, in setting your police and the army against the Parisian workers, in maltreating with an unforgettable brutality, men and wonnen who only made use of an essential liberty granted to their comrades in every other country, you have distegarded the devotion and the sacrifice which the working class exlibited during the war.

The resignation of $\mathrm{MI}$. Joulanx was followed by that of two others,- two Socialist Ieputies from the positions 
of general eommissioners in the Govermment,-M. Bouisson, eommissioner for the merchant marine, and $\mathrm{M}$. Compère-Norel, commissioner for agriculture. It will be recalled that at the last Congress the Socialist party roted to eease immediately all participation in a bourgeois ministry. The delays which had prevented such a cessation were now overcome, but the ineident of the First aeeelerated this separation from the Government. Consequently the administrative eommission of the Socialist party "decided as a result of the ineidents of the First of May in Paris," to ask the two Deputies to resign without delay. The Soeialists thus completed the poliey whieh their Congress had adopted of deelaring war on the Government. They erowned their unreasonableness on May 6th by an interpellation which was opened by Mareel Cachin, who eriticized the concentration of troops in Paris and again asserted the peaceful intent of the manifestation. After considerable debate, M. Pams, Minister of the Interior, rose to respond to the interpellation for the Government. But before he eould say a word, MI. Ernest Lafont demanded, in the name of the Socialists, if the Minister's declaration was to be the only one whieh the Government would make and if the President of the Comneil, M. Clemenceau, was not to explain his policy. M. Pams replied that aceording to parliamentary custom, and as the poliee were under his control, he had come to respond. The Socialists would not even permit him to finish; but, with the exeeption of three, rising in a group, they all left the Chamber in silence. The Socialists had talked a great deal abont liberty, but as M. Delahaye remarked in the debate, they did not eare to grant liberty to others, even the liberty of explanation. There seemed to be little justification for their ill-reasoned action. 


\section{SYNDICALISM : PROGRAM AND TACTICS}

M. Pams then very calmly proceeded to explain the Government's position. It was the Government's desire to permit the manifestation upon the First of May, but it felt that it was its duty to take precautions in certain questionable eenters. It had authorized the prefeets throughout the departments to permit manifestations on condition that the labor organizations promise to maintain order. At Paris, however, things were different. Certain seetions were inhabited by dangerous and foreign elements, zealous to overturn order. The Govermment had awaited propositions from the C. G. T., as to means of safeguarding such a manifestation. The C. G. T. manifested no desire whatever to talk the matter over. But upon the 17 th of April, the Minister said, the C. G. T. itself warned its members of the dangers of a manifestation; and it was not until the 28th that it announced its decision to hold one. This decision appeared to have been taken against the will of the majority. A man by the name of Bertho, an anarchist, freed from a prison term of two years, urged the Syndicalists to hold the parade. The measure was passed by a majority of only nine, with many members absent. After this decision, the promoters still refused to ask the Government for the authorization necessary under the state of siege. With such eonditions, the Governinent could only guard the publie seeurity. It had tried to eonciliate the mobs; it had ordered the troops not to be armed. The crowds had wounded one fifth of the police force. After asserting the sineere desire of the Government for social reform, M. Pams said, "No reform and no progress can be aecomplished in a eivilized nation except with order and public peace."

Although the statements of the Minister and the as- 


\section{CONTEMPORARY FRENCH POLITICS}

sertions of the C. G. T. were contradictory on some points, the Chamber eompletely vindieated the former by a vote of eonfidenee of 338 to 1 . The Socialists and the C. G. T. were again on the defensive; and they were in a doubly embarrassing position on aceount of their rather humorous withdrawal from the Chamber.

\section{VII}

Rumors were afloat to the effect that the C. G. T. would soon loold another manifestation, as a protest against the First of May. But nothing eame of it immediately, and no unusual disturbances in the Labor world occurred during the month of May. Beginning with the last days of May, however, and eontinuing through Jume, France experienced widespread and persistent strikes. The first eause of these strikes was the failure of the Government to apply the eight-hour day. Although June 1st had been the date set for its application, employers and employees eould not agree on its details. Wage increases were another demand; the eomposition of so-ealled discipline eomeils upon whieh laborers were to be represented, was yet another. The metallnrgists and the subway employees were among those who threatened to stagnate French industry eompletely. Space does not permit the diseussion of the economic demands and results of these strikes. An attempt will be made, however, to show the political aspirations of some of them and why they failed.

Althongh originally all of these strikes were for direet, eeonomie purposes, indieations of a change in objective were soon apparent. On Jume 5th it was announced that the iron-workers of Ivry had adopted the following puroly political resolution: 


\section{SYNDICALISII : PROGRAM ANI) TACTIS'}

The iron worker's of Irry, 15,000 in number, protest energetically arainst intervention in Rossia; they demand inmediate demobilization and the inmediate liberation of polition and military prisoners. They place the realization of these demands along with their others; and they are thoronghly derided not to go back into the shops until all of these questions have been setlled.

This was the supreme extension of the Syndicalist plan,-the control of the government by direct action. If successful, there was a hope that from such a eontrol, possession of the government might eventually be secured, a possession which was the incarnate desire of both Socialists and Syndiealists. Similar expressions eame out of St. Denis, where on June th the following motion was voted:

The Inter-syndieal committee of St. Denis, transformed into a strike eommittee, decides to enter into relations with the regional inter-syndical committees to examine... if it is not time to ask the C. G. 'T. to make the necessary moves upon the gorernment to oblige it to leare to the proletariat the care of the destinics of the country.

This was one more advance towald the desire for proletariat control.

The strikers on the l'aris subways, however, resisted this revolutionary movement, for on . Jume 5th they "affirmed on their honor" that the strike. . . is exclusively economic. . ." Likewise the Administrative Commission of the C. G. 'T., recognizing the hoprelessness of coneerted artion for any other than material purposes, on June 7 th declared that "these strikes have their origin in the resistance eneountered to the applieation of the eight-hour day.... No one ean deny the economic character of these movements. . . The work- 


\section{CONTEMPORARY FRENCH POLITICS}

ing elass intends to conserve the original charaeter of these strikes." Thus the anarchist and syndicalist agitators at work in divers federations received a direet check from the supreme Labor body.

But even this did not silenee the revolntionary movement, for the Union of the Syndicates of the Seine at the same time published a note registering "with satisfaction, the new spirit of the working elasses which no longer limits their aspirations to ends of a uniquely material order." And the Railway Federation passed a defiant resolution which read: "Considering that the Russian, Hungarian, and German revolutions have the only governments which apply the principles whieh we have always defended; and that eapitalist expropriation remains the prineipal objeet of our propaganda and our action,... . we favor immediate action to stop the circulation of all trains carrying troops and war supplies, except leave trains, in order to prevent the enterprises of the Government against the strikes in course, against the peoples in revolution, and against refractory soldiers."

If the railwaymen had been sueeessful in earrying out this poliey, their complete victory over the Government and Labor's assumption of power would have been assured.

At the same time agitation for a general and sympathetie strike grew up; at a meeting of the "cartel," on June 10th, it was decided to "apply measures of solidarity which will rapidly assure the victory of the professional demands of the miners and the marines." Meanwhile, the C. G. T. had been won over to the idea of a political strike, internationally organized, and was conferring with labor delegates from England and Italy. On the 24 th of . June the metal workers asked 


\section{SYNDICALISII : PROGRAM ANI TACTICS}

the "eartel" to support their demands by a general strike also. But after a long and vigorous debate, the idea of a sympathetic strike was given up. The "cartel" refused to support such a strike in the ease of the metal workers, but it declared itself in favor of an international demonstration, which was already being organized.

This international strike was decided upon at Southport, England, upon the 27th of June. In agreement with British and Italian Labor leaders, the C. G. T. deeided to hold a twenty-four hour demonstration against (1) the imperialism of the Peace Treaty, (2) Allied intervention in Russia, and for (3) immediate demobilization, (4) full ammesty, and (5) the reëstablishment of constitutional liberties. The only eeonomic demand, one which the strike could not hope to settle but rather to attenuate, was for (6) the reduction of la vie chère.

In aecordance with this agreement, the C. G. T. organized claborate plans for a nation-wide strike, surpassing in extent that of the First of May. No demands were to be made for the improvement of Labor conditions; it was not a question of using the bargaining power of Labor to foree Capital to terms possible for it to make. On the other hand, it was another political demonstration, a protest against so-ealled bourgeois oppression and stupidity. If it succeeded it would prove the tremendous political power of the proletariat and would be of fundamental importance to the Syndiealists and the Socialists, being the first step in organizing I abor for the purpose of completely assuming the direction of society by force.

The strike, however, did not onenr, or rather it was "postponed," -again proving the impossibility of or263 


\section{CONTEMPORARY FRENCH POLITICS}

ganizing Labor in a demonstration from which it would receive no direct value. The reasons for the failure of this strike, which had been set for the 21st of July, were three. The first was the firm attitude of the Government. As members of the C. G. T., the railway men, the members of the postal and telegraph service, and other Government officials were planning to obey the orders of the Supreme Labor Body to strike on the 21st. This would have resulted in the disruption of vital public services whieh the Government decided it eould not tolerate. Conseruently, on the 10th of July, after a special meeting of the Council of Ministers, M. Claveille, Minister of Transportation, addressed a note to the federation of railway men, which stated that the stoppage of transportation, especially during the time of reconstruction and of demobilization, "would eonstitute a veritable crime against the nation." Those who hindered the operation of the publie serviees upon the 21st, were threatened with prosecution before the Conncils of War. A similar note was sent by other Ministers to functionaries in their serviees. This firm attitude of the Govermment, although defied by the $\mathrm{C}$. G. T. anthorities, was somewhat discuieting to the rank and file of their following, who did not relish the manhandling which the Comncil of War usually gave offenders brought before it. This perhaps was one of the greatest rauses for the strike's failure.

$A$ second reason, and one arising from the first, was the attitude which many of the organizations of the C. G. T. took towald the strike. like the Socialist party, the C. (t. 'T'. was divided, rather indistinctly, into Conservative and Radical factions. The Conservatives, leel hy M. Joulanx and inchuling most of the funefionaries lately athreent to the C. G. 'T', were for the 
strike in a lukewarm lashion, or not at all. 'The liadicals, who now were getting the supremary, were completely for the strike; while the extreme Radicals were dissatisfied with a mere strike of twenty-foul hours. They advocated a strike of molimited duration, to end only when the workers should have appropriated the goods and control of society. Begimning with the First of May and through tactics familiar to unserupulous minorities, it seemed as if the Radicals were going to foree their hand.

IIowever, the demand for another strike on the 21st of July, mate for no apparent economie purpose, and in defiance of the Govermment's prohibition, was resented by many of the semi-bourgeoss elements of the C. G. T., who had joined it because of its great bargaining power, merely to secure salary amelionations. On the Sth of July, the men on the Paris-Etat railway declared that they were firmly attached to the pursuit of professional demands, but that they opposed with all their foree the commands of the C. G. T. to engage in a political strike. Despite a renewed appeal from the C. G. 'T. on the 14 th of July, the P'. L. M. railway men who met in Dijon the next day, made a similar declaration. The employees of the Midi line, in a meeting at Toulouse, likewise decided not to strike. At a gathering in Strassburg, the delegates of sixteen labor organizations, representing 78,000 to 80,000 members in Alsace and Lorraine, highly disapproved of this strike, which was "inspired by purely political reasons." The agrieultural syndirates of Montpellier manimously revolted against the strike; on the 16th the dramatic artists decided not to join it; while different organizations of functionaries sent in protests daily.

The third reason for calling off the strike, and that 265 


\section{CONTEMPORARY FRENCH POLI'TICS}

which the C. G. T. leaders named as the principal one, was the assurances given by the Clemenceau Government. The President of the Council ealled the leaders of the C. G. T. into eonferenee with him on the 18th of July. He assured them that the Government would take every means to prevent the strike, but that it would also speed up demobilization, introduee a projeet of amnesty, freeing 150,000 prisoners, and immediately solve the eost of living. During the interview, M. Jouhaux reeeived a note stating that $M$. Boret, Minister of Agrieulture, had just fallen at the Chamber by a vote of 227 to $213,{ }^{17}$ upon a motion eondemning the eeonomie poliey of the Govermment. He did not open the note until after the session, and labor leaders asserted that the onteome of the conferenee would have been different if he had. The press, however, stated that M. Jouhanx was already aware of the Minister's defeat from a delegate arriving late.

At any rate, on the evening of the 18th, after a long session, the Administrative Commission of the C. G. T. adopted a resolution whieh stated:

After studying the situation, it rejects the measures taken by the Government concerning the cost of living, but recognizes the new situation created by the vote of the Chamber of Deputies which has heard the voice of the working elass condemning the economie policy of the Government;

It recognizes, on the other hand, the dispositions drawn up under the menaee of the projected strike, eoncerning amuesty and demobilization;

It therefore deems that a new examination of the situation has become necessary, ... and that the demonstration of July 21 shall be postponed.

17 ine p. :326. 


\section{SYNDICALISM: PROGRAM AND TAOTIC'}

In this manner the greatest effort made in France to bring about an exclusively politioal strike, failed. Along with those previonsly eited, this attempt showed the improbability of securing the adherence of workmen to a movement in which no other than political demands are to be made. Prowlhon's words, "Jamais au grand jamais, il ne satisfera les appétits de la multitude, procédât-il à un partage général. . . L Ouvier, l'ignorant, l'insolent, l'intraitable, têtu, veut être le maître des fabriques, maître de l'Etat, qu'il prétend gouverner; il a pris an pied de la lettre sa souveraineté," may be true so far as the desires of Labor are eoneerned. But when it comes to realizing them, the eost is too mueh.

The failure of these strikes which had been attempted for other than purely economic reasons, is perhaps the most convincing answer to the whole argument of Syndicalism which Georges Sorel so effectively advances in his interesting book, entitled, Reflections on rio- lence. MI. Sorel believes that the enthusiasm of revolution, brought about by the burning eonviction that existing conditions are unrighteous, is the only force which ean stimulate workingmen to that high plane of sacrifice necessary to introduee the Marxian order. Confliet is the very essence of faith, even in religion, he asserts; whenever Catholicism succeeds in stamping out Protestantism and has no other enemies to eonquer, its followers soon lose the holy zeal which once inspired them. If Labor is to be content with purely economic gains, it will never be aroused to the consciousness of its full grandeur and the potentiality of its own strength. "When working-class circles are reasonable, as the professional sociologists wish then to be, when conflicts are eonfined to disputes abont material in- 


\section{CONTEMIPORARY FRENCII POLITICS}

terests, there is no more opportunity for heroism than when agrieultural syndicates discuss the subject of the price of guano with mamure merehants. . . ."18

The recent efforts of the French syndicalists to earry out this theory must be disappointing to the doctrinaires who have fumished them with their principles. Perhaps the working elasses are as incapable of real "heroism" to-day as the eapitalists. Perhaps the very comfort which they derive from a period of inflated wages and from the benefits of concerted action has dulled their sonls to the essential "injustice" of the place which they now hold in the existing social order.

Whatever be the reason, French experience seems to establish the fact that direet aetion has its limitations. The strike is a powerful weapon when it is used for the accomplishment of immediate and "reasonable" ends (despite M. Sorel). But when its purpose lies beyond this point and attempts to secure the fulfillment of some political end-of benefit to working people generally, but not affecting them intimately and individually as does a wage increase-the strike is likely to fail. ${ }^{19}$ The very materialism of the doetrines of the Marxian order permits of no martyrs except when the end to be achieved is inmediately at hand.

Furthermore, soeiety is demanding that direct action

"Refletions on liolenee, 246.

19 'The amount of wages lost by the strikes in Junc, 1919, was:

Metal workers' strike ................. F. Franes Chemilanl workrirs . . . . . . . . . . . . . . . . . . 18,000 transport workers $\ldots \ldots \ldots \ldots \ldots \ldots \ldots \ldots \ldots \ldots .58,500,0 \ldots 00$ gfiday strikr in mines . . . . . . . . . . . . . . . $58,500,000$

$270,000,000$

The knowlerlge of these tremembous losses is an ample deterrent to strikes without an economire purpose. 
SYNIDCALISUI RTOGRAM AND TACTISS

for the areomplishment of politioal ends give way to political action. It demands that it be spared the constant interruptions which industrial disorders enforer. For this reason, and berause of the limitations of direct artion, the creation of political parties by Labor seems to be inevitable. In fart, if Labor will give up its frequently mutiered threat of direct and open revolution, the development of political organizations among workingmen is to be welcomed. 


\title{
CHAPTER IX
}

\author{
THE PRESS AND THE CENSORSHIP
}

Il faut que l'éerivain puisse tout dire, mais il ne saurait lui être permis de tout dire, de toute maniere, en toutes cireonstanees et à toutes sortes de personnes.-Anatole France.

\section{I}

Oecupying a very large part in politieal life, French newspapers are quite as important as parties. In fact, they eonstitute one of the most unique characteristies of French polities, while they refleet in an illuminating manner the qualities of Gallie temperament. Unlike American newspapers which at least feign an aloofness from party groupings and an independenee in opinion, more fictitious than real, French papers are frankly partisan; they openly ally themselves with party doctrines if net with party groupings. They serve some eanse with the greatest intensity; they turn every political news item to their own profit, regardless of eontent. Thus the Royalist press does not eonfine itself to a dis"ussion of the justice or the injustice of some particular Labor demand. But after playing the trouble up to complete hopelessuess, it eries for the return of the King as the only solution. Similarly, the Socialist press will never discuss a matter such as foreign poliey upon its morits. Instead of weighing the respective claims of the Crochs and the Poles to Tesehen, for ex- 


\section{THE PRESS AND 'THE CHNSORSHII'}

ample, it dispatches the whole matter as anothor instance of Allied imperialism which the bourgeoisie am never eradicate.

There is nothing lukewarm about French newspapers,-they have no half-way opinions. Instead of being swayed by political thought, they attempt to direct it. Editors are chosen, when they do not choose themselves, chicfly because of their ability for pungent eritieism. The advantage of this stimulating feature of the Freneh paper is that it arouses a vigorous, healthy publie opinion upon political subjects. But at the same time, it is very difficult actually to judge French opinion from these printed utterances. Their effusiveness, the fact that they are always in the service of some cause, necessitates their being discounted as authoritative representatives of French thourht. To judge French people by their newspapers would be like judging the Ameriean people by several dozen $A p$ peals to Reason, or Menaces. Representing a suall element of thought, perhaps, each paper more often is an excreseence rather than the substance itself.

A French paper is not an institution ; it is a personality. Ordinarily much smaller than the most diminutive rural weekly in Ameriea, the war ent its size down to four pages four times a week and two pages three times a week. The small proportions of a French newspaper, eoupled with the predominant position the editorial plays, make it a purely individualistic affair. The editorial always appears on the first page, and often in larger type than the articles surromuling it. There are usually two or three of the editorials oceupying the greater part of the sheet, while the news is crowded off to the side or on the back. There is absolutely no anonymity about a French paper. If elitorials are not 


\section{CON'TEMPORARY FRENCH POLITICS}

signed, as they usually are, every one knows who writes them, and the editor's name must always appear on the top of the sheet. The editorial is very personal; it accepts full responsibility for everything it says; but this is no deterring factor, for it pounds everything and everybody. It has life, it is important, and eonsequently it is read.

The small dimensions of the French paper have several advantages. First, it allows men and movements of limited means to start a journal and give public expression to their ideas. Liberty of opinion in America, so far as its printed expression is eoncerned, is largely a constitutional fietion, because of the tremendous cost of a newspaper establishment. In France, however, any one ean go to Paris and put a paper into every kiosque, eompeting with the wealthiest sheets in town. News does not matter so much, so long as the editor is able to write. As for printing, there are any number of plants ready to run his stuff off. The more startling and the more original his paper is, the more it will sell. From among the present diversity of French opinion, he is practieally eertain of finding enough readers at least to pay expenses.

At the same time, the small size of the French newspaper makes it liable to ready purchase. On all sides one hears of this and that edition being bonght over,either to stop attacks or to eommence them. The secret funds of the Ministry of the Interior are liberally spent in subsidizing pro-Government newspapers. ${ }^{1}$ In fact, many Frenchmen accuse Le T'emps of recoiving such suppont. Gustave Hervé and La Victoire arouses much more suspicion. Itis transformation has been remark-

${ }^{1}$ In peace times they amount to $1,000,000$ franes a year; during the war this smm was increased to an anmual figure of $25,000,000$. 


\section{TIE PRESS AND TIIE CENSORSIII'}

able. Originally one who urged the peasantry to plant their "country's flag in the dumg-heaps" (which won for him the appellation of "Sans-Patrie" IIerve), he became so thoroughly nationalistic shortly after the war that he was expelled from the Soeialist party. IIe has even appeared to desert liberal principles, for in the Fiume tronble, La Victoire urged the settlement of the question, not upon principle, but with the sole view of maintaining Italian friendship, whatever the eost. The friends of $M$. Hervé say he has undergone a real ehange of heart. IIis enemies, with a sly wink, say it is money that has done it. Althougl Americans are rather ineredulous at believing such accusations, to Frenchmen they offer a very logical explanation for an otherwise inexplieable somersault.

The ease of Le Journal, which Senator IIumbert, MM. Lenoir, Desouches, and Ladoux were accused of trying to purchase with German funds for defeatist purposes, was a better founded example of eorruption. The case came to trial in the early spring of 1919. Although the Senator was arcpuitted, the other gentlemen were eonvicted of daaling with the enemy. As the Senator now owns Le Journal, and as it is one of the most widely read papers in France, its reputation does not seem to have been harmed by the accusations made against it.

Le Bonnet Rouge case was a still more notorious example. Although its editor, M. Almereyda, was mysteriously killed in prison, another gentleman comnected with it, M. Dural, was convicted of receiving several hundred thousand franes in May, 1917, from Germany, as a reward for defeatist propaginda. After a long trial before the Council of War, he was sentenced to 


\section{CONTEMPORART FRENCII POLITICS}

death and shot at Vincennes; seven of his accomplices were likewise convicted.

The case of Le Populaire, Jean Longuet's minoritaire Socialist paper, is perhaps the most scandalous of all. It has been repeatedly aceused of being financed by German funds, an accusation made plausible by Longuet's German comnections, he being a grandson of Karl Marx. Throughout the war it led an insistent campaign against the war and against the Government in power. Some Frenchmen explain why Le Populaire was never suspended from publication by a very ehoice piece of scandal: That Clemenceau is Longuet's godfather! an explanation made the more interesting because both gentlemen are now professed atheists. Whether such an accusation is true or not, it is an interesting side light upon the workings of French politics. At any rate, during the Socialist Congress at Easter, Socialist opponents were delighted at the insinuation which Pierre Renaudel, the former editor of L'Inmanite, the official paper of the party, made upon April 21 when Longuet was taunting Renaudel as to the decline of its eirculation under his management. At this, in the midst of a tremendous uproar, Renaudel angrily replied: "Where does Le Populaire get its money from?" M. Longuet denounced the implication as villainous; the Congress appointed a committee of inquiry; while L'Action Frangaise, which at one time or another during the war had accused most of its eontemporaries of treason, gloated over the acknowledgment of another of its accusations.

These examples will slow how surcharged the atmosphere of Paris journalism is with recrimination and areusation. The elarges are seldom established and less frefuently repudiated. A paper's reputation, instead 


\section{TIIE PRLAS ANO 'TIE CLNSORSIIP}

of being injured by them, secms to be improved. At any rate, it appeass that they flourish under it.

The suall size of the French press contributes to multiplicity in number. New York City may have a dozen morning papers; Paris, on the other hand, has at least fifty. Not only in newspapers, but in every class of periodical, there is the greatest fecmolity.

Although the predominance given to editorials may be the greatest strength of the French paper, it is also in many instanees the ehief source of its weakness. In fact, the papers which are the most partisan in editorial policies are least informed as to news. They prefer to oceupy space with editorials; news which they do print is colored to suit their partisanship. The Socialist press is perhaps the most at fault in this respect. Although a large part of the laboring elass loyally support L'II munite, they are foreed to buy another paper if they want to know what is going on. At the Soeialist Congress in April, Jean Longuet, editor of Le Populaire, said he wonld never print any news against the Bolsheviki because that task is being ably performed by the bourgeois press. Other papers, such as LAction Française, for the Royalists, and La Dímocratie Nouvelle, for the new party of that name, have the same fault to a less extent.

$A$ different angle of the French conception of news is illustrated by the coldorated Landru case. Landru was a modern liluebeard, aecused of seducing and mudering a large number of beantiful women in a commtry villa. Investigations were excitedly carried on for months, resulting prineipally in the exhmming of eats and other pets of the departed women. The case filled cnomous amomits of space in all the Paris papers, and it became a prominent subject of conversation. But 275 


\section{CONTEMPORARY FRENCH POLITICS}

according to some French newspapermen, the case was a newspaper fiction, solely created to kcep the public interest from moping upon the stupidity of the Peace Conference! $!^{2}$ Although this story was somewhat belied by the fact that accusations were being made after the Peace Conference had closed, they may prove to be a consummating touch to a masterful work in human psychology.

The inadequacy of the news service of the purely political press is overcome by a number of very reliable papers in Paris which simply denominate themselves as Republican. ${ }^{3}$ Nominally, they are non-partisan and independent; and they follow no fixed editorial policy. Le Matin, Le Journal, Le Petit Journal, and Le Petit Parisien are journals of this type. Their news service is usually accurate and complete; and although some Frenchmen scoff at them as "shopkeepers' papers," it is surprising to note that they have a larger circulation than the purely political papers. Their popularity justifies their existence. Frenchmen erave news as a necessity; the expression of political opinion is more of a délicatesse.

\section{II}

The chief representative of the Monarchist and Catholie press is L'Action Francaise, one of the unique papers in France despite the fact that it possesses but little influence. This paper was originally founded by

"The Landru case reminds one of Anatole France's story, T'utsis.

'These papers are of ten known as La Grande Prosse, for they maintain large newspaper establishments. The moro political papers aro known as La Irrese d'Opinion. 


\section{TIIE PRESS AND 'TIE CENSORSIII'}

IIenri Vangeois, and its politial diucotion is now in the militant hands of Charles Manrras and féon Dandet. The latter is the som of Alphonse Dandet, the well-known author of the Lrttres de Mon Moulin, Tartarin de Tarascon, and other widely read productions. Dandet, the younger, daily oecupies the two left-hand columns of the L'Action with an article usually full of seathing invective. Intensely personal in his accusations, he heaps scalding abuse upon every public man from Clemenceau down to Briand. He brings the most inclusive charges and makes the most sweeping statements; the only wonder is that he has not been subject to an endless stream of libel suits. These he has probably escaped because of his skill in indefiniteness and because there is practically no libel law in France. Ile defied "Viviani to remain in power forty-eight hours without the protection of the censor"'; last Aprit he aceused Briand of intriguing to overthrow the Clemenceau Ministry; he even went so far as to name the cabinet Briand had selected. In his treason accusations, - and he takes the credit for the conviction of Malvy and Le Bonnet Rouge, he has used his powers to the greatest advantage. "Squint-eyed erooks, traitors, liars, and bandit-fiends," quail under his mighty assaults.

Charles Maurras is the exact opposite in style and in temperament. $\Lambda$ very learned man, he exhibits little bitterness in his editorials, although he expounds monarehist doctrines with the greatest firmmess. Under the title of La Politique, he daily oecupies two eolumns with a discussion of everything from the eanonization of Joan of Are at Rome to the defects of the League of Nations. A keen and elever writer, he is widely read by his political opponents. 


\section{CONTEMPORARY FRENCH POLITICS}

Jacques Bainville, an aceomplished diplomatic writer, Maurice I'ujo, who is msually attacking the Socialists, and Louis Dimier, are other members of this remarkable editorial staff. Between the five of them, mere news is completely submerged.

An interesting story is told of L'Action Française activities during the war. A French priest, acting as censor for a certain military unit (and in that capacity), obtained some very damaging information against the Government which he illegally transmitted to the royalist paper. The information coneerned a German, living in France, who fraudulently obtained American naturalization papers. He then bribed Government officials so that several of his relatives were taken out of the trenches and sent to the rear. Naturally the publication of this seandal would be a great triumph for Léon Daudet, and undoubtedly result in the fall of the Ministry. But the Govermment, in turn, held. two pieces of evidence incriminating L'Action Française. The first was that the priest in question had, while a censor, revealed confidential information from which the Government conld stir up another anticlerical struggle; the second was that the Govermment had obtained a list which Lidction Françaisc had compiled of army officers who at the time of a revolution had promised to bring their troops under the banner of Philippe VIII. By a mutual agreement, both parties kept quiet.

La Vicille-France is not a newspaper and it can searecly be ealled a magazine. Jint withal, it is one of the most interesting and most moreasonable publications in France. It appeals one a week, and the reader is always assured of enotting his eight cents' worth. Its editorial policy is fixed only upon two points-it is uproarionsly anti-Semitie, and as far as 


\section{TIIE PRESS AND TIIE CENSORSIIIP}

the censor permitted it, it is insistently anti-Ameriean. It contains absolutely no advertising, yet it consists of thirty pages an issue. Ilow it is financed is a popular mystery. It is generally supposed that Urbain Gohier, its irrepressible editor, gladly foots the bills in order to appear so prominently in the public light. M. Gohier is a very eceentric gentleman, and if hearsay is reliable, he also exhibits the common journalistic propensity to change politieal faiths as frequently, almost, as a suit of clothes. Ten or fifteen years ago he edited a Socialist paper in Grenoble. Now, however, the Socialists and the Bolsheviki are his principal objects of attack.

His unholy hatred of the Jews is illustrated by the following gleanings:

The Freneh will not enter Frankfort. But the people of Frankfort have never left Paris.

Reinach at the Figaro,

Gruenbalum at the Government,

Stem at the chamber,

Cahen, Kahn, Weill, Iasch, Bermstein, Rappoport, Passim. Rothschild everywhere.

Paris is a suburb of Frankfort.

In its advocacy of the ammexation of the left bank of the Rhine, La Vieille-France said:

The Jews will not allow the left bank of the Rhine to be returned to Gaul because the pupulations of these provinees are followers of the Catholic religion and their incorporation with Franee would pertraps bring about an awakening of our enervated Catholies against Semitism. It is eonsequently necessary to choose again between the vital interests of France and the will of Jewry. . . . .

There is an abyss between the French and the German. But there are twenty abysses between the Jew and the Frenchman. 


\section{CONTEMPORARY FRENCH POLITICS}

IIc proclaims his weekly as "the rallying point for honest and courageous men," and he is so convinced that his strength is the only protection of France that he announced that La Vieille-France is the last obstacle which hinders the complete conquest of France by the Hebrews." 4

II. Klotz, Minister of Finance; M. Rothschild, the great financier; Joseph Reinach, the prominent writer; MI. Mandel, Clemenceau's secretary, are all mercilessly berated merely on account of their origin. This extreme position would be humorous unless it were for the fact that it represents a serious anti-Semitic feeling in Franee. ${ }^{5}$

The most conservative paper in Paris next to $L$ 'Action Française, if judged from its Peace Conference editorials, is L'Echo de Paris. At present directed by IIenry and Paul Simond, it is the official mouthpiece of the Action Liberale Populaire party. It is strougly nationalistic in opinion, as shown by the frequent editorials by Maurice Barrès. The pseudonyns of L'Echo de Paris are its distinction; Custos is a regular contributor upon domestic policies; and Pertinax, a writer on foreign affairs, has perhaps attraeted wider attention in Paris and abroad than any other commentator on the Peace negotiations. Tis name and French chauvinism are synonymous. As a sturdy reënforcement of his conservative philosophy, he possesses an accurate knowledge of foreign history and polities.

Le Trmps, founderl in 1860 and which L'Action Française calls the "greatest paper in the Republic," is

- For Cohier's anti-Americanism see Chapter XV; various news. faper opinions on foreign affairs are given there also.

It is a remarkable paralox that one of the most bitter antisomitir as woll as pro-elerioal papers in Paris, Le Gaulois, is edited by a German Jew, Arthur Meyer! 


\section{'THE PRESS ANI) 'THL ('HNSORSHIP'}

without question the leading journal in France; strangely, it is also the least influential. Larere in size than its eompetitors, using a better grade of paper, very subdued in make-up, it presents a real literary appearance. Its Bulctins du Jour, which oceupy its lefthand colnmn, are known the world over for their seholarly treatment of diplomatic affairs. They are also regarded as being the monthpiece of the Freneh Foreign Affairs office. It was by his writing of this column that André Tardien first won his recognition as a diplomatic authority. M. Jean Herbette is said to write them now. Le Temps is the organ of the great bourgeoisie. Cousequently it is quite conservative in policy; but it has always stood for eertain reforms. Though it is supposed to be partly subsidized by the Govermment, it does not hesitate to criticize it caustically. It was an ardent eritic of the Govermment's State Socialist polieies, it was particularly urgent for electoral reform, and the chice feature of its foreign policy was the destruetion of German unity. Its foreign correspondence is excellent and anthentic. Its editorial policy is vigorous. It is indeed strange tlat it is not more widely read for it is a redit to France and to French journalism. Can it be that the chief reason for its neglect is that it is a two-penny paper while the more popular journals sell at one ${ }^{6}$

- Among other members of the conservative press may be mentioned Le Gaulois, an organ of the old nobility; La Croix, a elerieal paper with 104 provincial editions, which carriel on a virorous campaign against the Republie at the time of the Dreyfus atlair; L'Intransigeant, La Libcrté, Le Figaro, edited formerly by the ill-fated Gaston Calmette; L.Ordre Public, just started in 1919: and Lé Journal des llébats edited hy Auguste Gauvain, a distinguisher diplomatic authority. All of these papers aro of somo influence; but they aro more moderate than their contemporaries discussed above. 
A paper of the "milieu"-eonservative, as shown by its anti-Wilson attitude and its attacks on the Socialists, radical, in its demands for internal reform, La Démocratie Nouvclle is rapidly attracting a wide reading. This paper is a mere child in the eurious family of Parisian papers, but its husky eries for domestic reform assure it a vigorous growtl. It was founded in $1917 \mathrm{by}$ M. Letailleur, who writes under the psendonym of Lysis, whose books upon the reorganization of France are widely eirenlated. As a leader of, the party of the "New Demoeracy," this paper attacks the anti-Semitie movement as a reopening of religions struggles; it insists upon the union of elasses and consequently it berates the Socialists; and it is eontinually offering suggestions for the improvement of French commeree and government. André Chéradame, whose books on PanGermanism are well known, eontributed frequent articles commenting upon the diplomatic situation during the Peace Conference. As will be noted in another chapter, MI. Chéradame has a good grasp of diplomatie problems, but like many authorities upon military strategy, lie shows a eomplete lack of sympathy with any other than strictly military prineiples.

The Radieal Press is not very strong. In the supplement of the brochure giving the accomt of the Thirteenth Congress of the Radical and Radical Socialist party at Pau, 1913, a list of abont thirty-five journals is found of "adherents of the party." Of these but ahout half a dozen are Parisian papers, of which only two or three in 1919 were to be found in the news stands. La Lanterne, bitterly anticlerical, was founded forty282 


\section{TIIE PRESS AND TIE CHNSORSIIIP}

three years ago; Le Rappol is another Radical paper of limited cirenlation. Le Pays, searecly three years old, and edited by Gaston Vidal, is a paper of the Ratieal Soeialists. L'IIomme Libre, formerly L'Ifomme Enchainé, until it had to change its name to continue publication, is a Radical paper only in so far as it supports Clemencean, its former editor. Doubtless because of its enforeed neutrality, it does not appear to be as widely read as in the early days of its belligerency. L'CEuve has radical tendencies, but is a completely independent paper. It is also a cliild of the war; Gustave Tery is its editor; his particular hoblies are regionalism and the defects in the French bureancracy. An insistent opponent of seereey at the Peace Table, it declared as early as November 15, 1918, "Le grand jour et le frane jeu, voilà désommais les deux premières conditions d'un gouvernement do lis République française." Tery later wrote, "The peace of the world cannot be assured by a few men whispering in a salon at the Palais d'Orsay, outside of which neither the peoples nor their representatives know anything exeept from distorted information which filters throngl the cracks in the doors or through half-split walls."

The chicf weakness of Paris journalism is that there is no great Radieal paper, standing for the liberal, democratic principles in which the greater part of the French people believe. The strong papers are extremist; that is, they are either too conservative or too radical. Although in the past a policy of democratic moderateness has been pursued by provincial papers, no ontstanding journal in Paris now has such a program, and the creation of such a journal is a great need.

The ease of Gustaye Ifervé and $L_{a b}$ Vrictoire has already been mentioned. In polities, La Victoire is now 283 


\section{CONTEMPORARY FRENCII POLITICS}

supposed to support national soeialism, but no difference between it and the Radical press ean be seen. In addition to Ifervé, André Jichtenberger is a regular eontributor to this widely read sheet. II is characteristic style may be judged from the following squib comparing Germany to a restive eow:

What shall we do with her? Deprive her of food . . . and let her perish of want for our revenge? What! Take revenge on a brute? No, this is what we shall do. After liaving passed a strong iron ring through her nose to insure against surprise, we shall feed and take care of lier just so far as it is necessary to keep her in a fit state to work for us and to supply us with milk. . . Her horrid ealf-the German people-will be permitted, at stated times, to approach lis mother. For it won't do for him to perish, either. But it goes without saying that we shall not let him enjoy limself. He will be endowed with a good muzzle omamented with nails. It will be removed long enough for him to suck just as much as is necessary. It will then be replaced in order that all the milk which is not indispensable to him will go to feed our own children. . . . It will be seen that my reasons for treating Germany with care do not arise from an excess of lumanitarianism, but rather, I think, from a most conerete and prosaic regard for our own interests. . . In other words, let us not kill the goose which lays the golden egg.

\section{IV}

$A$ produet of a very effective organization, the Soeialist newsplapers are the most numerous and the strongest in Paris. It is remarkable how so large and varied number of sheets, representing not only the party, but different seetions of it, ean be financed. The Nationalists aceuse them all of having Jewish or German support; but perhaps the real souree of their suceess is in party organization and in the contributions, low- 


\section{TIIE PRESS $\Lambda$ ND TIIA CENSORSIIP}

ever small, from a large class which feels that its interests are vitally aided by sympathetic newspapers.

L'ITumanité is the most unique and the most snecessful attempt at a newspaper solely and officially devoted to and supported by a political party. This paper was founded by Jean Janrès sixteen years ago. Under his direction, until his death at the eve of the war, it experienced few difficulties and little criticism. The outbreak of the war and its progress, as we have seen, brought about serious divisions in the party which plaeed L'ITumanité in a diffienlt position. Pierre Renaudel had suceeeded Jaurès as the political direetor of the paper. Although he was a supporter of the Govermment and in sympathy with the old majoritaire element, he did not openly ally himself with any division because of his responsibility to the paper which should at least attempt neutrality. In L'IIumanité, however, he loyally supported the prosecution of the war. As long as the majoritaires kept their majority, Renandel's position was maintained. But he was subject to repeated attacks from the minoritaires; and beeause of the eautious poliey the paper was eompelled to adopt, and because of the rise of journals supporting the different sections of the party, the cireulation of L'IIumanité dropped from about 150,000 in July, 1914, to 39,163 in August, 1918. The blame for this decrease was fastened upon Renaudel by the minoritaires who, after the meeting of the National Council in the summer of 1918 , were strong enough to eanse him to resign. A special eommittee of fifteen was then appointed to supervise the paper, and its immediate direction was eonfided to Mareel Cachin. Culminating events sueh as the Villain trial, the Easter Congress, and the demobilization of many Socialists, made Cachlin's direction a sueeess. Its 285 


\section{CONTEMPORARY FRENCII POLITICS}

daily sales in October, 1918, amounted to 56,700 ; but this number on April 17, 1919, inereased to 140,800 , or nearly the average maintained under Jaurès' editorship.

La France Libre was born with the division of the Socialist party, it being only two years of age in 1919. It represents the elements who were onee the majoritaires, the moderate Socialists who gave the war their support. It opposes the extreme soeialism of Loriot; and when 'the other members of the Soeialist family were cheering the Bolsheviki, La France Libre was vigorously criticizing them. Like L'IIumanité, its editorials are usually written by sympathetie deputies. It is edited by Compère-Morel, Arthur Rozier, and Adrien Veber.

Le Populaire, edited by Jean Longuet, is the organ of the new majority of the Socialist party. Although it is only four years old, this journal presents some remarkable features. Its reports of labor and Soeialist movements throughout the world are very instructive. Openly sympathetie with the Bolsheviki, it was through the columns of Le Populaire that their response to the Prinkipo proposal was given to the Peace Conference. MI. Chicherin, the Foreign Minister of the Bolsheviki Government, on Jamuary 24, 1919, sent a telegraphic response to Le Populaire while the official reply was being transmitted to their representative in Sweden. This was a novel way of earrying on diplomatie correspondence and it raised a storm of eriticism against Le P'opulaire. The editorial staff of this paper is notable. $\mathrm{Al}$ though the editor-in-chief is Panl Faure, Longuet eompletely dominates it. Phedon, another psendonym, is the direct opposite of Pertinax, but he equals him in eondemning the Peace Conference. Possessing a remark- 


\section{THE PRESS AND TIE CENSORSIIP}

able knowledge of international affairs, his logic freruently nettled the more conscientious supporters of the Conferenee; but his destructive and propagandist purposes weighed heavily against the influenee of his artieles. Finally, IIenri Barbusse, one of the best known literary writers in France, is the literary editor of $L e$ Populaire. Usually his novels are printed in daily installments before their publication in book form.

Still further "advanced," as the revolutionary Soeialists prefer to eall themselves, is Le Journal du Peuple, ${ }^{7}$ edited by IIenri Fabre. It now for four years has brought sympathy to the revolutionists, terror to the worshipers of order, and hatred to Léon Daudet. $L e$ Journal du Peuple does not trouble itself a great deal about news or even diplomatie discussions. It direets its tirades against the rieh, American jazz bands, and other matters of grave polities. Its text is the Revolution. "We are not responsible for it-it is you, the culpalyles, who are forcing us into another revolt whieh will win what 1789 left undone." With what sareasm, it writes en manchette, "Once more Clemeneeau has been assassinated-but it is the worker Lorne who is dead!",

The most violent of the Socialist papers is La Tague, a little four-page weekly. It is edited by M. Brizon, one of the delegates to the Kienthal conferenee, and a compatriot of Loriot. It is now in the seeond year of its existence. La Tague ammonnes itself as "Pacifistie, Feministic, Socialistie," while above all of these eharacteristies, it very contradictorily declares itself as a

${ }^{7} \mathrm{~A}$ Journal du Pcuple existed as early as 1s41; in 1843, however, it changed its name to La liéforme', forsaking its socialistic sympathies for the democraey of the Idedru-Rollin type. Cambridge Modern II istory, xi, 24. 


\section{CONTEMTORARY FRENCH POLITICS}

"Journal du Combat." Its editorials are the most violent. They range from the "Fourth Republie," "The Sabotage of Liberty," and "The Bcast," to the "Old World Condemmed." After this, the "Greatest of all Wars will eome," the war of the proletariat, and "the greatest of all Revolutions." "The Worker's Springtime is here, the springtime of new Republies.... It is the springtime of the new rorld. Down with the wicked beasts who rove" and who devour the fruits which Labor should itsclf proeure.

Notre Toix is a new representative of the Socialist press. $^{8}$ As a typically "intellectual" journal it devotes itself chiefly to literary subjects. The series of eartoons, ruming as cover pages, and strongly reflecting upon the so-called justice of the last war, is remarkable. Some of them have been so severe that they have been suppressed by the censor. The following poem illustrates the spirit of Notre Voix:

\section{L'APPEL,}

Nous sommes les cerveanx, les âmes et les torses, Manquerions-nous de volonté,

Pourquoi n'osons-nous pas le bean geste de force De libérer la Liberté?

Nous vivons aujourd'hui comme vivent entr'eux Les cloîtrés dans les monastères,

Nons semblons acecpter, avee mu coenr heureux, La loi qui dit: "Il fant se taire."

Le penple n'est-il done qu'm Oéan qui porte Les orrneilleux steamers riches de eargaisons? Ponrquoi ses flots dressés en des tempôtes fortes Ne menacent-ils pas les ports ì l'horizon?

"La Politique, L'Jeure, and La l'erité are threo other Socialist piapers. 


\section{TIIE PRESS AND THE CENSORSIIIP}

Etre le nombre et n'être rien. Mais les blés lèvent Car e'est la loi du 'Temps et le droit de la Sève,

Qu'importe les vieillards qui serrent le Ponvoir, Fébrilement ainsi qu'un avare un sae d'or.

Qu'importe les peureux dont le eoeur bat moins fort Que le tris lent tic tae d'mne horloge.-L'Espoir $\Lambda$ vee ses poings tendus ou ses mains qui travaillent Est le bon général qui gagne la Bataille

Sans enrégimenter les houmes en troupean, Nons voulons un pays plus lange qu'un drapeau, Et s'il faut pour bâtir des lendemains de joie Abattre les Prisons, les Banques, les Palais Ou l'ileensé, eoupable on non, est une proie Si l'avenir le veut, eh bien abattons-les.

Mais si vons n'osez pas ce greste nécessaire, Peuples, résignez-rous,

Portez le lourd fardeau des impôts et des suerres, Aimez le bâton et les eoups,

Et taisez-vous!...

Sueh is the French press. It now may be seen why the newspapers of Franee are not representative of opinion. Many of them are read for emriosity and amusement. The Monarehist will try to buy La Vague every Thursday just as the Socialist will do. Tle counts himself lucky to get one before the issue is sold out. Likewise people of all classes will read L'Action Francaise; and even though they may agree with Daudet's and Maurras' indietments, they may not aeeept their solutions. The remarkable thing about the French press is that the least representative paper is the best clited. This naturally attracts readers unsympathetie with the cause for which the paper stands. Consequently when the L'Action Française says it has more than doubled its cireulation within the last four years, it does not necessarily mean that the number of French 289 


\section{CONTEMIPORARY FRENCII POLITICS}

Royalists has increased to that extent. It means that the war has provided an extraordinarily interesting theme for the Orleanist journal to write upon. La Vague elaims to liave a hundred thonsand rearlers. Yet by no means are there a hundred thousand workers in France who desire an immediate revolution. Frenchmen, as much as, if not more than, Americans, read for pleasure. Nevertheless they do not take their newspapers seriously. The extremeness of the press reacts upon its influence. It contributes to its saleability, which, from the standpoint of the newspaper, perhaps is of the chief importance.

\section{$\mathrm{V}$}

In normal times the legal restrietions upon the French press are very limited. Any newspaper may be published without authorization or without the deposit of security. It is only necessary to place a declaration with the proper authority before publication, giving the title of the publication, the name and the residence of the editor, and the nane of the establishment printing it. Every journal must have a director who is a French citizen in full enjoyment of his civil rights. Every publication must bear the name and the address of the printer. It is not necessary that artieles be signed, as they usually are; but at the time of publieation of cach issue, two copies signed by the director must be delivered to a court of first instance. Another deposit must be made for Paris with the Ministry of the Interior. As to individual responsibility the director of a paper is obliged to print a reply of any person whom he has named or designated in his paper. Furthermore, if a libclous statement is printed, both the director and 290 


\section{THE PRESS AND TIIE CENSORSIIP}

the author of the article can be brought before a correctional court. Journals published in foreign countries and those printed in France in a foreign language are subject to police control. ${ }^{9}$

The outhreak of the war naturally placed restrictions upon the freedom of the press. On August 5, 1914, a law was passed "suppressing the indiscretions of the press in time of war,"' which prohibited under the severest penalties, the publication of information and of intelligence upon everything directly relating to the national defense, except what the Government or the military authorities should communicate to it. The law speeified particularly mobilization operations, the transportation of troops and of material, the strength of the army, nomination and changes in the high command, the disposition, location and movement of armies and of the fleet. The law finally broadened the scope of the censorship by inchuding "any information or article concerning military or diplomatic operations of such a nature as to favor the enemy and to exercise a vexa. tious influenee on the spirit of the army and of the population." The law was to become invalid after the eessation of hostilities at a date to be fixed by a Governmental decree.

Although this law was very broad, giving the Government considerable liberty of interpretation, it did not

- establish a preliminary censorship, but simply provided a penalty for the violation of the law. This penalty was from one to five years' imprisomment and from two hundred to a thousand dollars' fine. Although the law did not determine the anthority to interpret

${ }^{0}$ For the press law of July 29, 1851, embolying these provisions see A. Cimpentior, Codes et Lois pour la France, l'. Hucrie ct les Colonies, ii, 851 . 


\section{CONTEMPORARY FRENCII POLITICS}

and enforee the eensorship, it was generally reeognized that sueh a task would fall on the judiciary. However, as those familiar with the Freneh censorship know, there existed a preliminary eensorship-and of matter not ineluded in the law of August 5, and it was the military, not the judicial authorities, which interpreted and enforeed it. Beeause of this, it was natural that many newspapers should attack the eensorship administration as illegal; but as a matter of fact, the eensorship did not lest upon the law of August 5, but upon the declaration of the State of Siege, made August 2, and later confirmed by a law of August 5. ${ }^{10}$ The effeets of the State of Siege are laid down by a law passed on August 9, 1849, the chief result of which is to substitute the military for the eivil authority. ${ }^{11}$ Normal guarantees of individuals are suppressed by it; military tribunals are given eognizance of erimes against the safety of the Republie, against the Constitution, against order and the publie peace. The military is also given the right of perquisition and the right to prohibit pub. lieations and meetings which it judges of a nature to excite disorder. By this latter authority the French Govermment maintained, from the declaration of the State of Siege to Oetober 13, 1919, a eensorship limited in power solely to its own judgment.

The establishment of the censorship was announeed to the newspaper's in a note, Angust 4, which said: "The Govermment counts on the good and patriotie will of the

${ }^{10}$ In ease of the aljournment of the Chambers, the President of the Republic may leclare the state of Siege with the consent of the Couneil of Ministers, but the Chambers must be assembled two lays afterward and either confirm or reject the P'resilent's action.

"The law of the State of Siege, of August 9, 1819, may be foumd in Codes et Lois pour la France, l'Algéric ct les Colonies, compiled by $\Lambda$. Carpentier, ii, 431. 


\section{TIE PRESS AND 'TIE CHNSORSIII'}

press of all parties, at Paris and in the provinces, not to publish any information concerning the war, whatever may be its sonree, its origin or nature, without having it visécel by the press burean established at the Ministry of War.'

The eomposition of this bureau varied, but it was always of an exclusively military character in membership and in policy. In the provinees, it was usually directed by commissions created by the Prefects, subject to eontrol by the press burean of the War Ministry at Paris. As penalties, the Govermment deereed that if a paper published an article which the eensor refused to visé, it was warned for the first offense; for the seeond, it might be suspended for a period arbitrarily set. Suspension from publication, which was ordered by a decision of the "President of the Council of Ministers" was aceompanied by the seizure of all the eopies of the journal suspended.

In three respects, then, the French censorship exceeded that established by Parliament in 1914. It was administered by military anthorities, it was preventative (preliminary to the publication of an article) and universal, and it extended to matters not included in the law of August 5 .

The censorship, thus constituted, knew no bounds; it censored subject matter for which there appeared to be no justification, news which was given complete publicity in other countries. Furthermore, it repeatedly discriminated in its applications; news and opinions of an identical nature were denied to some papers, while their publication was allowed to others.

L'Europe Nouclle, an outspoken, liberal weekly, felt the censor's lash as frequently as any. Often whole columns of foreign news would appear blank except for 


\section{CONTEMPORARY FRENCII POLITICS}

a line explaining that "230 lines had been eensored." On November 9, the censor prevented it from saying that certain elauses in the Austrian armistice caused considerable emotion among the Croats and Slavs, when the entire English and Italian press was full of controversies over it. It was even prohibited from speaking of the movement in Spain for a revision of the Constitution. Likewise, it could not comment upon the November electoral campaign in the United States when L'Echo de Paris was allowed to publish unfair dispatehes from its New York eorrespondent about it. It was forbidden to eite eertain articles in the program of the Revolutionary Socialists in Switzerland, when that program had appeared in extenso in Le Temps, the day before. It was forbidden in its Polish dispatches of November 16 to show how the coup d'état of the nationalists in Poland harmed the demoeratic movement, when L'II umanité was authorized to publish violent attacks against its chief nationalist leader, Dmowsky. It could not print the irredentist demands of Greee, two days after they had appeared in full in the New Europe in London. Finally, it was not allowed to point out to its readers that the products of the Saar valley were of an inferior quality when inchustrial groups, such as the Committee of Forges, were publicly expressing such opinions.

French papers were not allowed to print dispatches containing news of the rice riots in oapan, or even of the United States Srmate Airraft Report when the entire Allied press was giving botll events the fullest publirity. The military authorities qave no reasons for the censorship of such articles or for allowing some papers to print reports denied to others. Charges were even insinuated that papers, which were refused the 


\section{TIIE PRESS AND 'TIIE CENSORSHIP}

right to publish an article, would turn around and sell it to another where the censorship had no objection to its publication: Whether it was graft or enstomary military stupidity that caused this situation, it justly aroused a tremendous opposition.

La Tieille-France was a frequent, though a deserved victim of the censor's knife. Consequently it was violent in the demunciation of the Govermment's repressive policy. President Wilson could say that European eabinets were without valor, prudenee or foresight, but Urbain Gohier could not say what he thought about the Ameriean President. Although the whole world accused France of imperialism and although everybody defended Germany, patriots like Gohier "eannot reply a word to them. We cammot risk ruffing a German (eensored)!"’

A newspaper was started recently in Paris, ealled $L a$ République Russe, whose purpose was to eombat Bolshevism and Czarism at the same time. The censor naturally allowed its articles against Bolshevism to pass, but it refused to allow the publication of an editorial which denonneed "the open or disguised attempts of monarchist restoration." The League of the Rights of Man vigorously denounced such an abuse of the censor in the service of any party, especially a party of reaction.

As has been seen, the censorship did not cease with hostilities. Some of its greatest flagrancies ocemred during the armistice. The case of L'Information, an independent paper, edited by Léon Chavenon, with the reputation of being one of the most sincere and liberal paper's in Paris, attracted a great deal of attention. On Mar'h 2, 1919, it pullished an article upon the "Essential Clauses of the Peare Preliminaries." 'The article 295 


\section{CONTEMPORARY FRENCII POLITICS}

apparently was not viséed by the eensor for upon its publieation the editor and the writer of the article, Charles Omessa, were charged with violation of the law of August 5, 1914, and Linformation was suspended for eight days. M. Chavenon asserted that the eensor had only informed him of its decision at a very late hour on Saturday, at a time when the printing had already commenced. When the eensor finally did send his disapproval the article was immediately removed. The few eopies already distributed it was impossible to reeall. Furthermore, the very same information had appeared in another paper the day before.

Other similar instances were frequent. On the 8th of May, Le Temps published, apparently with the permission of the censor, a long and detailed summary of the restitutions, reparations and guarantees eontained in the Treaty of Versailles. It published this information in the face of a statement that no evening paper would receive this news upon that day. But Le Bonsoir, the evening edition of the L'Wuvre, edited by Gustave Tery, had also arranged for the publication of an identical artiele; but the censor formally forbade its printing, threatening seizure in ease of disobedience. Aroused by this diserimination, MI. Tery took the matter to the eourts, and entered a "double complaint in forfeiture," one of the most serious eharges in French law, with the Military Governor of Paris against the chief censor, Najor Nusillard, and against M. Mandel, II. Clemenceau's Chef de Cabinet. Mandel has often been referred to in the Chamber of Deputies as Clemencean's "Grey Eminenee," many claiming that while M. Clemencean was busy with the Peace Conference, Mandel was the real Prime Mlinister. After the filing of 296 


\section{TIIE PRESS AND TIE CHNORSIII'}

this complaint Major Nusillard was reported to have resigned, but to have subsergently withdrawn his resignation. Tery made it clear that he thought Mandel was the real offender. Regardless of the outcome of the ease, it increased the demand for the censorship's removal.

During the last week of April, 1919, the censor was especially stern. Marshal Foch had given out another of his interviews to the London papers urging the annexation of the left bank of the Rhine. As a result of trying to reproduce the article from the British papers, Le Bonsoir, La Patrie and La Démocratie Nouvelle all went down under the censor's swoop. To obtain this interesting news, Parisian readers had to wait for the London mail! In fact, Le Bonsoir was seized three times during this week.

On May 15, the Paris edition of the New York IIerald attempted to print the measures which the Allies were going to take in the event that the Treaty was not signed by Germany. The information merely told of Foch being ordered to the Rhine to make all preparations for immediate military operations. In the very same number of the Chicago Tribune, exactly the same information was given in a little different phraseology. The eensor had either forgotten his deeision in the one case when he eame to the other; or he had decided to change his mind, the possession of which many papers were begiming to donbt. For the IIerald artiele was suppressed and the Tribune's was passed.

The fact that the censorship exceeded considerably the provisions of the law which the Parliament passed on August 5, 1914, joined with its onerous policy, led to early attempts to put it upon a legislative basis. In 
March, 1915, M. Paul Meunier ${ }^{12}$ introdueed a bill into the Cliamber declaring the State of Siege lifted in Paris and in all the non-invaded departments. As it finally failed of passage, M. Meunier in October, 1915, introduced a bill whieh the Commission on Civil Legislation adopted whose object was to provide for a legal, preliminary censorship in time of war, placing it under the control of the civil authority-the prefect of police in Paris, and the prefects in the departments, and to limit strietly its application to articles of a military and diplomatic eharacter which would be of a nature to injure the national defense. Articles upon interior politics would be excluded from the censorial seissors. The bill did not come up for diseussion until January, 1916. The debate upon it occupied all the sessions from the 21st to the 25th. Finally, M. Briand, the Premier, admitted that some errors had been made by the censor, but he insisted that the national defense exacted its maintenance; consequently the proposition was returned to the Commission.

After the armistice, the Socialist and Radieal parties, the C. G. T., and many newspaper organizations demanded that the State of Siege be raised and that the censorship be removed. Because of the peace negotiations, the Govermment did not believe it wise to allow freedom of diseussion. But after the German signature of the Treaty, the editor of Le Matin (Jime 25, 1919) wrote to the l'resident of the Press Syndieate, asking it to demand the raising of the censorship, now that the conference was virtually closed, in order that the French publie be informed as equally as the public of other nations. Inspired by this letter, M. Jean Dupuy, Presi-

\footnotetext{
${ }^{2}$ It is an interesting coincilence that Meunier was arrested in the fall of 1919 for having had communications with the enemy.
} 


\section{TIUE PRESS AND TIIE CENSORSHIP}

dent of the Syndicate, addressed a letter to MI. Clemencean, upon July 2, asking that the consorship be removed. On July 8, another bill sponsored by Mr. Paul Meunier, demanding the abolition of the State of siege and the eensorship, eame up in the Chamber for diseussion. MI. Stephen Pichon, Minister of Foreign $\Lambda \mathrm{f}$ faires, declared that the same reasons demanded the continnanee of the State of Siege and the censorship until the French ratification of the Treaty as existed during the peace negotiations. As a result of his speech and his assurance that the censorship would be repealed immediately upon ratification and before the time of the elections, the IIcunicr proposition was defeated by a vote of 256 to 202 . It was only upon the 12th of Octoiver, 1919, a few days after the Chamber ratified the Treaty, that presidential deerees were issued raising the State of Siege and abolishing the censorship.

Thus it appears that the French censorship was of longer duration and of much greater unreasoned severity than that of the other Allied eountries. Yet it should not be judged too harshly. During the war, France, unlike most of her Allies, was the field of operations, where the greatest precautions had to be taken. During the Peace Conference, she was the host of the world; the bitterness apparent everywhere at times, it was a considerable task to suppress. The discriminations, of course, eamnot be justified. They appear to be faults inlerent in the French bureancraey and magnified by the military part of it. In comparison with the American eensorship, the French censorship may seem unduly severe and dietatorial. But as a matter of fact the expression of opinion is much more free in France than it is in America to-day. No efforts were made to suppress the mutterings of the minoritaire Socialists dur299 
ing the war. In America every one of them would have been jailed for violating the sedition acts.

Has the French Chamber ever expelled its Socialist members as the New York Assembly has just done? Jamais. Raffin-Dugens and Brizon almost daily breathed out "seditious" utterances, to which the Chamber replied with laughter,-after all, the most effective answer. Frenehmen realized what Ameriean legislators apparently cannot realize, that to make martyrs of men is merely to increase their following. Consequently, the Freneh policy was to await the commission of overt acts before taking measures to deny Socialist elements a right to be heard. In so doing, France has probably avoided the very end which New York legislators and Ameriean Congressmen, if they persist in their suppressive actions-will invite,-namely, a revolution by force. If the Freneh Chamber had expelled its hundred Socialist members during the war, it would have had a revolution on its hands in ten minutes. Why? Because so long as these gentlemen were openlungedly venting their opinions at the tribume of the Chamber, there was nothing to revolt about. They were not being suppressed; they could work in the open and they could be repelled in the open. The Government believed that the people of France had suffieient good sense not to suceumb to the "terrifying", doetrines of 'Socialism, without the self-asserted guardianship of legislatures and Govermment officials who, by foree, might attempt to coneeal from them doctrines which, on account of their very nature, eamnot be concealed. It was far better to have the arguments for proletariat dictatorship debated in the forums of public assemblies, where they could be analyzed and where their errors eould be readily pointed out, than to have 300 


\section{TIIE PRESS $\Lambda$ ND TIIE CENSORSIIP}

those arguments bottled up in a ealdron of discontent, whose seething waters were sooner or later bound to seald those who fed the fires which kept them hot.

The toleranee of the "seditious" elements in Franee during the war-repulsive as the tacties of those elements were-was essential to the winning of the war. If they had been "stamped out" by the "iron force of the law," France would have been so weakened internally that she would have had to sue for a humiliating peace.

It may be an irritation to the amour propre of Ameriea to say it, but it nevertheless remains true that republiean Franee, whose attempts at self-govermment we have too often ridiculed, can teach us some badly needed lessons in the basie principles of demoeraey. 


\section{CHAP'TER $\mathrm{X}$}

THE BUREAUCRICY AND STATE SOCLALISM

Si les Français mangeaient le papier, ils seraient le peuple le micux nourri de la terre.-EDOUARD HERRIO'T.

The French bureaueracy is noted for its magnitude, its centralization and as a Paris editor has said, "its honest sloth." Not only does it eompletely monopolize the management of many services left to private enterprise in other countries, but it exercises this management inefficiently from the standpoint of public aecommodation, and unprofitably from the budgetary point of view. Its eondition has led to the most insistent demand for administrative reform. This demand, which calls for both the decentralization of publie services and the surrender of present industrial prerogatives of the Government to individuals, is more urgently advanced than the demand for purely political regeneration.

Upon the general weaknesses of this administrative system Professor Villey has written:

The central authority, charged with deciding every affair of the comntry, is overwhelmed by an inextricable task. The heads of the ministerial departments themselves camot have a personal knowledge of even the most important affairs and they have to unload them upon an irresponsible burean- 


\section{BUREAICRACY AND STATE SOCIALISII}

eracy. The questions which arise in one district, in a determined eenter, often at the extreme ends of the country, are treated without competence, often oven settled without disenssion. More frequently it is the deputies of the place who decide, and usually they are men of parties. Polities is mixed II) with every question, and favoritism is given a free rourse.

'The multiple formalities which centralization brines with it, lead to interminable delays, very prejudicial to the publie interest. ${ }^{1}$

A complete deseription of the French bureaucracy camnot be given, but a few instances of its method of functioning may be cited.

The French railway system perhaps offers one of the best instances of the incfficiency of public inclustry. The State line, and the Western line, having a mileage of about 5,600 miles, are owned and operated by the French Government; while the greater lines in France, such as the Paris and Orleans, the Paris, Lyons and Mediterranean, the Northern, the Eastern, and the Midi roads are privately operated under Government leases. Aecording to the figures of the Ministry of Publie Works, the State line in 1913 was the least profitable of the roads in France, in spite of the fact that it runs through one of the most richly developed parts of the eountry. Its gross carnings were $\$ 10,560$ per mile compared with $\$ 26,800$ per mile earned by the Northern road. The net earnings would doubtless have made the comparison worse. As for service, the State line is notoriously inferior to the private roads. At the time of the purehase of the Western line by the Govcrmment in 1908 it had a defirit of $\$ 5,260,000$. In the operations of 1913, the Govermment reached a defieit

${ }^{1}$ Edmond Villey, Les Viecs de la Constitution Frangaise, 138. 303 


\section{CONTEMPORARY FRENCH POLITICS}

upon this line of $\$ 15,280,000$, an increase in one year of $\$ 10,000,000$, and during the five years of Government operation the total deficit reached was nearly $\$ 47,000,000$. In technical terms, the coefficient of exploitation (ratio of operating expense to ineome) of the State road, Government operated, in 1918 was 120 per cent, in comparison with that of the Midi, which was 87 per eent; of the Orleans, which was 85 per eent, and of the P. L. \& M. road, which was 90 per cent. The coefficient for the State road even exeeeded that of the private companies operating in the devastated regions96 per cent for the Eastern and 112 per eent for the Northern. ${ }^{2}$

During the war all of the private roads were requisitioned and placed under a military régime by authority of the law of 1889 ; at first, they were under the direction of the Ministry of War, and later, of the Ministry of Publie Works. The great majority of the military commissioners who took over the operation of these railways knew little of their organization and functioning. Althongh the roads eventually responded to the military needs of the comntry, it was at nearly a doubled operating expense. Perhaps this was to be expected under war conditions; but in addition, the economie needs of the nation were sacrificed by what appeared to be unintelligent managenent. After the elose of hostilities, France experienced a transportation crisis which was one of the great causes of the height of prices; cars could not be obtained to meet the demands of the

\footnotetext{
'Journal des Débats, June 7, 191!'.
}

A very good aceount of the operation of the French railways during the war (although it does not touch directly on the cffect of (iovernment operations) will be found in La Revue Politirque et I'arlementaire, Feloruary 10, 1920, in an article by Marcel P'eschaud entitled "La C'rise des Transports.", 


\section{BUREAUCRACY AND STATE SOCIALISM}

devastated regions. Meanwhile, there were hundreds of cars lying idle in the American military yards, such as at Gièves, which the French Government refused to take over. Government control and operation of railways may have other justifications than mere economy; but the State-owned and the State-controlled roads in France conelusively show that so far as efficieney is concerned, private roads are unquestionably superior.

Not only is the post-office in France operated by the Government, but under the same service come the telegraphs and telephones. France has some 13,000 postoffices, 16,000 public telegraphs, and 219,000 telephones, all controlled from Paris. Such a control is so centralized that even the setting up of a letter-box, the ereation of a substation, or the extension of a telegraph line must have the eonsent of the Central Ministry. This absoluteness of direction doubtless prevents the extension of these facilities. Aceording to a statement of Lazare Weiller in a report to the Chamber of Deputies in Feb. ruary, 1915, two thirds of the 36,536 commmes in France do not have post-offices; half of them do not have telephone. service, and a great number of them have no official communication with the outside world exeept through a daily rural postman. Telegraph offices, situated in the momtains, have their lines blockaded during the winter and their wires ent; and the Government service is satisfied to leave them for months in a useless condition.

On the 29th of March, 1919, the Paris papers published the details of a "Telegraph Scandal" which an investigating committee of the Chamber of Deputies had mearthed. It charged the Telegraphic Control Section, of which M. Tamery was the head, with seandalous abuses. M. Tamnery, during the investigation, 


\section{CONTEMPORARY FRENCII POLITICS}

admitted that 40,000 dispatehes had been held back by his section daily. The majority of them were never delivered, being thrown into the basket, and upon aecumulation, destroyed. The senders and those to whom they were addressed were never informed. On the oecasion of the last national loan, for some inconceivable reason this Section stopped and suppressed large stoek exchange orders and dispatches of funds for the loan. During the war, it even destroyed telegrams from munition factories at Le Crensot and Firminy with the result that some of them had to close down for want of supplies. Telegrams from or to foreign sovereigns reeeived no privileged treatment, and even the eorrespondence of the French Foreign Office became lost in the maze of treasonable stupidity or intrigue of this Section. At first unknown to the French Foreign Office, diplomatic telegrams sent by the French Ambassadors in Rome and London to Spain, were pigeonholed, as were telegrams to the Paris office from M. Bapst, the French Minister at Copenlragen. The Ministry of Foreign Affairs, in a complaint, said that, "under its present head, the Telegraphic Control Section is an organ of confusion and of disorder which has engendered extraordinary abuses and risked compromising the Government seriously and hampering its general poliey." As a result of these revelations, M. Tannery was relieved as head of the Section. But he retained his post at the Cour des Comptes, and in addition, he was appointed to the exchange commission sent by the Minister of Finances to Alsace and Lorraine! It was only after the Chamber had given publicity to its investigation that he was finally dismissed from this post.

The French Govermment operates monopolies in 306 


\section{BUREAUCRACY AND STATE SOCIAIISM}

matches, gun powder, and tobaceo. During the war it increased the prices of some of these articles in the hope of additional revenue; but it disgnised its real purpose by informing the public that the supply was nearing exhaustion. Although the provinees went smokeless, the Govermment saw to it that members of P'arliament were amply supplied. $\Lambda$ s a reason for the tobaceo shortage, the Government also contended that consumption during the war had greatly increased. Yet in a report made to the Chamber upon the 27 th of February, $1918,{ }^{3}$ by M. Grodet, figures were quoted, showing that consumption had diminished 3 per cent and 4 per eent during 1915 and 1916, in comparison with 1914; and that consumption in 1917 was exactly the same as that of 1914. The little Republic of Andorra was manufacturing eigarettes, paying customs duties on them, and selling them in the French Pyrences for fifteen and thirty. centimes a package, while the French Government was selling identical cigarettes for eighty eentimes and a franc. Althongh this tobaceo incident is comparatively insignificant, it illustrates the extravagant, if not extortionate, character of a Gorermment monopoly.

One of the noticeable failures of Govermment operation during the war was the Arsenal at Roanne. This was a project of Albert 'Tlomas, a former Minister of Armament, who decided to erect this arsenal in October, 1915: The buildings eovered an area of about seventy-five acres and the plant employed workmen, varying in number from 11,500 to 40,000 . By 1)ecember 31, 1918, the expenditures npon the plant had surpassed $\$ 56,000,000$, while the total value of

\footnotetext{
"Quoted in L'Etatisme, brochure of "Union des Intérêts Economiques,' 35.
} 


\section{CONTEMPORARY FRENCII POLITICS}

the shells produced up to this time searcely came to $\$ 4,000,000{ }^{4}$ The Roamne Chamber of Commeree, in a report made on the 7th of December, 1918, protested against the manner in which this establishment was being operated. It aceused the Government of having no idea of continuity in its development, of employing irresponsible and ineompetent cmployees, of exereising no intelligent control, and of inexeusably squandering publie funds. $\Lambda$ s an example of the deeeption under which the arsenal was operated, the Chamber eited an instance when M. Thomas, wishing to determine the arsenal's eapacity, examined certain maehinery for turning shells. With this as a criterion of the arsenal's productive power, he pronouneed himself completely satisfied. But as a matter of fact, aceording to the Chamber, the machinery had been purposely erected that morning, and upon the Minister's departure, again dismantled. In regard to salaries, a earpenter, paid three dollars a day in a private concern, made a hundred and twenty dollars in four weeks at the arsenal. $A$ laborer, paid fifteen cents an hour in a steel plant at Roame, was able by pieee work to make five dollars in three hours at the arsenal. In regard to eomparative costs of production, $155 \mathrm{~mm}$. shells at the arsenal cost more than a hundred dollars; while the Government paid private firms a maximum of ten dollars for exactly the same product.

The control and development of ports is another affair direeted by the Central Govermment. The port of IIavre was recognized forty years ago as being insufficient for the needs of French commerce. Five years of agitation were necessary to secure the voting of a

\footnotetext{
- I' Etatisme, 38.
} 
project providing for its development lyy the C'hamber, which was finally aclieved in 1882 . Nine yoars were then necessary for the Senate to examine 1lue bill. Finally in 1891 it rejected it to the extent of rofusiner the greater part of its provisions. So the aritation had to start over again and a still more modest project was placed on foot. Four more years were this time neressary for Parliament to adopt the latter project, which was doue in 1895. Thus nineteen years were taken to reach a decision upon a necessary publie work which it required seven years more to earry out. Twenty-six years elapsed between the coneeption and the achievement of this project. In the meantime business interests languished. Apparently the administration is not moved by their protests; when it is, it votes supplementary budgets and makes patchwork additions to calm them; but in the years of delay, the prodnetive eapacities of France are unutilized. As a result, France has few harbors, a feeble mereliant marine and an inadequate system of transportation; costs of production are high and other countries easily outdistance her in eommereial ficlds.

In addition to the incident of the port of Havre, the development of the port of Marseille necessitated a list of formalities which filled two eolumms in the Journal Officiel, a publication of about the same size as, and eorresponding to our Congressional Record. The port administration is itself dependent upon six different ministries.

The Saigon bamboo ease is another eelebrated instance of the workings of the French bureaucracy. The Freneh arsenal at Saigon in the Orient was in need of bamboo, a need which was eommunicated to Paris. It happened that Saigon was the eenter of one of the most 


\section{CONTEMIORARY FRENCII POLITICS}

prolific bamboo districts in the world. The technieal services in Paris knew this; but becanse of an aneient rnling that colonial arsenals should be supplied from home arsenals, they ordered that bamboo be seeured and shipped from Toulon to the Orient. Six months of time were lost in the transaction as well as several hundred dollars. But that was immaterial to the bureaneracy. It had acted aceording to regulations and its own "responsibility" was elear.

Instances of Government ineffieieney in the national printing establishment, where expenditures exceeded by twenty-three times the original estimates; in the fountains of Versailles, which take an immense amount of water; in the Gobelin manufactures; in the mint; in the management of the Journal Officicl; in the seandal of the Rodin forgeries; and in the reeonstruetion of the devastated regions, do not need eiting to establish a fact which Frenchmen have almost come to tolerate as an inevitable neeessity.

Aecording to L'Euvre, a vigorous opponent of the bureancracy, the American army officials were eonstantly interfered with in the erection of a stadium at Joinville which the United States was to give to Franee. Arrangements were made with the National Committee of Physical Education as to its ereetion, which was to be completed by June 1, 1919. But subordinate Govermment officials deliberately delayed construction by petty persecution of contractors and even by summonses against American drivers. L'Eure wondered whether French bureancrats were deaf, blind, or criminal.

The French I)iplomatir Service, from the standpoint of training, is supposed to be the most skilled in the world. But acourding to a report to the Chamber by 310 


\section{BUREAUCRACY ANI) STATE SOCIALISAT}

Louis Marin, in 1912 over a hundred diplomatic agents were removed from their posts and transfered to others either before they were, or when they were just upon the point of being, acpmainted with the conditions of their posts. Ont of thirty-two legations, only eleven were directed by the same head between 1912 and 1914. Even during the war, thirty-seven diplomatic agents were displaeed and transferred to other offices. The constant replaeing of agents, rendering them incapable of aequiring full knowledge of their posts and anthority sufficient to regulate affairs to the satisfaction of both eountries, could not but be prejudicial to France.

French administrative methods in Alsace-Lorraine have caused eonsiderable discontent among the inhabitants of these recovered provinces. Contradictory orders, eomplete destruction of German organization and the substitution for it of French disorder, have reeeived not only the criticism of such eonservative papers as the L'Echo de Paris, ${ }^{6}$ but of the Socialist papers sueh as L'Heure.

In addition to these governmental activities, the Freneh administrative system practically controls every phase of local govermment, the edurational system of the country, and a large army and navy. The number of Govermment employees engaged in these enterprises is as follows:

Functionaries belonging wholly or in part to the State 60,5,023 Functionaries belonging to departments, communes,

colonies, or public establishments........ 330,226

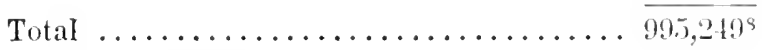

\footnotetext{
${ }^{5}$ (Quoted in Le correspondant. January 10, 1919.

- Number of Fobruary 26, 1919.

7 Number of March 1, 1919.

${ }^{*}$ Estimate of budget project for 1913.
} 


\section{CONTEMPORARY FRENCII POLITICS}

Furthermore, the number of civil employees inereases each year; in 1906 they numbered 702,596; in 1907, 727,$792 ; 1908,740,290$, and 1909, 778,565. This great number of citizens-it is generally estimated that one out of every eleven voter's is a Govermment official-in the employ of the Government creates a vast politieal problem. The evils arising from such a eondition are plainly apparent.

The French bureaucraey not only reaches into fields ordinarily. left to private enterprise, it not only commits the most eostly blunders in its activities, it not only is an enormous political machine; but it habitually interferes with the exercise of private initiative in the realm theoretically left to it.

Even to fence a field along a publie road or to change the sign-plate upon a street ear in a small town, the approval of the eentral authorities is necessary. Authorization is required also to build a shack upon waste land for which a tax of seven cents must be paid, and which requires going through twenty-four formalities. If one wishes to place a rowboat upon a river, sixteen different negotiations with the eentral authorities must be gone through. To fence a field, mineteen negotiations are required. It takes two years of bargaining to get the consent of the Government to build even a shed upon a wharf. ${ }^{9}$ These complieations, and this endless red tape could be done away with if loeal authorities were empowered to handle these affairs. There seems to be no reason why consent of any nature should be required for such purely personal and insignificant artivities.

Speaking of the interminable delays of French funetionaries, a French eritio writes:

"Sice lysis, Iers la límocratic Nonvelle, 19 


\section{BUREAUCRACY ANI) S'TATE SOCIALISII}

Those interested can petition, intrigue, or vituperate arainst the Government, either in eonterence or throngh newspapers ... but they are vigoronsly forbiden to do anythiug thenselves and to earry ont the work which their own districts need, and their advice has no effect on functionaries, in the matter of industrial development.

There is no liberty for citizens to act; it is impossible for them to make a move without being entangled in the network of authorization, of paper-work, and of formalities, ending in an ommipotent, incompetent, inert and incolserent State, which has reserved to itself the initiative in every gnestion interesting national or regional life, while it is eapable of solving nothing by its very constitution. Forty years of this treatment have killed initiative and originality in our provinces. Thed down, held in leash, onr population leads a languishing life and its faculties little by little are atrophied. ${ }^{10}$

Aceording to this writer, the excessive number of Govermment officials is due to the fact that Statism almost completely prevents the exereise of independent oceupations whose development is so hopelessly curtailed by restrictions. In desperation husiness men give up and aceept a starvation but certain wage in Government employment. "Tecause of these precarious eonditions every Frenchman is more or less a candidate for publie employment, toward which he is attracted by the law of least resistance, because under our centralized administration, the poorly remmerated functionary leads a miserable life, but exempt from anxiety; far from his employer, the State, who does not know him and for whom he is only a register, he works antomatically, without taking any responsibility ; he is even forloidden to take any initiative and his advancement is made by seniority, whatever may be his merit and his application....'

${ }^{10} 16 i d ., 23$. 


\section{CONTEMIPORARY FRENCII POLITICS}

\section{II}

In every belligerent country the war necessitated an inereased State control over private aetivities. Particularly was this so in France, where the Government not only assumed supervision of, but the direct participation in, industrial processes. Food control naturally became imperative; and by a law of October 16, 1915, the Ministry of Food Supply was organized and entrusted with supplying the eivilian population with wheat and flour. A eredit of $120,000,000$ franes was placed at its disposal and the Ministry was instrueted to make an annual statement of profit and loss. In the first year of operation, it had a deficit of $142,156,000$ franes, to which should be added eustoms duties and registry fees. Later, this deficit rose to $400,000,000$ franes, to which should be added $225,000,000$ franes in 'ustoms duties, ete. The policy of maximum prices, which has generally proved futile, was adopted early in the war; at first, it was applied to wheat, oats, rye, barley, bran, grain offals; later, it was extended to sugar, coffee, potatoes, milk, margarine, aliment fats, edille oils, dried legumes, paraffin and petrol, commercial fertilizer, copper, sulphate, and sulphur. In 1917 , coal, bread and sngar cards were instituted whieh allowed each family a limited ration of each of these commodities. This rationing was not entirely done awaly with until the summer of 1919. Its ineffectiveness may be illustrated by the sugar famine which Paris and the provinees underwent in April and May, 1919. Sugar was mobtainable and the sugar cards were useless; although they entitled the holder to purehase 750 grams of sugar a montli, no sugar could be found to 314 


\section{BUREAUCRACY AND STATE SOCIAIASA}

buy. But in the midst of this famine, the Govermment in an "official explanation" asserted that it lad amply supplied the eity of l'aris with sugar for a period of two months, but that certain groeers were deliberately loarding it for speculation purposes. This the latter hotly denied, at the same time pointing ont that the Government was allowing confectioners an unlimited amount for eandies and pastries. Finally, B. Vilgrain, Underseeretary of State for Food Snpply, offered another "solution" of the problem hy securing a thousand tons of American gramulated sugar, which he placed in the shops and in his own ereation, the Vilgrain booths, which were really Govermment stores, supplied by Government-purchased supplies, transported by Government earriers. Even this did not appear to relieve the situation, especially not in Paris and eertainly not in the provinees. The shortage became so noticeally due to Government inconsisteney that the municipal comneil of Iyyons, in its session of June 16, 1919, passed a resolution, asking the Govermment why it was that industries of pure luxury, such as pastry-makers and brewers, were given sugar when it was rofused for family consumption.

One of the food-eontrol measures, also prompted by the necessity for economy in ocean tommage, was the Government requisition of the Merehant Marine. Under authority of a law passed February 10, 1918, a Govermment deerce, issmed five days later, requisitioned the entire merchant fleet. According to the eommission eharged by the Chamber to examine the Govermment operation of this flect, it was found that under it importations dropped off 839,695 tons or 5 per eent; this figure would have amomted to $2,500,000$ tons or 15 per eent if it had not been for the increased assistance from 


\section{CONTEIIPORARY FRENCH POLITICS}

the English and American fleets. Examples of boats with half-filled eargoes, doeks loaded down with goods awaiting shipment for weeks, ships sent to ports too small for their draught, are multiple. M. Lavoinne in the Chamber reeited an instance of the Government landing 22,500 quintaux ${ }^{11}$ of wheat at Havre (May 23, 1918), and shipping them by rail up to Ronen. This involved another handling of the eargo and the utilization of railway transportation sorely needed elsewhere, when the cargo could just as easily have been taken by ship to Rouen. In an artiele on the obstruetion of the Port of Marseille, in Le Petit Parisien, ${ }^{12}$ it was pointed out that under private operation of shipping a merehant asked three days to unload a ship of 3,000 tons at Marseille; but now under State eontrol the same task, in some eases, had taken from the 14th of November to the middle of February. Instanees are known of cargoes of eggs making the voyage three times from Philippeville to Marseille, before being finally unloaded; while at the time of writing the artiele, 100,000 tons of perishable material were slowly deteriorating at the port beeause of lack of attention. ${ }^{13}$

\section{III}

One of the most important features of the eontrol of food and of industry during the war was the interministerial eommittees and "Consortiums" established

"Quintal-a hundredwejght.

12. Number of February 13, 1919.

${ }^{13}$ As to the general extent of Statiom during the war, Maxime Leroy says, "Salaries, length of work, prices, the purchase, sale and circulation of gools, travel, thought itself, everything, is regulated and controlled ly the sitate. France has lost its former conomic physiognomy." Jour Goucerner, 172. 


\section{BUREAUCRACY AND STATE SOCIALISII}

by the Government to monopolize and distribute importations eompletely. Unrestricted importations were prohibited by a law passed May 6, 1916, ${ }^{14}$ which at the same time raised tariff rates and gave the Government complete control of the contingencies of foreign materials to be brought to France. This action was part of the inter-Allied plan of apportionment of resourees. It arose from the difficulty of foreign payments, from the necessity of giving the military needs of the eountry priority, and of utilizing to the best advantage the merchant marine. Finally, the most powerful and diligent manufacturess could not be allowed to import freely under disrupted war eonditions, beeause they would have exhausted the market for weaker or later competitors. 'The Govermment believed it would be better to divide or ration supplies methodieally, giving to each aceording to his production eapaeity. With this principle established, the State itself became judge of tomnage availabilities and purchaser and negotiator for foreign importations and payments. Despite the necessity of evading industrial anarchy, the French Government could have aeted as a controlling agency, as did the British Government; but it chose the most extreme altermative of State Soeialism, and precipitated perhaps as great a danger as the one it avoided.

By virtue of the law of May, 1916, a Government decree of March 22, 1917, ereated a Committee of Derogations and Prolibitions, charged with determining quarterly contingents of importations for determined produets and forming a plan for the apportionment of these contingents. ${ }^{15}$ By a strange parliamentary proeedure, a law passed Jamuary 20, 1919, ratified this deeree. The

${ }^{14}$ See Journal des Economistes, Mareh 15, 1919.

${ }^{15}$ Ibid., April, 1917, 105. 


\section{CONTEMPORARY FRENCII POLITICS}

first State institutions arising from these deerees were inter-ministerial committees, organized for each industry. Their method of operation was illustrated by the Inter-ministerial Committee on Wool. This eommittee, as disclosed in the Chamber's interpellation of the Government upon June 28, 1918, ${ }^{16}$ was charged with the enactment of measures destined to assure the supply of wool under the best possible conditions to the different branehes of the French textile industry, so as to satisfy the general needs of the country for goods manufactured in wool (being certain that the needs of the army .. . have priority over all others). Speeifieally this eommittee was (1) to centralize needs of all kinds; (2) to establish (the needs of the army first being attended to) the order of priority for the other national needs; (3) to determine, by limitation, if necessary, the nature of products to be manufactured from raw materials, and the labor and the materials to be used; (4) to fix, in agreement with unions or industrial groups eonstituted under anthority of the Ministry of Commerce, the maximum prices of transformation for important parts in manufacture, such as eombing, spinning, dyeing, ete.; to fix the maximum selling priees of products obtained from these transformations and delivered, either to industry or to eonsumers; (5) to determine quantities and classes of the different materials for manufactured products to be imported for all purposes; (6) to study the order of urgency for the introduction of diverse products, under the reservation that the materials necessary to the army always be given priority; $(7)$ to give advice on the kinds of consortims or gromps which it will be necessary to form

'Ibirl., March 15, 1919. 


\section{BUREAUCRACY AND STATE SOCIALISAT}

between agents or mamufacturers, to regularize industrial production and to facilitate relations between prodncers and consumers, under the control of the Minister of Commerce; (8) to make any proposition to rogulate the sale of materials of products of wool eventually, and, if necessary, to restrain eonsumption; (9) to give advice on questions of exportation concerning wool or objects manufactured from it; (10) finally, to examine all other questions relating to this textile and which they judge useful to submit to the different ministries interested.

As will be seen from these powers, such a committee, composed only of Cabinet Ministers with no technical members upon it, was empowered to eontrol completely the amount of raw materials given to private industry, the amount and price of ontput, and the wages of labor engaged upon it. This was perhaps the most extensive task a modern State has undertaken. ${ }^{17}$

Subjected to the eontrol of these inter-ministerial committees, the "Consortium" was created with the object of grouping together manufacturers who deal in a eertain raw material. With a few exeeptions, it was only by belonging to such a group that manufacturers could obtain raw materials. "The consortium ... is a species of joint-stoek eompany, a kind of coöperative association which has as its shareholders the members of a determined industry and which enters into a contract with the State with a view to obtaining from it, upon certain eonditions, the materials needed by this industry to funetion." 14

The eontract between the State and the consortium

${ }^{17}$ An excellent article on the French importation policy is " $L a$ politique francaise en matione d'importations." in ia lievue d'Economie I'olitifue, Mareh-April, 1919, 164-1s?.

${ }^{18}$ Europe Nonvelle, May 4, 1918. 


\section{CONTEMPORARY FRENCH POLITICS}

specified that the manufacturers lost the right of buying, individually or collectively, the raw materials neeessary to their business. The State alone could make these purehases, that is, if they must be imported. The consortinm therefore received its raw materials from the hands of the State, and these it was obliged to reeeive in whatever amounts the State should wish to dole out, and to reimburse the State for all expenditures made by it in seeuring the material. This lot received from the hands of the State was then divided among the members of the consortium according to determined rules of apportionment and at a price which the State fixed in a manner to assure a certain profit to the consortium, to remunerate the capital invested in it. Finally, the State also fixed the price at which the products obtained by the manufacturers by means of this raw material, should be sold to the consumer.

An example of the composition and the operation of such an organism, was that of the French Oil Companies. This consortium was eonstituted in the form of a joint-stoek company with an initial capital of 5,000 ,000 franes, divided into 10,000 shares of 500 franes each. These shares were purchased and held by all the manufacturers of oil arising from foreign grains, such as cottonseed, flaxseed, and eastor oil plants, in determined proportions, according to the extent of the business of each. Each nember's share of the seeds imported by the Govermment was irrevoeably fixed by the respective stock subseriptions. Upon notice of the comsortimm, the State bought the sced, passed it on to the consortium, and was reimbursed for the purehase. The consortium, in turn, sold the material to its members according to the amount of stock each held in the consortium, with the understanding that the State 


\section{BUREAUCRACY AND STATE SOCIALISU}

would fix the selling price of the seed delivered by the eonsortium to its members and also the price at which the products manufactured from the sced should be sold. By this means, a business which before the war aggregated a figure of more than a billion franes, found itself subjected to the rigid control of the French bureaucracy.

This system of consortiums it was only logical to extend to as many raw materials as possible; and the Ministries of Commerce, of Blockade, of National Reconstruction, and of Armament organized consortium after consortium, extending even to such articles as glassware, jute, leather and hides, oils, pit-coal, petroleum, lead and cotton.

The grave feature of this policy was that it held private industry in the absolute grip of the State, it sub. stituted State action, incompetent and dishearteningly slow, for the action of those interested-the bureaueratic buyer, for the industrial buyer. The French Govermment did not wish a simple understanding between mamufacturers and the State (as the British Gorermment had with the British $\Lambda$ ssociation of Oil Brokers), limiting their activities to the national welfare but at the sance time allowing the excreise of intelligenee and energetic business ability. But on the contrary, the French administration took everytling into its own hands. Although nominally receiving advice from the consortiums as to business needs, it made the purchases itself and enfored them upon industry.

Whether or not the Government admitted it, the result of this policy was the total monopoly of control over those French industries which utilized imported raw materials. The State completely held the raw material. It therefore berame the absolute master of in- 


\section{CONTEMIPORARY FRENCH POLITICS}

dustries dependent on it. A merehant not a member of a consortium, either because of his own unwillingness to come under the dictatorship of the State or beeause of his inability to buy the stock when it is offered to him, is practically shut out of raw material, and if his business is dependent upon it, he is obliged to elose down. "Outside of the consortium," M. Emmanuel Brousse said in the Chamber upon the 28th of June, 1918, "there are neither raw materials, labor, orders nor the possibility of transportation." At the same time, M. René Germond, one of the important members of the Srndicate of Iron Merehants, illustrated a similar result in these words:

The consortium régime absolutely prevents retail merchants from procuring merchandise, because they cannot belong to a consortium. Formalities must be gone through which are impossible for them; they do not possess the office help necessary for all the paper-work needed to make out the orders. The merchant is therefore obliged to purchase his goods from an important member of the consortium. But the latter prefers to sell them to his large clients. . . . No longer being supplied, the retailer finds himself prevented from carrying on his rôle, so indispensable, of supplying a small patronage. ${ }^{19}$

The partial destruction of French retail trade by the suppression of freedom of purchase, was one of the results of the consortium systen; the result was the more serions because this trade paid more taxes than the wholesalers did, and it was the foundation of French industry.

In sum, the French consortium system did its best to monopolize and to control in every particular the major portion of French industry. It almost meant the total

"Quoted in L'Elatisme, 13. 


\section{BUREAUCRACY AND STATE SOCIALISM}

suppression of freedom of industry and of industrial competition. It was probably a larger attempt at an all-inclusive State Soeialism than even the demagogic advocates of the theory had contemplated. That a group of inexperienced Government officials, unstimulated by business interests, should attempt intelligently to determine the vast needs of national industry, upon which the minds of thousands of the most intelligent men have been oceupied, was an absurdity, a few of the results of which may now be pointed out.

This inability of the State to determine industrial needs was partly recognized in the summer of $1918 \mathrm{by}$ II. Clémentel, the Minister of Commerce. He consented to allow the consortium in American eotton to make its purchases direct; but for some unknown reason, he reserved the preliminary sanetion of these purchases. This approval took so much time that when his signature finally was obtained, usually ten or twelve days after its request, the market had changed, priees had mounted. and the eonsortium had to pay tens of millions more for the product beeause of the intervention of the Goverument.

The State rationing of industry also had another effeet. According to the rules of the eonsortium, materials were divided among its members aecording to the amount of stock originally procured by each. This provision absolutely overlooked the varying needs of different manufacturers. Contraction or extension of industry had no influence upon the amount of raw material each would receive. Consequently, those manufacturers wishing to develop and extend production were handieapped for want of supplies; those who for one eause or another diminished output had a surplus of supplies on land. In the one instance, progress was diseouraged 


\section{CONTEMPORARY FRENCH POLITICS}

and in the other, extravagance and waste stimulated. The result of the consortium poliey upon general price levels was another indication of Government inefficiency. Before the war there was practically no difference in the price of eotton in France and England. The first restrietion in French importations raised the price of cotton in France until it was twenty-four dollars higler per hundred kilograms than in England. In 1918 this difference increased as follows: ${ }^{20}$

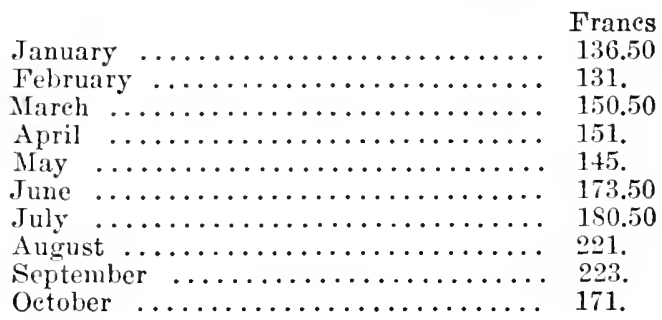

Consequently, in the month of September the Freneh cotton mill had to pay 223 franes (\$44) more for cotton than the English mill, and for a material which in both instances came from the United States. This differenee upon a free market, subject to speculation, might have been explained; but under a State régime especially designed to aroid such a condition, it had no justifieation.21

Other instances of a like effect upon priees are cited in a report issued by the Marseille Chamber of Commerce upon November 26, 1918.22 In one instance the

${ }^{20}$ For the average of the ton months the Froneh mills paid 168 franes more por hundred kilograms than the England mills. Multiplied by the 700,000 hales imported, this represents a difference of mor" than $\$ 51,70(1),(1) 00$.

${ }^{21}$ Quotol from L'Europe Nourclle, May 1, 1918.

2 Ibid., Inecmher 14, 191s. 


\section{BUREAUCRACY AND STATE SOCIALISM}

French Government bounht rice, a food necessity, from England and resold it in France at an increase of 140 per eent upon the purehase price. Many such oceurrences offer a ready explanation for the extreme cost of living. In another case the State imposiel a price upon requisitioned distilleries for a liter of aleohol, of one frane (.20), which was 100 per cent above the usual price. It then foreed the distilleries to sell this aleohol, on the State's account, to the manufacturers of colors and varmishes, to perfume makers, and to vinegar manufaeturers for three franc's and a half. In the meantime, Switzerland was selling exaetly the same alcohol for forty-two centimes; the Freneh price was over eight times greater than the Swiss price.

Newsprint paper, six months after the armistice, was sclling for 45 franes ner 100 kilograms in England and 200 franes in France, a difference of over 400 per cent. During the war, the Ministry of Armament by an interAllied agreement obtained a monopoly of the American market on linters. This made the french Govermment the sole purchaser, which should have permitted it to operate under extremely favoralole circumstances. Private manufacturers, griven such an opportunity, eertainly would have profited by the monopoly. On the contrary, it happened that each time the Freneh Govermment decided to make a purchase, the price of linters went up one or two hundred, to fall again as soon as the Government had finished its buying.

In another instance the French Govermment was offered Plata tallow by private firms at fifty-eight dollars a ton. Asserting that the price was too dear, the Government itself negotiated for the tallows at a supposed price of fifty-six dollars a ton. Despite this appearanee that the State was a better huyer than free eom- 


\section{CONTEMPORARY FRENCII POLITICS}

meree, its price amounted to a great deal more, for the fifty-six dollar quotation did not include expenses of purehase operations, such as cablegrams, and of administration which a broker includes in his prices. These the Government can write off into general budget expenses, falling upon the taxpayer. Furthermore, this State purehase included wastes which the brokers eliminated; moreover it was of frozen fats, lacking the qualities of standard tallow.

These instances demonstrate the effeet of the consortium poliey upon French industry and upon the French eonsumer. In drying up the wells of private enterprise the French consortium policy seemed to be on the verge of causing an economic drought. This, at any rate, appeared to be the opinion of the Chamber of Deputies, when it voted M. Victor Boret, the Minister of Agriculture, out of office because of the height to which prices were continuing to rise. On the 18th of July, 1919, the Chamber voted the following order of the day :

The Chamber, believing that the price of living has diminisherl one-half in Belgium since the month of January, 1919 ,

That the price of living has diminished one-quarter in lingland since the armistice,

That it has not ceased to increase in France since the same date,

Judging this result to be due to the economic policy of the Government,

l'asses to the order of the day.

Tmmediately after the passage of this resolution, the Minister resigued. ${ }^{23}$

${ }^{23}$ Some of the other features in this policy, namely, the general prohibition of importations, which cansed the Minister's resignation, will be diseussind in the following pages. 


\section{BUREAUCRACY AND STATE SOCIALISM}

Of the most serions importance was the evident intention of the State to contime this consortium policy as a permanent basis of industry after the war. Suspicions to this effect were aroused by the stipulations inserted in consortium contracts which provided for their renewals after the signature of peace. M. Clémentel, Minister of Commerce, was accused by many of conceiving of the methodical and administrative reorganization of Freneh industry in which individual industrial enterprise would be completely suppressed.

Moved by this prospect, the Bordeaux Chamber of Commerce, in a session upon March 20, 1918, adopted this resolution:

Whereas, deelarations publiely made by persons in touch with the Ministry of Commerce give the impression that the consortium system is to be considered... as the basis of economie organization after the war;

Whereas, if it is legitimate and in certain cases necessary that, during hostilities, the public powers, . . . control importations, and the apportionment and the sale of certain produets, it cannot be admitted that the Government may profit from the patriotic self-denial with which the French producers have inclined themselves before the necessities of the hour, to prepare an even partial dispossession of enterprises which their capital and their labor have successfully established;

Whereas, the régime of consortiums, represented as a paet between the State and those interested, is in faet imposed upon the latter by an administrative measure and without any possibility of discussing the solutions presented to them, since any firm which does not adhere to the combination finds itself immediately deprived of raw materials;

Whereas, this rigine, which completely overthrows the conditions of national economic life and which places those upon which it is imposed in a situation of inadmissible inferiority toward other French prodneers, has been adopted without Parliament's having been called to deliberate upon it, and withont its having thonght best to consult preliminarily the 


\section{CONTEMPORARY FRENCH POLITICS}

qualified representatives of the great economic interests of the country such as the Chambers of Commerce and the professional groups;

Whereas, it would be easy to show by precise and suggestive examples, that the results obtained up to the present by the consortiums in fuctioning are far from encouraging, that, on the contrary, they bring to light the insufficiency and the errors of State management, the excessive expenses which it involves for a feeble return, its absence of elasticity, and its incapacity to adapt itself to the changing exigencies of a troubled period;

Resolved, that it protest energetically against every measure tending to give as its basis, for the economic organization after the war, an industrial "corporalism," which would certainly be a costly and sterile régime of incompetence and indolence. ${ }^{24}$

\section{IV}

After the signing of the armistiee, reconstruction needs added another aspeet to the eommereial policy of the Government. Attention now became eentered upon the general prohibition of importation and exportation, a restriction which the Government was foreed by public opinion to raise in the spring and summer of 1919. This policy was followed for two reasons: First, a flood of importations would completely unsettle the state of exchange, already so unfavorable to Franee; second, the protectionist argument carried to the extreme,-namely, French industry must be allowed to reconstitute itself, unhindered (as well as unaided) by foreign competitors. The unrestrieted entrance of foreign products into France would overwhelm French manufacturers. The solution of the first of these arguments, which had some weight, appeared

"Qnoted in L'Europe Nouvelle, May 4, 1918. 


\section{BUREAUCRACY AND STATE SOCIALISH}

to rest in the arrangement of credit in foreign (o) tries for French importers, instead of in the total exclusion of foreign products. The second argument had little foundation. France needed foreign products to rebuild her devastated regions; she needed foreign machinery if she was to manufacture products for exportation. To ereate tine tools herself for her rebuilding would be fatal to the suecess of reronstruction and of foreign trade. $\Lambda$ few examples of the working of this protectionist poliey will demonstrate its weakness.

Occasions were numerous during the armistice of French manufacturers whose factories had been ruined in the war, who wished to reëstablish their industries immediately. Machinery formerly purchased in Germany now could only be obtained in the United States where, largely in sympathy for Franee, the orders were filled. But to import it, permission from the Freneh Government beeame neessary. At the manufacturers' request, the Government replied that sueh an importation was impossible without the payment of a seventyfive per cent ad valorem tariff. In addition, a certain number of French manufacturers must declare to the Govermment that this machinery was not to be found in France and that it could not be manufactured. All this to encourage French production! It was useless for the French manufacturer to point out to the Government that machinery had to be obtained before his factory could be reopened; and that if he could not import it from the United States, it would take five years to build the outlay and to manufacture the machinery in France. If the importation were allowed, the machinery could immediately produce the materials which France sorely needed and which eould not elsewhere be obtained. Furthermore, hundreds of work- 
men would be given immediate employment. These arguments were vain, because the eonsortiums or the inter-ministerial eommittees lod decided that Freneh industry must be "protected." The Government was obdurate; for the sake of a theory French industry was foreed to lose invaluable time and effort in manufaeturing implements which foreign merehants already had on hand and at a cheaper figure than the French could hope to produce them. There was one other alternative-to do without; and in most eases, this was what Freneh industry was obliged to do.

What appeared to be an inexcusable application of this theory, was the diffieulty which the Ford Automobile Company had with the Freneh Govermment. During the war the Government had purchased 4,500 commereial automobiles from this company which, on account of the armistice, were never used. They were stored in Bordeaux, new, and ready for use. Aecording to the terms of the Ford Company's eontract with the Government, the former had a privilege of repurehase, with the Govermment's eonsent, of all unused ears at half the original price. The eompany now offered the Government the full price for the ears, plus a profit of 10 per eent, the 70 per cent ad valorem eustoms duty, and the luxury tax. From the financial standpoint alone, the revenue resulting to the Government from such a transaction would have been nearly 9,000,000 franes $(\$ 1,800,000)$. The Government would have recuperated the sum of $8,437,000$ francs which it had paid for the cars, and the French automobile dealers, who held the Ford agency, would have made a gross profit of 8,000 ,000 franes by the sale of the cars to French firms. The sale would have inmediately resulted in the termination of warehouse and upkeep expense of the ma- 


\section{BUREAUCRACY AND STATE SOCIALISM}

ehines. It would have partially alleviated the great transportation crisis, then paralyzing French industry; it would have employed thousands of dealers, mechanies and repair-men, and in a number of other ways it would have contributed to the stimmlation of French industry. But the Govermment did not see fit to accept the proposition, saying that French automobile manufacturers would soon fill all French needs. Incidentally, M. Loucheur, the Minister of Industrial Reconstruction, had considerable interests in the Citroën Company; but so far this company has not supplied automobile needs, although it enjoys considerable profits on those it does sell. Monopoly privileges apparently are enjoyed as much by Govermment officials as by mere business men. In any ease, it was better to allow several thousand automobiles to continue in a state of foreed idleness than to permit an American firm to profit by their utilization!

Another regrettable incident arising from this poliey followed the Lyons Trade Fair, an annual event of national importance. Canada had had an important seetion at the Fair, and her merchants took a large number of orders upon samples exhibited. When they attempted to fill them, the Freneh Government refused the permission to import the goods. Upon the intervention of Sir George Foster, the Canadian Minister of Commerce, the Government responded that the "Lyons Fair, being purely a local enterprise, the Govermment could not grant it special favors."

Le Temps, ${ }^{25}$ always a vigorous opponent of the statist polieies of the Govermment, eommented as follows upon this instanee:

${ }^{25}$ Issue of May $15,1919$. 


\section{CONTEMPORARY FRENCH POLITICS}

As a result, it is no longer neeessary for individuals, manufacturers, agrieulturists or merehants to be aware of their needs and to supply them, at their own risk and perils, by exereising their knowledge, experience, and ambitions for the country; but following such and such resolutions, taken in such and such administrative bureaus, these needs are now catalogned, estimated, submitted to regulations; always ehanging, however, in a manner to dominate individual initiative which is too much given to boldness,-deemed unreasonable.

The Mayor of Lyons, MI. Iferriot, responded to the Temps' comment, in part as follows:

The Canadian ineident is only an example. Merchants and manufaeturers, highly qualified, eagerly attempt to obtain results; but a small anonymous bureaucraey completely annuls their efforts. The Minister of Commerce makes solemn engagements; he promises some liberties; but no engagement is kept. Clients whon we have gained with great difficulty are going away irritated and exasperated. ... We want less talk and more action. We lo not ask that they be interested in our work. That would be an indiscretion. But at least, they can let us work! 26

Aside from the evil effect upon the internal welfare of the country of the Govermment control of importations, it was creating an international diffieulty. Allied merchants were very glad to trade with France. They were not prompted solely by commereial motives - though the French Government seemed to believe this was their single preocempation-but by sympathy. They desired to give French reconstruction needs every priority; but when the Freneh Government, indiscreetly, it seemed to them, refused their coöperation, it was only natural that they should look for markets elsewhere, Germany included. Not only was France los-

${ }^{29}$ Le Temps, May 29, 1919. 


\section{BUREAUCRACY AND STA'TE SOCIALISM}

ing Allied trade, but she was losing markets which she eould have had in Rommania, Greece, South America and the Orient. If she would not import their offerings, she could not expect to export to them. Conseciuently, Franee was beginning to face an economic isolation.

\section{V}

As we have already seen, the eommereial poliey of the Government was by no means aequieseed in. Industrial sentiment, save that of a few large firms profiting from the benefits of a monopoly market, was wholly against it, and earried on a vigorous eampaign for its repeal. Among politieal parties, only a few Radicals and Socialists upheld it. Moderate Republieans to Royalists were its strenuous opponents-opponents not only of this restrietive regulation but of statism in general.

The National Association of Eeonomic Expansion, after an investigation of the consortium, ${ }^{27}$ roundly condemned them as wastefully exhausting raw materials necessary to national industry. In regard to the effect upon reconstruction, the Federation of the $\Lambda$ rehitects of Northern Franee, upon whom such a task would naturally fall, deelared:

Private initiative ... is the only means for the rapid reconstruetion of our eities and villages. ${ }^{28}$

Similarly, after hearing the report of its President, II. Maurice Charpentier, the Chartres Chamber of Commeree resolved that "the return to the commercial

"q Quoted in Le Temps, January 24, 1919.

2x Ibid. 


\section{CONTEMPORARY FRENCH POLITICS}

and industrial life of before the war be effected with the briefest possible delay." ${ }^{29}$ The French Society of Political Economy, an organization including many eminent economists, likewise aceused the Government not only of violating the most fundamental economic principles, but of awkwardly and inefficiently controlling industry.

At a meeting of the Republican Committee of Commerce and Industry, attended by 500 delegates from all over France, upon May 14, 1919, its President, Senator Maseuraud, denounced Govermment Statism in these words :

We have seen how the State buys, manufactures, and sells. We have seen, under its management, a deplorable diserepancy produced between the cost of production and that of the products, so much so that the cost of living and the level of salaries always increase without satisfying any one.

The experience is conchusive. There is only too mnch of it. Enongh of State socialism and of monopolies! If we wish to heal our wounds, to meet the needs of a formidable budget and to overcome our foreign indebtedness, we must liave liberty in importations and in exportations, liberty in production and in circulation, and liberty in exchange.

The Union of Economic Interests also declared that "every one who wants to work for the resumption of economic life conflicts with the State. In place of enconraging good intentions and of aiding initiative, it discourages the one and paralyzes the other. The State wishes to regulate everything and to eontrol everything: importations, exportations, production, distribution, and exchange." 30

In addition to these business elements, Labor entered

20 Meoting held on Dee. 17, 1916, Le Temps, Jan. 24, 1919.

3" (quoted in ibial. 


\section{BUREAUCRACY ANU S'ATE SOCIALASA}

the lists against one feature, at least, of this policy. At a meeting of the Confederal Committec of the General Confederation of Labor, held on July 22, a resolution in favor of Flee 'Trade, the suppression of eustom halriers, and the free entry of raw materials and manufacturers, was adopted by a vote of ninety-one to sixteen. This was a somewhat radical departure for this Labor organization; but it was strongly supported by the Soeialists-all of the Socialist papers demanded the suppression of the exportation ban-and the eity dwellers generally, who were sorely afflicted by high prices. For the publie, L'Euvre and Le Progrès Civique denomeed the theory of Protection and demanded the institution of Free Trade. It seemed that only the extremity to which the Govermment had carried the theory could rouse France from its traditional belief in this doetrine.

Under the great pressure which the most divergent interests were bringing to bear upon the Government, it gradually removed some of the restrictions upon the liberty of commerce. On Janmary 20, 1919, a deeree was issued removing the bans on exportation from all but 140 articles of the $65 t$ upon the tariff. Another measure placed all purchases for the public services under the supervision of the Minister of Finances, a move of economy. A further deeree, amnomeed in Le Temps, on May 14, 1919, removed the ban still more on exportations, only nineteen articles remaining subject to the prohibition. These included many important items such as live animals, ehemicals, metals, and paper. 'Tlese removals did not apply to importations and conserpently did not allay public eriticism. But upon the 17th of May, a letter was published written by M. Loncheur, Minister of Industrial Reconstruetion, 


\section{CONTEMPORARY FRENCH POLITICS}

to MI. de La Trémoille, who had laid a resolution before the Chamber asking for freedom of importation of raw materials, manufactured articles necessary to French export trade, and agricultural machinery. In this letter, the Minister stated that the Ministers had decided to ask the President of the Republie to sign a deeree almost completely restoring the liberty of importation so far as raw material was concerned; and after adjustments with the Allies, another deeree would be issued, more nearly suppressing all restrietions on importations. The Minister, who had apparently forsaken the desire to fasten this policy upon peace-time industry, elosed by saying: "We are thus eompletely in aecord with you . . upon the projected resolution which you have presented."

Perhaps to the surprise of the Freneh publie, the Government kept its word, for upon May 20, the Journal Officiel published a decree allowing the importation of principal raw materials necessary to the resumption of French produetion. Further decrees were announced on Jume 19, July 7, and 8, whieh suppressed nearly all prohibitions on importations, about a dozen articles remaining. The value of the deerees, however, was largely overeome by the fact that they increased certain tariff rates on needed eommodities to an almost prohibitive height.31 Thus it was ahout eight months after the close of hostilities before the Freneh Government surrendered its eontrol over private enterprise. There may have been some justification to its poliey; but the dangers in which it resulted appear mueh greater than those it avoided.

"See L'Eeonomiste Français, July 19, 1920, 74, “Le Régime commereial frangais.", 


\section{BUREAUCRACY AND STATE SOCIALISM}

\section{VI}

The defeets in funetioning and the defeets in theory of the French bureaucracy have been vigorously attacked. In addition to those opposed to the war policies of the Government, there are many equally opposed to the ordinary extent and mode of operation of the Govermment administration. The remedy which the business interests, inchuding the upper bourgeoisie, urge, is the return to private enterprise of activities now direeted by the State. As it is extremely improbable that the State will ever surrender any of its present industrial prerogatives, the success of such a remedy seems slight. Realizing this unlikelihood, the anticollectivist movement has limited its demands to the prevention of future State extensions into industry. The Union of Eeonomic Interests, embracing about seventy-five eommercial organizations, is the leader in this movement. It was olganized in 1909 with 201 insuranee syndieates as its basis. Its purpose is to eombat State Sorialism and to defeat any candidate for Parliament who does not promise to vote against measures inereasing it. In the elections of 1910, the aetivities of the Union suceeeled in pledging 366 Deputies to vote against the creation of new State monopolies. In 1910 , Le Réveil Economique was founded; it has proved an energetic organ in earrying on the Union's eampaigns. On the 15th of Deeember, 1913, it assembled the presidents or delegates of forty great national groupings of commerce, industry, and agriculture, to inangurate an anti-statism program for the 1914 elections. As a result of its aetivities, 270 Deputies declared themselves against the extension of Govermment activities in indus- 
try, 127 opposed the program set up by the Union, 29 were for it with reservations, and $16 t$ were doubtful. At a meeting held at Paris upon the 12th of May, 1919, the Union adopted another program which pledged itself to "formal opposition to the establishment of new monopolies, to any attempt at collectivist socialization, to any encroachment of the State upon services of a commereial and an industrial eharacter, to the operation by the State of services at present leased to individuals, and, generally, to any interference of the State in the management of private enterprise.", 32

This program was submitted to the candidates for election to the Chamber of Deputies last November. Each candidate was asked to subseribe to its principles. As a result of this canvass and of the election, it was found that 377 of the elected Deputies approved the program; 35 made reservations to it; 96 were doubtful, and 81 were opposed to it.

Despite the activities of the business interests, the statist movement seems to be growing and the evils of the bureaucracy remain unchecked. The Government has decided to eonvert all of its munition plants into industrial factories, operated upon a peace-time basis. It is not apparent why these plants were not sold to private firms. Bills have been introduced into the Chamber for the Govermment monopoly of insurance ${ }^{33}$ and for the monopoly of petrol; the Chamber has voted a bill providing for Government participation in the profits and eventually in the operation of mines; likewise, a bill monopolizing industrial alcohol has been

${ }^{32}$ Artive II of the program, printed in brochure, Union des Intérốts Economiques.

"Sice article on "La question du monopole des assurances", in Le I'arlement et l'Opinion, March, 1919. 


\section{BUREAUCRACY ANI) S'TATE SOCLALISH}

passed. Agitation for Goremment ownership of hydranlic power is strong. In the latter part of Jume, 1919, M. Albert 'Thomas, supported by the railway men's folerations, introdneed a moject for the nationalization of the railways.

Despite the distinction which some Socialists attempt to create between Statism and Socialism, ${ }^{34}$ the French Socialists with the left wing of the Radical-Socialists are the supporters of statist policies and projects. The statist activities of Parliament are being strenuously objected to by moderate elements beeause of the faet that the power's of Parliament should have expired in 1918 , if the war had not prevented it. It has no right, aceording to them, to impose its will upon an uneonsulted eountry.

This issue doubtlessly was one of the most important in the elections of 1919. Anti-statism is always eertain to be the rallying ery of moderate Republicans. They will be supported by many eolleetivists because of the antipatriotism and Bolshevism with which the chief supporters of Statism, the Unified Sociatists, are assoeiated..$^{35}$

${ }^{34}$ See Emile Vandervelde, Le Socialisme contre l'Etat.

${ }^{35}$ Two other solutions suggested for the defeets of the French bureaneracy will be considered in the next two elapters: (1) decentralization by service and professional government, and (2) decentralization by regions, or the extension of local governing powers. 


\title{
CHAPTER XI
}

\author{
GOVERNMENT BY INTERESTS AND EXPERTS
}

Aux lois politiques vont de plus en plus succéder des lois économiques ou administratives.-Pour Gouverner.

\section{I}

The increase of State control over industry, of which the period of the war has given an illuminating example, is regarded by many Frenchmen as an inevitable if not a welcome evolution. Unlike the interests which desire a return to the old freedom and to the poliey of laissez faire, this new school after reorganizing the basis of the present State, wishes to extend its functions. It offer's one of the two real suggestions for remedying the defects of French administration-decentralization by service as opposed to decentralization by geographic regions. ${ }^{1}$ Finally, it goes much farther and suggests an entirely new political framework for the State.

French administration, as previously noted, owes many of its faults to the concentration of power at the head of its various departments. Thus the Cabinet Ministers are not only part of the political government responsible to larliament, but they are chiefs of all the public services belonging to their departments. Dependent upon them, a great number of directors, underdirectors, thief of services and inspectors exist, whose

\footnotetext{
inee Chapter XII.
} 


\section{GOVERNMENT BY INTERESTS}

powers are more or less extensive aceording to the Ministry; and who, under the authority of the Minister's, act as agents of the Government, exereising, as a French legal anthority has stated, the three powers of eommand, surveilanee and control.

In other words, these officials are directly controlled by, and at the absolute mercy of, the Government; they have no other than a political status. The Govermment exereises complete freedom in choosing or removing them. Beneath these political agents are several hundred thousand ordinary employees performing the most diverse functions, many of whom, on aecount of their organization, already enjoy a relative permaneney of position.

Deeentralization of service means that Goverument officials, particularly Government agents, will no longer be placed under the command of department Ministers, but only under their control. The inerease of public services is foreing this evolution, for it has become an impossible task for the head of the department to command what should be done in every case where a deei. sion is necessary. In the interest of the good management of the publie services, initiative in deeisions must be left with under-officials. With a decentralized administration, ${ }^{3}$ the heads of departments will only refuse to approve measures taken by subordinates when they are in violation of law, and not when they are illjudged. The power of surveillance aceompanied by a power of revocation will still rest with the central authority but it will be strictly limited to the above purposes. Thus the deeentralized agent will have an initia-

\footnotetext{
${ }^{2}$ Léon Duguit, Traité de Iroit Constitutionnel, i, 4\$7-457.

${ }^{3}$ For an impartial discussion of arministrative decentralization, see IIaurion, Irécis de Droit Administratif, 143-15t.
} 


\section{CONTEMPORARY FRENCH POLITICS}

tive, as well as a comparative freedom from officious interference of department heads now frequently exereised for political or other reasons. ${ }^{4}$ As a necessary complement to the granting of initiative must go the personal responsibility of the agent. Otherwise his freedom would be unrestricted. At present the Minister, as head of the department, is alone responsible to Parliament, a responsibility which often amounts to nothing at all. Under a thoroughly decentralized administration, every negligent or careless service would imply a personal responsibility of the official concerned for which he could be held pecuniarily liable. The creation of a common fund by the organizations of the functionaries, supplied with a share in the profits which the French public services make, would furnish a source

${ }^{4}$ Professor Jèze elassifies public serviees into two categories: (1) those who interest the imhabitants in gcneral, i.e., the national defense, posts and telegraphs, ete.; and (2) those who, while interesting the mation as a whole, more partieularly coneern individuals residing in each locality, i.e., tramways, street lighting, paving etc. The second alass of public services may become decentralized to a certain point. M. Jèze states the argument as follows:

"Centralization seems to have the advantage of a more impartial administration because the centralized agents are less engaged in loeal quarrels; but this is not always the case. On the contrary, a centralized administration is very slow, since it is necessary, for the most insignifieant things, to await the decision of distant authorities. Centralization places an enormous responsibility upon the Government, since it not only must take account of national considerations, but also of the smallest details of loeal administration. Finally centralization loes not interest the inhabitants in the management of publie afrairs and does not aceustom them to govern themselves.

"This, on the other hamd, is the great advantage of decentralization. The dominant idea of modern political seience is that individuals must gotern... themselves. The time scems to have passed when families or social elasses were eluarged with governing or administering others. lndividuals more and more desire themselves to direct their affairs and to eseape from the selfish rule of so-ealled directing families and elasses and their agents. . . ." Droit Public ol Administratif, 1:30-33. 


\section{GOVERNMENT BY INTERESTS}

from which their joint responsibility could be net. According to Professor Duguit, the supporter of this system, some such reorganization must be effected if the growth of the public services and the protection of the individual against the ommipotence of Govermment authorities is to be reconciled.

This theory further implies the supplanting, by technieians and experts, of those officials in the Government service who are incompetent and who owe their appointments solely to political influence. The greater number of public services are technical; and, to be efficiently operated, they require skilled direction. If initiative and responsibility are to be placed on subordinate officials, they must be granted to those who, by training and aptitude, are able to exercise them intelligently. This applies likewise to officials at the head of administrative departments. IIence this is a movement to place the expert in the Government, and to place it upon a seientific basis.

\section{II}

The participation of subordinate functionaries and of experts in the control of the public services already exists to a very limited extent. By a law of 1896 the national service of education, through comneils elected largely by tearhers themselves, beeame partially decentralized. The University Councils are composed of the deans and two delegates elected from each faculty of the same university. Although the deliberations of this Comneil must be submitted to ministerial approval, nevertheless they practically control the direction of the miversity coneerned.

By deerees issued in January, 1910, M. Millerand, 343 


\section{CONTEMIPORARY FRENCII POLITICS}

then Minister of Public Works, provided for the representation of the employees of the Posts, Telephones and Telegraphs in the regional councils of diseipline, in the central eouneil of discipline, and in the central promotions council. The personnel also choose delegates to serve with the Minister, the department directors, and the ehief of the service.

As members of M. Clemeneeau's last Cabinet, M. Clareille, the Minister of Transportation, was a railroad man; M. Vietor Boret, Minister of Agrieulture, was a grain merehant; M. Loucheur, Minister of Reconstruction, was a financier and manufacturer; M. Vilgrain, Underseeretary of State to the Food Ministry, was a miller. Thus even a few heads of departments have been selected because of their technical knowledge and experience.

The Chambers of Commeree have a few governmental powers delegated to them. Aecording to a law of April $9,1898,{ }^{5}$ the Government is obliged to consult their national assembly, which meets every two months in Paris, upon all matters or ehanges considered in eommercial, tariff, or economic legislation. The Government, however, is not compelled to follow its advice. Of more importance, the Chambers may themselves operate certain public works and services, especially those involving ports and navigable ways; and they may conduct technical education. They may also issue certain denominations and quantities of paper money for local circulation. A special Chamber of Commerce

'Parlement et l'Opinion, March, 1919, Du Rôle des Chambres de Commerce. Unlike the American Chamber of Commeree, the French Chamber is a public institution; it is established by a Government dereve. There is one for every department. See Chamber of Commerce organization law, April 9, 1898, Codes et Lois, ii, 1.14. 


\section{GOVERNMENT BY INTERESTS}

tax," granted them by the Govermment, insures their financial support. Except for one other, the President of the National Assembly of the Chambers, was the only technician appointed on the Committee of Importations, a body in general charge of war importations. The Chambers are also represented in the Regional Committees of Economic Action and in local committees charged with adjusting terms for ships requisitioned by the Govermment. On April 7, 1919, Le Journal Officinl announced that 136 of the Chambers of Commeree were authorized to organize themselves into seventeen groups, aecording to economie regions. M. Clémentel, the Minister of Commerce, was responsible for this grouping. It was his idea ${ }^{7}$ to assoeiate these Chambers in a common action, giving them general power to supervise the economie reconstruetion of the different regions of Franee. A regional committee was to be formed in which the Chambers were to be represented aecording to their numbers. This eommittee was to "receive from the Ministry of Commerce a letter of service acerediting it to the different public administrations," implying that the committees would be given a part in the administration of the regions and departments in which they were located. The powers which were to be aecorded to these purely professional bodies were left vague; and although the idea is received with favor in regionalist eireles, it remains a question whether the Govermment will ever willingly give these bodies any amount of effeetive authority.

Aside from the Chambers of Commerce, other profes-

'M. Leroy, “Les I'roducteurs au pouvoir,' La Grande Revue, Mareh, 1919.

"L'Opinion Régionaliste," L'Opinion, April 26, 1919. 
sional bodies are supposed to be consulted by the Government. According to a law of $1852,{ }^{\circ}$ Consultative Chambers of Agriculture were ereated to give advice upon subjects of agricultural development and coördination. This function, when now carried out, is left to the smaller unions of agriculturists. During the war, they have been represented upon many committees such as those of Economic Action and of Agricultural Labor. They were likewise charged with distributing fertilizer to wine growers.

An old law further created the Consultative Chambers of Arts and Manufactures, but it is lifeless. According to a decree of 1894 a Superior Council of Commerce and Industry comprised of appointed members was established, which the Minister of Commerce was obliged to consult upon tariff laws and treaties of commerce. A similar function was delegated to a Superior Labor Council, composed of seventy-two members, twenty-nine of whom were to be elected by labor unions, twenty-nine by employers' organization, one by coöperative soeieties, one by the Chamber of Commerce of Paris, one by the Bourse du Travail of Paris; there were also to be three Senators and five Deputies upon it. This Council has only a consultative rôle, but it has dore a great service in supplying the Ministries of Labor and Commeree with invaluable Labor information, and in penetrating them with a new soeial spirit.

A Consultative Committee of Railmays is also in existence, which now has seventeen representatives of the Railway Unions upon it. During the war the Ministry of Armament constituted permancut committees

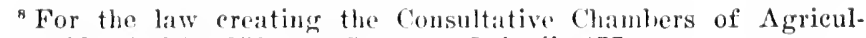
ture, March 25, 1852, see Codes ct Lois, ii, 477. 


\section{GOVERNMENT BY INTERESTS}

of eonciliation and arbitration, composed equally of employer's and workers.

In the Goverument committee of Chemical Products, there were four specialists who were chemical manufacturess, and two merchant sperialists in chemical products. In the Central Committee on steam engines, there were five business men; on the Inter-ministerial Committee chared with determining the national machinery needs, there were five representatives of employers' organizations using machinery, three machinery dealers and two manufacturers, as well as other representatives of the business world. ${ }^{9}$

Presumably in response to the demand for competence in Government, the Prèsident of the Couneil announced on July 16, 1919, the formation of an "Economic Commeil charged with assuring the preparation and the execution of general measures concerning the supply and distribution of products and supplies of any nature, the diminution of the cost of living, the repression of speculation, the development of eeonomic life and the reconstruction of the liberated regions." This eouncil was to meet at least once a week. It was presided over by the President of the Commeil. It included the Ministers of Public Worls, Commerce, Industrial Reconstruetion, Agrienlture, Colonies, Labor of the Liberated Regions. Its resolutions are submitted to the Conncil of Ministers.

To this Eronomic Conncil (which, as will be noted, is nothing but a division of the Cabinet) is to be added a commission charged with framing propositions to present to it. This commission is partially of professional

\footnotetext{
"For diseussion of these War Committes and for other examples of experts in French administration, see M. Leroy 's article quoted above.
} 


\section{CONTEMPORARY FRENCII POLITICS}

composition, for it contains: (1) the Undersecretaries of State of the President of the Council, and of the Ministries of Public Works, Finance, Interior, Food Supply; (2) the commissioner of maritime transports; (3) the president of the Section of Economic Studies of the Presidency of the Council; (4) the president of the inter-ministerial commission in the Liberated regions; (5) three representatives of employer's' organizations; (6) three representatives of labor organizations.

This commission will receive opinions from municipalities, agrienltural, industrial or commereial groups, workingmen's and employers' organizations, and eooperative societies.

The experts thus delegated to a share in the administration have been too few, according to the reformists; their powers, when exercised at all, have been merely consultative and of no binding force; and they have always been outweighed by non-expert officials, actuated largely by political motives. The decentralization movement must permeate the regular Government services with this professional clement which the Government has been in a partial degree forecd to take into its war administration. It must increase their numbers and their power, and ultimately, it must place the complete control of these services in their hands.

In the spring of 1919 the Ligue des Gouvernés was organized by Maxime Leroy, IIenri Dumay, and others to agitate this development. The purpose of the organization is declaredly non-partisan, and is solely directed toward the improvement of the administrative system.

One of its brochures says: "Tle (the public) are never consulted upon the organization or the improvement of services which at every instant and in a serious manner affect our interests and our welfare. Arbitrary 


\section{GOVERNMENT IBY INTERESTS}

power, negligence, and rarelessness, blind and injure us. It is to roform this state of things that the Ligue des Gouvernes is fomuded. By its specialists of every order, it will study . . . the improvements whose need is revealed on every side, and will pursue, their immediate application by every legal means."

The Leagne announced that it would concern itself with all of the public services which the State now exercises; and its definite purpose is to improve the service of the railways, telegraphs, post offices, telephones, omnibuses, street cars, taxis, water, gas, electricity, ports, navigation, State and other monopolies, bridges and roads, tariffs and octrois, tax collection, municipalities, burials, ministerial offices, police, insuranee, reeruiting, public assistance, publie hygiene, and education.

The more comprehensive purpose of the League is to work out a plan of organized coöperation between the Goverument employees and the general public through great professional groupings. The organization of public employees is an essential element in the decentralization of administration and in the establishment of their responsilhility. Of equal importance is the necessity for developing some relationship between the general public and the functionaries to insure the proper use of their decentralized power. As a matter of fact, this plan of administration is founded on syndicalism or guildism, that is, upon numerons autonomous groupings, coöperating with each other, independent of a continued Government intervention. According to the proponents of this theory, this is really taking authority away from the State and conferring it upon experts, responsibly and efficiently organized. 


\section{CONTEMPORARY FRENCII POLITICS}

\section{III}

The organization of Govermment funetionaries has met the same resistance in France which it has experienced in other countries. France has two laws upon professional organizations: One, the law of 1884, which permitted the organization of professional associations, such as labor mions, for the urging of professional demands and which stated "that professional syndieates have as an exelusive object the study and defense of economie, industrial, commereial and agricultural interests"; the other, the law of 1901, which permitted the general organization of "assoeiations" among . those excluded from the benefits of the law of 1884 . These associations were intended to be of a social and eultural nature rather than for the furtherance of strietly eeonomic improvement. ${ }^{10}$

The Government has repeatedly refused to interpret the law of $188+$ to include Government officials. By circulars issued in 1892, 1895, 1897, and 1904, different ministries denied all requests of their funetionaries to organize themselves into syndieates. In 1910 the tribunal of the Seine declared that Government officials could not form professional syndieates such as were provided for in the law of $1884 .{ }^{11}$ The case was upon the legality of a syndicate formed by post office employees. But the Comneil of State in 1909 had ruled

${ }^{10}$ The Organization law of March 21, 18s4, is given in Codes et Lois, ii, 954. The Association law of July 1, 1901, is found in the same volume, 1483-84.

11 The Government has always allowed mere workers holding no authority to organize into syudicates of the 1584 type. Thus the arsenal workers and those engaged in labor on State monopolies are logally syudicalized. 
that functionaries might form associations under the law of 1901. The chief practical difference between the two was that a syndicate formed under the law of $188+$ would probably adhere to the General Confederation of Labor, in order to increase its hanaining power. The Govermment did not relish demands for increased wages nor, in ease of their refusal, strikes and the disruption of public services essential to the nation. A functionary, in accepting public employment, entered into a special status earrying with it the obligation to insure the eontinuanee of governmental activities. The functionaries' retort has always been that if theirs is a special status, which limits them in this respect, it should offer offsetting compensations in permaneney of position and adequaey of income. Despite the illegality of syndieates among the postal employees, they persisted in maintaining their organizations and in 1909 they adhered to the C. G. T.

The sehool-teacher's (instituteurs), a majority of whom it is said are Socialists, were pionecrs in the functionaries' struggle for the privileges of the law of 1884. Their eampaign was begun in 1887 when they first eonceived the material advantages of organization. Upon Govermment intervention, organized labor in France was very quick in eoming to their support. As a result of a motion roted in 1902 at a Congress of the Bourses $d u$ Travail, a committee on Syndieal Education was appointed, composed of six teachers and five workmen. In 1905, upon the oceasion of a great syndicalist movement in France, an open struggle began between the Govermment and the school-tadohers for the possession and exereise of this right. In the same year, the leaders in the "Instituteurs", organization in the Seine distriet were arrested by the Govermment for attempting 351 


\section{CONTEMIPORARY FRENCH POLITICS}

to enforce its rerognition; a year later a project of amnesty was passed and the proceedings against them were dropped.

In the meantime a Central Committee for the Defense of the syndical Right of the employees of the State, the Departments and the Commmes, was organized; while on February 26, 1907, the National Federation of Teachers' Syndieates was created and its statutes were filed with the Government. A year later, the Central Committee addressed to M. Clemeneean, the President of the Council, an open letter exposing their coneeption of a new social organization and asking the benefit of the law of 1884 upon srndicates. M. Clemencean denied this request, stating that the law was framed only for industrial workers, and that the Govermment would not countenance a movement antagonistie to it. The Govermment, howerer, was asked by Parliament to tolerate the syndicates of "instituteurs", already existing, while forbidding the creation of any new group. This modus vivendi existed for a number of years. But finally after the Congress of Chambery in 1912, M. Briand ordered the syndicates dissolved, aceusing them of being centers of political agitation and national disintegration. Some of the teachers obeyed; others did not, and the members of the Syndical Comncil of the Syndiaate of the seine were again prosecuted. Proceedings were soon dropped, but the teachers' organizations continued to develop. ${ }^{12}$

At present the functionaries, 300,000 of them, are grouped into a National Federation of Functionaries.

\footnotetext{
${ }^{12}$ At the "Instituteurs" "' ('muress at Marseille, Iune S, 1919, thirty-three syndiantes, eighteen "amiral" associations, and fortytwo erroups of mohilized trarluers (still in the army) were represented.
} 


\section{GOVHRNMENT IBY INTEREST'S}

They are divided into so-called Amicales, associations of the 1901 type, and illegally constituted syndieates of the $188 \pm$ type which the Government has been powerless to suppress. Their organization has been acentuated by the almost pitiful salaries which French functionaries reeeive. By all odls they are the poorest paid Government officials in the world. An Engrish official, corresponding to the freuch grade of redacteur, receives $\$ 1,000$ a year, while the French employee receives $\$ \$ 00$. When he becomes chief of a burean the English official receives $\$ 5,000$; the similar position in France pays $\$ 2,400$. The French Ministry of Marine presented some particular abuses. Candidates for positions are required to be university graduates, but such low salaries are paid (9,025 franes for the chief of the burean down to a third-class redacteur, who receives only 2,375 franes $(\$ \pm 75)$, that it is impossible to fill the positions, fifteen of them having been open since the begiming of the war.

On the 22nd of June, 1917, the Senate manimously passed a law extending the civil eapacity of professional syndicates by removing some of the restrictions as to property-holding, placed upon them by the law of 1884. No mention was made of extending the rights of the law of 18st to functionaries. The bill did not come up for discussion in the Chamber until the winter of 1918. A Socialist prepared the report upon it, and when it appeared before the Deputies it contained some interesting additions, the ehief one of which granted nearly all of the functionaries the right to organize. The Socialists had wished that this right be made universal in its extension to all employees of the state, departments, and communes. But the Chamber, reticent to extend a right which would even include the judges 


\section{CONTEMPORARY FRENCII POLITICS}

of the country and other officials upon which the public welfare vitally depended, passed a law on February 21, 1919, granting the right to organize to the funetionaries and employees of state, departments, and communes, except members of the military forces, the police, the magistrates, prefects and sub-prefects. The Govermment wished a provision inserted to prohibit definitely the right to strike among functionaries; but the Chamber, under Socialist impulsion, voted it down.

On the 19th of April the Senate voted the Chamber's law with two definite modifieations. Firstly, it granted the right to organize to those functionaries holding no part of the "public powel.", This was an attempt to introduce a principle into the question which the Chamber had attempted to settle merely by a list of exemptions. The Senate feared that the Chamber's precedent would lead to the easy and gradual repeal of the exemptions until every class of Govermment official could legally organize. The Chamber, on the other hand, argued that it was impossible to draw a distinetion between employees holding and those not holding publie power. Secondly, the Senate inchuded a provision to the effeet that any Govermment employee, striking in a coneerted effort to stop public services, by that act would become discharged. On the return of the bill to the Chamber, both of these provisions were stricken out; and on July 18 , the hill was again voted with substantially the same exemptions.

The question of the legality of functionary syndicates, however, is largely an academic one. Not only did the organizations among the school-teachers and postal employees persist in spite of their formal prohibition; but other groups of Covermment officials organized in the spring of 1919, and became affiliated 354 
with the General Confederation of Labor. Many accused the Government of a fatal weakness in allowing these wholesale violations of the law of 1884 . The Govermment itself verbally protested; but by refusing to increase the umbelievably low salaries of its officials it allowed the greatest reason for organization to remain.

On the Sth of March what was known as the "Revolt of the Functionaries" oeeured. Three great federations of the publie services, the milway men, the funetionaries, and workers of the State, took part at a meeting directed by the secretary-general of the C. G. T., and adhered to the Bourse du Travail at Paris. ${ }^{13}$ On the 13th they voted "that all the administrative employees should adhere as quickly as possible to the $\mathrm{C}$. G. T. so they might participate in the organization of a more humane and just society." The "revolt" aroused the fear among publie and Govermment eireles that these organizations wonld now resort to strikes in order to force their demands. This insinuation was vigorously denied by functionary leaders. ${ }^{1+}$

This example was followed on $\Lambda$ pril 5 by the General Association of Under-Agents of the P'osts which ehanged itself into a national syndicate affiliated with the C. G. 'T. On June 9, 1919, the National Union of the secretaries and employees of the Freneh Mayors, in its twelfth national eongress, roted by 2,200 to 300 to affiliate with the C. G. 'T. It the same time, the Freneh tax colleetors at their tenth eongress transformed their association into a syndicate; and although they did not adhere to the C. G. 'T., they opened negotiations with the Treasury employees to effect a mion. On May 3,

${ }^{23}$ The Boness du Tracail are part of the C. G. T.

"See I'ctit Journal, March 13, 1919. 
the National Federation of State, Department, and Commune employees expressed a desire to adhere to the C. G. T. On the 13th of May at their annual congress at Strassburg, the General Union of Customs Agents, representing twenty-seven regional groups, decided to change their association into a syndieate and to ask to be affiliated in the C. G. T.

On the 24th of September, the Congress of the Schoolteachers' "Amicales," or associations of the 1901 type, roted to join the $\mathrm{C}$. G. T., and become syndicates by a vote of 170 against 43 .

These examples suffice to show the universal organization of Freneh Government employees. With the exception, of course, of soldiers and sailors, it seems that every class of functionary is compactly grouped. The professors in the lycées ${ }^{15}$ are even associated through the Federation of Lycie and College I'rofessor's. The employees of every Government serviee, postal clerks to policemen, are organized, most of them in syndieates of the $188+$ type. If the present evolution continues, they will all be in syndicates and members of the General Confederation of Labor.

So far, purely eeonomic demands have occasioned this mania for organization. This the National Congress of Functionaries, meeting on July 6, 1919, illustrated. At that time the immediate realization of salary increases by July 20 and the recognition of the syndical right in every class of officials were demanded. The Congress also invited "all the federated associations to transform themselves. into syndieates affiliated with the C. G. 'T. before October 1...' Due to their insistent agitation, the Govertunent, upon July 8, asked aredits for

"Lycer, a school corresponting to our high school and first two years of college. 


\section{GOVERNMENT BY INTERESTS}

salary increases. fipon the 10th, the C'hamber voted neeessary credits so as to advance 200 frane's to all functionaries, to apply on future salary increases.

To the Socialists and to the revolutionary Syudicalists, the organization of fovermment employees means quite another thing than the amelioration of living conditions. To them it is an essential step in the assumption of power by the proletariat. Tho the advocates of decentralization, on the other hand, this organization is weleomed as the basis of administrative reform. By no means going to the length of the Socialists, they would extend the powers of functionary organizations to a direct participation in the management of publie services. For example, the secondary school-teachers, through their officials, would be empowered to decide the character of education, rather than accept policies dietated by the Ministry of Education. The Ministry might lay down a few general principles to be followed, but the toachers themselves would be given the initiative and independence in carrying on the work. Doubtless, such a system of decentralization would go to the extent where the heads of the Ministerial departments and even the Minister would be chosen from, if not elected by, the educators themselves. Competence and democracy, it is urged, would then be instilled into French administration.

The organization of Freneh functionaries is an assured fact; the next step, and one of equal importanee to the success of the decentralization movement, is to bring them into relationship with, and make them responsible to, the publie, whose interest they must serve. So far no one las offered a practical way of bringing this about. If it is not solved, any amount of power granted to great organized bodies of public employees 


\section{CONTEMIPORARY FRENCII POLITICS}

risks serious abuse. The public services monst always be administered by officials directly responsible to the electorate. The present elective method, or that of ministerial responsibility to Parliament, to a certain theoretical extent, supplies this need. Without the establishment of responsibility, it will be impossible to allow organizations of employees any considerable independence in the management of the public services.

\section{IV}

There are those who do not stop with the revision of French administration. They would install professional competence in the legislative as well as in the executive branch of the government. In other words, they advocate professional represcntation in Parliament. Their conception of the State is that of a mere "coöperation of public services, organized and eontrolled by" 16 the governing power. With the evolution of society these services are being continnally diversified. The governing power which administers these services, has no legitimate hasis and there is no such thing as sovereignty. The gouverments govern because they are the strongest, and the gouvernis are governed because they are weaker than the gouvernomts. But

${ }^{10}$ Léon Duguit, Manuel de l roit Constitutionnel, i2.

Professor Duguit's doetrines may be fomel in greater detail in his L'Etat, le Iroit Objcetif ot la Loi Positire. 20? ff. I, Droit Sorial, le Droit Individuel ot les Transformations re l'Etat, 25 ff, sinq.

${ }^{17}$ Professor Fsmein is the most vienorous opponent of Professor Juguit, in Franee. He declares that it is anarehy to deny the existence of sovereignty. See Esmein, Droit Constitutionmel (4th ed.), 40. Professor Fsmein also says that the Dnguit theory of group control is a return to feulalism. See the 6 th elition of his Droit Constitutionucl, 45 . 


\section{GOVERNMENT liY INTERLSTS}

the governing fores is under the obligation of exeresing itself through the liens of social soliclarity and in the interests of all. Furthermore, the old political basis of the nation is passing away; sorial mits such as the home and googlaphie political cutities are being supplanted by groupiugs foumded upon a community of professional interest and the promise of mutual assistance. This gromping of Fremeh professional interests is defined as "the movement by which all of the different social classes tend to organize themselves and to give themselves a definite juridicial structure for the defense of class interests and for the eoneiliation, by collective eontracts, freely consented to, of divergent interests. . . Thus two goveruing forees aetually appear in France: the numerical majority of male citizens, and the professional syndicates." 18 As the function and the romposition of the State have changed, the govermment must be directed by professional groupings, fitted for the task by strength and competenee. In other words, the homme de politique must give way to the homme des affaires-the politician to the business man.

Maxime Leroy in his very remarkalble book, Pour Gouverner, devoted to this new conception of government, says that the old State is based upon regalian coneeptions; it is monarehical. Political philosophers have hitherto addressed their observations to it. Their arguments against State Socialism apply only to this old State based upon privilege and anthority. Even our idea of democracy has been false. "The wiskom of number," he says, "the equality of individuals, the idea of the 'General Will' inspuring the rôle of citizens

s* Esmein, op. rit., 62. 


\section{CONTEMPORART FRENCII POLITICS}

by a sort of quasi-divine illumination, the infallibility of the people in its assemblies and of the Government deliberating in its councils . . . who still dares conseientiously to defend these democratic forms with a disinterested voice?" 19 The principles of the Revolution are unsound, but they still are retained in government; they must be supplanted by doctrines recognizing the fundamental factors in modern life.

"At our head, we ask fewer drivers of crowds, fewer professional leaders, fewer pontiffs; but more observers, endowed with an experimental sense; fewer masters of our spirit, but more sterards, capable of assuring the management of our common goods. . . ." 20

According to M. Leroy, we must be skeptics in govermment, we must be penetrated with the experimental method, which is as necessary to politics as to science. Our gouvernants must be more eager to learn than impetuous to command.

What the State needs is the participation of productive forces in its control; and he firmly believes "that the association of producers, employers, employees, savants, artists, each of these groupings remaining in its original sphere, without a false confusion of interests, is destined to regulate the traditional antagonism between the gouvernants and the gouvernis, between workers and employers, between those administrating and those administered." 21

Professional groupings are becoming stronger and are demanding an effective part in the Government. Both laborers and emplovers are insistent on the destrue-

19 Nlaxime Leroy, Pour Gouverner, 342.

${ }^{20}$ Ibid., 324.

I Ibid., 52. 


\section{GOVERNHENT BY INTERESTS}

tion of the old contralizing mity which excluded them from Govermment.

The most seathing as well as the most unscientific attack against the system of political representation in France, has been made by Lysis, the head of the party of the New Demoerary:

Our method of understanding universal suffrage is an insult to grood sense. We invite 20,000 citizens living in a certain area $^{22}$ to designate a person to represent their interests and their eonceptions which they may have upon every economie, social and political question. It is easy to understand that this eonsultation must end in the nomination of a person who represents no one at all.

From the first, he does not represent the interests of his electors since the latter exercise the most diverse and often the most antagonistic professions, and sinee they are enruloyers and workers, producers and consumers, proprietors and lodgers, large merchants and small shopkeepers. All these interests neutralize and annul each other. There is no means of defending them all at the same time; to protect one is to destroy the other... . Thus a deputy inserts in his profession of faitl words with a double meaning, able to make the most opposed interests believe that they are the object of the eandidate's particular solicitude. . . Our electoral system terminates in selecting and bringing into power, it may be said, mechanically, the most unfit and the most skeptical men, those the most destitute of beliefs and ileas; in a word, those who are morally and intellectually the least meritorious. ${ }^{23}$

As a solution Lrisis adrocates professional representation, or a legislature composed of delegates elected from and by economic interests, grouped in great categories.

The Orleanist party, as part of a Royalist régime, adrocates an assembly lased upon professional inter-

22 Inder the old system, an arrondissement was the electoral district.

${ }^{23}$ Lysis, I"ers la Démocratic Nouclle. 


\section{CONTEAIPORARY FRENCH POLITICS}

ests, entirely supplanting the present politieal Parliament. Its powers would be confined to purely professional subjects. Although it does not go to this extreme, the Liberal Action party includes professional representation in its plaţform. At its Congress in 1909 it expressed the belief that "the epoeh of purely politieal Parliaments is closed," ${ }^{24}$ and that the Senate should be formed of professional elements. The party's advoeacy of such a measure is suspected of being based upon a desire to secure reeognition of Catholic interests in the Government.

Professor Léon Duguit also outlines a system of professional representation, applying it to the Senate, but leaving the composition of the Chamber of Deputies as it now is. ${ }^{25}$ M. Charles Benoist, as far back as 1895, advocated the election of a Chamber of Deputies by voters grouped into seven classes aecording to their professions: (1) agriculture, (2) industry, (3) transports, posts and telegraphs, (4) eommerce, (5) public administration, (6) liberal professions, (7) eapitalists. ${ }^{26}$

Thus, aceording to M. Benoist, instead of having 300 lawyers, professors and journalists in the Chamber, under a system of professional representation their number would be redueed to 13 , while the number of deputies representing agrieulture, industry, eommeree, transportation, workers and employers, would rise from 120 to 450 !

A carefully worked-out plan of professional representation was devised hy the League of I'rofessional Representation and Regionalist Action, in a bill presented to the Chamber upon the 29th of April, 1915.

\footnotetext{
24 Quoted in Jacques, op. cit., 330.

${ }^{25}$ Duguit, op. cit., 167.

${ }^{20}$ Villey, Les Vices de la Constitution Fransaise, 94.
} 


\section{GOVERNMLNT RY INTERESTS}

Its application was limited to the Government of the new regions which it wished to create. ${ }^{27}$ Voter's of each region were to be gromped into five chases, each of which would elect representations to the rengional assembly. Professions were to be divided into (1) agrieulturists, (2) merchants, (3) mamufacturers, (4) liberal professions, (5) Government employees. It was not eompulsory to be inseribed upon any one of these lists; those not wishing to inscribe themselves upon a professional list and those not roming within the classification would be placed npon a general list. No one could be inseribed upon two lists nor conld one be elected by electors of a list unon which lie was not enrolled. For each of these professional electoral lists, whatever the number emrolled on each might be, there was always to be one representative. linfore each clection the number of seats in the Assembly was to be divided among the lists; the first half was to be apportioned equally; the second half was to be divided among the lists aecording to their numerical importance. To insure labor representation, it was provided that upon the petition of a quarter of the legally eonstituted labor unions in the region, half of the seats in the first half of those equally apportioned to each professional list would be reserved for employees, the other half for employers.

This proposition was not adopted by the Chamber in 1915 ; and it is interesting to note that in the last regionalist bill reported to Parliament this provision was omitted. The reason for such an omission was given by M. . Tean IIennessy, the rapporteur for the Administra-1 tion Commission, himself an enthusiastic advocate of the theory of professional representation, who said:

${ }^{27}$ See P. 395. 


\section{CONTEMPORARY FRENCII POLITICS}

It seemed desirable to many to enter upon a discussion of regional interests, that is, economic interests, representing economic groupings of the region. If an equitable solution would have been proposed, it would have been acepted by a great many of the members of your commission. But can one be found? How can the share of each association in the deliberations of the regional comeil be determined? The right of association . . . exists; but it is a right, not an obligation; in each profession an unlimited number of groups ean be constituted, ... many of them formed only of one or two persons. The practical difficulties in the proper representation of these interests appeared so insurmonntable to the Commission that it was unanimons in deciding that the members of the Regional Council should hold their powers from the whole of the electoral body. ${ }^{28}$

\section{V}

Such is the theory of professional representation and such are the proposals for its application. The basis of the plan is that of the grouping tendeney which for the past thirty years has swept over France. Professional organization, extending to every class of French tradesmen, to every form of laborer, even to the choir singers, who are organized in an Amical Association, is undoubtedly the most marked eharacteristic in modern French political life. Coöperation is now the dominant form of industry. On January 1, 1914, there were 16,713 syndicates in France, eontaining:

6,667 agricultural syndicates with $1,029,727$ members.

4,967 industrial and commercial employer's syndicates with 403,143 member's.

4,8 t6 labor syndicates with $1,020,302$ members.

233 mixed syndiontes with 51,111 members. 159.

${ }^{34}$ Jein ILennessy, Réorganisation Administrative de la France, 


\section{GOVERNMENT IYY INTERESTS}

These syndicates are in turn eombincd into 485 unions of symlicates:

9S atyrieultural unions" of symdicales.

177 employer's' unions of symelicates.

201 labor inions of syndicates.

!) mixed unions.

The employers' mims contained 4,092 synlicates.

The labor combinations contained 4,380 syodicates.

The organization of French labor has been diseussed in another chapter. ${ }^{30}$ The General Confederation of Labor (C. G. T.) is a powerful and an extensive organization; but it has two serious problems to face. The first is that of securing the organization and adhesion of the labor elements not yet ineluded in it. There are 5,642,000 laborers in France (including woman and foreign labor), and the C. G. 'T. eontains only 1,000,000 of them at the most. The larger part of this ontside labor is doubtless unorganized; but a good share of it is grouped in organizations, such as the National Federation of Labor, the Christian Syndieates, containing about 55,000 laborers, and the Union of Free Workmen, -antagonistic toward the C. G. T. and its high-handed direction.

The C. G. T.'s second problem is that of securing the adherence of other than strictly proletariat elements, but which are necessary to the strength of the organization. We have aheady seen its suecess in wimning over the funetionaries. Going even farther, it has welcomed purely intellectual and bourgeois groupings to its bosom, surely horrifying to the shades of Karl Marx and freorges Sorel. These arcessions have inereased its

"o Chéron report on symdieal bill passed by senate, June 22 , 1917.

30 see $1 \mathrm{p} .237-239$. 
membership to at least 2,000,000. It was amnounced on April 26, 1919, that certain university professors, because of discontent with salaries and the powerlessness of their present associations to bring pressure upon the Government, were to ask the National Federation of Professors to convert itself into a syndicate and join the C. G. 'T. On the same day the lyrical and dramatie artists, at a meeting at the Paris Bourse du Travail, organized a syndicate and adhered to the Labor Confederation; the journalists were reported to be considering the same thing. To disseminate "intellectual" propaganda, Parisian anthors of radieal tendeneies organized a group ealled "Clarté"'; its members included such notables as Anatole Franee, Charles Gide, Hemri Barbusse, Romain Rolland, Victor Margueritte, Georges Duhamel, and Cyril Berger. 'This movement appeared to be spreading so rapidly that many Paris editors began to wonder' facetiously if the Freneh Academy was going to adhere to the C. G. T.! The stumblingblock in the way of the C. G. T. is the adherence of the peasant population. In imitation of the Socialists' effort, on May 17, it addressed a cireular to all of its federations and departmental organizations asking them for opinions upon an agrarian program. At a meeting of the Confederal Committee on May 27, it was decided to create a union fédérative terrienne, which after January 1,1920 , is to have a plaee in the C. G. 'T. If the C. G. T. is successful in winning the adherence of these non-proletariat groups the failure of revolutionary syndicalism will be assured. The intelleetual and the peasant rlasses of France are very jealous of their individualism; they will eonntenance no revolution; and their position in life makes the doctrine of the class struggle repugnant to them. 


\section{GOVERNMENT ISY INTERESTS}

'The Govermment has untertaken to organize grompiugs in order to offect the predominane of the C. C. 'T. In March, 1919, M. Clémentel, Minister of Commeree, organized a Federation of the Employers of Labor. M. Vietor Boret, Minister of Agrienlture, scemed to be responsible for the organization of a General Confederation of Agriculture, to include the peasant workers of France and to be independent of the General Confederation of Labor. - Another organization among the peasants has been effeeted in the Ligue des Paysans, whose purpose is "the extension of individnal property and the protection of the interests of all the producers of the soil."

Among the employers 149 Chambers of Commerce provide the most general organization. The French Association of Industry and $\Lambda$ griculture; the Society of Agriculturers; the Committee of Forges; the Committee of Forests; the National Confederation of Commerce and Industry, composed of 150 employers' syndicates; the General Association of Textile Commeree and Industry; the Syndical Alliane of Commeree and Industry; the Union of National Industries; the Union of Commeree and Industry; the Federation of French Manufacturers and Merchants; and the Central Committee of Coal Mines of France, are other examples of the extended organization among French business men.

.The Union of Eronomic Interests, not solely a professional organization, but existing for propagandist purposes, is composed of the largest employers' organizations in France, 'ontaining abont seventy-five Associations, Syndieal Chambers, Federations, Alliances, and Committees, from the greatest diversity of industries. This organization represents one of the first attempts toward the representation of interests in Parliament. 
In July, 1912, it organized the "Republican Group of Economic Interests," composed of over 100 members pledged against State Socialism. At the same time "The Republican Group of Economic and Social Studies" was formed with an identical program. Both of these groups later mited in the French "Parliamentary Committee of Commerce."

Other groups have been formed in both the Senate and the Chamber, upon purely professional bases. In the Senate there are a half dozen of such groupings, including those based upon agrieulture, insurance, commeree and industries. In the Chamber there have been thirty-six economic and social groups, ranging from the defense of Breton interests to those of physicians.

\section{VI}

From this review of eeonomic organization in France it will be seen that the foundation for a government based on professional representation is now partly laid. Whether these organizations will ever be strong enough to bring about the ereation of such a govermment is another question. The advantage of their existence is that they make collective hargaining between labor and capital a possibility. Restricted to purely economic activities, functioning outside the realm of government, the creation of great economie grompings bargaining with each other, offers an application of industrial demoeracy which may go far in aring soeial ills.

It is very mulikely, howerel, that the movement will go farther than this and take charge of the legislative and administrative functions of govermment. The expert has his place in gorerument, hut it is a limited one; 


\section{GOVIRNMENT BY INTERESTS}

the fart that he is an expert handieaps him in the direction of large affairs or in the making of great decisions stretching beyond the field in which he is skilled. Men with a gencral knowledge of a great number of things, men with tact and an intimaery with human nature, men who can compromise means without rompromising ends, must always be the gourernants. Teohnians, by all means, should be given a free field and full responsibility in the activity in which they are expert; but the eoördination of polities must be left to men of larger capacity who are directly responsible to political bodies. As l'rofessor Joseph Barthélenry has pointed out in his recent book on Le Problime de la compétence dans la. démocratic, a strong demorracy should be conducted by men of general culture, administered by specialists, and controlled by public opinion. Jut it is essential for a demoeracy, as for any régime, to possess an élite well prepared for the task of direction.

The professional man in legislation presents even stronger diffuculties than in administration. However successful a porcelain merchant may be, he is probably ignorant of other economic affairs, such, for example, as the tariff on steel. A Chamber composed of professional men, elected purely for their business knowledge, would individualy be competent in regard to everytling; but collectively it would be competent in nothing. ${ }^{31}$

Furthermore, despite the assertions of such philosophers as Professor Duguit and Naxime Leroy, government has not only economic problens to solve; legislation is not wholly a matter of eommeree, markets or stocks: representatives are not intended to be mere

${ }^{31}$ For an argmment agrinst professional representations, see villey, op. cit., $92-96$. 


\section{CONTEMPORARY FRENCII POLITICS}

lobbyists, seeuring appropriations or protection for their constituents. Especially in France, legislative problems are becoming increasingly economic; but they will never become entirely so and they must be approached from other than economic points of view. Questions of national education and of culture; questions determined purely by political philosophies, i.e., federalism versus eentralization, have only an indirect bearing on economics. In regard to questions of foreign policy, daily becoming more important and requiring a general knowledge of history, geography, diplomacy and human nature, a glass-blower or even an iron merchant would doubtless be ignorant. On the other hand, questions considered from merely a productive standpoint will receive an entirely different solution when coördinated with other considerations; for example, the extension of the government into private enterprise, from the economic standpoint is wasteful, inefficient, and sometimes even corrupt. From the standpoint of labor, of industrial democraey and of the prevention of profiteering and private monopolies, such an extension may become desirable. What is necessary is a balancing of interests, involving a broad knowledge of them all and a capacity for fair judgment, in which a system of professional representation would fail.

From the standpoint of national unity the results of professional representation would again be highly questionable. The excossive number of French political parties, it is recognized, causes a great many of the defects in French government; but a system of profossional representation, to inrlude all the industrial rategories of the conntry, would undonbtedly exaggerate the number of groupings in Parliament. Wach grouping, laving the material inferests of its own pro- 


\section{GOVERNMENT BY INTERESTS}

fession at heart, would engage in harters and coneessions fatally harmful to the national unity and welfare. There would not be the Three Estates of fendal assemblies but a countless number of equally harmful antagonisms.

As M. Jean IIemessy coneluded, the practiral difficulties in the way of professional representation are in. surmountable. Groupings and professions are changing in composition and character. The proletariat is constantly merging into the petit bourgeois, and the latter merges into the renticr, making their accurate classification into professional categories impossible.

These objections many upholders of competence in government realize. The Liberal Action party, the Union of Economic Interests, the National Association for the Organization of Demoeracy restrict their professional bodies to purely eonsultative duties. Consultative bodies, composed of professional representatives, would doubtless improve legislation. As noted, the French Government is utilizing their services, but the very fact that they are merely consultative prevents the enforeement of their advice upon Parliament. That force can come only from a vigorous and an enlightened publie opinion guided, as Parliament must be, by other than strietly economic motives.

There appears to be only one cause which will force the institution of professional representation upon France. That is the imminence of Socialist and Symdiealist suecess. The alarming growth of the C. G. T. has already caused the bourgeois interests, partly instigated by the Government, to group themselves in selfdefense. If the Socialists and the C. G. T. become able seriously to threaten the overtinow of the present form of government, these other bourgeois organizations will 


\section{CONTEMPORARY FRENCII POLITICS}

be willing and donbtless strong enough to substitute a government based upon all eeonomic interests. Such a government of "guild" syndicalism, offered as a compromise, may appease the advocates of revolutionary syndicalism.

The defects in theory of such a "professional" government appear to be grave. Yet it is very doubtful if they will outweigh the defects in our present governmental systems. Demoeracy is still in its apprenticeship, and it contains many defects whose real canse of existence is public apathy. In France, especially, material considerations rather than political theories influence govermments. This perhaps is due to the Freneh tendency to appeal to the State for all personal as well as collective needs. This tendeney itself appears to be both a cause and a result of French statism. At any rate, the present generation has no Montesquiens or Benjamin Constants to expound theories to it. If it had, perhaps the governments of all democracies would be improved. But it is more reasonable to believe that, however logical their doctrines, this age would not listen to them. Practical considerations and an economie opportunism seem to rule the political world. 


\title{
CHAP'TER XII
}

\author{
REGIONNISISM ${ }^{1}$
}

Il y a en France trop d'infuence ecutrale; je voudrais moins de force à l'aris et plus dans chaque localité.-NAPOLEON.

\section{I}

A product of long centuries, Franee has a centralized or "unitary" govermment, the direetion of which is almost entirely vested in Paris. ${ }^{2}$ Although the French Parliament now exereises immense power, this authority has often varied with an altered constitutional régime. But in matters of administration, especially of loeal affairs, there has been slight change since Napoleon I left France its present form of administrative organization. Powers of local bodies have been extended or contracted; but the fundamental principles of French departmental administration ${ }^{3}$ have remained aloof from political battles.

${ }^{1}$ This ehapter, dealing with decentralization by the erention of regions, outlimes the third remely proposed for the defects of the Feneh bureaueraey.

" "Paris is in the habit of governing France. For two centuries in this centralized country, the worl of commanil has come from the capital. ...' G. Hamotaux, Contemporary France, i, 15.

"Franee, inhabited by a population of different origins, sub.jeet on lier frontiers to the attraction of neighboring l'owers, ean only preserve her power, and perhaps her existenee, hy making eonstant sacrifices to the cause of mity.' Ilanotaux, op. eit., i, 239 .

${ }^{3}$ For a liseussion of French administrative law, see the different Traités de Droit Aministratif, by Professors Berthélemy, II ruriou, Morcau, and Jèze. 
France is divided into eighty-six departments, ${ }^{4}$ each one of which is directed by a l'refect who is appointed and removed at will by the President of the Republic through the Minister of the Interion. The office is therefore a political one and the inembent is usually displaced with a ehange in Ministry. Two prineipal duties fall to it-that of direeting matters of general administration, applicable to the whole eountry, and that of the direction of the local department affairs. The Prefect is theoretically an immediate agent of the Ministry of the Interior, but really he earries out orders from all the Ministers. He is absolutely subject to them in the execution of general laws and decrees; but in such matters as the direction of the police and the supervision of local bodies, he has more freedom. In the greater number of cases, he ean still be overruled by the Govermment and he ean always be removed. Whatever independence he may have is largely lost by the pressure which the deputies of the department exert upon him. Consequently questions of policy usually are referred to Paris for decision. Thus the eentralized control over department administration is nearly absolute, and the Government at Paris concentrates tremendous powers in its hands. In theory this power is not exercised irresponsibly, for the parliamentary responsibility of the Minister of the Interior prevents too flagrant aluses of arministration. But at the same time, the vast centralization of power and the tremendous extent of governmental activity enalles an enormous amount of patronage to be disposed of, for politi-

\footnotetext{
"Exclurling the three new departments (Moselle, Haut-Rhin, and Bas lihin) formed out of Alsacelorraine.
} 


\section{REGIONALISM}

cal purposes; and the actions of the Prefect are larengly controlled by such considerations."

The Prefect is assisted in matters of general administration by a Prefectoral Council, composed of three or four members appointed by the President of the Republic. But with the exception of its duties as an aclministrative tribumal, its powers are purely advisory.

The representative borly of the Department is the General Council. ${ }^{6}$ Each eanton of the Department elects one member to this Council for a term of six years, one half of the members retiring every three years. The Comeil holds only two short sessions a year; and, as may be imagined, it has no important powers. It may adopt resolutions upon purely local matters not connected with general polities. It apportions direct taxes among the arrondissements. It may participate in the administration of highwars and edneation, ete. But all of its acts are subject to the veto of the Govermment. The Prefect carefully guides its deliberations. The prepares the budget which it nust vote. When the Council does rote a measure which it regards as a law, its execution is entirely dependent upon the Prefect; the Comncil cannot enforce it. The Prefect, on the other hand, ean enforce his own decrees as law. The very existence of the Council is dependent upon the Central Govermment for the latter may dissolve it, except when Parliament is insession.

\footnotetext{
SSce Jean Hennessy, Reorganisation Administrative de la France, 12.

- For a detailed study of the powers of the governing bodies in France, particularly those of alministration, see Giston . Teze, Elements du Iroit Public et Administratif. 'The powers of the department, the arrondissement, and the commune are disenssed, 138-160. See also Ilaurion, I'récis do Droit daministratif, 258. 333.
} 


\section{CONTEMPORARY FRENCH POLITICS}

Unfortunately, the powers of the general councils appear to be in the proeess of curtailment. Under a law passed August 10, 1871, ${ }^{7}$ these bodies could definitely legislate upon the construction and the concession (lease) of local railways. But this power was taken away from them in a law passed July 31, 1913, which provided that thereafter departmental assemblies could not even enter into a formal inquiry of such projects without first seeuring the authorization of the Government. The State justified this law on the ground that it alleady subventioned local railways, and that General Councils had appeared too radieal and too extravagant in the granting of privileges. But, nevertheless, another step was taken toward the deerease in local governing power. ${ }^{8}$

In the matter of publie works, the Central Government has also intruded upon the Council's activity. Formerly, the highway service of every vicinity was eontrolled by the General Council of each department under the terms of the Organization law of 1871, a power whieh apparently had been exereised with profit and discretion. But the Govermment, wishing to unify the road services under the Board of Bridge and Road Engineers already in charge of national roads, recently deprived the General Comneil of another of the few prerogatives left it.

Similarly, the Central Govermment has taken over the selvice of social assistance and of public hycciene, an essentially departmental and local function. By a law passed on Mareh 15, 1893, upon gratuitous medical as-

${ }^{7}$ For the General Council law of $A$ ugust 10, 1871, sec Codes et Lris.s, 6969.

"Ser IBuncheron, "Ta Réforme Administrative aprò la Gucre", in the .Junc, July, Augnst, 19ls, numbers of La Revuc Politique it I'arlementairs. 


\section{REGIONALISA}

sistance, the right of individuals to medical aid was substituted for former optional assistance, limited to publie resources. This law was of unquestionalole social benefit; but it neeessitated additional funds. However, instead of levying a special tax upon the departments or communes, Parliament preferred to subvention groups of departments directly; the departments, in turn, each receiving their share, were to subvention the eommunes within them. With the establishment of State finaneial aid, the Central Government in Paris laid down rigid rules, making for complete and unintelligent uniformity in the administration of medical assistance. The law virtually provided for the detailed operation of this eharity, and under the guise of financial support, it passed wholly out of the eompetence of the Departments and the General Councils.

The law of February 15, 1902, on the Protection of Publie IIealth contained the same financial and regulatory provisions. Likewise the law of 1905 upon Old Age Assistance, the law upon Numerous Families, and the law on Maternal Assistance provided for the indirect control of the Central Govermment over charities hitherto and more intelligently directed by loeal bodies. Loealities no longer care for their poor as under the eeclesiastical laws and the laws of the Revolution. The result of the change, according to French students, ${ }^{9}$ has been to create an undignified scramble among communes, for department subventions, to overlook the needs of intelligently atministered charities, and to impose upon the dignity of the poor. From the financial standpoint, extravagance in charity administration has greatly increased.

\footnotetext{
${ }^{9}$ See Louis Boucheron's article eited above.
} 


\section{CONTEMIPORARY FRENCII POLI'TICS}

By these means, the powers once exereised by the General Councils have gradually been taken away by the Central Government until, as representative bodies, they are inactive and uminfluential.

When the General Council is not in session, a Departmental Commission, usually composed of from four to seven members, sits as a permanent body; but like the Council, it has no power of control over the Prefect.

The arrondissement is an administrative subdivision of the department. There are 362 of them in Franee. Each is directed by a sub-prefeet, a representative of the prefect and the Central Government, who usually amounts to nothing more than a political agent, relying for advancement upon winning the electoral support of the arrondissement for the Government. The people are represented in an Arrondissement Comeil, usually eomposed of nine members elected by manlood suffrage for a term of six years. But this Council has little power because the arrondissement has no property and no budget. Consequently, its activities are restrained to apportioning among the communes the quota of taxes allotted to the arrondissement by the General Council. The arrondissement is an artifieal mit, and especially since the abolition of the scrutin d'arrondissement in the elertions to Parliament, ${ }^{10}$ there are few reasons for its existence.

The arrondissements, in turn, are divided into cantons, of which there are now about 3,000 . The canton likewise has no personality although it is used as an electoral and a judicial mnit. It serves as a district for the Justice of the Peace and for choosing members of

${ }^{10}$ See Pr. $102 f f$. 


\section{REGIONALISH}

the General and the Arromlissement Comncils. It has few, if any, administrative funetions.

The eommune, of which there are more than 36,000 , is the basis of loeal govermment in France. ${ }^{11}$ Its size varies from the smallest village to the largest city. With the exception of laris, Lyons, and IIarseille, every commune possesses the same form of government. The Mayor of the commune eorresponds to the Prefect of the department. IIe is the agent of the Central Government and the administrator of local affairs. Although not direetly appointed by the President of the Republie, lie is not directly responsible to the people, for he is elected by the communal council of which he must be a member. He serves for a term of four years and is assisted by adjoints whose number varies with the size of the commme. The IIayor has considerable appointive power, and, with the exception of the police, he also may suspend or dismiss any municipal officer. The only authority able to review his acts in this regard is the Council of State, the highest administrative court in the Republic. Ile also has general charge of the finaneial affairs of the eommune. But the Nayor's deeisions upon matters such as eommunal poliey and publie health can usually be annulled by the Prefeet, who in many instances can order him to earry out certain measures. Financial aceounts must be submitted to the Prefeet for approval. The Prefeet may suspend the Mayor from office for a month; the Minister of Interior, for three months; and the President of the Republic may remove him altogether. Thus the Nayor is actnally

"For an extended account of the powers of communes, communal councils, mayors and other municipal officials, see L. Morgand, La Loi Municipale, 2 vols. 


\section{CONTEMPORARY FRENCH POLITICS}

subjected to the greatest restraint, and conformity with the desires of the Central Govermment is assured.

The Communal Comeil, the representative body of this unit, varies in size, according to the population, from ten to thirty-six members. It is elected by manhood suffrage for a term of four years. The powers of this body are much more extended than those of the General or Arrondissement Councils. Many of these powers, however, are subject to approval by higher officials, such as measures involving the disposal of municipal property, the control of strcets, and the framing of the communal budget. In the latter, the Prefect may increase or diminish receipts; but with several exceptions, he can only reduce and not increase expenditures. In the matters of fire protection, municipal cemeteries, parks and other local services, however, the Council and Mayor exercise an independent control. But the Prefect ean always suspend the Municipal Council for a month; while the President of the Republic may entirely dissolve it and appoint a commission with limited powers to direct the commune for a period not longer than two months, when a new council must be elected. IIcre again the Central Government weighs down with a firm hand. ${ }^{12}$

The extent of Govermment intervention in strictly communal affairs is shown by several incidents connected with the municipality of Lyons, the second largest city in France. During the war when the Central Govermment should have been completely oceupied with problems of national defense and when the cities would naturally have been allowed to exercise their

${ }^{12}$ For a more extended leseription of the local system of government in France, see Munro, The Government of European Cities, Chapter I. 


\section{REGIONALISM}

greatest initiative, the city of Lyons eould not even revise a street-cleaning eontract withont securing the approval of the Govermment in the form of a regular deeree. This case was in regard to an agreement with a Mladame Monin relative to the collection of dirt upon the city streets; the decree was issued September 24, 1917. Another example occurred on the same day when the Govermment approved an agrecment entered into by the Mayor of Lyous and a Blast Furnace Company at Pont-à-Monsson for the delivery of some water pipes. ${ }^{13}$ By these means the Central Government at Paris definitely rhecks, or at least controls, loeal autonomy and independence.

Partieularly as to the commune, a Freneh student writes:

Unfortunately, the French commune does not yet have its liberties. Placed mder the nominal dependence of the prefeet and his ministers . . . it ean only aet, develop and prosper with the permission of irresponsible bureaus; it ean only reform with the consent of foreign seribes and be resigned to interminable delays. In order to make a local affair "emerge," as it is said, from a ministry . . veritable exoreisms are necessary. ${ }^{14}$

Such is the present state of centralization in loeal govermment. It presents two vital objections: Firstly, it deprives the people of a direct participation in what should be purely communal activities. With the exeeption of a very few local officials, the only elected representatives are deputies, and the members of the general arrondissement, and commmal eouncils. Elections do not eome with the frequency necessary to inspire public interest in local affairs. In addition to the small num-

${ }^{13}$ Quoted in E. Merriot, Crér, ii, 1si, note.

"Ibid., ii, 186. 


\section{CONTEMPORARY FRENCH POLITICS}

ber of officials popularly chosen, interest in their selection is further diminished by the complete subordination in which they are hold. When representative bodies have their natural powers absorbed by a distant authority, the training of citizens in the responsibility of government-a training which they must have if a democratie régime is to be a success--is prevented. The success of American Government institutions has its roots in the New England town meetings, and in local governments everywere carried on by eitizens, independent of bureaucratic interference. In France, on the other hand, and for historic reasons previously discussed, the Republic is fed from above. This is perhaps its greatest weakness.

Secondly, the centralization of local governing powers in Paris makes for confusion and inefficiency. The testimony of Frenchmen offers the most eonchusive evidence. M. Barthe, in introducing a resolution for decentralization, said to the Chamber:

Conceived and dereloped by the administrative authority itself. our administrative system is too visibly inspired by the solicitude of hierarchical control and not enongh by the solicitude of service. Formalistic to an excess, our administrations are increasingly clogged with red tape and routine. They create serions obstacles to the economic activity of the country by their systematic ignorance of the realities . . . of production and exchange. ${ }^{15}$

MI. Jean Hemnessy, one of the foremost advoeates of decentralization by the increase of self-governing powers, has written:

Before 1914 an over-centralized France adapted itself with difficulty to the rreat ecommic transfornations of the century; it dirl not exploit all of its natural resomeres; it did not profit from its inromparable gengraphie position. Its

"so (2uoted in Hlenmessy, op. ait., 131.

$$
382
$$




\section{REGIONALISM}

economic wealth was dereloped too slowly; the convergence of its railway system toward l'aris dicl not sufficiently place its different regions in relation with agch other and with foreign comtries. 'The interior of the country was not commerted by means of communication directed fowald the ports, with foreign eountries; river navigation was not organized; now waterways had not been developerl; heary merehandise condel not reach the coast without being overburdened with enormous freight: lacking return freight and because they eould not find well-equiped ports, the great ships of commeree turned away from our coasts; and our merehant marine, notwithstanding large subrentions, did not, so to speak, exist. ${ }^{16}$

Senator ITerriot expressed the opinion of perhaps the majority of Frenchmen when he wrote in regard to the aeeumulating ills of over-centralization, as follows:

Our administrative régime appears to-day as a mosaic. It borrows elements from all the former regimes. The eonception of authority has prevailed over the temdeney to liberty. The Freneh commmes lack liberties granted to similar units in foreign countries. The departments are administered by prefeets whom nsage has made sort of electoral intendants, displaced according to the raprices of central or local polities. The commmes remain in warkhip. The department no longer has the advantages of liberty nor the benefits of national administration. . . . The liepublie has had cminent Prefects in general, entirely due to their own personality. But to what removals have they not been condemned? Hazand redneed them; hazard raised them. The political shoal has little by little eorrupted the institution. Cimrotted mayors, meertain prefects; this is what om democracy retains to assme our future. It deserves better. A vetorions France camot, without essential injury, be content with such a régime-which is neither that of authority or that of liberty. ${ }^{17}$

The celebrated words of Iamemais epitomize these defeets as follows: "With centralization, you have apoplexy at the center and paralysis in the extremities."

\footnotetext{
16 Ibirl., 114.

"Créer, ii, 179.
} 


\section{CONTEMPORARY FRENCII POLITICS}

To understand the movement, present and historical, for the restoration of local governing powers in France, a brief history of their development will first be given.

French eentralization is a result of long centuries which worked for the ereation of French unity and the French nation. From a country originally composed of feudal holdings, independent and antagonistie, in which the king was merely a baron upon his limited estates along the Seine and the Loire, a nation has emerged. The feudal domain was gradually absorbed into the royal domain; seigneuries were united and feudal power was transferred to the king. A continual series of foreign wars, of attacks by or upon enemies on every side-Spain, England, Austria, Prussia, Sweden, and the Netherlands-stimulated this process and brought the royalty greater power. War was always imminent and a strong central authority became a contimuous necessity.

It was Louis XIV who erowned the work of French unity. At his accession France divided its legal jurisdiction between a written law and local eustom. A majority of Frenchmen were ignorant of the national language. France was simply a federation of provinces, each of which used its own laws. The Chancellor used two seals, one for Dauphine, the other for the rest of the kingrom. Cities were independent ritadels. Regional States-Generals, estalolished by financial neessityr, aried for independence. But through the intendants, the predecessors of the modern prefects, the king overcamo local independence and contralized adminis- 


\section{REGIONALISM}

tration; armies, citics, provinees, judges, came under his direct control. Louis XIV traced the outlines which Napoleon was to fill.

The weakness of succeeding sovereigns postponed the eompletion of the work Lonis had started. The Revolution found France still a divided and morcellated comtry. Lorraine was regarded as a foreign province; Béarn demanded a distinct sovereignty ; Dauphiné pretended to be at the same time in and ont of the kingdom; Boulogne and Nararre started separatist movements, deelaring null the royal ediets joining them to France. The situation confronting the Revolution was a serious one and led to the appeal for unity without which the Revolution could not suceed. The Constituent Assembly of $1789^{18}$ relied upon a common devotion of the commumes of France to the fatherland to enforce this unity. The institutions of local government which it established were marked, consequently, by local independence. The Assembly divided France into about eighty-five departments, which in turn were formed into districts. The intendant, a regalian office, was suppressed and elective officials held the executive eontrol of the departments. The central power had no representatives in local assemblies. The communes or paroisses, of which there were about 44,000 , were uniformly organized as self-governing units with a mayor and council elected by nearly universal suffrage. They also were practically independent of the central authority. The Revolution thus achieved a demoeratic and a decentralized system of self-government; but French unity had not become firmly enougl established to prevent the

${ }^{14}$ A bricf history of French arministrative organization and decentralization sinco 1789 will he found in G. Jèze, Eléments du Droit I'ublic et Aministratif, 134-137. 


\section{CONTEMPORARY FRENCH POLITICS}

abuses of suel extensive liberty. Consequently in 1795, because of the excesses of the Reign of Terror which arose under loeal governing bodies uncontrolled by the central authorities, a reorganization beeame neeessary. The Directory immediately upon coming into power suppressed the eommunes as a self-governing unit and substituted for them the canton, whose administration was placed in the hands of a directory of five to nine members popularly elected. As many small communes were grouped into a single canton, mueh of the loeal and unrestrained independence was destroyed. Although this cantonal system led to a more effective control of the country, it could not become the satisfaetory basis of local govermment beeause the canton was an artificial division. The eommune, by tradition and by natural boundaries, has been and always will be the natural unit of local administration.

Napoleon may have recognized this fact, for in February, 1800 (twenty-eight pluviôse, Year VIII), upon his advent to power, he reëstablished the commune as the governmental unit. Completely out of sympathy with popular demands for freedom in govermment, he did away with the election of offieials. Henceforth mayors, adjoints and eonncilmen were to be appointed by the central régime. The department was retained, but at its head was placed an appointive prefect; the arrondissements appeared in place of the old districts, and were presided over by the sub-prefeet, also appointed. These foatures the Third Republic still maintains. With the growth of the Empire, France little by little lost its local and regional liberties.

To these centralizing tendencies, men like Villèle and Corbière were not slow in objecting. But no fundamental change in the Napoleonic administration was 386 
made even after the Restoration in 1815. Numerous projects appeared urging the extension of local selfgovernment. In 1829 the Martignae project was introdueed, sulbstituting the election of the general and arrondissement councilors for their appointment by the central power; but it failed of passage and eaused the fall of the eabinet. It was only after the Revolution of 1830, bringing Louis Philippe into power, that this movement bore fruit. By the laws of 1831 and 1837 munieipal govermments were reorganized so that couneilors could be elected indirectly by a suffrage based on property and edueational qualifieations. The mayors and adjoints still were appointed, but were now to be taken from menbers of the council; the municipal councils were granted limited power in eertain matters of local administration. In 1833 slight ehanges were also made in departmental organization.

The Revolution of 1848 gave a new impulse to the movement for decentralization. A project with that purpose was submitted to the Couneil of State, which provided for the substitution of commissions of the arrondissements, formed of the general eouncilors of each arrondissement, for the old arrondissement and eanton councils. But the National Assembly did not approve the measure. However, municipal couneils in communes of not more than 6,000 inhalitants were permitted to select their own mayors. But the larger eities eontinued under the old jurisdiction. The Seeond Empire in 1852 took away this privilege from the communes, and the Govermment also abolished the praetiee of ehoosing mayors from members of the numicipal eomneil. The cntire spirit prevalent in the Government of Napoleon III was in complete agreement with that of 387 


\section{CONTEMPORARY FRENCH POLITICS}

Napoleon Bonaparte. ${ }^{19}$ The prefects exereised complete power not only over the departments but over communes. In 1866 and 1867 laws were passed somewhat enlarging the attributes of the general and municipal couneils, but they were already so effectively controlled by the central authority that mumicipal life remained practically extinet.

This repressive poliey naturally met with opposition. Demands for reform culminated in the program of Naney in 1865, to which representatives of nearly every political faith adhered-Berryer, de Broglie, CasimirPérier, d'Haussonville, J. Simon and Jules Favre. ${ }^{20}$ This conference proved a landmark in the movement for self-government. It officially gave birth to the regional idea-the ereation of a region of considerable powers, supplanting and greater than the departmentalthough several writers had previously made the suggestion. Auguste Comte in 1854 urged the gromping of departments into seventeen regions; while Le Play, in his hiforme Sociale en France in 1864, urged the grouping of the departments into thirteen "provinees."

The Assembly of 1871, after bringing the war to a close, partly oecupied itself with the administrative reorganization of France. As a temporary measure it decided, except for a few alterations, to return to the system used in 1848. One of these changes was that in all cities, except those having over 20,000 inhabitants, the mayols might be thosen by the municipal eouncils. The Assembly having retained the general features of the centralized government laid down by Napoleon I, op-

\footnotetext{
"See De la (ioree, Mistoire du Second Empire, ii, 48 et seq. for Napolron III and decentralization.

2" For the Naney frogram, as advoeated hofore the National Assembly, see G. IImotaux, op. cit., i, 234, 235.
} 


\section{REGIONALISI}

position in favor of incrased local freedom arose in the Third Republic. In an effort to silence it by oppression, and to make its own position permanent, the MacMahon Government secured the passage of a law in 1874 which suppressed the right of eommunes to choose their own mayors. This law was repealed upon the aceession of a new govermment in 1876; and in 1882 every commune, regardless of its size, was allowed to choose its own administrative officials. On April 5, 1884, a municipal code ${ }^{21}$ was promulgated combining and organizing the many different laws upon municipal government which previous régimes had framed. With the exception of a few amendments, it provides the present basis of municipal organization in France, which has been outlined at the beginning of the chapter.

\section{III}

Throughout the history of this development two eurrents of reform may be discerned. The first limited itself to the extension of the powers of local assemblies and units at present in existenee. Such a movement was suceessful enough to extend the financial powers of the general conneils by a law passed in July, 1898, and also those of the municipal comncils, in a law passed on April 7, 1902. Nore recent attempts for increasing the powers of local assemblies are too numerous to recount. Three propositions upon communal organization were introduced in Parliament about 1900; since then, at least thirteen propositions upon cantonal organization and eleven bills.upon departmental organiza-

${ }^{21}$ For the Law of Munieipal Organization of April 5, 1sst, see Codes et Lois, ii, 95i5-967. 


\section{CONTENIPORARY FRENCH POLITICS}

tion, including the suppression or the reduction of the under-prefect, have also been introduced. The reforms advoeated place much of the present initiative of the prefeet upon the general comeil, and free him from the constant interference of Paris anthorities. A few even advocate the election of the prefect or of the under-prefeet; many advocate the total suppression of the arrondissement. The extension of the powers of the commune receives the strongest supporters because it is the natural and traditional unit of govermment in Franee. $^{22}$ The increasing responsibilities of munieipal-

${ }^{22}$ The most extensive effort toward decentralization in France was that attempted by the Paris Commume of 1871. According to the Official Journal of the Commune (April 20, 1871), it demanded:

"The absolute independence of the Commune and its extension to every locality in France; the assurance by this means to each person of his rights in their integrity. .. The imlependenee of the Commune will have but one limit-the equal right of independence to be enjoyed by the other Communes who shall adhere to the contract. It is the association of these Communes that must secure the unity of Franee.

"The inlerent rights of the Commune are these: the right of voting the Communal budget of receipts and expenditure, of regulating and reforming the system of taxation, and of direeting loeal services; the right to organize its own magistracy, the internal police and public education; to administer the property belonging to the Commune; the right of choosing by election or competition, with responsibility and a permanent right of control and revocation, the communal magistrates and officials of all sorts. ...

"Paris desires no more than this, with the conlition, of course, that she shall find in the Grand Central Administration, composed of delegates from the Federal Communes, the practical recognition and realization of the same principles. . . The unity which has hitherto heen imposed upon us by the Empire, the Monarchy, and the I'arliamentary fovermment is nothing but a centralization, despotie, mintelligent, abitrary, and burdensome. I'olitical nuity as desirel by l'aris is a voluntary assoeiation of each local initiative, a free and spontaneous coipheration or all individual enereries with one common ohjert-the woll-heing, liberty and security of all. ..." Quoted by II. M. IIymlman in Clemencean, the Man and His Time, to."

See also (r. Ilanotaux, op. rit., i, 16s, 169. 


\section{REGIONALISM}

ities makes an increased freedom imperative. As Senator IIerriot says, "the cities of France are not only inert statues upon the Place de la Concorde. They are aeting, living, growing beings, obliged to prosper under penalty of suecumbing. They must, in spite of constraint and stupidity, defend their interests, create wealth, and improve by their efforts, the welfare of their citizens. . . . It is by the reorganization of the commune... that administrative reform can be suitably eommeneed." 23

IIowever, the efforts to increase the independenee of bodies at present existing, as noted, have largely failed, and the tendeney in France is toward a greater concentration of power in the State authority. In the belief that the present units of government, espeeially the departments, beeause of the strictures in which history and their composition lold them, will never be given any amount of autonomy, the movement of Regionalism has developed. This movement aims at the total suppression of the departments which it considers as artifieial and over-numerous units of government. In their place it would erect a great region based upon natural eeonomic and historie boundaries. ${ }^{24}$ These regions would be much larger than the present departments and consequently there would be a smaller number of them. They would be goverued by a recrional assembly, endowed with autonomous powers which would extend to the development of regional interests, economic and po-

${ }^{23}$ Créer, ij, 189.

${ }^{24}$ For example, the region of Lille is characterized by its textile industries; the region of Dijon by its unique system of inland water transportation; the region of Cirenoble by its electric power and manufacturing; the region of Marseille by its port facilities and by its Oriental and Afriean trade. The regionalists wish to impose upon these economic delimitations a political delimitation. 


\section{CONTEMPORARY FRENCH POLITICS}

litical. As a result trade would be stimulated and govermment administration be intelligently carried on.

The first argument, then, for the ereation of such a unit of administration is that if new powers are to be actually exercised, it is necessary to wipe out old local organs of government and start with a elean slate. The second argument is that the department is artificial in its composition and that consequently it cannot intelligently direct the economic interests of the locality. Because of its small size and its lack of dignity, it does not attract men of ability to its publie offices. The third argument is one of economy. A larger administrative unit will decrease the number of Government employees, reducing finanial expenditures and political profiteering. Aceording to the report upon, the regional proposition, introduced by M. Rognon in 1916, the adoption of the region would result in suppressing :

53 prefects

275 sub-prefects

20 secretary-generals

159 comneilors of the prefecture

53 general treasurers

362 financial receivers

53 recristry directors

53 indirect tax directors

362 road overseers and a great number of tax eollectors and justices of the peace. ${ }^{25}$

The fourth aroument for the creation of a region, supplanting the department, has arisen out of the problem of reconstruction: Finst, in regard to the government of Alsace-Lorraine. Although the people of these provinces have welcomed their return to France, they

${ }_{25}^{25}$ Quoted in Hemuessy, op. cit., 133.

$399^{6}$ 


\section{REGIONALISH}

do not relish the restrictive, bureaucratic and inefferent control of the French Ministry of the Interior. Cunder German rule, and because of a desire to conciliate the Alsatians, they were given, at least so French regionalists assert, more administrative autonomy than that which the French department is accorded. Consequently only a regional organization, embracing these provinces in their entirety, with local administrative liberties, will assure the haply reabsorption of the lost provinees in La Patric. Secondly, the devastated regions lave asked for liberation from the binding restraints in which the Paris Government was holding them in their efforts at relabilitation. The cities and the Chambers of Commerce of Lille, Roubaix, and Tourcoing requested the Govermment to organize the devastated regions upon the regional principle. Through this type of organization, they believed the liberated area of France conld best utilize its own energies in the tremendous task of reconstruction.

Sympathy with this argument was expressed by the Congress of the League of l'rofessional Representation and Regionalist Action, held at Lyons, April 20 and 21, 1919, which adopted the following resolution:

Whereas it is happily inpossible to frustrate the people of Alsace and Lorraine from the benefits of their regional organization or to submit them to the narrow and tyrannical régime of our old, imperial administration;

Whereas the populations of the liberated regions find themselves in many respects in the same situation as the prople of Alsace and Lorraine, with this single difference, perliaps, that they lave suffered more larm from the war and that they hase fewer means of hringiner a remedy to it;

Whereas, they have therefore every reason to have their right realized to be admitted to all the benefits of regional, autonomous organization, alone capable of hastening, in a 


\section{CONTEMPORARY FRENCH POLITICS}

larger and more flexible framework, their economic reconstruction;

Resolved, that the Leagne of Regionalist Action would neglect its very principles if it did not express the wish that prompt satisfaction be given them and to the other regions of France at the same time;

And that for these reasons, the Regionalist Congress of Lyons ask Parliament to vote without delay the law upon regional organization. ${ }^{26}$

\section{IV}

Since the congress of Naney in 1865, the regionalist movement has been effectively earried on by many different organizations. In 1895, the National League of Decentralization was formed, only to sueeumb shortly afterward. In the same year, MII. Paul Deschanel, the present President of the Republie, de Lucay, and de Marcère, produced books urging the reform. About this time, La Nouvelle Revue published a series of articles urging decentralization, to which the great Provenȩal poet, Frédéric Mistral, contributed. In 1898, a Breton Regionalist Union was organized, to be followed in the next twenty years by some ten other provineial organizations.

The French Regionalist Federation arose from the combination and the federation of smaller organizations. Founded in 1900 and eonstituted "outside and above all political parties," it proposed to coördinate the efforts of every society and individual interested in

${ }^{26}$ Euvre, April 23, 1919.

Another unique argument for regionalism was adranen at this Congress by a Walloon from Tiége; lie urged the ereation of regional autonomy to overeome the only obstacle in the way of Jelgian union with lrance! That such a thing is contemplated is interesting, to say the least. 


\section{REGIONALISM}

regional reform. It did not supplant existing organizations, it merely feeterated them. liy means of press campaigns and conferences, it was able to arouse considerable interest in this new idea of government. Among its members were such prominent statesmen and politieians as Alexandre Ribot, Paul Deschanel, Jean Hemnessy, and Lonis Marin, and such literary men as Mistral, Barrès, and Duerocq. In fact, the regional movement was as much directed toward the revival of regional art and literature as toward the institution of a purely political reform.

The League of Professional Representation and Regionalist Action was founded in April, 1913, by M. Jean Hennessy, who beeame and still is its President. Differing from previous organizations, it asked for the election of a Regional $\Lambda$ ssembly composed of representatives of economic and professional interests in addition to the mere ereation of the regional unit. ${ }^{27} \Lambda$ month after the organization of the League, in May, 1913, a bill upon regional reform, creating professional regional assemblies, was introduced in the Chamber of Deputies. ${ }^{28}$ After its introdnction, the League organized eonferenees in the principal cities of France to arouse popular interest in the reform. On February 1, 1914, a Congress was held in Toulouse to which the Federation of Agriculture, Commeree and Industry, and the Chambers of Commeree sent delegates. But despite the propagandist efforts of the League, all attempts at regional reform have so far failed to pass Parliament.

${ }^{27}$ See PI. $362-364$.

${ }^{24}$ Before this date, seren similar projects had been unsueessfully urged before the chanber. In 1910, M. Briant, then Premier, alvoeated the region as a neessity for electoral reform. He was unable to convince Parliament of his point of riew.

395 
During the following four years, four bills upon regionalism and decentralization were introdueed.

The Administrative Commission of the Chamber of Deputies, of which MI. Hemnessy was the rapporteur, took these various measures and combined them into a compromised proposition which was a very poor substitute for the regionalist idea.

The first step in administrative reform, according to the report of this Commission, should be the ereation of a region and the fixing of the powers of its representative assembly, its method of selection, and the establishment of a budget. With this step achieved, the reform of other loeal institutions may be brought about, as well as that of the publie serviees.

The delimitation of the region was recognized by the Commission to be a diffieult task. It finally deeided to pass this responsibility on to the Couneil of Ministers who by decree should fix the limits and the capital of each region after having received the advice of the Council of State. This latter body, before emitting its advice, should consult the wishes of the loeal bodies, such as Chambers of Commeree, general, munieipal, and arrondissement eouncils, and professional organizations. On the petition of at least one fourth of its voters each arrondissement might protest against the incorporation of the arrondissement in one region, in favor of another.

The administration of the region was to be vested in a representative of the central power. In theory the Commission believed it hetter for each region to elect such an official; but beeause of the presence of war conditions, it did not believe the State could safely relinquish its control. In addition to this prefect, a regional commission was to be erected. Its method of election, its powers and those of its president, were to 396 


\section{REGIONALISA}

be the same as those of the present departmental organizations. Many members of the Commission believed that the region should be directed lyy a sur-prefect, underneath whom would be the department prefects. But this idea was also abandoned, and the direction of the region was confided in the l'refect of the department in which the capital (chef-licu) of the region was to be loeated. The representative body of the region, known as the Regional Council, was to be elected by the department general councils. Each arrondissement was to have at least one representative in a Regional Couneil. The number of the regional councilors was to equal one fifth of the general councilors. The powers of this Comneil, naturally difficult to define, were left rather vague. The principle was laid down that the Council should control the administration of all public services extending beyond the department and not essentially of a national character, and those of a local nature which at present congest State administration. The three matters speeifically intrusted to this Regional Couneil were edueation, to the extent of its adaptation to local needs; social assistance, such as aid to the hlind, deaf and dumb and to tubercular patients, which extends beyond the needs of single departments; and public works, such as regional water transportation and local railways. In general, even if the regional eouncils were granted no more power than the present departmental councils, they could do immensely more in the development of industry because of the natural, economic delimitation of the region. The departments are organized so that they have competitive and conflicting economic interests whieh their general councils cannot effectively develop. The region, in combining departments of similar composition and interests, will inmeasurably improve their 397 


\section{CONTEIIPORARY FRENCII POLITICS}

produetiveness. In place of the conflicts and the antagonism whieh the present departments engender, the region, it is urged, will coördinate and confederate mutual interests.

The financial resources of the region, the Commission left to the determination of the Fiscal Legislation Commission, except to suggest that the regional budget be composed of additional centimes, levied upon the national taxes, and voted by the regional couneil. Furthermore, the region should be given the right to create new taxes, a right which the local assemblies of France do not now have. In this respect, they are denied a prerogative which nearly every local assembly in the world enjoys. The problem of a regional budget is of the most extreme importance, because without financial independence from the central power, local self-government will be almost impossible.

This, the last proposition upon regionalism, presents many serious defects. First, it does not suppress the department; maintaining it with its present powers, it merely superimposes another unit of government-that of the region. The executive power of this region is vested in an appointee of the State. So far the bill appears only to add an additional complication, through which the Ministry of the Interior will be able to increase its interferences. Secondly, the composition of the Regional Council is disappointing; the couneilors are not elected, as are the nembers of the general, arrondissement, and communal councils; but they are ehosen by the general councils themselves. A very valuable opportmity has here been lost to increase popular participation in government. The powers of this Council are also open to criticism. Edueation has become a national function; and unity of language has with too 


\section{REGIONAIISM}

much difficulty been imposed to renomner this national eharge. Social assistance is an affair of the eommmule; while public works, as local guarrels over roats and the needs of national railways, have shown, is also largely a national affair."20 Finally, aceorting to the terms of the bill, the Council is given no authority to impose its decisions upon the departments and the communes within it. Its powers would therefore be advisory. In sum, this bill does not introduce any effective imnovation in decentralization and in self-government. Because of its compromises, it does not receive the support of the regionalists, ${ }^{30}$ and naturally it is opposed by the opponents of the theory.

\section{V}

The principal objection to the adoption of regionalism is the same bete noire which haunts French polities generally-the fear of the destruction of national unity. As noted, this fear arises from profound historical causes. To empower regional assemblies with any amount of independence would open the temptation to destroy this unity. Such an argument is disapproved, however, by the fact that the strongest nationalist elements in Franee, the Orleanists and the Ligue des Patriotes, through Naurice Barrès, are ardent adroeates of regionalism.

The strongest opponent of any measure of decentralization and espeeially of regionalism, is the French Government. Despite its ehanging composition, succeding

* This statement does not apply to purely local undertakings such as tramway lines, power plants, ete., which there is every reason to believe a regional assembly could efticiently administer.

${ }^{30}$ For a more detailed account of the Regionalist. Plan, sce Jean Hennessy, Régions de France (1911-1916). 


\section{CONTEMPORARY FRENCH POLITICS}

Govermments jealously guard and attempt, openly or by stealth, to extend their absorbing and penetrating arms. Any attempt to deprive the eentral power of its strength, therefore, is bound to be unwelcome and to be bitterly and effectively opposed by the wide organization which the Govermment ean muster against it. ${ }^{31}$. Finally, imnovation, involving the complete change of one institution of government for another, is much more difficult to accomplish than the reform of existing institutions. For these reasons, it may be that the movement for selfgovernment in France will be satisfied with the extension of the powers of existing bodies. From the politi-

${ }^{3}$ The most recent defense, written in the light of the lessons of the past war, of the French administrative system as it now exists, is that given in the preface to the ninth edition of Maurice Hauriou's Précis de Droit Administratif (Librairie de la Société du Recueil Sirey, 1919).

M. Hauriou maintains that the existence of a highly centralized and bureaucratic Germany deniands that France support a system equally strong. He belieres that it was the system of eentralization in France, Russia, and Italy, which succeeded in rapidly mobilizing military preparations and therefore preventing Germany from winning the war. It was the French system of centralization, he says, which enabled the French army to stand the first shoeks of the war until the slower processes of English decentralization came to her aid. "If eivilization was saved, it was by centralization.',

He believes that it is impossible to maintain a permanent and molile army along with a decentralized politieal and administrative system.

From the standpoint of interior problems, Professor Hauriou says that a strong centralizel government is needed to cope witl the fores now endeavoring to overthrow it. To prevent the control of the state by labor syndicates or by eapitalistic trusts, "a strong centralized executive is neeessary which will exercise a preventive action, thanks to the ommipotence of its police, and it neessiry, ly the direet participation in the enterprises which may be of public inferest.',

The traching of the war has shown that there has been too much lawk of courdination hetweon the different ministries, and that what is really necessary is a new eentralization which will unite the different hearls of the publie services into one coördinating borly. 


\section{REGIONALISM}

cal standpoint such a reform would be satisfartory ; from the eeonomic point of view, because of the artificial structure of the departments retained, it would be valneless.

Whatever direction this movement may take in Framee, whether it be in the adoption of regionalisin or in the mere enlargement of departmental or communal powers, it is very likely that France will soon achieve some sort of administrative reform. The present system is a remnant of the Empire, based upon authority, clothed with stupid inefficiney, and inconsistent with a Republican régime. It is only through vigorous, local institutions of govermment that citizens ean be rigidly trained in eivie responsibilities. It is snch an edncation which French democracy appears to need. Now aceustomed to regard the Govermment as something foreign to them, many Frenchmen have lost interest in the maintenance of its spiritual integrity. Dependent upon it, on the other hand, for almost all of their economic needs, they regard every means of influeneing it as legitimate. The extension of local, decentralized power and responsibility will do much toward overcoming this attitude. 


\section{CHAP'TER XIII}

WHAT TIE FRENCH PEACE TERMS MIGITT HAVE BEEN

Chaque puissance chrrehe ì regagner au moins quelque chose de ce qu'clle a perdu $\mathrm{cn}$ empechant une troisième de s'agrandir: tous les ćléments politiques sont en combustion; ct le dénouement final n'est attendu par personne.-METTERNICH.

The one enduring thought in the French mind throughout hostilities and one which remained dominant through every phase of the peace negotiations, was that terms should be imposed at the end of the war which would forever wipe out the menace of another German attack. A fear of Germany was the eontrolling impulse in the French heart. When the armistice was signed (the 11th of November, 1918) French opinion was definitely obliged to formulate the terms or "guarantees" embodying this security. It was quite natural that strategic considerations should suggest themselves as alone capable of supplying these guarantees. The precedents of history and the past policies of the enemies of France, motived more by a desire for aggrandizement than French impotence, were certain to affect her present statesmanship.

France remembers her history. She remembers those years of the Napoleonie tribulation which flanked her on all sides with hostile powers-the Low Countries, the German Confederation, a neutralized Switzerland, a 402 


\section{FRENCH PHACE TERMS}

Tegitimist Spain. She remembers low the Count of Artois was forced to avanate fifty-three of her fortresses, laving France to traat with her enenies at the Congress of Vienna wholly disarmed; and after Waterloo, those three long years of foreign occupation in which the Austrians, the Prussians, the Spaniards, came pouring into her departments across the Alps, the Rhine and the Pyrenees-a million and a half soldicrs swarming over an already war-ridden eomntry. Pillaged villages, prefects replaced by Allied governor's, savings bauks confiseated, arhitrary requisitions appropriating not only eommunal hut individual wealth-these things, generations do not forget.

The Duke of Wellington, writing to Lord Castlereagh, expounded these principles of diplomacy as follows:

The coalition has no reason to favor the French people; its sensibility is only a wounded vanity. It is more desirable, from a number of points of view, that the people of France, if they do not yet know that Europe is too strong for them, may be warned of the fact and that the day of retribution must come. Thus, according to me, it would not only be unjust for the sovereigns to favor the people of France on this subject at the expense of their own people, but the sacrifice wonld be impolitic, seeing that it would deprice then of the oceasion of giving to the people of France a grand lesson in morality. ${ }^{1}$

Franee remembers 1870 even more vividly-not only the brutal origin of the war, not only Alsaee-Lorraine, but the four months' siege of Paris, the occupation, and the indemnity. The exactions of the victor first exhibited themselves in the feverish haste in which France

\footnotetext{
i, 79 .

'Quoted from Debidour, IIistoire Diplomatique de l'Europe,
} 


\section{CONTEMPORARY FRENCH POLITICS}

was compelled to sign a peace. The peace preliminaries which France was compelled to sign upon the 26th of February included one of the largest indemnities in history (5,000,000,000 franes) and the cession of AlsaceLorraine-about 5,600 square miles of territory and 1,600,000 inhabitants. She had already been the victim of the dispatch at Ems, of ravaged departments, and of a besicged Paris. The people of her country were starving, and among nations she had no friends-Switzerland alone brought aid to her. ${ }^{2}$

Smarting under past oppression, especially from that heaped on her by Germany, it was but natural that the people of France should now demand retaliation in the spirit of revenge. To their credit, it must be said that such a spirit was considerably repressed, and that their demands were limited to reparation and to security. President Poincaré, at the first plenary session of the Peace Conference, upon January 18, 1919, ably expressed the nation's desires in these words:

You search only justice and a justice which has no favorites. Justice in territorial problems, justice in financial problems, justice in econonic problems. But justice is not inert, it does not take the part of injustice. It demands from the first, when it has been violated, restitutions and reparations for

2M. Thiers vividly described the effects of the War of 1870 on France in a speech on the 19th of February, 1871:

"Franee, hurled into a war without a serious motive, without sufficient preparation, has seen half her territory invaded, her army destroyed, her fine organization shattered, her aneient and powerful unity compromised, her finances shaken, the greater part of her children torn from their labors to go and ilie on the battlefield; public order profoundly distubed by a sulden apparition of anarehy, and after the foreel surrender of Paris, the war suspended for a few days only, realy to break out again, if a Government enjoying the estrem of Furope, courageously accepting fower, assuming responsibility for painful negotintions, does not ariso to put an end to terrilile calamities!" Ilanotaux, op. (it., i, 70. 


\section{FRENCII PEACE TERMS}

the peoples and the individuals who have been despoiled or maltreaterl. In formulatine this legitimate claim, it is obediont, neither to hatred nor to an instinetive and a thomghtless desire for reprisals; it pursues a domble object: to render to carh his due and to discomage the recmence of erime, by pumishment.

Justice still demands muder the inflnence of the same sentiment, sanetions against culprits and efficacious wnarantees against an offensive retmon of the spirit which perverted them, and it is logical in demanding that these gnarantees be given, first of all, to the nation which has been and who still may be the most exposed to agrression or menace, who has many times risked sulmersion mder the periodic wave of the same invasion. Justice excludes dreams of eonquest and of imperialism, the disdain of national desires, the arbitrary exchange of provinces between States, as if their peoples were only property or pawns in the game.

Forty-eight years ago, day for day, the 1Sth of Jannary, 1871, the German Empire was proclaimed by an army of invasion in the chatean of Versailles. It demanded the rape of two French provinees as its first eonsecration. It was thus vitiated in its very origin and carried in itself the germ of deatls: born in injustice, it las ended in opprobrium. You are assembled to repair the wrong which it has done and to prevent its retmm.

It was also to be expected that France would prevent, so far as possible, the "return" by the methods which Germany and other enemies of France had always used to render her powerless-by the measures which the "old diplomacy" invariably took to insure the gains of victory. So far as they were limited to guarantees there was nothing directly immoral about these means eompared with the ends they attempted to serve; but their defeet lay, as the world was gradually coming to see, in their impotency to bring about and to insure their original intention.

Despite the burdensome cost of the "old diplomacy," 405 


\section{CONTEMPORARY FRENCII POLITICS}

and the smoldering flames which it failed eventually to extinguish, no considerable clement in France, at least until the entrance of Ameriea into the war, thought of any other means of inaugurating a peaee, provided, of course, that the war ended in an Allied victory. Throughout the peaee negotiations, Freneh publie opinion, in regarding territorial "guarantees" as absolutely essential to national existenee, looked askanee upon substitutions based on future uncertainty and untried by experience. Despite the defects of the old methods, there was some assuranee at least of their temporary sueeess; realism was preferable to ideology.

\section{II}

The guarantees which French public opinion desired, as reflected by several war ministries and by the press, were of a strategie and territorial character. The most advaneed of these demands was that which ealled for the total dismemberment of the German Empire and its disintegration into the States from which it was originally constituted in 1866. The most insistent supporters of this drastic exaction, mildly corresponding to the Roman treatment of Carthage, were the royalist journal, L'Action Françuise, through the pen of Charles Maurras, and Le Temps, a representative of the grand bourgeoisie of France.

$L$ 'Action Française proclaimed this doetrine in these words :

We have often declared ourselves as moderate annexationists. Above all we are hostile to the unity of the German Empire. . . Our guarantee is the Rlune. But the Rlime in its turn must be cruaranted by the partition of Germany. We have never conceated the apprehension which the pure and 


\section{FRENCII PEACE TERIS}

simple annexation of the left bank of the Rhine wonld leave in us, if upon the right flank of our eonguests the great Germany of Bismarck and of Itilliam is allowed to exist. It is too elear that the immense magnet of a unified Germany, agitated by a spirit of revenge, will exercise an influence and an attraction upon the Rhenish provinees which will profumdly impede the action of the French spirit. ${ }^{3}$

There is no equitable basis for the German Empire, the argument proceeds; it was founded upon force and through the means of three wars of aggression. To dissolve it now would not institute a new wrong but repair an old one. As a practieal step to enforee this dissolution, M. Maurras writes:

The Allies must in every case refuse to treat with the Empire,-with a mified Germany. They must only invite or admit to their audiences the states which composed the former Empire or whieh were framed from its débris. ${ }^{4}$

And this idea he developed to the extent of levying the indemnity, not upon the Empire, but upon its several States-such as Saxony and Bavaria.

The attitude of Charles Maurras and Le Temps toward the destruction of the German Empire finds a curions precedent in 1815-the only differenee being that the object of destruetion was France and not Germany. After the return of Napoleon from Elba, the governorgeneral of the Prussian provinees of the Rhine issued a proclamation on the 15th of April, 1815, part of which read as follows:

$A$ comintry (France) so delivered up to anarehy and disorder would menace lunrope with complete dissolntion if every brave Teuton did not arm himself against it. . . We must arm ourselves to-day to divide this unholy ground and indemnify ourselves by a fair partition of its provinces for

s Issue of April 3, 1919.

Ibia., April 5, 1919. 


\section{CONTEMPORARY FRENCH POLITICS}

all of the sacrifices which we have made for twenty-five years in resisting its disorders.

At the same time the Rhenish Mercury wrote:

War must be declared on the whole nation and this depraved people must be ontlawed. . . The world eannot remain in peace so long as a French people exists; therefore they must be changed into peoples of Burgundy, Nenstria, Aquitania, ete.; they will tear each other up among themselves; but the world will remain tranquil for centuries. ${ }^{5}$

Another advocate of the dismemberment of the German Empire is MI. Yves Guyot. In his book, The Causes and Consequences of the War, M. Guyot, advocated the total dismemberment of Prussia, the German Empire, and Austria-Hungary. He insists that Prussia must be reduced to the old frontiers which she had before the partitions of Poland in 1772, 1793, and 1795. The Rhine province and Westphalia must be declared autonomous. Saxony must recover the two fifths of her kingdom lost in 1815. Frankfort must return to the status of a free city. The amnexation of Hanover, Brunswick, Hesse and Nassau must be declared null and void, since from the point of view of law, the I'russian Diet had no right to sanction it. With the kingdom of Saxony as a nucleus, M. Guyot wonld form a Central German confederation. He would form a second union of the Southern States, Bavaria, Württemberg, Baden, and IIesse, with the severed Prussian provinces of the Rhineland and Westphalia. M. Guyot's suggestions surpass for severity any of the Prussian proposals in regard to the dismemberment of France, made in 1814 and 1815. Other writers such as Maurice Barrès, G. Hanotaux, and M. Eticnne, have considerable difficulty in

\footnotetext{
${ }^{\circ}$ Quoted from Debidour, IIistoire Iiplomatique de l'Europe, i, 52, footnote.
} 
disguising the sentiment which M. Guyot so boldly expresses.

The reasons for the demand of the dismemberment of the German Empire are not altogether political. Perhaps the greatest one of them is found in the increasing numerical inferiority of France compared with Germany -or in other words, the depopulation question.

The followin gtable will show the birth rate, death rate, and rate of natural increase of France and Germany from 1901 to 1912 :

\begin{tabular}{|c|c|c|c|c|c|c|}
\hline \multirow{2}{*}{ Year } & \multicolumn{3}{|c|}{ France } & \multicolumn{3}{|c|}{ Germany } \\
\hline & $\begin{array}{l}\text { Birth } \\
\text { Rate }\end{array}$ & $\begin{array}{c}\text { Death } \\
\text { Rate }\end{array}$ & $\begin{array}{l}\text { Natural } \\
\text { Increase }\end{array}$ & $\begin{array}{l}\text { Birth } \\
\text { Rate }\end{array}$ & $\begin{array}{l}\text { Death } \\
\text { Rate }\end{array}$ & $\begin{array}{l}\text { Nat. } \\
\text { Increase }\end{array}$ \\
\hline $\begin{array}{l}1901 \ldots \ldots \\
1902 \ldots \ldots \\
1903 \ldots \ldots \\
1904 \ldots \ldots \\
1905 \ldots \ldots \\
1906 \ldots \ldots \\
1907 \ldots \ldots \\
1908 \ldots \ldots \\
1909 \ldots \ldots \\
1910 \ldots \ldots \\
1911 \ldots \ldots \\
1912 \ldots \ldots\end{array}$ & $\begin{array}{l}22.0 \\
21.6 \\
21.1 \\
20.9 \\
20.6 \\
20.5 \\
19.7 \\
20.1 \\
19.5 \\
19.6 \\
18.7 \\
19.0\end{array}$ & $\begin{array}{l}20.1 \\
19.5 \\
19.3 \\
19.4 \\
19.6 \\
19.9 \\
20.2 \\
18.9 \\
19.1 \\
17.8 \\
19.6 \\
17.5\end{array}$ & $\begin{array}{r}1.9 \\
2.1 \\
1.8 \\
1.5 \\
1.0 \\
0.6 \\
-0.5 \\
1.2 \\
0.4 \\
1.8 \\
-0.9 \\
1.5\end{array}$ & $\begin{array}{l}35.7 \\
35.1 \\
33.9 \\
34.1 \\
33.0 \\
33.1 \\
33.2 \\
32.0 \\
31.0 \\
29.8 \\
28.6 \\
28.3\end{array}$ & $\begin{array}{l}20.6 \\
19.5 \\
19.9 \\
19.5 \\
19.8 \\
18.2 \\
18.0 \\
18.0 \\
17.1 \\
16.2 \\
17.3 \\
15.6\end{array}$ & $\begin{array}{l}15.1 \\
15.6 \\
14.0 \\
14.6 \\
13.2 \\
14.8 \\
15.2 \\
14.0 \\
13.9 \\
13.6 \\
11.3 \\
12.7\end{array}$ \\
\hline Mean rates & 20.3 & 19.3 & 1.0 & 32.3 & 18.3 & 14.0 \\
\hline
\end{tabular}

The marriage rate between the two nations was almost identical-8 per cent. Just before the war with Prussia in 1870 the French birth rate was 26 per eent; in the five years between 1911 and 1915 it averaged only 18.2 per eent. After the war it dropped still further. ${ }^{6}$

\footnotetext{
${ }^{\circ}$ See p. 150.
} 


\section{CONTEMPORARY FRENCII POLITICS}

If French population remains stationary or even deereases annually, and if German population increases 11 per cent or 12 per eent a year, France soon will be hopelessly outdistanced. Just before the war Germany had nearly 70,000,000 inhabitants to about $40,000,000$ of Frenchmen. Hence the fear of a still greater inerease on the part of Germany has led to the demand for the break-up of the Empire.

A seeond demand of the old diplomacy was for the annexation of the left bank of the Rhine. To a nation whose safety reposes solcly upon military prowess, unassisted by the proeedure and the sanction which a League of Nations would supposedly provide, the question of strategic security, of frontiers guarding eertain gateways of invasion, assumes a prë̈minent position. Such a consideration was one of the German excuses, indeed a veiled one, for the annexation of Alsace and Lorraine in 1871. It has been urged with more justice lately by Belgium in Limburg, by Poland in Danzig, and by Italy in the German Tyrol. To Franee the Rhine is a natural frontier the possession of whieh is the only certain guarantee against a German attack which she believes will eome again if effective measures are not taken to prevent it. For this reason the annexation of the Rhenish provinces was urged by Generals Foeh and Gourand, the Royalists, such Conservatives as Charles Benoist, and perhaps the majority of the so-called Radieal elements. Maurice Barrès, writing in L'Echo de Paris, attempted to soften the ammexationist feature by arguing that the Germans inhabiting the left bank were not of German ilk, that originally they were nurtured by French culture, and that now they were eager to return under its influence. In his literary style of argument, M. Barrès quoted Victor Hugo as the original advoeate 410 


\section{FRENCII PEACE TERAS}

of the "return" of these provinces to l'rance. At the end of the $\mathrm{War}$ of 1870 Hngo ammonneed that France would achieve la revanche only when she had retaken, not only Lorraine and Alsace, but Trèves, Mainz, Coblenz, and "all the left bank of the Rhine which the German States took from France in 1815." $\Lambda$ s far back as 1838 Ingo wrote in the "Rhine": "France will only return to its normal form and to its necessary proportions . . [when] it will have its portion of the Rhine and its natural frontiers." ?

In a brochure distributed by the Nantes Committee for the Left Bank of the Rhine, some interesting demands are found. This pamphlet, scareely daring to ask for complete anmexation, which it admits is inconsistent with the ideals for which the war was presumably fought, asks:

1. That all the eis-Rhenish country, as far as the IIolland frontier be taken from Germany for political, military and economic reasons;

2. That the military hegemony of France be exereised, either by its or Belgian garrisons, upon the principal fortresses on the Rhine, extending as far as its entry into IIolland;

3. That the economic zone of France and of Belgium be extended to all of the eis-Rhenish country where it will be substituted for the German Zollverein.

IIow such a system, involving the alienation of the territory froniffermany and the surrender of its military and economic control to France, differs from outright ammexation, it is difficult to see.

Other Frenchmen who realized the boldness of such projects and the diffieulty in carrying them ont, advo-

${ }^{7}$ Echo de Paris, March 5, 191!. 


\section{CONTEMPORARY FRENCII POLITICS}

cated the formation of a Rhenish republic, under French hegenony, to serve as a buffer state on which a German attaek would first have to spend itself. The French Catholies were supposed to be adrocates of such a republie which was to include the German territory oceupied by the Allied troops, extending from Cleves on the north to Saarbrück and Landan on the sonth. This territory, including Westphalia, has a population of about 15,000,000 people, of whom about 8,000,000 are Catholies. The ecelesiastical element in these provinces supported by Catholie opinion in France, believed that its influence would be more effectively exercised in an independent republic where it would be numerically strongest, than muder the German Government, where its influence was now neutralized. This. combination of the religions and the military motives brought the demand for a Rhenish republic into considerable prominence in France. The separatist movements thronghont Germany were given an exaggerated publicity by the French press; attempts to form republies in Bavaria and in the Palatinate were portrayed as completely suecessful when in reality they were purely local manifestations. In fact, there seemed to be cause for suspicion that many of these attempts were instigated by the French military anthorities themselves.

IIistory, however, lent some support to the French suggestion of a Rhenish Republie. Although these disputed provinces are now German in raceand in culture, in times past they have been Freneh in feoling. The Armies of the Revolution in september, 1792, penetrated these provinees under the leadership of Custine, who inspired them with the following principles:

The weight of our arms in the future must only strike those who abne a contided power-despots and their satel- 


\section{FRENCH PEACE TERIS}

lites. When we will earry the firebrands of war into a country, we will respect the liberty of the peaceful inhabitant: let none of our arms be dishonored in shedding the blood of an imoeent citizen. ${ }^{8}$

Under the infection of the principles of the Revolution, the armies of Custine rapiclly compuered the rountry, winning over Speyer, Mainz and Strasshmrg by the last of October. At Mainz, Custine again announced with fervent sincerity, the principles which led to the conquest :

The war which we wage to-day, so different from those which have preceded it, is directed a gainst all those who have betrayed the usage of conferred powers, and not against peoples. Your magistrates alone must support the ransom which is imposerlupon your city; such is the will of the French nation. ${ }^{9}$

Shortly after the French oecupation of Mainz the liberal element, following the example of the French clubs, organized a "Society of German Friends of Liberty and Equality." With the impetus which such an organization gave to the insurgent peoples of the Rhenish territory, and with the stimulus of the French revolutionaries in their midst, a wave of liberalism swept over the country, earrying with it not only the demand for separation from German suzerainty, but, as in the ease of Nainz, for ineorporation with the Freneh Republie. Custine, aecenting this invitation, established a provisional govermment upon the 19 th of November, which consisted of ten members and whicll sat at Mainz. ${ }^{10}$ In

\footnotetext{
"Quoted in L'Europe Nourelle, February S, 1919.

${ }^{9}$ Ibia.

"See Albert Sorel, L'Europe ot la Rénlution Francaise, Part 11l., "La Cucrre aner liois," 97-114; also I'art IV., "Les Limites Naturelles," 15!), 2270, 301 .
} 


\section{CONTEMPORARY FRENCII POLITICS}

the winter of 1793 a Rhenish eonvention was held which, on the 18th of March, declared the forfeiture of its former sovereigns and the erection of all the territory between Landau and Bingen into a free and independent state, "which will obey common laws and which is founded upon liberty and equality." Three days later, however, because of the fear that Prussia and Austria were determined to prevent their withdrawal from the German Federation, the Assembly decreed the incorporation of the Rhenish-Germanic peoples in the Freneh Republic. In the summer of 1793 Germany retook Mainz and the outlying provinces, insuffieiently protected by the Republic, and (although the French do not urge the point) inadequately eonvinced of French superiority. A year later, however, the armies of Hoche and Championnet retook the territory with the exception of Mainz. Theneeforth the Republic worked to establish order, commerce, and industry in the provinces. The peace signed at Basel, April 5, 1795, with Prussia, virtually recognized the conquests of the Revolution by stating that the troops of the French Republic would continue to oceupy the part of the states of the King of Prussia situated upon the left bank of the Rhine. The task before the Convention was the disposition of this country, either by the ereetion of a cis-Rhenish republie or by its incorporation with Franee. The latter secmed to have prevailed, except for the intrigues of the King of Prussia who forestalled aetual amexation. However, in August, 1796, he signed a secret convention by which he consented to the cession of these provinees in eompensation for the incorporation of certain ecclesiastical principalities in his kingdom. The Directory, now at the head of the French Republie, inaugurated an antonomous government and divided the provinces into 


\section{FRENCII IEACE TERMS}

six districts, each locally administered. Iiberty of the press was reestahlished and the University of Bomm was reopened. Fear of losing the provinees altogether because of the increasing strength of I'russia caused General IIoche to create a cis-Rhenish republic, a move which aroused considerable opposition. After the coup d'ctat of the th of September, 1797, the Directory instrueted the General not to form a Rhenish republie unable to sustain itself, but rather to secure its prompt reunion with the Republic. This task was accomplished by General Angereau, General IIothe's successor; and in the last of December, Mainz was taken from the Germans, their last hold across the Rhine. The entire Rhenish country was again in the bosom of France. From 1802 to 1814 France slowly overeame whatever opposition its inhabitants had to its new gnardian; and thus for a period of eighteen years (1796-1814) the Rhenish provinees were virtually under French tutelage, either as a Republie or as a part of the Revolutionary conquests of France. When Napoleon was finally defeated and peace made, the Rhinelands were divided among I'russia, IIesse-Darmstadt and Bavaria. Despite the burdens which the Empire had imposed upon them, their separation from France, according to such men as Maurice Barrès, was accompanied with a lasting attachment to French institutions and culture which they still secretly cherish.

Whether or not this Gallophile sentiment in the Rhenish provinces can be revived to such an extent as to lead to the erection of a Rhenish remblic or to the union of the provinces with France is a question. Its deeision, however, involves a creat deal more than the mere redrawing of maps by the leace Conference. The people of the provinees themselves should be the judge 


\section{CONTEMPORARY FRENCII POLITICS}

of their destinies, unaffected by French armies or propoganda.

The fourth strategie guarantee which the old diplomaey desired was the amnexation of the valley of the Saar. This valley, lying north of Alsace and Lorraine, contains about seven hundred square miles of territory; two thirds of it lies in Rhenish Prussia, one third in German Lorraine, and a very small portion in the Palatinate. Saarlouis, on its eastern edge, and Saarbrïck, on its western edge, delimit its extension along the Lorraine frontier.

The historical claim to this territory on the part of France goes back to 1552 when Ifenry II united the three bishopries of the region to his crown, the possession of which was eonfirmed in the treaty of Münster. In the treaty of Rrswick, Lonis XIV surrendered a good portion of this territory to the German count of Nassau-Saarbrück; but in reality, the French assert, the entire territory was under French culture and was virtually a French fief until the Congress of Viemna. After 1789, the feudal attaehments of the Saar distriet to Germany were broken, and it became a part of the Repullic. Altlongh agriculture was the chief ocenpation of the Saariens, the exploitation of its coal fields rapidly developed under the Repulsic. In 1796, 456 quintanx ${ }^{11}$ were extracted; twelve yoars later, this production had tripled. Napoleon, realizing the rital importance of such an industry, distributed coal concessions in 1808 to sixty arpondissements, created a sehool of mines at Geislauten, and cansed the rompilation of a magnifivent atlas of sixty-six maps, containing wellordered plans of exploitation. The first treaty of Paris

"Quintal, a hundredweight. 


\section{FRENCII PEACE 'TERMS}

of May 31, 1814, still included the cantons of Saarlonis and Saarbriek, until the Nied, within the frontiers of France. But after the IIumbed Days and Napoleon's defeat at Waterloo, Prussia, with the determination to ruin France, demanded that it be deprived of one sixth of its territory and be forced to pay an indemnity of $600,000,000$. Only a portion of its desires were earried out, and in the treaties of November 20, 1815, Saarlonis was given to Prussia while Landan and the former department of the Saar fell to the lot of Austria. The historie claim to this area, therefore, is largely based on a Revolutionary comqnest, a claim which, if pressed, wonld extend to the Netherlands, Spain and Italy.

The eronomir arguments in favor of the amexation of the Saar were the most tenable of those advaneed. The first of these argmments was the increased military and industrial strength the coal fields of the Saar would give to France. 'The serend was that the Saar coal was necessary for the profitalle exploitation of Alsatian industry and its irom mines. The third was that the indemity could partly be paid by the cession of the district to France at its capitalized value.

One of the strongest elements in German military strengtl was its self-suffieiency in raw materials, especially in coal. Comparatively, its strength in terms of resourees, was as follows:

\section{Tons}

Germany ......................... . 433,000,000,000 (ireat Britain . . . . . . . . . . . . . . . 189,000,0000,000

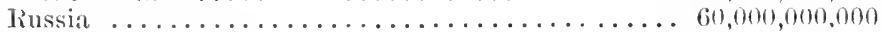

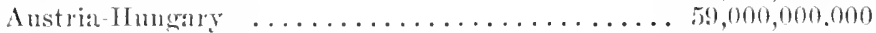

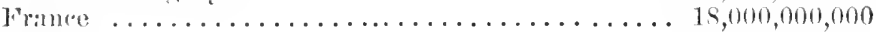
Belgimm .................... 11,000,000,000

From the military stankpoint, then, any measure depriving (anmany of a portion of this immense supply of 


\section{CONTEMIPORARY FRENCII POLITICS}

coal, over twiee that of Great Britain, was looked upon as legitimate by the old diplomacy. The weakening of German resourees meant the weakening of her power to earry on a prolonged conflict.

Before the war France produced 40,800,000 tons and eonsumed $64,800,000$ tons of coal, necessitating the annual importation of $24,000,000$ tons. In 1915 this latter figure increased to $40,000,000$; in 1916 , to $42,000,000$; and in 1917 to $47,000,000$. On aceount of the destruction of the mines in the North of France and beeause of the demands of the industry of Alsace and Lorraine, it is estimated that the ammual coal deficit in the future will be about $40,000,000$ tons. At a price of ten dollars a ton this will burden the French balance of trade, to the extent of $\$ 400,000,000$ a year. Soaked as it is with the protectionist idea, the French bureaneracy is alarmed at sueh a prospect.

As to the second point, Alsace and Lorraine had again become French provinces, dependent industrially and politically upon France. Their steel manufactures and their industries generally, which were of the greatest strength, had formerly been supplied with German coal, ${ }^{12}$ eoming largely from the basin of the Saar. Coal was necessary to the industrial life of these provinees; but if it now had to come from French mines, the industries of these provinces wonld beeme a drain upon the French eoal supply and industry generally. If France did not get the source of the former Alsatian coal supply along with the provinces, the value of their return to the mother country would be frittered away. The sentimental feature of the Alsace-Lorraine ques-

\footnotetext{
${ }^{2}$ See artieles hy Louis de Lamnay in Ta Revue des Deux Mondes, July 15, 1919, and Nov. 1, 1919, on "La valeur minière et industriclle de l'Alsace-Lorrainc.',
} 


\section{FRENCII PEACE TERAS}

tion was of course predominant; but perhaps the economie factor was of as much elementary importance. To the French business man, Alsace-Lorlaine was a poor investment without the Saar to make it profitable.

Finally, the anmexation of this basin was urged as a restitution in kind, of material which Germany had destroyed. Annex the territory, capitalize its value, and deduct it from the sum total of the indemnity chargesuch was the most reasonable argument urged for the annexation. Germany was a debtor, unable to meet her obligations. Like an individual in similar cireumstances, why could not her property be attached to meet these olligations? National bankruptey followed by national liquidation was the remedy proposed. The fact that the Prussian Government itself was the owner of most of the mines of the Saar lent color to the argument.

As to the resources of the Saar basin, estimates vary from $45,500,000,000$ to $53,515,000,000$ tons. $^{13}$

In 1913 there were 80 shafts in operation in the basin from which the following amounts were produced:

\section{Tons.}

In the Prussian part of the district. . . . . . . . . 12,406,523

In the Lorraine part of the distriet. . . . . . . . . . . $3,795,9392$ Bavarian (Palatinate) $\ldots \ldots \ldots \ldots \ldots \ldots \ldots \ldots \ldots \ldots \ldots . \$ \ldots 10,546$

Total production of distriet in $1913 \ldots \ldots \ldots \ldots \ldots \overline{17,013,001}$

Of the $17,000,000$ tons of eoal which the Saar valley ammually produces, it itself consumes $7,850,000$ tons; leaving about $9,000,000$ tons for disposal elsewhere.

${ }^{13}$ Authorities differ on the amount of coal in the Saar. Although beschen estimates the reserves as amomiting to 45,500 , 000,000 tons (see the American licview of Reviews, Mareh, 1979, 313), the German I'eace Delegation in their comments on the leace 'Treaty placed the amount at only 11,000,000,000 tous. 


\section{CON'TEMPORARY FRENCII POLITICS}

Considering solely these tonnage figures, this surplus would supply the $7,200,000$ tons of coal which Alsace and Lorraine need in addition to what they themselves produce. It would constitute about a fiftl of the amount which France would otherwise have to import.

On the other hand, the quality of the Saar coal is mediocre. It contains a great deal of volatile matter, it is lower in heating value than the coal in northern France, and it is not particularly adapted for use in the iron industry where its employment in Alsace-Lorraine is especially needed. ${ }^{14}$ The Prussian Government operates twenty-seven mines in this district and it is barely able to make operating expenses. In the fiscal year of 1913-191t its expenditures upon the mines amounted to $93,899,200$ marks and its reeeipts 104,110 ,438. Under these eonditions, whether or not these mines would be of distinct profit to Frencl industry, is questionable; while the disjuncture of 50,000,000,000 tons of coal resourees from the military standpoint would not affeet materially the 433,000,000,000 tons which Germany possesses. However, the addition of such a resource to the $18,000,000,000$ which France now has would bring its eoal supply up to that of Russia and what was formerly Austria-IIungary. In other words, the coal basin of the Saar would increase by three times the present coal resonrces of France. The possibility of such an increase was naturally looked upon with covetous eyes, although the quality of the coal itself was of an inferior character, the mining of which, under the

"It is very signifieant that the French censor refused to allow the French elitor of the New York IIerald, liere Veber, or I'Europe Nouvelle, to print these facts about the inferiority of the Saar coal. It was only after their revelation in the Chamber of Ineputies, near the elose of the Peace Conference, that they became generally known. 


\section{FRENCH PEACE TERMS}

French bureaucracy, would undoubtedly be a profitless enterprise.

The one outstanding argument against the amnexation of the Saar, was that it would to a smaller extent repeat the German seizure of Alsace-Isorraine. The Saar hasin is an integral part of the German Empire. The elections of the German Republic were held in this region in Jannary, 1919, and such a large vote was cast for the Centrist, the Social Demoeratie, and Demo"ratic parties, that there is no reason whatever to believe that the Saar wishes to be detarhed from Germany. Ordinarily, the old diplomacy would not attempt to protect the right of self-determination, if the higher prin(iple of strategic or economic security stood in the way. lint because of the nominal aceeptance of this principle, French opinion tried to square it with their desires by alleging that the population, of the Trèves region at least, which contained only abont 650,000 people in 1913, was too small to make the principle applicable. Of these, they said, only about 200,000 or 300,000 were German miners, while the greater part of the population was of a eosmopolitan character-Poles, Lorrainers and eolonials. The direetors and the engineers of the mines, being employed by the Prussian Govermment, would naturally witldew upon French occupation; and within twenty years, so the argument goes, Franee would have the valley cleared of German sympathizers, and merged morally and economieally into French Lorraine. ${ }^{15}$ Although there is little question that France,

"The German answer to this French argument is given in the "Comments by the cierman Delesation on the Conditions of leace," under "Territorial Questions"':

There is no industrial district in Germany whose population is as homogeneous, as purely (ieman, and as little "complex", as that of the saar district. Among the $6,50,000$ inhabitants there 


\section{CONTEIIPORARY FRENCII POLITICS}

if given the opportunity, will soon rid this basin of its German tinge, the argument is certainly not to the point, so far as Germany's desire to win back the provinee is concerned. ${ }^{16}$

\section{III}

As to the immediate question of the disarmament of Germany, the old did not differ materially from the

were in 1918 not eren 100 French, For more than 1,000 years (since the treaty of Meersen, in the year 870 ) the Saar district has been German. Temporary oecupations, brought about by enterprises of war on the part of Franee, always terminated at the conclusion of peace, after a short lapse of time, in the restitution of the comntry. In a period stretehing over 1, 048 years France has possessed the country no Ionger than sixty-eight years. When, in fixing the frontier in the first Peace of I'aris, 1814, a small part of the territory now claimed was retained by France, the people rose in protest and demanded "reunion with their German Fatherland," with which they were "related", by bonds of "language, customs and religion." After an occupation of one and onc-quarter years duration, this demand was satisfied in the second Peace of Paris, 1815. Since then the country has been attached to Germany uninterruptedly and owes to this connection its ceonomic prosperity.

${ }^{16}$ That the Allies had actually agreed upon the major features of the demands of the Ohl Diplomacy, ahove ontlinel, is shown by the following seeret telegram from the Russian Foreign Minister to the Russian Ambassarlor in Paris, from the 30th of January to the 12th of Felruary, 1917:

"At an Imperial audience M. Doumergue (French Ambassador in I'etrograll) informed II is Majesty the Emperor of France's wish to assure herself of the restoration of Alsace-Lorraine after the conclusion of the war, and also of a sperial position in the Sair valley, and to hring about the detachment from Germany of the territories west of the Rhine and their reorganization in such a way that in future the lihine may form a permanent strategic obstale to any German advince....'

In a secret telegram of the Russian Foreign Minister to the Russian Amlassador in Paris, the 9th of Mareh, 1916, Russia "agreed to leave to France and England full freedoul to fix the western frontiers of Germany. ...',

From the eorresponelenee pullished by the Bolshevist Government, in Noremher, 19I7; reprinted ly the Nou Europe, Norember 29,19$] 7$, supplement. 


\section{FRENCII PEACE TERMS}

new diplomaey. The disarmament of nations is an ideal to be striven for and is the essential element of peace. But the old idea was not universal disarmament; it was the complete reduction of German armament and the maintenance, if not the increase, of Allied armament; or, in other words, the permanent maintenance of German inferiority by Allied superiority. The French feeling upon this subject expressed itself in a resolution which was signed by 22:3 French Deputies. It was unanimously approved by the Chamber Committees on the Arny and on Foreign Affairs, and presented by $M$. Raynaud after the Conference decision as to German disarmament, to the President of the Chamber upon the 4th of April. The resolntion, expressing great discontent with the Conference decision, invited the Government to insist at the Peace Conference "that Germany must conserve neither army nor military organization, nor armaments of any sort, and that there ought only to be maintained in each of the German states, forces of police neeessary to maintain internal order." This resolution was not roted upon, beeause M. Deschancl, the President of the Chamber, ruled it unconstitutional on the grounds that the President of the Republic alone carried on treaty negotiations. But it represented, exeept perhaps for the Soeialists, the unanimous opinion of the Chamber. ${ }^{17}$

The French apprehension as to the spirit and intent of the new German Republic was aroused by the voting,

\footnotetext{
${ }^{17}$ During the ratification debate on the Treaty in the French Clamber, in September, 1919, Anuré Lefèvre introdueed a motion, to be attached as a ricler to the Treaty of Versailles, ealling for the complete disarmament of Germany, in view of its present intentions to evade Allied. orders and to rebuild her military system. The day after the Truaty was ratified, his motion was withdrawn (October 3d) for one "inviting the Government to +.):3
} 


\section{CONTEMPORARY FRENCH POLITICS}

in the latter part of April, 1919, of a law by the Weimar Assembly, reorganizing the German army. The preamble of this law read as follows: "The organization of the future army in time of peace depends upon the conditions of peace and the Constitution of the German State. Because of technical difficulties, the ineorporation of conseripts cannot be constituted with certainty. This is why it is necessary to reeur to volunteers in a period of transition." This preamble apparently indicated the German desire to restore its army eventually, and it gave French opinion greater cause than ever to demand the complete destruction of the German military system.

Finally, the Older Diplomats demanded an alliance between the present Allies to enforee these and other terms imposed upon Germany with the simple intent of keeping it in a state of subjection. Through this alliance Germany would he kept perpetually impotent, forever unable to threaten the peace and liberties of the world. If it should be bold enough to eross the Rhine again, even to win back the cis-Rhenish provinees, this alliance would immediately, through armaments inereased by the past war and maintained sinee it, force it back to the confines which the Peace Treaty had delimited. To insure the economic subjection of Germany, this alliance would do everything possible, by discriminating tariffs and boycotts, to keep it out of the markets of

reach an understanding with the Allied and Associated powers with a view of the execution of the measures rendering the disarmament of Germany and her Allies effective by the interdietion of certain manufactures of war and other necessary measures.' Nominal reconciliation of this motion with the plan for universal disarmanent was secured by the adoption of an amenelment, inserted after the word "powers," "in agreement with Presibut Witson who should convoke a conferenee under tho provisions of the covenant of the Ieacrue of Nations." 


\section{FRENCII PHACH TERMS}

the world. This determination, the Inter-Allied Eeonomic Conference in Paris, 1916, very forcibly exposed.

These conceptions of a peace were part of what the French ealled the Victoire Intrgrale. 'T'o sum them up, they included, on the part of the extremists, the disintegration of the German Empire; on the part of the more moderate, the ammexation of the left bank of the Rhine, or the creation of a cis-Rhenish republic, and if both of these did not materialize, at least, the annexation of the valley of the Saar; the total reduction of German armament; and finally, the erection of a permanent alliance among the present Allies.

There was very little of imperialism or aggression about such a peace. France is not imperialistic; she desires no conquests for the sake of conquest. But the principle of reparation and of security is superior, in her mind, to that of self-determination. Even the matter of the Saar camnot be looked upon as a mere desire to increase resources at the ruthless expense of the defeated. When considered in the light of the terrible suffering and material ruin which France was compelled by Germany to undergo, the mines of this basin, from the standpoint of reparation, belong to France. In justice to her, it must be said that she does not dream of "Mitteleuropa."

A peace of the Old Diplomacy might not have been reprehensible. In fact, its purpose was commendable, the difficulty being that the means did not always bring the desired result. Sucll a peace, embodying strategie and economic superiority of the Allies over Germany, was the only one to expect from European powers. Backed by generations of the bitterest rivalry and schooled in realist philosophies, they still cherish its thought even after their nominal acceptance of the 
League of Nations idea, oceasioned by Ameriea's entry into the war. The Enropean code was of distant origin, and tradition was with it. Europe was not eonvineed, and it is still unconvinced many months after the 28th of June, 1919, that an Ameriean settlement is superior. Time may prove that Europe is right. But at any rate the Old Diplomacy had centuries of failures behind it; and the League of Nations idea remained the only untried surcease of international conflict.

\section{IV}

Generally speaking, the Old Diplomacy is based on the assumption of national antagonism-the antithesis of national interests. To guard against the effects of this confliet of desires, national security has beeome the prineipal object of diplomaey. To insure it, the principles of protected markets, strategic frontiers, military power and alliances-all swallowed up in that obseurism of the Balance of Power, have becn assidnously practiced.

Unfortunately, national antagonisms are always bound to exist. However, to irritate them, to assume their contimul predominance, to fan them into war whenever one nation feels strong enough to wage it, was the result, if not the intent, of the Old Diplomacy.

Furthermore, the means which it employed of proteeting national security not only proved ineffective but violated certain definite principles. The attempt to secure economic superiority through protected markets, when carried to the point of discriminating against one nation in favor of another, led to the worst form of economic exploitation of subject peoples and to the exaggeration of national rivalries. Although it resulted in 


\section{FRENCII PEACE TERMS}

quasi-romplete economic independence, so dear to the Elder Statesmen in time of war, the theory was false so far as commercial adrantage was concerned and its practice led to the grossest form of economic imperialism. Strategie frortiers justified the annexation of any territory, especially if supported by historic and economic arguments. Mistorie arguments, particularly their present abuses, have been used to justify the worst robberies. Most of them have their source in epoehs where possession was to the strongest and people were pawns, moved upon a board of foreed treaties and balanced armaments. Eeonomie demands were absolutely unjustifiable when they violated the will of peoples and when they could only be exeeuted by forced appropriation. Furthermore, and of more praetical importanee, strategic frontiers were ineffeetive and relative. Their acquisition by the nation against whom they were direeted was a natural desire. Their maintenance, as well as that of national superiority, involved armaments, eonseription and fortifieations, the weight of which was overwhelming.

Military power was also a eomparative power, subject to international competition, and thus bound to become inereasingly burdensome. Alliances and the Balance of Power idea arose from the combined advantages which a number of friendly nations gave against a common enemy. Alliances arose for a definite protection or a definite aggression. But when one allianee beeame strong enough to subjugate another, the misuse or the fear of the misuse of its power, subsequent to disagreement among its members, led to its regrouping, and the composition of an opposing alliance able, either potentially or directly, to control the first. Every alliance in the 


\section{CONTEMPORARY FRENCII POLITICS}

world's history has been marked by this changing, shifting process. Its formation was to guarantee static things; but the forees of the world and the interests of nations were, and are, dynamic. They ehanged; interests which were mutual became conflicting; and an alliance offered no means of adjusting the evolution. When this disintegration, these "diplomatic revolutions," oceurred, they were usually followed, sometimes very distantly, by war. If the change itself did not thus result, the new organisms-two sets of comparative strengthsinevitably clashed. Their reason for existence was not only the opposition but the superiority of the one over the other. In the feverish race for supremacy all of their members were engulfed in this hopeless circle. The security resulting from it was at the most relative; its uncertainty and its temporariness made it no security at all. And despite this offsetting of national strengths in which the Balance of Power resulted, somebody was sure sooner or later to tip the scales and to throw the world into another mêlée of disaster.

The German Empire was the supreme embodiment of these principles. But in addition to the mere desire for security, it had designs of aggression for its own sake. The Old Diplomacy could be exercised for the one purpose as well as for the other. But at the same time, it so hopelessly interwove the maintenance of security with measures of aggression that the two motives were scarcely distinguishable. In the great number of cases, under the Balance of Power régime, security meant aggression. As such it not only was morally objectionable but physically unable to endure.

In the particular case of the French demands for the disintegration of the German Empire, and the annexa- 


\section{FRENCII PEACL TERAS}

tion of the left bank of the Rhine, inchuding the Saar, morally they would have violated the clearly rerognized right of peoples to govern themselves. With the Freneh installed on the Rhine, Germany would have exactly the same motive of antagonism against France as France has had against Germany since 1870. To over'eome the fear of a German attack, would have involved the maintenance of armies which no people was in the mood of sustaining and which France, unsupported, was ineapable of sustaining. The same competitive basis - that of keeping Germany in a state of inferiority and France in a state of superiority-would have been reverted to. Perhaps it could be done; but without the help of the Allies, it was impossible. This made an alliance a necessity. But to an alliance framed especially in the face of the legitimate desire of Germany to unite to herself purely Germanic peoples, the United States certainly would not have been a party. Such an alliance would lave been a Iloly Alliance to maintain an unloly status quo. Although the Frencl Peace Delegation came to see that the help of England and the United States was more to be desired than the left bank of the Rhine, it is very strange that French opinion should still prefer the latter to the former.

In regard to German disarmament, it may be said that history teaches a sad lesson as to the attempts of one nation to enforce disarmament upon another. On the 8th of September, 1808, Prince William of Prussia signed at Paris the famous "Articles Séparés," the first of which read as follows: "II Majesty the King of Prussia, wishing to avoid everything that may give umbrage to Flance, undertakes the engagement of maintaining for ten years, begimning Jamualy 1, 1809, only 


\section{CONTEMPORARY FRENCH POLITICS}

the number of troops speeified below." 18 'This specification comprised 22,000 infantrymen, 8,000 cavalry, 6,000 artillerymen, sappers, etc., 6,000 of the King's guardsmen-a total of 42,000 men. This provision was overcome by Prussia throngh the creation, under the clever supervision of Scharnhorst, of a militia deprived of all visible comnection with the permanent army, and maintained supposedly for interior order, but which, by repeated military exercise, was capable of serving as a reserve army in case of the outbreak of war. ${ }^{19}$ Although Napoleon interfered with the training of such a militia, Prussia again evaded the law by instructing soldiers for a few months, then returning them to their homes, after which others came to take their plaees in the ranks of the permanent army. Thus a large body of reserves was built up. To deceive French inspectors, regiments would leave part of their men in the barracks when the inspectors went on the drill field. As a result of this deception, instead of the 42,000 men Prussia was supposed to have, she had a trained body of 150,000 , the worth of which the armies of Blücher upon the fields of Waterloo ably demonstrated.

Although armaments in modern warfare are singularly more difficult to conceal than those of the Napoleonic epoch, what is gained in national superiority from this fact is more than overcome by the rapidity with which armies at present act, and with which munitions can be produced. The disarmament of Germany presents the same problem to-day as it did in the Napo-

\footnotetext{
${ }^{19}$ Quoted in Le Temps, March 2, 1919.

" lor the evasions of this agreement by Scharnhorst and Gneisenan, see 'Treitschke's IIstory of Germany in the Nineteenth Contury (English translation), i, 336-347.
} 
leonie era. It means the establishment of an Allied espionage in Germany which she will hiterly resent and assicluously dererive, especolally when sle knows that the Allies are increasing their own anmaments.

The difficulty of enforement of disallmament was alpparent within six months after the signature of the 'Treaty of Versailles, ${ }^{20}$ and it constituted the first, fractiral difficulty in the way of the Old Diplomary's solution. $\Lambda$ second oljection against the continued maintenance of French and Allied armaments in the face of a supposedly prostrate Germany, was a moral one. For the maintenance of such a force is quite likely to arouse a desire of conquest on the part of the oecupying troops, even though masked under another name. As a praetical example, French opinion ardently desires the left hank of the Rhine. If the Old Diplomacy has its way, inspired as it is by the example of the Rommanians in Budapest and the Italians in Finme, it is very probable that France will annex the Rhenish provinces which her troops already hold, and even take over other parts of Gernany. The probahility of such a move is increased hy the helplessness which the Allies have attempted to cuforce upon Germany. It is also increased by America's reaction atainst participation in European affairs. Franee, no doult, is not eonscionsly plotting this annexation; she has no official desires of imperialism; but the arousal of such a spirit is always to be feared when one nation becomes predominantly powerful and especially when hitherto what it regards as "legitimate" desires have been thwarted.

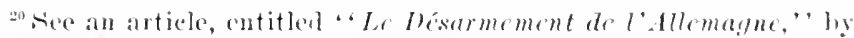
Anlré Tardieu, in L'Mllustration, for Febuary 2s, 1900, for the extent to which the Allies lave thus far suceeded in disarming Germany. 


\section{CUNTEMPORARY FRENCII POLITICS}

\section{IV}

Such were the dangers which the devices of the Old Diplomaty involved. They not only were morally questionable but, and because of it, they were eventually ineffective. The League of Nations idea theoretically induced the European powers to consider the guarantees which it substituted. It promised France reparation and security; it, however, rejected in theory the annexation of territory in distinct violation of the will of the people inhabiting it. It desired partial German disarmament; but after the Treaty had been complied with, it demanded the disarmament of all nations as the only sure means of removing the pretense for any one nation to arm. In place of war as a settlement of international disputes, it substituted compulsory arbitration. To compel the enforcement of the decision of such an arbitration and to prevent attacks of one nation upon another, it offered an international military force.

To what extent the Leagne of Nations idea was incorporated in the Treaty of Versailles, how far it was successful in defeating the demands of the Old Diplomaey, and why French opinion was dissatisfied with the character of the League as established, will be discussed in the next chapter. 


\section{CHAP'TER XIV}

THE FRENCII CONCHITION OF A IE.IGTE OF N.ITIONS

Pendant longtemps chore, l'idíal aura besoin de gros canons.Josepir BaRTHÉLEMY.

French opinion upon the League of Nations-offieial as well as popmlar-miderwent a remarkable evolution during the war. MI. Clemencean's blunt characterization of the idea as "a myth" was later repudiated by his open support of a commission of French publieists, (harged with designing a draft of Leagne organization.' Political parties, notably the Unified Radicals and the

\footnotetext{
${ }^{1}$ Senator Léon Bourgeois, the French representative at The IIague Conferences, and a former Primo Minister, was chairman of this eonmission.

'The sincerity of $\mathrm{N}$. (')emencan's change of heart may be judgad from the following extract of one of his early speeches as Prime Minister:

"I lave been askel to explain myself in regard to war aims, and as to the illea of a league of Nations. I have replied in $\mathrm{my}$ declaration, 'We must conquer for the sake of justice.' That is elear. We live in a time when words have great power, but they have not the power to set firee. The worl 'justice' is as olil as mankinl. Do you imagine that the formula of a League of Nations is going to solve everything?

"There is a committere at the Ninistry of Foreign Atrairs even now preparing a scheme for a league of Nations. Among its memlers are the most authoritative exponents of international law. I undertake that immediately their labors are finished I will table the onteome of it in this (hamber, it I am still Prime Minister-Which loes not seem likely.' Quoted in IIyndman, Clemenceau, the Man and his Time, 325.
} 


\section{CONTEMPORARY FRENCH POLITICS}

Unified Socialists, urged the League's creation; entirely unofficial societies sprang up to propagate the idea; finally the press, although without any great enthusiasm, it is true, eame to acknowledge its inevitability. The great force behind these outward manifestations was the inchoate belief of the French common people that the old poliey of Balance of Power had egregiously failed and that in a League of Nations lay the only hope for future peace.

The extent to which public opinion had foreed M. Clemenceau from his original position was illustrated by his remarks at the second plenary session of the Peace Conference, on January 25th, 1919. At that time, he said :

At the time of the armistice the five powers had altogether $12,000,000$ men under arms on the battlefield. Their dead can be counted by millions. If the idea, that great notion of the Leagne of Nations, was not above the whole of our work here, it wonld have been possible for us, the five great powers, to consult only ourselves in the settlement. That wonld have been, after all, onr right. Well, that has never been our thought. We have asked the nations interested in the settlement to meet us. We have asked them to give us their cooperation and their belp.

As for myself, I have come here ready to sacrifice many of my opinions in order to eonciliate, in order to reach the eonchusions we all wish for, and I hive already made sacrifices, and I have done it with joy, for the great common cause which unites us here. I hope we will all be inspired by the same spirit.

It was in aceordance indeed with this spirit that the Conference adopted a resolution setting forth the prineiples which were to govern its debates: (1) It is essential to the maintenance of the world settlenent, which the Associated Nations are now met to establish, that 


\section{FRENCII CONCEPTION OF A LAAGUE}

a League of Nations be created to promote international coöperation, to insure the fulfilment of aceepted international obligations, and to provide saforgards against war. (2) The League should be treated as an integral part of the general Treaty and should be open to every civilized nation which can be relied upon to promote its

- objects. (3) The members of the League should mect periodically and they should have a permanent organization and secretariat to earry on the business of the League.

Thus, at the outset, the Conference pledged itself to the creation of a treaty based upon principle. It decided, further, that the League and such a treaty were absolutely inseparable; without the one the other eould not exist. If peace alone were made-omitting the guarantee of the Leagne-it would necessarily assume the forms of the Old Diplomary. There were only two choices: Security by means of the League, or security through the diseredited policy of Balance of Power. To postpone the creation of the first wonld have been to institute a peace dependent on the latter.

$\Lambda \mathrm{s}$ in the United States, a strong element in France clamored for an immediate treaty with Germany, leaving the formation of the League of Nations mintil later. But most of those who took this stand appeared to be enemies of the principle of the League, either because of their imperialism, their avowed hatred for Germany, or a natural lack of confidence in the League guarantees. They did not dare to demand openly the rejection of the League; so they argued for its postponement. It is noteworthy that those who believed whole-leartedly in the League, were in favor of its integral inchsion in the Treaty. 


\section{CONTEMPORARY FRENCII POLITICS}

The French conception of the League of Nations, as revealed by the press and public utterances during the peace negotiations, was on the whole a very practieal one. It was not so much concerned with the methods of organization of the League as with what it desired to sec it accomplish. The first test of the League's reality was a financial one. Originally, in the hot enthusiasm of victory, French opinion demanded the exaction of an indemnity from Germany which should compensate not only for the damage done to civilian life and property, but also for the entire expense to which France had been put in waging the war. In some instances, demands were heard for the return of the indemnity of 1871. But gradually it dawned upon Freneh economists that these sums represented a figure so enormous that, even if Germany could conceivably pay, a century or more of annuities would be required. To place such a burden upon the old Empire would probably force her into total insolveney. Moreover, to maintain a threatening trusteeship over the German people for an indefinite period, from the standpoint of a return to normal international relations, threatened a further political disaster."

In addition to Germany's inability to pay, the indemnity was limited for a theoretical reason-a principle

${ }^{2}$ Tlıe Treaty of Versailles, Part VIIT, Art. 232, recognized Germany's inability to pay, as follows: "The Allied and Associated Govermments reeognize that the resourees of fiermany are not alequate, after taking into aceomit permanent dimintions of such resources which will result from other provisious of the present treaty, to make complete relaration for all such loss and damage." 


\section{FRENCII CONCWRTON OH A LEAGIS}

which favored remitting the direet rost of carrying on a war, becanse smeh exartions, if fastoned on a defoated power, would but encourage nations to agresession, theil. people being given the hope that victory would rompensate for every saterifice. In other words, it was folt that the formula must be laid down that war profits no nation. In the rase of France, the demand for the payment of war charges was thoromghly legitinate beamse she had not been the aggressor. But the Conference obviously feared to establish a precedent which might eneourage future agressions. ${ }^{3}$

Principle, and Germany's ability to pay, therefore, limited the amonnt of the French indemnity to the reparation of civilian damage. With the recognition of this fact, only onc conchusion conld be reached-Germany could be comted on to pay France only a fraction of the damages she had inflicted. In plain figures, this meant that France had to face with her own resourees, a national debt of $\$ 30,060,000,000$, and a budgetary defieit for 1919 of at least $\$+000,000,000.4$ During the four years of the war the French Govermment had expended $\$ 34,000,000,000$ in military expense alone, i. e., munitions and army supplies. The damage to the dev-

${ }^{3}$ The exchusion of an indemnity eovering direct war charges was implied in the note of Seeretary of state Lansing to the German Government, of November 4, 191s: "In the conditions of peace latid down in his arlitess fo Congress of January 8, 1918, the I'resident declared that invaded territories must be restored as well as evacuated and freed. The Allied Governments feel that no doubt ouglit to be allowed to exist as to what this provision implies. Tyy it they understand that compensation will be male ly Germany for all damage done to the arilian populations of the Allies and their property hy the ageression of fiermany ly lamb, hy sea, and from the air.",

* The prearions financial sifuation in Franee was fartly orea. sionel by the questiomale policy followed of raising tunds by loans instearl of by taxation. See Aplendix B, "French Taxation During the War.'” 


\section{CONTHMIPORARY FRENCH POLITICS}

astated regions amounted to $\$ 15,000,000,000$ at least. For the latter sum, France eould expect indemnifieation; for the former, more than twice as large, she must renounce all hopes of compensation.

The realization of this precarious situation came not without a natural bitterness. Must this great burden whose payment it is impossible to exact from Germany be borne by France alone? Or will the Allies jointly assume it? Will the League of Nations prove its worth by taking the debt over? To the practical-minded Frenchmen, this question was the first test of the genuineness and the efficacy of the new Society of States. It was also a test of the sincerity of the assertion repeatedly made by her Allies that France had "saved the world."

This point of view was expressed in an editorial in Le Petit Parisien:

The world has placed its hope, it may be said, its faith, in the League of Nations. . . But it does not suffice that a League of Nations shall superimpose upon its component States a permanent Arbitral Court, that it control their armaments and even certain of their productions. The war has set forth problems which each country, taken alone, will be practically powerless to solve but which the world collectively may settle with relative ease. . . One of the grave questions of the present and the future is the financial question. It rose suddenly before us and our Allies on the morning of the armistice. Every one foresaw its difficulties, and realized that the liquidation of the charges coutracted cluring the years of struggle could not be dealt with by transitory expedients. . . . No one serionsly contests that Germany and her allies must pay the most pussible . . but it is recomized that Germany and her allies, whatever measmes they may take, will be malble to bear the whole burclen. It is for the liquidation of the balanee that the Leagne of Nations must intervene.

What will this halanee he? We do not know. But the 438 


\section{FRENCII CONCEPTION OF A LEAGUE}

principle which must inevitably be followed is clear: The nations whieh have mited around Belgimm, Serbia, and France, have contracted themselves in a life-long pact. If one of them had defaulted during the first or in the last six months of the war, the Central Powers would have attained their ends. If in the future, one of them (the Allies) should be finaneially or economically wiped out, the League of Nations mnst lose in prestige as a protecting remedy. Men, ships, food, and railways have been put in common usage. It is essential that the eharges shall also be placed in a joint aceount; otherwise the people who have consented to the greatest saerifice in the common cause will be the ones most surely destined in the future to a definite collapse. By economic disaster they would atone for the heroism which they have displayed in the service of universal liberty. ${ }^{5}$

Similarly, Mr. Antonin Dubost, President of the Senate, said:

The League of Nations can alone become the basis of an international finaneial organization eapable of meeting the burdensome eharges (of the war). By any other means, the task appears hardly surmountable. ${ }^{6}$

In the course of a remarkable speech before the Senate, M. Ribot, former President of the Council, de. clared:

We have suffered more than any one else. . . . But because our comntry has been the theater of the war, beeause this struggle has been fonght upon our soil, must they (the Allies) leave us alone to support all the eonsequences of the war, and to face the uncertainty of German payment? No, I say that this is an injustice! My conclusion is that the expenses of reparations and the expenses of pensions as well must be placed in common... . The debt must be supported not by ourselves alone, nor yet in proportion to our sufferings and

Issue of March $\tau, 1919$.

- At a meeting of the General Couneil of the Isère, hell at Grenoble, April 2S, 1919. 


\section{CONTEMPORARY FRENCH POLITICS}

our sacrifices, but in proportion to the resources of each. That is what justice demands. ${ }^{7}$

An interesting plan for a finaneial seetion of the League of Nations was laid before the Chamber of Deputies in February. This ealled for the ereation among the Allied powers of a Finaneial League of $\mathrm{Na}$ tions which would divide among them, proportionately to their populations and to their respective contributing power, the fiscal charges neeessary to eover the expenses caused by the war. These charges, which amounted, aecording to the Deputy, M. Jaeques Stern, who introduced the measure, to over $\$ 100,000,000,000$ would be eared for by a eommon fund, underwritten by the members of the Leagne. To assume this debt, international bonds would be issued, upon whieh each member of the League would be obliged to pay his share of interest and amortization eharges. Subseribers to national war loans, ete, would exehange their bonds for this new, international security, collectively guaranteed. The share of each nation would have to be determined by its ability to pay and not by its share in the debt. If a nation should fail to meet its payments upon this international debt, it would have to surrender to the Leagne of Nations a pledge-such as its tariff reeeipts or railways-to be internationally operated until the debt be paid.

The Stern project was not received with a great deal of favor in France, first, because it diel not provide for the exaction of an indemnity from Germany; second, because it made no provision for the division of debts according to war losses.

A more dobaled project was earofully worked out

"Wou May 30, 1919, several weeks after the Treaty had heen presentod to Germany. 


\section{WRENCII CONCE'TION OH A LEAGUE}

in a brochure by M. Marcel Bouilloux-Lafont, entitled: "An Essay upon the Economie and Financial Rôle of the Society of Nations." 'The settlement of the inclemnity, according to him, should follow these principles:

1. Distribute the payment over a period long enough so that the operation may be materially possible.

2. In addition to payments in gold and restitutions in kind, place an indemnity, of say $300,000,000,000$, mpon the eneny nations, for the payment of damages eaused to civilians.

3. Place the surplus of the war expenses upon the League of Nations, to be paid in the form of annuities.

4. Create an international bank of issue which should be created to issue the financial instruments necessary to the work of liquidation, to make the necessary advances to participant countries, and to be supplied with resourees allowing it to pay off the debt in from fifty to seventy years.

5. Create a tariff union among nations, which, by the application of a minimum, an ordinary, and a "penalty" tariff upon groods of a defaulting nation, may enforce international obligations.

As an example of the method of operation of sueh a system, France, whose war expenses the writer estimated at $\$ 30,000,000,600$, would reeeive:

1. Nine billion dollars in international bills from the international bank, six billion of which would be paid to the Bank of France, as security for French paper issnes.

2. Nine billions in intemational bonds, seven billions of which would offset the bonds of the "National Defense" and consernently lighten the anmul interest charge.

3. Twelve billions would be paid by the international bank in the form of annuities, with $4 \frac{1}{2}$ per cent interest, plus the amortization rate, to rum for a maximum period of seventy years.

In this way, the $\$ 30,000,000,000$ which France could not exact from Germany, would be paid in seventy years through her own and international aid. 


\section{CONTEMPORARY FRENCH POLITICS}

To supply the resources for this novel bank, the writer would institute a series of international taxes: (1) a tax on land, sea or air transportation of .01 frane or its equivalent, upon each kilometrie ton of merehandise transported upon any railway among the assoeiated nations; (2) a tax on passenger travel of 1 per cent; (3) a tax of half a frane (10 eents) upon each ton of shipping entering a port of one of the associated nations; (4) a special surtax on importation or exportation of 1 per eent ad valorem; (5) a speeial tax on the produetion of aleohol, sugar, opium, iron, wheat, cotton, petroleum, rice, eoffee, eopper, wines, wool, coal, tobaceo, tea, beer, and silk; (6) a special surtax upon telegraphie, telephone, and radio communieations of 1 per cent; (7) a tax of .001 frane per kilowatt hour produeed in every electrical establishment.

The intended effect of the assumption of the war debt by the League of Nations would be to relieve France of a burden which she felt was disproportionately large and to plaee a share of this load upon nations who had not suffered to the same extent but who had profited as greatly from her sacrifice. This meant that the share of the United States would be greatly inereased. Such a result and that of the general apportionment of war debts was worked out by Professor Charles Gide, the eminent economist. According to the table given such a division wonld relieve France of a yearly charge of over 4,000,000 franc's or 63 per eent of her present burden; it would relieve Italy of over half, or 57 per cent, and Great Britain of 21 per cent. On the other hand, it would increase the United States' annual eharges from $7,500,000,000$ to $16,000,000,000$ franes $(\$ 3,000,000$,$000)$, an increase of over 100 per eent. ${ }^{8}$

"lievue d'Fromomic I'olitique, January-lebruary, 1918. 


\section{FRENCII CONCEITION OF A LAAGUE}

Gide's App untionment or Wak Deits

\begin{tabular}{|c|c|c|c|c|}
\hline & $\begin{array}{c}\text { War } \\
\text { Expenses }\end{array}$ & $\begin{array}{l}\text { Annual } \\
\text { Interest } \\
\text { Charges }\end{array}$ & $\begin{array}{l}\text { Yearly } \\
\text { Income }\end{array}$ & $\begin{array}{l}\text { Proportional } \\
\text { Share of In- } \\
\text { terest Charge }\end{array}$ \\
\hline $\begin{array}{l}\text { France........ } \\
\text { British Empire } \\
\text { Italy ........ } \\
\text { United States. }\end{array}$ & $\begin{array}{c}\text { milliards frs. } \\
130 \\
180 \\
50 \\
150\end{array}$ & \begin{tabular}{|c} 
milliards frs. \\
7.8 \\
9 \\
3 \\
7.5
\end{tabular} & $\begin{array}{c}\text { milliarels frs. } \\
33 \\
80 \\
15 \\
180\end{array}$ & $\begin{array}{c}\text { milliards frs. } \\
2.9 \\
7.1 \\
1.3 \\
16\end{array}$ \\
\hline & 510 & 27.3 & 308 & 27.3 \\
\hline
\end{tabular}

Although it is certain that the French Peace Delegation urged some such plan of division of war indebtedness, the Peace Treaty omitted all reference to it. Consequently, the general financial provisions of the Treaty were disappointing to the French.

Although the principle was laid down that compensation might be exacted from Germany for damage to persons injured from acts of war, eruelty, and violence; for the eapitalized eost of pensions, for allowances paid by the Allied Govermments to families of soldiers during the war, and for damage to property, exeepting naval and military works and materials, it did not definitely state what the amount of the indemnity wonld be or when it would be paid. The Treaty merely said that the amount of this damage for which eompensation was to be paid by Germany should be determined by an InterAllied eommission, to be called the Reparation Commission. ${ }^{9}$ This Commission on or before Nay 1, 1921, should notify the German Govermment of the extent of its obligations; and payments were to be made in the form of annuities for a period of thirty years, begiming

- Treaty of Versailles, Article 233. 


\section{CONTEMPORARY FRENCH POLITICS}

with the 1st of May, 1921. In other words, France was obliged to wait until 1921 before receiving anything definite in the way of reparation, while her territories must, necessarily to her very existenee, be immediately restored. It is true that the Treaty provided for a payment of 20,000,000,000 marks during 1919, 1920, and the first four months of 1921. But out of this sum the expenses of the armies of occupation subsequent to the armistice of the 11th of November, 1918, must first be met, ${ }^{10}$ in addition to that of the supplies of food and raw materials advanced by the Allies to Germany. It was quite apparent that this deduction would largely consume the 20,000,000,000 marks. To the French public, this priority even appeared to be little more than a guarantee that the British and American merchants, indirectly supplying the armies of oecupation and the material advanced to Germany, would receive first payment. They could not understand why their own devastated regions had not been given first consideration.

Another ineonsistency concerned the German annuities. Starting in 1921, they were to run for thirty years; but the Allied Army of Oecupation, the only guarantee of payment, was to be withdrawn in fifteen years (except upon the express decision of the League of Nations to the eontrary) when probably not more than half of the indemnity would have been paid.

These financial defeets might have been pardoned if

${ }^{10}$ Ibid, Article 235. Twenty billion marks gold hearer bonds, payable not later than May 1, 1921, without interest, were also to be issued, toward the amortization of which the above sum of $20,000,000,000$ marks was to be applied after deduetion had been marle for the reimbursement of the expenses of the armies of oceupation and for payment of foodstuliss, ete., ardvancel by the Allies to Germany. See 'Treaty of' Versailles, Article $2+4$, Ammex II, 12, e (1). 


\section{FRENCII CONCEPTION OF A LEAGUE}

the Conference had granted what the French considered the most important of all their financial requests: the assumption of the actual war expenses of the Allies by the League of Nations. Of these charges, - the most formidable item in the French debt,-the Treaty made no mention whatsoever; while absolving Germany from its payment, it substituted no other policy of liquidation in its place. The brunt of this overwhelming debt now lay upon France alone. The world had praised lier for the heroie saerifices she had made, yet now refused to help heal her wounds. Qui payera? La France! This was the moumfully reiterated commentary upon the whole Treaty docmment."

The request of Franee for financial help-aceording to newspaper announcements made during the first week of Mareh, 1919-was definitely refused by the American Peace Delegation. It is not yet publicly known why and in what form this refusal was made. To acquiesee in this burden, which assuredly would fall the heaviest on the United States, was a grave measure of policy. The American delegates took their stand probably because the proposed measure would increase hostility to

\footnotetext{
${ }^{11} L$ 'Europe Nouvelle, Nay 17, 1919, thus protested against the financial provisions of the Treaty: "The financial stipulations of the Treaty will cause... an immense deeption throughout the whole of France. They place the entire country before a formidable uncertainty. They constitute, in our opinion, the most Hagrant injustice. . . The stupid error, the unpardonable error, of our negotiators has been not to lay down as the basis of all negotiations, the financial settlement of the war, the listribution of the expenses of the war by a pro rata of efforts, of human capital sacrificed and of efrective capreities of production. . . The aloption of this equitable and fair principle alone... can permit the establishment of a just and durable peace. . . Victorious by its arms, raliant in glory and set in the purest halo male from saerifice and from the obseure devotion of millions of heroes, France will he controlled in the future by the narkets of london and New lork. Is it for this that we have fought?"'
} 
the League in the United States to such an extent that the whole idea would be defeated. Whatever the reason, the refusal to reimburse France for what she considered a common sacrifice aroused the first suspicion among League supporters of the impotency of the League as created and of the insincerity of the Allies. It was this - suspicion, growing into a firm conviction, which caused the obstinate exaggeration of other demands by France.

\section{III}

In addition to the financial test, the French public weighed the value of the League of Nations by the guarantees it offered for future peace as compared with those furnished by the policies of the so-called "Old Diplo. macy." French hatred of Germany naturally affected its conception of a League of Nations. France believes that Germany will always be her enemy and that she will always meditate a fresh attack. Even M. Clemenceau was indiscreet enough to declare publicly last February that the armistice was "only a lull in the storm." The French attitude, the intensity of which cannot be overemphasized, was completely justified by the past conduct of its adversary, by the hideous conduct of the war and by German breaches of faith during the armistice. The establishment of a republic did not appear to alter German character. The sinking of the German fleet at Scapa Flow, the destruction of the French flags taken in 1870, and the brutal attacks upon Poland at the very time of the signing of the peace, all reënforced the French belief that something more than a treaty must be drawn up. Sure and positive means of enforeing its provisions must be provided. 


\section{FRENCII CONCEP'TION OF A LEAGUE}

It was this instinetive fear of Germany and the open distrust of its word which led France to insist upon its exelusion from the laague, at least mutil such a time (as Article VIl of the Covenant draft expressed it) when Germany "is able to give offective guarantees of its sineere intention to observe its international obligations." From the French standpoint, this poliey of exclusion, and the belief that Germany must be kept in a state of constant surveillance, was perhaps justified. From the standpoint of the success of a League of Nations, it is more difficult to defend. Several times during the eourse of the war, the ereation of a League among the Allied belligerents had been urged. President Wilson demonstrated the error of this argument when he said: "The League of Nations . . . cannot be formed now [during the progress of the war']. If formed now, it would be merely a new allianee confined to the nations associated against a rommon enemy." 12 To sueeeed, a League must be eomposed of the entire world and be designed as an instrument of peace.

But although the formation of the League was deferred for this very reason until after the war, the logie of the argument was not earried ont. Germany and the other enemy powers were excluded-only temporarily, it is true.

But when they are eventually taken in. they will always resent the Leagne and suspect it of being a eombination of the present Allies to keep them in permanent subjection. In short, the League as established, was little more than an alliance-which if stronger than any predecessor, possessed little more than the essential elements of an allianee, i.e., one group of nations joined

12 Speech at New York, September $27,1918$. 


\section{CONTEMPORARY FRENCII POLITICS}

together against another. ${ }^{13}$ With this entering wedge, the way was opened for the perpetuation of the old system of partial allianees and the Balance of Power. These principles were implicitly recognized in the Treaty, although subject to certain limitations. ${ }^{14}$ The alliance between Fngland, America and France was an example of this inconsistency. ${ }^{15}$ The League may work without Germany, but it cannot hope to be successful so long as it maintains an unofficially hostile attitude toward a considerable portion of Europe.

In addition to excluding Germany from the League, the Freneh attitude insisted upon her disarmament and military subjection. In general terms, the French demanded that a compulsory sanction reënforee the desire of the League to maintain the peace of the world. Although the Treaty provided for the disarmament of all nations, no eertain assurance was given of this policy being carried out. Article VIII of the Treaty spoke only of "the full and frank exchange of information" as to military and naval programs. Article IX speeified that a permanent Commission shall be eonstituted to advise the Couneil upon the exeention of the provision of Artiele VIII and on military and naval questions generally. This commission was given no adequate powers of investigation or of enforcement. Although for a periol of fifteen years the Allies are to maintain an army in Germany enforcing disarmament, thereafter no means

${ }^{13}$ In the same speech the President sail, "There ean be no leagues or alliances or special covenants and understamdings within the general and common family of the Loanue of Nations. . . . Special alliances and economic rivalries and hostilitios have been the prolific sonrce in the modern world of the plans and passions that prohuce war."

"Sice Articles 16, 19, and 20, Treaty of Versailles.

15 . we discussion of this alliance, 11). $1623,463$. 


\section{FRENCII CONCEPTION OF A IEAGUE}

of knowing whether or not Germany is re-arming or not, is provided. A nation's word, espeeially Germany's word, France tid not regard as sufficient. Upon the matter of disarmament, she urged the creation of a eommission vested with inquisitorial powers to determine whetler the leagned nations were keeping their promises. An amendment to this effect was unsurecessfully urged before the Commission on the League of Nations by the Freneh delegation. At the second plenary session of the Conference, at which the draft was presented, M. Bourgeois, the French member of the commission, said:

In order to assure the exeeution of international sentences, there must be a limitation of armaments.... The nations who are the contracting parties of the eovenant pledge themselves mutually to eommunicate to each other full information about their armaments and their means of production. This is a very good plan, with which I an partieularly satisfied. At the same time, I proposed an amendment which I think I ought to mention; I thought that it would be necessary to institute a permanent organization for purposes of insprection, but this amendment was not embodied in the text. We have aecepted the text, as it is before you, and if we now mention the amendment, it is because, as the whole seheme is going to be discussed by the world, it is better that all the points that have given occasion to important observations should be mentioned.

The rejeetion of this amendment was another indieation to the French of the weakness of the League as created. A more vital weakness was the total absence from the Covenant of provisions for a military force of international eomposition to give a sanction to the League's decision or in plain terms, capable of preventing immediately or even anticipating the attack of one nation upon another. Article XIl of the Treaty provided that disputes between members of the League should be 


\section{CONTEMPORARY FRENCH POLITICS}

submitted to arbitration before resorting to war, or to inquiry by the Executive Council; and that any disputant should not go to war until three months after the award of the arbitrator or until a recommendation by the Council had been made; and (Article XIII) that not even then would the disputants resort to war against a member of the League which complied with the deeision. Article XVI provided that violation of these provisions would be considered as an act of war against all other members of the League, who would immediately sever all trade and finaneial relations with the offending State, thus placing it in a state of economic isolation. The article further said:

It shall be the duty of the comcil in such a case to recommend to the several Governments what effective military, naval or air force the members of the League shall severally contribute to the armed forces to be used to protect the covenants of the League.

This word "reeommend" -in the light of Freneh experience-was not very reassuring. Moreover, the artiele did not even state whether or not the member-States were obliged to aceept the Council's recommendation. It even implied that they were not. There was nothing certain laid down concerning eontributions. In fact, this article, the most important in the whole eovenant, from the French standopoint-one which was supposed to substitute the securities of the League for those of the Old Diplomaey - was quite unsatisfactory. French security from the German menace was an affair of vital importance, yet what did the proposed Leagne put forward to meet this concrete situation? Even if the nations were obliged to make contributions to an armed foree, who would enforee this obligation? It obviously 450 


\section{FRENCII CONCEPTION OF A IEAGUE}

reposed on international good faith. But nations have broken faith; not only Germany, but others. If it were not a matter of abiding faith, it might become one of "interpretation." And while nations were deciding whether or not to send quotas, or even while they were engaged in raising and sending them, the damage would be done. France did not wish again to stand waiting through two desperate years until England made ready, or three years until America joined the lists. To relieve this uncertainty the French delegation wanted to endow the League with an international military force, directed independently of national quotas and policies, suppressing aggression as quickly as a fire department extinguishes a loeal blaze. Moreover, it was only the assurance of such a force which would convince France of the League's reality.

Senator Bourgeois stated the French view on this subject at the session of the Conference, on February 14th, in these words:

Here is a point. Take a State which violates the International Covenant. That State is supposed to be in a state of war against all the members of the League, and all are prepared to exeente its obligations. But war is not something that ean proceed at once, especially when the question is how to bring together forces belonging to States which are very different from each other and may be at the four corners of the world. Each people will have to wait in order to act, in order that the procedmre has been gone through, in order that for each partieular nation a vote may be taken by its parliament, and so on. This means time and delay.

And supposing that there is on the part of the agroressor a will of precipitating a situation, then we must provide for the possibility. For this purpose it would be desirable to have all the means of resistance studied, and coneerted action prepared before the oceasion arises. This would be the best eheck against all ill designs. If the would-be argressor knows that 


\section{CONTEMPORARY FRENCH POLITICS}

the resistance is fully prepared against any action like the one he anticipates, then he will be constrained.

On the contrary, if he knows that no such preparation exists and that a sulden action on his part would encounter no prepared and well-thought-out resistance, perhaps he would not be restrained and it would be extremely dangerous. If we do not wish to see the terrible ordeal that the world has passed through renewed in the future, we ought to have a permanent organization to prepare the military and naval means of execution, and make them ready in case of emergency.

This has been objected to by some members of the Committee beeause it involved some diffieult constitutional problems. This is why we agreed to the text without that amendment, but we think the princille of that proposed amendment ought to be put before public opinion at the same time as the scheme that we have agreed to.

The rejection of this amendment was the greatest blow of all to the French confidence in the guarantees of the League. ${ }^{16}$ It gave the conservatives fresh ammunition for their attack on its principle and on the Fourteen Points; while those who believed in the ideal had their faith in the form of its application considerably weakened.

Thus Jaerues Bainville, after the publieation of the draft, wrote:

There can be no real League of Nations withont a firm engagement to come to the help of an attacked adherent. There can be no engagement of this kind without the principle of obligatory intervention being solemnly established. There ean be no possible intervention without armies ready to make it effective. But under the proposed plan, each in ease of appeal will remain free to diseuss its military participation. 'Thus through concessions made in order to assure its

${ }^{16}$ See an article on "French lileals and the Covenant," by Leon Bourgeois, London Times (Froncli number) of September 6, 1919. 


\section{FRENCII GONCLP'TION OH A LEAGUL}

existence, the leante of Nations has to deprive itself ot its most essential elenrent.

L'Echo de l'aris, commenting in a similar manner, wrote as follows:

We are thus forced to conchde that the twenty-six articles do not hring us real seenrity. As bore as they are not changerl, we can by no means sacritice to them our means of defense.

Upon another oceasion this same paper wrote:

All the amendments capable of giving to the League bone, museles, and norves, esperially the French amendments, have found little merey in the eyes of those two great doctrinaires, Wilson and Robert Cecil. The control of armaments? Useless. An Inter-Allied Staff? Superfluons. . . Truly, the constitution of the Leagne is in harmony with its program, the spectacle of which we have admired for three months. The theory is worth the practice.

La France Libre, a Socialist papel, also said:

To constitute the Soriety or League of Nations-the word matters little provided we have the hling-to impose eompulsory arbitration and to create an international police force strong enough to make Law and Justice prevail,-such ought to be the program of reason and of humanity inspiring the peace plenipotentiaries.

It must be admitted that there was some merit in the French conception. If the League of Nations was to be anything more than another ITague Tribmal, it must neeessarily contain some clements of force. If its purpose is to establish compulsory arloitration, it is obliged to inclute the means of making aplitral decisions aompulsory. The French amendments gave life and blood to the Jeagne; they amerl at estahlishing definite sancetions and ones to be respected. 


\section{CONTEMPORARY FRENCII POLITICS}

It is generally believed that the American Peace Delegation was responsible for the defeat of all the French suggestions, financial as well as military. Although the members of the delegation itself were doubtless in favor of them with certain modifications, it appeared that the Republican opposition in Ameriea would completely kill the entire League if it embodied such definite and preeise responsibilities. This seems to be one of the explanations for the creation of a vague and unorganized Covenant.

This Republican opposition to the League of Nations was the final factor in the French suspicion of its value. The results of the November elections, returning Republiean majorities, naturally led many Frenehmen to believe that a treaty of peace embodying a League would be rejected by the American Senate. Consequently a reliance upon the guarantees of a League, whose very existence was in question, as a substitute for the seeurity which the territorial exactions of the Old Diplomacy offered was something which no Frenchman could countenanee.

\section{IV}

Reverting now to the effeet the principles of the Leagne of Nations had on the Freneh peace demands, it may be said that they resulted in the rejection of the Rhenish fronticr; they compromised the Saar question and German disarmament; but they met defeat almost completely in the matter of the Anglo-French-American Alliance.

As a temporary substitute for the Rline frontier, the Treaty provided that Germany would not "maintain or construet any fortifications either on the left bank of $45 t$ 


\section{FRENCII CONCEP'TION OF A IAEAGUE}

the Rhine or on the right bank to the west of a line drawn fifty kilometers to the east of the Rhine." 17 'This provision the League Conncil was to enforce. The exeeution of the Treaty was further assured by the Allied oceupation of the German teritory west of the Rhine, together with its bridge-leads, for a period of fifteen years.

The temporary oecupation of the Rhine has been vigorously attacked by so-called "liberals" as being as ineonsistent with the Fourteen Points and the League of Nations idea as the annexation of the Rhenish provinces to France would be. It is said that this policy means the physical subjection of Germany to the Allies, resulting not in the restoration of international friendship but in the continuance of a hostility which sooner or later must again violently express itself. Although this may be the result, it is diffieult to see how it could be otherwise, even under the agis of a vigorously constituted League of Nations. Germany has been the immediate cause of an international conflagration, the damage of which she was under the deepest retributive obligation to repair. Like any other culprit, there was no reason to believe that she would voluntarily, or without the fear of compulsion, submit to her sentence. The maintenance of a police force upon the Rhine, under the direction of a League of Nations or of a given number of Allied powers, until the obligations of Germany had been eomplied with, was a practical necessity, despite its moral objections. It has been urged that the duration of this occupation and the charges placed upon Germany which the occupation was to enforce, were both onerous and impossible. But this can hardly be

${ }^{17}$ Treaty of Versailles, Article 42. 


\section{CONTEMPORARY FRENCII POLITICS}

said of the indemnity feature, the amount of which was left to the determination of the Reparations Commission, and whose provisions in fact completely relieved Germany of the Allied war expense. Although the eeonomic clanses of the Treaty seemed to impose great hardships, it must be remembered that France, especially, has suffered hardships which Germany ean never repair. To pervert the Fourteen Points so as to absolve Germany completely from the eriminal responsibility of starting and of continuing the war, and even to prevent all retribution for snch a responsibility is an error which ean only encourage futmre aggressions. The punishing of wrong-doing is no injustice; in faet, the absolution of impenitent wrong-doers is a perversion of justice. The League of Nations indeed aims at the prevention of international erime, but it would fall short of this purpose if it neglected to punish severely its eommission.

Although the oeeupation of the Rhenish provinees does not necessarily conflict with the principles of the League of Nations, the solution of the Saar controversy is more diffienlt to defend. According to the Treaty, and "as eompensation for the destruction of the coal mines in the north of France and as part payment toward the total reparation.'"1s Germany ceded to France the full ownership of the coal mines of the Saar basin. To aroid the appearance of violating the will of the population of the district, it is to be governed by a Commission of the Leagne of Nations, consisting of five members, one French, one a native of the Saar, and three others representing different countries other than France and Germany. After fifteen years a plebiscite will be held by communes to determine whether the

"Treaty of Versailles, Artiolo 45. 
population wishes to continue under the regime of the League of Nations, or to mite with either Franes or Germany. In any portion of the distriet which may be restored to Germany, the latter Government must huy out the French mines at an appraised valuation. Aurl if Germany does buy back the mines, the Leagne will decide how much of the coal shall be ammually sold to France.

Although the French demand for amexation of the Saar was rejected-as a violation of the principle of self-determination-the compromise appeared so fictitiously veiled to $L$ 'II umanité, the Socialist organ, that it was moved to write:

The partisans of a peace of violence and of rape must be satisfied by the proceedings of the last session of the council of Four. Only economic alrantages are to be conceded to the French eapitalists for the exploitation of the basin of the Saar. Some "administrative rights" will permit the French Govermment to exercise a "comtrol" over the basin which is to become a "State analogous to Lnxembure." And it is already announced that the French military anthorities have alrested in this region, Germans aceused of being at the same time Nationals and Bolsheriki. The French army takes up the role played by the Prussian soldiery in their treatment of the people of Alsace-Lorraine, this time against a German population. What an infany! The bourgeois press pretends that $M$. Clemencean has French opinion hehind him. We are certain that (censored) ${ }^{19}$ will not be deceived by this impulent falsehood. They know, on the contrary, that the real French people, those who work and those who have fonght, protest with indignation against a policy unworthy of our great country. The "khaki" deputies of Iloyd (ieorge are exerting pressure on the English Government to obtain a peace entirely opposed to Wilsonian principles. The Franktin Bonillons of our Palais Bourbon lead the sime campaign in France and Clemenceau serves them at his best.

"Probably the Amerirans. 


\section{CONTEMIPORARY FRENCII POLITICS}

These gentlemen may triumph at the Quai d'Orsay. But we will again tell them that their peace will not be ratified by the people,-that the reoresentatives of the working class will not rote for it. ${ }^{20}$

A friendly neutral, whose opinion earries more weight than that of L'Humanité, likewise wrote:

France at present offers the spectacle of a man who loses his prey for its shadow. In order to have the Saar, it has given up the help of President Wilson and its intimacy with England; it follows a policy whose ultimate consequenees will be to throw Austria and Italy back into the arms of Germany and at the same time it prepares for itself a splendid isolation in Enrope. It is again committing, in another manner, the disastrous fault of the Napoleons. ${ }^{21}$

The possession of the Saar, from the standpoint of seeurity, did not appear necessary. The seizure of its eoal, from the standpoint of reparation, was perhaps justified; but there seemed to be scant reason why the Treaty did not stipulate that Germany annually deliver to France the amount and the quality of coal which the latter herself wanted to take from the Saar. ${ }^{22}$

${ }^{20}$ Issue of April 11, 1919.

${ }^{21}$ William Martin, in Le Journal de Genève, Switzerland, Mareh 19, 1919.

22 The principle of restitution of coal, directly by Germany and irrespective of French ownership of the mines from which it is to come, is recognized in two places of the Treaty. Chapter III, section 37, of the Annex of Part III, of the Treaty (the provisions governing the Saar), states that if the inhabitants of the Saar at the end of fifteen years voto to return to Germany, and after Germany buys back the mines from France, "the French State and French nationals shall have the right to purehase such amount of coal of the Saar Basin as their industrial and domestic needs aro found at that time to require."

The prineiple is more directly admitted in Articlo IT, Annex $\mathrm{V}$ of lart VIII, on Reparation which states that "Germany undertakes to deliver to France $7,000,000$ tons of coal per year for ten years. In aldition, (iermany undertakes to deliver to France anmually for a period not exceeding ten years an amount 


\section{FRENCII CONCEP'TION 'OF A LEAGUE}

Such a solution would satisfy the French elaim for indemnity, but leave inviolate the principle involved. An Inter-Allied Commission to govern the district is certainly a poor sop to the self-determination theory. It will be noted that a German representative upon the Commission is earefully exeluded, except the one "native of the Saar" whose vote is hopelessly outweighed by four foreign delegates. There is little assurance that the district will be governed any differently than if it had been amexed outright by France. Germany, at least for fifteen years, will be inspired by the same desire, although perhaps of less intensity, to win baek this district, which so strongly animated France from 1871 to 1918 with respect to Alsace-Lorraine. The irritation remains, and with it an always threatened peace. $^{23}$

The compromises npon the question of German disarmament, as affected by the League theory, followed two lines: First, the treaty did not provide for the complete disarmament of Germany; and second, it pro-

of coal equal to the lifferenee between the annual produetion before the war of the coal mines of the Nord and Pas de Calais, destroyed as a result of the war, and the production of the mines of the same area during the years in question." If Germany is to mako such a restitution, it is not apparent why the amount of coal which Franee is to derive from the Saar by way of reparation could not be delicered to her in a similar manner, freed from the questionable foreign ownership of the Saar mines whieh the Treaty inposes.

${ }^{23}$ The justifieation of the Saar settlement, considered in the light of other Treaty provisions, was that other nations were urging and virtually obtaining territory to which they did not havo as mueh claim as France. France felt that her interests alone, among the Allies, were being sacrificel to the prineiple of self-determination. Although one wrong does not justify another, there was mueh to be said on this point. The ehief thing against it, made while Franee was urging the point, particularly before the settlement of other territorial questions, was that the establishment of such a preeelent would lead other nations to inerease unjustified demands. 


\section{CONTEMPORARY FRENCH POLITICS}

vided for the disarmament of all nations after Germany had been partially disarmed. But even so, the provisions as to disarmament went farther than the French General Staff estimate of an army of 200,000 or the American estimate of an army of 400,000 , advised. The Treaty provided for: (1) the reduction of the German army to 100,000 men; (2) the dispersal of the German General Staff, the number of its officers being limited to 4,000 ; (3) the recruiting of the German army (conseription being abolished) in terms of twelve consecutive years, the number of discharges before the expiration of that term not to exceed in any year five per eent of the total effectives, an arrangement designed to prevent the accumulation of reserves; (4) the dismantling of all of Germany's fortifications within a fifty-kilometer zone on the east bank of the Rhine, as well as on the west, within three months; (5) the closing of its munitions factories, with some specifie exceptions, and the dismissal of their persomnel. ${ }^{24}$

The purpose of the policy of limited disarmament was to make possible its more rigid enforcement, for as the experience of history had tanght, this could not be accomplished if the complete elimination of armed forees was attempted. It was believed that Germany would have less incentive to avoid the stipulation of the Treaty if she was allowed an army large enongh for police purposes.

The second principle foreshadowed by the Treaty and the League theory was the eventual disarmament of all nations. But this could not be contemplated until Germany had made amends and indicated an earnest intention never again to upset the work's peace. But

2* Treaty of Versailles, Section I, Part V, Articles 159-213. 460 


\section{FRENCII CONCEITION OF A LEAGUE}

at the same time, the theory inplied that the world never could return to a normal basis so long as the Allies kept Germany in a state of disarmament while they themselves kept up great establishments purposely to subdue Germany. Such was the policy of Pertinax and $L$ 'Action Française. The disarmament of all nations was not only essential to the peare of the world, but it was the only thing which would lead Germany to disarm willingly. The immediate fear of Germany, however, predominated in the Treaty over the desire for eventual peace. Instead of working out a definite seheme for universal disarmament, the Treaty aims were again eompromised by the old idea of a neressary German inferiority. Thus the following article reads:

The Members of the Leagne recognize that the maintenance of peace requires the reduction of national armanents to the lowest point consistent with national safety and the enforcement by common action of international ubligations.

The Council, taking aceomnt of the geographical situations and ciremnstances of each State, shall formulate plans for effecting such a reduction for the consideration and alction of the several Governments. . . After these plans shall have been adopted by the several Governments, the limit of armaments then fixed shall not be exceeded without the oceurrence of the council. ${ }^{25}$

Disarmament therefore became a matter for each Government to decide; and no obligation was imposed. on the respective members. It is certain that if one power refuses, other powers, however fervently they may desire and believe in miversal disarmament, will hardly dare to subject themselves to the military predominanee of the objecting power. ${ }^{26}$

${ }^{25}$ Treaty of Versailles, Article 8 .

29 Althongh Franee jarticularly has cause to object to disarmament before Germany las fulfilleil her Treaty obligations, there are 


\section{CONTEMPORARY FRENCH POLITICS}

The final eompromise of the diffieult questions arising at the Peace Conference was found in an alliance between England, France, and the United States, the purpose of which was the immediate support of France in ease of an unprovoked German attack. From the standpoint of the League theory, as President Wilson pointed out in his speech at the Metropolitan Opera House, such an alliance could not be justified. The alliance was based on perpetuated international suspieion. In fact, its preamble stated: "The United States of Ameriea and the Government of the Freneh Republie apprelrend that the stipulations eoncerning the left bank of the Rhine camnot assure immediately to France, on the one hand, and to the United States, on the other, as signatory powers to the Treaty of Versailles, appropriate security and protection."

This certainly implied the probability of attack, if the alliance were not ereated to deter it. From one standpoint, this allianee might be placed in the same category of necessity as the military oceupation of the Rhine; that is, if it were temporary and if it were terminated with the fulfilment of the Treaty obligations. But on consideration it becomes evident that this alliance vitally differed from the military occupation. First, its existence was not limited-as was the oceupation-to fifteen years; and secondly, it definitely reëstablished

at least two indications that certain elements demand relief from the burlens of militarism. Thus the Rarlical Congress, July 26, 1919 , voted for the abolition of the three-year military service law and the gradual reluetion of disirmament in view of the securities offered by the League of Nations. But the Radieal party before the war opposed the three-year law, and this decision may not indicate any changed opinion. But the military bill introdueed in the Senate, and diseussed in September, 1919, called for the substitution of a one-year period in place of the present three-year perioul, in view of the League sceurities. 
the old idlea of a Concert of Nations and the Balance of Power. As noted previously, the French insistence upon Germany's exolusion from the leagno provided a precedent which was logically followed by an alliance, though a defensive one, arainst Germany. There semed to be no reason why the protertion offored by the alliance did not extend to Belgium ; or why Italy and Japan were exchuded from its membership, that is, if it was to exist at all. But why indeed did it not beeome a universal alliance against universal offenders? Why should it not include every member of the League of Nations, each bound to move against every member or non-member of the League who insisted upon upsetting the peace of the world?

The answer to all of these inconsistencies within the League of Nations Covenant and the Treaty is quite evident. $^{27}$ It lay in the French skepticism with respect to the guarantees offered by the League: In other words, France might have been willing to surrender the guarantees, economic and military, which the Saar settlement and the Alliance gave her, if a Leagne of Nations had been constituted with real force and sanction, compelling the arbitration of disputes, and preventing un-

${ }^{27}$ The real ineonsistencies of the Peace Treaty and the Fourteen Points did not so mueh come with the terms arising from the French demands for territory aml the Alliance. They came in the Central and Eastern Huropean settlement, where the self-iletermination principle was frequently violated, to prevent the future growth of a strong Germany. These latter terms, as seen in the prevention of German Austria's minon with Germany, were inspired by the Fronch peace delegation, to enact a strategic sulstitute for that which the League fialed to provide. Incilentally, it may be said that the conference, ly pitifully redueing Austria to nearly an economie and political nonentity, gave it the strongest possible ineontive for mion with Germany, an event which though it temporarily may have thwarted, will eventually and inevitably assert itself. At least, that is the teaching of Alsace-Lorraine and of Poland. 


\section{CONTEMIPORARY FRENCH POLITICS}

warranted attacks by means of an international police foree. If a League policy had been adopted which would have assumed, to a partial extent, France's war indebtedness, she doubtless would have easily relented in the matter of the Saar. This is not to absolve France from a liopeless attachment to a "European" settlement, but it is merely to point out that the eonstruction of a vigorous League of Nations, invested with a sanction to enforce its will, would have gone a long way toward loosing that attachment. The failure to establish such a Leagne led to the insistence upon the old devices of frontiers and alliances. ${ }^{28}$

The success of the Leagne idea in securing the repudiation of the Rhine frontier and the outright annexation of the Saar was bitterly resented by the French publie. The Alliance might be an equivalent seeurity, it was argued; but there was no assurance that England or America, through their legislative bodies, would support such an arrangement. Frenchmen had no reason to believe that the United States Senate would ratify the Alliance, which imposes so many more definite obligations than the Leagne upon America, any more than it would ratify a League of Nations. ${ }^{29}$ Furthermore, if the Allianee did beeome effeetive, what would insure British or American adherence to it fifty years hence? Good faith, they argued, was not as satisfying a security as the incorporation and garrisoning of the Rhinelands by France. This idea was repeatedly expressed during the debate on ratification, not only by the Royalists, but by

23 On Jamuary 19, 1919, L'Echo de Paris wrote: "For us French, there is only one means of ajpreciating the worth of the leagues of Nations which are proposed to us. In what ways do they assure our security on the hinine, the most exposed region in the worla?",

${ }^{24}$ see HI. $173,174$. 


\section{FRENCII CONCEPTION OF A LEARUE}

such conservatives as Charles Benoist. Hven after the ratification of the Treaty by the French Chamber on Oetober 2, Maurice Barrès explained, to a carefully attentive andience (October 3), a plan for the French colonization of the Rhinelands, virtually amounting to annexation. ${ }^{30}$

It is easy to maintain that even if the French idea of a League of Nations lad been incorporated in the Covenant, there would have been a demand for the guarantees of the Old Diplomacy. But it is equally reasonable, however, to believe that they would neither have been so insistent nor so universal. 'The Leagne of $\mathrm{Na}$ tions, as finally constituted, was eonsidered by French opinion as lacking the most essential elements of strength. It came not as a substitution for, but in addition to, the old principles of the Balance of Power. The important thing to be noted, howerer, is that the theory of the League was finally accepted-along with the principles embodied in the Fourteen Points. The League was born. If it is properly protected during its infaney, the jealous guardians of the Balance of Power may not be suecessful in killing it off, as they are now bent on doing. The eritical stage is already at hand.

The responsibility for the failure to provide the League of Nations with the seenrity upon which Franee justly insisted was largely due to the Ameriean Peace Delegation. Although doubtless favorable to a structure of the French design (as pointed out), fear of op-

${ }^{30}$ In the course of his allless he said: "We ask that every measure be taken to associate more intimately the Rhinelands with France through commerce, througl ways of communieation, through coördination of lailway tariffs, through a program of publie works, through banking and coöperative institutions, and through the coördination of labor and social laws. To this end there should be created without delay, mixed commissions com. posed of Rhinelanders and Frenchmen.', 


\section{CONTEMPORARY FRENCII POLITICS}

position at home compelled the vetoing of any project placing definite burdens upon the United States. Consequently, every Frenehman conscious of the German menace, every one upon whom fell the responsibility of the national defense, would have been reereant to his eountry's cause if he did not urge, at least, the Allianee to supplement the hazy guarantees of a League, whose whole principle the American Senate might reject. Looking at it in this light, MI. Clemenceau pursued as a patriot the only policy possible, and Mr. Wilson, in the face of a fast-developing home opposition to a "genuine" league, found himself obliged to acquiesce.

Mr. Wilson has been bitterly attacked for aeceding to many compromises respecting his avowed principles. He has been aceused of frivolously and recklessly condoning the violation of all of his Fourteen Points, except the fourteenth, which called for the creation of the League. But had it not been for the idea of the League of Nations, overshadowing the proceedings of the Peace Conferenee, one shudders to eonsider what the settlement might have resulted in. It seems eertain that the "secret treaties" would not only have been enforced, but they would also have been exaggerated. When viewed from the standpoint of "how much worse the 'Treaty might have been,'” it may be considered remarkable that Mr. Wilson achieved so much.

France, perhaps, has been too insistent upon her own seeurity, for it appears unlikely that Germany will soon be in a position again to attempt to eonquer the workl. But there has been something very much larger involved in the l'eaee Settlement than the mere "fixing" of Germany. A "peace" erected on such a basis cannot, by its very nature, endure. Europe is large enough for a strong Germany and a strong France. In fact, the 466 


\section{FRENCII CONCEPTION OF A LEAGUE}

happy future of Europe depends upon the existence of these two nations-not antagonistic toward each other, but eoöperating with each other. It was the Marquis de Gabriae, the first chargé d'affaires that France sent to Berlin after the War of 1870, who said: "The two nations (France and Germany) are not predestincd to mutual extermination. They are two strong races, of different aptitudes, but they ought to live side by side in good understanding united by the ties of a common eivilization. . . ." It is the hope of such an understanding, and this hope alone, which makes the suecess of a true League of Nations an enduring possibility. 


\title{
CHAPTER XV
}

\author{
WIIAT FRANCE THOUGHT OF AMERICAN "IDEALISM"
}

Intelleetuel: individu qui ne persuade que la soeiétédoit se fonder sur la logique et qui méconnaît qu'clle repose en fait sur d.s nécessités antèrieures et peut-être étrangères à la raison individuelle.-Maurice BarRès.

\section{I}

One of the greatest tributes that Paris ever paid to a visiting statesman was its reeption of President Wilson in December, 1918. The Etoile has presided over many such trimmphal entries; it has seen the royalty of Europe greeted with enthusiasm; it has seen its own men of valor weleomed with pride. But that beautiful arch, now looming more proudly than ever at the far 'nd of the Champs Elysćes, never witnessed an ovation of more eordiality than that which the President recoived. In him the people of Paris and the people of France at last beheld the true symbol of peace. The embodiment of the spirit of America, be stood forth as the spokesman of a new international order, destined dofinitely to prevent the recurrenee of the miseries and privations which Europe had suffered during five apoealyptic years.

Not only did the unorganized masses show the most spontaneous onthusiasm, but every organized politieal element in France was more than generous in its reeep- 


\section{FRANCE AND AMERICAN "IDEAIISM"}

tion and in its acclamation. L'I umanité, the official journal of the Socialist party, issued a special edition in the President's honor on the day of his arrival; in its colums such writers as Anatole France and Romain Rolland praised him in the highest panegrries. Many of the newspapers printed the President's biography. They reealled with what "skill" the P'resident led America into the war. They characterized and praised him both as an idealist and a realist; and they pointed to his share in the raising of an army of 3,000,000 men from among an "inherently pacifist people" as a remarkable achievement. Journals of the Right as well as of the Left united in this eommon admiration; each found in the President an interpreter of their own philosophies. L'Action Franģaise, the monarchist mouthpieee, saw in Mr. Wilson "one of the three politieal directors, who, with Lloyd George and Clemencean, was able to erown the glorious decision of the war." La Croix, a elerical paper, ealled lim l'ami de la justice, who at the same time would surely recognize the neeessity of an American alliance with France to insure the freedom of democracy. Auguste Gauvain in Le Journal des Débats assured his readers that the legitimate interests of France would not eneounter any resistance from the President; while Le Tcmps asserted that the President would surely sympathize with French insistenee upon real guarantees of future peace.

The Socialist press, represented by the L'Heure, expressed Labor sentiment in an article by Marcel Sembat, entitled, "From What Ie Saves Is; Whither Ife Leads Us'":

He has saved us from a German peace which, as we know from the text furnished by Count Bernstorff, would have been 469 


\section{CONTEMPORARY FRENCH POLITICS}

enforced upon us. He leads us to ends opposite from those which our diplomats have in view. For these, as well as for a great number of other Frenchmen, Bismarck remains the model and the guide. They would prepare for us a Bismarckian peace, a peace of oppression, an armed-to-the-teeth peace. ... Upon this ideal Wilson turus his back. He has another plan.... His ideal is the disarmament of the world within the Society of Nations.

Upon the day of the President's arrival in Paris, the General Confederation of Labor and the Unified Socialist party joined in a declaration which they presented to Mr. Wilson. In this document they asserted Labor's sympathy with the President's idealism; they warned him of the overwhelming forces arrayed against him, and of the designs he would have to thwart. They had planned an immense manifestation of working men in his honor, apart from the general welcome which Paris had prepared. But the Government refused its authorization to this eeremony as the only effeet of it would have been to antagonize publie opinion and to injeet into the President's reception a spirit of class consciousness.

L'Europe Nouvelle, liberal in opinion, said in its number of December 14, 1918:

$\Lambda$ the very hour when these lines appear, President Wilson will have made his solemn entry into the eapital of the Fintente.

All the people of Paris, all the true sons of French democracy will be there, present in body, their hands stretehed forth to their $\Lambda$ postle. With enthusiasm and also with respect, they will greet this Messiall of Peace, of the Just Peace.

No king, no emperor, ever received a similar weleome.

He is not yet here, but we already seem to breathe a purer air. 


\section{FRANCE AND AMERICAN "IDEALISM"}

With his presence, a new era of justice, of reason and of understanding will open. ...

The democracies of the Entente have the insecure fecling that certain diplomatic eireles have not completely renouncer the spirit which guided the negotiations of the Treaty of Vienna in their selfish work.

And it is because they have learned the rude lesson of actual confliet, because they well know that the words "social reconstruction," "political regeneration," or "durable peace," are not vain words to-day-dust thrown in their faces by the diplomats of the Paris Conference, that they look with confidence, that they greet with an intense and a profound joy, this new man in whom they have placed all their hopes in a better future for mankind. . . .

The hounds bay; the caravan passes. Mr. Wilson is a man of wisdom. And we who have never ceased in these columns to bespeak the confidence with which this just and righteous man inspires us, we, convinced democrats, who have always regarded him as the leader of modern democracies, greet his coming to-day as the dawn of a new era toward which, thongh displeasing to the timid, to the greedy or to the sluggard, an irresistible force impels the peoples of the world.

\section{II}

Underlying all the cordiality expressed toward the President, there was, however, from the outset, a certain distrust-even fear. To eertain circles this amounted to open suspicion; to others it bordered upon bitter dislike. The imperialists,-and to the credit of France, they were few,-saw in the Fourteen Points a definite impasse checking their ambitions. They felt that they were to be unjustly robbed of spoils which Germany would have taken had she won the war. The conservatives (including many of the so-called Radicals) felt that the security of France was to be sacrificed for some rague ideal-perhaps sound in theory, but certainly 


\section{CONTEMPORARY FRENCII POLITICS}

incapable of execution. As for the liberals-but there are no liberals in France as far as the new internationalism is concerned! To all Frenchmen alike the German menace is too real. Four times it has crossed the Rhine; four times it has been driven back again. With the exception of the last, its coming has been followed by the loss of French territory-living parts of France. The unspeakable miseries of the last four years of fighting-though the end was won-can never be forgotten. The terrible foreboding of a future German victory was never more firmly imbedded in the French mind. Security against future attacks and guarantees against a German revanche, are the principles which must dominate French foreign policy. The means by which this security is obtained is immaterial-it may or may not sacrifice "principles." Certainty is the thing. To the French nation liberal principles applied internationally, meant uncertainty. Hence they questioned them. Apart from the Socialist press, which made of internationalism a purely class issue, no newspaper in Paris sincerely and whole-heartedly supported the full application of the principles of which the President had become the champion.

Open opposition to the things for which the American Peace Delegation stood was preceded by a readjustment of personal estimates. The American army had come to France filled with enthusiasm and with somewhat of an appreciation of the French. Yet, because of difference in language, the disparity of social customs, and countless "little things" there were many misunderstandings. French shopkeepers were repeatedly accused of overcharging Americans. It was alleged that there was one price for them and one for the French. Generosity and considerateness were not to be found among French com- 


\section{FRANCE AND AIERICAN "IDEALISH"}

mercial virtues. $A s$ a matter of fact, as Americans found on returning to the United States, ovoreharging was no more prevalent in France than in America. In both comntries, profiterers appeared anxious to drain the soldiery. Morality is not delimitated by lines of nationality; but the average doughboy in France made of it a diplomatic issue. $A$ still greater prejudice was aroused by the thousands of prostitutes who thronged the streets of practically every town where soldiers were stationed. Perhaps this was an inevitable accompanment of war, but the French authorities appeared to be elearly negligent in controlling the situation. As a result, too many Amerieans drew their opinions of French women from those they saw on the streets; eonseruently, to most of them, France was the most immoral nation in the world. They failed, through no fault of their own, to meet the real France, to know the essential piety of the French family, to understand, in short, the Freneh point of view. The French, on the other hand, gained a similar opinion of the Amerieans. The conduct of many members of the A. E. F. was disereditable. From the irrepressible aetion of many permissionaires, coming to leave areas for a week, with no expenses to meet and perhaps several months' pay to spend, many Frenehmen eame to believe seriously that the chief social interests of Amerieans were limited to the demi-monde and eognae. Le Matin, upon January 27, 1919, printed the following signifieant statement:

Official statistics give for the month of December just past, a total of 34 murders, 220 day or night attacks, and nearly 500 bloody encounters, caused by American soldiers in the single department of the Seine. 
It is needless to say that these figures ware carelessly and tactlessly exaggerated. The bases of these mutual prejudices were completely and equally unsound. But their cxistence could not help but prejudice America's position at the Peace Table.

\section{III}

America's entranee into the war had been accompanied, in France, by a sort of halo. IIer assistance had been invaluable; yet both Amerieans and Frenchmen had perhaps overprized it. When the war ended a reaction naturally set in. The average Frenchman could not fail to compare the casualty lists of the two nations. It was only natural for him then to believe that America had been given too much credit. America had derived great profits from the war. America had been in the war a year-France, five. Yct now it eame before the Peace Conference to dictate peace. Indced the surprising thing about this changing attitude lay in the fact that it was not expressed more foreibly. Frenchmen were very courteous in repressing what they surely must have thought, and they were equally tolerant in listening to repeated boastings of Ameriean superiority. Those who did give vent to their feeling appeared to be dominated more by desires which the presence of Ameriea thwarted than by a wish to seeure Franee a just part in the peace deliberations.

An interesting article appeared in Le Rire de Paris, a popular weekly, shortly after the armistice had been signed, upon the value of American participation in the war. It stated that up to April 6, 1918, the United States only manufactured $880,000.75$ shells, a number 474 


\section{FRANCE AND AMERICAN "IIDEALISM"}

which at the time of the signature of the armistice had increased to 2,400,000. In August, the daily production did not reach 50,000. The production of shells of a larger caliber was even less. France, on the otler hand, turned ont 300,000 shells a day. In ten days it produeed all the shells which the United States manufaetured in twenty months. Of course, American production would have increased had the war lasted, but it is upon actualifies, not surmises, that judgment shonld be passed. The United States sent 109 eannon to France up to September, 1918. But no American .75's eame from American factories up to the time of the armistice, and the first tubes for the $155 \mathrm{~mm}$. guns were not expeeted until Narch, 1919. As a result, France furnished the United States armies with its field artillery, amounting to $22,000.75$ 's-enough to equip eighty divisions. Out of the 4,000 aëroplanes used by the Americans, 2,700 were furnished by the French.

La Vieille-France, perhaps the most anti-Ameriean paper in France, likewise said that America and President Wilson aspired to regulate the affairs, the constitution, and the frontiers of the nations of Europe, all for having brought over 109 cammon and lost 36,154 men in the war! ${ }^{2}$

\section{IV}

The next line of attack had as its result the attempt to diseredit the President as misrepresenting the will of the American people. As far back as October, 1918, L'Echo de Paris, through its Ameriean correspondent, Welliver, gave great prominence to the Republiean opposition to the P'resident. There was seareely a criticism

\footnotetext{
${ }^{1}$ Issue of February 13, 1919.
} 
which this journal did not repeat. Sueh papers as $L e$ Matin and Le Petit Parisien, on the other hand, attempted to interpret American opinion more sympathetieally. Instead of quoting entirely from the antiWilson press in America, especially with respect to the significance of the November elections, they quoted organs like the New York Times, which did not consider their results so much a criticism of the President's foreign policy, as determined by purely domestic issues. This attitude L'Europe Nouvelle also maintained. In regard to the opposition of such men as Roosevelt, Lodge, and Penrose, this journal very boldly said that "they support as a domestic poliey, the maintenance of the trust régime and an impassable tariff wall; as a foreign policy they desire the creation of a permanent army and a powerful navy, the one and the other for the service of imperialist aims"!

La Tieille-France, with its customary exaggeration, was still more naïvely eritical :

It has been observed that Mr. Wilson is surrounded nearly exclusively by politicians from the southern states. This is natural since Mr. Wilson was elected by the Democratic party and since the sonthern states are Democratic against the Republican North, slave holders against abolitionists. Thus we understand why our Bolsheviki, our Thomas-Renaudels ... who lead their following of stupefied proletariats around as slaves, acclaim the American slave-owning party!

This was certainly a remarkable explanation of the Socialist support of the President!

André Chíradame, in numerous, outspoken articles in La Démocrutie Vourelle, continued an attempt to show the existence of a breach between Mr. Wilson and the Ameriean people. II endeavored to prove that the President directly contradicted his mandates and ex- 


\section{FRANCE AND AIERICAN "IDEALISII"}

ceeded his powers by not eonsulting the Senate during the peace negotiations. According to him, for more than six months, the most important Senators at Washington, Senator Lodge at their head, declared, with increasing insistence, "We wish a complete victory over Germany - that is, a dictated peaee. Consequently we are opposed to any negotiated peace which the II un eriminals would be permitted to discuss. We entered the war with two well-determined and definite ends: to save Franee and to put an end to the Pan-German peril by imposing on Germany eonditions of peace so radieal that she can never commenee again. IBut now, before realizing these objects, it is said to us: 'First form a League of Nations, then we will settle the war.' But such a general League of Nations eonstitutes an entirely different aim from that which determined our exceptional intervention in Europe. A League of Nations would engulf us in obligations much heavier than those which we wish to assume. We cannot witl any exactitude determine what would be its consequences. We Amerieans desire then first to settle the war in conformity with the principles which determined our intervention." Aceording to M. Chéradame, this was the opinion which the American electorate emitted during the election of November 6. Consequently, the President, in pursuing his intention to incorporate the League in the Treaty, was violating the expressed wish of the Ameriean people. In another editorial, he spoke of Senator Lodge as the most representative man in the United States Senate charged with ratifying the Treaty, and that "the Senate at Washington reflects American opinion," and that, "it will not consent to ratify a Treaty resulting in the assassination of the France of Lafayette and of Rochambeau." The author of the above now is prob- 


\section{CONTEMPORARY FRENCII POLITICS}

ably aware that he somewhat misinterpreted American opinion; but such editorials had an unsettling effect upon French political thought. ${ }^{2}$

Personal attacks against the President went to even greater lengths. Thus the irrepressible Urbain Gohier, returning to the eharge, spread across the entire cover of La Vieille-France the following:

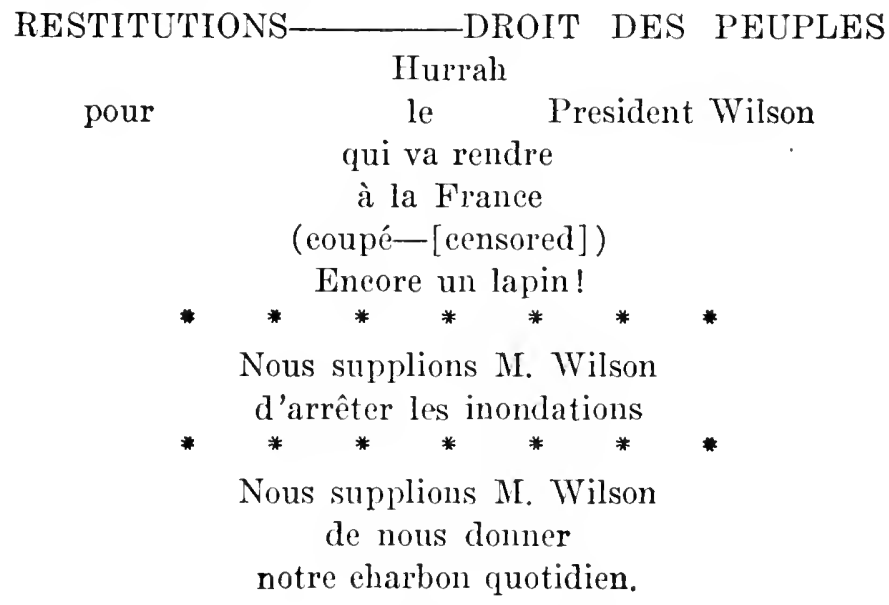

In the same issue M. Gohier assailed Mr. Henry White, one of the members of the American Peace Delegation. He charged him with the grievous erime of having married his daughter to Count Von Seherr-Thoss, a German officer, of visiting the Kaiser upon numerous oceasions, and a month after the declaration of war, of writing the following to the Kreuzzcitung of Berlin:

Every American who knows Germany will be a friend of the Germans. Everybody who has seen the holy earnestness

2In one issuc, M. Cheradame expressed the lielief that the American censor was keeping from the rrench publie tho division of opinion in the United States as to the Treaty, etc. 


\section{FRANCE AND AMERICAN "IDEALISU"}

and the iron-like will-power which every German shows in fulfilling lis duty toward the Fatherkand . . . cannot believe that Germany's defeat is possible.

M. Gohier then inquires, "Just how well does Mr. IIenry White fit in as an American delegate?"

La Vieille-France eertainly possesses, with all of its defects, what the French term the "virtue of indiscretion."

Charles Maurras was also eritieal:

A magistrate foreign to France and even to our continent, eseapes all responsibility. ... We are not a herd of sheep with whose pasturage and protection he is charged. ${ }^{3}$

After the President's New York March address in which he charged European statesmen with having neither valor, foresight, nor prudence, M. Maurras wrote:

If the sentence is not explained or denied, what will prevent the statesmen of the ofd Europe from calling the President's attention to the example afforded by the Italian Cabinet, which from the tenth mouth of the war, entered it for prineiples of morality and the welfare of man; the Enclish Cabinet, who joined this holy cause fully armed from the second day; and the Belgian Cabinet, which was ready under arms from the first?

Valor, Prudence, Foresight; $O$ eardinal virtues of the American moralist, where were you then? In the cabinets of Albert I, George V, and Vietor Fmmannel III, hereditary sovereigns of the old continent, or in the eabinet of the autoerat of the new world, to whom more than two years and a half of hesitation were necessary to make up his mind to take the terrible step? O Valor, O Prudence, O Foresight, remove our doubts. Foresight, I'rudence, Valor, respond!"

M. Maurras wields at least a trenchant pen.

'L'Action Fransaise, February 11, 1919.

- Ibid., Mirch 8, 1919. 


\section{CONTEMPORARY FRENCII POLITICS}

Yet another charge-more sineere and reasonablebrought against $\Lambda$ merican idealism, was its impracticability. "It is very well for you Amerieans to have sueh lofty prineiples," these erities would say, "but you live far from the neighborhood of a traditional enemy whose temper is eternally hostile, one who will seize every opportunity to attaek. You have no frontiers to guard or to dispute. Finally, the full applieation of your ideals will only result in the liberation of dozens of minor nationalities, totally unable to defend themselves! Europe will become Balkanized and if any one profits by the situation it will be Germany."

In sueh a tone, L'Action Française wrote:

Too often and over-ambitiously it has been declared that a new Europe is about to be constructed. What sort of Europe are they going to build for us? A simple heap of rubbish, from which a Germany has already emerged, the only state in this chaos to possess a form. . .

The policy founded on the principle of nationalities and the riglit of peoples has failed before even receiving its integral application or the consecration of treaties. The other policy-that of the balance of power, has been held up to contempt. It is always easy to make light of plysieal lawsor those of experience. This enceit never fails to bring its own punishment. But the pity of it all is that France will be the first to feel the revenge of realities. . . .

It was the American doctrine of the rights of nationalities which led to the destruction of the AustroIIungarian Empire, many Frenchmen said. This dissolution led to the Italian--J ngo-Slay eonflict over Fiume, to the Rommanian-Serbian eonfliet over the Banat, and

'Issue of February 14, 1919. 


\section{FRANCE AND AMERICAN "IDEALISM"}

to the Czecho-Polish imbroglio over Teschen. This same doctrine threatened the dissolution of Russia, and led to disputes in Turkey, in Asia Minor, and in the Dodeeanese. Finally, it was quoted in support of disturbing revolts in the British protectorate of Egypt and in the Empire of India. It lent fire to the Irish movement. In sum, American principles, the President's principles, shook the old fabrie of Europe to its foundation; they were destructive, for they were not strong enough to be construetive. In the opinion of many Frenchmen they wreaked a damage which will keep Europe in constant turmoil for years, a turmoil from which will arise a new, a more powerful Germany. Such was the belief of those Frenchmen to whom order seemed more important than national ideals. They failed to realize that the absence of the second would eventually upset the first.

L'Echo de Paris, through the violent pen of Pertinax, voiced its exasperation at such a state of affairs in these words: "Is it possible that mere idealism should longer obstruct the achievement of a victory so dearly won?" 6

Le Figaro said, "His (the President's) philosoplyy to-day eauses onr vanquished enemies to rely upon his ideas to eontest the reality of our victory; and they will invoke his name to-morrow in refusing us its frnits." " Jaeques Bainville, likewise said that these principles, "put into articles of a treaty, will engender catastrophes."

But while the conservative element in France was thus loudly insistent upon the uselessness of Ameriean idealism, the Socialist press, of course, resented such a contention. It maintained that only the applieation of

- March 11, 1919.

${ }^{7}$ Mareh 11, 1919. 


\section{CONTEMPORARY FRENCII POLITICS}

a wholly new set of principles would restore Europe to a stable basis. They also believed that no bourgeois soeiety would earry these prineiples into effect. Thus the belief was strengthened that French Labor must fall in behind the President's attempts. This was the opinion of L. Jouhaux, who wrote in La Bataille, a syndiealist journal :

While Wilson has opposing him a handful of intrigners or of simpletons who in good faith believe that folly is the supreme retrenehment of wisdom, he also has behind him the profonnd masses of the people who march beneath his banner erying, Vive la franchise et vive la liberté!

The radical and demoeratic journals, such as L'Euvre, Le Pays, La Victoire, and La Lanterne, although not so eloquently, showed open sympathy for the Fourteen Points. Thus Gustave Hervé wrote:

Our acclamations of the speeches made by the President of the United States are only disgnsting hypocrisies if we do not decide to demand that onr representatives resolutely exert themselves toward the realization of a "Wilsonian Peace."

Le Temps and Le Journal des Débats, conservative and critical, yet scholarly and fair, realized that the basis of the organization of Europe must be changed. The Ameriean suggestions, they were ready to believe, offered the solution.

\section{VI}

Another eharge soon beeame eurrent, directly reflecting upon Ameriean sincerity. This was to the effect that her ideals directly affected none of the vital interests of America-that, in fact, they benefited them. As II. Bainville wrote, these "Fourteen Points, a hundred 


\section{FRANCE AND AIERICAN "IDEALISII"}

less than Mohamet's Koran, have in no manner the appearance of contradicting the interests of America. They may even coincide with some of her immediate interests, above all. with the commercial interests of an $\Lambda$ ngloSaxon association. ..." The conservatives seemed thoroughly to believe that the United States has imperialist designs upon the western hemisphere. One would not see it so much in print as he would hear it in eonversation. "Oh," they would deelare, "you Americans are inevitably going to amnex Nexico and Canada; look how even now you are holding on to Cuba and l'orto Rico! And have you not your own designs on our possessions in the Indies, or upon Guiana? You wish to monopolize the trade of South America. Why else did you start the Spanish War? And you are really going to give the Philippines their independence? If you really believe in self-determination, why did you fight the Civil War? And, you lovers of democracy, you believers in the equalities of men, why do you lynch negroes and deny them their eivil rights? Or why do you diseriminate against the Japanese?" These opinions, frequently heard in Royalist circles, emanated from those who believed that nations can only be inspired by self-interest and the desire of aggrandizement. They did not represent, it is true, any considerable portion of French thought; but they paved the way to a much more serious line of criticism: American insistenee upon the Nonroe Doctrine, and its inconsistency with the prineiples governing the proposed League of Nations.

President Wilson's classic position was that the League should extend the application of the Monroe Doctrine to the world. This was entirely acceptable to the Freneh. But, as is so well known, it did not satisfy a very considerable element in America who insisted upon the spe483 


\section{CONTEMPORARY FRENCII POLITICS}

cific incorporation of this historic principle in the Covenant. This attitude was interpreted by many members of the French press to mean that the Americans would tolerate no intervention of European States in western disputes, but, on the other hand, that the Monroe Doctrine would permit the eventual political or commercial absorption of other American nations by the United States. That the doctrine had never given rise to the latter interpretation made no difference to the French critics who rested their theories upon future possibilities rather than on precedents.

Professor Scelle, of the University of Dijon, moderately expressed this view as follows:

What is the principal cause of the opposition which has arisen in the American Senate to the text of the League Covenant? It is the fear of seeing the United States pledge itself to intervene in all the quarrels of Europe and of the world, and the reluetance to guarantee the status of nations outlined by the Conference; the fear also of seeing the Society of Nations control American policy on the American continent, contrary to the Monroe Ioctrine. The Republican party wishes to retain for the United States the right of being neutral in certain eases, in others of playing the rôle of arbiter. ...

We do not hesitate to say that if these reservations are admitted they will become generalized; and sueh a course will bring to an end the Leagne of Nations as a guarantee of the permanence of peace. They are ineompatible with the high duties of nembership in the League of Nations. If they earnestly desire the advantages of this membership, if they wish to enjoy its seenrity, they must be ready to aecept its eventual obligations, and in particular, to fulfill the duties it involves. Surely the most onerous but the most essential, is of concentrating, if necessary, all of the national energies, against the enterprises or the menaces of any disturber of publie order. ${ }^{8}$

' L'Europe Nouvelle, April 5, 1919. 


\section{FRANCE AND AMERICAN "IDEAIISM"}

The Italian trouble over Fiume, aroused Jaeques Bainville to criticize Anerica on this seore, though from a different angle. He wrote:

In these latter days Ameriea has again proclaimed her attachment to the Monroe Doetrine. She is right and we are not desirous of seeing France meddle in Ameriea, sending, it may be, at the account of the Society of Nations, another expedition to Mexico. But if America is to be closed to Europeans, why should liurope, at this time which is to determine, it may be, its future for centuries, submit to the arbitrariness of a single American? What titles ean Mr. Wilson invoke to overthrow, even in the name of Right, the maxim: "Do not do unto others that which you do not wish them to do unto you?" He speaks of "the services which the United States rendered the Allies." We do not forget these services and we value them. But has France ever protested against the Monroe Doetrine? Has she ever pretended to control Amerjean policies in the name of the aid she once bronght (and before the eleventh hour) to the Americans in their struggrle for independence? ${ }^{9}$

France saw England insisting upon her supremacy on the high seas, a supremaey tacitly admitted by the Conference. She allowed England to enforee a proteetorate upon Egypt, struggling for independence. She saw her traditional guardianship in the Near East threatened by the British armies in Constantinople. She saw Shantung suceumb to Japanese control. She admitted the full validity of the Monroe Doetrine. IIelpless to prevent the huge trade interests Anglo-Saxon business men were building up on the wreckage of Germany's eommereial empire, she knew that the control of the trade and money markets had definitely passed to London and New York. The United States had talked a great deal about disarmament, of redueing armies to

'L'Action Frangaise, April 2t, 1919.

485 


\section{CONTEMPORARY FRENCH POLITICS}

a "police force" intended to guard domestic order or to furnish a quota to the new international army. Yet during the peace negotiations, congressmen, the General Staff, even military authorities directing the A. E. F. University at Beamme, were urging universal service. At the very time Lloyd George was talking about the abolition of conseription and the French Senate was considering a bill reducing the period of military service in France, the United States War Department announced a plan of universal military training! A French paper, printing the requests of Secretary of the Navy Daniels before the IIouse Naval Committee for extraordinary appropriations of three and a half billion franes and for the increase of the fleet persomnel from 143,335 to 260,000 men, very dryly asks, "Is this the disarmament which America is commeneing?"

These were the glaring and apparent inconsisteneies which French opinion found difficulty in understanding. Little wonder that France felt her own vital interests sacrificed for ideals which the Allies were hypocritically violating!

Even the Socialists, usually eager in their defense of American principles, were quick to point out what they considered defects. Thus La Vague, in a paragraph entitled " 800 ' Years in Prison," pointed out that the total convictions in the trial at Chicago of ninety-three members of the I. W. W. were as follows: Fifteen of the accused, eaeh twenty years in prison and $\$ 20,000$ fine; thirty-three of the accused, ten years and $\$ 30,000$; seven of the accused, five years and $\$ 20,000$; twenty-six of the accused, seven years and $\$ 30,000$; twelve of the aecused, one year and $\$ 30,000$. Total: 859 years in prison and some millions indemnity. It dryly adds that this is an 486 


\section{FRANCE ANI AIERICAN"IDEAIASU"}

indemnity for a class war. "All this in Wilson's conntry!"

At the Easter Congress of the Socialist party at Paris, an order of the day was adopted which expressed sympathy with all laborers who have been "victims" in every country of capitalist repression. It enceretically protested against the imprisomment of Eugene Debs and all other Syndicalists and Socialists in America, as persecutions "which ean only enfeeble the firht of the Ameriean delegates against the imperialists and the reaction of the Peace Conferenee."

One of the most spectaeular eriticisms direeted against the consisteney of American principles, charging us with what virtually amounted to economic imperialism, eame from the pen of André Chéradame in an article entitled "Ne Cherehons Plus Midi à Quatorze ILeures." He charged Ameriean financiers with receiving eoncessions from the Bolshevist government in Russia in order to develop Russian railways, forests and mines. MI. Chéradame charged that as passports were necessary to have effected such a negotiation, the American Government must have been fully aware of its responsibility and given its tacit consent. Matters had gone to the extent, he claimed, where the French Legation at Stoekholm was obliged to declare that the coneessions aeeorded by the Soviet govermment in Russia to foreign financiers for the construction and exploitation of railways in Russia were not recognized by the French Government in whose opinion the Bolshevist government was only a de facto govermment, maintained by the aid of terror; as such it had no right to grant eoneessions and dispose of national property.

M. Chéradame then indignantly comments: 


\section{CONTEMPORARY FRENCH POLITICS}

We must reach this formidable conclusion. The Wilsonian principles are applicable to the West of Europe, but not to the East. For three months, in the name of his principles, Mr. Wilson has sharply questioned France, whose sacrifices have saved the world, respecting her rights to reparations and to guarantees. Mr. Wilson is rery much preoceupied by French imperialism in the matter of the mines of the Saar. But this same Mr. Wilson sees no inconsistency in coming to an understanding with the Russian Bolsheviki, whose atrocities surpass all those recorded in history.

IIe then cites the instance, reported in Le Matin of April 14, of "two strange decisions," secretly arrived at in the conference, under the Presidency of Mr. Wilson. One vote designated Geneva-in preferenee to Brussels-as the seat of the League of Nations. This vote conformed to the wishes of Mr. Wilson, who declared, "The majority has passed judgment. Geneva is adopted." Then came the vote on the Japanese amendment proclaiming the equality of nations. This time the majority voted for Japan against the United States. "A majority is not enough," Mr. Wilson then declared. "A unanimous vote is necessary; therefore the Japanese amendment is not adopted."

Thus Le Matin eoncludes, "In the sessions of the League of Nations commission, there are majorities which eount and majorities which do not count. They count when they are for us. They do not count when they are against us!'”

MI. Chéradame asks: What sort of peace can be established under such auspices? Can we accept such a method of "making the world safe for democracy"?

The wind was taken out of the sails of Mr. Cheradame's article, the next day, when the American State Department issued a statement denying that any Russian concessions had been granted. But even this did not 488 


\section{FRANCE AND AIIERICAN "IDEALISH"}

alter the opinion of many Frenchmen-that Americans were liberal only when they profited thereby.

During certain periods of the negotiations, the French press, despite the rigorous restraint imposed by the censorship, made it very uncomfortable for the American delegates. Many Parisian journalists appeared to think that articles in the French language remained a sealed book to the Americans in France. The humorous weeklies, such as Le Sourire and others of similar bacchanalian propensities, ridiculed Amerieans and their idealism in rather indecent eartoons. The Soeialist IIumanité seemed to be the only organ which consistently resented this storm of eriticism. Toward the end of the conference it wrote, in an artiele entitled "Ingratitude" :

In imitation of the conservative and jingoist journals from across the Channel, our French press with shoeking manimity-indireetly or direetly-leads the eampaign against President Wilson.

Stupid ironies, and sareasms, woumding and injurious attacks, what a speetaele of ignominy!

$\Lambda$ year ago, when the German armies direetly menaced Paris and when the hearts of all were moved with somber anxiety, this same press implored the Americans to hasten to our aid. With what disinterestedness and how eompletely they obeyed these agonized appeals! We ought never to lose the thought of it. They sent us 3,000,000 soldiers and consolation; to the enemy, terror. What thanks our journalists then offered them and what panegyries in honor of the noble nation which turned the balance of destiny in our favor!

At this lom what a differenee in tone! We will not take up all the insinnations: the insolence of Pertinax and of Le Temps, of the great orrans of l'aris or their provincial understudies. In plain terms, this is disgraceful. . . .

And all this because the President has wished to remain faithful to his ideas of universal peace, of moderation in victory, of solicitude for international justice. Mr. Wilson en489 
dearors to foresee the future and to conclude a clean and just peace so that it may be durable. He resists-as much as lies within his power-the imperialistic conceptions and the designs of territorial conguests advanced by his Allies. He appeals to reason, and the necessity of calming inexpiable hatreds, - the psychosis of collective follies to which humanity at this time is a prey. These are the reasons for the blind wrath of a press which, with an indelicacy wholly unworthy of our traditions, has so quickly forgotten the service rendered us.

Because he stands alone in resisting certain sinister forces, the President must be ontflanked. And what will be the result gained by the nationalistic bourgeoisie of all the belligerent countries? It is not difficult to perceive. A peace based on the Fourteen Points, a League of Nations involving universal disarmament, would be admittedly able to bring to exhansted men a relative consolation and to leave them some hope for the future. Now that these "illusions" are thrust aside and that the "chimeras" and other Wilsonian ideologies have been exorcised, peoples no longer have confidence in themselves. The last great bourgeois will be unable to prevent the ineritable.

L'Humanité was in part right. Nueh of the eritieism directed against America and the President came from those who found in our representatives the chief obstacle to their own illegitimate ambitions. On the other hand, it must be admitted that many of the eharges which France brought against us were true. America is not perfect; her nature is essentially human. But the ideals which she has asked Europe to adopt are not wholly new, they have not arisen from her inherent moral superiority. Their origin may be traced to Europe and their most fertile growth was fostered by the minds of French philosophers: Abbe Saint-I'ierre, Rousseau, Bergasse-even that pseudo-idealist Napoleon III. On the other hand, a peculiar set of eireumstances has made America their appropriate mouthpiece. Her optim490 


\section{FRANCE AND AMERICAN "IDEALISII"}

ism, the optimism of youth, born of the serenity which national isolation has given us, carried these ideals, renewed and reënforced, to a Enrope in turmoil. It was the moral foree of America arising from this hope, which to a limited extent fastened these principles upon European polities. The misunderstandings were mutual; the best way to smooth them ont was by a frank interchange of ideas, even of mutual criticism.

\section{VII}

The rejection of the Treaty of Versailles by the United States Senate in November, 1919, was viewed with natural alarm in France. The first expressions of opinion were to the effeet that the United States wished to repudiate the obligations to which it had pledged itself. The French press reiterated its former position that the assurance of American participation in the Leagne of Nations had led France to give up her demands for a strategie frontier. Now if $\Lambda$ merican coöperation was not fortheoming, France, deprived of the guarantees it had demanded, would find itself defenseless whenever Germany wished to renew hostilities. Under these conditions, it was natural that France should charge America with bad faith. The French press, notably Le Matin and L'Action Française, was full of such recriminations. Those who did realize that the Treaty debate was a struggle between the executive and the legislative powers, believed that even that eould not exeuse the endangering of the peace of the world. Those who believed that the President was supported by Ameriean opinion, eharged the Senate with playing polities. Those, like L'Echo de Paris and André Chéradame, who be- 
lieved that the President had acted in contradiction to the will of the American people, continued their attacks on Mr. Wilson.

The real cause of the Treaty delay, however, the French press did not realize: American opinion, keyed to the highest pitch of idealism during the war, had suffered a reaction. The American Senate perhaps never had been imbued with that idealism; but there is little question but that in his original appeals to international morality, the President had been followed by the people, heart and soul. At the elose of the war, however, with the succeeding months of a monotonous armistiee, with the return of Ameriean troops from Franee, and with the growing evidence of Allied imperialism, Ameriean idealism commeneed to wane. Public opinion did not repudiate the President's ideals-it simply forgot about them. Its enthusiasm had been burnt out by the war, and it was natural that mpon the return to peace, a shortsighted and a languid opinion should occupy itself with domestic pursuits and internal problems. During the war, importunate realities had stimulated an interest in European affairs; the dangers of German imperialism public opinion had been foreed to realize. With Germany's defeat, however, probably the majority of the American people felt that the menace was over. They speedily forgot about the eauses of the menace. And their powers of thought were too exhausted to think of means of preventing its recurrence. Furthermore, the agencies of public opinion which the Govermment had ereated during the war, now passed out of existence. A propagandized opinion which had had facts and ideas literally jammed down its throat, heaved a sigh of relief when the supply of medicine was exhausted. P'ublic opinion demanded a vacation; most of 492 


\section{FRANCE AND AMERICAN "IDEALISH"}

the people who really thought, realized that America had certain definite and immediate obligations to Enrope. But numbers of people, perhaps, cared little more about the Treaty debate in the Senate than they did about the Einstein theory. And although the Senate was accused for its ineptitude and although it doubtlessly misrepresented public opinion, there is every reason to believe that, had the public been inspired with the same interest and feeling which dominated it during the war, the Senate would have been literally forced into a decision against its own will.

Although America had an innocent conseience, in lapsing back into an isolation made easy as well as comfortable beeause it required no thought-and thinking was a hard task for most people-France was wide awake to the seriousness of the prospeet of Ameriea's withdrawal from Europe. If the Senate had ratified the Peace Treaty immediately, not only would France's fear have been allayed, but her subsequent efforts to revive the system of alliances which has eaused so much harm in Europe, would have never been made neeessary. The Senate's retieence and the bitter hostility which a minority within it showed toward Europe, inereased French insistence, however, upon the guarantees of the Old Diplomaey. ${ }^{10}$ Although America had eondemned the

${ }^{10}$ The notification by Premier Millerand, on February 10, 1920, to Germany that the time of occupation of the Rhenish provinees would be exterided indefinitely beeause of the failure of Germany to comply with some parts of tlee Treaty, may be looked upon as a disguised annexation of the left bank of the Rhine by France. It marks the first step in the erection of the guarantees which France unsuceessfully urged at the Conference. Now that American participation is uncertain, France is bending every effort to restore the peace which would have been negotiated originally, if America had not participated in the Conference. Millerand's announcement and the efforts being malle to negotiate alliances indicate the results of Ameriean hesitation. If Ameriea had acted promptly, the 
tactics of the Elder Statesmen, she was now driving Europe again to resort to them. In fact, to many Frenchmen, America presented the piteons speetacle of a nation which lad given birth to a new idea and now refused to make the saerifices necessary to keep it alive. During the arearisome months which the Senate listlessly eonsumed, France and the whole of Europe eame to believe that althougl the foremost republic in the world has its virtues, it is perhaps controlled as mueh by self-interest and as little by altruism as any other nation in the world.

But even so, France realized that a system of European alliances, necessarily unstable because of ehanging and conflicting national interests, would not supply her with the protection against a German attack which a League of Nations, eren with limited American help, would do. Consequently, Franee was willing to have Ameriea enter the Leagne with reservations. France was not satisfied with these reservations. But it finally eame to believe that they were better than nothing at all. This led to a direct volte-face. Le Temps, which had originally attacked the reservations as destructive of the Treaty of Versailles, now came to the conclusion that they did not vitiate it in any respect. This diplomatic attitude was held by France generally. It was disappointed in American hesitation; ret it aceepted the inevitable and tried to make the best of a bad situation.

IIowever, a radical revision of the system upon whieh the world for a eentury had operated, was too mueh to expect. Reaction was sure to set in; the pendulum was bound to swing back. I3ut at least one step in advance

olıl régime perhaps would have been griven a death hlow. Now it is speedily reviving, and it is foreing the Leagne of Nations into a state of imocuous obseurity. 
has been made. There will be more wars and there will be more peace conferences. With rach sucreeding one, however, the world may hope for some betterment and for some progress. Just as the Treaty of Versailles is a vast moral improvement over the Treaty of Vienua, each sueceeding treaty may bring to the worlet hopes for a brighter futme. Real peace, however, is not an inert thing. It does not consist in the adjustment of boundary lines nor in the disposition of groups of peoples. It lies in the hearts of men and it will be realized only when the character of lumankind has been changed. 


\section{APPENDIX $\Lambda$}

\section{GEORGES CLEJIENCEAU}

M. Clemenceau was born in La Vendée, September 28, 1841. At the age of nineteen he went to Paris to study medicine, where three years later he received his degree. In 1866 he went to the United States, and for a time tanght French at a girls' school at Stamford, Commecticut. He fell in love and later married one of his students, Miss Mary Plummer. M. Clemencean then returned to Paris and devoted himself to the practice of medicine, chiefly among the poor of the Montmartre district.

After the proclamation of the French Republic on September 4, 1870, Clemencean was elected mayor of the Montmartre district. It was this district which sent him to the National Assembly at Bordeaux as its representative. Clemenceau roted with Lonis Blane and the other "irreconcilables," against the peace preliminaries with Germany, because of the cession of Alsace and Lorraine.

The urgency of his mayoral duties called M. Clemencean back to Paris on the 5th of March, 1S71. On the 1Sth, the ill-fated Commune was established. Because he struggled to prevent the murder of Generals Lecomte and Thomas, Clemenceau became a "suspect" of the Central Committee which removed him from his position. Shortly afterward, M. Pyat ordered his arrest. Fortunately for M. Clemencean, a lirazilian who resembled him was seized instead; and as he was about to be shot, the mistake was discovered.

After the fall of the Commme, Clemencean withdrew from active polities. For five years he engaged in the practice of medicine. During this period he also served as a municipal councilor, finally becoming President of the Paris municipal council.

In 1576 he was again elected to the Assembly, where he 


\section{CONTEMPORARY FRENCII POLITICS}

made himself both unpopular and prominent by advocating the passage of an amnesty bill freeing the participants in the Commune, notably A. Blanqui. Although he was but thirty-five years of age at this time, he was already advocating the program which later carried lim into national prominence: freedom of speech, of belief, and of the press; the separation of church and state; the expulsion of the Jesuits. He urged the inanguration of social reforms of a collective nature. He was bitterly opposed to eolonization beeause he believed it would dissipate the strength of the nation which should be continually prepared to avenge the cruel losses of 1871. Consequently he opposed the penetration of Tunis, Tonkin, Annam and Madagasear by France. It was he who was largely responsible for the French withdrawal from Egypt in 1852. M. Clemencean deserves some of the credit for uneartling the decoration scandal in which Daniel Wilson, the son-in-law of President Grévy, was involved.

Perhaps the greatest service of M. Clemenceau to the Republic is that between 1876 and 1893 he kept alive the spirit of the French Revolution within Parliament-during a period in which the Government was almost daily on the verge of succumbing to the Royalists.

M. Clemenceau was Boulanger's cousin; this doubtless was one reason why the Old Tiger at first supported this militant troubadour in his eseapades of 1887-18S9. But he soon saw his mistake and later repudiated his connections with him.

Clemenceau's enemies attempted to entangle him in the Panama Canal affair (1592-1893) in which wholesale embezzlements consumed great sums originally intended for the construction of the canal. At this time Clemencean was editor of La Justice. One of the ringleaders in the Panama seandal had subscribed $\$ 5,000$ to this newspaper in its early days. With this evidence, M. Clemenceau's opponents, of whom he had many, urged that lis paper lad been deliberately "bought" over by the Panama crowd. The eliarges were never proved; and Clemencean ably defended himself against them in the Chamber.

In 1893, however, his opponents had become too strong for him. He was bitterly accused of atheism, of opposing the alliance with Russia, even of being pro-knglish; and as a result, he was defeated for election to the $\Lambda$ ssembly from 


\section{GEORGES CLEMENCEAU}

the district of Dragnignan. Thus after serenteen years of active partiamentary life, he retmed to jomnalism, at the age of fifty-two.

But he did not lose interest in public atfinirs, for throngh the colmuns of Liturore he preached the doctrines of social reform and hatred for Ciermany. He led the strmgle for the defense of Ireyfus; in fact, it was he who sugrested that Zola write that terrible indirtment of the army, J'Accuse, which appeared in Clemencean's own paper.

In 1902, Clemencean again entered active political life, for he was elected to the Senate from the Var. For the first time in his eareer he aecepted a Government position in March, 1906, when he was appointed Minister of the Interior in the Sarrien Cabinet. He was immediately called upon to solve the terrible colliery disaster in Comrières, the wine growers' revolt in Sonthern Franee, and the electrieian and other strikes in Paris. In Oetober, 1906, Clemeneeau himself beeame head of the eabinet.

Despite the fact that his uncle is a priest, Clemeneean is a bitter anti-Catholie; and the first task eonfronting his ministry was the enforcement of the anticlerical legistation of 1905 . At this he was unsneessful, as the supplementary law of 1907 amply denomstrated. The Clemencean Ministry was responsible for the first step in the rationalization of the Freneh railways, the Govermment taking over the Western road. Althongh the Prime Minister was an ardent believer in the right of labor to organize and to strike, he was opposed to the mionization of Govermment employees because of the minne status which they oecmpied. Clemencean was finally driven ont of office in July, 1909, by Deleassé, whom Clemencean had bitterly attacked for his Morocean poliey. Now it was Deleassé who aecused the Prime Minister first for failing to overcome weaknesses in the nary which Clemeneeau himself had eriticized, and finally for pursuing a eontradictory policy in Moroceo. MI. Cleneneean was at that time even more impatient than he proved to be in later years; for in the debate he deliberately flamnted the Chamber. As a result he failed to win a rote of confidence; and retired from the ministry at the ace of sixty-eight.

In 1913 and 1914 he eontimually preached the danger of a German invasion through the columns of L'Homme Libre. 


\section{CONTEMPORARY FRENCII POLITICS}

Then war came, he gave it his sturdiest support. At the same time he was courageous enough to point ont in no delicate terms the defects in the administration of the French army. So strongly did he condemn the defeatist movement which was rapidly undermining the morale of France, that in November, $191 \vec{\imath}$, the country turned to him as the one man who conld rally every Frenchman to the support of La Patrie. At the age of seventy-six, this "grand old man of France" assumed the direction of the French Government, himself taking the arduous position of Minister of War. He made quick work of the traitors, as Le Bonnet Rouge and other trials proved; -he reorganized and reinvigorated the whole war machine. To him, more than to any other statesman, France owes her victory.

M. Clemencean is a teetotaller; he does not smoke. $\mathrm{He}$ rises every morning at three o'clock. His chief hobby is animals, and of these, dogs hold the first place in his beart. $\mathrm{He}$ is the most dangerous duelist in France-the President of the Republic, Panl Deschanel and the former Nationalist, M. Déroulède, can attest to that from experience. M. Clemencean is an enraptured collector of Japanese art; and he is a devoted student of Joln Stuart Mill. $\mathrm{He}$ is an orator who despises the conventions of oratory. He speaks evenly, and his one gesture is that of a weighty index finger with which he drives home point after point upon unwilling and willing andiences alike.

The strength of M. Clemencean rests in his conrage-in his fearless denunciation of injustice and of inefficiency. His weakness lies in the fact that he too often is destructive without being constructive, that he is intransigent to the point of stubbornness, and that he is cynically mimaginative so far as a conception of amicable relations between European nations is concerned. Time only will judge him aright. But it is not too much to say that despite his faults he is one of the great men of the Third Republic, and that his name may properly be enshrined among those of the Immortals. 


\section{APPENDIX B}

\section{FRENCH TAXATION DURING TIIE WAR}

It is not the purpose of this appendix to give a complete aceount of the French system of taxation or even to mention all of the taxes employed during the war, but merely to point ont the change in the basis of the system from "real" to "personal" taxes and the faet that the change has not been suecessful.

The former system of taxation was based on what were ealled the "four direet eontributions." These taxes were: (1) A tax on land. As no ehange in the assessment of property values had been made since 1850 , this tax was naturally subject to the grossest discriminations. Lands which at the time of their evaluation in 1850 were productive, niglit have beeome unproduetive sinee then; but they were subject to the same tax as before. There was also a tax on landed property. This tax was somewhat fairer for it was based on the annual rent of houses and faetories,- - estimated every ten years. (2) The so-ealled patents tax-nominally a tax on ineomes and professional eamings. This tax was also based on the rental value of the premises upon which the business of the taxpayer was being conducted. Consequently it was upon apparent rather than actual earnings, and open to the greatest diseriminations. (3) The tax on doors and windows. This tax, long recognized as utterly unsocial beeause it really imposed a tax on light and air, was in theory repealed by a law passed July 18, 1892; but suceessive financial bills postponed its aetual demise until the financial law of July 31,1917 finally provided that it should not be levied after Jamuary 1, 1918. (4) Taxes on personal property. This tax was also levied on the signs of wealth rather than on the wealth itself; instead of attempting to assess the amount of personal property actually held, it was levied on ostensible tokens, sueh as the amount of rent paid, ete. 


\section{CONTEMPORARY FRENCH POLITICS}

The objections to these "real" as opposed to "personal" taxes-the fact that they were not in any true sense based on the faculty theory of taxation-led to insistent demands for reform. For the last twenty years the advanced parties in the Chamber of Depnties have demanded the enactment of an ineome tax, but it was not until 1914 that the Senate finally gave its consent. The law passed July 15, 1914, levied a tax upon incomes greater than 5,000 francs, an amount which by the law of December 30, 1916, was lowered to 3,000 franes (\$600, normal rate of exchange). Those having an income less than 3,000 franes are exempt from the tax, a sum which is increased 2,000 francs in the ease of a married man having one or more children. Taxpayers having dependents more than seventy years old or who are infirm, and children of less than twenty-one, receive a further exemption of 1,000 franes for each in case the total number of dependents does not exceed five; if it does, the exemption increases for each person beyond the fifth, to 1,500 franes.

The rate of this tax is (law of June 30, 1918) :

1. Taxable incomes up to 5,000 franes $-1 \frac{1}{2} 2$ per cent.

2. Taxable incomes between 5,000 and 150,000 franes $-1 \frac{1}{2}$ per cent to 16 per cent, with a progression of one centime per hundred franes.

3. Taxable incomes between 150,000 and 550,000 franes 16 per cent to 20 per cent, with a progression of one centime per thousand franes or fraction thereof.

4. Taxable incomes greater than 550,000 franes -20 per cent.

Of the several other direct personal taxes levied during the war the most important was the "extraordinary or supplementary war-profits" tax, or in other words, an excess profits tax. This tax, which was first passed July 1, 1916, was supposed to be levied on all business and commereial enterfrises, inchuling mining operations, whose profits cane within the terms of the law. The profit to be taxed is determined by subtracting from the total net profit of the current year, the normal profit. The latter is based on an average of the profits of the three years preceding Aurnst 1, 1914. The normal profit in no case can be estimated at a sum lower than 5,000 franes or less than 6 per ent of the invested eapital. The rate of this tax (by the law of December 31, 1917) is 50 502 


\section{FRENCII 'TAXATION DLRING TIIE WAR}

per cent of the excess profits less than 100,000 franes; tit per cent of the excess profits between 100,000 and 2.50,000 finnes; 70) per cent of the excess frotits between 250,0000 and 500,000 franes; so per cent of the exeess protits greater than 500,000 franes.

The point which should be noted is that, mlike the experience of other comtries, the inamguration of income taxes in France has sueceded neither in equalizing the burden of taxation nor in securing the neessary revenne. When the income tax law of July 15, 1914, was passed, it was estimated that the tax would return abont $80,000,000$ franes annually. For the year 1916, however, it only produced $40.000,000$. As a result of a redneed exemption, etce, the tax in 1918 produced abont 200,000,000; in England, having a population but slightly larger than France's, on the other hand, the same kind of a tax produced over five times as mueh. Similarly the Exeess Profits Tax in France anmually realized but $800,000,000$ franes, while in England the same tax produced between $7,000,000,000$ and $8,000,000,000$-ten times as much. In comparing these two eountries, it must be remenbered that before the war per capita taxation in both were ahont the same. Taking into eonsileration all the different taxes, it has been estimated that taxes increased in England 2.77 times during the war, but in France only 1.14 times, and that England raised about six tines the amomt of money during the was by means of taxation that France raiset. For the financial year ending Deember 31, 1919, the direct taxes in France yielded $733.970,000$ franes; elaims, however, had been issned for 1,135,578,400 franes. Thus the Government failed to eollect nearly $400,000,000$ franes.

The reason for the failure of personal as opposed to real taxation in France is fomd partly in the eharacter of the French business man. IIe resents bitterly any interference with his accomts, especially by the forermment. Few Frenchmen, it must be admitted, were sermpulonsly honest in rompiling their returns. Many laborer's refused ontright to pay the tax, saying it was an ontrige to tax men with an ineone as low as $\$$ trion when the walthy were getting ofi almost for nothing.

The erasions of the excess-profits tax were as numerous as those of the ineome tax,-perhaps more so, beranse evasion 503 


\section{CONTEMPORARY FRENCII POLITICS}

was easier. Companies might invest their profits in lands and other property, thus eseaping the tax. This eaused considerable speculation and several subsequent failures. It was notorious that many large munition firms, notably the Hotehkiss company, eseaped their share of the burden.

Furthermore, the income tax had been enacted just at the outbreak of the war. There was no organized administration for its collection. Mobilization and eoncentration on war activities prevented the Government from establishing such a system. The war also upset the ineomes of perhaps the majority of the people so that it was an impossibility aceurately to estimate what these ineomes would be.

The failure of these taxes led the Govermment to resort to eredits, bond issues and indirect taxes for the greater part of its revenue. Only abont one fifth of the finaneial resources of the French Government were raised by taxation. As a result of this loan and credit poliey, the note issues of the Bank of France increased from $6,000,000,000$ in 1914 to $33,000,000,000$ in 1918; and the amount was increasing even in 1919. This naturally inflated values and was the main cause of the high eost of living. It should be added in defense of the French poliey that the war was being fought on French soil. England was not being invaded and its industries were not being destroyed: it conld resort to direet taxes. But in France one tenth of the country was actually being devastated and the whole nation was living in momentary fear of attack. Consequently, the Government felt justified in alleviating the immediate financial burdens which burdensome direet taxes would impose.

The failure of the personal taxes led many elements in France, among them Le Temps, at the close of the war, to demand the abolition of the ineome tax and the return to the Four Direct Contributions. Francois Marsal, in numerous articles (see Revue Politique et P'arlementaire, Jannary 10, 1920 ), advocated a similar procram. Upon his appointment as Minister of Finance in the Millerand Cabinet, it is interesting to note that he at once became indefinite in his plans to return to the old system whose injustice had been reeognized in every combly which had tried it. In one of his first speeches to the Chamber, M. Marsal said that for the present he would continue the financial policy of M. Klotz, 


\section{FRENCII TAXATION DURING TIE WAR}

M. Clemeneeau's Finance Minister: Although Klot had planned to retain the old taxes as well als to institule some new ones, such as a tax on business figures, he relied for the greater part of the 1920) budget npon loans.

His estimate, made in Jannary, 1920, follows:

Franes

Ordinary expenditures . ........... 17,\$(i1,140,000

Expenditures arisingr from hostilities, ete... $7,508,083,05,5$

Expenses for reeonstruction, pensions, ete.,

but which are recoverable from Germany. 22,089,597,500

Total in round numbers........... 47,500,000,000

M. Klotz planned to meet only the ordinary expenditures of $17,861,140,000$, by taxation. M. Marsal indeed will do well if he can come up to his standard, for the ordinary revenue assured for 1920 amomnts but to $9,368,000,000$ franes, leaving a deficit of $8,493,000,000$ franes which must be met by taxation. It was M. Klotz's idea to raise the amounts neeessary for the extraordinary expenditures from loans, in the hope of eventually recouping the sums from Germany by the payment of the indemmity. Even if this hope is realized eventually, France still has a tremendous problem on its hands in meeting the defieit in the ordinary expenditures, amounting, as we have seen, to over $8,000,000,000$ franes. The 1914 budget was only $5,000,000,000$; the 1920 ordinary budget is $17,000,000,000$; and although the depreciation of values will accomnt for part of this difference, the conelusion seems inevitable that the French Govermment, aceustomed to the luge expenditures of war, has become extravagant in financing its ordinary activities.

The reticenee-it may be the impossibility-of France to adopt a plan of taxation which would place a greater burden upon its taxpayers, was one of the reasons that the Allied Governments wonld not consider the proprortional division of war indehtedness among themselves. They believed it would be grossly unfair to level additional taxes upon their own citizens who already were being taxed more heavily than Frenchmen,- to relicse the latter of their burdens. Aithough this argument was of weight as far as the ordinary govern- 


\section{CONTEMIPORARY FRENCII POLITICS}

mental expenditures were concerned, it had less bearing when the matter of strictly war expenses was considered. But the fact still remains that, not only from the standloint of international support, but from that of her own internal economy, France must soon bend every effort to free herself from the vicions pulicy of loans which at the present time merely accentnates, if it does postpone, financial dilliculties. 


\section{INDEX}

Aetion Frangaise (see also Orleanist party, Press, Journalism, Charles Maurras, I'hilippe VIIT, Iéon Daudet), 14, $15,110,183,274,275,276$ $278,280,289,406,461,469$, $479,480,491$

Action Francaise, Ligue d', 8, $11,132,197,196$

Action Libérale Populaire. Sce Liberal Action party, Ralliés Catholieism, 278

Action Républiraine ct Sociale, group of (1920), 204

Adjoints, 379, 387

Arministration. Sce Centralization, Decentralization, Department, Prefeet, Regionalism

Agrienltural classes. Sce Peasants

Alcoholism, 144, 242

Allemane, 33,91

Alliances (sec also "Old Diplomaey,' Balanee of Power, Ieague of Nations), 424, 447 , 469,494 ; poliey of, 207,426 428 ; ineonsisteney of proposed American - British - Freneh, $173,448,462,463$

Almereyla, leath of, 273

Alsace-Lorraine, $17,152,194$, $198,203,265,311,374,403$, $404,410,411,416,421,457$, $459,463,497$; League of $\mathrm{Pa}$ triots and, 16; attitude of Socialists towarl, 100 ; appointment of bishops in, 133; results of 1919 elections in, 192; demands regionalism,
392-39.4; neels German coal, 418

Americaus, French opinion of, $\mathrm{xv}, 473$; attitule of, toward France, 472

Amette, Mgr., 188

"Amical" assoeiations, 352, $353,356,364$

Amiers, Soeialist Congress of (1914), 91

Ammesty demanded, 251, 253, $261,263,266,352$

Amsteriam, Socialist pact of $(1904), 35,81,91,94,102,107$, 123,178

Andrienx, Louis, 148

Anticleriealism. See Catholicism, Rarlical and Rarlical Socialist party

Anti-Semitism, 13, 234, 278 . 280, 282

Arago, François, 199, 205

Arrondissement, (see also Serutin, Electoral reform) ; 152 , $375,386,387,390,396,397$; government of, 378

Artieles Sćparés, 429

Artois, Count of , 403

Assembly. Sce Chamber of Deputies, National Assembly

Assistanee, soeial, 377, 397 , 399

Associations, law of, 1901,350

Aubriot, Paul, 177, 178

Aularil, Professor, 189

Authority, French respeet for, viii

lBainville, Jaeques, $13,278,452$, $453,48.3,48.5$

Pakunin, 125 
Balance of Power, 426-428, 434, $435,415,463,465$

Ballot. See Elections, Electoral reforms, suffrage

Barbusse, Henri, 257

Barrès, Manrice, 2S0, 40S, 46s; President of Leagne of Patriots, 16-1S; adrocates: family rote, 151, annexation of Rhine, 173, 410-411, 415, 465; regionalism, 395,399

Barthe, 352

Barthélemy, Joseph, 199; eited, $73,222,369$

Barthou, Lonis, 63, 90, 160, 172, $173,174,205$

Bataille, 452

Bebel, 35

Benoist, Charles, 24, 158, 173, $362,410,465$

Birth rate (sce also Depopnlation), French and German compared, 150,409

Bismarek, 201, 407, 470

Blane, Alexandre, 100

Blanquism, 33, 35

Bloc National Républicain (1919), formation of, 179 ; composition of, 180 ; program of, 180 ; hourgeois opposition to, $187-190$

Bloc of Left (1900-1906), 22; origin of, $\mathrm{SO}$; relation of members to each other, 8487 ; dissolution of, 82.84

Bluni, Léon, 120

Bolshevism, (sce also Kienthal, Zimmerwald, Loriot faction, Internationale), 105,106 , $120,123,127,128,129,139$, $165,177,178,179,186,190$, $206,209,210,262,275,286$, $295,339,457,476,487$; defeated in 1919 elections, 195

Bon, Jean, 133, 148

Bonapartism (sce also Napoleon I, Napoleon III, I'rince Napoleon, Vietor Napoleon), $9-11$; in Assembly of 1871,5 ; fear of, 232
Bonds, international (see also Cost of War, Indemnity), adrocated as a means of equalizing War Debt, 440, 4.1

Bonnet Rouge, 273, 277

Bonsoir, 296, 297

Bordeaux, Heuri, 13

Bordeaux, Socialist Congress at (1917), 103-105

Boret, Victor, 67, 205, 266, 326, 344,367

Boncheron, Lonis, cited, 376, 377

Bouffandeau, M, 163

Bouillon, Franklin, 32, 136, 173, $175,197,457$

Bouilloux-Lafont, 441

Bouisson, M, 258

Boulanger, General, 16, 80, 153, $233,234,498$

Boulangism, fear of, 233

Bouniols, Gaston, eited, 155

Bourbons. See Count of Chambord, Legitimists

Bourgeois, Léon, 5S, 199, 433, 96 ; relation of, to Radicals, 32,136 ; Ministry of (1895), 28, $80,87,225$; demands strong League of Nations, 449,451

Bourget, Panl, 13

Bourses du Travail, 238, 346, $351,355,366$

Bracke, M., 41, 103, 163, $16^{1}$ 176,178

Briand, Aristide, 34, 42, 56, 57, S7, 95, 134, 137, 207, 277; ministries of, $58,63,74,88$, 96, 102, 225, 29S; and Fede. ration of left, 89 ; and Socialists, $36,82,186$; demands: electoral reform, 159, 16t; woman suffrage, 148; eight-hour day, 24s; part in 1919 elections, 184.156

Bribery, 15.t

Brisson, Henri, 28, 80

Brizon, M., 100, 105, 195, 287, 300 


\section{INDEX}

Broglie, de, 388

Brousse, E., 202, 322

Brousse, l'aul, 33, 34

l3urlget (sce also Douzicmes provisoircs ), 375, 378, 396, 398 ; control of, ly l'arliament lost during war, 75 ; 1920 and $1914,302,505$

Buffet, André, 234

Bureau of 1920 Chamber, 199

Bureaucracy (sce also Funetionaries, State Soeialism), inefficiency of, 299, 302-313, 321,338

Buyat, Louis, 158

Cabinet. Sce Ministry

Cachin, Mareel, 98, 107, 255, $256,258,285$

Caillaux, Joseph, Ministry of, $63,83,160,225$; Minister of Finanees, 90 ; charges against, 83, 90, 235 ; relation to Radicals, $32,135,196$; part in 1919 elections, 136

Calmette, Gaston, 109, 135, 281

Cambon, Victor, 187

Camelots du Roi, 15

Canton, 375, 386; government of, 378

Carnot, Adolphe, 26, 179, 180

Carnot, President, 64

Casimir-Périer, M., 61, 220, 388

Castleneau, General, 197

Castlereagh, Lord, 403

Catholicism (sce also Liberal Action party, Ralliés), 187, $278,279,412,499$; attitule of, toward: Republic, 5, Wo. man Suffrage, 147; Radicals oppose, 30, 134, 175, 196; policy of "pacification" toward, 134, 186; edueational demands of, 19, 189, 207; part of elergy in elections, 188

Cavaignac, General, 233

Carour, 10

Censorship of press, 251; based on State of Siege law of
1849, 292; methor of operation of, 29:3; complatints against, $29+298$; repeal of, 299

"Center" of Chamber, 9

Centralization in goverument (see also Department, l'refect, Administration), 220, $361,373-383$; of publie serviees, 302, 313; listory of, $384-389$; defense of, 400

Centrists. See Socialist party

Chamber of Agriculture, 346

Chamber of Arts and Manufactures, 346

Chamber of Commerce (see also Regionalism), 396; official nature of, 344; grouping of, 345,367

Chambor of Deputies (see also Parliament, Political partics), 362; how elected 165-169; control of, over government, 64-69; during war, 69-76; 1914 Chamber, $193 ; 1920$ Chamber: by parties, 193, by groups, 204, by profession, 193; future policy of, 206-208; bureau of, 199

Chardon, Jules, cited, 158

Charpentier, A., cited, 30,84 , 85,235

Chastenet, M., 101, 131

Chaumet, Charles, 12, 132, 173, 179,197

Chavenon, Leon, 295, 296

Chéradame, André, 18i, 282, $476,487,491$

Chicago Tribunc, 297

Church. Sce Catholicism

Clarté, 366

Class struggle (see also Social. ism), doctrine of, $37,99,113$, $123,186,237$; attitule of French toward, 39, 130, 366; given up in Sacred Union, 94

Claveille, M., 63, 264, 344

Clemenceau, Georges, $7,67,68$, $77,80,137,172,173,174$, 


\section{INDEX}

$179,182,186,185,189,196$, $215,2+6,256,257,258,274$, $27 \overline{7}, 2 \mathrm{~s} 0,2 \mathrm{~s} 3,2 \mathrm{~s}, 296,299$, $352,446,45 \%, 469,505$; life of, Appendix A; Ministries of, $63,82,155,203,206,225$, 266, 344; attitule of, toward: Soeialists, 68, 104, League of Nations, 433, electoral re form, 61, $89,158,162$; and Radical party, 29, 32, 83 , 136; assassination attemptel, 109; cefeated for the Presideney (1920), 199-201; reakness of 201,500

Clémentel, M., (sce also "Consortiums''), 63, 196, 197, 199, $323,327,345,367$

Clericalism. Sec Catholicism

Coal resourees of European nations, 417; neels of France, 249, 418; amount in Saar basin, 419; German eoal needed by Alsace-Lorraine, 418; Treaty provisions concerning, 456 , $45 \mathrm{~S}$

Coehin, Denys, 58, 96,

Collectivism (see also State Soeialism, Nationalization), 242, 243; and indivilualism, xiii; arlrocated hy: Radicals 30 , Soeialists, $115^{\circ}$

Colliard, M., 196, 248

Combes, Emile, 23, 32, 5s, 81, $96,134,136$

Commissions, parliamentary, 71 73 ; of inquirs, 71 ; control of government hy, during war, 71, 73; how chosen, 53

committee, Seeret, 73

Commune, 212, 3\&5, 3\&6, 389: government of, $379-391$; inereased jowers of, allocated, 342,$390 ;$ of 1871,126 , 890 , 497

Compiere.Morel, M., 11, 52, 9s, 107, 259, 246

Comte, Aususte, 389

"'Concentration," poliey of, 79 , 80
Concordat, 133

Confédération Générale du Travail (sce also Labor, Strikes, Syndiealism), 20, 61, 82, 245, $335,351,355,356,371$, 470; organization of, 237 ; attitude of, toward war, 16, 239; Minimum Demands of, 240.243; adherence of bourgeoisie to, 366 ; diffidence of peasants toward, 366

Congress of Vienna, 403, 416

Conseil de Prud'hom.mes, 141

Conservatism (sec also Progress. ism), 7,81 ; wins in 1919 elections, 208

"Consortiums," poliey of (see also Importations, State Soeialism), 196, 316; resulted in: state monopoly of industry, 322, inereased prices, $324-326$; attempts to continue policy after war, 327 ; protests against, 320-328, 332

Constant, Benjamin, 372

Constitution of 1875 (sec also Parliamentary government, Separation of Powers), 214; a modus vivendi. 216; embodies two theories of government, 215, 217, 222; amendment of, 227; uneoustitutional laws, 2.27; demand for changes in, vii

Corbière, $3 \$ 6$

Cost of Living (see also Foori e o n tro l, "'Consortiums,', Boret), 67, 213, 263, 266; rise of prices, 245 ; effect of, on Labor, 244, 246; partly caused by govermment policy, $324-326$

inst of War (see also Bonds, lnifnmity), division among "'" is adrocated, 437; now alls on France, 437; Stern imil Lafont plans of division, 4 40.4.42; effect of division on [T. S., 442 


\section{INDEX}

Cottin, Emile, attempts to assassinate Clemenceau, 101; trial of, 109

Council, of War, 127, 177, 264, 273 ; general, 198, 375-378, $379,359,396,395$; of the arronilissement, $195,378,379$, $357,396,395$; of the commune, 379-350, 387, 368, 389), 396,395 ; of Ministers, 57 , 396; RegionaI, 397, 398, 399

Count of Chambord, 5, 6, 9, 215

Count of Paris, 5, 9, 11

Croix, 281, 469

Custine, 412, 413

Danzig, 173, 410

Daudet, Léon (editor deputy), 15, 132, 187, 212, 277, 278, 287,289

Debates, parliamentary. See Jnterpellations

Debiclour, A., eited, 6, 403, 408

Deht, national, 203,437

Debt, war. See Cost of War

Deeentralization (sce also liegionalism), 339, $340, \quad 390$; characteristics of, 357 ; demand for, $13,24,302,345$

Deerees, regulating drinking plices, 144; in regard to state of Siege, 69

Defeatism, 99, 273

Delahaye, Jules, 151, 258

Delahaye, M., 165

Deleassé, M., 57, 499

Demoeraey, lack of training for, 381,401

Demoeratic Republiean Alliance, $25,49,84,132,178$, $186, \quad 202, \quad 204, \quad 205, \quad 206$; founding of, 8 , 9 ; noderate and anti-socialistic program of, 26, 138; organization of, 26; strength of, 26 ; relation of, to Bloc of Left, 8.3, 86; to Bloc National Rémublicain, 179, 180, 189: learlers of, 27 ; future of 133,197
Démocratie Nouvelle (newspaper), 43, 18:3, 213, 223, 256, $275,242,297,476$

Démocratie Nourelle, party of, $43,178,187,227,282,361$, 367

Department, 153, 383, 385, 386, $389,291,392,397,394$; goverument of, $374-378$; increase in powers of, advocated, :390, 401

Iepartmental Commission, 378 Depopulation (see also Father's Vote), 150-151; elforts to overeome, 150 ; effect of, on peace demands, 409-410

Deputies. Sce Chamber of Deputies

Déroulèle, Paul, 18; founds League of Patriots, 16; attempts coup d'état, 234

Desehanel, J'aul, 27; I'resilent of Chamber of Deputies, 93, $96,199,227,423$; alvocatrs decentralization, $394, \quad 395$; President of the Republie, 200, 201-202

Desclaux, 135

Desmartres, P. F., eitell, 34

lessoye, M., 162, 164

Dietatorship) (sec also Bonapartism, Boulangism), 2:32-235; of the proletariat, 114,118 , $120,123,243,261,300$

Diplomacy, the "Old.", Sec "O],I Diplomacy"

Diplomatic service, instability of, $310-311$

Direct Aetion. Sec Strikes, Srmulicalism

Directory, the, $386,414,415$

Disarmament (sce also Threeyear military law), of Germany, 422-424, 425, 449, 454; Raynaud resolution asking for total disarmament of, 227 , 429; as attemptel ly Napoleon in 180s, 429-430; in Treaty of Versailles, 414449 , 459-4(i) ; America's inconsist- 


\section{INDEX}

ency in regard to, 485.486; in France, advocated, 32, 120, $124,184,241,251,462$

Dissident Socialists, 177, 178, 196

Dissolution, right of, (see also Parliament), 70, 219.220, 222, 235

Doumergue, M., 89, 96, 134, 135,

Douzièmes provisoires (see also Budget), 75-76

Dreyfus affair, 80, 82, 234

Droit du Peuple, 101, 131

Drunkenness. Sec Alcoholism

Dubost, Antonin, 199, 439

Dufaure, Jules, 59

Dugage, R., 49, 151

Duguit, Léon, 230, 343, 369; denics existence of sovereignty, 358 ; advocates: syndical organization of State, 359, professional representation, 362 ; cited, $69,75,159,161$, $152,216,218,341,362$

Duke of Orleans. See Orleanist party, Philippe VIII

Dumay, Ifenri, 348

Dumont, Charles, 88

Dupuy Cabinet, 225

Echo de Paris, 280, 294, 311, $410,453,464,475,481,491$

Economic Couneil, 241; organization of (1919), 347-348

Filucation (sce also Schools), $343,344,357,366,370,375$, 397,398

Eight-hour day law, 183; advocated by C. G. T., 241,246 247 ; passage of, 248 ; cffect of, 249

Election laws (sec also Electoral Law of July 12, 1919), $\mathrm{v}$; concerning biłl pasting, 181-182

Elections: 1898, $80 ; 1902,81$; $1906,81.82 ; 1910,83 ; 1914$, $92 ; 1919,72-198$; issues of, 175 ; results of, 192.198 ; 1920, of Senate, 198-199;
Presidential, 200-202; supplementary, 85, 162, 165, 170 ; influence of govern. ment on, 154-155; part of clergy in, 188; charges of corruption in, 154; of local officials, 375; fewness of, 381-382 ; minority control of, 157

Electoral law of July, 1919, provisions of, 165-169; effect of, on parties, 169-171; assisted in formation of tho Bloe, 190-192; reduced Socialist seats, 194-195

Electoral reform. See Electoral law of July, 1919, “Father's vote,", Family vote, Proportional representation, Scrutin d'arrondissement, Scrutin de liste

Electoral system (see also Scrutin d'arrondissement and Scrutin de liste), 84-85, 165$169,198,361$

Emergency legislation, 74-75

Encyclical, Papal, of 1892. See Ralliés

Engerand, Fernand, 11

Enquête sur la Monarchie, Orleanist "Bible," 13

Entente Démocratique et Sociale, parliamentary group, 88

Esmein, Alhemar, 146, 157, 216

Eugénic, 5, 10

Europe Nourelle, 164, 319, 445, 476 ; and censorship, 293-294; praise of President Wilson, $470-471$

Execlsior, 149

Exceutive power. Sec President of the Republic

Experts in government, 43, 343 , $349,368.369$; existence of, in France, 343-348; extension of, demaniled, 348

Extreme Ieft. $\quad S c c$ Socialists

Family vote, as a memorial to sons killed in war, 18, 151 


\section{INDEX}

"Father's Vote," as reward for large families, 149,151

Faure, Félix, 64

Faure, Paul, 120, 124, $2 \$ 6$

Felleration of the Iseft (1914), 90

Feminism, See Woman suffrage

Ferry, Jules, 1, 22, 80

Figaro, 135, 281, 481

Finances, state of, in 1919, 203, 504; control of, 75

First of May, 243; history of, 250 ; demanils male on, 251 ; celebration of $(1919), 252$. 257 ; sequel of, $257-260$

Fiume, 207, 273, 480, 485

Flandin Bill. See Woman suffrage

Floquet, Charles, 28, 250

Foeh, General, 197, 297, 410

Food control, 314-316

Ford Autonobile "afiair," 330

Forge, Anatole de la, 16

"Four Direct Contributions" (sce also Taxation) 31,501

France, political forces in, $i$, ii, iii, iv, vi, viii, ix; movements for reform in, $v$, vii, xi, xii, 337 ; opinion of as to the Treaty, xiii, xiv; as to America, $\mathrm{xy}$

France, Anatole, 270, 276, 366, 469

Franee Libre, 106, 286, 453

Franchise. See Suffrage

Freedom of opinion, in France and Ameriea, compared, 372, $299-301$

Frecilom of the press (see also Censorship), 290

Freneh Feleration of Socialist Workingmen, 33

Freycinet, Clarles, 58, 96

Fullerton, Wm. Worton, cited, 254

Functionaries (sce also Bureaucracy), 264, 341; number of, in Franee, 311 ; organization of, 349,352 ; right to form syndicates denied, 82, 351,
353 ; salaries of, 241, 353, 355 ; "Revolt" of, 355; join C. G. T., 355 ; and lecentralization of pullic services, 442 , 357 ; "status"' of, 22, 351

Gabriac, Marquis de, 467

Gimbetta, Léon, 7, 27, 80, 153, 215

Gaulois, 280, 281

Gauvaiu, Auguste, 281, 469

General Couneils. See Couneils, general

General Strike (see also Strikes, Symdicalism), adrocated: 1906,$85 ; 1914,93 ; 1919$, 262; principle of, 236,268

Germany, 207, 215, 233, 273, $284,297,329,400,404,435$, 467 ; attitude of Socialists towarls, 122; fear of, by France, 402, 405, 446, 46i, 472; dismemberment of, demanded 281, 406-410, 425; cxclusion of, from League, 447

Giile, Charles, 366,442

Goblet, 2.8

Gohier, Urbain, 279, 295, 478, 479

Gorce, de la, cited, 155, 388

Goverument, forms of, in French history, 63; instalility of, 56 ; parliamentary, in France, 48 ; eriticisms of, 56 69 ; contrasted with American form, 214; centralization of, 373,383 ; lack of loeal, 381 382,401 ; history of local, $384-389$; ineffieieney of, 302 Grévy, Jules, 64, 217,498

Gromps, parliamentary (see also Action Rémulicaine et So. ciale, 9; Tndependents, Republican Democratic Entente, Repuhlican Demoeratie Ieft), professional, 369; nominate Commissions of Chamber, 5.3. 54 ; lack of relationship with 


\section{INDEX}

political parties, $45,48-53$; reaknesses of system of, 55 , 56 ; makes parliamentary régime unstable, 56-64; permits Parliament to tyrannize over ministry, 64-69; in the 1920 Chamber, 204, 205

Guarantees, French insistence on, in Peace Treaty, 173, 175, $402,405,406,446,454,471$, 491

Guérin, Jules, 234

Guerre Sociale, 95

Guesde, Jules, 239 ; pioneer of French Socialism, 33, 34, 35; and Sacred Union, 57, 58, 94, $95,96,103$

Guilbeaux, M. (Socialist), 127 Guyot, Yves, advocates dismemberment of Germany, 408

Habeas corpus, absence of, 108 Habert, Marcel, 234

Ianotaux, Gabriel, cited, 5, 33, $41,216,373,388,390,404$

Harbors, State control of, 308

Hauriou, Maurice, defends celltralization, 400 ; cited, 341 , 373,375

Haussonville, d', 388

Haute-Vienne motion (see also Socialist party), 97

Iennessy, Jean, 363, 371, 375, $392,395,396$

Herriot, Eilouard, 32, 136, 137, $138,145,198$; cited, 302,381 , 383,391

Hervé, Custave, 283, 284, 482; antimilitarism of, 85 ; desertion of Marxism, 95, 101, 137, 272

IIcure, 288, 311, 469

High Court of Justice (see also Senate), 136, 225, 234

IIomme Libre, 283

IIugo, Victor, arlvoeates annexation of Rhine, 410

II umanite, 98, 107, 112, 274, $75,285,294,457,469,489$
Humbert, Charles, 273

Hyndman, H. M., cited, 390, 433

"Irlealism," American (see also United States), charges against, $\mathrm{xv}$

Ignace, M., 179, 205

Importations, prohibition of, 317,328 ; complaints against, 329 ; repeal of, $335-336$

Income tax, 31, 83, 89, 115, 134; passage of (1914), 60; rates of, 502; evasions of, 503

Indemnity (sce also Cost of War, Bonis), 203, 436; why the Treaty provisions were unsatisfactory, 443-446

Independents, group of (1920), 204

Individualism, 2-3; effeet of, on polities, 76-78; as an obstacle to Socialism, xiii, 37 . 40,366

Inclustry, control of by state. see also "Consortiums," State Socialism

In formation, 295-296

Instituteurs, (see also "Amical' associations), organization of, 351-352, 357; adhere to C. G. T., 356

Interests, representation of, in government. See Professional Representation

Interuational military force, arlvocated by France (see also League of Nations), 449-453

International Workingmen's Association. Sce Internationale

Internationale, First, 125; Sceond, 126; attempted Session of, during War, 10.3; confercuce of 13erne (1919), 126; French Socialists arlhere to (1919), 129; withliraw from (1920), 210.211; Thirl, 125; origin of, at Moseow (1919), 


\section{INDEX}

127 ; debates in Socialist party as to adherence, 120 . 125; Strassburg deeision, 209 211

"Internationale," Socialist hymn, 253-254, 255

Interpellations, rules governing, $65-67$; abuses of, 67-68

“'Intransigeants,"' 27,79

Invasions, of 1815, 402; of 1870,403

Isc̀re, 97, 101, 106, 189

Jacobins, 27

Jacques, Léon, eited, $3,5,18$, $19,22,50,228,362$

Jaurès, Jean, 34, 81, 82, 112 , $248,285,286$; as a reformist 34-35, 138; founds Freneh Socialist party, 36 ; attenupts to resurrect Bloe of Left, 90 ; assassination of, in 1914, 93, 108

Jerome, Prince, 5, 9, 10

Jerrold, Laurence, eited, 80

Jeune République, 7, 22

Jews. See Anti-Semitism

Jèze, Gaston (professor), eited, $342,373,375,385$

Joan of Are, 17, 277

Joinville, Prince of, 11

Jonnart, M., 185

Jouhaux, Léon, seeretary of the C. G. T., 239, 240, 255, 264, 266, 482; resigns from French peace delegation, 257

Journal, 276

Journal des Débats, 207, 281, 469

Journal du Peuple, 110, 287

Journal Officicl, 65, 204, 309, $310,336,345$

Journalism (see also Press, Censorship), political nature of, 270 ; instances of corruption in, 272.274; personal element in, 271 ; suppression of news, 275

Judiciary. Sce Haheas Corpus, Justice, Supreme Court
Justice, Freneh, defeets in, 108 . 110

Kienthal, Soeialist Conferenco at $(1916), 100,195,287$

Kienthalians. Sce Socialist party

Klotz, Louis, ex-Minister of Finanee, 63, 90, 154, 158, 203, 280,504

La Bruyère, 130

Labor (sce also Confédération Générale du Travail, Strikes, Eight-hour day), 368; wages of, $244,246,353$; organization of, $20,237-239,365$

Labor Legislation (sec also Eight-hour day), advoeated by: Radicals, 31, Liberal Action party, 34,91 , Socialists, 116, C. G. T., 242

Labor party, 34, 91

Labor Union (see also Confédération Générale du Travail), $237,238,241,250,350$

Lafferre, M., 63, 197, 199

Lamennais, 393

Land. See Peasants

Landru case, 275-276

Lanterne, 282

Laval, M., 195

Le Gléo, M., 91

Le Play, 385

League, Civie, 61, 162, 180

League of Nations (sce also International military foree, Indemnity, Disarmament); $32,173,241,243,277,410$, $477,488,490,494$; prineiple of, 432; French coneeption of, xiv, 448; objections to the form ereated, 452, 463; Socialists and, 117, 122; financial section demanded, 26, $438-443,445$

League of Professional Representation and Regional Aetion, 44, 61, 362, 393, 395 


\section{INDEX}

League of Proportional Representation, 44, 61, 158

League of the Rights of Man, $44,61,295$

Ledru-Rollin, 27, 154

Lefèvre, André, 34, 174, 199, $202,205,423$

Left Bank of the Rhine, annexation demanded, 18, 173, 207, $279,410-414,425,429,431$; occupation of, $454,456,462$, 464,493

"Left" of Chamber, 9, 203

Legitimists (see also Count of Chambord), 5, 9

Lemaître, Jules, 13

Lenoir, M., 273

Leo XIII, Pope, 6, 7

Leopold I, 10

Leroy, Maxime, 369 ; theory of the State, 359-361; founder of the Ligue des Gouvernés, 348 ; eited, 316

Leygues, M., 63

Leyret, Henry, eited, 212, 225

Liberal Action party (sce also Catholicism, Ralliés, 7, 9, $132,134,179,180,189,204$, $206,228,280,371$; history of, 8,18 ; religious and social program of, $18-20,207$; organization of, 20 ; strength of, 21 ; future of, 133; gains in 1919 elections, 193, 196

Liberals, 7, 453, 472

Lichtenberger, André, 284

Ligue d'Aetion Française. See Orleanist party, Aetion Française

Ligue des Gouvernés, 44; alvoeates decentralization of publie services, 348

Ligue des Hommes Libres, 44

Ligue des Patriotes, 16, 399

Ligue Nationale contre l'Alcoolisme, 144

Longuet, .Tean, 41, 54, 121, 173, $177,194,195,210$; grandson of Karl Marx, 97, 107; cditor Populaire, 106, 27.4, 275; leader of ex-majoritaires, 98 , $100,107,113,286$

Loriot faction (Socialist), 41, $106,114,119,124,125,195$, 209

Loubet, Emile, 27, 64, 234

Loueheur, M., 63, 205, 331, 335, 344

Louis Philippe, 5, 9, 387

Louis XIV, 64, 384, 385, 416

Luxemburg, Rosa, 35

Lyautey, General, 74

Lyons, trade fair at, 331 ; control of, by central government, 380

Lysis, 187, 252; founds New Demoeraey party, 43; advocates professional representation, 361 ; cited, 2, 244, 312, 313,361

MacMahon, Marshal, 64, 70, $216,217,220,389$

Maginot, M., 88

Maine, Sir Henry, 220

Maistre, Joseph de, 172, 212

Majoritaires (Socialists), 97 $106,177,285,286$

Malvy, Louis, 135, 234, 240, 351

Mandel, Georges, 182, 280, 296, 297

Mangin, General, 27

Marin, Louis, 173, 175, 311, 395

Marsal, François, 202, 504-505

Martignae, M., 387

Martin, Menri, 16

Martin, Senator, 148

Marx, Karl, 33, 34, 97, 107, $237,274,365$

Mascurand, Senator, 334

Matin, 276, 298, 473, 476, 488, 491

Manpassant, Guy de, 4

Manrras, Charles, 13, 15, 132, $277,289,406,479$

May Day. Sce First of May

Mayéras, M., 54, 98, 195, 255

Mayor, French, 380, 383, 385, $386,387,388,389$ 


\section{INDEX}

Méline, Jules, 22, 23, 24, 68, 80,96

Mereliant marine, 309 ; government operation of, during war, 315-316

Merrheim, M., 99

Mennier, ]'aul, 298,299

Militarism. See “Old Diplomacy," Injerialism

Millerand, Aleximdre, $28,34,35$, $41,52,57,90,95,137,203$, $343,493,504$; nlember of Republiean Socialist party, 42,203 ; policy of', as J'rime Minister of 1920 Cabinet, 202, 203

Millerand "Case" (see also Socialist party), 34-35

Minister of State, 58

Minister without portfolio, 57

Ministerial instability, 56 ; 11 mber of changes nineler Third Republic, 59; eompared with England, 59; eauses lack of Cabinet leadership, 60; leads to dominance of Parliament over Ministers, 64; group systenr, a cause for, 54-56; $\mathrm{c}$ aggeration of the defects arising from, 61-64; overeome by permanent functionaries, 62; and by public opinion, 76-78

Ministerial " participation," Socialist opposition to, 37 , 123, 258; changed attitude during war, 94-96, 104

Ministerial responsibility, 60, 220-222, 223, 224, 226, 230, $342,358,374$

Ministry, dependence of, on Parliament, 60 ; reconstruetion of, 62 ; members not necessarily members of Parliament, 202, 222; composition of, luring the war, $57,94,96$, 104 ; power of, over allministration, 340-342; over loeal government, 374; Millerand $(1920), 202$
Ministry of the Interior, 59, 279, 374, 379, 3993, 398

Minorilaires (sece alse tiocialist party) ; $95-106,285,299$

Mirabean, rited, 158

Mistral, Frédéric, 394, 395

Mistral, M., 41, 18

Monarelists. Sce Orleanist party, Jegritimists, and lonal partists

Monatte, Jierre', 2.10

Monis (fovernment, 86,160

Monopolies, State. S'e Sitate Socialism, Nationalization

Monroe Doctrine, Frencll interpretation of $48:-485$

Montesquien, 214, 227, 372

Morality. See Aleoholism, Prostitution, Bribery

Muel, Léon, cited, 59

Multiple voting. Sice Fanily vote, "Father's vote",

Mun, M., 6, 18

MLurat, l'rinee, 197

Naney program, regiomalist (1865), 358, 394; Radieal (190(1), 29

Napoleon I, 9, 19, 232, 373, 385, $388,407,415,416,417,430$, 458

Napoleon III, 5, 10, 155, 216 , 233,387

Napoleon, Prince, 10

Napoleon, Victor (see also Bonapartists), !

National Assembly (1871-1675), 368,497 ; parties in, 5, 55; monarchical majority in, 215; effeet of, on constitution, 216

National Assembly, to eleet the Presilent of the Repullir, 200,219 ; to amend the Con titution, 227

National Association for the Organization of Demoeracy, $44,223,208,871$

National Association of Econonic Expansion, 333 


\section{INDEX}

National Federation of Funetionaries, 61,352

National Socialists. See Repulblican Socialists

Nationalists, 9

Nationalization (sce also Railroarls, Socialism, Syndicalism), 115, 120, 138, 183, 225, $242,338,370,499$

New Democracy, party of. See Démocratie Nouvelle

New York Herald, 297

Newspapers. Sce Press and Journalism

Notre Voix, 288-289

Nusellard, Major, 296, 297

Octroi, 243, 349

Euvre, 188, 283, 310, 335, 482

Ogg, F. A., cited, 226

" Old Diplomacy,', principles of, $405,406,425,431,435$, $446,450,454,465$

“'Opportunists," 27, 79

Ordre Public, 11, 28

Organization, law of (1884), $350,352,353$; industrial, neeessary to professional representation, 360 , 364, 368 ; extent of, $364-368$

Orleanist party (sce also Philippe VIII, Action Française), 9, 11, 23t; in Assembly, 1871-1875, 5; demanis an absolute monarcliy, 12-13; social and religious program of, $6,14,361-362$, 399; organization of, 15; strength of, 1516, future of, 132

Ostrogorski, M., 139

"'Pacification,", policy of, 79, 80

Painlecé, Paul, 42, 63, 104, 189, 197,203

Pains, Jules, 63, 87, 88, 162, $164,258,259$

Paris, Count of. Sec Count of Paris
Parliament (sce also Chamber of Deputies, Senate groups, Political parties); dominance of, over Ministry, $6 t-69$; permanent commissions of, 53 , 71.73; sessions of, 69,161 , 181,199 ; during the war, 69-76; never dissolved since $1877, \quad 70,222$; political groups in, 48, 204

Parliamentary form of government (see also Ministerial instability), as distinct from the congressional form, 46 , $214,224,230$; parties necessary to, 47, 139; difference between French and English system, $53,57,60,70$; defects in French system, 56, 213 , 228; unfair eriticisms of, 61-64; clianges in, during the war, 69-76

Parti Socioliste de France, 35

Parti Socialiste Français, 35

Parties. Sce Political parties

Pau, Radical Congress (1913), $50,89,134,206$

Pays, 283, 482

Peace Conference (sce Treaty of Versailles, Indemnity, International nilitary force), $122,276,286,299,404,415$, $423,434,468$

Peace Treaty. Sce Bonds, Indemnity, International military force, Saar, League of Nations, Treaty of Versailles Peasants, growth in number of, 38 ; attitude of, towarl Socialism, $37-40$; attempted organization of, 366,367

Péret, Raoul, 199

Personality in polities, $76-78$

Pertinax. Sce Echo de Paris

Petit Journal, 276

Petit Parisicn, 276, 316, 438439,476

Pherlon. Sce Populaire

Philippe VIII (sec also Orleanist party), 11-12, 14, 132, 278 


\section{INDEX}

Pichon, Stephen, 63, 133, 207

Piou, M., 18, 132

Plébiscitaires, 9

Poinearé, Raymond, 27; Ministry of, $63,84,87,160$; President of the Repmblic (1913$1920), 58,58,93,221$; elected to Senate $(1920), 195$; quoted, 40.4-405; cited, 222

Political parties (see also Bona. partists, Liberal Aetion party, New Demoeracy party, Orleanist party, Progressists, Demoeratie Republican Alliance, Republican Socialists, Socialist party) ; multiplieity of, 1-8, 370; philosophies of, $\mathbf{i}$; organuzation of, $15 \mathrm{ff}$; their relation to Parliament, 48-56; their combinations: Bloc, 80 . 87, Sacred Union, 93, future realignments, 131-140; effect of electorial reform on, 169171

Pope (sce also Leo XIII), 19, $22,189,203,207$

Populaire, 105, 274, 275, 286 . 287

Possibilists, 33

Post-Office, French, 305

Prefeet (sce also Department), $259,293,298,383,384,386$, $388,390,396,403$; powers of, 374,379

Prefectoral Council, 375

President of the Republie, 227, $374,375,380$; election of, 200,219 ; term of, 219; a “parliamentary clerk," 218, $220-222$; movement to inerease powers of, $19,201,223$ 224 ; obstacles to such an in. crease, 232-235; election of M. Desehanel 1920, 200-202

Press (see also Journalism, Cen. sorship), ix; individualism of, 271 ; charges against, 272 275 ; does not reflect opinion accurately, 271, 2s9; Royalist press, 276.278; Conservative press, 278-281; Liberal press, 282.28 .4 ; Socialist press, 284 289 ; legal restrictions on, $290-299$

Presse de Paris, 183

P'ressemanne, M. (Socialist), 95, 100

P'rime Minister, diffieulty of selecting, 57

Prince Imperial, 5

Private enterprises, obstacles to (see also State Socialism), 312-313, 321, 337

Professional representation, 24, 4.3, 358; advocated by: Lysis, 361, Benoist, 362, Duguit, 362 , Liberal Aetion party, 19,362 , Orleanists, 13,361 . 362 ; principle of, 362 ; syndical organization necessary, for, $360,364,365$; defects in, 368.372

Programs, politieal. Sce Political Parties

Progrès Civique, 335

Progressism, 81

Progressist party (see also Republican Federation), 22, 179, 204 ; formation of, 23 ; conservative program of, 23 , 228 ; opposed by Bloc of Left, $81,178,180$; organization of, 24 ; strength of, 23 ; futuro of, 133; gains in 1919 election, 193,196

Proportional division of school funds. See Sehools

Proportional representation (see also Electoral law of July, 1919), 134; agitation for, $19,22,24,83,115,156$; parliamentary attempts to $\mathrm{en}$ aet, 158-161; prineiple of, 166-168, 194; effect of, on politieal parties, 169-171

Prostitution, 145, 473

Proulhon, eited, 267

Pullic opinion, 231; control of, over deputies, 78; supreme under parliamentary form of 


\section{INDEX}

government, 47, 231; hindrances to exercise of, in France, 70; in United States, 231, 492

Question, the parliamentary, 65 Questor, 199

Radical and Radical Socialist party, $9,50,60,119,162,175$, $179,184,187,200,203,204$, $205,235,333,339,443$; history of, $8,27,28$; Anticlerical and collectivist program of, 29-32, 138; organization of, 32 ; Congresses of : Tours, 87, 88, Dijon, 30, 85, Nancy, 85, Pau, 50, 89, 134, Nîmes, 86, Toulouse, 87, Sejtember, 1919,178 ; relation to $B l o o$ of Left, 84-87; opposes Progressists, 89 ; relation to $B l o c$ National Républicain (1919), 180, 188; demands abolition of three-year military law, 32 , $58,89,134$; lack of leaders in, 136 ; divisions of, 136 ; future of $134-137,206$; defeat of, in 1919 elections, 193, 195; newspapers of, 282

Raffin-Dugens, 100, 195, 300

Railroads, 376 ; State $v$. private, $303-305$

Ralliés, 6, 133

Referendum, 19, 22

Reform, organizations of, 44

Refornism, doctrine of, 7,81 , 119

Regional Councils. See Councils, regional

Regionalism, xii, 13, 383, 388; economic, 345 ; prineiples of, 391-394; proposed bill for, $396-399$; obstacles to, 399

Reign of Terror, 386

Reinach, Joseph, 145, 280

Renaudel, Pierre, 97, 98, 106, $107,121,177,210,274,285$

Renoult, René, 32, 197

Reparations. See Indemnity
Representation. See Professional representation; Proportional representation, Elections

Republic. See Third Republic, Parliamentary form of gov. ernment

Republican Democratic Alliance. See Democratic Republican Alliance

Republican Democratic Entente, group of (1920), 204

Republiean Demoeratic Left, group of (1920), 204, 205

Republican Federation, 8, 9, 49, $133,138,178,179,180$

Republican Socialist party, 9, 51, 138, 178, 186, 189, 196, $203,204,205$; history of, 8 , 41-42; difference between, and Radicals and Radical-Socialists, 42-43; prominent members of, 42 ; strength of, 43 ; future of, 137 ; relation of, to the Bloc of the Left, 87

Republicans of the Left (see also Demoeratic Republican Alliance), 193, 196, 200, 204, 205

République Russe, 295

Revanche, 16, 233, 411, 472

Revisionism. See Reformism

Revolution, French, 12, 27, 113, $360,377,412,413,498$; effect of, on administrative system, 385 ; of $1848,27,141,154$, 387

Revolution, Social (sec also Socialism, Syndicalism, Lo. riot faction), demanded, 113 , $118,127,128,182,241,287$, 288 ; attitude of France towarl, $130,183,290,366$

Rhenish Republic, history of former, 412-415; creation of, arvocated, 412, 415, 425

Rhine. See Left Bank of the Rhine

Ribot, Alexandre, 22, 24, 57, 


\section{INDEX}

$58,59,63,92,95,96,104$, 395 ; alvocates division of war debts, 439

Ricard, 27, 153

"Right", of Cliamber, 9, 178

Rire de Paris, 474

Roanne Arsenal Seandal, 307

Rochette Case, 71, 90, 135

Rolland, Romain, 366, 469

Rouller, 5

Rouvier Cabinet, 80, 81, 83, 225

Royalists. See Bonapartists, Orleanist party, Legitimists

Russia. See Bolshevism

Saar, annexation demanded, $416,425,429,454,488$; history of, 416 ; population of, 421 ; coal in, 294, 417, 419; Treaty terms coneerning, 456459

Saarbrïck, 412, 416, 417

Sabatier, Paul, eited, 7

Sacred Union, $94,169,185,190$

Sadoul, Jaeques, 177, 195

Saigon bamboo case, 309

Sailliens, E., eited, 142

Sarrail, General, 189, 197

Sarrien, M., 28, 63, 81

Saumonneau, Mme., 120

Scelle, Georges, 484

Schools, 24, division of funds for, advocated, 20, 189; lay, advocated by Radicals, 89

Scrutin d'arrondissement (see also Electoral law of July, $1919)$; as an election district, 152 ; "gerrymandering", features of, 155 ; defeets in, 153 ; abolition of, 165

Scrutin de liste, 24, 29 ; trial of, in 1885,153 ; advantages of, 156 ; legislative efforts to enact, 158-161; adoption of, $1919,162-169$

Seeret Committee. Sce Commit. tee, Secret

Secret press funds, 272

Sembat, Marcel, 34, 41, 94, 98, 173,469
Sinate (sec also United States Senate), 362; method of election, 198, 218; as a lligh Court of .Justice, 136, 225, 234 ; control of, over Ministry, 225; attituile of, toward electoral reform, 160, 164 . 165; conservatism of, 224; movement to strengthen in. fluenee, 224; existence of, in. consistent with parliamentary government, 225; eleetion of, 1920,198

Separation of Powers, government based on, 180; difference betweesl, and parliamentary government, 214-215, 218,219 ; alvocated in France, 223-229; defeets of, 231-232, 235

Siegfried, M., 145

Sillon, 7, 8, 21-22, 108

Socialism (see also Socialist party, Class Struggle, Stato Socialism, Republic Soeialist party), 7, 208; history of, in France, 33ff.; doctrines of, $37,112-119,121-125,236$

Soeialist party (Unified), (sce Pact of Amsterdam, Jean Jaurès, Dissident Socialists, Ministerial "participation''), 9, 51-52, 138, 176, $177,178,184,186,191,192$, $204, \quad 205, \quad 300, \quad 333, \quad 335$, $339,357,371,433,470$; formation of, 8, 33-36; growth of, 40 ; seeks peasant support, 37-40; relation of, to Bloc of Left, 36 ; organization of, 40 ; strength of, 36 ; antimilitarism of, 92.93 ; future of, 137, 206; adheres to the Sacred Union, 94-95; the first break in the Sacred Union, 97,98 ; origin of the Kienthalians, 99-100; of the minoritaires, 98 ; of the majoritaires, 98; of the Centrists, 98 ; struggles between these 


\section{INDEX}

factions, 98-107; victory of the minoritaires, 106-107; attitude toward Villain trial, 110 ; 1919 program, a compromise between minoritaires and majoritaires, 112-119, 243 ; distinction between rev. olution and violence, 113 ; political and economic reforms demanded, 115-118; Easter Congress, 1919, 120$129,176,209,211,274,275$, 285,487 ; motions on general policy, 121-125; on electoral discipline, 124; victory for radicals, 125 ; adherence to Second Internationale, 128; Socialists withdrawal from the Chamber, 257-258; opposition of, to Peace Treaty, $172-173,175$; formation of Bloc against, 131-132, 137, 179-181; defeat in 1919 elections, 193, 196; causes of, 194-195; Strassburg congress, February, 1920, 208-211; qualified adherence to the Third Internationale, 209; character of learlers of, 41, 184; newspapers of, 284.289

Sorel, Albert, eitel, 413

Sorel, Georges, 236, 365; tlieory of strikes, 237, 267

Sous-prófet, 154, 278, 386, 390

State of Siege, law of, 69, 75, $94,251,259,292,298,299$

State Socialism (see also "Consortiums,' Bureancracy), 23 , $43,115,138,186,187,196$, $281,359,372$; extent of, in France, 306, 338; agitation against, 206, 333-338

Stecg, M., 87

Stern, .Tacques, 440

Stockhold question, 103, 126

Strassburg, Socialist congress at (1920), 208-211

Strikes (see also General strike), 354, 355 ; causes of, 246, 260; postal (1909), 82; railway (1910), 82; newspaper (1919) 182; political, 260-263; failure of, 263.269 Suffrage. See Woman suffrage, Multiple voting, Electoral reform

Supreme Court, with power to declare laws unconstitutional, advocated, 19, 24, 226-228; inconsistency of, with parliamentary form of government, 229

Syndiealism, (see also Confédération Générale du Travail, Sorel, Georges), theory of, 236, 261, 267; difference between, and Socialism, 236237

Syndicates, 238; Christian, 20, 365

Tannery, M., 305, 306

Tardicu, André, 173, 179, 205, 281

Taxation, Appendix B.; former system of, 31, 501; change of basis during war, 502 ; failure of, to provide revenue, 503 . 504

Taxes (see also Income tax), 375 , 37s; excess profit, 115 , 502-503; international advoeated to pay for war debt, 442

Telegraph and telephone service, 305-306

Temps, 162, 185, 186, 272, 280, $294,296,331,406,469,489$, 494

Tery, Gustave, 188, 283, 296

Thierry, 88

Thiers, Adolphe, 10, 27, 64, 201, 216,404

Thire Republic, criticisms of, $212 \mathrm{ff}$; compromised basis of, $217 \mathrm{ff}$.; attempts to overthrow, 233.234

Thomas, Albert, 41, 96, 99, 102, $104,107,137,172,175,240$, $248,307,308,339$ 


\section{INDEX}

Three-year military service law, $32,58,83,89,134$

Tirard Cabinet, 225

Toequeville, de, 3

Treason trials, 273-274

Treaty of Friukfort, 403-404

Treaty of Versailles (sce also Ieft lank of lihine, Bonds, International military force), $176,177,197,263,295,296$, $432,436,444,494,495$; compromises in, $454-463$; ratifieation of, by Parliament, 54, 172-175; rejection of, by United States, 231.232, 491. 494

Treitschke, eited, 430

Unified Radieals (see also Radical and Radical-Socialist party), 51

Unified Socialists. Sce Socialist party

Union of Commeree and Industry, 44

Union of Economic Interests, $44,334,367-368,371$; membership of, 337 ; anti-statist program of, 337.338

United States, 294, 435, 445; part of, in war, 474-475; ideals of, charged with impracticability, 480-482, with insineerity, 482.489 ; responsibility of, for a reak Ieague of Nations, 454, 465-466; failure of, to assume international obligations, 207, 491494

United States Senate, rejection of Treaty by, 231 ; attitude of France towarl, 484, 491-492, 494 ; reasons for rejection, 492

Uzès, Duchesse d', 234

Vague, 252, 287.288, 289, 290, 486

Valois, Georges, 12

Vandervelde, Emile, cited, 339
Varenne, Alexanilre, 98, 107, 158,175

Vangeois, Henri, 13, 277

Verfeuil, M., 120, 121

I'crité, 110

Iictoire, 95, 272, 273, 283, 482

lictoire Intégrale, 405

Vietor Emmanuel II, 10

I'ie Ouvriere, 240

Vicille-France, 278-280, 475, $476,478,479$

Vilgrain, M., 245, 315, 3.t

Villain, Raoul, assassinates Jaurès, 108 ; aequittal of, 109 , 285 ; ails Soeialist cause, 111 Tillèle, 386

Villey, Edouard, cited, 59, 302, 362

Tiviani, René, 12, 34, 36, 63, $95,96,104,108,137,148$, 172; Republican Socialist, 42; Ministry of (1914), 57, $58,59,94$

Vizetelly, F. A., cited, 10

Toix du Pcuple, 239, 251, 252

Vote of confidence, 66

Walleck-Roussean, 23, 27, 34, 81, 225

War, declaration of (1914), 69, 93,161 ; Socialist attitude toward, 94, 122; women and, 143

War deht. See Cost of War

War of $1870,403,411$

Weill, Georges, eited, 44

Weiller, Lazare, 305

Wellington, Duke of, 403

Wertl, Iéon, 17

Wilson, Presilent, 240, 295, 447, $453,483,485,488,489,490$; reception of, in Paris, 469 . 471; changed attitude toward, 472, 481; personal attacks against, 475-479; success and failure at Paris, 466

Woman suffrage, v; demanded as reward for women's war work, 143; also to aid solu. tion of moral problems, 144; 


\section{INDEX}

arguments against, 146; leg- Zimmerwald, Socialist conferislative activities for, 147 - ence at, 99

149 ; Flandin bill, 148

Zévaès, Alexandre, cited, 35,

Women, French attitude to-

ward. 142; war work of, 143 Zévort, E., cited, 7, 16 


$$
\text { . }
$$


UC SOUTHERN REGIONAL LIBRARY FACILITY

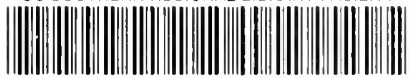

AA $001139414 \quad 5$

CENTRAL UNIVERSITY LIBRARY University of California, San Diego

DATE DUE

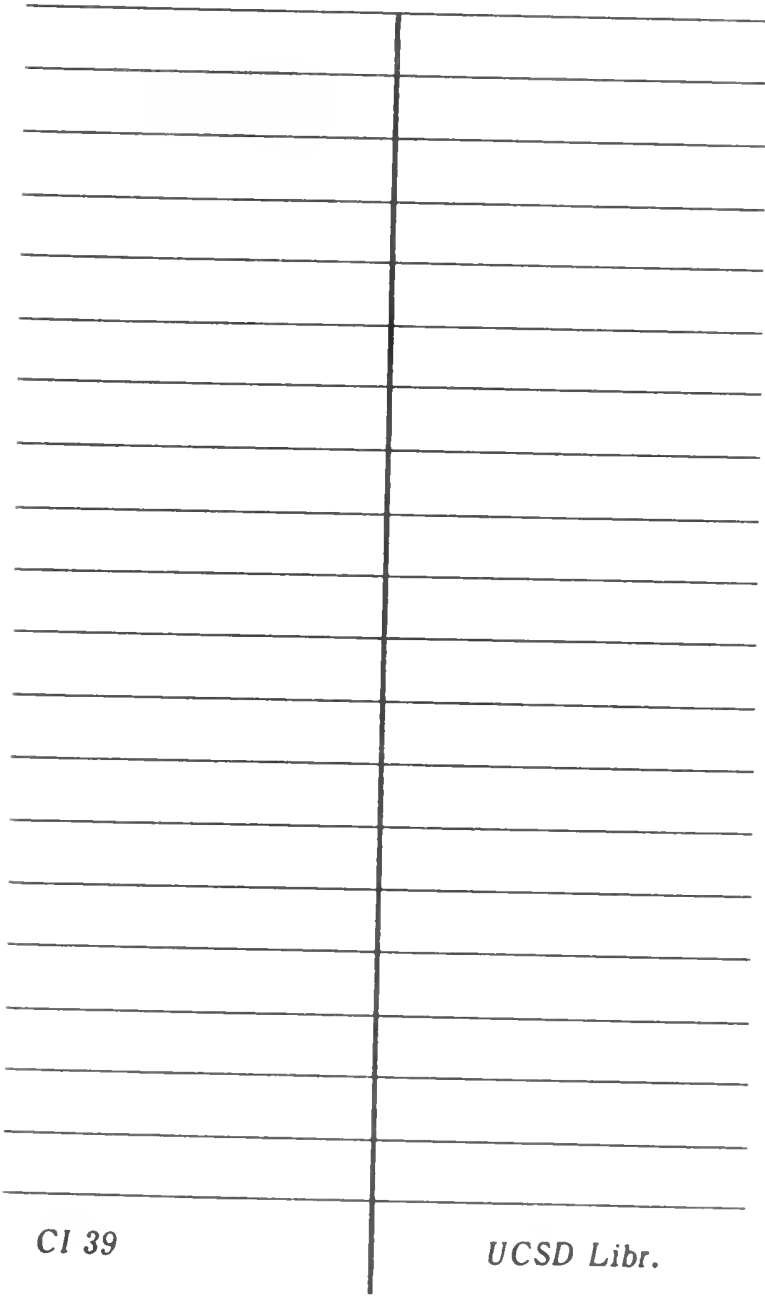


